\title{
The Clemente and Herminia Hinojosa Site, 41JW8: A Toyah Horizon Campsite in Southern Texas
}

Stephen L. Black

Department of Anthropology, Texas State University

Follow this and additional works at: https://scholarworks.sfasu.edu/ita

Part of the American Material Culture Commons, Archaeological Anthropology Commons, Environmental Studies Commons, Other American Studies Commons, Other Arts and Humanities Commons, Other History of Art, Architecture, and Archaeology Commons, and the United States History Commons

Tell us how this article helped you.

This Article is brought to you for free and open access by the Center for Regional Heritage Research at SFA ScholarWorks. It has been accepted for inclusion in Index of Texas Archaeology: Open Access Gray Literature from the Lone Star State by an authorized editor of SFA ScholarWorks. For more information, please contact cdsscholarworks@sfasu.edu. 
The Clemente and Herminia Hinojosa Site, 41JW8: A Toyah Horizon Campsite in Southern Texas

\section{Creative Commons License}

(c) (i) (8)

This work is licensed under a Creative Commons Attribution-NonCommercial 4.0 International License 
THE CLEMENTE AND HERMINIA HINOJOSA SITE,

41 JW 8:

A TOYAH HORIZON CAMPSITE IN SOUTHERN TEXAS

Stephen L. B1ack

\section{With Contributions by}

R. G. Holloway, J. G. Jones,

H. D. Murray, R. L. Robinson, and D. G. Steele

Work funded by the National Park Service, Interagency Archeological Services-Denver, Under Contract C53007(80)

Report prepared under the supervision of Dr. Thomas R. Hester, Principal Investigator

Center for Archaeological Research The University of Texas at San Antonio ${ }^{\circledR}$

Special Report, No. 18 


\section{FOREWORD}

Although archaeologists have all too often been inspired by idle curiosity or the desire to acquire objects for their own sake, it remains profoundly true that the only scientific purpose of digging things up is to assemble material from which to interpret the past.

Grahame Clark

Archaeology and Society, 1939

The results of an intensive field and 1 aboratory research effort of site $41 \mathrm{JW}$ 8, the Clemente and Herminia Hinojosa site, in Jim Wells County, southern Texas, are presented in this monograph. The investigations were based on a research design that has now provided new information on several facets of the extensive Late Prehistoric occupation at the site. Additiona $11 \mathrm{y}$, the researchers have been able to integrate these findings with materials of similar date from other sites in the region.

The present study builds on more than 15 years of research into the sites and materials of the Late Prehistoric era in south Texas. As 1 ate as the mid1960s, little was known about the prehistory of the region, and the Late Prehistoric was known only from surface finds of diagnostic arrow point types (the occurrence of ceramics as part of Late Prehistoric material culture in southern Texas was not recognized until 1968). During the 1970s, substantial advances were made in our knowledge of the south Texas Late Prehistoric. Some 1 inks to the Late Prehistoric of central Texas could be noted, but with further study, the regional materials began to assume an identity of their own. Variations in Late Prehistoric cultural patterns could be documented from the Dimmit and Zavala Counties area (where sites were studied by T. C. Hi1 T, Jr., and this writer) across south Texas to the coast.

A wealth of information on the Late Prehistoric came to 1 ight during archaeological research in the Choke Canyon Reservoir basin in the late 1970 s and early 1980s. Reports published by Grant Ha11, Lynn Highley, Ken Brown, and others, have given new dimensions to our developing concepts of the Late Prehistoric period. It was indeed fortunate that the research program at Choke Canyon was underway at the time the investigations at $41 \mathrm{JW} 8$ were carried out. This created an environment in which several archaeologists working on sites of a related time period could exchange information and ideas; as a result, interpretations of data derived from both projects have benefited.

Stephen Black's report on the research at 41 JW 8 constitutes a significant addition to, and synthesis of, our knowledge of the Late Prehistoric in the region. The materials found at the site have been described in detail, the studies by various consultant experts have been added, and a set of very useful, and in some cases, far-reaching interpretations have been offered. I. believe that this volume will allow future researchers to develop and address a variety of interesting questions involving the Late Prehistoric period in southern Texas and in adjacent areas. Indeed, as with any good archaeological report, this study suggests more problems and questions than it resolves.

Thomas R. Hester, Principal Investigator 


\section{ABSTRACT}

Site $41 \mathrm{JW} 8$ is a major prehistoric occupation site located along Chiltipin Creek in Jim Wel $1 \mathrm{~s}$ County, in southern Texas. Excavations at the site in 1981 evidenced a single component that can be 1 inked with the Toyah horizon. Radiocarbon dating of three fire features, al though not without problems, p 1 aces the occupation to around A.D. 1350-1400. The excavation of $82 \mathrm{~m}^{2}$ clustered in blocks produced an abundance of we11-preserved data. Special studies of faunal and botanical remains and analyses of artifacts and cultural refuse distribution provide the basis for addressing various research problems. The site is shown to be a base camp where hunting and animal processing were major activities. Contrary to earlier interpretations, deer were more important than bison, although the remains of over forty other species suggest a diverse subsistence base. The site is thought to have been occupied while Chiltipin Creek was a spring-fed reliable water source surrounded by a mosaic of grassiand, riparian, and thorny brush vegetation. A review of regional Late Prehistoric sites suggests that the site represents an occupational pattern--the Toyah horizon--that spread from central Texas in the 14 th and 15 th centuries during a period of increased rainfall.

KEYWORDS: South Texas, Toyah Horizon, Late Prehistoric, Radiocarbon Assays, Environmental Conditions, Bone Cluster Features, Rock/Charcoal Features, Macrobotanical Remains, Vertebrate Faunal Remains, Bison, Deer, Freshwater Bivalves, Soils Chemistry, Perdiz Arrow Points, Beveled Knives, End Scrapers, Bone Tempered Ceramics 


\section{TABLE OF CONTENTS}

FOREWORD (Thomas R. Hester) . . . . . . . . . . . . . . . . i

ABSTRACT ........................... ... i i

LIST OF FIGURES . . . . . . . . . . . . . . . . . . . . . . $v i$

LIST OF TABLES ........................... . . vi i

I. INTRODUCTION . . . . . . . . . . . . . . . . . . . . . . 1

Previous Investigations .................... 1

1981 Investigations . . . . . . . . . . . . . . . 2

To The Reader ......................... 3

II. RESEARCH DESIGN .. . . . . . . . . . . . . . . . . 4

Major Problems at $41 \mathrm{JW} 8$. . . . . . . . . . . . . . 4

Research Hypotheses .. . . . . . . . . . . . . . 4

Excavation Strategy . . . . . . . . . . . . . . 7

Additional Problems ................... . . 9

III. RESEARCH METHODS ....................... 10

Field Methods .................... . . 10

Excavation Controls................. 10

Excavation Techniques................ 12

Recording Techniques ............... 14

Soll Sampling................... . . 16

Chronological Outline of the 1981-1982 Season . . . . . . 17

Laboratory and Analytical Methods . . . . . . . . . . 18

Initial Processing ................. 19

Data Analysis................... . . 20

Laboratory Records ... . . . . . . . . . . . 20

IV. ENVIRONMENTAL SETTING .................. . . . 22

Climate ....................... 22

Hydrology ......................... . . . . 24

Physiography, Geology, and Soils . . . . . . . . . 25

Vegetation . . . . . . . . . . . . . . . . 27

Site Setting Circa A.D. 1350 . . . . . . . . . . . . 30

v. ARCHAEOLOGICAL AND ETHNOHISTORICAL BACKGROUND . . . . . . . . . . 34

Southern Texas Prehistory . . . . . . . . . . . . . . . . 34

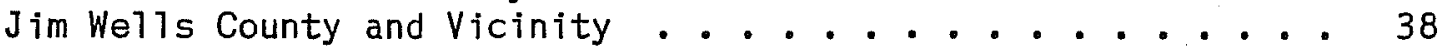

Historic Indians of Southern Texas ............. 40

Aboriginal South Texas . . . . . . . . . . . . . . 43

VI. ARTIFACT ANALYSIS . . . . . . . . . . . . . . . 45

Lithics ........................ . . . 45

Lithic Materials and Sources ........... . 45

Lithic Classification System ........... 48

Unmodified Lithic Material . . . . . . . . . . . . 48

Pebbles, Rocks, and Gravels . . . . . . . . . . 48

Asphaltum Pebble............... . 50

Burned Rock ................... 50

Chipped Stone................. 50

(C) Cores ........................ 50

Debitage .................... . . 51

Unmodified Debitage ................ 51

Modified Debitage............... . 54 
Bifacial Artifacts ............ 56

Arrow Points ............. . . 56

Finished Bifaces ............. . . 65

Fragmentary and Unfinished Bifaces ....... 76

Unifacial Artifacts .............. . . 77

Nonchipped Modified Stone.............. 86

(MS1) Ground Stone . . . . . . . . . . . 86

(MS2) Hammerstones . . . . . . . . . . . . . 87

(MS3) Abraders ................ . . . . 87

(MS4) Sandstone Pipe Bow1 . . . . . . . . . . 87

Prehistoric Ceramics . . . . . . . . . . . . 89

Methods................... 90

Attribute Definitions .............. 90

Exterior Surface Treatment . . . . . . . . . 99 90

Postfiring Decoration ............ 91

Interior Surface Treatment . . . . . . . . . . . . 91

Paste Matrix . . . . . . . . . . . . . 92

Paste Inclusions . . . . . . . . . . . . . 92

Sherd Thickness ............. . . 93

Vessel Fragment ............... 93

Vessel Forms . . . . . . . . . . . . . 99 93

Ceramic Figurine Fragment ............... 94

Ceramic Summary and Discussion ............ 94

Baked Clay Lumps . . . . . . . . . . . . . . . . . 97

Modified Bone and Shel1.............. . . 97

Modified Bone.................. 98

Ulna Tools........................ 98

Bone Needle ............... 102

Bone Beads . . . . . . . . . . . . . . 102

Modified Shell ................ 102

Shaped Musse1 Shel1 ............ 103

Incised Mussel Shel1 ............. 103

Marine Shell ................ 104

Historic Artifacts ................. 104

VII. SPECIAL STUDIES ................. 108

Analysis of Vertebrate Faunal Remains (D. Gentry Steele) . . . 108

Analysis of Macrobotanical Materials (John G. Jones) . . . . 137

Freshwater Bivalves (Harold D. Murray) . . . . . . . 144

Radiocarbon Assays .............. . . 146

Perdiz Arrow Point Special Studies . . . . . . . . . 155

Neck Width Hypothesis . . . . . . . . . . 156

Plow Damage Study ................ 158

Arrow Point Breakage Patterns ............ 159

Sol1s Chemistry ................. 163

Soils Chemistry Background ............ 163

Methods ................... 164

Phosphate Spot Testing . . . . . . . . . . 164

Tota1 Phosphate Determination .......... 165

Results ............... 165

Axial Interval Sampling . . . . . . . . . . . 167

Additional Soils Chemistry ............. 169

Conclusions ............................. 170 
Water Separation .................. . . 171

Pollen Analysis (Richard G. Holloway) . . . . . . . . . 174

Biosilica Analysis (Ralph L. Robinson)........... 176

Biosilica Analysis: Materials and Methods ........ 176

Processing of Sediment Samples.......... 176

Processing of Flora and Fauna ........... 179

Mounting of Samples for Light Microscopy ........ 179

Mounting of Samples and Operating Procedures for

Scanning Electron Microscopy (SEM)........ 180

Analysis Methodology .............. 180

Biosilica Analysis: Results and Conclusions . . . . . 187

VIII. CULTURAL FEATURE ANALYSIS . . . . . . . . . . . . . 189

Bone Clusters................... ... 189

Rock/Charcoal Features ................. 197

Living Surfaces .................... 210

IX. ARTIFACT AND FEATURE DISTRIBUTIONS . . . . . . . . . . . . . 219

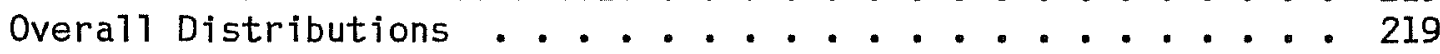

Horizontal Artifact Distributions ............. 219

"Bone Bed" Area ...................... 222

Wagon Trait Area ........................ 225

X. SITE INTERPRETATIONS ....................... 236

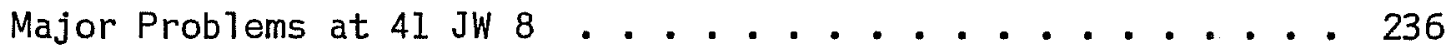

Research Hypotheses ................. 239

Additional Problems .................. . . 242

XI. THE LATE PREHISTORIC IN SOUTHERN TEXAS . . . . . . . . . . . . 243

Previously Defined Cultural Patterns . . . . . . . . . . 243

Late Prehistoric Chronology in South Texas . . . . . . . 246

The Toyah Horizon .. . . . . . . . . . . . . . 254

XII. A TOYAH CAMPSITE IN SOUTHERN TEXAS . . . . . . . . . . . . . . 258

Occupation Period of the Site . . . . . . . . . . 258

Subsistence at $41 \mathrm{JW} 8$..................... 258

Environmental Conditions During the Site Occupation . . . . . 259

Site Function . . . . . . . . . . . . . . . . . 262

Toyah Horizon Peoples . . . . . . . . . . . . . 262

XIII. ACKNOWLEDGMENTS .......................... . . . . . 264

XIV. REFERENCES CITED . . . . . . . . . . . . . . . . . . . 266

XV. APPENDIX 1. PROVENIENCE DATA: LOT NUMBERS . . . . . . . . . 290

XVI. APPENDIX 2. DATA TABLE .................... 296 


\section{LIST OF FIGURES}

1. Site Map of $41 \mathrm{JW} 8$. . . . . . . . . . . . . . . . . 11

2. Environmental Model of Site Vicinity . . . . . . . . . 32

3. Cores (C)...................... 52

4. Perdiz Arrow Points $(A 1)$. . . . . . . . . . . . 58

5. Arrow Points . . . . . . . . . . . . . . . . . 60

6. Beveled Knives (Bl) . . . . . . . . . . . . . . 66

7. Bifacial Tools . . . . . . . . . . . . . . 73

8. Unifacial Tools................... . . . . 79

9. Nonchipped Modified Stone Artifacts . . . . . . . . . . . 88

10. Ceramic Artifacts . . . . . . . . . . . . . . . 95

11. Modified Bone Artifacts . . . . . . . . . . . . . . . . 100

12. Modified Shell Artifacts . . . . . . . . . . . . . . 105

13. Radiocarbon Assays from 41 JW 8 . . . . . . . . . . . . 149

14. Arrow Point Fragments . . . . . . . . . . . . . . . . . . 160

15. Axial Interval Sampling, Feature 5. . . . . . . . . . . . . 168

16. SEM Photomicrographs of Phytoliths from 41 JW 8 and Comparative

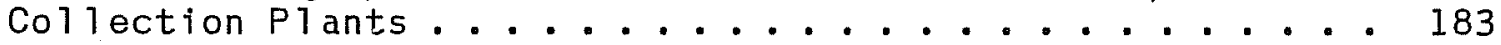

17. SEM Photomicrographs of Phytoliths from $41 \mathrm{JW} 8$ and Comparative Collection Plants . . . . . . . . . . . . . . . . . 185

18. View of Feature 3 and Plan Map . . . . . . . . . . . . . . 193

19. Plan Map and View of Feature 9 . . . . . . . . . . . . . . 195

20. Views of Feature 5 . . . . . . . . . . . . . . . . . 200

21. Plan Map and Profile of Feature 6. . . . . . . . . . . . . 203

22. Plan Map of Feature 8. . . . . . . . . . . . . . . . . 209

23. Plan Map of Feature 7 . . . . . . . . . . . . . . . . . 213

24. View of Feature 7 . . . . . . . . . . . . . . . 214

25. Plan Map of Feature 11 . . . . . . . . . . . . . . . . 217

26. View of Feature 11 . . . . . . . . . . . . . . . . . . 218

27. Excavation Unit Profiles . . . . . . . . . . . . . 220

28. WTA Cultural Feature Distribution . . . . . . . . . . . . 226

29. WTA Rabdotus Distribution, Level 2 and WTA Sherd Weight,

Levels 1 and 2 . . . . . . . . . . . . . . . . . . 228

30. WTA Burned Rock Distribution, Levels 1, 2, 3, and 4 . . . . . . 229

31. WTA Baked Clay Distribution, Levels 1-3 and Modified Debitage

Distribution, Levels l-3 . . . . . . . . . . . . . . . . . 231

32. WTA Cores, Biface Fragments, and Debitage Distributions . . . . . 232

33. WTA End Scrapers, Beveled Knives, and Arrow Points Distributions . 234

34. Location of Select Late Prehistoric Sites . . . . . . . . . . . . 248

35. South Texas Late Prehistoric Radiocarbon Assays . . . . . . . . . . 252

36. Radiocarbon Assays of Late Prehistoric Horizons in South Texas . 253 


\section{LIST OF TABLES}

1. Lithic $\mathrm{Cl}$ assification System .............. 49

2. Core Attribute Data ................. 53

3. Perdiz (Al) Attribute Data ............... 62

4. Perforator Metric Data ... . . . . . . . . . . . . 74

5. 01mos Biface Metric Data ............... 75

6. End Scraper (UI) Attribute Data ............... 82

7. Modified Bone Descriptions .............. 99

8. Marine Shell Identifications .............. 106

9. Systematic List of the Identified Vertebrate Remains Recovered from 41 JW 8 during the 1975 and 1981/1982 Field Seasons . . . . 110

10. Tabulation of the Feature Bones . . . . . . . . . . . . . 113

11. Tabulation of the Nonfeature Plotted Bones, WTA Units . . . . . 117

12. Tabulation of the Vertebrate Remains Recovered from Selected

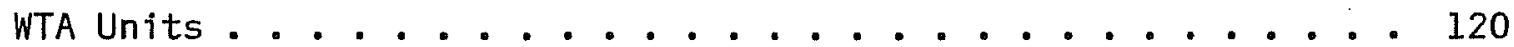

13. Results of Macrobotanical Analysis ............. 138

14. Radiocarbon Assays ... . . . . . . . . . . . . 148

15. (AI) Arrow Point Breakage ................ 161

16. (A4) Arrow Point Breakage ................ 161

17. Phosphate Testing Results . . . . . . . . . . . 166

18. A Comparison of Spot Test Ranks to Total Phosphate . . . . . . 169

19. Soils Testing Laboratory Results . . . . . . . . . . . . 170

20. Water Separation Data . . . . . . . . . . . . . 174

21. Summary of Step 1 of Biosilica Processing........... 178

22. Types of Biosilica in 41 JW 8 Sediment ............ 186

23. Plotted Items Associated With Feature 3 . . . . . . . . 192

24. Plotted Items from Feature 9 . . . . . . . . . . . 196

25. Plotted Items Associated with Feature 6............ 202

26. Plotted Items Associated with Feature 8........... 208

27. Plotted Items Associated with Feature 7 . . . . . . . . . 212

28. Horizontal Artifact Densities by Excavation Area . . . . . . 221

29. WTA Debitage Recovery Compared with Biface Fragment and Core Frequencies .............. 233

30. Minimum Estimated Artifact Quantities at $41 \mathrm{JW} 8 \ldots 238$

31. Comparative Data on Select Late Prehistoric Sites . . . . . . . . 249

32. Late Prehistoric Radiocarbon Assays from South Texas ...... 251 


\section{INTRODUCTION}

The Clemente and Herminia Hinojosa site, $41 \mathrm{JW} 8$, is a prehistoric Indian campsite located on Chiltipin Creek in Jim Wells County about 40 miles west of Corpus Christi, Texas. This report presents the results of an archaeological project conducted at $41 \mathrm{JW} 8$ by members of the Center for Archaeo1 ogical Research, The University of Texas at San Antonio (CAR-UTSA). The author served as project archaeologist and directed the field work and subsequent analysis. A11 of the illustrations in this report were done by the author, with the exception of the artifact photographs (J. Poindexter) and the SEM biosilica photographs (R. Robinson).

The site is named after the 7 ate $C l e m e n t e$ and Herminia Hinojosa, former 1 andowners of the property on which the site is located. The property is currently owned by Mrs. Eva Jimenez, daughter of Clemente and Herminia Hinojosa. Throughout the remainder of this report the site will be referred to in an abbreviated fashion as the Hinojosa site or simply as $41 \mathrm{JW} 8$.

\section{PREVIOUS INVESTIGATIONS}

The Hinojosa site was first recorded in 1974 during an archaeological survey of properties along the Chiltipin and San Fernando Creeks that were to be affected by flood control projects sponsored by the Soil Conservation Service (SCS; Hester and Bass 1974). The site was recommended for intensive site survey, including mapping, surface collection, and testing, in order to evaluate the site's potential eligibility for nomination to the National Register of Historic Places.

In 1975, members of the Center for Archaeological Research returned to 41 JW 8 for a week of intensive survey and testing (Hester 1977). The field work was directed by Feris A. Bass, Jr. The 1975 investigations consisted of surface collection, plane table mapping, and the excavation of a number of test units. Twelve $2-\mathrm{m}^{2}$ units were excavated to depths ranging between 15 and $110 \mathrm{~cm}$ below the surface. In addition, a vertical cut was made into the bluff edge adjacent to the site (Hester 1977). In most units cultural debris was concentrated in the upper $30 \mathrm{~cm}$. In the "bone bed" area (Units $\mathrm{K}$ and $\mathrm{L}$ ), a hearth feature and a concentrated deposit of bone continued to a depth of about $56 \mathrm{~cm}$. Burned rock or caliche clusters were observed in several test units in the upper $30 \mathrm{~cm}$. These were described as "disturbed." Two lower clusters were encountered, the one mentioned previously in Unit $L$ and $\mathrm{Aa}$ scatter" in Unit B at 75-95 cm.

Hester (1977:33-37) suggested the fol lowing preliminary interpretations concerning 41 JW 8: (1) it was a single component Late Prehistoric campsite dating to approximately A.D. 1300 ; (2) the site was seasonally occupied during the winter to early summer over a few years of at most a few decades; (3) the site was primarily a bison-hunting camp; and (4) the "bone bed" represented an erosional gully used as a refuse discard area and may, in addition, represent a bison processing locality.

The Hinojosa site was recognized during the 1975 project as an important and significant prehistoric archaeological site. Subsequently, the site was 
nominated to the National Register of Historic Places. Later in 1975, the Hinojosa site, $41 \mathrm{JW}$ 8, was officially designated as an archaeological site on the National Register of Historic Places in recognition of the significance of the site. The 1977 report called attention to the fact that the site was located within the detention pool and on the edge of the 50-year sediment pool of the proposed floodwater structure on Chiltipin Creek (Floodwater Retarding Structure No. 5). Due to the potential for site damage during reservoir construction or through long-term inundation by floodwaters, additional archaeological work was recommended at the site.

\section{INYESTIGATIONS}

In the spring of 1980, the National Park Service, Interagency Archeological Services-Denver, issued a Request For Proposals (RFP 530050) for further archaeological work at the Hinojosa site. The Center for Archaeologica 1 Research submitted a proposal dated July 21, 1980 (Hester, Eaton, and Black 1980). The proposal was accepted, and Contract No. C53007(80) was entered into by the CAR-UTSA and the National Park Service, Interagency Archeological Services-Denver. Dr. Thomas R. Hester served as principal investigator, and Jack D. Eaton served as co-principal investigator. The initial contract cal1 led for work to begin in the fal1 of 1980. Access problems caused the work to be postponed for a year.

The access problems stemmed from the change of ownership of the Hinojosa property. At the time of the 1975 testing at $41 \mathrm{JW} 8$ the ownership of the property was in transition following the death of Clemente Hinojosa. Subsequently, the property was divided between the Hinojosa heirs, and several of the parcels were sold. The CAR crew arrived in Alice (county seat, Jim Wel1s County) in November 1980 to begin work. at the site. At that time the site was bel jeved to 1 ie on the property of Francis Ba 11. Mr. Ball had been contacted and had given his permission for the archaeological work. It was soon discovered that in fact the site was located on an adjacent property owned by Mrs. Eva Jimenez of Corpus Christi, daughter of Clemente and Herminia Hinojosa.

Efforts to obtain permission from Mrs. Jimenez were hampered by misunderstandings arising from the 1975 SCS project. In addition, a 1 ively oral tradition concerning buried treasure on the property had been maintained by the Hinojosa family for many years. The family was unaware in 1980 of the scientific significance of the prehistoric deposits at $41 \mathrm{JW} 8$. Thus, the negotiations to obtain permission from Eva Jimenez took many months. A borderlands history professor, Dr. Gilbert Hinojosa (no relation), from UTSA served as mediator. Ultimately. Eva Jimenez agreed to al low the excavations subject to certain provisions. A family member was to keep watch on the work to insure that any valuables found would be properly reported. In addition, Mrs. Jimenez would retain ownership of any valuable materials recovered from the site. These and other provisions insuring that the work would be done promptly and that the excavation area would be backfilled were specified in a forma 1 agreement signed on September 11, 1981.

Field work at the Hinojosa site began in early October 1981. The work continued through the middle of January 1982. The author served as field 
director and project archaeologist. A. Joachim McGraw served as assistant project archaeologist and was primarily responsible for the laboratory processing. Beverly Marshal1 $\mathrm{V}$ an Note served as 1 aboratory assistant. The primary field crew consisted of Tom Mil1er, Cecil Pee1, Mike Woerner, and Courtenay Jones. A total of approximately 2024 man hours was spent during the 1981 field investigations (including the two weeks in January 1982). Some $39 \mathrm{~m}^{3}$ of soi 1 were removed from $82 \mathrm{~m}^{2}$ of excavation units during the 1981 season. The excavations centered on an irregularly shaped main excavation block referred to as the "Wagon Trail Area." Numerous cultural features and hundreds of artifacts were recovered from the site. Most of the project research goals were met or exceeded during the 1981 season, as will be discussed in the following sections of this report.

\section{TO THE READER}

A number of conventions are adhered to in this report. Al1 site numbers are given in the trinomial system, wherein the first two digits refer to the state (Texas is 41), the second two characters refer to the county within the state ( $\mathrm{Jim}$ Wel $1 \mathrm{~s}$ County is $\mathrm{JW}$ ), and the final digits refer to the chronologic sequence of officially recorded archaeological sites on file at the Texas Archeological Research Laboratory at The University of Texas at Austin. In other words, $41 \mathrm{JW} 8$ is the eighth archaeological site officially recorded in Jim Wel 1s County, Texas.

The metric system is used throughout this report for al1 measurements unless specifically noted otherwise. The following metric abbreviations are used: $\mathrm{cm}=$ centimeter, $\mathrm{mm}=\mathrm{mi} 11$ imeter, $\mathrm{m}=$ meter, $\mathrm{km}=\mathrm{kilometer,} \mathrm{mg}=\mathrm{mil} 1 \mathrm{igram}$, $\mathrm{g}=$ gram, $\mathrm{kg}=\mathrm{ki} 1 \mathrm{ogram}, 1=1 \mathrm{iter}, \mathrm{m} 1=\mathrm{mi} 11 \mathrm{i} 1 \mathrm{iter}, \mathrm{cc}=$ cubic centimeter, $\mathrm{nm}=$ nanometer, $\mu \mathrm{m}=$ micrometer.

A number of other abbreviations are used in the report. These include: UTSA = The University of Texas at San Antonio, CAR = Center for Archaeological Research, NPS, IAS-D = National Park Service, Interagency Archeological Services-Denver, SCS = Soil Conservation Service, WTA = Wagon Trail Area, $L_{.}=1$ eve1, $\mathrm{Z}_{0}=$ zone, Col. = column, $\mathrm{N}=$ north coordinate, $\mathrm{E}$ = east coordinate, NPS $=$ Noise Pit South, WFNP $=$ Wheat Field Noise Pit. 


\section{RESEARCH DESIGN}

The 1981 investigations at 41 JW 8 and the subsequent analysis were carried out according to research p 1 ans specified in the proposal (Hester, Eaton, and B lack 1980). These plans addressed both the RFP specifications and the research interests of the principal investigator and the project archaeologist. Field conditions made certain minor changes in the research $p 1$ ans necessary, as will be discussed. The overall research design will be discussed in four segments: major problems at $41 \mathrm{JW}$ 8, research hypotheses, excavation strategy, and additional problems.

\section{MAJOR PROBLEMS AT $41 \mathrm{JWH} 8$}

The proposal specified seven problem areas to be addressed by the investigations at $41 \mathrm{JW}$ 8. These prob 7 em areas focused on questions raised by the 1975 testing and questions pertinent to regional problems.

1. Site Limits: The boundaries of the site needed further definition, especially the southern limits.

2. Site Depth: Were earlier components present below the extensive Late Prehistoric deposits?

3. Bone Bed: What did the "bone bed" actually represent in terms of Late Prehistoric activities at the site?

4. Seasonality: Was the site exclusively occupied during the winter and spring months?

5. Occupational Span and Frequency: Over what periods of time was the site occupied, how intensively, and at what intervals? How did these relate to the regional cultural-historical sequence? Did the rock clusters and bone bed, along with other aspects of intrasite variability, help solve this problem?

6. Eaunal Exploitation: Did the faunal materials actually indicate a bison emphasis? Were the faunal remains of species expected in the immediate site vicinity? What kinds of exploitative patterns were represented?

7. Cultural Pattern: How did the Late Prehistoric component compare with the regionally defined cultural patterns for the period? What was the nature of the tool kit? What kind of functional or adaptive pattern is indicated (e.g.g bison hunting[?]).

\section{RESEARCH HYPOTHESES}

In an effort to answer the previously stated questions concerning the Hinojosa site, four research hypotheses were formulated. Following each hypothesis is a list of expectations that were to be tested through the proposed field and 7 aboratory methodology. These hypotheses were based on 
previous work at the site, previous work in the region, and the personal experience of the principal investigator and the author.

\section{HYPOTHESIS 1 : SITE FUNCTION}

The majority of the cultural debris present at $41 \mathrm{JW} 8$ is related to the Late Prehistoric component. The Late Prehistoric component resulted from a pattern of repeated seasonal occupations emphasizing a specialized resource. Specifical1y, Late Prehistoric groups periodically visted $41 \mathrm{JW} 8$ during the winter-spring months while herd animals (bison, and to a lesser extent, antelope) were present in the general area. While men hunted herd animals around and away from the base camp, women and children stayed near the camp and hunted and gathered a variety of small animals and botanical resources which supplemented the less reliable herd animal resources.

Expectations:

1. Block excavations would reveal similar overlying features, including bison processing areas, refuse discard areas, cooking areas, and occupational floors (indicative of repeated occupations).

2. Meat weight analysis would show bison and, to a lesser extent, antelope were the most important food resources (bison emphasis).

3. Minimum individual analysis would illustrate a large number of smaller faunal species (supplemental resources).

4. Bison bone distributional studies would reveal processing patterns that served to maximize the resource (see Hypothesis \#2).

5. Faunal analysis of species present and age groups present would indicate a winter-spring occupation (seasonality).

6. Continuation of select excavation units below the upper $50-60 \mathrm{~cm}$ containing exclusively Late Prehistoric material might evidence occasional earlier occupation. The earlier occupation if present would not follow the seasonal bison hunting pattern and would be of a much lesser extent.

7. Upon comparison of the Late Prehistoric cultural material to other Late Prehistoric sites in the region the closest similarities would be found to the north in sites within the proposed "bison corridor" (see Section XI). Sites south, east, and west of $41 \mathrm{JW} 8$ would evidence fewer similarities, although some contact with coastal groups was expected.

\section{HYPOTHESIS 2: BISON-HUNTER'S CHIPPED STONE TOOL KIT}

During the Late Prehistoric period, within the "bison corridor" in portions of south and central Texas, a specific bison hunting and processing technology existed utilizing a distinctive chipped stone tool kit. . The chipped stone tool kit is the preserved portion of a total tool kit which would have included wood, leather, and other perishable components. The chipped stone 
tool kit consisted of Perdiz arrow points, smal1 unifaces (end scrapers), and beveled bifaces (knives). Perdiz points functioned as hafted projectile points and were used to hunt and kill bison. The end scrapers were probably hafted and were used to deflesh bison hides. The beveled bifaces were knives that were probably hand-held and used to butcher bison (cutting hide, flesh, and sinew).

Expectations:

1. Al1 three tools would be found in direct and indirect association with bison remains, although end scrapers might be found in clusters away from the main butchering localities (separate activity area).

2. A11 three tools have distinctive morphologies and would exhibit similarly distinctive wear and breakage patterns consistent with the hypothesized functions.

\section{HYPOTHESIS \#3: FUNCTION OF CLUSTER FEATURES}

Burned rock or caliche cluster features have been accorded very 1 ittle careful examination in most south Texas site excavations. The cluster features at 41 JW 8 represent several different functional activities, including cooking hearths, warmth hearths, and discard piles. These might have occurred as intact features buried fairly rapidly, or dispersed features exposed on the surface for a period of time, or purposefully scattered. Cooking and warmth hearths would have served as focal points for specific subgroups such as family activity areas.

\section{Expectations:}

1. Systematic field excavation methods, recording, and subsequent 1 aboratory analysis of cluster features would reveal subt le and perhaps obvious differences related to function. The following types of clusters were expected to occur:

a. Hearths would evidence direct burning (stained soi 1), charcoal and/or ash, and a high percentage of burned flakes inadvertent 1 y present around the hearth. Cooking hearths as opposed to warmth hearths would also evidence charred food resources such as seeds or bones and very high phosphate levels.

b. Discard piles from hearths or possible stone boiling would evidence 1 ack of direct burning, i.e., absence of charcoa1, ash, and charred food remains; and 7 ow or average percentages of burned flakes. In addition, discard piles would tend to be more dispersed or scattered than hearths.

2. Analysis of artifact patterning around hearths would reveal functionally related clusters such as flintknapping or plant processing areas. Similar patterns would not occur around discard piles. 


\section{HYPOTHESIS 4: THE "BONE BED" ACTIVITY AREA}

The "bone bed" area of 41 JW 8 functioned as an activity area where bison butchering and bone disposal occurred. Bison butchering or processing occurred on the edges or banks of a southwest to northeast trending erosiona 1 gul1y. The gul1y floor was used as a refuse discard dump for bison bone, other bone, and broken tools.

\section{Expectations:}

1. Careful exposure and recording of the "bone bed" would reveal in plan and profile an erosional gul $7 \mathrm{y}$.

2. The gully would contain refuse, as previously mentioned. Partially articulated bison bone segments might have been present.

3. Adjacent to the gully but at a slightly higher elevation (on the gully banks) the bone concentration would be noticeably less. Some discarded butchering tools might have been present. Some rock clusters might have occurred which served as warming fires rather than cooking fires (see Hypothesis \#3).

\section{EXCAVATION STRATEGY}

In order to address the major site problems and most effectively test the hypotheses, the general approach to the excavation strategy was carefully considered. In general, the proposal called for the excavation of specific portions of the site, emphasizing careful and consistent excavation techniques, recording procedures, and collection of supplementary nonartifactual data. Rather than maximizing the amount of excavated area at the expense of adequate analysis, the proposal called for the excavation of only as 1 arge an area (and obtain as 1 arge a sample) as could be thoroughly analyzed.

The consideration of the specific excavation strategy to be employed at 41 JW 8 took into account two important RFP specifications. Section IV,B of the RFP stated that "If in the event that 1 ess than $100 \%$ of the available data from the site is to be recovered, the contractor must insure that the sample drawn is both adequate and representative." Given the monetary 7 imits set forth in Section VIII,A of the RFP $(\$ 50,000)$, it was obvious that only a relatively small fraction of the site could be excavated. The site surface area had been estimated at $3000 \mathrm{~m}^{2}$ (Hester 1977:6). The area of the site containing subsurface (buried) deposits was unknown but probably covered an area of less than $3000 \mathrm{~m}^{2}$.

The questions of sample adequacy and representativeness are complex problems that have no fixed answers. A review of regional and North American approaches to sampling finds a great deal of controversy and a wide range of approaches. Most discussions of sampling are oriented toward surface surveys, al though similar techniques can often be applied to excavation. One of the better discussions of sampling strategy is Mallouf's review of the literature in Mallouf, Baskin, and Killen (1977:89-93). The most important 
schools of thought can perhaps be divided into two groups: those who favor probability or statistical sampling (cf. Redman 1974; Muel 1er 1974) and those who favor judgement sampling (cf. Jelks 1975). The view taken here is that judicious, nonrandom, systematic procedures of exploration and observation are far more useful in solving archaeological problems than random sampling particularly with regard to the problems at 41 JW 8 . This is especially apparent when one considers that purported random samples are not truly random, as Jelks $(1975: 6)$ points out. A true random sample can on 1 y be obtained if and on $1 y$ if the total sample (sample universe) is known. The on $1 \mathrm{y}$ way that the sample universe of a buried site can be determined is by excavation of the entire sample. Otherwise, the random sample is only a sample of an arbitrary grid system, NOT the cultural deposits under consideration.

In south Texas, two principal excavation methods have been employed: sondage or test pit excavations, and block or horizontal excavations. The most often used technique is the sondage method which, while useful for preliminary testing, results in comparatively 1 ittle information on spatial patterning. Block excavations, also referred to as open area or horizontal excavations (Hester, Heizer, and Graham 1975:76-78), have been increasingly used in south Texas and elsewhere. By excavating a block of contiguous excavation units, one is sometimes able to detect spatial relationships such as that existing between hearth features and related activity areas which are not apparent in smal1 test units. An example of the usefulness of this technique is provided by 41 LK 67, a site excavated by the CAR-UTSA during the Nueces River Project (Brown et a1. 1982). By opening up a large area, archaeologists were able to plot artifact patterning in relation to small rock clusters or hearths. Similar techniques have also been successfully employed at the Mariposa site (Montgomery 1978) in Zavala County, the Loma Sandia site in Live Oak County, and at several sites in Bexar County, such as the Panther Springs Creek site (B1 ack and McGraw 1985).

The proposal called for the use of the block excavation technique (discussed previously) at $41 \mathrm{JW}$ 8. The 1975 testing had revealed areas of the site with a high probability of intact cultural features. Opening a 1 arge excavation block in one or more of these areas would allow the exposure of several cultural features and related artifact patterning. The "bone bed" was one area of the site with proven research potential (see Hypothesis \#4). An excavation block in this vicinity, containing a minimum of 16 contiguous square meter units, was proposed. In order to address the problem of site 1 imits, especial1y in the southern periphery, additional testing in the form of shove 7 testing and $2-\mathrm{m}^{2}$ units was proposed. If another area containing significant deposits was revealed during the additional testing, a second block of at least $16 \mathrm{~m}^{2}$ would be excavated. Flexibility of the exact excavation strategy was considered an absolute necessity. In order to emphasize the exposure and recording of cultural features, the features would have to be followed by opening more excavation units. It was recognized that at the Hinojosa site, 1 ike at most sites with 1 imited prior testing, the exact configuration of the excavation areas should be determined as the excavations progressed.

Additional methodological aspects of the site research design are discussed in Section III. 


\section{ADDITIONAL PROBLEMS}

Several problems were addressed during the analysis that were not considered in the research proposal. These represent research questions or hypotheses that were formulated as the analysis progressed. The two problems are 1 isted here and are further discussed el sewhere in this report.

1. Lithic Sources: Where were the source areas for the 1 ithics at the site? How far was the material transported? Was the material brought in as intact cobbles or flake blanks?

2. Fawcett's Neck Width Hypothesis: The author became aware of a reference to 41 JW 8 during the analysis phase of the project (Fawcett 1978). Fawcett has hypothesized that projectile point neck width measurements could be used to estimate the occupation date of single components in southern and central Texas. This hypothesis was initially tested using data derived from the 1975 testing at $41 \mathrm{JW} 8$ (Hester 1977). Does the 1981 projectile point data support Fawcett's hypothesis? Can the hypothesis be used to estimate the length of occupation for the Hinojosa site? Is the hypothesis useful for dating other sites in the region? 


\section{RESEARCH METHODS}

A variety of field, laboratory, and analytical techniques were employed during the current research project. Descriptions of and references to many of the techniques can be found in standard archaeological texts, such as Hester, Heizer, and Graham (1975), Fladmark (1978), and Hole and Heizer (1973) to name but a few. In this section, the specific techniques used during the current project are discussed in enough detail to clearly describe how the data were obtained, processed, and analyzed. In some cases the research methods actually used during the project are contrasted with the p 7 anned methods outlined in the proposal. In these cases the reasons for deviation from the proposal are discussed.

\section{EIELD METHODS}

The research methods employed at 41 JW 8 during the 1981 season vary somewhat from the $\mathrm{pl}$ anned methods discussed in the proposal. Some changes resulted from the year delay in beginning the field season and the expenses involved in negotiating access. Other changes were caused by unexpected field conditions and problems in relocating the 1975 grid system, as will be discussed.

\section{EXCAVATION CONTROLS}

When field work began in early October 1981, the site had undergone a number of changes since the 1975 testing. As mentioned, the property had been divided into several smaller tracts, some of which were newly fenced. The fencing and new property lines led to several of the changes affecting the site. In 1975, an old road leading from the ruins of the Amargosa Stage Stop east of the site (Fig. 1) could still be driven. By 1981, the road was fenced off in several places, heavily overgrown, and washed out on the hillside east of the site. Heavy secondary growth had covered the road adjacent to the site and had extended some 3-5 m out from the fence 1 ine (shown parallel to the 1981 main baseline in Fig. 1) into the plowed field. Thus, one of the first tasks undertaken at the site was to clear the undergrowth.

The brush clearing was accomplished with machetes, a chain saw, and a heavy duty Green Machine ${ }^{\circledR}$ equipped with a brush blade. The Green Machine ${ }^{\oplus}$ proved to be a very effective tool for clearing most of the mesquite, whitebrush, huisache, briar, and other brush species. The old road (herein referred to somewhat euphemistically as the "wagon trail") was recleared along with the edge of the field and the fence corner area where the 1975 datum was located. In addition, several east-west transects were cleared between the field and the bluff edge.

After the site was recleared, a search was begun for the 1975 datums and excavation units. This was complicated by two factors: (1) the 1975 alidade map did not accurately tie-in the 1975 grid system with identifiable 1 andmarks; and (2) the primary 1975 site datum was a wooden stake. As is apparent in Figure 1, the fence line running the length of the site has 
Figure 1. Site Map of 41 JW 8.

PAGE 11 REDACTED 
several angles and corners. Only one corner was shown on the 1975 field map, and it was not identified. A1 1 the 1975 grid stakes, including the datum, were wooden with the exception of one iron rebar driven into the northeast corner of Unit L. This iron rebar was not located until several months into the field season.

The 1981 field crew made measurements from various fence corners and used shovel scraping techniques in an unsuccessful attempt to relocate various 1975 grid points and excavation units. The 1975 excavation units had apparently been thoroughly backfilled as no trace could be found of any of the 12 units. Field plowing, brush regrowth, and erosion subsequent to 1975 effectively concealed the 1975 testing. Although several of the 1975 test units were ultimately relocated, we were forced to establish a new grid system in 1981. It was decided that the old roadbed offered a safer location for the 1981 datums since the road could no 1 onger be traveled, and it was inside the fence 1 ines and thus protected from agricultural disturbance.

The main horizontal datum (N100 E100) was established near the center of the wagon trail about $2.5 \mathrm{~m}$ east of the fence (Fig. 1). The main datum consisted of a 20-inch long steel rebar (concrete reinforcing rod) one inch in diameter set into a bel1-shaped concrete anchor inscribed with the site number and the grid coordinates. Backup datums were established at N110 El00, N100 E103, and N90 E100. The backup datums were also steel rebars set into concrete. A cross was filed into the top of each rebar to indicate the precise grid point. A11 grid stakes were set by using a transit and steel tapes.

The vertical datum was established by driving a $20 d$ nail into an anaqua tree on the bluff edge. The elevation of the nail was arbitrarily designated as $100.00 \mathrm{~m}$ above datum. Prior to setting up the vertical datum, a number of excavation units were completed using 1 ine level measurements from a string tied at ground level in the southwest corner of each unit. The actual elevation of these grid stakes was later established using the transit. All elevations mentioned in the text refer to the vertical datum unless specified as below the surface.

The grid system was a metric grid with an arbitrary center point of N100 E100. Each excavation unit was given the coordinates of the southwest corner. Thus, any point within a given unit could be referenced by measuring the distance east and west of the southwest corner. For example, an artifact given the coordinates N104.35 E98.75 was found $35 \mathrm{~cm}$ north and $75 \mathrm{~cm}$ east of N104 E98, the reference corner of the excavation unit. The site grid system was established parallel to the wagon trail and to the fence 1 ine running the length of the site for ease of operation. Grid north was actually oriented some $45^{\circ}$ west of magnetic north. Cardinal directions indicated in the text are based on grid north unless specified otherwise, such as "to the magnetic north."

\section{EXCAVATION TECHNIOUES}

The size of the excavation units at $41 \mathrm{JW} 8$ varied from $1 \mathrm{~m}^{2}$ to $2 \mathrm{~m}^{2}$. Most of the excavation focused on $2-\mathrm{m}^{2}$ recording units which were excavated in $1-$ $\mathrm{m}^{2}$ quadrants or cel1s. Provenience was maintained in al1 excavations to the 
$1-m$ unit and $10-\mathrm{cm}$ leve1. The purpose of the $2-\mathrm{m}^{2}$ recording units was to cut down on the amount of paper work involved. These $2-m^{2}$ recording units were referenced by the grid coordinates of the southwest corner of the entire $2-\mathrm{m}^{2}$ unit followed by the quad designation. The quads were 1 abeled SW, SE, NE, and NW in reference to their location with respect to the grid system and the 2- $\mathrm{m}^{2}$ unit. This practice was conceived as a method to reduce errors introduced by keeping track of the specific grid coordinates of each quad. In retrospect, the quad designations probably introduced just as many errors (confusing NE with NW, for example) and created extra work in the laboratory converting the quad designations back to grid coordinates. Throughout this report al1 proveniences are given as grid coordinates of the southwest corner of a given unit. Unless followed by " $(2 \mathrm{~m}) "$ a 11 proveniences refer to the southwest corner of a $1-\mathrm{m}^{2}$ unit or to a specific location if centimeters are given.

The standard excavation unit-level was $10 \mathrm{~cm}$ in thickness and measured $1 \mathrm{~m}^{2}$ ( 0.1 cubic meter of deposit). This was varied only in Level 1 of some units. For examp 1e, if a $2-m^{2}$ recording unit was $p 1$ aced on an uneven surface, a 11 quads were taken down to the same elevation in Level 1. Thus, if the surface varied from 99.89 in the northwest corner of the recording unit to 99.80 in the southwest corner, Level 1 ended at 99.70 in a 17 quads. In some cases with artificially high humps such as along the fence 1 ine, in the plowed field (ridges and furrows), or near the 1975 units (old backfill piles) the raised portion was either shoveled off or included in Level 1.

A11 excavated soil was passed through 1/4-inch mesh hardware cloth. A11 artifactual material except as noted below was collected. The proposal called for the use of 1/8-inch mesh. Initial attempts to use 1/8-inch mesh proved extremely time consuming due to the heavy clay deposits in the grid eastern sections of the site (in the plowed field) and due to the exceptionally high frequencies of cultural materials in all excavation units within the main site area. Many excavation levels would have 1 iterally required hours to pick out the cultural material recovered on 1/8-inch mesh. The on $1 y$ practical alternative would have been water screening; however, we 1 acked a source of water. The subsequent loss of data by the use of 1/4-inch mesh was compensated by the collection of various soil and matrix samples as discussed later.

A1 1 bone, chert, burned rock, marine she11, prehistoric ceramics, ground stone, and historic refuse (metal, glass, etc.) retained on 1/4-inch mesh or recovered in situ were col1ected. A11 freshwater mussel umbos or intact valves were collected; unmodified fragments were not. Land snails presented a problem as they occurred in exceptional1y large quantities in most areas of the site. No 1 and snail fragments were collected. Whole identifiable 1 and and water snails were collected only from designated "snail pits," with the exception of Rabdotus snails. Rab.dotus snails are believed to be a primary food resource and were collected in al1 excavations.

The actual excavation technique varied according to location. The upper levels of most units were excavated using shovels. Sharpshooter shovels were often used as were flat shovels and cutoff round point shovels ("cutting shove1 (s"). Each type of shovel had a specific use. Sharpshooter shovels were useful for maintaining a vertical face and removing a 10-cm-thick cut at 
a time. Square and cutting shovels were used to shovel scrape (schnitt) and to level off floors. In areas with intact features or undisturbed deposits (such as the main excavation block), all excavation was done with trowels or finer digging instruments, such as dental tools, bamboo splints, and brushes. In areas with unknown deposits, the first quad unit-level in a $2-m^{2}$ unit was usually dug with a trowel. If the deposits appeared disturbed, the remaining quads at the same level were shovel dug. Thus, the disturbed deposits were quickly excavated, while the intact deposits were dug very slowly and carefut ly.

An effort was made in a11 trowe1-dug excavations in areas with intact deposits to expose as much material as possible in situ. Exposed materials were pedestaled and left in place while the surrounding area around them was excavated. In cases of isolated materials not associated with a feature or 1 iving surface only the pedestaled items considered significant were mapped. For example, a Perdiz point would have been mapped in place while a single burned rock would not have been mapped. In the case of artifacts associated with a feature or 1 iving surface the crew attempted to leave as much as possible in place until it could be plotted in place. In practice one often had to make decisions as to what was left pedestaled and what was removed. In many areas the cultural materials were so numerous that plotting all the materials that could have been left in place was simply impossible. Emphasis on what to leave was always placed on clustered material, identifiable tools, identifiable bone, prehistoric sherds, and unusual artifacts. Small burned rocks, unmodified flakes and chips, and bone and snail fragments occurred in very high frequencies and were rarely pedestaled.

Particular emphasis was placed on faunal recovery. All identifiable bones (whole bones or bones with articular ends) were either pedestaled or collected as soon as they were observed. This was done to improve the recovery of identifiable bone. Because of this emphasis, many small bones were recovered that would have otherwise passed through 1/4-inch mesh or been crushed during the screening process. When concentrations of microfauna were observed in features or on 1 iving surfaces, a matrix sample was collected for flotation and fine screening in the laboratory.

Emphasis was also placed on charcoal recovery. Charcoal from undisturbed deposits was collected in aluminum foil pouches. Particular care was taken with concentrated charcoal deposits from cultural features. Feature charcoal was collected with clean forceps, with minimal handling. Additional charcoal was collected from the level excavations. In some areas of the site considerable quantities of scattered chunk charcoal was present. This scattered charcoal was collected by hand and placed in small aluminum pouches within the unit-level bags. The scattered charcoal was collected only for the purpose of wood species identification, hence we only attempted to collect a sample of the we1 1-preserved charcoal chunks rather than the entire amount of pulverized charcoal present.

\section{RECORDING TECHNIOUES}

A variety of records were maintained during the 1981 season at $41 \mathrm{JW} 8$, for example, level notes, a field journal, survey notes, feature notes, plan and 
profile drawings, a site map, and sample inventories. These records provide a permanent chronicle of the excavations.

The level and feature notes were written in paragraph style on loose leaf paper and kept in a three-ring binder. This method of keeping field notes was used over preprinted forms for several reasons. Preprinted forms are most appropriate for use with inexperienced crews or on a site excavated over a 1 ong period of time to maintain consistency. In the 1981 season the crew was very experienced, the site deposits were comparatively uniform, and the field season was relatively short. Paragraph style notes can be written more quickly with an emphasis on what actually needs to be recorded. A similar approach was taken during Phase III of the Nueces River Project (Grant Hal1, personal communication).

The daily field journal was kept primarily by the author. The journal recorded the daily events of the field season: crew members present, weather, visitors, excavation progress, field observations, changes in methodology, and problems encountered. The field journal was kept in the field notebook along with the survey notes and various other records. The survey notes largely consist of a daily record of the transit H.I. (height of instrument). The survey notes also discuss minor problems with using several different transits. For example, the transit used to set up the grid system was off 51 ightly when used to turn $90^{\circ}$. Fortunately a better transit was used to set the back-up datums.

Record photography was done with $35 \mathrm{~mm}$ and $120 \mathrm{~mm}$ cameras. A11 photographs were recorded in the field notebook. Plan and profile drawings were done at several consistent scales on grid paper or film. Detajled drawings were made of the features. Al1 materials recorded in situ were plotted on one of the plan maps. Plotted items from each unit-level were given a sequential item number. Each unit-level was numbered separately as the items were recorded and bagged. The plotted items were placed in small individual bags within the level bag. The provenience was maintained in the laboratory by adding a hyphenated number to the lot number.

Inventories were kept of features, soil samples, and charcoal samples (only those that could be potentially used for radiocarbon assay). The cultural features from the entire site were given a sequential number as they were formally designated a feature. Some clusters were not formally recorded as a feature in the field but were 1 ater given a feature number in the laboratory. The charcoal and soil sample inventories recorded the specific provenience details of each sample.

A plane table and alidade map of the site was made during the final weeks of the field season. Care was taken to avoid the mistakes made on the 1975 plane table map. The fence 1 ines and corners were carefully shot in as were a 11 excavation units and site datums. Topographic information was recorded for most of the site area. Some difficulty was encountered mapping the heavily vegetated steep bluff slope area. Figure 1 is based on the 1981 site plane table map (actually done in January 1982). 


\section{SOIL SAMPLING}

The proposal called for the collection and subsequent analysis of soil samples for several purposes, including flotation, soils chemistry, phytolith analysis, and pollen analysis. Samples for these purposes were collected by several methods: feature matrix sampling, axial interval sampling, and column sampling. In addition to sampling the excavation areas, two off-site "noise pits" were excavated.

Matrix samples were taken from all formally recorded cultural features as we 11 as from several areas that appeared to have high concentrations of microfauna or charred materials. Al1 matrix samples were collected in heavy salt bags (triple layered with moisture sea1). An effort was made to collect at least $20,000 \mathrm{cc}$ of matrix for each sample so that a consistent-sized flotation sample could 1 ater be processed.

The axial interval sampling was an experimental approach to feature interpretation detailed in the proposal. As proposed, the axial interval sampling was conducted only in situations when intact features were encountered and recognized while most of the surrounding unit-levels were still intact. Axial interval sampling involved superimposing a grid oriented on cardinal directions over the approximate midpoint of the feature in question. Small (75 cc) samples were then taken at consistent intervals along the grid 7 ines. The idealized sampling interval was $10 \mathrm{~cm}$ within a feature and $50 \mathrm{~cm}$ outside the feature. The length of the axial vectors varied depending on location and size of the excavation block. Al 1 axial interval samples were collected with sterilized phosphate-free equipment. Each sample was collected from a carefully cleaned surface and placed in a sterile phosphate-free glass vial. The sample removal equipment (a smal1, sharp trowel) and the glass vials were sterilized and cleaned with dilute hydrochloric acid (HCL) and distilled water.

Column samples were coll ected from a number of 1 ocations within the site. Two consistent volume sample (CVS) columns were collected in the main excavation block as the excavations progressed. Additional column samples were collected from the profiles of completed excavation units, including N80 E102 $(2 \mathrm{~m})$, N78 E90 $(2 \mathrm{~m})$, and N123 E106 $(1 \times 2 \mathrm{~m})$ as well as the noise pits. Each column consisted of a series of samples taken from the least disturbed profile of a given excavation unit. These were collected after the profile had been divided into stratigraphic zones and $i 11$ ustrated. During samp $1 e$ collection, the wall sections were cut back with a sharp trowel to expose a fresh face. Samples were collected from the middle of each zone except in cases where the zone was extremely thick. Thick zones were divided into upper and lower sections. From each zone or half a zone, a matrix sample, phosphate sample, and a sediment sample (for grain-size analysis) were collected.

Two background noise pits were excavated well away from the site area. "Noise Pit South" (NPS) was a $1-m^{2}$ unit excavated south of the site on the edge of the creek bluff at approximately grid point N17 El04. The only trace of prehistoric occupation recovered was a couple of smal1 chert flakes. A second background pit, the "Wheat Field Noise Pit" (WFNP), was excavated east of the main site area in the middle of the plowed field at approximately grid 
point N89 E37. No trace of prehistoric occupation was recovered. Both noise pits were shovel excavated in 10- cm levels. Each unit was screened, and all bone, rock, and snails were collected. Column samples were collected from each pit profile upon completion of the excavation. The purpose of these off-site pits was to provide a control sample of screen recovery, microfauna, and botanical remains (flotation) as well as soils chemistry. Theoretical7y, the difference in recovered materials between the noise pits and the site excavations could be attributed to the prehistoric occupation.

\section{CHRONOLOGICAL OUTLINE OF THE 1981-1982 SEASON}

October 1981: In early October the final details of the 1 and access negotiations were completed with Eva Jimenez. On October 12, the CAR crew arrived in Alice to begin work. During the first week the site was cleared, the 1975 excavations were searched for in vain, a new grid system was established, and the excavation of additional test units was begun. The test units $\left(2 \mathrm{~m}^{2}\right)$ were partially in response to the proposal specifications and partially due to the failure to accurately relocate the 1975 work. A cold front moved through south Texas on October 22 dumping several inches of rain in the site area. Wet conditions did not al1 ow a return to the site until 0ctober 28. By the end of the month, two 2-m units had been completed, and two others had been opened.

November 1981: Considerable progress was made during the month of November as ideal conditions prevailed (cool and dry). By November 13, eight test units had been completed (a11 2-m units except one $1 \times 2 \mathrm{~m}$ ). With the exception of one unit, no intact features or living surfaces had been found. Most units evidenced disturbances caused by plowing, field leveling, and bioturbation. The approximate area of the "bone bed" appeared to be taken over by a very large leaf cutter ant bed complex.

An exceptional unit, N106 E98 $(2 \mathrm{~m})$, evidenced three discrete bone clusters (Features 2A, 2B, and 3). Based on these promising features, 2-m units were added on the grid north and south sides of the first unit. By the month's end a row of $1-m$ units had been added along the grid west side of the three 2-m units. The resulting 6- $\times$ 3-m unit was dubbed the "Wagon Trai 1 Area" (WTA).

Dr. Hester was able to pinpoint the location of the 1975 "vertical cut" during a visit to the site on November 24. Using this as a reference point the crew was able to more precisely locate the "bone bed" area. This area still 1ay close to the large leaf cutter ant bed complex. On November 30, the crew began excavation of a $1-\times 4-m$ trench (four $1-m$ units) designed to bisect Unit L from the 1975 testing.

December 1981: The excavations were concentrated in two areas in December, the "wagon trai 1" area and the "bone bed" area. The 1- $\times$ 4-m trench bisected Unit L from 1975 (iron stake found beneath the surface). Unfortunately, 1 ittle or no evidence was found of the "bone bed," leading the crew to suspect that this feature was very localized and almost completely excavated in 1975. An isolated "1 iving surface" (Feature 7) was recorded in this area. The crew attempted to expand the trench grid east and west, unfortunately 
1 arge portions to the east were extensively disturbed by the 1 eaf cutter ants. After removing Feature 7, finding no trace of the "bone bed," and encountering the ants, the decision was made to terminate excavations in the area.

The WTA $6-\times 3-\mathrm{m}$ b lock was expanded to the west to form a $6 \mathrm{~m}^{2}$. The west hal $f$ of this area was excavated in $1-m$ units to the level of Feature 6, a 1 arge hearth feature centered in Unit N106 E97. Feature 6 was a complicated "hearth" or cooking feature with an irregular rock cluster, an adjacent pit filled with charcoal and ash, several lobes of baked clay extending out from the pit, a snail cluster, and numerous artifacts and faunal materials all in tight association.

On December 16, three television crews from San Antonio and Corpus Christi, newspaper reporters from Alice and Corpus Christi, and News and Information representatives from UTSA visited the site. The media and field crew were cooperative; a number of 1 argely factual news stories resulted, providing good publicity for the project and the various agencies involved.

A 2-m unit was begun adjacent to the grid northeast corner of the WTA in order to examine the immediate creek bank area. A two week break was taken at the end of December for the holidays.

January 1982: Field work was completed during the first two weeks of January. The crew worked 1 ong and hard under some extreme conditions (subfreezing with wind chill factors below $10^{\circ} \mathrm{F}$ ) to complete the excavations. The northeast corner of the WTA was expanded to a 4- $\times 3-m$ area to expose two cultural features, a charcoal cluster (Feature 8) and a bone cluster (Feature 9). The 4- $\times 3-\mathrm{m}$ area was completed on the 1 ast day of the field season.

Major activities during the final two weeks included plane table mapping, soil column collecting, noise pit excavation, profile illustration, and the installation of additional backup datums. Late in the afternoon on January 15, a backhoe was used to backfill the excavation units. Modern beverage containers and white caliche were used to mark the corners and edges of the excavation units in case archaeologists return to $41 \mathrm{JW} 8$.

\section{LABORATORY AND ANALYTICAL METHODS}

The data recovered from 41 JW 8 during the 1981-1982 project were processed at the archaeological 1 aboratory of the CAR-UTSA. Al1 materials were assigned a provenience or lot number, cleaned, and inventoried during the initial processing phase which ran concurrent with the field work. During the subsequent data analysis phase all materials were reexamined and placed in the final analytical categories used in this report. The CAR-UTSA will be the curator of al1 data collected from 41 JW 8. 


\section{INITIAL PROCESSING}

Most of the initial 1 aboratory processing took place as the field season progressed. Completed material bags were brought into the 1 aboratory at the end of each week. Accompanying the bags was an inventory sheet with the provenience information and whether or not the provenience had been closed out (i.e., the unit-level was finished). The bags were crosschecked with the inventory and a lot number card index. Occasional inconsistencies such as coordinate errors or dup 1 icate level numbers were rectified when the crew returned the following week.

Each separate provenience was assigned a sequential 1 ot number, beginning with 56 (the first 55 numbers had been assigned in 1975). Dup 1 icate index cards were filled out for each lot number (Appendix 2). One set of cards was organized by lot number, while the other was arranged by provenience (smallest north coordinate to largest, smallest east coordinate to 1 argest). This card system has been used in several 1 arge projects at the CAR and was found to be an efficient way of keeping track of provenience data. The lot numbers were also placed on each field bag.

The field bags were then emptied, and most of the cultural material was washed. Several artifact types were not initially washed. For example, beveled knife fragments were not washed until they could be checked under magnification for organic residue (cf. Holloway and Shafer 1979). The faunal material included many small and fragile bones, hence the initial washing amounted to little more than rinsing.

Once cleaned the cultural materials from each unit-level bag were divided into major material categories and counted and/or weighed. In many past CAR projects, cultural materials were inventoried as they were cleaned and then reinventoried as they were analyzed. This was often due to 1 ack of experience on the part of the initial processor and 1 ack of agreement between the processor and the analyst concerning the desired analytical categories. This duplication of effort was 1 argely avoided by using experienced personnel and using the 1975 materials to decide on many analytical categories prior to beginning the 1981 field season. Unmodified debitage, burned rock, snails, and historic materials were sorted and placed in final analytical categories as they were inventoried. These materials were placed in 1 abeled plastic bags and stored for posterity (burned rock was counted, weighed, and discarded). Other artifact types such as bifaces, projectile points, and ceramics were divided into simple inventory categories (complete versus incomplete, rim sherd versus body sherd, etc.) and stored for further analysis.

A1 1 soil and charcoal samples were assigned a lot number and allowed to dry if damp. They were then inventoried and set aside for further processing. Faunal materials were weighed and set aside for final processing and identification. The initial processing system allowed the laboratory personnel to keep up with the field crew until the final part of the field season when large volumes of material were brought in every week. 


\section{DATA ANALYSIS}

Upon completion of the field work and initial laboratory processing phases a data analysis phase was begun. This phase took several years to complete and resulted in this report. Special studies were conducted by consultants on the faunal data, botanical remains, radiocarbon assays, pollen, phytoliths, and mussel she115. The consultant reports are presented in Section VII. Additional analyses were done on various data categories by the author and are discussed in detail elsewhere in this report.

The data pertinent to the special studies done by the project consultants were delivered or majled to the appropriate expert after complete inventory. In most cases only a sample of the available data could be analyzed by each consultant due to fiscal limitations.

\section{LABORATORY RECORDS}

A11 data recovered during the field season and amassed during the subsequent analysis are permanently curated at the CAR-UTSA 1aboratory. The materials, notes, and illustrations are filed in various locations in the laboratory. The following is a 1 ist of the types of records and data that were collected and a brief description of how they are maintained. A11 project records are available for examination by qualified researchers.

Cultural Material: A11 materials are stored in boxes according to the final analytical category as detailed in this report. Within each box the materials are stored either in plastic bags or other appropriate containers. The materials that were sorted into final analytical categories during the initial processing, such as unmodified debitage, are stored in 1 ot bags by major category (i.e., all flakes and chips from a single 1 ot are bagged together). All the materials that were further examined are stored within the final artifact grouping (i.e., by alphanumeric code) in appropriate containers. This allows researchers interested in a specific artifact type to quickly locate the materials of interest for comparative analysis.

Lot Number Index: The lot numbers are maintained on a card system as discussed earlier. These are kept in a cardboard index box.

Inventory Sheets: A separate inventory sheet was maintained for each provenience. Each sheet shows the initial processing material breakdown. These sheets were done in large format (18- $\times 24-i n c h$ gridded sheets). This size proved awkward. Regular 8-1/2 $\times 11$-inch sheets (several if necessary) are recommended. These sheets are stored with the illustrations.

Field Notes, Field Journal, Field Inventories, Level Notes, etce: The Field Notebook is maintained in a blue three-ring binder in the project files.

Data Sheets: The data sheets show the counts by provenience of the final analytical categories. These forms were filled out during the analysis and used to make distribution studies and to compile the final provenience data (Appendix 1). 
Plotted Item Sheets: These forms were used to compile the provenience data and final analytical category for each artifact or item plotted in place.

Field Photographs: The field photographs, black and white prints, and color slides were carefully identified based on the field photograph logs.

Illustrations: Al1 field plan maps, profile drawings, and plane table maps are stored in a map cabinet in the laboratory along with rough draft copies of the final illustrations. Final illustrations and the original of this manuscript are stored under. 1 ock and key in a separate location.

Project Files: A11 other notes, correspondence, and records of the 1981-1982 41 JW 8 project are stored in the CAR-UTSA 1 aboratory. 


\section{ENVIRONMENTAL SETTING}

Today the Hinojosa site is located on the banks of a dry stream that holds water only after periods of heavy rainfall. About half the site and most of the uncultivated 1 and in the area is overgrown by dense thorn brush. The other half of the site 1 ies in a plowed field where wheat and other crops are planted semiannual1y. Looking at the area today, the factors that influenced the Indians to camp at the Hinojosa site are certainly not obvious. Six hundred years ago, the creek held water year round, and the site 1 ay in a narrow wooded band surrounded by grass covered prairies interspersed with mottes of brush and prickly pear. To understand what the environmental setting was 1 ike at the time that $41 \mathrm{JW} 8$ was an Indian campsite one must consider a variety of modern, historic, and prehistoric environmental data.

\section{IMAIE*}

Jim Wells County has a fairly mild climate characterized by hot summers and comparatively warm winters. The annual growing season usually 1 asts over 280 days (continuous days without freezing temperatures). Annual rainfal1 averages between 26 and 28 inches a year but varies widely on a year to year basis from the annual mean. Late spring (May) and early fall (September) are usually the wettest times of the year. March is the driest month of the year. The heaviest rainfall usually occurs in the early fall when tropical storms and hurricanes strike the Coastal Bend area. Humidity is fairly high most of the year due to the nearby coast (A1ice 1 ies about 45 miles due west of Corpus Christi Bay). The prevailing winds blow moist Gulf air in from the southeast.

A considerable amount of the annual precipitation is lost due to evaporation. Annual evaporation rates far exceed the annual precipitation. The average annual temperature is $72^{\circ} \mathrm{F}$. During July and August the average temperature is $85^{\circ} \mathrm{F}$, and the average daily high is over $96^{\circ} \mathrm{F}$. The extremely hot conditions in July and August cause most of the soil moisture which is built up in the late spring to evaporate. Dry conditions are also common in the winter when northers bring frequent bursts of cool dry air down. These northers disrupt the normal prevailing wind pattern and push the moist Gulf air off the coast. The total rainfall from December through March averages 1 ess than five inches.

Two periodic climatic phenomena create serious problems in the Jim Wel $1 \mathrm{~s}$ County area: tropical storms and droughts. Tropical storms and hurricanes periodically strike the Coastal Bend area of Texas causing hundreds of thousands of dollars worth of damage to homes, crops, and urban areas. The Texas Coastal Bend area near Corpus Christi averages four years between occurrences of major tropical storms or hurricanes, five years between occurrences of hurricanes, and 16 years between occurrences of extreme

* The information in this section was compiled from a variety of sources in addition to those cited. These include: Minzenmayer (1979); The Texas. Almanac (1983-1984); the U.S. Weather Bureau, San Antonio; and maps from publications cited elsewhere. 
hurricanes (Henry, Driscol1, and McCormack 1975). The damages are caused by high winds, associated tornados, and extremely heavy rainfal1 rates. Alice received over 13 inches of rain from a tropical storm on September 13, 1951. Because the topography in the area is relatively low and flat, large areas of the county are inundated for days following a severe storm. One of the most unpleasant 1 ingering effects of a major storm in the coastal plain area is the presence of hordes of vicious mosquitos for weeks or months fol lowing major flooding.

Droughts also periodically create extreme conditions in Jim Wells County. Major droughts lasting over a year occur about once every 20 years. Shorter droughts lasting up to a year occur about once every 10 years. Periods of several months with 1 ittle rain occur almost every year. Drought conditions are usually created when stable high pressure cells remain centered just off the coast southeast of Corpus Christi (Carr 1967). These high pressure cells may dominate the weather pattern for many months, effectively blocking all sources of moist air. The recent (1984) drought conditions in southern and central Texas exemplify this problem.

Jim Wel 1s County 1 ies within a climatically sensitive area that is currently classified as having a dry subhumid or a humid semiarid climate. This area borders 1 arge semiarid to arid regions to the west and 1 arge subhumid to humid regions to the east. Comparatively minor climatic shifts can and apparently have caused significant changes in south Texas climatic conditions. Gunn et a1. (1982) have defined a south Texas climatic threshold that is 1 inked to the average temperatures of the Northern Hemisphere. When the average annual temperature of the Northern Hemisphere exceeds $15-16^{\circ} \mathrm{C}$, south Texas has a more arid climate. Conversely, when the average annual temperature is below the threshold, south Texas has a more humid climate. The south Texas climatic threshold model is based on a statistical analysis of various climatic factors, including global temperatures, atmospheric shielding, solar activity, and precipitation (Gunn et a1. 1982). Projecting the climatic threshold across the estimated temperatures of the Holocene produces a series of dry and wet intervals.

The past climatic conditions in south Texas have not been studied enough to construct an accurate prehistoric climatic chronology. This is due to several factors, including a general 1 ack of interest in the subject and very poor preservation. Paleoclimatic studies usually rely on the analysis of pollen, tree rings, fossil pack rat middens, and other environmental indicators. South Texas has notoriously poor preservation conditions due to alternating wet and dry conditions. Pollen analysis has been attempted with 1ittle success at a number of prehistoric sites (Hester 1977:28). One promising avenue for research has been suggested by Robinson's (1979, 1982) work with phytoliths. Unfortunately, Robinson has only published preliminary results to date, and these are not directly applicable to the $41 \mathrm{JW} 8$ site area. The preliminary results appear to document major shifts between cooler, more mesic periods and hotter, more xeric periods in the Holocene.

Holloway (1986) has recently reported the results of macrobotanical (charcoa1) identification of samples collected at sites in the Choke Canyon Reservoir area dating back to 4000 B.C. Hol loway summarized relevant macrobotanical, pollen, and faunal data and suggested that the region has had 
a relatively stable environment characterized by increasing aridity for 6000 years. He also criticized Gunn et a 1. (1982) and Robinson (1979, 1982) for relying on the identification of a definable Hypsithermal Interval in their climatic interpretations of south Texas. The Hypsithermal Interval is an inferred wetter/cooler interval around 4000-3000 B.C. that is 1 inked to a glacial advance episode in the Northern Hemisphere. Holloway cites numerous studies that have failed to evidence this climatic interval in southern Texas and the surrounding region.

\section{HYDROLOGY}

In the current century the availability of reliable subsurface and surface water in south Texas has grown progressively worse. Large and small reservoirs provide adequate surface water supplies for localized areas during wet years but wel 15 and springs continue to dry up. Most streams draining the eastern Reynosa Cuesta (Goliad Formation), including Chiltipin Creek, have not flowed regularly this century (Price and Gunter 1943:8). A number of 1 ines of evidence suggests that at the time that the Hinojosa site was occupied, Chiltipin Creek was spring fed and held water year round.

A study of springs in Texas by Brune (1981) documents 10 now dry springs and seeps in Jim Wel1 s County. Most of these were active reliable sources of water in the 19th century (Brune 1981:265-267). It is very interesting and informative to note the locations of many former smal1 springs and seeps in the inland south Texas area that is today so dry. Of particular interest are the Amargosa Springs which are located very near the Hinojosa site. Brune gives the location of the Amargosa Springs as $16 \mathrm{~km}$ north-northwest of A1 ice near the junction of Chiltipin Creek and Amargosa Creek. This p.7aces the springs within a few hundred meters of $41 \mathrm{JW}$ 8. In fact, Brune (1981:266) mentions a "way station for stagecoaches" near the springs. This is undoubted $1 y$ a reference to the Amargosa Stage Stop, the ruins of which 1 ie some $200 \mathrm{~m}$ east of the Hinojosa site. Thus, 41 JW 8 is located at or just downstream from springs active less than a hundred years ago.

The water quality of the spring water that once kept Chiltipin Creek flowing may have left something to be desired. The name of the springs, Amargosa, is Spanish for "bitter." Brune (1982:265-266) notes that the springs flowing out of the Goliad and Lissie Formations, such as the Amargosa Springs, have very hard, alkaline, sometimes slightly saline, water. Thus, during dry periods in the prehistoric era, when the only water in Chiltipin Creek was provided by springs, the water may have tasted bad. After the mud settled out following heavy rains. Chiltipin Creek would have had much more drinkable water. In a 1 and where surface water was hard to find, the taste of the water may not have been important.

Confirmation that the site was located near a spring-fed creek was provided by several of the project consultants. William Murray concluded that Chiltipin Creek had been a spring-fed creek at the time of the prehistoric occupation based on an examination of the freshwater mussel shel15 found in the site deposits (Section VII: Macrobotanical Analysis). Murray identified several clam specimens from the prehistoric occupation that evidenced seven to twelve years of growth and suggested that Chiltipin Creek "was a sma 11 
(couple of meters wide) constantly running (possibly artesian source), sha 110 ( $1 / 2$ meter deep) stream. The substrate bottom was probably mud or mud-sand base." Gentry Steele (Section VII: Vertebrate Faunal Remains) identified a number of water proximate faunal species from the site deposits, including aquatic birds, riparian mammals, soft shell turtles, and fish.

\section{PHYSIOGRAPHY, GEOLOGY, AND SOILS}

The Hinojosa site 1 ies within a vast physiographic province known variously as the West Gulf Coastal Plain, the Rio Grande Plain, and the South Texas Gulf Coastal Plain (cf. Fenneman 1938; Bogush 1952; Carr 1967). This vast area of comparatively $f l$ at topography stretches from northeastern Mexico north to the Balcones Escarpment and east across Texas into adjacent Gu $7 \mathrm{f}$ coast states.

Site 41 JW 8 lies at an elevation of about 250 feet above mean sea level on the edge of a northeast-southwest trending P1 iocene age geological formation, known as the Gol iad Formation (Barnes 1975). The Gol iad Formation, or the Reynosa Cuesta as it is termed in early publications (Price and Gunter 1943), can be characterized as a dissected rolling upland area with eroded ridges and valleys (Minzenmayer 1979). The Goliad Formation is made up of calcareous sands with some gravels and calcium carbonate concretions. This formation forms a 15- to 25-mile-wide band that provides minor topographic relief and has significant vegetational and soil associations that contrast with the Beaumont Formation to the southeast. "The Beaumont Formation is a massive Pleistocene clay accumulation that forms the flat coastal prairie. The Hinojosa site occurs within a narrow band of the Lissie Formation sandwiched between the Beaumont Formation and the Gol iad Formation. The Lissie Formation is a Pleistocene accumulation of sand, silt, and clay that forms a transition in soils and relief between the Goliad and Beaumont Formations. Thus to the north and west from the site, the topography is rol $1 \mathrm{ing}$ and eroded, while to the south and east the topography becomes progressively flatter as one nears the coast.

The site 1 ies on a raised area adjacent to Chiltipin Creek. From the perspective of the creek, the site lies atop a steep bluff. From the opposite perspective, the topography gradually slopes downhil 1 from a sandy ridge some $1.4 \mathrm{~km}$ west of the creek to a low point approximately $200 \mathrm{~m}$ west of the site and then gradually rises adjacent to the creek. The slight rise adjacent to the creek appears to be a natural levee of Chiltipin Creek to which has been added cultural debris. No evidence was observed of layered sedimentary deposits or erosional facies, however, the fine sandy clay loam that dominates the site deposits would appear to be primarily alluvial rather than aeolian in origin. Some wind borne sediment has definitely been added to the site deposits. The best evidence of this was seen along the fence row (Wagon Trail Area) were vegetation has trapped fine aeolian sediments that are no doubt derived from erosion of the adjacent plowed fields.

The sandy loam soil on the topographic rise drains much better than the clayey soils in the eastern site area and in the field. The farmer who has leased the property for a number of years commented, "that corner [the site area] has always disked up real fine but the crops never do well there." He 
went on to attribute this phenomena to the fact that clayey soils hold moisture better and have more nutrients. The correlation between archaeological sites and poor crop growth has been noted in many areas of south Texas. Vela (1982) has suggested that stunted grain sorghum in site areas may be due to mineral deficiencies caused by concentrated 1 and snails. The $41 \mathrm{JW} 8$ situation suggests that localized variation in soil characteristics may be the determining factor responsible for the difference in crop growth and that the snail concentrations are an unrelated coincidence.

Immediately adjacent to the main site area Chiltipin Creek is rather deeply entrenched; the west creek bank is a steep bluff some $4 \mathrm{~m}$ high. Upstream and downstream the bluff is noticeably less abrupt. The creek bed adjacent to the site is partially filled with recent clay loam sediments and heavily overgrown with grass and weeds. Every 50 or $75 \mathrm{~m}$ along the creek bed are smal1 depressions some 5 to $10 \mathrm{~m}$ long that hold water for extended periods of time. The depression adjacent to the site is one of the larger depressions observed for several hundred meters in either direction. Under wetter conditions the modern creek has a series of shallow muddy pools of water. It appears 1 ikely that the Late Prehistoric creek would have been 1 ess clogged by sediments and vegetation and would have had somewhat 1 arger and deeper pools.

A 1 inear depression occurs in the plowed field some 250 to $300 \mathrm{~m}$ west of the site. This topographic feature appears to be a filled-in stream channel. The abandoned channel runs parallel to present-day Chiltipin Creek. Examination of topographic maps and aerial photographs reveals that the abandoned channel once joined present-day Chiltipin Creek at the modern junction of Amargosa Creek less than a kilometer upstream from the site. It is suggested that the abandoned channel is a relic channel of Chiltipin Creek. Dating the abandonment is difficult. It can be assumed that this event took place at least 500 years ago (prior to when the site was occupied). Given the fact that the abandoned channel is still quite distinct, topographical1y, it is suggested that the change in stream channels took place within the past several thousand years.

Across Chiltipin Creek from the site are a series of low ridges with thin calcareous soils. The Amargosa Stage Stop 1ies on the slope of one such ridge. Erosional gullies on the slopes of these ridges reveal caliche and calcium carbonate concretions only a few inches below the surface. The soils associated with the ridges are not very fertile and do not support mid and tal1 native grasses. The ridges do provide an overlook of the lower lying areas west of the site.

Site 41 JW 8 1ies within an area mapped by the Soil Conservation Service as having Opelika fine sandy loam, depressional soils (Minzenmayer 1979). As is usual1y the case, more variation was observed in the field than is recorded on the soils maps. Opelika fine sandy loam, depressional soils are characterized as deep calcareous loamy soils that form on nearly 1 evel up 1 and areas. (The SCS refers to a 11 of Jim Wel15 County as an "up 1 and" area except for a narrow stretch of "bottomland" adjacent to the Nueces River.) Excavation profiles seem to fit the general description of Opelika soils except in the eastern edge of the site where a much darker clay loam was encountered. 
In the main site area, adjacent to Chiltipin Creek, the soil is a gray brown fine sandy loam that becomes more compact and more calcareous with depth. Opelika soil is described as having an eight-inch-thick surface layer that is "friable, neutra 1, gray fine sandy 1oam" (Minzenmayer 1979:25). Between 8 and 22 inches, the soll is "firm, moderately alkaline, dark gray sandy clay loam." From 22 to 33 inches, the soil is "firm, moderately alka1ine, gray sandy loam that has brownish mottles." A mottled white sandy clay loam occurs below 30 inches. The SCS descriptions of Opelika soil are similar to that observed at the site, although the lower zone in several excavation units appeared to be caliche rather than white clay.

The general soil map of $\mathrm{Jim}$ Wells County shows some interesting soil distributions with respect to $41 \mathrm{JW}$ 8. The soil distributions mirror the differences observed in surface geology and topography. The site occurs within a one- to two-mile-wide band of deep loamy and clayey soils. Surrounding this band to the northeast, north, and northwest is a large area of shallower loamy soils that extends across northwestern Jim Wells County. Southeast of the site the band of deeper soil broadens to encompass most of the eastern section of the county. Minzenmayer (1979) notes that the deeper clayey soils provide excellent native range plants. These soils support the highest yields of native mid and tall grasses of any soil in the county. The imp 1 ication is that $41 \mathrm{JW} 81$ ies at the head of an area which would have originally been a mid and tall grass prairie.

The detailed soils photomaps of Jim Wells County demonstrate another very interesting fact about the site location; the soils in the general site vicinity are significantly more diverse than comparable areas north and south as wel1 as most of the rest of the county. This statement is based on a study of the photomap sheets showing the distribution of the 52 mapped phases of the 27 named soils series defined by the SCS in Jim Wells County (ibid.). The detailed soils distributions across the county are shown by 45 aerial photograph sheets. Each sheet covers an area of about 21 square miles. The Hinojosa site occurs on Sheet 16. Sheet 16 has a total of 35 out of the 52 mapped phases (67\%), representing 22 out of the 27 named series (81\%) for the entire county. Adjoining Sheet 16 to the west and following Chiltipin Creek upstream is Sheet 15. Sheet 15 has a total of 27 out of the 52 mapped phases (52\%), representing 16 out of the 27 named series (59\%). The photomap sheet adjoining Sheet 16 to the south along Chiltipin Creek is Sheet 20. Sheet 20 is almost as diverse as Sheet 16. Sheet 20 has 33 out of the 52 mapped phases (63\%), representing 20 out of the 27 named series (74\%). Farther downstream, soils diversity drops rapidly after Chiltipin Creek flows into San Fernando Creek north of A1jce. Sheet 24 covers the eastern half of Alice and San Fernando Creek to the east. Sheet 24 has on 1 y 18 out of 52 (37\%) of the mapped phases, representing only 11 out of 27 (41\%) of the named series.

\section{VEGETATION}

South Texas lies within the Tamaulipan Biotic Province as defined by Dice (1943) and revised by Blair (1950). The Tamaulipan province is characterized as a thorny brush plain dominated by a relatively small number of species, including mesquite, Acacia, Mimosa, granjeno, Iignum vitae, cenizo, 
whitebrush, prickly pear, and tasaji110 (ibid.:103). Abundant evidence suggests that substantial changes have occurred in the vegetation patterns in south Texas during historic times (cf. Price and Gunter 1943; Bogush 1952; Inglis 1964; Weniger 1984). Today northern Jim Wells County is dominated by brush in uncleared and uncultivated areas. Evidence suggests that more of the area was covered with native grasses prior to the 1ate 18005.

In 1833, Benjamin Lundy crossed $\mathrm{Jim}$ We1 $1 \mathrm{~s}$ County from west to east just south of the site. He described the area as "delightful" and mentioned that the stream courses were wooded but that the uplands had "scarce a bush" (quoted in Ing 1 is 1964:35). Lundy also pointed out that the country was "abounding in excellent grass." Other travelers such as Bonnell in 1840 and Michler in 1849 passed through sections of $\mathrm{Jim}$ Wells County and described prairie conditions with mesquite and oak concentrated near creeks and rivers (Inglis 1964:36). By 1885, the western area of $\mathrm{Jim} \mathrm{Wel15}$ County and adjacent Duval County were apparentiy covered in dense brush as indicated by Harvard's comments (ibid.). Harvard did note that eastern Jim Wel1s County was covered in a sparse scrubby chaparral that was absent in places "leaving the ground covered with thin sparse grass."

In examining the historic accounts of south Texas, the terms "prairie" and "grass prairie" are frequently used to describe much of the region particuTarly prior to the mid 1800 s. This usually brings to mind a picture of an endless grassland. This picture may be misleading. Del Weniger (1984 and personal communication) has recently compiled hundreds of pre-1860 historic references to the 1 andscape, water resources, vegetation, and fauna of Texas. Weniger emphasizes that the term "plain" refers to an endless level expanse of grass whereas "prairie" actually refers to a rolling topography covered with both grass and brush. Weniger argues that early travelers clearly indicate that the southern Texas prairie areas had dense stands of grass interspersed with mesquite, 1 ive oak, acacia, prickly pear, and other brush species. "Grass prairies" may have referred to areas of the prairie that had particularly dense stands of grass between the brush mottes. Early travelers often discussed vegetation from a practical perspective--from having had to cross through it. One can readily imagine that a reference to a prairie would emphasize the ease of passage after having to cross through or find a way around the extensive chaparral thickets bordering the major streams and rivers. Thus the terms "delightful" and "grass prairie" may have referred to areas of the praire that had ample grassy areas that al lowed easy travel between the brush mottes.

In addition to the grass prairies, however, there are early historic accounts of unusually 1 arge concentrations of dense prickly pear (Opuntia engelmannii) west of the lower Nueces River in parts of Live Oak, Jim Wel15, Duval, Nueces, and Kleberg Counties (Campbe11 and Campbe11 1981:7). Campbel1 and Campbe1 1 (1981:14) make specific reference to a concentration of prickly pear 1 ocated near $41 \mathrm{JW}$ 8: "the greatest concentration of prickly pear plants nearest to the Mariames [group of Indians Cabeza de Vaca 1 ived with] was in Duval and Jim We1 15 Counties, particularly between San Diego and Alice on the north and Falfurrias on the south." The Campbel $1 \mathrm{~s}^{\prime}$ statement is based in part on data collected by Davenport and We1 1s (1918-1919) who interviewed long-time inhabitants of the area. The prickly pear fields were much reduced 
after the "great freeze of February 189g" (Davenport and We11s 19181919:209).

The nature and extent of the recent changes in the vegetation of south Texas are the subjects of considerable debate. Some have argued that thorny brush has "invaded" a pristine grass 7 and aided by overgrazing, bovine digestive tract seed dispersal, and the cessation of natural range fires (cf. Bogusch 1952). Others seem to agree that the cited factors have caused a marked increase in density of thorny brush but contend that the brush was al ready present (cf. Inglis 1964). Del Weniger (1984) has recently created some controversy over his contention that dense stands of brush have long been present in the area. Weniger rejects the "natura1" range fire argument by noting that of a 11 the many pre-1860 range fires that he has found references to, none were attributed to natural causes. Weniger also attempts to demonstrate that range burning only became prevalent after the arrival of European settlers.

The role played by fire in maintaining grassland in southern Texas has long been discussed (Cook 1908; Johnson 1963). Weniger's contention that historic prairie fires were caused by man does not rule out the possibility that man has been setting prairie fires for many thousands of years (cf. Sauer 1950). Cabeza de Vaca noted that the Mariame sometimes controlled the movement of deer by burning 1 arge areas of the open prairie, thus concentrating the deer in the smal1er unburned areas (Campbe 11 and Campbe11 1981:17). The Campbe17s point out that the burning could have on $1 y$ been done during times when the grasses were dry and combustible (fal1 or winter?). Weniger does not cite the Cabeza de Vaca evidence due to controversy over the exact route of de Vaca's trave1s. In doing so, Weniger chooses to ignore the earl lest and most detailed account of purposeful burning of the prairies by the aboriginal inhabitants of the region. This cal1s into question Weniger's contention that the Indians did not burn the prairies prior to being taught how to do it by the white settlers.

A recent review of the "historic role of fire on the Rio Grande Plains" by Charles Scifres (1980) emphasizes both the drastic nature of the recent change from grassland to brushland predominance in south Texas and the role fire and man have played in this change. Scifres argues that the ability to control fire is one of the principal reasons that prehistoric man adapted to grasslands and by extension to south Texas. Scifres believes that the historical vegetation changes can be attributed to the cessation of mancaused fires, elimination of the original grazing species (bison and pronghorn), and climatic change to an increasingly xeric climate. Scifres advocates the use of prescribed (control 1ed) burning to improve range pasture by increasing the grass and forage species.

The effect of fire in controlling south Texas brush has been studied by several groups of range management specialists (Box, Powel1; and Drawe 1967; Scifres and Kel 1 y 1979; White 1980). Experimental burnings at the Welder Wild life Refuge have demonstrated that fire helps maintain grass density and diversity and reduces brush species density in the areas between brush mottes or thickets. The actual brush mottes themselves were 1 ittle affected by fire as they 1 acked adequate fuel (dry biomass) to burn quick $1 y$. This suggests that prehistoric range fires could have helped maintain corridors and pockets 
of grass but would not have eliminated the 1 arger brush mottes. In the era before extensive overgrazing by sheep and cattle the grasses were a much more dominant aspect of the vegetation as numerous travelers attest. Prehistoric fires would have had more fuel (dry biomass) during wet climatic intervals when grass stands reached maximum densities. Therefore, prehistoric fires, whether started by man or natura1 causes, may have been more effective in controling brush spread than modern experiments in grazed areas suggest.

One factor which is not often emphasized in discussions of vegetation changes is the effect of short-term climatic cycles. An excel lent example of how drastically the vegetation of a particular 10cality can change over a 20-year period is 111 ustrated in Drawe, Chamrod, and Box (1978). The Welder Wildi ife Refuge in Sinton County (about $80 \mathrm{~km}$ east of $41 \mathrm{JW}$ 8) has been careful1y monitored and studied since the mid-1950s. Drawe, Chamrod, and Box (1978) 111 ustrate a series of photographs of. one area of the refuge over a 22-year period. In 1956, just after the terrible drought of the early fifties, the area had a prickly pear and short grass vegetation community. The photograph (ibid.:frontispiece) shows a dense field of cactus with very sparse native short grasses. Later photographs, taken in 1965 and 1977 (Drawe, Chamrod, and Box 1978:Figs. 5 and 6), show the area changing to a mid grass and mesquite community. The 1977 photograph shows dense thick grasses, 10w mesquite, and almost no prickly pear. Drawe, Chamrod, and Box attribute the change primarily to increased moisture, al though reduced grazing pressure was certainly a factor in the improved grass. Prickly pear is thought to have decreased because of disease and insect problems created by a decade of higher rainfa 1 .

J im We 11 s County is often included in the Coastal Bend region of Texas for purposes of vegetation and wildiife studies. Several studies sponsored by the Welder Wildife Foundation in Sinton. Texas, provide detailed identification 1 ists of native vegetation. Jones (1975) provides an identification key to roughly 1150 species and varieties of Coastal Bend flora exclusive of the grasses. Gould and Box (1965) provide very detailed identification of the grasses of the Coastal Bend. The study by Drawe, Chamrod, and Box (1978) discusses plant communities similar to those that might have been present in the $\mathrm{Jim}$ Wel $1 \mathrm{~s}$ County area prior to intensive grazing and agriculture.

\section{SIIE SETTING CIRCA A.D. 1350}

To construct an environmental model at the time that the Hinojosa site was occupied, a number of 1 ines of evidence were considered, and a number of assumptions were made. It is assumed that the local climatic conditions at that time (circa A.D. 1300-1400) were wetter than today. The average annua 1 rainfal1 was probably similar to that of today; however, it is assumed that absence of clearing, plowing, overgrazing, and historic erosion would yield more effective rainfal1. It is also assumed that the area had relatively uneroded soi 15 that were generally deeper than today in the up 1 and areas. Nonetheless, present-day soll trends are considered reliable indicators of trends present 600 years ago. In other words, it is assumed that thin soils today would have also been comparatively thin then. Chiltipin Creek would 
have been spring fed year round, although during dry periods the creek would have only held water in the deeper holes.

It is assumed that with increased effective moisture and without modern impact (overgrazing and cessation of the prairie fires) the general region would have had 1 ess brush and more grasses than today. The same species that are present today were undoubtedly present 600 years ago. Brush mottes contained the same thorny species that today are so widespread. It is assumed that periodic fires did occur, whether natural or man-made. The fires would have kept brush-free corridors open in most areas. It is assumed that the prickly pear fields noted the following century by Cabeza de Vaca were not as extensive during the occupation of the Hinojosa site. These assumptions are made based on the published evidence cited previously and on archaeological evidence that will be presented 1 ater in this report.

The environmental model is shown in Figure 2. The model recognizes four general vegetation patterns: mid to tall grass prairies, riparian woods, short grass and thorny brush uplands, and short to mid grass and scrub brush uplands. These general vegetation patterns reflect the major native plant communities that would have been present in the area. The complex array of soil type distributions noted around the site suggests that a number of smaller microenvironments with associated plant communities would have been present in addition to the major plant communities. The model presented here is a schematic interpretation that wi 11 be used in 1 ater sections of this report to discuss the environmental exploitation patterns evidenced by the archaeological data. It is recognized that any such model is a simplification of the complex array of plant communities that would have existed.

The model shows that the mid to tall grass prairie covered the areas that today have deep clayey and loamy soils. The mid to tall grass prairie would have extended south and east of the site area. Smal1 mottes of mesquite, $1 \mathrm{ive}$ oak, and prickly pear would have been interspersed throughout the prairie, particularly in depressional areas with increased soil moisture. The site 1 ies on the edge of a 1 inear band of riparian woods or galeria forest (Weniger 1984:36) paralleling Chiltipin Creek. This wooded area would have included mesquite, anaqua, el $\mathrm{m}$, $1 \mathrm{ive}$ oak, and hackberry trees, and a variety of vines and bushes. Larger trees would have been clustered around the shaded water holes along the creek. East of the site, the ridges with shallow soil would have been covered with short grasses, thorny brush, and plants suited for shallow calcareous soils such as ceniza. Short to mid grasses and taller thorny brush would have occupied the lower slopes of the ridges east of the site where soil depth increases. Prickly pear thickets (not shown in the mode1) would have occurred west and southwest of the site in the lower lying areas with deeper sandy soils between the upland ridges.

Thus, we see that 41 JW 8 was situated in an broad ecotone situation with a variety of habitats nearby. It should be emphasized that the boundaries between the posited habitats would not have been as sharp as shown in the mode 1. Most topographic, soil, and moisture gradients are gradual rather than abrupt. One good reason for the variety of habitats that are postulated for the aboriginal site area is the soils diversity as noted earlier. Diverse soils support diverse flora which in turn support diverse fauna. The faunal assemblage recovered from the site supports the hypothesized broad 
Figure 2. Environmental Model of Site Vicinity.

PAGE 32 REDACTED 
range of habitats rather we11. Bison and antelope would be associated with the mid to tall grass prairies. The fish, mussels, soft-shelled turtles, and aquatic birds attest to the presence of a we11-watered riparian zone. The javelina, Rabdotus 1 and snails, and rats would have been associated with thorny brush and prickly pear thickets. 


\section{ARCHAEOLOGICAL AND ETHNOHISTORICAL BACKGROUND}

The archaeological and ethnohistorical background of the southern Texas region and the $\mathrm{Jim}$ Wel1s County area is briefly summarized. The Late Prehistoric era is discussed in general terms in this section. Late Prehistoric cultural patterns and chronology are discussed in greater detail in Section XI. For additional prehistoric background and the history of archaeological research in the region the reader is referred to Ma110uf, Baskin, and Killen (1977), Hester (1980a), and Hall, Black, and Graves (1982). Campbel1 and Campbel1 (1981) and Campbel1 (1983) summarize the ethnohistorical record for south Texas.

\section{SOUTHERN TEXAS PREHISTORY}

Intensive archaeological research has only taken place in southern Texas during the last decade (Hester 1980a; Hall, Black, and Graves 1982). Therefore, many problems in the regional prehistory have yet to be addressed. One of the greatest problems in understanding southern Texas prehistory is the 1 ack of a tightly controlled chronology. Much of what is known about the chronologic development of southern Texas prehistory is based on comparisons with adjacent regions such as central Texas and the lower Pecos River area. The fact that even less is known about adjacent northeastern Mexico compounds the problem.

In broad terms, the prehistory of southern Texas and adjacent regions can be divided into three eras or general time spans: the Paleo-Indian, the Archaic, and the Late Prehistoric. These three eras are seen by some as being developmental stages of a theoretical progression of culture toward civilization (cf. Willey and Phillips 1958; Prewitt 198la). Herein, the three eras are seen as 1 ittle more than gross divisions of cultural change through time. It can be argued that southern Texas has always offered a generally inhospitable environment for cultural development. Climatic and environmental conditions have provided challenges to cultural adaptation that have been successfully met by only a limited range of adaptive strategies. A1 1 known prehistoric cultures in southern Texas were hunting and gathering cultures that depended on the $10 \mathrm{ca} 11 \mathrm{y}$ available natural resources for surviva1. Agricultural subsistence and sedentary 1 ife styles were nonexistent in southern Texas prehistory. Evidence for extra-regional trade and contact is rare for most areas of south Texas (Ha 11, B 1ack, and Graves 1982:468-469).

The Paleo-Indian era in southern Texas, as well as in most areas of North America, has been traditional $7 y$ viewed as a big game hunting adaptation to a 1 ate Pleistocene and early Holocene environment. The earliest human inhabitants of southern Texas are assumed to have been smal1 groups of nomadic hunters who used spears tipped with fluted projectile points such as Clovis and Folsom to kill large Pleistocene anima $1 \mathrm{~s} 1 \mathrm{ike}$ the mammoth and bison 10,000 to 12,000 years ago. Archaeologists are becoming increasingly aware that these ear 1 y peop 1 es a 1 so depended on a variety of resources in addition to extinct megafauna (Hester 1980a:28). Other resources notwithstanding, Early Paleo-Indian cultures remain best known for the distinctive remains of their hunting weapons. Surface finds of fluted projectile points 
are known from most areas of southern Texas especially in the interior. The 7 ate Pleistocene coast 1 ine is believed to have been much 1 ower than the modern Gulf coastline due to the global lowering of the sea level (Hester 1980b). Evidence for Early Paleo-Indian adaptations to the 1 ate Pleistocene coastal environment may 1 ie on the now inundated continental shelf (Coastal Environments, Inc. 1977).

Although many fluted projectile points have been collected in south Texas, only a few localities have been found that contain buried Early Paleo-Indian components. One such 1 ocality, the Buckner Ranch site, is 1ocated in Bee County some $50 \mathrm{mi}$ les northeast of 41 JW 8 (Se 1 lards 1940). Hester (1980a: 142-146) interprets the Buckner Ranch site as an occupation site used by a succession of Paleo-Indian groups over a comparatively long time. The occurrence of 1 anceolate projectile points at Buckner Ranch along with stemmed dart points usually considered "Archaic" may be attributable to changing adaptive patterns during the later millennia of the Paleo-Indian era.

A series of unfluted 1 anceolate projectile points, including the Plainview, Golondrina, Scottsbluff, and Angostura types, are believed to represent successive Late Paleo-Indian occupations in south Texas (Hester 1980a). Adjacent regions once again provide the best excavated evidence of similar cultural adaptations. Sites 1ike Baker Cave in southwest Texas (Word 1970; Hester 1983; Chadderdon 1983) document a shift to a more modern environment and toward small game hunting and plant gathering adaptations during the Late Paleo-Indian era. It is argued here that at least by 7000 B.C. human adaptation in southern Texas focused on a variety of plant and animal resources. Population increase during the later part of the Paleo-Indian era can be inferred from the much larger numbers of artifacts and sites in comparison with those attributable to Early Paleo-Indian occupation.

Hester (1980a:146) dates the end of the Paleo-Indian era to rough1y 6000 B.C. and defines a transitional cultural period, the Pre-Archaic, between 6000 and 3500 B.C. in south Texas. This author has el sewhere argued that the term "Pre-Archaic" is no 1 onger a useful cultural construct (B1 ack 1980). If human adaptation in southern Texas al ready focused on a wide variety of resources by 7000 B.C. as is argued here, then an "Archaic" 1 ife style was obviously present during the so-called "Pre-Archaic." The term "Pre-Archaic" should be replaced by the more appropriate term, the "Early Archaic," as it has been redefined by Story (1980).

The Ear1y Archaic era embraces rough 1 y 3000 years of prehistory in south Texas, 6000 to 3000 B.C. The adaptive patterns evidenced across south Texas during this era are common to a large area of the Western Gulf Coastal Plain (Story 1980; Mckinney 1981). Early Archaic sites in deep south Texas are poorly represented in comparison to Early Archaic sites along the Balcones Escarpment area that borders southern Texas on the north. This may reflect a very 1 imited occupation in deep south Texas during this era or it may simply reflect the poor preservation of these sites and the relative dearth of archaeological research in the region. It has been suggested that drier, warmer climatic conditions occurred during the Early Archaic (Bryant and Shafer 1977). Higher rainfall and reliable springs along the Balcones 
Escarpment may have made this area a much more favorable environment than in 1 and south Texas.

Evidence of prehistoric occupation of south Texas during the succeeding millennia after 3000 B.C. is much more abundant. Excavations in the Choke Canyon Reservoir area have uncovered evidence of the Archaic era at dozens of sites. One of the problems of dealing with the Archaic cultures of south Texas is that they did not produce as many distinctive dart points in comparison with central Texas Archaic peoples. In south Texas, triangular and leaf-shaped bifaces are much more common than stemmed dart points. This is a problem because most of the Archaic chronologies in Texas and el sewhere rely on projectile points as chronological indicators. Various central Texas style Archaic dart points are often found in surface collections from south Texas. It has long been assumed that excavations would eventually document these artifacts in context and thus provide an equivalent south Texas Archaic chronology. This assumption has been called to question by recent investigations. The Choke Canyon excavations sampled buried Archaic components at many sites, yet stemmed projectile points were recovered in only very smal1 numbers. Unifacial tools, simple bifaces, and distally beveled tools (gouges) were much more common. Grant Hall (personal communication) believes this reflects a much greater reliance on plant and small game resources in south Texas in comparison with an emphasis on deer and bison hunting in central Texas (Ha11, Black, and Graves 1982; Ha11. Hester, and B1 ack 1986).

One unusual Archaic site in south Texas is the Loma Sandia site in Live Oak County (Hester 1980a). The 1977-1978 excavations at this cemetery site produced many Archaic burials believed to date to the 1 ater part of the Archaic era. The variety and quantity of the grave goods found with the Archaic burials may be linked to participation in a regional exchange system extending many hundreds of miles to the east (Hall 1983). Hall has suggested that cemeteries such as Loma Sandia may be located in areas with high concentrations of important natural resources such as pecans.

The later part of the Archaic era in south Texas, during the first mitiennium A.D., is recognized primarily by the widespread occurrence of smal1, expanding stem dart points such as the Ensor type. An overall reduction in size of projectile points also occurs in central Texas during the Late Archaic. Sometime around A.D. 1000 the Late Prehistoric era begins. Late Prehistoric cultures in south Texas are recognized by the presence of true arrow points and several distinct tool forms such as the small end scraper and the beveled knife. Bone-tempered ceramics occur over a wide area of south Texas by A.D. 1300. Accompanying these changes in artifacts are changes in adaptive strategies. Hall (in Hal1, Black, and Graves 1982:471) sees a broader, more diversified hunting emphasis during the Late Prehistoric that often included large animals such as deer, bison, antelope, and possibly javelina. These changes in hunting emphasis may be partially attributable to the adoption of the bow and arrow and partial1y due to wetter conditions created by a significant climatic shift.

The Late Prehistoric era in south Texas is better known than preceding eras because of better site preservation and better site visibility. The chronology of the Late Prehistoric era in south Texas remains in question. In central Texas, the Late Prehistoric is divided into two phases, the Austin 
phase and the Toyah phase (Prewitt 1981a). The division between the early and 1 ate segments of the Late Prehistoric is not as clear in south Texas. Hester (1980a:158) has argued on the basis of excavated assemblages that in parts of south Texas the expanding stem arrow points (Austin phase) may have been used at the same time as the contracting stem arrow points (Toyah phase). The overlapping dates between some Late Prehistoric sites in the Choke Canyon area may support Hester's contention.

Several broad patterns of cultural adaptation have been defined for southern Texas. Hester (1976, 1981) sees a major division between coastal and in 1 and adaptations which he terms the "maritime" and "savanna" traditions. The maritime and savanna traditions can be traced back several thousand years to at least the middle part of the Archaic. Ethnohistoric sources indicate that there were physical, 1 inguistic, and cultural differences between coastal groups (whom Cabeza de Vaca termed the "canoe peoples") and in 1 and groups. The maritime tradition involved ful1-time occupation along the bays and barrier islands of the middle and lower Texas coast. Subsistence was primarily based on fish, shellfish, and coastal fauna and flora. By contrast, the savanna tradition involved more diverse adaptations to a variety of 1 ocalized in 1 and resources.

The inland area of southern Texas had highly variable resource distribution. Areas with concentrated resources, termed "high resource density" areas, were surrounded by much 1 arger "low resource density" areas (Hester 1981). High resource density areas often occur along perennial streams or rivers where concentrations of plants, anima 1s; water, and 1 ithic resources were found in close proximity. These "generalized resource areas" (Ha11, Black, and Graves 1982:467) were repeatedly occupied through time, producing long 1 inear archaeological sites paralleling the water courses. The distribution of water is one of the most important factors governing prehistoric settlement patterns in southern Texas. Virtually all of the perennial streams and rivers in south Texas evidence repeated occupation throughout prehistory. Smaller, more ephemeral streams and smal1 springs were less heavily occupied. Sites along these less predictable water sources were probably occupied during periods of wetter climatic conditions. Upland areas located we 11 away from reliable water sources evidence less intensive occupations that may be 1 inked to the seasonal exploitation of certain plant resources (McGraw, Van Note, and Jones n.d.).

Hester (1981:123-125) suggests that along the coast and in 1 and in high resource density areas the aboriginal groups may have developed wel1-defined, restrictive territories. These restrictive territories would have been the areas containing adequate resources year round. Hester believes that the 1 arge cemetery sites such as Loma Sandia in Live Oak County and the Late Prehistoric cemeteries along the coast reflect the existence of restricted territories. In contrast, most areas of south Texas did not have the high resource density necessary to sustain restricted territories. These areas would have been occupied by groups with much broader territories. 


\section{JIM HELLS COUNTY AND VICINITY}

The present study is the only intensive archaeological project ever conducted in Jim Wel $1 \mathrm{~s}$ County. As of 1983, only 13 archaeological sites had been officially recorded in Jim Wel $1 \mathrm{~s}$ County. Sites $41 \mathrm{JW} 1$ and $41 \mathrm{JW} 2$ are located in the southern part of the county. Both sites are known only from surface collections of mostly Archaic materials. Sites $41 \mathrm{JW} 3,41 \mathrm{JW}$, and 41 JW 5 were recorded by $L$. W. Patterson along Lagarto Creek in the northern part of the county. Al1 three sites have 1 ithic materials that may be attributable to Archaic occupations. Of particular interest is $41 \mathrm{JW} 3$ which Patterson says is located on a rise that is one of the few 1 ithic sources in the area.

Alvin C. Boldt, a former resident of $\mathrm{Jim} W e 11 \mathrm{~s}$ County, recorded $41 \mathrm{JW} 6$, $41 \mathrm{JW} 9$, and $41 \mathrm{JW} 12$ east of Alice. A recent interview with Boldt revealed that $41 \mathrm{JW} 6$ and $41 \mathrm{JW} 9$ are actual $1 \mathrm{y}$ two of a series of four to six smal1 localities within an area about $700 \mathrm{~m}$ in diameter. Boldt collected a variety of Archaic and Late Prehistoric artifacts from these sites over a 15-year period. Some two and a half kilometers to the east Boldt made surface collections from four or five other localities along a low drainage. One of these localities was recorded as a separate site, $41 \mathrm{JW} 12$, based on Boldt's recollection that he had collected only Paleo-Indian and Archaic points from it. T. C. Kelly is currently studying the Paleo-Indian points from this site. A11 of Boldt's localities are small areas less than $100 \mathrm{~m}$ in diameter. Most are located on 51 ight 1 y raised topographic features adjacent to or overlooking sma11, unnamed drainages that flow into Agua Dulce Creek. Judging from Boldt's collection of burned rock, snail, and $f l$ ake concentrations, most of the localities appear to be smal1 occupation sites. The presence of chronologically sensitive materials dating to virtually the entire prehistoric sequence suggests the area was long a favored campsite. Boldt stated that prior to 1 and modification in the 1930 s the area had running creeks that held catfish and shallow rainy season 1 akes or swampy areas. Several of the localities are located adjacent to former 1 akes.

Gunnar Brune (1981:266) mentions that the Amargosa Springs near the Hinojosa site was visited by early man as evidenced by a Clovis point he says that Alvin Boldt collected near the springs. This statement is in error. Boldt actually found the Clovis point on an eroded ridge several miles northeast of the springs. The point was an isolated find (designated as $41 \mathrm{JW} 13$ due to the possible significance) that was not associated with any known or visible site. Chandler, Knolle, and Knolle (1983) discuss additional Paleo-Indian projectile points that were collected along Javelin Creek in northern Jim Wel $1 \mathrm{~s}$ and adjacent Nueces Counties.

The Hinojosa site and $41 \mathrm{JW} 7$ were initially recorded during a survey of SCS project localities in 1974 (Hester and Bass 1974). Site $41 \mathrm{JW} 7$ is 1ocated across Chiltipin Creek from the Hinojosa site near the Amargosa cemetery. The site is described as a 1 ight scatter of $f 1$ akes, burned rock, and a few artifact fragments and is believed to represent a temporary campsite.

Jim Wel 15 County remains archaeologically poorly known. Based on the few recorded sites and observations by $10 \mathrm{cal}$ collectors, site density is comparatively low. Most site locations occur along the many small drainages in the 
county. One factor that may partially account for the reilative low density of visible sites is the overall flat nature of much of the county. In contrast with areas to the west and north, Jim Wel $1 \mathrm{~s}$ County is 1 ess eroded and has deep soils. 01 der archaeological sites may be buried. On the other hand, cultivation and deep plowing have exposed many of the known sites, including $41 \mathrm{JW} 8$.

Warren (1984) recently surveyed a 100-acre-tract in Jim Wel is County, seven miles south of 41 JW 8 along Resaca de Enmedio, a tributary of Chiltipin Creek. He did not 10 ate any prehistoric sites despite backhoe trenching along the stream.

Adjacent to $\mathrm{Jim}$ Wel1 $1 \mathrm{~s}$ County are some of the best known and least known counties in south Texas in terms of archaeological resources. Duval, Brooks, and $\mathrm{Kleberg}$ Counties are very poorly known. Nueces and Live Oak Counties are comparatively well known whereas San Patricio County fal1s somewhere in between. C. K. Chandler (1982, 1983) has published several articles describing archaeological materials from San Patricio County.

Duval County archaeology has been recently summarized by McGraw, Van Note, and Jones (n.d.). They note relatively low site densities in upland areas and overall 1 ow densities of cultural materials in the southern part of Duval County.

In contrast, Nueces County has a much higher known site density, especialiy near the coast. Several hundred sites have been recorded in Nueces County, including in 1 and campsites (B1 ack 1978), cemetery sites along Oso Creek (Patterson and Ford 1974; Hester 1980a), sites on the barrier islands along the coast (Campbel1 1964), and shel1 midden sites on the bay shores (Highley, Gerstle, and Hester 1977). The most recent summary of Nueces County archaeology can be found in Carlson, Steele, and Bruno (1982). Archaic and Late Prehistoric sites are well represented while Paleo-Indian sites are much less common. The Gulf coast and the bay systems offered a very different set of resources than was available inland.

The archaeological resources in the area south of $\mathrm{Jim}$ Wells County in Brooks County and in adjacent counties have been summarized in Mallouf, Baskin, and Killen (1977) and more recently in McGraw (1984). Much of this area occurs within the "sand plains" of southern Texas where surface water has long been a 11 but nonexistent. Site densities appear to be low except near the few available water sources, such as the small aeolian depressions which hold water after periods of heavy rainfal1.

The archaeological resources along the coast and margins of Baffin and Gru110 Bays in Kleberg and Kenedy Counties are known from reports by Hester (1969, 1971). Recent work by Herman Smith (1982, 1983) may soon offer new insights into the prehistory of this area.

Live Oak and McMullen Counties are comparatively we 11 known after years of work in the Choke Canyon Reservoir area. Twel ve volumes in the Choke Canyon Series have been published by the CAR-UTSA to date. These include ethnohistoric work (Campbel1 and Campbel1 1981), historical archaeology (Everett and Bandy 1981; Fox 1984, 1986), survey work (Thoms, Montgomery, and Portnoy 
1981; Roemer 1981), survey and testing (Weed and Shafer 1981; Hal 1, B 1ack, and Graves 1982; Hal 1, Hester, and B1 ack 1986), and major site excavations (Brown et a 1. 1982; Scott and Fox 1982; Highley 1986). These reports document the best known archaeological area in southern Texas.

\section{HISTORIC INDIANS OF SOUTHERN TEXAS}

Historic contact in south Texas first occurred in the 1530 s with the appearance of Cabeza de Vaca on the Texas coast (Campbe 11 and Campbe11 1981). In the following centuries the native inhabitants of south Texas were decimated by disease and disp 1 aced due to pressure from Spanish colonial occupations spreading from the south and groups of Apaches and Comanches. moving in and raiding from the north. Within a few hundred years the native inhabitants of south Texas 1 ost a 11 ethnic identity. The sma 11 amount of ethnohistoric data known was collected by the Spanish. This information is spotty and motivated by an interest in converting the natives to Catholicism rather than recording native 1 ife styles (Campbe 11 1983).

The ethnohistoric sources suggest that south Texas was inhabited by hundreds of smal1 bands who spoke many dialects of several 1 anguage groups (Goddard 1979). An erroneous picture of 1 inguistic and cultural homogeneity was fostered by use of the term "Coahuiltecan" to refer to virtual1y a 11 the native groups of inland south Texas (cf. Ruecking 1955; Newcomb 1961). Campbeli's work has called attention to this problem and has provided an accurate summary of the 1 ittle that is known about the native inhabitants of south Texas and adjacent northeast Mexico.

The most accurate source of information on the aboriginal inhabitants of southern Texas comes from several documents written by survivors of the i11fated Narvaez expedition to Florida in 1528. The most important and most famous of the survivors is Cabeza de Vaca, the treasurer of the expedition. Cabeza de Vaca's personal narrative and a similar narrative written by a historian, Oviedo y Valdes, based on a joint report of several of the survivors of the Narvaez expedition, provide perhaps the only accurate ethnographic data that is available for the inhabitants of southern Texas (Campbe11 and Campbe11 1981).

It is very unfortunate that Cabeza de Vaca's account has been misinterpreted by many Texas historians. The key to understanding the account 1 ies in accurately tracing Cabeza de Vaca's route across Texas. As Campbel1 and Campbel1 note, a careful study of the Narvaez expedition accounts reveals that Cabeza de Vaca traveled across southern Texas and crossed the Rio Grande in the vicinity of Falcon Lake. This interpretation is based on a we 11reasoned study of the 1 andmarks mentioned in the accounts as we 11 as the Indian groups, direction of travel, and the repeated clearly stated goals of the survivors. A similar interpretation, published in the early 20th century (Davenport and Wel1s 1918-1919), has been virtually ignored by many historians as recent public school history textbooks attest (Campbell and Campbe1 1 1981:65). The probable travel route of Cabeza de Vaca is shown by Campbe11 and Campbe11 (1981:Fig. 1) to cross Jim We11s County. The Campbe11s provide an excel lent summary of the Indian groups mentioned by Cabeza de Vaca as well as by later accounts. The following pertinent details of the groups 
that ranged near Jim We11s County are extracted from Campbe 11 and Campbe 11 (1981).

Cabeza de Vaca spent several years among a group known as the Mariames (Campbe11 and Campbe11 1981:13-22). The Mariames had a bilobate territory: most of the year they 1 ived in the lower Guadalupe River valley. During the summer they traveled southwest along the coast and then moved in 1 and to the northeastern edge of an extensive concentration of prickly pear. Campbel1 and Campbe11 (1981:14) place the Mariames' summer territory west of the Nueces River in parts of $\mathrm{Jim} W e 11 \mathrm{~s}$ and Duval Counties. In 1533-1534 when Cabeza de Vaca was with the Mariames, their summer territory may well have included the $41 \mathrm{JW} 8$ area.

The Mariames relied on the vast fields of prickly pear for survival during the summer months. Apparently the superabundance of prickly pear fruits (tunas) provided a stable food source for several months. Periodic movement is indicated in order to find areas with ripe fruit. The fruits were usually eaten as they were found or after they were brought back to camp. In the 1 ate summer prior to the Mariames return to the 1 ower Guadalupe River, the juice of the prickly pear fruit was extracted, and the tunas were split and dried in the sun so that they could be carried on their return to the winter territory. Land snails were noted in the Oviedo account as being an additional important food resource in the summer. The snails were searched for very careful1y. Water was sometimes scarce in the summer territory of the Mariames as Cabeza de Vaca notes that tuna juice was squeezed into holes in the ground; the resulting sweet juice was consumed as a substitute for water.

Few other details of the Mariames summer subsistence pattern are direct $7 y$ stated in the accounts, however, a number of activities can be inferred from general statements and from suspicious missing comments. For example, it can be inferred that a wide variety of small animals were hunted, including snakes, rats, and fish. These animals were eaten as well as their bones which were saved and pulverized to be eaten later. Deer were hunted during the semiannual migration between the territories by chasing them into the bays and forcing them to swim until they became exhausted and drowned. Bison were mentioned as used by the Mariames for clothing and shields. No mention is made of bison hunting during Cabeza de Vaca's stay among the Mariames. This may be due to the occurrence of drought conditions as it can be inferred from several statements that the years 1533-1534 were unusually dry (ibid. : 15).

The Mariames 1 ived in smal 1 circular huts consisting of a four pole frame covered with mats. The mats were presumably made from some sort of woven plant fiber. The simple structures were transported every two to three days to a new encampment. Comparatively few items of material culture are discussed in detai1. Bows and arrows were used. Some bows were obtained from the Avavares during the prickly pear season by trade. Small bison hide shields were used. Flint knifes, flint flakes, scrapers, digging sticks, and mortar and pestles are not directly mentioned but can be inferred (Campbe 11 and Campbe11 1981:18-19). Campbe11 and Campbe11 (1981:19) state that: "Pottery was evidently not made because it is said that prickly-pear juice was collected in holes in the ground for lack of suitable containers." Some 
type of woven or flexible basket was used to carry the dried prickly pear fruits. A small net is mentioned and described as being about five and a half feet in length and width. Cooking features used by the Mariames that might be preserved include open hearths and some type of pit oven.

The Avavares are another group described by Cabeza de Vaca that 1 ived at least part of the year in the $\mathrm{Jim} \mathrm{We} 11 \mathrm{~s}$ County area. Campbel1 and Campbel1 (1981:24-27) suggest that the Avavares may have ranged on both sides of the Nueces River in parts of JimWe1 1s, Duva 1, and San Patricio Counties. The seasonal movement of the Avavares is not clear. They are mentioned as collecting prickly pear in the summer and trading bows with the Mariames. They are also mentioned as remaining in the prickiy pear area after the other groups had left. They apparently spent considerable effort (up to five days) searching for late ripening prickly pear. One passage describes the Avavares locating a stream valley with trees containing an edible pod after spending several days searching in vain for ripe tunas. Campbel1 and Campbell believe that these trees may have been the Texas ebony which has seed pods that hold edible seeds into the winter.

The Avavares hunted deer and used the deer skins to keep warm in the winter. The Avavares suffered greatly during the winter of 1534-1535 when the Spanish stayed with them for eight months. The Spanish noted that they mostly ate roots during the winter and suffered much more hunger than the Mariames. Cabeza de Vaca told of an interesting legend among the Avavares that involved a strange man known as Mala Cosa ("bad thing"). Mala Cosa was alleged to enter houses at night carrying a torch and a large flint knife. He would select a man and preform surgery on the man's abdomen and elbow. Other strange behavior is associated with this legendary character. Mala Cosa probably represents the trickster, an almost universal mythological figure among North American Indian groups (Radin 1956).

The Avavares had contact with a number of groups in the area, including the Mariames, the Fig People, the Cutalchuches, the Maliacones, and the Susolas. The Fig People were a coastal group that Campbe 11 and Campbe11 p 1 ace just south of Corpus Christi Bay. The Avavares apparently had friendly contact with the Fig People with whom they visited and traded. The Cutalchuches, the Maliacones, and the Susolas are mentioned as collecting tunas in the same area as the Avavares. Few details are available for these groups.

Campbe11 and Campbe1 1 a1so summarize ethnohistoric data for the 17th and 18th centuries for south Texas, but detailed information such as that just summarized is simply not available for these later periods. Cabeza de Vaca and his companions were the only Europeans to have actually 1 ived among the aboriginal Indians of south Texas. Later accounts are almost a 11 passing references made in connection with various duties of the Spanish colonialists. During the 18th and 19th centuries, the native groups were disp 1 aced by the Spanish from the south and the marauding Apache from the north. European diseases also played an important role in the destruction of native culture. Remnants of the native south Texas groups entered various Spanish missions in the area, including the missions at Guerrero, San Antonio de Bexar, and Goliad. It is obvious from the mission records that the groups were fragmented, displaced, and disoriented (Campbel1 1979, 1983; Campbe1 1 and Campbel 1 1985). 
By 1828, when Jean Louis Berlandier traveled through southern Texas, the only remaining Indian groups in the region were the Lipan Apaches, the Comanches, the Tonkawas, and a few surviving Karankawa along the coast. The Lipan Apache were forced into south Texas by the Comanches from the north. The Comanches actually only ventured into southern Texas to raid the Spanish and later Anglo settlements. The Tonkawa were a central Texas group that ranged into south Texas to hunt bison. By the 1870s, even these groups had been eliminated from south Texas. Today there are no known descendants of the aboriginal peoples who once lived in southern Texas.

\section{ABORIGINAL SOUTH TEXAS}

To generalize, the aboriginal cultural history of southern Texas can be viewed as a series of specialized hunting and gathering adaptations to a demanding environment. These specialized adaptations developed from a long culture history beginning at least 9000 years ago. Some of the groups present when the first Europeans chanced upon south Texas were probably direct descendants of the Paleo-Indian peoples who settled in the region. Outside influence through trade, migration, or the diffusion of ideas was probably minimal and restricted to similar peoples in adjacent regions. Northeast Mexico, the lower Pecos River area, and central Texas were the most important adjacent regions in terms of influence on and similarity to southern Texas groups. Population density probably remained low during al1 but the most favorable climatic conditions. Even during the most favorable climatic cycles the yearly climatic variations probably held the populations to relatively 1 ow densities. Most groups 1 ived a nomadic 1 ife style governed by the seasonal availability of resources. Plant resources probably provided a much greater amount of the subsistence than did animals. Small animals, insects, snails, and snakes probably contributed more to the daily diet than did 7 arger animals.

Social organization probably never involved much more than a band level society. The basic social group was probably the band (microband). The size of the microbands probably varied a great deal depending on subsistence patterns, climatic conditions, and territory size and location. Estimates of band sizes range from 30 (Hester and Hill 1975) to several hundred (Campbell 1983). Seasonal aggregation of related microbands into macrobands was governed by the availability of superabundant resources. The bands had territories centered on certain geographical features such as stream valleys or bay systems. Seasonal availability of favored resources often caused the bands to range over considerable distances and to develop oddly shaped territories such as the bilobate territory of the Mariames (Campbel1 and Campbel1 1981). Coastal groups remained on the coast year round and were wel 1 adapted to the marine environment. Inland groups had more varied adaptations dependent on climatic conditions, territory resources, and culture history.

Considerable interaction occurred between band groups. Related bands exchanged gifts, intermarried, shared territories, and camped together during certain seasons when superabundant resources were available. Most groups probably had patrilineal descent systems. Warfare was uncommon although certain groups were hostile to one another. Valuable or uncommon resources 
44 Hinojosa Site, 41 JW 8

were often traded between groups. Flint, flint tools, marine shel1s, shell ornaments and tools, bows, asphaltum, and red ochre are items that were common 1 y traded. Coastal groups traded with in 1 and groups from adjacent territories. 


\section{ARTIFACT ANALYSIS}

The artifactual materials recovered from the Hinojosa site were divided into the following material classes: 1ithics, prehistoric ceramics, baked clay, modified bone and shel1, and historic materials. The provenience of these materials can be found by referring to Appendix 1 . Additional nonartifactual materials such as mussel she $11 \mathrm{~s}$, faunal remains, and soil samples are discussed in Section VII.

\section{LITHICS}

Lithic materials make up the bulk of the cultural debris recovered from 41 JW 8. This is particularly significant when one considers the fact that very few 1 ithic resources are locally available, hence most of the 1 ithic materials at the Hinojosa site were brought in from many kilometers away. This section provides a discussion of the lithic materials and sources used by the peop $1 e$ that camped at $4 I \mathrm{JW} 8$ and a descriptive classification of the recovered 1 ithic artifacts.

\section{LITHIC MATERIALS AND SOURCES}

The Hinojosa site is located within an area of very 1 imited 1 ithic resources. The only usable 7 ithic materials available with in a kilometer of 41 JW 8 are calcium carbonate concretions and caliche exposed in erosional gullies on the ridge east of Chiltipin Creek. Over $99.9 \%$ of the 7 ithic artifacts (not including burned rock) recovered from $41 \mathrm{JW} 8$ are made of siliceous 7 ithic materials transported to the site from sources at 1 east $35 \mathrm{~km}$ distant. To the north, the nearest sources of siliceous materials occur some 50 to $60 \mathrm{~km}$ away, along the Nueces River. To the south and southeast, surface exposures of siliceous materials do not occur. The two closest sources of siliceous materials are the Nueces River some $35 \mathrm{~km}$ to the east-northeast and northwestern Duva 7 County some $45-50 \mathrm{~km}$ to the northwest of the Hinojosa site.

The Nueces River valley provides the nearest source of siliceous 1 ithic material to $41 \mathrm{JW} 8$. Chandler (1984) has recently documented the occurrence of at least two 7 ithic source areas along the Nueces River below Lake Corpus Christi. These two source areas, "pebble beach" and the "Piedras Crossing," have deposits of chert, silicified wood, and agate cobbles and gravels along with Targer pieces of sandstone. Based on a sample collected by Chandler (on file CAR-UTSA), most of the cobbles are oblong shaped and relatively small (1ess than $15 \mathrm{~cm}$ in length). Chert colors range from tan to gray to brown with darker colored thin cortex 1 ayers. Fine-grained, unflawed chert cobbles are less common than $f l$ awed, variable grain, poor quality chert cobbles. The silicified wood from these sources is very friable and poorly suited for chipped stone tools. Unusual materials such as quartzite and volcanic rocks may occur in small quantities. Most of the chert materials found at 41 JW 8 were probably derived from sources along the Nueces River.

Hil 1 top gravel exposures occur in northwestern Duval County northwest of Freer as well as other areas of south Texas farther to the west and north of Freer. The hilltop gravel exposures represent the remnants of gravel 1 ag 
deposits left behind tens of thousands of years ago by long vanished rivers. Today these gravels often occur miles away from and many meters above any modern stream.

Present in these hilltop exposures are smal1 we 11 -rounded cobbles and pebbles of various lithic materials, including chert, silicified wood, chalcedony, and igneous rocks. Overall, the hilltop exposures offer a greater variety and higher quality of 7 ithic materials than the Nueces River sources. Some overlap occurs. The Duval County cherts include the tan-gray-brown cherts typical of the Nueces River sources in addition to white chert and many exotic-colored cherts (red, yellow brown, and green). The fine-grained, glossy white chert seems to have been a favorite material based on surface collections in northwestern Duval County (4I DU 4, 41 DU 5, and 41 DU 6; notes on file CAR-UTSA) and in northeastern Duval County (McGraw, Van Note, and Jones n.d.). The silicified wood cobbles from Duval County tend to have more comp 1 ete rep 1 acement by silica, hence they are less friable than the Nueces River samples collected by Chandler. The presence of white chert, exotic-colored chert, and igneous materials in 1 ow percentages at $41 \mathrm{JW} 8$ may suggest that the Duval County 7 ithic sources were used less frequently than the Nueces River sources by the inhabitants of the Hinojosa site.

The following is a brief description of each distinctive 1 ithic material found at $41 \mathrm{JW} 8$ :

Chert: Also known as flint, chert is a cryptocrystalline siliceous material with conchodial fracturing properties that make it an ideal material for chipped stone tools. Most of the chert recovered from the Hinojosa site range from tan to gray to brown in color. The cortex layers are dark brown to almost black in color and tend to be thin and very hard. The curvature of the cortex on the flakes and cores from 41 JW 8 suggests that most chert cobbles were small in size. Artifacts and flakes of exotic-colored yel low brown chert were found in smal1 numbers. Many flakes and most artifacts have glossy waxy surfaces and/or pink to purple tinges that indicate thermal a)teration.

Thermal alteration, or heat treatment, is the purposeful improvement of siliceous 1 ithic materials through gradual and prolonged application of indirect heat (Purdy and Brooks 1971). Prehistoric heat treatment of siliceous materials was a very widespread practice in North America (Hester and Collins 1974; Epstein 1979). Black and McGraw (1985) provide references to the 1 arge body of 1 iterature that has been devoted to heat treatment. In general, heat-treated chert can be recognized by one or more of the following properties: (1) a change in color to a darker and/or redder (or pink or purplish) color; (2) a change to a waxy or greasy texture; and (3) a change in appearance to a vitreous ( $\mathrm{g}$ lassy) luster of a 11 flaked surfaces except the relic surfaces in existence prior to heat treatment (Hester and Col1 ins 1974; Skelton and Meredith 1977). These changes were noted on many chert artifacts from $41 \mathrm{JW} 8$, particularly the Perdiz arrow points.

White chert: As mentioned, white chert has been observed to be a favored material type in southeastern Duval County (McGraw, Van Note, and Jones n.d.). It should be noted that McGraw, Van Note, and Jones (n.d.) refer to this material as white chalcedony even though it is not transiucent. This 
writer does not use the term "chalcedony" to refer to a totally opaque siliceous material.

White chert is comparatively rare at $41 \mathrm{JW} 8$ but it is an important 1 ithic material for several of the bifacial tool types. The white chert recovered from $41 \mathrm{JW} 8$ is typically fine grain and glossy, with numerous tiny crysta1filled inclusions. The glossy appearance and sometimes greasy feel of many of the white chert artifacts may suggest heat treatment, al though the raw material is glossier than most types of chert in south Texas.

Silicified Wood: Petrified or silicified wood is a 1 ithic material formed by the replacement of wood by silica in such a way that the original form and cel1 1 structure are preserved. The Nueces River and Frio River val leys of south Texas are famous among rock collectors as source areas for silicified wood. A few chipped stone artifacts from $41 \mathrm{JW} 8$ are made from silicified wood.

Quartzite: Quartzite is a metamorphic rock that has a granular structure completely cemented by silica. Artifacts made from quartzite have a spark 1 ey appearance due to the individual quartz grains visible within the matrix. The grain size and appearance of this material have given rise to the colloquial description "sugar quartzite" that is often applied to quartzite artifacts. In western south Texas, quartzite was frequently used for a specific 7 ithic tool type, as defined by Hester, Gilbow, and Albee (1973), the Clear Fork tool. These authors suggested that quartzite was chosen over chert due to its hardness and durability. The source area for the sma 11 number of quartzite artifacts found at $41 \mathrm{JW} 8$ is not known.

Chalcedony: Chalcedony is a term used to describe a cryptocrystalline quartz that appears more translucent than ordinary chert. Chalcedony occurs in northwestern Duval County. A few artifacts and $f 1$ akes made of chal cedony were recovered from $41 \mathrm{JW} 8$. Milky colored, semitranslucent chalcedony is known colloquially as "moonstone" by rock collectors (Black and McGraw 1985). Several flakes and bifacial fragments from 41 JW 8 are made from moonstone.

Calcium Carbonates: Calcium carbonate, $\mathrm{CaCO}_{3}$ or calcite, is the rock-forming mineral that is the principal constituent of 1 imestone and caliche. These rocks are the only naturally occurring 1 ithic materials in northern $\mathrm{J}$ im Wel $1 \mathrm{~s}$ County (except for pebble and sand-sized materials). Calcium carbonates were used for ground stone tools, abrading tools, and for hearth rocks at $41 \mathrm{JW} 8$. Erosional gullies on the ridges overlooking Chiltipin Creek east of the site provide exposures of calcium carbonate.

Sandstone: Sandstone is a sedimentary rock composed of cemented sand grains. Silica and calcium carbonate are common cementing agents. Surface exposures of sandstone occur along the Nueces River and in northwestern Duval County. Sandstone was the preferred material for ground stone tools at 41 JW 8 as well as many other southern Texas archaeological sites.

Volcanic Materials: Several hammerstone fragments and chipped stone tools from 41 JW 8 are made of purple or brown igneous (volcanic) materia1. The exact composition of these materials is unknown. The purple material has a finer matrix texture, smaller phenocrysts, and choncoidal fracturing. The 
brown material has a coarser matrix texture with 1 arger and more abundant phenocrysts and 1 acks chonchodial fracturing properties. The igneous materials from the Hinojosa site were probably derived from the northwestern Duval County source area.

\section{LITHIC CLASSIFICATION SYSTEM}

The 1 ithic materials from 41 JW 8 are classified according to the morphological and technological attributes commonly used by archaeologists in the region. Most of the artifact classes and types have functional differences that are related to morphology and technology. In other words, most 1 ithic artifacts were made a certain way in a certain shape to perform a specific task or range of tasks. Functional considerations for most of the finished artifact types are discussed in considerable detail based on microscopic wear pattern studies.

The classification of the 41 JW 8 lithics was simplified by the facts that only one cultural group is believed to be responsible for al 1 the material and the range of artifact types is rather 1 imited. This is in stark contrast to the situation often faced with multicomponent sites where the analyst must deal with 1 ithics produced over thousands of years by many different groups (cf. B1 ack and McGraw 1985).

The Hinojosa site 1 ithic material can be divided into three major classes based on the degree and type of modification of the material. These classes are unmodified 1 ithic material, chipped stone, and nonchipped modified stone. Each class can be divided into subclasses that can be divided into groups that can be divided into forms. The chipped stone class is much 1 arger and more complex than any of the other classes. Table 1 shows the complete breakdown of the lithic classification system. Most artifact groups or forms were given alphanumeric artifact codes. The artifact codes are used where necessary throughout this report to simplify references to specific artifact types.

\section{UNMODIFIED LITHIC MATERIAL}

\section{Pebblese Rockse and Gravels}

Small quantities of rounded pebbles, gravels, flakes, and calcium carbonate rocks were found throughout the site deposits. The grave1-sized rocks ( $>64 \mathrm{~mm}$ ) are almost al1 calcjum carbonate concretions. These were most common in the lower excavation levels. The pebble-sized rocks (4-64 $\mathrm{mm}$ ) are predominately stream worn (rounded to wel1-rounded) pieces of chert and other siliceous materials. These represent redeposited alluvial materials. Several unmodified calcium carbonate slabs 10-15 cm in diameter were recovered. These could represent incipient ground stone artifacts or, more 1 ikely, rocks brought to the site for use as hearth stones or anvils used to break open 1 ong bones. One slab was assocjated with Feature 3, a bone cluster. 
TABLE 1. LITHIC CLASSIFICATION SYSTEM

Artifact

Artifact Code

UNMODIFIED LITHIC MATERIAL

Pebbles, Rocks, and Gravels

Asphal tum Pebble

Burned Rock

BR

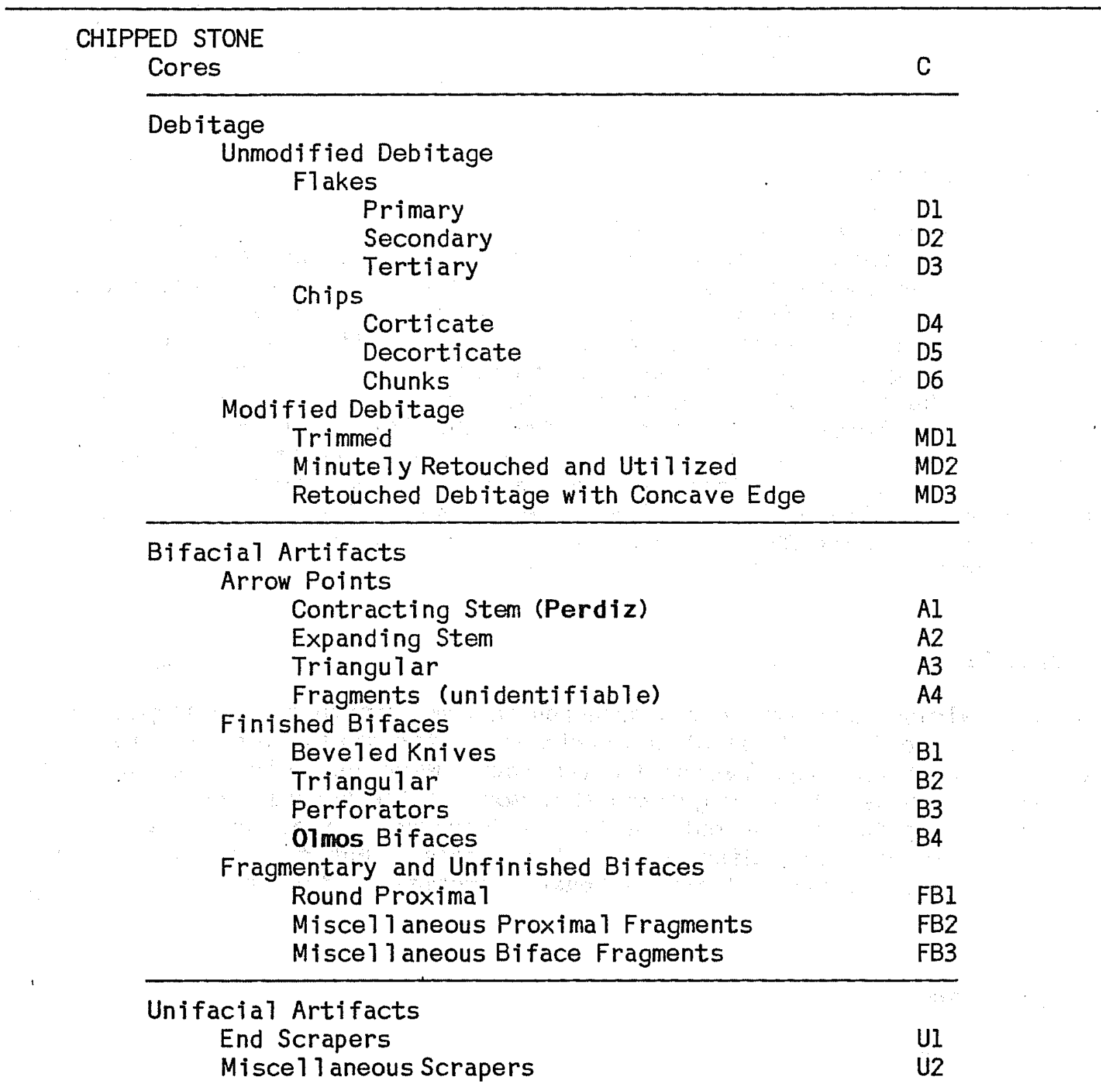

NONCHIPPED MODIFIED STONE

Ground Stone 
A number of smal1 flakes were recovered from the upper levels that have rounded edges and smoothed flake ridges. These seemingly appear to be stream-worn flakes. An alternative explanation that seems more 1 ike $1 y$ in view of the ephemeral nature of Chiltipin Creek was suggested by Kenneth $M$. Brown. Brown (personal communication) has observed identically worn flakes eroding out of cow paddies (dung) in southern Texas. The flakes are apparently accidentally ingested by cattle while they are eating grasses growing on archaeological sites. The flakes become uniformly rounded and smoothed while passing through the bovine digestive system. The redeposited flakes become reincorporated into the site deposits as the cow dung breaks down. Tending to support this explanation are the facts that most of the worn flakes were recovered in the upper disturbed levels at $41 \mathrm{JW} 8$, and Clemente Hinojosa ran cattle on the property for many years.

\section{Asphaltum Pebble}

A small pebble-sized piece of asphaltum was found at $41 \mathrm{JW} 8$ (Lot 372). This piece is rounded and measures about $8 \mathrm{~mm}$ in length and weighs $0.2 \mathrm{~g}$. The smooth, rounded exterior gives the pebble a natural weathered appearance identical to modern examples of asphaltum that are often found along the beaches of the Texas coast. Under 20-30X magnification, small subrounded to we11-rounded quartz sand grains were observed embedded in microscopic folds in the aspha1tum. It is suggested that this artifact represents beach asphaltum collected by or traded to the inhabitants of the Hinojosa site. Asphaltum decoration has been documented on several artifact classes present at the site, including pottery and the sandstone pipe. Asphaltum pieces have been recovered from several inland sites in south Texas, including two Late Archaic sites in the Choke Canyon Reservoir area, 41 MC 55 (Ha 11, Black, and Graves 1982) and 41 LK 201 (Hightey 1986).

\section{Burned Rock}

Burned calcium carbonate rocks occurred in comparatively high frequencies in the site deposits. Most of the rocks are quite smal1 in size (1ess than 5 $\mathrm{cm}$ in diameter). The 1 arger burned rocks were usually associated with cluster features. It is suggested that most of the burned rocks are remnants of rocks used to 1 ine or outline hearth features. It is possible that some burned rocks represent discarded boiling stones, but the extremely fragile nature of most of the calcium carbonate material in the area casts doubt on this possibility.

\section{CHIPPED STONE}

(C) Cores (N=35; Fig. 3)

A core is the portion of a chert cobble that remains after the removal of one or more flakes. In other words, cores are the by-product of flake production. Cores tend to be blocky in shape and 1 ack the careful 1 y shaped twosided configuration of bifaces. Cores can be sorted into a number of categories based on attributes, such as the number of flake removals (scars), 
direction of $f l a k e$ removals, size, and types of $f 7$ ake platforms. The cores from $41 \mathrm{JW} 8$ are only sorted by size because very 1 ittle variation or distinct patterning of other attributes was observed. The cores are sorted into size classes based on the minimum diameter: three cores are less than $2.5 \mathrm{~cm}$ in diameter, 29 are between 2.5 and $5 \mathrm{~cm}$ in diameter, and three cores are between 5 and $7.5 \mathrm{~cm}$ in diameter. Table 2 presents attribute data for each core.

The 35 cores recovered from 41 JW 8 could almost al1 be categorized as "exhausted cores." That is to say, a 1 most a 11 possibilities for useful flake removal have been exhausted. The Hinojosa site cores can be further characterized as generally small in size with multidirectional flake removals. Single facet and natural platform types are the most common, but multifaceted platforms are also present.

The collection of cores from 41 JW 8 can be characterized as a group of small exhausted cores that have had every useful flake removed from every possible platform and direction. The cores represent the maximum utilization of a scarce resource. Several of the hammerstones from 41 JW 8 are recycled exhausted cores. In contrast, sites in areas with plentiful chert, such as the sites in the Choke Canyon Reservoir area (Hal1, Black, and Graves 1982), often have 1 arger cores that were discarded 1 ong before they were exhausted. Five of the cores appear to be modified; one by hammerstone wear and four by trimming. These represent recycled artifacts.

\section{Debitage}

The definition of debitage is the fragments of chipped stone that are removed from larger pieces of chert such as cores or bifaces. Most of the debitage represent the waste products of chipped stone tool manufacture. Unmodified debitage pieces are the fragments of chert that 7 ack definite evidence of modification. Modified debitage pieces are the fragments of chipped stone that have been further chipped or altered through use.

\section{Unmodified Debitage}

The unmodified debitage category includes a 11 chipped stone debris that 1 acks evidence of modification (further chipping or use). This debris is sorted into the following: primary flakes, secondary flakes, tertiary flakes, corticate chips, decorticate chips, and chunks. The two considerations used to distinquish between the debitage groups are whether or not a piece of debitage has a platform ( $f 1$ ake vs. chip) and how much cortex remains on the exterior (ventra1) flake or chip surface. A flake is a purposeful1y removed piece of chipped stone that has a striking platform, a bulb of percussion, and dorsal (exterior) and ventral (interior) surfaces. A chip is a flake fragment that lacks a striking platform. 


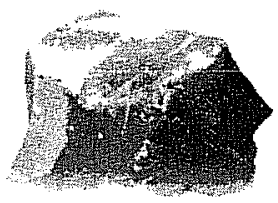

a

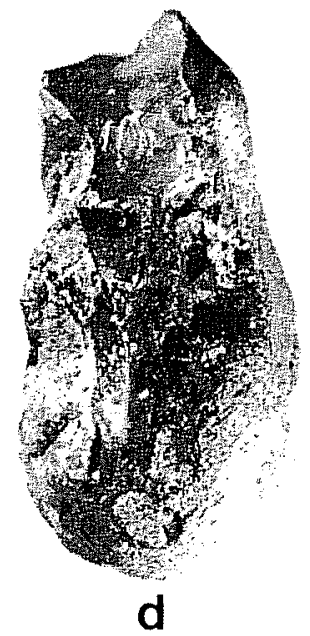

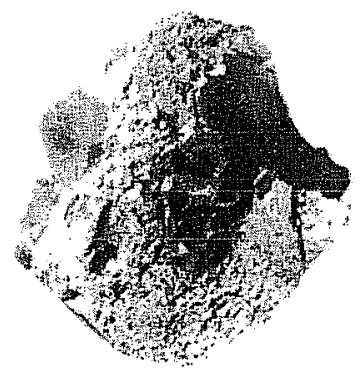

b

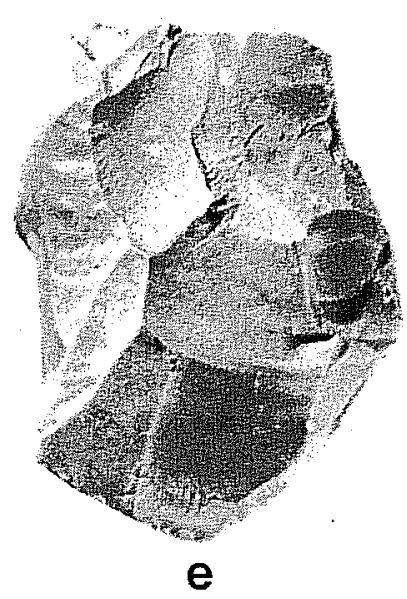

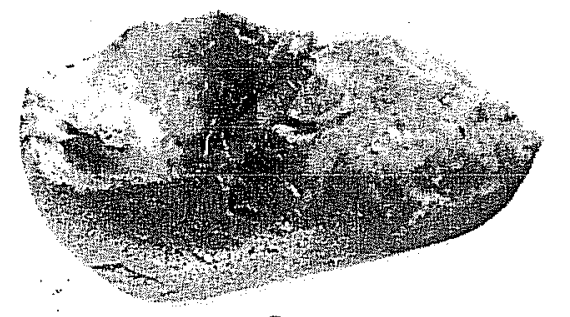

C

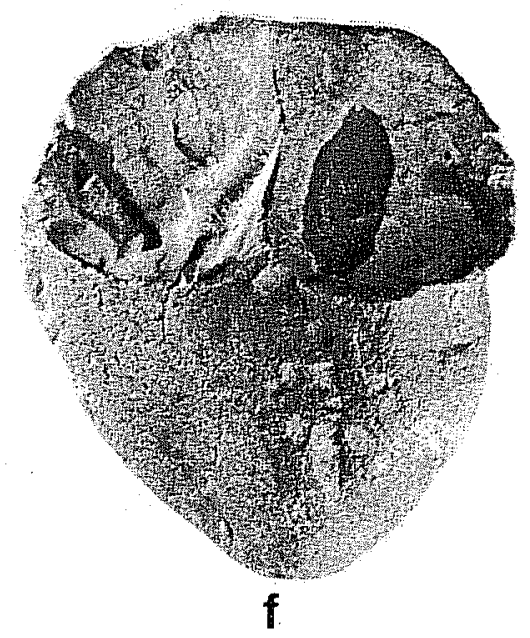

g

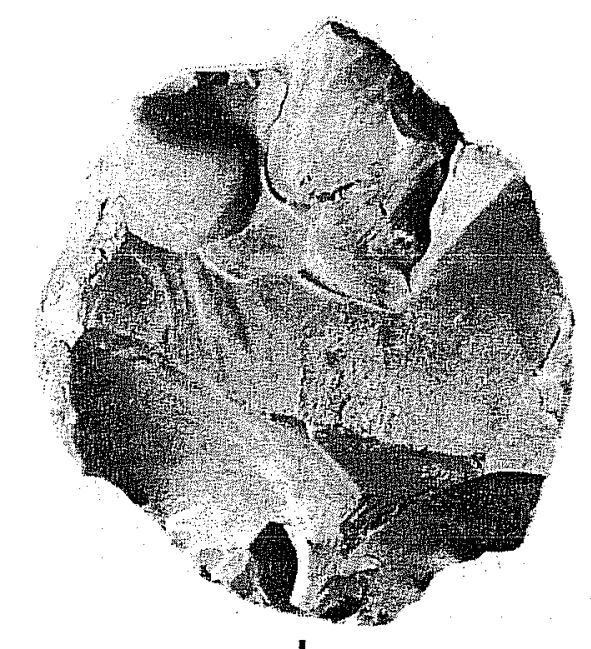

h

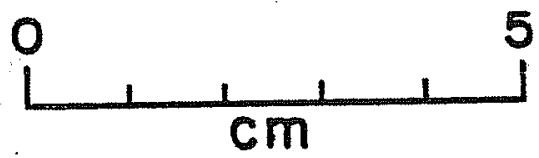

Figure 3. Cores (c). Lot numbers: a, 195; b, 285; c, 179; d, 189; e, 437; $f, 342 ; g, 264 ; h, 344$. 
TABLE 2. CORE ATTRIBUTE DATA

\begin{tabular}{|c|c|c|c|c|c|c|}
\hline \multirow{2}{*}{$\frac{\begin{array}{l}\text { Lot } \\
\text { Number }\end{array}}{56}$} & \multirow{2}{*}{$\begin{array}{l}\text { Size } \\
\text { Class }\end{array}$} & \multirow{2}{*}{$\frac{\text { Cortex }}{1}$} & $\begin{array}{l}\text { Flake } \\
\text { Removals }\end{array}$ & $\begin{array}{l}\text { Removal } \\
\text { Direction }\end{array}$ & $\begin{array}{l}\text { Platform } \\
\text { Types }\end{array}$ & \multirow{2}{*}{$\frac{\text { Modification }}{3}$} \\
\hline & & & 2 & 3 & 2,3 & \\
\hline 62 & 2 & 2 & 2 & 3 & 2 & 1 \\
\hline 62 & 2 & 1 & 3 & 1 & 2,1 & 1 \\
\hline 62 & 2 & 1 & 3 & 3 & 2,3 & 1 \\
\hline 62 & 3 & 1 & 3 & 3 & 2 & 1 \\
\hline 74 & 1 & 1 & 2 & 3 & 2 & 1 \\
\hline 107 & 3 & 1 & 3 & 3 & 1,2 & 1 \\
\hline 110 & 2 & 2 & 3 & 2 & 2 & 2 \\
\hline 124 & 2 & 1 & 3 & 3 & $1,2,3$ & 1 \\
\hline 131 & 2 & 1 & 3 & 3 & 1,2 & 1 \\
\hline 142 & 2 & 2 & 2 & 2 & 2,3 & 1 \\
\hline 173 & 2 & 1 & 3 & 3 & 2 & 1 \\
\hline 179 & 2 & 1 & 3 & 2 & 2,3 & 1 \\
\hline 189 & 2 & 1 & $?$ & 1 & 1 & 1 \\
\hline 195 & 1 & 2 & 3 & 3 & 2,3 & 1 \\
\hline 240 & 2 & 1 & 2 & 3 & 1,2 & 2 \\
\hline 240 & 2 & 1 & 3 & 3 & 2,3 & 1 \\
\hline 264 & 2 & 1 & 3 & 3 & 1,2 & 1 \\
\hline $281-10$ & 2 & 1 & 3 & 3 & 1,2 & 2 \\
\hline 284 & 2 & 1 & 2 & 3 & 1,2 & 1 \\
\hline 285 & 2 & 1 & 3 & 3 & 1,2 & 1 \\
\hline 312 & 2 & 1 & 2 & 3 & 1,2 & 1 \\
\hline 313 & 2 & 1 & 2 & 3 & 1,2 & 1 \\
\hline 320 & 2 & 1 & 3 & 3 & 2,3 & 1 \\
\hline 321 & 1 & 2 & 3 & 3 & 2,3 & 1 \\
\hline 326 & 2 & 2 & 3 & 3 & 2,3 & 1 \\
\hline 335 & 2 & $?$ & 3 & 3 & 2 & 1 \\
\hline 342 & 2 & 1 & 1 & 1 & 1 & 1 \\
\hline 344 & 2 & 1 & 2 & 3 & 1,2 & 1 \\
\hline 344 & 3 & 1 & 3 & 3 & 1,2 & 1 \\
\hline 417 & 2 & 1 & 2 & 3 & 1,2 & 1 \\
\hline 437 & 2 & 1 & 3 & 3 & 2,3 & 1 \\
\hline 438 & 2 & 2 & 3 & 3 & 2,3 & 1 \\
\hline 515 & 2 & 1 & 2 & 3 & 2 & 2 \\
\hline 519 & 2 & 1 & 2 & 3 & 2 & 1 \\
\hline \multicolumn{2}{|l|}{ Size } & Cortex & \multicolumn{2}{|c|}{ Flake Removals } & \multicolumn{2}{|c|}{ Removal Direction } \\
\hline \multicolumn{2}{|c|}{$\begin{array}{l}1=<2.5 \mathrm{~cm} \\
2=2.5-5 \mathrm{~cm} \\
3=5-7.5 \mathrm{cml} \\
4=>7.5 \mathrm{~cm}\end{array}$} & $\begin{array}{l}1=\text { present } \\
2=\text { absent }\end{array}$ & \multicolumn{2}{|c|}{$\begin{array}{l}1=1-2 \\
2=2-5 \\
3=>5\end{array}$} & \multicolumn{2}{|c|}{$\begin{array}{l}1=\text { single direction } \\
2=\text { bidirectional } \\
3=\text { multidirectional }\end{array}$} \\
\hline \multicolumn{2}{|c|}{ Platform Types } & \multicolumn{3}{|l|}{ Modification } & 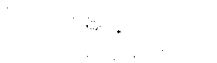 & \\
\hline $\begin{array}{l}1=\text { nat } \\
2=\text { sin } \\
3=\text { mu } 1\end{array}$ & $\begin{array}{l}1 \\
\text { facet } \\
\text { acet }\end{array}$ & $\begin{array}{l}1=\text { none } \\
2=\text { trimming } \\
3=\text { hammerst }\end{array}$ & tone & & . & . \\
\hline
\end{tabular}


(D1) Primary Flakes $(N=103)$

Primary $f l a k e s$ are the first $f l a k e s$ removed from a chert cobble. They have cortex (the weathered exterior surface of a cobble) entirely covering the ventral surface. Small patches of missing cortex from the ventral face were disregarded when it was obvious these patches were the result of platform shatter or postchipping damage:

\section{(D2) Secondary Flakes ( $N=1564)$}

Secondary flakes have cortex only on a portion of the ventral surface or on the platform. As the name implies, secondary flakes are removed from chert cobbles after the primary flakes and usually before the tertiary flakes.

\section{(D3) Tertiary Flakes $(N=3585)$}

Tertiary or interior flakes do not have any cortex. Tertiary $f l a k e s$ are commonly smaller and much more numerous than primary or secondary flakes.

(D4) Corticate Chips ( $N=2319)$

Corticate chips have some cortex on the ventral surface.

(D5) Decorticate Chips $(N=4507)$

Decorticate chips do not have any cortex.

(D6) Chunks $(N=246)$

Chunks are angular pieces of chipped stone that do not have a platform or we11-defined ventral or dorsal surfaces. Chunks are often battered chert pieces that are no longer recognizable as chips or flakes. Chunks can also represent angular shatter fragments created when $f l$ awed chert is knapped.

\section{Modified Debitage}

The modified debitage category consists of $f 1$ akes, chips, and chunks with edges that have been altered or modified after removal from the parent mass (core or biface). The regional 1 iterature contains a number of analytical or descriptive terms that have been applied to modified debitage, including trimmed flakes, retouched flakes, utilized flakes, and edge-damaged flakes. The view taken here is that it is difficult if not impossible to easily distinguish between flakes with minutely retouched edges, flakes with utilized edges (worn through use), and flakes with damaged edges. Detailed wear pattern studies would be necessary to begin to meaningful1y differentiate between these categories of edge modification. 
Flake edges are characteristically sharp, thin, and fragile. Many factors unrelated to prehistoric culture cause damage to flake edges, such as agricultural modification (clearing and plowing), cattle and horse tromp, trowe 1 damage, screen damage, and bag damage. Recent edge modifications, such as that occurring during excavation, typically result in fresh looking broken edges. Obviously recent edge-damaged debitage was purposefully disregarded during the sorting process. Similarly, debitage with random nicks or irregular broken edges were not considered modified. Tiny chips with very smal1 amounts of edge modification were also disregarded. The intent was to categorize as modified on 1 y those pieces of debitage that were prehistorical$1 \mathrm{y}$ and purposefulty modified.

The modified debitage pieces from $41 \mathrm{JW} 8$ are described in three groups. It should be noted that overlap occurs between the first group, trimmed debitage, and some of the minimal1y modified unifaces. It should also be noted that occasional trimmed flakes appear to have specialized morphological attributes, for example, a beaked projection. These are not assigned to a separate group due to the very small number of artifacts in question.

\section{(MD1) Trimmed Debitage $(N=51)$}

Trimmed debitage pieces, for the purpose of definition, are considered those flakes, chips, and chunks that have flaked edges with at least five en echelon (side by side) $f 1$ ake removals at 1 east $2 \mathrm{~mm}$ in 1 ength. If $\mathrm{flake}$ removals cover most of both faces, then the artifact is considered a biface. If the $f l$ ake removals are only on one face and form a regular edge that significantly alters the original shape of the flake, then the artifact is considered a uniface. This category commonly includes both incipient bifaces that were never completed and $f l$ akes with one or more regular edges that have been $f 7$ aked to form a working tool edge. It is often difficult to distinguish between these two categories.

The MD2 category (minutely retouched and utilized debitage) is by far the most numerous type of trimmed debitage in the Hinojosa site 1 ithic collection. A1 1 types of flakes and chips are purposeful1y trimmed. Trimmed chunks are uncommon. Larger flakes, particularly secondary flakes, tend to be carefuliy trimmed more often than smaller tertiary flakes and chips.

\section{(MD2) Minutely Retouched and Utilized Debitage $(N=776)$}

The MD2 category contains flakes, chips, and chunks with edges that have minute retouch, utilization, or edge damage for at least five continuous mil1imeters. In other words, pieces of debitage with irregular edge modification are nat included. This group forms the most numerous tool category at $41 \mathrm{JW}$ 8. MD2 specimens are believed to represent informal flake tools. These informal flake or debitage tools are simply pieces of debitage that were picked up from discarded waste and used with 1 ittle or no special preparation. Typical1y, these tools may have been used to perform cutting, incising, scraping, and sawing functions for a limited time (single use episodes?) and then discarded. The specific function that a given tool was used for is difficult to determine even with microwear analysis, due to the 
very short-term nature of most of the hypothesized tool functions. A f1ake used for two minutes to sharpen a stick is not going to develop much wear.

A1 1 types and sizes of debitage occur in the MD2 category. Due to the ephemeral nature of the modification, many pieces of debitage classified as unmodified would probably be classified as minutely retouched and utilized if examined under magnification.

\section{(MD3) Retouched Debitage with Concave Edge ( $N=43$ )}

The MD3 category consists of modified debitage specimens that have a retouched concavity (semicircular notch) on at least one edge. $F 1$ akes or chips with irregular concavities or concavities formed by a single blow are not included in this group. Similar artifacts are usually referred to as "spoke shaves." It is often suggested that spoke shaves were used to smooth arrow shafts. The 41 JW 8 MD3 specimens are not uniform and vary consider$a b 1 y$ in the size and shape of the concave edge.

\section{Bifaclal Artifacts}

Bifaces are two-sided pieces of chert that have been shaped by flaking on both faces. Most of the bifaces from 41 JW 8 are flake bifaces. That is to say, the bifaces were made from flake blanks rather than from an entire cobble (core biface). This is evidenced by the overall small size of most of the bifacial artifacts and the presence of $f 1$ at $f 1$ ake plane remnants on many specimens. A few of the larger bifaces may be core bifaces.

The bifacial artifacts are divided into several functional and morphological groups. The smallest bifaces are arrow points. The distinctive size and shape of the arrow points from $41 \mathrm{JW} 8$ leave 1 ittle doubt as to their functional identification. The 1 arger complete bifaces and fragments of complete bifaces are described under the heading "Finished Bifaces." Four morphologically distinct groups of finished bifaces are defined. These four groups represent tool types that have been previously recognized in southern Texas. Functional differences are suggested for most groups based on morphology and microscopic examination although some functional over $1 \mathrm{ap}$ occurs.

The remaining bifacial artifacts are unfinished and fragmentary and do not fit into wel1-defined groups. These are divided into groups based on general morphological similarities. These bifacial artifacts were not microscopically examined.

\section{Arrow Points}

\section{(A1) Contracting Stem (Perdiz) ( $N=99)$}

The Al category consists of complete and identifiable fragments of sma 11 contracting stem arrow points (Figs. $4 ; 5, a-n)$. The b 1 ades are triangular with straight or rarely concave (recurved) or convex edges. The distal tips 
are usually very sharp when preserved. The blades have very distinct shoulders that usually form downturned prominent barbs. A few specimens have right angle or rounded shoulders. The stems usually contract gradually with a pointed or rounded base. Three specimens have atypical stems that slightly expand before contracting ( $F i g .5, a-C)$. These may be similar to "bulbar stem" points (Corbin 1963, 1974). Some crude arrow points (Fig. 5,d-f) appear to have never been completed. These are classified as Perdiz points rather than as cliffton. The occurrence of a small number of obviously unfinished arrow points along with a much 1 arger number of finished arrow points makes it clear that the Cliffton type has little validity (see High ley, Graves, and Judson 1978; Black and McGraw 1985).

The Perdiz points from 41 JW 8 are typical1y made on heat-treated tertiary percussion $f l$ akes using pressure flaking. No evidence of blade technology was observed. Flake platform remnants occur on both the distal and proximal ends. Over 90\% of the complete specimens exhibit glossy flake scars, a greasy feel, and/or the pink discoloration typical of heat-treated chert. Many specimens ( $F i g .5, g-i$ ) have 1 arge remnant $f 1$ ake $p l$ anes on one or both blade faces that have been minimally modified. Virtually all of the stems have been completely flaked on both faces. Edge beveling was often used to shape the arrow points and to resharpen broken blades. Several examp 1 es (Fig. $5, i, m, n$ ) have stubby, reworked blades.

Sixteen stem fragments are classified as Perdiz points based on a comparison with the larger number of complete or nearly complete specimens. These stems (Fig. 5,j-1) are careful1y shaped and bifacial1y worked, leaving no doubt as to their identity. The identification of these same types of fragments as Perdiz may not be possible at sites where many other types of arrow point fragments are in the collection. At $41 \mathrm{JW} 8$, the Perdiz arrow points are the only artifact type that has a thin, narrow, bifacially shaped pointed segment. When only the lower pointed proximal tip of the stem remains, they are classified as A4 specimens (miscellaneous arrow point fragments) due to the possible confusion with distal fragments. Special studies were made of the stem width measurements and Perdiz arrow point breakage patterns (see Section VII: Perdiz Arrow Point Special Studies).

Perdiz Metric, Attribute, and Wear Pattern Data

A careful macroscopic and icroscopic study was done of 34 of the most complete Perdiz points. Tak ?e 3 presents the results of this study. Each of the major attributes of the Perdiz points is discussed.

Metric Data: Each of the j4 points was measured and weighed. In cases where a smal1 portion of the artifact is missing, the measurements reflect the estimated dimension based on the assumption that the missing section is similar to complete specimens (i.e., the artifact was assumed to be symmetrica1). The weight is not added to because the missing sections are mostly very tiny barb or tip sections. The Perdiz points show considerable variation in size although the standard deviations were not calculated. Length ranges from 14 to $37 \mathrm{~mm}$ and averages $22.9 \mathrm{~mm}$. Width ranges from 10 to $24 \mathrm{~mm}$ and averages $13.2 \mathrm{~mm}$. Thickness is less variable (probably due to the 


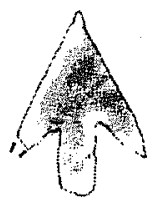

a

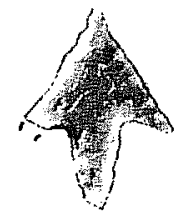

g

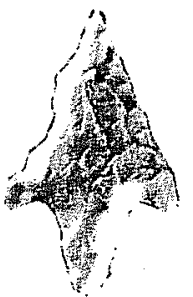

m

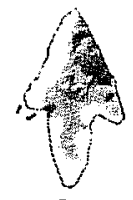

b
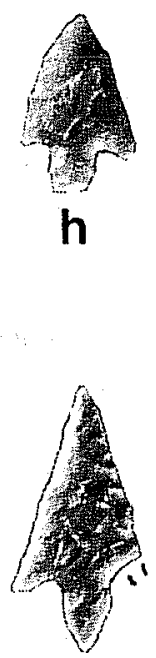

n
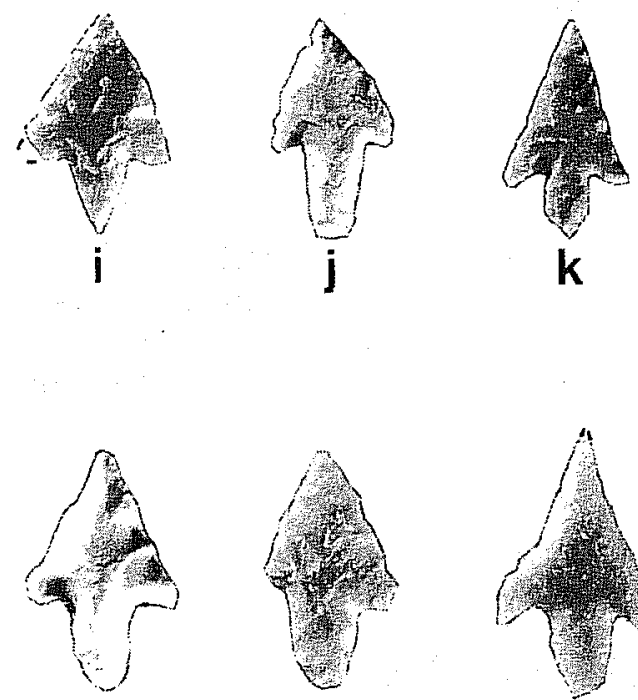

p

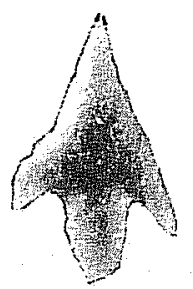

q
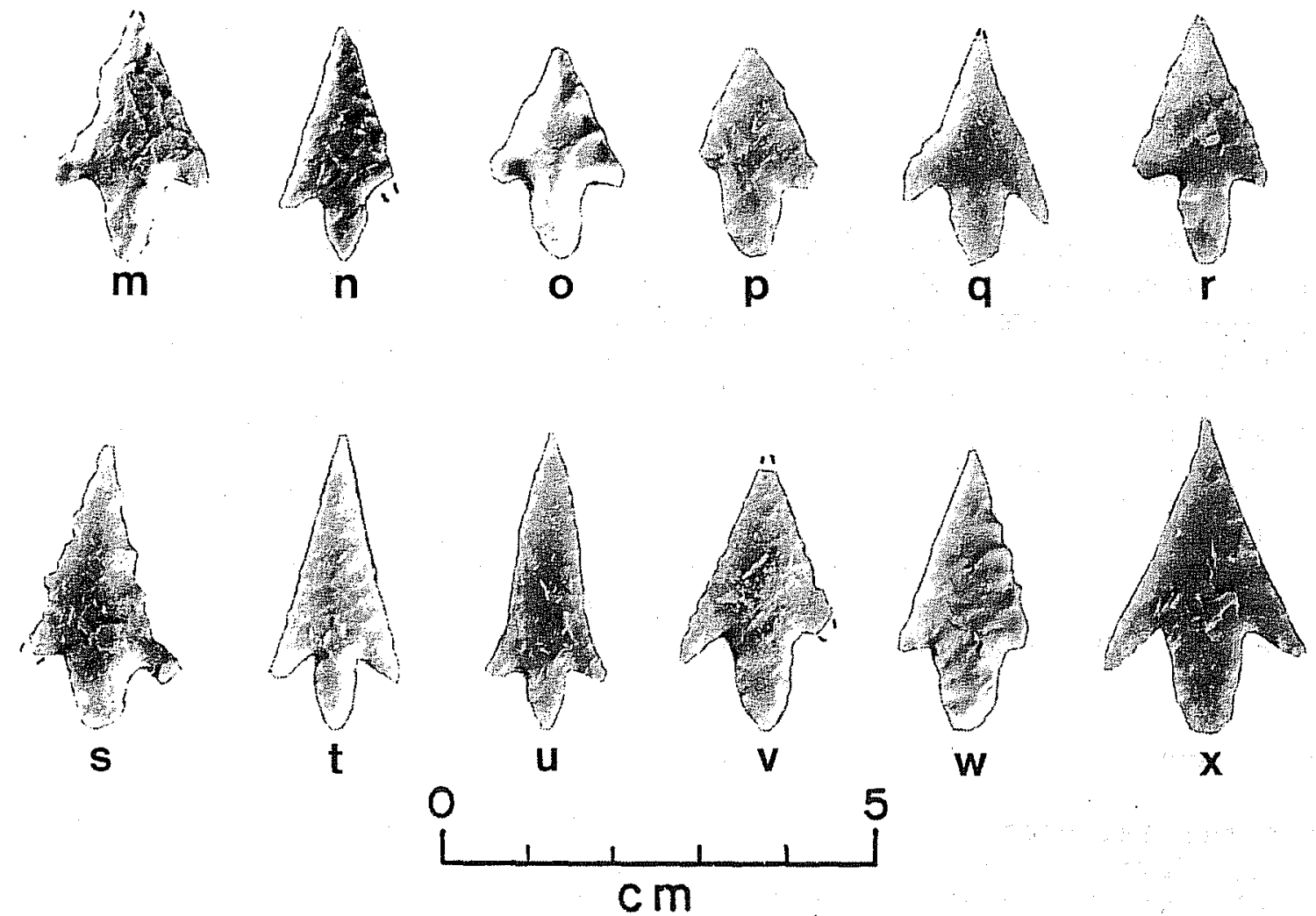

Figure 4. Perdiz Arrow Points (A1). Lot numbers: a, 316; b, 443; c, 312; d, 245; e, 327; f, 429; g, 443-1; h, 435; i, 437; j, 312; k, 429; 1,476 ; $\mathrm{m}, 157 ; n, 450 ; 0,456 ; \mathrm{p}, 259 ; \mathrm{q}, 445 ; \mathrm{r}, 523 ; \mathrm{s}, 107 ; \mathrm{t}, 485-5 ; \mathrm{u}, 110$; $v, 321 ; w, 294-5 ; x, 67$. 
fact that most were made on sma 11 , thin $f 1$ akes), and ranges from 1.8 to $5.0 \mathrm{~mm}$ and averages $2.8 \mathrm{~mm}$. Weight ranges from 0.3 to $1.5 \mathrm{~g}$ and averages $0.72 \mathrm{~g}$. Stem width (measured at top of stem) ranges from 3.3 to $8.8 \mathrm{~mm}$ and averages $5.6 \mathrm{~mm}$. Stem 1ength ranges from 4.2 to $11.7 \mathrm{~mm}$ and averages $7.4 \mathrm{~mm}$.

Chert Description: Most of the Perdiz points examined are made of fine grain, heat-treated chert. Tan, brown, and gray are the most numerous colors of chert, followed by pink, yellowish, and white. Over half of the specimens appear to be definitely heat treated (18), and eight others may be heat treated. Thus, the 34 specimens are for the most part made of good quality chert that was treated to improve the flaking quality. The illustrated specimens in Figure 4 show the fine workmanship of many of the $41 \mathrm{JW} 8$ Perdiz points.

Distal Morphelogx: Over half (18) of the complete specimens still have distal tips that are sharp to the touch. Six of the remaining specimens have noticeably dul 1 tips, while the others have fractured or intermediate tip morphologies.

Blade Morphology: Six of the specimens have serrated edges. Most of these are only partially or slightly serrated. Thirteen have beveled blade edges. Edge beveling is a major blade flaking technique and is necessary due to the extreme thinness of many of the blade edges (i.e., the edges were too thin to biface). Edge beveling is commoniy present on resharpened specimens. Based on obvious changes in edge angle, flaking technique, and blade shape, at least five of the specimens appear to have been resharpened.

Manufacture: Twenty-six specimens are completely bifacial. The remaining specimens have flake plane remnants on one (12) or both (7) sides. Platform remnants are present on the distal or proximal end of several specimens.

Microwear: The wear pattern study of the 34 Perdiz points involved a low power (10-40X) microscopic examination of all specimens followed by a high power (50-200X) microscopic look at four specimens with the heaviest wear. The major wear patterns observed are light to moderate blade edge and facial ridge rounding and polish, edge attrition, stem grinding, and stem edge and facial rounding and polish. In contrast to the end scrapers, the Perdiz points have neither heavy use wear nor consistent wear patterns. Instead, most Perdiz points appear to have comparatively little definite wear. The wear patterns that are present vary to some extent from specimen to specimen. Of the 34 specimens, seven have definite use wear, 11 have possible use wear, 12 are not worn, and four are indeterminate ( $p 10$ wamage prevented accurate use assessment).

One problem with Perdiz point microwear study is the difficulty encountered in distinguishing between edge attrition and abrasion due to use and edge damage caused by manufacture or resharpening. A number of specimens have edge-damaged blade edges that have crushing, rounding, and various types of microfractures that appear to this author to be the result of edge grinding, partial flaking, and edge resharpening rather than use wear. 


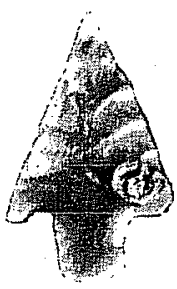

a

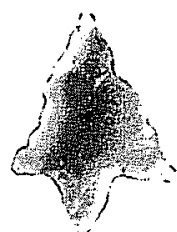

g

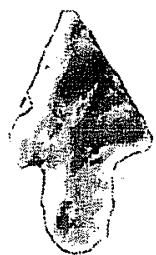

b

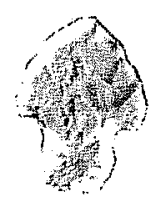

C

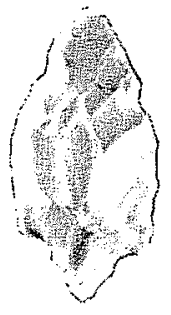

d

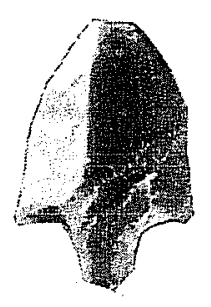

e

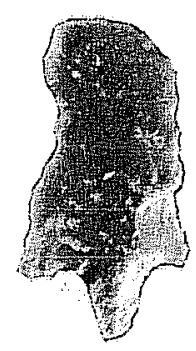

$f$

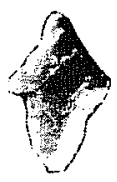

m

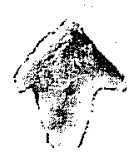

n

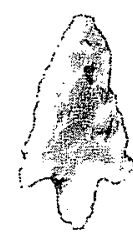

h
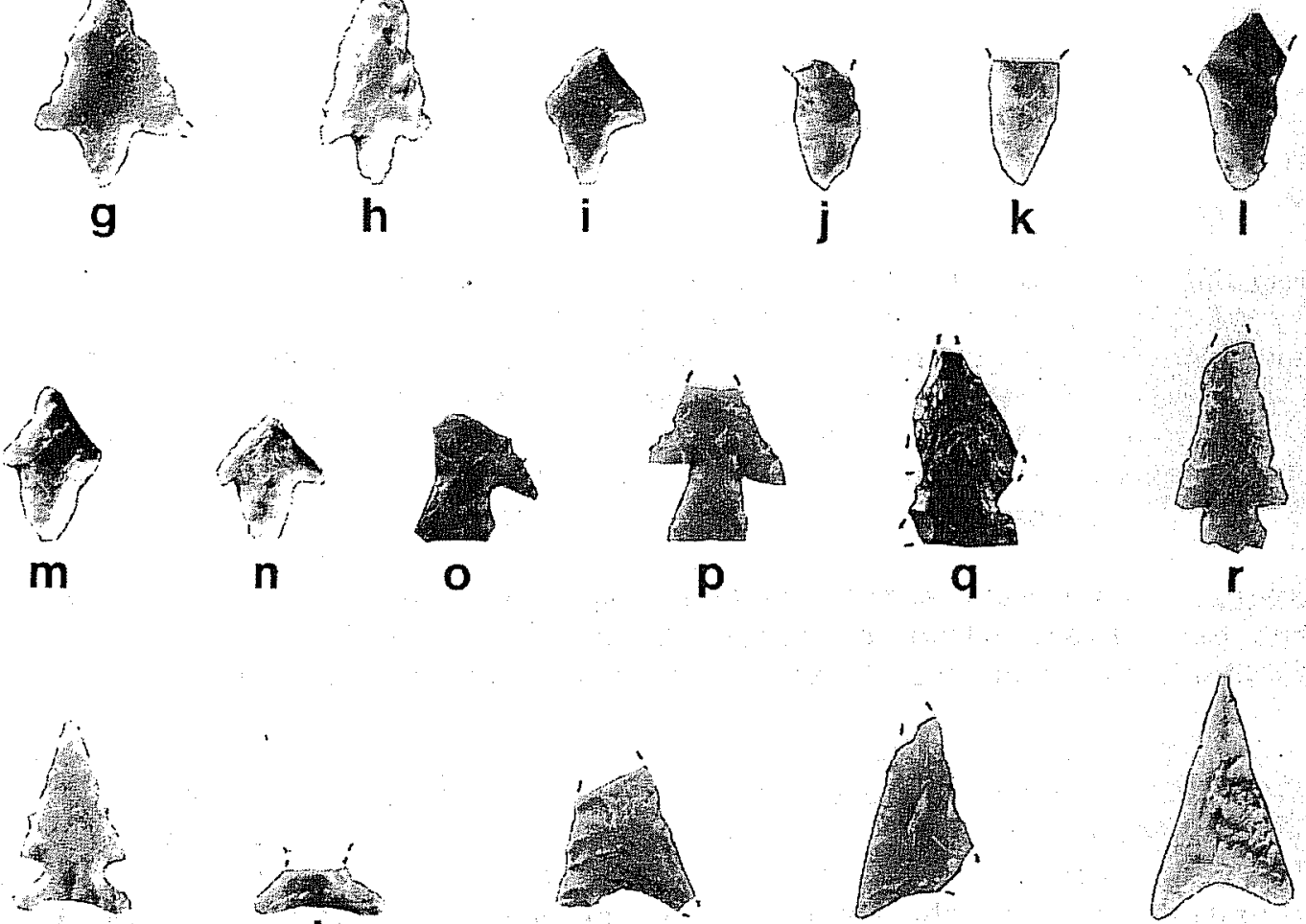

S

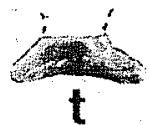

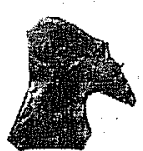

0

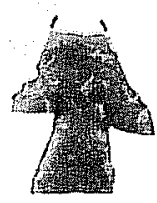

$p$

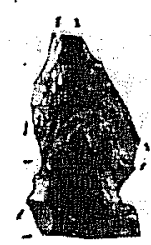

q

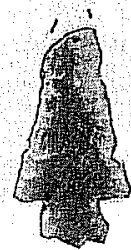

$r$
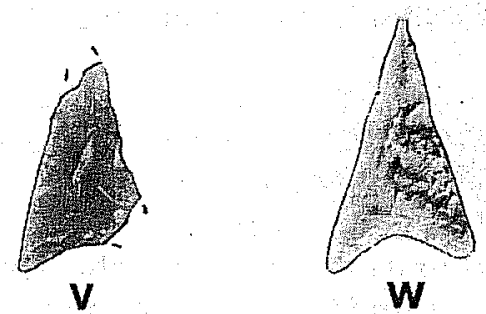

w

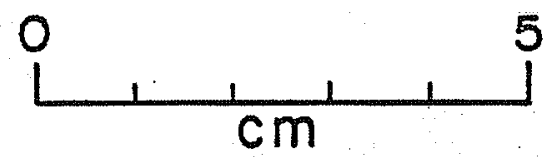

Figure 5. Arrow Points. a- $n$, Perdiz. (Al); o- $r$, expanding stem with straight bases (A2:1); s,t, expanding stem with concave bases (A2:2); u-w, triangular (A3). Lot numbers: a, 523; b, 300; c, 443; d, 226; e, 379-1, f, 435; g, 236; h, 450; i, 383; j, 447; k, 157; 1,$325 ; \mathrm{m}, 366 ; \mathrm{n}, 333 ; 0,519-2$; $p, 304-1 ; q, 107 ; r, 431 ; s, 366 ; t, 446 ; u, 328 ; v, 81 ; w, 478$. 
consistently occurs most heavily along the distal third of the blade. The edge rounding and polish are comparatively $1 \mathrm{ight}$ and are confined to the immediate edge. Under high power magnification the polish appears to be only moderately reflective and covers an irregular surface (i.e., follows contours of irregularly rounded edge). No striations or built-up polish was observed. The edge rounding and polish are evenly present along the protruding sections of the blade and do not extend for any distance onto either edge aspect. Many of the specimens with edge rounding and polish also have 1 ight rounding and polish on the flake ridges on both faces. Once again, this was most noticeable on the distal third of most specimens. The facial ridge rounding and polish appear very similar to the edge wear and do not exhibit striations.

Edge attrition in the form of step fracturing, irregular nicking, and edge crushing was observed on many blade edges. Most specimens with these attributes are believed to be the result of resharpening and the accompanying edge grinding ( $p 1$ atform preparation). However, on several specimens the edge attrition removed smal1 areas of the rounded and polished edge and appear to be use damaged. These apparent use-damaged edges have bifacial edge damage (i.e., present on both aspects of the edge).

Wear was also observed on the stem edges and face. Many stem edges are heavily abraded by grinding but 1 ack polish. A few specimens have 1 ight polish along the abraded stem edge. Ridge rounding and polish are noticed on the stem faces of some specimens. Most have only 1 ight to moderate rounding and polish, however, the polish seems to be more reflective than the polish observed on the blade. The most reflective polish was observed on the most prominent flake ridges near the central area of the upper portion of the stems. One specimen has noticeable polish that extends past the top of the stem (even with top of barb notches).

The interpretation of the Perdiz wear patterns is somewhat difficult in view of the absence of consistent wear patterns. Other researchers have had difficulty in evaluating arrow point wear as the "Stockton Point controversy" attests (Nance 1971; Hester and Heizer 1973; Sheets 1973). The 1 ack of extensive or consistent wear may be a function of the tool type. Arrow points, used exclusively as arrow tips, would be expected to exhibit different types of wear depending on what was struck. Animal meat, hide, and bone are all likely to have been struck as are earth and wood (from misses or practice). In addition, the fact that Perdiz points are usually very thin and made of heat-treated material suggests that point breakage was very common. Given a comparatively short 1 ife span and the diversity of potential target materials, perhaps the inconsistent wear patterns and overall 1 ight use wear are to be expected.

The hafting modification (stems) and presence of stem grinding and occasional stem edge and facial polish strongly support the idea that Perdiz points were hafted. The most prevalent blade use wear patterns are edge and facial flake ridge rounding and polish. The 1 ight irregular nature of the polish is consistent with use produced by hide or meat (Keeley 1980). The presence of light polish on both the blade edges and face suggests penetration of soft material. The examined specimens from 41 JW 8 do not have any indications of scraper wear or heavy sawing or cutting wear. Thus, the hypothesis that 
TABLE 3. PERDIZ (AI) ATTRIBUTE DATA

\begin{tabular}{|c|c|c|c|c|c|c|c|c|c|c|c|c|c|c|}
\hline \multirow[b]{2}{*}{$\begin{array}{l}\text { Lot } \\
\text { Number }\end{array}$} & \multirow[b]{2}{*}{$\begin{array}{c}\text { Proventencel } \\
\text { Level }\end{array}$} & \multirow[b]{2}{*}{ Length } & \multirow[b]{2}{*}{ Width } & \multirow[b]{2}{*}{ Thickness } & \multirow[b]{2}{*}{ Weight } & \multirow[b]{2}{*}{$\begin{array}{l}\text { Stem } \\
\text { Width }\end{array}$} & \multirow[b]{2}{*}{$\begin{array}{l}\text { Stem } \\
\text { Length }\end{array}$} & \multirow[b]{2}{*}{$\begin{array}{l}\text { Heat } \\
\text { Treatment }\end{array}$} & \multirow[b]{2}{*}{$\begin{array}{c}\text { Macro } \\
\text { Observations }\end{array}$} & \multirow[b]{2}{*}{ Manufacturing } & \multicolumn{4}{|c|}{ Missing Segments } \\
\hline & & & & & & & & & & & Distal & Barb & $\begin{array}{l}\text { Two } \\
\text { Barbs }\end{array}$ & Stern \\
\hline $249-5$ & N107. E97 L.3 & 33 & 16 & 3.0 & 1.2 & 8.6 & 9.8 & $x$ & VST, BB & B. & & * & & \\
\hline 523 & N106 E94 L.2 & 28 & 18 & 3.5 & 1.3 & 8.3 & 6.5 & $x$ & $\mathrm{ST}, \mathrm{BB}$ & B, FPB & & & & $x$ \\
\hline 107 & Surface & 33 & 18 & 4.2 & 1.5 & 7.0 & 7.2 & $?$ & ST, BB, SB & $B, A$ & & * & & * \\
\hline 366 & N76 E91 L.3 & 17 & 11 & 3.0 & 0.5 & 7.1 & 7.3 & ? & $D T, B B, R$ & $B, F P B$ & & & & \\
\hline 316 & N105 E96 L.1 & 19 & 13 & 1.8 & 0.4 & 3.6 & 7.2 & $x$ & VST & $\mathrm{B}, \mathrm{FP}$ & & & & \\
\hline 236 & N92 E93 L.3 & 22 & 17 & 3.2 & 0.7 & 6.5 & 6.1 & ? & UF, BB & FPB & * & & & \\
\hline 67 & N79 E90+E9I L.3 & 3. 37 & 24 & 3.4 & 1.5 & 8.8 & 11.7 & $\mathrm{x}$ & VST, BB & $B, F P B$ & & & & \\
\hline 321 & N106 E96 L.I & 32 & 20 & 3.4 & 1.2 & 7.0 & 11.3 & $\ddot{q}$ & $\mathrm{BB}, \mathrm{SB}$ & $B, F P$ & * & $x$ & & \\
\hline 333 & N73 E92 L.2 & 14 & 12 & 2.4 & 0.3 & 6.2 & 7.0 & & $\mathrm{DT}, \mathrm{R}$ & $B, F P$ & & & & \\
\hline 445 & NIIO El02 L.2 & 27 & 17 & 2.7 & 0.8 & 6.1 & 8.4 & & BB & FPB & * & & & \\
\hline 429 & N108 E100 L.2 & 19 & 12 & 2.1 & 0.4 & 3.3 & 5.1 & $x$ & ST, BB & $\mathrm{FP}$ & & $x$ & & \\
\hline 429 & N108 E100 L.2 & 23 & 13 & 2.2 & 0.5 & 4.0 & 6.9 & & ST, SB & $\mathrm{B}$ & * & & & \\
\hline 435 & N108 E101 L.2 & 19 & 12 & 2.2 & 0.5 & 5.0 & 4.8 & $?$ & $S T, R$ & FP & & & & * \\
\hline 437 & N108 E102 L.1 & 23 & 15 & 2.6 & 0.7 & 6.1 & 7.8 & $x$ & $R$ & $B, F P B$ & & & & \\
\hline 443 & NIIO E101 L.2 & 18 & 13 & 3.6 & 0.9 & 7.3 & 7.4 & & DT & B & & & & \\
\hline 443 & N110 E101 L.2 & 19 & 10 & 2.4 & 0.4 & 4.2 & 8.0 & $x$ & ST, BB & $B, P P(?)$ & & & & \\
\hline 384 & N106 E95 L.2 & 23 & 14 & 4.9 & 1.3 & 8.1 & 7.6 & $x$ & ST & $\mathrm{B}$ & & & & \\
\hline 523 & N106 E94 L.2 & 29 & 16 & 3.5 & 1.2 & 6.1 & 10.7 & $\hat{\imath}$ & ST & B, FP & & & & \\
\hline $485-5$ & N109 E102 L.3 & 35 & 15 & 2.7 & 0.9 & 4.5 & 8.6 & $x$ & VST, BB, SB & $B$ & & & & \\
\hline $525-1$ & N110 E101 L.3 & 20 & 16 & 2.4 & 0.6 & 5.1 & 8.7 & $\hat{\imath}$ & ST, BB & $B, P P$ & & * & & \\
\hline 334 & N73 E92 L.3 & 22 & 19 & 3.1 & 0.9 & 7.1 & 10.0 & $x$ & $D T, R$ & $B, P P(?)$ & & & & * \\
\hline 456 & N104 E94 L.5 & 25 & 16 & 5.0 & 1.3 & 6.8 & 9.2 & $\hat{x}$ & DT & $B, P P(?)$ & & & & \\
\hline 450 & NIII E102 L.2 & 27 & 14 & 3.0 & 0.7 & 4.9 & 8.0 & $x$ & $\mathrm{ST}$, BB & $B$ & & $x$ & & \\
\hline 450 & NIII EI02 L.2 & 22 & 12 & 2.7 & 0.6 & 4.4 & 5.5 & & DT & FPB & & & & \\
\hline 476 & N108.5 E103 L.I & 125 & 13 & 2.2 & 0.6 & 4.0 & 6.3 & $x$ & ST & $B, F P$ & & & & \\
\hline 312 & N105 E95 L.I & 23 & 12 & 2.7 & 0.7 & 6.1 & 9.8 & $x$ & & B, PP & $x$ & & & \\
\hline 312 & N105 E95 L.1 & 14 & 10 & 1.9 & 0.3 & 3.5 & 4.2 & $x$ & ST & FP & & * & & \\
\hline 300 & N109 E99 L.2 & 25 & 14 & 3.8 & 1.0 & 7.1 & 9.0 & $x$ & $\mathrm{BB}$ & $B$ & $x$ & & & \\
\hline 327 & N108 E95 L.1 & 20 & 10 & 2.6 & 0.4 & 3.3 & 5.3 & 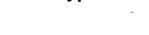 & $\mathrm{ST}$, BB & $B, F P$ & & * & & \\
\hline 110 & N125 E92 L.5 & 35 & 14 & 3.0 & 1.0 & 4.8 & 7.8 & $x$ & VST, SB & $\mathrm{B}$ & & & & \\
\hline 74 & N126 E92 L.I & 26 & 13 & 2.8 & 0.9 & 6.8 & 8.6 & $?$ & BB, SB & FP & * & * & * & * \\
\hline 157 & N92 E92 L.I & 28 & 18 & 3.8 & 1.4 & 8.4 & 9.0 & & & $B, F P, P P$ & & & & \\
\hline 245 & N96 E83 L.2 & 17 & 10 & 2.2 & 0.4 & 3.3 & 6.7 & $x$ & & $\mathrm{FP}$ & & * & & \\
\hline 259 & N111 E92 L.2 & 25 & 14 & 3.3 & 1.0 & 7.5 & 8.2 & & & $B$ & * & * & & \\
\hline
\end{tabular}

Note: All metric data are expressed in millimeters; welght is expressed in grams.

\section{Legend:}

Heat Treatment: $x=$ heat treated; $?=$ posslbly heat treated

Macro Observations: VST = very sharp tip; ST = sharp tip; DT = dull tip; $B B=$ blade beveling; SB = serrated biade; $R=$ resharpened; UF = unfinished Manufacturing: $B=$ bifaclally flaked blade; FP = flake plane remnant one face; $F P B=$ flake plane both faces; $A=$ asymmetrical; $P P=$ proximal

Missing Segments: * $*$ tiny segment $m i s s i n g ; x=$ significant segment missing 
Perdiz points were indeed arrow point tips used as projectiles to kil1 mammals (judging from the faunal analysis, predominately deer, antelope, and bison), remains highly viable. Thorough replicative studies would be needed in conjunction with wear pattern analyses to conclusively demonstrate the specific function of the Perdiz arrow point.

\section{(A2) Expanding Stem Arrow Points}

Six expanding stem arrow points were found at $41 \mathrm{JW} 8$. A71 six fall within the broad descriptions of either Scallorn or Edwards arrow points. These specimens are not classified under either formal type because of the fo 1lowing factors: (1) a11 six 41 JW 8 specimens are atypical of the formally defined types; (2) all six were found in association with Perdiz points; and (3) the accurrence of atypical expanding stem arrow points has been recognized at several sites with we11-defined Toyah assemblages (see Section XI). The expanding stem arrow points are divided into two forms according to basal morphology.

\section{(A2:1) Expanding Stem with Straight Base ( $N=4$; Fig. 5, $-r$ )}

A11 four arrow point fragments have expanding stems and generally straight bases. The shoulders are distinct and are right angled to s7ight $7 y$ downturned. The stems appear angular with straight stem edges and a straight base. Al1 four specimens fall within the broad descriptive range of Scal1 orn arrow points (Suhm and Jelks 1962:285); however, they do not appear typical of most Scal1orn points from south Texas (see Ha11, Black, and Graves 1982:295). The atypical attributes include the relative small size, the relative thinness, and the angularity of the stem. Similar specimens have been found with we11-defined Toyah assemblages at the Rowe Valley site in Williamson County (Prewitt, personal communication) and at 41 LK 201 (Highley 1986). At the Wheatley site, Greer termed similar specimens Scallorn points and used the presence of "Scallorn" points to argue that the Toyah and Austin phases overlapped in central Texas (Greer 1976:108, Fig. 16, i,j).

A11 four specimens are incomplete. The specimen from Lot 304-1 (Fig. 5,p) is noticeably asymmetrica1, thin, and angular. The length is estimated at rough 7 y $23 \mathrm{~mm}$; it is $15.0 \mathrm{~mm}$ in width, $2.1 \mathrm{~mm}$ in thickness, $5.4 \mathrm{~mm}$ in neck width, and $8.6 \mathrm{~mm}$ in stem width. The specimen from Lot 519-2 (Fig. 5,0) is somewhat similar although less complete due to thermal fracturing. Only the stem measurements can be given; it is $5.8 \mathrm{~mm}$ in neck width, $7.0 \mathrm{~mm}$ in stem length, and approximately $9 \mathrm{~mm}$ in basal width. This specimen has a prominent shoulder formed by a downturned barb, which is not typical of the Scal1orn type. The specimen from Lot 107 ( $F$ ig. 5,q) has a central knot (hinge fractured thick area) on one face and is thermal1y fractured. It is $8.5 . \mathrm{mm}$. in neck width and $6.3 \mathrm{~mm}$ in stem 1ength. The specimen from Lot 431 (Fig. 5,r) has a right-angled shoulder and an angular stem. The base is unusual in that it has two incipient basal notches. The length is incomplete but is estimated to have been about $30 \mathrm{~mm}$. It is $11.7 \mathrm{~mm}$ in width, $5.2 \mathrm{~mm}$ in neck width, $5.2 \mathrm{~mm}$ in stem length, and $6.8 \mathrm{~mm}$ in basal width. 


\section{(A2:2) Expanding Stem with Concave Base $(N=2 ;$ Fig. $5, s, t)$}

A complete arrow point and an arrow point fragment from 41 JW 8 have expanding stems and concave bases. The complete specimen has a short, triangular blade and a short, expanding stem. The shoulder is right angled. Side notches form a distinctive flaring base on both specimens. The bases are comparatively wide and markedly concave. Both specimens fit within the Edwards type as defined by Sollberger (1967, 1978) a1though they are atypically small and far south of their usual south-central Texas distribution. Sol1berger notes that the Edwards type is the 1argest arrow point in southcentral Texas.

The complete specimen (Fig. 5,s) is $20.5 \mathrm{~mm}$ in 1 ength, $11.2 \mathrm{~mm}$ in blade width, and $6.5 \mathrm{~mm}$ in thickness. The stem length is $4.9 \mathrm{~mm}$, the neck width is $6.6 \mathrm{~mm}$, the basal width is $12.7 \mathrm{~mm}$, and the depth of the basal concavity is $1.4 \mathrm{~mm}$. It weighs $0.6 \mathrm{~g}$. The fragmentary specimen (Fig. 5,t) has an approximate neck width of $6.5 \mathrm{~mm}$, a basal width of $14.0 \mathrm{~mm}$, and a basal concavity depth of $1.0 \mathrm{~mm}$.

\section{(A3) Triangular Arrow Points (N=3; Fig. 5, u-w)}

Three unstemmed triangu 1 ar arrow points were found at $41 \mathrm{JW} 8$. A11 three have concave bases and straight to very 51 ight 1 y convex or concave blade edges. One specimen (Fig. 5,u) has a deep, V-shaped concavity and resembles the McGloin which is found in the Nueces Bay area (Hester 1980b:106). A11 of the specimens share most of the attributes of the Starr arrow point (Suhm and Jelks 1962:287) although they lack the distinctly concave blade edges that are usually typical of the type. These three triangular points are not assigned to a formal type due to their low frequency and somewhat atypical characteristics.

A complete specimen from Lot 478 ( $F$ ig. $5, w$ ) is $25.1 \mathrm{~mm}$ in 1 ength, $15.2 \mathrm{~mm}$ in width, $2.9 \mathrm{~mm}$ in thickness, $3.2 \mathrm{~mm}$ in basal concavity, and weighs $0.8 \mathrm{~g}$. The fragmentary specimen from Lot 81 ( $F i g .5, v$ ) has a shallow basal concavity of approximately $2.3 \mathrm{~mm}$. The length is estimated at about $26 \mathrm{~mm}$ and the width at $15 \mathrm{~mm}$. It is $2.1 \mathrm{~mm}$ thick. The specimen, which resembles the McGloin type (Lot 328), has an estimated 1 ength of about $26 \mathrm{~mm}$ and a width of about $16 \mathrm{~mm}$. It has a basal concavity of over $5 \mathrm{~mm}$ and a thickness of $2.8 \mathrm{~mm}$.

\section{(A4) Unidentifiable Arrow Point Fragments ( $N=85)$}

The A4 specimens consist of distal, medial, and 1 ateral arrow point fragments that could not be confidently placed in any of the other groups. The majority of the A4 specimens are distal fragments. Most if not al1 of these are Perdiz fragments that have snapped stems. No metric measurements of A4 specimens are provided. The A4 specimens were included in the special study of Perdiz arrow point breakage patterns (Section VII: Perdiz Arrow Point Special Studies). 


\section{Finished Bifaces}

Four groups of morphologically distinct bifaces are described. These bifaces are considered finished "functional" tool forms or "formal" tool types. A11 four groups have been recognized, described, and defined by previous researchers in south Texas. The effort here is concentrated on $B 1$, the beveled knife, because it is the most numerous finished biface type from the site (although technically most Perdiz arrow points are finished bifaces) and also because of specific research design problems. The other three types of finished bifaces are comparatively rare at $41 \mathrm{JW} 8$.

\section{(B1) Beveled Knives ( $N=13$; Fig. 6,a-g)}

Within the beveled knives category are two complete bifaces and 11 fragments representing eight additional tools. Two fragments (distal and proximal) fit together to form a complete tool; two fragments (distal and medial) fit together to form most of a too 1; and two fragments (distal and media 1) are obviously sections of a single tool, although they do not fit together. The remainder of the group consists of a proxima1, a media1, and three distal fragments.

The beveled knife is an interesting tool form that is temporally restricted to a very brief time period in southern Texas, probably for only a 300-year interval between A.D. 1300 and A.D. 1600. Where found in single component sites, they occur only with the Toyah phaselike assemblage of Perdiz arrow points, ceramics, end scrapers, and flake drills. The research proposal for the $41 \mathrm{JW} 8$ work called for a special study of the beveled knife. Ken Brown's (Brown et a 1. 1982:55-63) recent work on the collection of these tools from the Choke Canyon Reservoir area, provides an excellent discussion of this tool type.

Brown notes that considerable confusion occurs in the archaeological 1 iterature with regard to beveled knives. The most widespread Late Prehistoric beveled knife form is a four-sided, diamond-shaped biface that is alternately beveled on all four sides. The 4-beveled forms ("Plains" or "Harahey" bifaces) "appear during the Late Prehistoric in the southern Great Plains and elsewhere in Texas, occurring with low frequency but with widespread geographical distribution" (ibid.:55). Brown cites the presence of these artifacts in numerous defined 1 ate cultural manifestations and notes that most of the occurrences are found "in the southern Great Plains or the B 1 ack 1 and Prairies, with few occurrences on the Edwards Plateau . .., the eastern woodlands, or the Gulf coastal plain" (Brown et a1. 1982:55).

The beveled knife form that does occur on the Gulf coastal plain of southern Texas in the Choke Canyon Reservoir area and at $41 \mathrm{JW} 8$ is a predominately 2beveled biface that "has a short, convex-edged, 'proximal' portion that is rarely beveled" (ibid.). Brown terms this form the "quadrilateral 2-beveled biface" and notes that while some sites in central and northeastern Texas have occurrences of both forms, the 2-beveled form is the only Late Prehistoric beveled knife that has been found in southern Texas. 


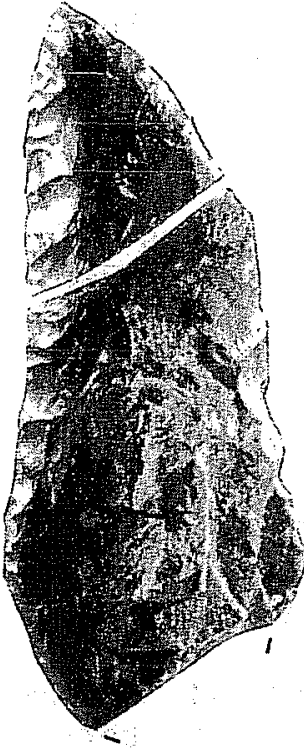

a

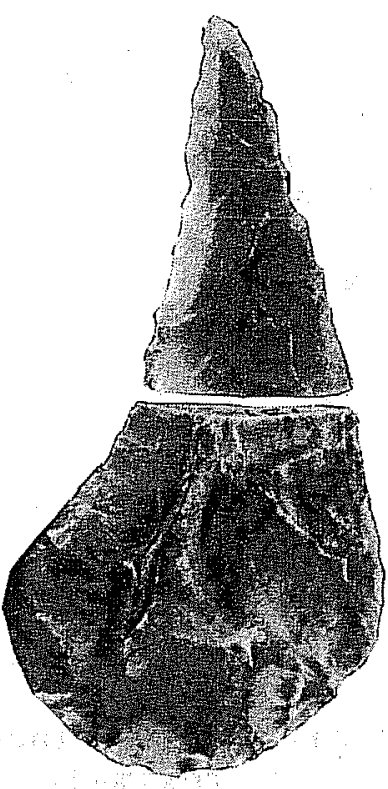

b

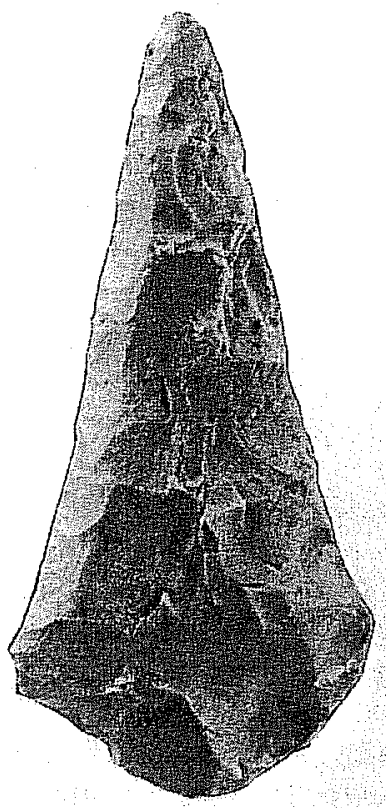

C

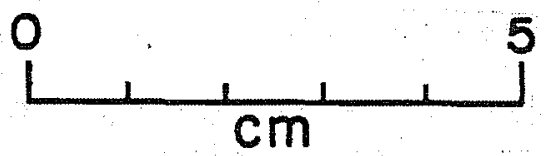

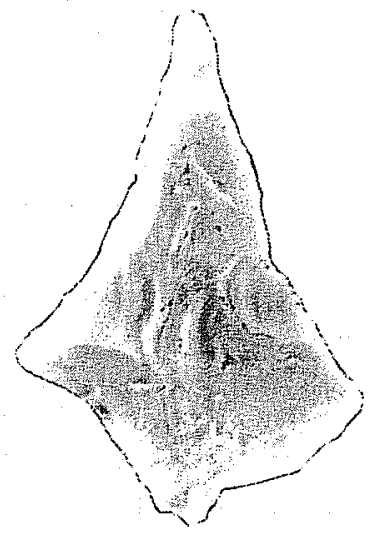

d

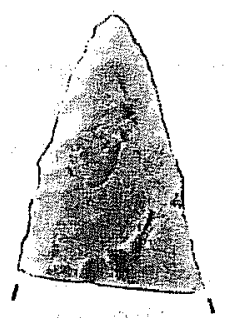

e

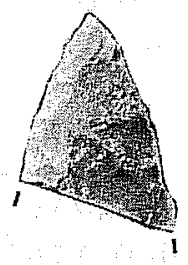

f

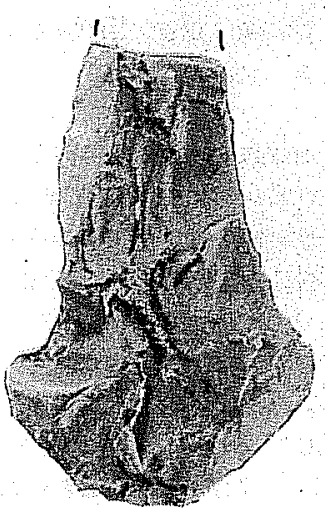

g

Figure 6. Beve1ed Knives (B1). Lot numbers: a, 433; b, 131 (proxima1) and 321 (dista 1 ); c, 320; d, 56; e, 248; f, 519; g, 157. 
The 2-beveled form apparently begins as a well-thinned, large, ovate biface that has a slight distal bevel. Brown was able to trace the use history of the 2-beveled form by studying the comparatively large sample of the tools from the various Choke Canyon area sites (see Brown et a 1. 1982:Fig. 22). One of the most important aspects of this artifact form is that "the characteristic shape is a result of repeated rejuvenation, not the manufacturing process" (Brown et a 1. 1982:56). Brown argues that the beveling probably served to increase the edge angle for the purpose of "heavy-duty cutting as wel1 as minimizing width reduction due to resharpening" (ibid.).

Significant aspects drawn from Brown's study of the beveled knife form indicate a frequent pattern of transverse breakage; no clear-cut evidence for hafting; an absence of covaring metric attributes; and the possibility of functional differences between different sections of the tool edge, suggested by the fact that the distal sections often had steeper spine-plane angles than the lateral corner sections. A1so, the average spine-plane angle (49$\left.53^{\circ}\right)$ for the Choke Canyon specimens accords with the "sawing" and "carving" functions found by a study of exceptiona 11 y we 11-preserved artifacts from Hogup Cave (Wylie 1975), and the many Choke Canyon specimens were al1 apparently made of local materials.

Brown discusses the wear patterns he observed on the 2-beveled bifaces at some length. Interestingly, he found that most of the Choke Canyon specimens showed "almost exactly the same kind of edge damage sustained by unifacial scraping tools" (Brown et a1. 1982:59), i.e., en echelon step flaking on the beveled side of the edge. Furthermore, Brown observed asymmetrical edge polish and abrasion occurring on the beveled side of the edge rather than the flat ventral side. He notes that if accepted uncritically, this wear would be interpreted as typical unifacial scraper wear and notes the similarity of the profile of a 2-beveled biface edge to the uniface in cross section. Brown suggests that the location of the wear is a function of the edge morphology and discusses his experimental efforts to produce analogous wear using beveled edge tools on heavy-duty cutting and sawing of hard materials (seasoned wood and dry antler). He argues that a steep working edge will not produce typical bifacial edge damage even when used in such a manner.

Brown noted considerable edge and facial abrasion and polish on the Choke Canyon specimens that he interpreted as evidence of considerable penetration during use. He also noted a variety of other wear patterns on some specimens, such as edge nicking and bifacially distributed edge damage (edge breaks, edge crushing, and step fracturing). He concluded that the Choke Canyon specimens did not demonstrate a single pattern of edge wear and appeared to have served more than one function.

Brown's conclusions merit repeating here as they are in part supported by the Hinojosa site assemblage (ibid.:61):

1. Quadrilateral 2 -beveled bifaces are a distinctive Late Prehistoric south Texas tool form, clearly of 1 ocal manufacture but occurring in contexts similar to those yielding diamond-shaped 4beve1 knives el sewhere in Texas. Limited evidence from Choke Canyon suggests close association with bison remains. 
2. Intuitive assessments of these tools as cutting implements seems to be substantiated by microwear observations. In at least some cases there is evidence of penetration and app 1 ication to yielding substances. However, significant variability of wear is documented even in the sma 11 Choke Canyon collection.

3. Most specimens demonstrate extended curation and maintenance of the working edge, in some cases probably followed by recycling into perforating or scraping tools. Patterned maintenance of this tool form is responsible for its distinctive shape.

The beveled knives from the Hinojosa site fit the 2-beveled tool description with one exception, a specimen with three beveled edges but otherwise similar to the 2-beveled form in outline shape. The 41 JW 8 specimens were examined microscopical1y and are discussed individual1y.

The atypical specimen mentioned (Fig. 6,d) was found on the surface in the plowed field (Lot 56). This specimen is very short $(53.5 \mathrm{~mm}$ ) and has three beveled concave edges. It is $36.3 \mathrm{~mm}$ in width, has a maximum thickness of $7.12 \mathrm{~mm}$, and weighs $10.4 \mathrm{~g}$. The artifact is made of a white chert. Like most 2-beveled quadrilateral bifaces, the blade is 1 eft beveled. The atypical third bevel occurs on one basal edge. The other basal edge is incomplete (an angular fracture, possibly caused by plow damage, removed a smal1 wedge-shaped section), but appears to have been slightly convex, and is not beveled. The extreme end of the distal tip has been removed by a impact 7 ike fracture.

Orienting the artifact as shown in Figure 6,d, each of the beveled edges wil1 be described. The right (forward) edge has a spine-plane angle of $65^{\circ}$ near the 1 ateral corner and $55^{\circ}$ toward the tip. Evidence of wear most $1 y$ occurs near the tip and near the 1 ateral corner. The distal $2 \mathrm{~mm}$ has heavy edge rounding (abrasion) over heavy step fracturing; proximal from this point, the edge rounding is 1 ight or not present. The proximal $12 \mathrm{~mm}$ (from 1 atera 1 corner) has moderate to heavy rounding, especially near the 1 ateral corner, with apparent polish on the bevel surface.

The left (forward) edge has wear similar to that found on the right edge. The 1 eft edge is noticeably steeper and has spine-plane ang 1 es of $89-90^{\circ}$. The tip and proximal sections of the edge show heavy rounding over step fractures with possible polish on the bevel surface.

The right (basal) edge is not beveled but is 51 ightly steeper on the upper face. The edge is bifacial1y retouched and has moderate rounding that mainly occurs on. the edge projections. The left (basa1) edge is beveled but does not show edge rounding. It appears to have been freshly resharpened.

The Lot 56 specimen is clearly a worn out tool that has been repeatediy resharpened to such a degree as to have severely concave edges and is very short. The wear consists mainly of edge rounding and some polish on the beveled edges, mainly concentrated at the tip and at the lateral corners. The virtual absence of wear in the central section of both forward edges is probably the result of a resharpening episode just prior to discard. The basal beveling on one edge and use wear on the other basal edge are unusual. 
It should be noted that the basal bevel is not 1 ocated on the same face as the opposing distal edge as is typical of "Plains" 4-beveled knives. The use of all possible tool edges underscores the fact that this tool was virtually exhausted at the time of discard.

The other intact beveled knife (Lot 320; Fig. 6,C) is made of a mottled gray, coarse grain chert. This artifact was discarded while still complete and apparently serviceable, although a flake has been removed from the distal tip. It is $80.6 \mathrm{~mm}$ in 1ength, $37.8 \mathrm{~mm}$ in width, $8.9 \mathrm{~mm}$ in thickness, and weighs 21.2 g. The spine-plane angles range from 65 to $82^{\circ}$ on the left edge (as oriented in Fig. 6, C) and 50 to $79^{\circ}$ on the right edge. The artifact may have been discarded due to the steepness of the edges.

The left edge of the Lot 320 specimen is partially plow damaged and has step fractures along both aspects of the edge which are only partially use related. The edge is moderately rounded and polished. The ventral face has hinge and step fractures which may be plow damaged. Some polish can be seen a 7 ong the edge and on the $f 1$ ake ridges 4-5 $\mathrm{mm}$ from the edge on the ventral face. The bevel aspect of the edge definitely has step fractures overlain by rounding and polish. The polish extends on the highest flake ridges to the bevel ridge (point where bevel begins on dorsal face) along most of the edge.

The right edge has a similar wear pattern but the wear is more pronounced. The entire edge is well rounded and polished. It is significant to note that this edge, like virtually all of the worn beveled biface edges from $41 \mathrm{JW} 8$, is evenly rounded with respect to the edge aspects. While more abrasion and polish occurs on the bevel aspect than the ventral aspect, the edge itself is even $1 y$ worn, in contrast to the end scraper edges which are consistently rounded toward the dorsal aspect. The prominent flake ridges on both aspects are rounded and polished wel1 away from the edge.

The proximal edges of this tool are ground but not polished. This may be a hafting modification. Another possible indication of haft wear is the flake ridge rounding and polish observed on both faces of the tool between the lateral corners.

A distal fragment (Lot $321 ; \mathrm{Fig} .6, \mathrm{~b}$ ) and a proximal fragment (Lot 13I; Fig. 6,b) fit together to form a complete too1. Figure 6,b shows the two fragments slightly apart (the distal section should be reversed for a $f i t$ ) but $i 17$ ustrates the asymmetrical shape of the complete biface. The uniquely shaped artifact is made of a yellow tan chert that is mottled with darker inclusions. The proximal section was recovered from the plowed field at least 5 to $10 \mathrm{~m}$ away from where the distal section was recovered during excavation. The break is a transverse snap fracture that probably dates to the site occupation. Both fragments have plow marks on both faces. The distal section has badly battered edges that appear to be the result of plow damage.

The blade edges of the proximal section are rounded and polished. The distal b 1 ade edges have unbattered sections that show moderate edge rounding and polish. It appears likely that some of the edge damage on the distal blade edges is the result of an attempt torresharpen the tool. The proximal edges are unmodified except for a $11-\mathrm{mm}$ section that is rounded and polished. 
A distal fragment and a medial fragment were recovered from the same unitlevel (Lot 433; Fig. 6,a) that fit together and form most of a beveled knife. This artifact is made of a fine grain, gray brown chert that contains large, coarse grain, gray inclusions. Pink discoloration and the glossy nature of the fine grain chert suggest heat treatment. The coarser areas of the artifact are thick knots where removal attempts have ended in hinge fractures. The length is estimated to have been about $82 \mathrm{~mm}$. It is $31.3 \mathrm{~mm}$ in width and $10.5 \mathrm{~mm}$ in thickness.

Light to moderate edge rounding and polish are present along the blade edges and at the lateral corners. Any wear present on the tip has been removed by unifacial flaking which left a step-fractured edge. The most worn section of the tool is on the right (as oriented in Fig. 6,a) edge about $20 \mathrm{~mm}$ from the tip.

A proximal fragment (Fig. 6,g) from Lot 157 represents over half of a complete specimen. Plow marks are visible on both faces and may be the cause of two recent flake removals on the left edge. The specimen is made of fine grain, tan chert. The spine-plane angle of the blade edges is steep, ranging from 70 to $88^{\circ}$. This fragment has very heavy and consistent wear on a 11 intact sections of both blade edges. This consists of extreme edge rounding and extensive polish along the edges and on flake ridges for a distance of 8-9 $\mathrm{mm}$. from the edge on both aspects. The most pronounced ridge wear occurs on the bevel aspect extending past the irregular ridge that paralle1s the blade edge where the bevel begins. The proximal edges are ground but not polished. Little ridge rounding or polish was observed on the proximal faces.

Two fragments, a distal (Lot 284) and a medial (Lot 285), were found about a meter apart and at about the same elevation. They are both made of a mottled gray chert that has an uneven texture, and they appear to be fragments of a single tool. Both fragments have moderate to heavy edge rounding and polish. The distal section also has considerable wear away from the edge on both faces. The medial section has moderate ridge rounding and polish on the bevel aspect and 1 ight wear on the ventral aspect.

One medial fragment (Lot 255) was recovered that has 1 ittle or no visible wear. This fragment is made of a white chert and is thermally fractured. It is $10 \mathrm{~mm}$ thick.

Another medial fragment (Lot 320 ) is a small section from near the tip of a beveled knife. The edges have a series of step fractures along the bevel aspect which are partially smoothed over and polished by wear. Flake ridge rounding and polish are obvious along the beveled aspect. It is made of gray mottled chert and is $5.5 \mathrm{~mm}$ in thickness.

A distal fragment (Lot 248; Fig. 6,e), made of 1 ight gray, fine-grained chert, shows considerable wear. The tip is rounded and polished as are both edges. Both edges show evidence of an attempt to bifacially sharpen the edge, but still retain noticeable bevels.

The final specimen (Lot 519; Fig. 6,f) is a sma11 tip fragment that shows 1 ight to moderate edge rounding and polish. 
In summary, the 41 JW 8 beveled knives and fragments have a very consistent wear pattern. This consists of an evenly rounded and polished edge that is usually accompanied by worn flake ridges that extend 4-9 $\mathrm{mm}$ from the edge on both aspects. The polish is comparatively light (in comparison to added or "corn gloss" polish) and follows the microtopography of the rounded surface rather than forming facets. No definite striations were observed. The heaviest wear along the blade edge usually occurs at or near the tip and near the 1 ateral corners. The heaviest wear on the edge aspects consistently occurs on the bevel aspect. Very 1 ittle additional edge damage was observed on the blade edges. The proximal edges show more variation. Several specimens have simil ar wear along the proximal edges as that seen on the blade edges. Other specimens have ground proximal edges.

The 41 JW 8 beveled knives are similar in most respects to the Choke Canyon collection (Brown et a 1. 1982). The most important difference is that a more consistent pattern of wear was observed. The development of extensively rounded and polished edges and flake ridges on most of the specimens appears consistent with use on soft yielding material such as meat and hide.

The similarity between the wear noted on the beveled knives and that noted on the end scrapers at $41 \mathrm{JW} 8$ suggests that contact with similar material produced the wear. The difference in wear between the two tool types is in location and morphology. The end scrapers have distal edges that are rounded by wear toward the dorsal aspect. The beveled knives have evenly rounded edges. This difference is interpreted as the difference between longitudinal and transverse usage motions. The other major difference is that the beveled knives have rounded and polished $f l$ ake ridges on both edge aspects that extend wel1 beyond the edge, while the end scrapers have 1 ittle wear on the ventral aspect, and the wear on the dorsal aspect on $1 y$ extends for a few militimeters. This difference reflects the amount of contact with the yielding material and the direction of use.

A strong case cannot be made for hafting. Certain beveled knives have ground proximal edges or proximal facial wear that could be interpreted as haft wear, but others do not. Some of the proximal wear could have resulted from the use of a protective leather pad bound or held around the proximal tool end to protect the hand and to provide a better grip.

\section{B2 Triangular Bifaces ( $N=3$; Fig. $7, a-c)$}

Three triangular bifaces were recovered from 41 JW 8; two specimens are complete, and one is missing the distal tip. Al1 three are comparatively thick bifaces with narrow triangular outline shapes, straight bases, and slightly convex blade edges. The blade edges have been resharpened on two specimens.

Triangular bifaces are the most ubiquitous bifacial artifact form in south Texas. Archaic assemblages are often dominated by triangular forms. These are traditionally referred to as dart points despite a general 1 ack of any functional evidence. The B2 specimens from $41 \mathrm{JW} 8$ are much thicker and heavier than the smal1, thin triangular arrow points, A3. A microscopic examination of the B2 specimens showed wear patterns consistent with a tool 
used in a cutting or penetrating motion on soft yielding material. This wear is similar to the wear found on the beveled knives, and it is suggested that both forms represent butchering tools.

The Lot 351 specimen (Fig. 7,b) is made of a very glossy white chert that has the tiny, crystal-filled inclusions that are typical of the material type. It is $38.9 \mathrm{~mm}$ in length, $18.5 \mathrm{~mm}$ in width, $6.7 \mathrm{~mm}$ in thickness, and weighs $4.3 \mathrm{~g}$. The edges appear to have been resharpened shortly before discard; they are fairly sharp but do show 1 ight abrasion and polish. Some of the remnant flake ridges several millimeters away from the edge show moderate rounding and polish on both faces. The wear is consistent with a penetrating use on soft material, such as meat or hide, in the same manner as a projectile tip or a butchering knife.

The Lot 370 specimen ( $F i g .7, a)$ is a fragmentary biface made of gray to yellow to pink quartzite with numerous voids. The coarse grain material is difficult to evaluate. All edges are abraded. No polish could be detected, however, the highly reflective quartz grains hampered observation. One blade edge is severely ground and also has a thick area adjacent to the edge. The grinding may have been connected with attempts to remove the thick flaw. The opposite edge is 1 ightly rounded. This specimen may have never been comp 1 eted. It is $24.4 \mathrm{~mm}$ in width and $7.9 \mathrm{~mm}$ in thickness.

The other B2 biface is a poorly thinned asymmetrical artifact (Lot 128; Fig. 7,c) made of tan chert. It is $44.0 \mathrm{~mm}$ in length, $20.7 \mathrm{~mm}$ in width, $8.8 \mathrm{~mm}$ in thickness, and weighs $6.3 \mathrm{~g}$. Although numerous hinge fractures along the edges attest to futile attempts to further thin this artifact, it was definitely used. Al1 edges have been rounded. The basal edge and the lower $10 \mathrm{~mm}$ of both blade edges are abraded but not polished. A1 1 of the remaining blade edges are polished. The distal tip is severely rounded and worn. Many smal1 step fractures are present on both aspects along the bladed edges; a 11 are rounded and pol ished to a distance of 4-5 mm from the edge. This artifact is very heavily worn. The wear is concentrated on the distal third of the tool but present along the entire edge. The basal and 1 ower blade edge grinding and 1 ack of polish suggest a haft. The blade edges are evenly worn (with respect to the aspects). This suggests a longitudinal action. The rounding and polish along the edge and on both aspects of the edge suggest use on a soft yielding material.

\section{(B3) Perforators (N=4; Fig. 7,d,e)}

Two proximal and two distal perforator fragments were found at $41 \mathrm{JW} 8$. The two proximal perforator fragments are from tools made on flakes; in other words they are $f 1$ akes that have been marginally shaped rather than completely bifacially flaked. These two specimens have widely flaring bases that are irregularly shaped. A11 four perforator fragments have narrow, careful1y shaped thick blade (bit) sections. Material types are brown chalcedony, white chert, tan chert, and gray chert. All except the chalcedony specimen appear to have been heat treated. Metric data are presented in Table 4.

Similar artifacts are found in many Late Prehistoric assemblages in southern Texas (Hester 1980a). Often these are described as "flake dril1s." The 


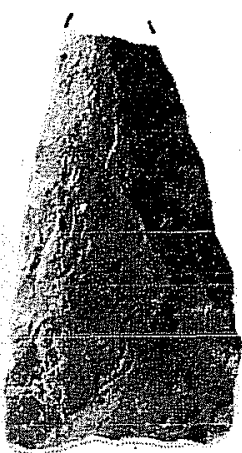

a

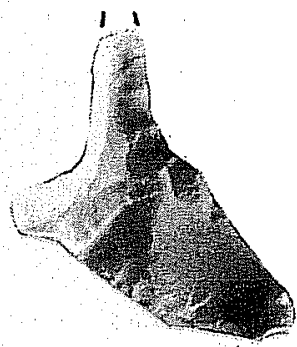

e

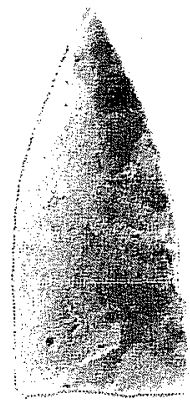

b

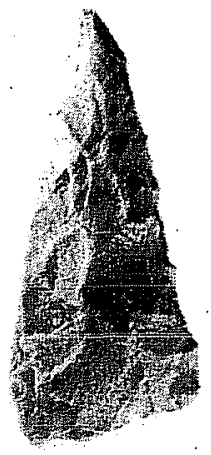

C

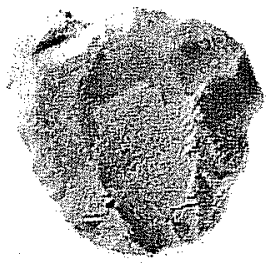

g

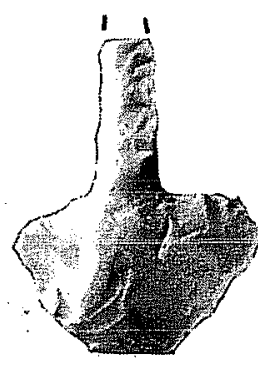

d

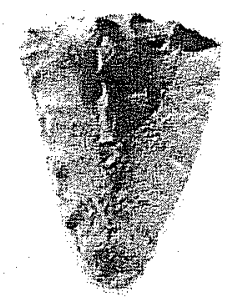

f
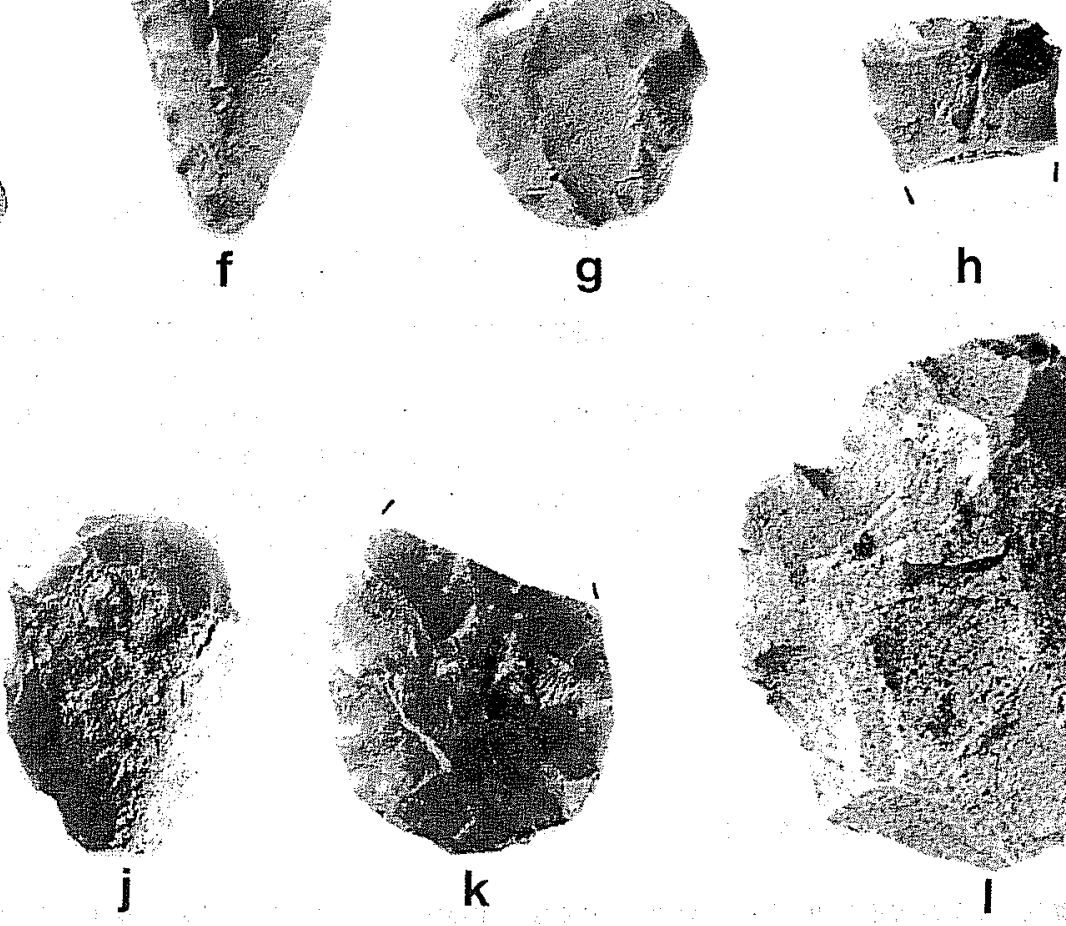

h

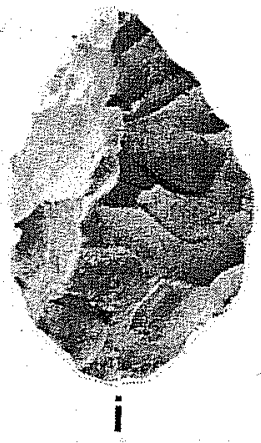

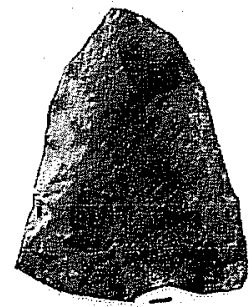

$\mathbf{m}$

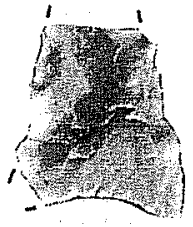

n

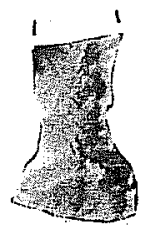

o

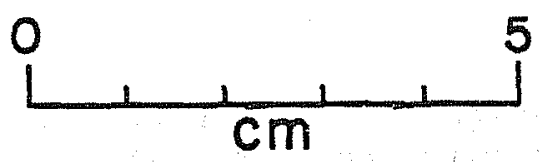

Figure 7. Bifacial Tools. a-c, triangular (B2); d,e, perforators (B3); f$h$, 01 mos biface (B4); $i-1$, round proximal (FBI); $m-0$, miscel 1 aneous (FB2). Lot numbers: $a, 370 ; b, 351 ; c, 128 ; d, 433 ; e, 131 ; f, 67 ; g, 369$; h, 113; $i, 421 ; j, 206 ; k, 261 ; 1,125 ; m, 345 ; n, 284 ; 0,289$. 
TABLE 4. PERFORATOR METRIC DATA

\begin{tabular}{lcccc}
\hline $\begin{array}{c}\text { Lot } \\
\text { Number }\end{array}$ & $\begin{array}{c}\text { Blade } \\
\text { Width }\end{array}$ & $\begin{array}{c}\text { Blade } \\
\text { Thickness }\end{array}$ & $\begin{array}{c}\text { Base } \\
\text { Width }\end{array}$ & $\begin{array}{c}\text { Base } \\
\text { Thickness }\end{array}$ \\
\hline 76 & 8.8 & 4.7 & - & - \\
131 & 5.3 & 4.3 & 31.0 & 10.4 \\
433 & 6.3 & 3.2 & 26.0 & 5.7 \\
482 & 9.3 & 5.8 & - & -
\end{tabular}

A11 measurements are expressed in millimeters.

term "perforator" is chosen here simply to indicate that the tool was used to make holes. The exact method used to make the holes could have been drilling, punching, or reaming. The functional difference can on ly be determined with extensive wear pattern and replicative studies.

A cursory microscopic examination of the B3 specimens revealed evidence of soft material wear (extensive edge rounding and polish) on one artifact (Lot 76) and harder, more resistant material wear (no polish, extensive edge crushing, and step fracturing) on two specimens (Lots 131 and 433). The remaining specimen (Lot 482) had mixed wear indications--edge rounding and polish near the tip and extensive edge damage farther away from the distal tip. Thus it would appear that the perforators from $41 \mathrm{JW} 8$ were used on several types of material.

\section{(B4) Olmos Bifaces ( $N=3$; Fig. $7, f-h)$}

Three 01 mos bifaces were recovered from $41 \mathrm{JW} \mathrm{8;} \mathrm{two} \mathrm{specimens} \mathrm{are} \mathrm{complete,}$ and one specimen is missing the proximal portion. These distinctive bifaces are subtriangular in outline and have a steep $1 y$ beveled distal bit (the broad end). The bit when viewed on end is convex. The artifact resembles a miniature gouge. A11 three specimens are made of chert. Metric data are presented in Table 5.

Shafer and Hester (1971) recognized the 01 mos biface as an unusually distinctive tool type with a limited spatial distribution. The distribution of 01 mos bifaces occurs within "a narrow band 70 to 80 miles wide, extending across southern Texas from western Kleberg County to central Webb County," according to Shafer and Hester (ibid.:7). More recent work has shown that the distribution extends northeast to almost the Nueces River (BIack 1978; Mokry, personal communication). The temporal placement of the 01 mos biface is 1 ess certain due to the 1 ack of excavated specimens. Shafer and Hester (1971) suggested a Late Archaic and Late Prehistoric placement. The $41 \mathrm{JW} 8$ specimens document the use of the tool during the Late Prehistoric. No other 01 mos bifaces have been reported from Toyah-1 ike assemblages. 
TABLE 5. OLMOS BIFACE METRIC DATA

Lot

Numbe

Length

Width

Thickness

Weight

67

113

369

$\begin{array}{cc}28.6 & 21.0 \\ - & 21.4 \\ 26.8 & 27.9\end{array}$

7.3

4.1

8.7

6.7

5.6

A11 measurements are expressed in mil1 imeters except weight which is in grams.

The precise function of the 01 mos biface is unknown. Some sort of gouging or scraping function seems most 1 ikely in view of the morphology. The distribution of the tool type coincides with the northern prickly pear field ("land of the tunas") described by Cabeza de Vaca (Davenport and We115 1918-1919; Campbe11 and Campbe11 1981). This author was tempted to speculate that this unusual and obviously specialized tool form may have been used to process prickly pear (remove spines?). This suggestion is unlikely given the wear patterns (discussed 1ater), the use spalls on the ventral surface, and the burinlike blows on the distal corners that Shafer and Hester believe are related to use wear. It is interesting to note the distributional coincidence of this specialized tool and one of the few documented ethnohistoric exploitation patterns for the area.

The three 01 mos bifaces were examined microscopically. Al1 three have extensive use wear.

The Lot 113 specimen (Fig. 7,h) is fragmentary; the proximal section has been removed by a transverse snap fracture. It is made of a coarse-grained gray chert. This artifact is very heavily worn. The wear is centered on and related to the bit. The central section of the bit edge is severely rounded and polished. The edge is rounded toward the ventral aspect. The we11developed pol ish extends across almast the entire ventral surface. The rounding and polish form a faceted surface adjacent to the edge that fades out toward the proximal end. This wear is not present on the sides of the ventral surface, only in the center. A series of smal1 microfractures (feathered terminations) adjacent to the bit is present on the ventral aspect on both sides of the heavily worn central area. Striations are present on the polished facet that begin at the bit and run perpendicular to the edge. Under high magnification, $80 x$, the striations appear as rounded, shallow grooves. The dorsal aspect (the beveled face) is severely step and hinge fractured a 71 along the bit edge. This appears to be from an earlier resharpening episode as the step and hinge edges are partially rounded and polished over. The polish occurs on the higher portions of the flake ridges and extends to the upper portion of the bevel. The side edges of the tool are not worn. 
The Lot 67 artifact (Fig. 7,f) is made of a fine grain chert that is ye 110 w tan in color. The bit edge is moderately rounded and polished. The ventral surface is covered by large shallow flake scars and shows no wear except for a narrow band of polish along the bit edge. The bevel surface has a number of hinge and step fractures along the bit that have well-worn and polished edges. The side edges of the tool are not worn except for some light rounding and polish along the proximal one-third. This may suggest haft wear or modification. Some of the prominent ridges on the ventral face at the proximal end are also rounded and 1 ightly pol ished.

The Lot 369 specimen (Fig. 7,g) is made of gray, variable grain chert. The distal (bit) edge is very heavily worn except for a small area on one side that has a recent removal. The intact section of the distal edge is severely rounded and highly polished. The ventral surface is also heavily rounded and polished adjacent to the bit edge. This pattern is partially interrupted by several wide but short hinge fractures, most of which have been we 11-smoothed and polished by use. Striations were observed on the heavily polished area of the ventral face which run perpendicular to the bit edge. The bevel or dorsal aspect of the bit does not have hinge or step fractures and is much less worn than the edge or ventral aspect. Moderate ridge rounding and pol ish are present. The 1 ateral edges of the tool are not worn except for along the proximal one-fourth of the tool. This section and the proximal edge are ground. Some edge rounding but 1 ittle polish is present on the flake ridges on the faces of the proximal end of the tool.

In summary, the three 01 mos bifaces from 41 JW 8 have consistent wear patterns that suggest extensive wear, hafting, use on a moderately hard material, and in a specific motion. The location of most of the wear adjacent to the bit edge and on the ventral aspect of the bit edge suggests that the tool was held dorsal side up and pushed (or pulled) bit forward with extensive contact along the ventral surface. The striations confirm the direction. The ventral aspect step fractures on two specimens suggest use on a resistant material but one in which extensive polish can develop. The polish present on two of the tools is much more reflective and extensive than that present on any other examined 1 ithic too1. This wear appears to be consistent with a wood-working function, perhaps as a push-p 1 ane. Replicative experiments are needed to substantiate this interpretation.

\section{Fragmentary and Unfinished Bifaces}

Biface fragments and unfinished bifaces that cannot be placed in the above descriptive categories are divided into three morphological subgroups.

\section{(FBI) Round Proximal ( $N=16$; Fig. $7, i-1)$}

Eight complete and eight fragmentary bifaces have rounded proximal portions. These specimens are not uniform, varying widely in size, thickness, outl ine shape, and degree of finish. Most appear to be unfinished preforms that were discarded due to breakage or flaws, excessive thfckness, and/or irregular shape. The smaller specimen (Fig. 7,i) probably represents a Perdiz preform. One specimen ( $F i g .7, j$ ) could be a preform for an 01 mos biface. The 1 arger 
specimen (Fig. 7,1) does not resemble any of the finished biface groups. Material types are al1 gray to brown chert except for one gray "sugar" quartzite specimen and one white chert specimen. In general, this group of artifacts represents manufacturing failures that could be expected given the relatively poor quality and small cobble size of the available lithic resources. No metric data are presented.

\section{(FB2) Miscellaneous Proximal Fragments ( $N=6$; Fig. 7,m-o)}

Group FB2 contains six proximal biface fragments (Fig. 7,m-o) that have 1 ittle in common with each other or the other biface groups. They appear to have been broken before completion. Material types are fine grain chert (2), coarse grain chert (1), white chert (2), and silicified wood (1). No metric data are provided.

\section{(FB3) Miscellaneous Biface Fragments $(N=154)$}

Group FB3 is a catch-a 11 category, including dista 1, 1atera1, and medial biface fragments as well as many bifacial failure fragments. The term "bifacial failure fragments" is used to describe the flakes, chips, flake fragments, and chunks that evidence bifacial flaking but were obviously never portions of finished tools. Material types are fine grain chert (119), white chert (20), coarse grain chert (5), burned chert (3), quartzite (2), cha1cedony (1), yellow jasper (1), and silicified wood (1).

\section{Unifacial Artifacts}

The unifacial tool category is comprised of $f l$ akes or $f l$ ake fragments of siliceous stone that have been worked or trimmed on one face to form a purposeful shape. Almost al1 the $41 \mathrm{JW} 8$ specimens are trimmed on the dorsal face to form a semicircular tool edge. For a discussion and illustration of the morphological terminology used to describe unifacial tools see Black and McGraw (1985). The trimming is usually located on the distal end of the f1ake, hence the rubric term "end scraper." Traditional1y, most unifacial stone tools are given the functional designation "scraper." These tools are characterized by comparatively steep edge angles, semicircular working edges, and comparatively 1 ittle elaboration. Wear pattern studies have usually borne out the accuracy of the term "scraper" (Wilmsen 1970; Wyl ie 1975).

The Hinojosa site unifacial tool sample is remarkably uniform in morpholagy. Group U1 comprises over 95\% of the unifacial tools. Group U2 contains a smal1 percentage of atypical unifacial tools. It should be emphasized that the unifacial tools at $41 \mathrm{JW} 8$ are 1 ittle more than trimmed flakes. Only the patterned trimming and shaping set them apart from the many MDI specimens. Functionally, a great deal of overlap may exist between the unifacial tool and the modified debitage categories. 


\section{(U1) End Scrapers ( $N=64$; Fig. 8, a-n)}

Group UI consists of complete and fragmentary unifacial tools that have a carefully trimmed semicircular distal end. The group could be divided into a number of subgroups depending on the criteria selected. For example, one could sort the group into $f 1$ akes with intact platforms (26), flakes with trimmed $p l a t f o r m s ~(4)$, and $f l$ ake fragments which do not have platforms (34). Flake type could also be used as a sorting criteria: interior (14), secondary (12), corticate chip (9), and decorticate chip (29). Some variation in trimming location and extent occurs; hence one can distinguish between distal end trimming on 1 y (19), distal end and one side (8), dista 1 end and two sides (15), and circumference trimmed (8).

These types of sorting criteria are considered to be functionaliy irrelevant by this researcher. It is suggested that all group UI end scrapers were used in similar ways to perform similar functional tasks (probably animal hide scraping). Variations in flake type, trimming extent and location, and platform presence are believed to be fortuitous differences reflecting raw material availability, individual flake morphology, and knapping skill or style.

Smal1 end scrapers have been described under a variety of terms, including: "thumbnail scrapers" (informal designation), "snub-nosed scrapers" (Jelks 1962), "smal1 snub-nosed scrapers," "smal1 turtle-back scrapers," and "trimmed flakes" (Ha11, B 1 ack, and Graves 1982). Most of these terms are used to describe the appearance of these tools.

\section{End Scraper Attribute Data, Metric Data, and Wear Patterns}

Table 6 presents attribute data for al1 64 UI specimens and metric and microwear data for 30 complete specimens that were examined in greater detai 1. The 30 examined end scrapers have very consistent wear patterns that strongly confirm the accuracy of the functional term "end scraper."

The 30 end scrapers recovered from $41 \mathrm{JW} 8$ that have intact or trimmed flake platforms were careful1y examined microscopically for wear patterns. The remaining 34 end scrapers do not have intact platforms, hence must be considered chips rather than $f 1$ akes. Most of these are thought to have been flake tools that were broken during or subsequent to use or resharpening. Some no doubt originally began as chip tools (i.e., a flake fragment was used as a tool blank). Due to the difficulty of distinguishing between broken flake tools and chip tools and because the end scraper wear patterns are extremely consistent, the 34 end scrapers (or end scraper fragments) are not included in the wear study. A quick examination of several of these 34 excluded artifacts revealed identical wear patterns as those in the following discussion.

During the initial examination of the entire Ul sample, al1 64 artifacts were examined for four attributes (material type, flake type, trimming location, and platform type). About a third of the way through this process, the author became aware that many of the end scrapers had readily observable edge rounding and polishing. The final two-thirds of the 64 end scrapers (41 


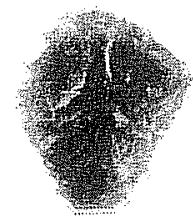

a

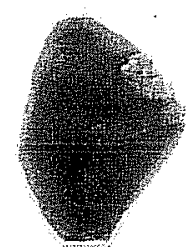

f
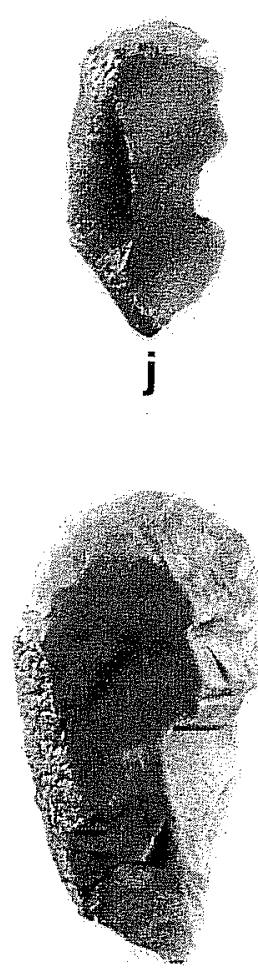

n

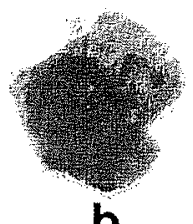

b
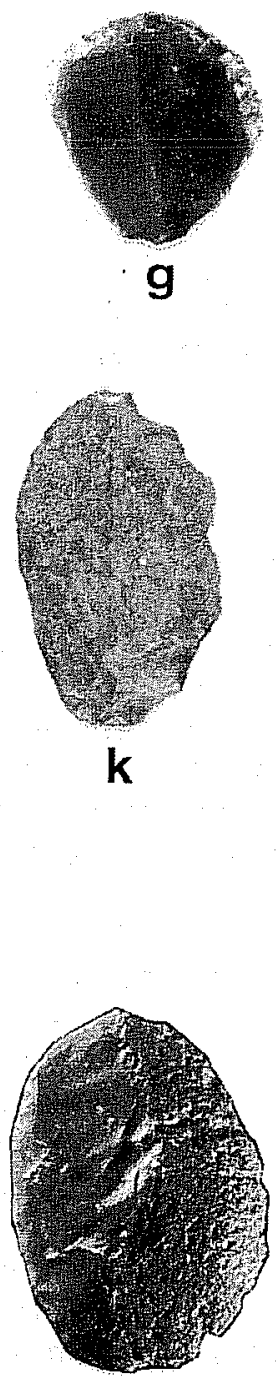

o

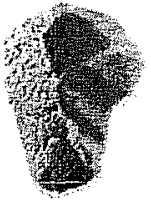

C

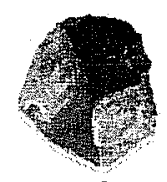

d
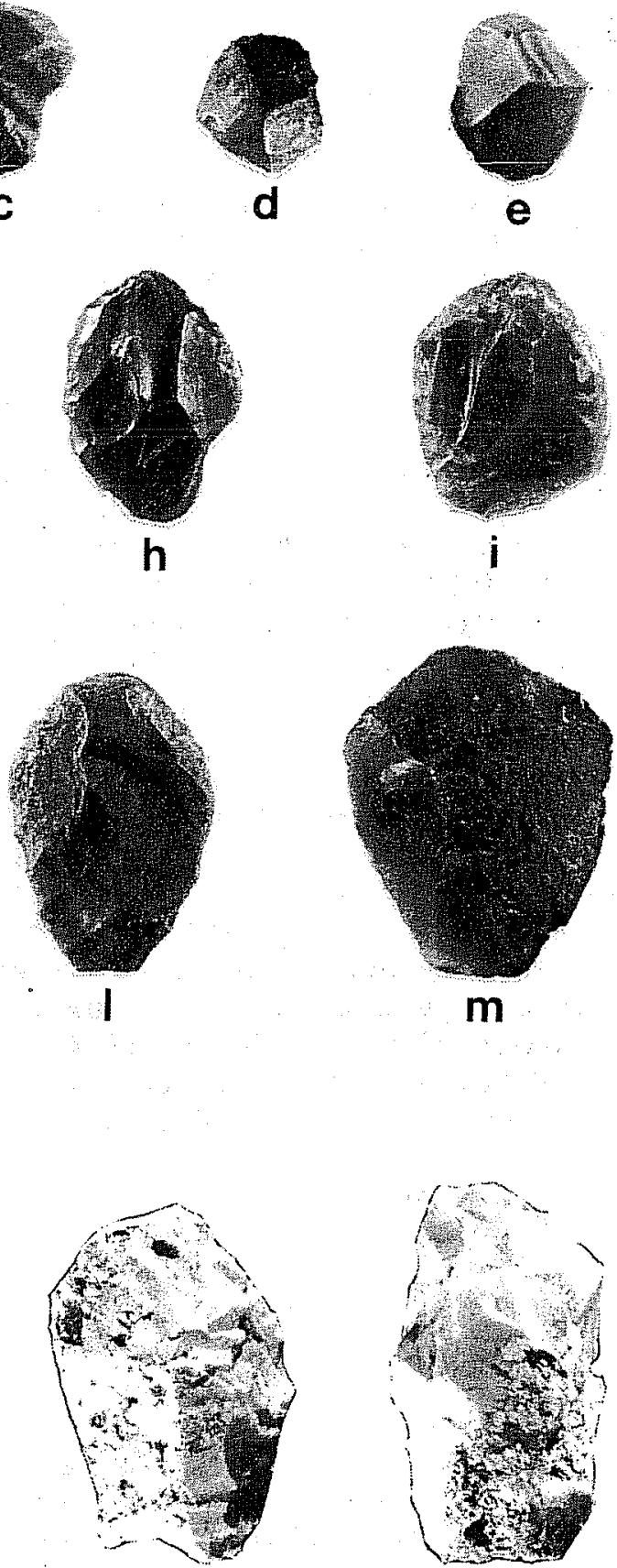

p
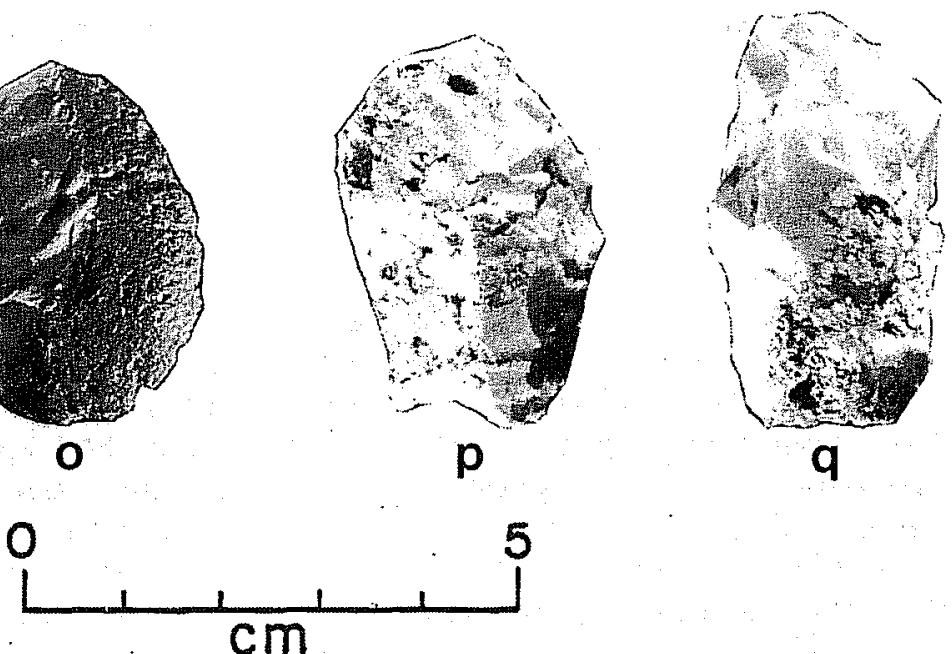

Figure 8. Unifacial Tools. a-n, end scrapers (UI); o-q, miscell aneous scrapers (U2). Lot numbers: a, 338; b, 311; c, 252; d, 339; e, 341; f, 375; $g, 316 ; h, 284 ; i, 111 ; j, 191 ; k, 523 ; 1,375 ; m, 275 ; n, 368-1 ; 0,159$; p, 327; q, 472-15. 
artifacts) were examined under good 1 ighting by the unaided eye, and the presence or absence of obvious edge rounding and polish was noted. Obvious wear was observed on 23 of the 41 (56\%).

The microscopic examination confirmed the macroscopic observations and revealed edge rounding and polish on all 30 complete artifacts, even those which did not appear to be worn in the first examination. The qualitative and quantitative extent of the edge rounding and polish varies from specimens that have on $1 y$ isolated traces of wear to artifacts which have completely rounded and polished working edges. This variation probably reflects the amount of use since the last edge rejuvenation rather than the total amount of use the artifact received. Evidence of edge rejuvenation was observed on 19 specimens (63\%). Additional polish and rounding were observed on the flake ridges and protrusions on the ventral face adjacent to the edge on 18 specimens $(60 \%)$. Use wear striations were observed on four of the specimens (13\%). Different types of wear, edge spalling and bifacial edge damage, were observed on 11 specimens (37\%). Each of these aspects of the observed wear is discussed in greater detail 1 ater.

A11 examined specimens have edge rounding and edge polish. Edge rounding and edge polish are easily observed under low magnification (10-30X) by holding the artifact with the edge angled toward the lense under high angle oblique 1 ighting. In a 11 but a few specimens the edge rounding and polish are concentrated on the semicircular end of the tool. Most specimens evidence this wear only over a 10 to $20 \mathrm{~mm}$ section of the end (equivalent to width of semicircular end or bit). A few tools with wider bits have correspondingly wider areas of polish (up to $35-40 \mathrm{~mm}$ ). The rejuvenated specimens only have isolated remnants of edge rounding or polish or very 1 ight wear, depending on the thoroughness of the edge rejuvenation.

The edge rounding (abrasion) and polish are on the extreme edge of the ventral tool face and extend over a much wider area of the dorsal face. This clearly indicates the ventral face of the tool was in minimal contact with the worked material while the dorsal face was in much greater contact. The worn ends have we11-rounded edges that are completely smoothed over and 1 ightly polished. The tools with the heaviest wear have an edge that is about as round and smooth as the back of a stainless steel table knife blade (although obviously more irregular and not of the same shape). The polish is fairly bright and uniform but does not appear to be built-up like "hoe" polish or silica polish. The end scraper polish seems to result from the complete rounding and smoothing of the edge and appears identical in description to experimentally produced wet hide and meat polish (Keeley 1980:4954). Protruding areas of the edge, such as flake ridges, are always the most heavily rounded and polished sections. Sections of the edge which have spine-plane angles approaching $90^{\circ}$ are almost always more heavily worn than sections with spine-plane angles approaching $60^{\circ}$. The spine-plane angle, while not consistently measured, varies on most specimens, and ranges from about 60 to $100^{\circ}$. Most artifacts have spine-plane angles in the range of 70 to $90^{\circ}$. The steepest areas of the edges are invariably the end sections.

The ventral face of the artifacts (i.e., the flat side of the flake) has very $1 \mathrm{ittle}$ indication of wear except for the portion of the face immediately adjacent to the edge. Along sections of the edge, which are we 11 rounded and 
polished (mostly along the bit), 1 ight polish can be observed on the ventral face along a narrow band that extends no more than $1 \mathrm{~mm}$ from the edge. Two artifacts have minute traces of a very reflective high polish. These areas are near the edge but do not appear connected with the edge polish or any other visible wear. It is suspected that the apparent high polish is actual1y. the result of 1 imited contact with a hard material. Given the minute amount and the 1 ack of any regular pattern, these patches could be the result of impact with a piece of flint or even an excavation tool. The only other wear observed on the ventral face was the edge spalling or random nicking that wi11 be discussed later. Thus, the ventral face of these tools seems to have 1 ittle wear and must not have been in contact with the worked material except along the immediate tool edge.

In contrast, the dorsal face of the tools has much more extensive wear on most specimens. As mentioned, most edge rounding and polishing extend several millimeters onto the dorsal surface of the tool. It should be noted that while the ventral face is flat, the dorsal face is curved both by the original form of the flake and especially by the unifacial flaking along the dorsal face on the end (i.e., the end trimming that formed the tool edge). An additional aspect of the dorsal wear is the rounding and polishing of flake ridges and protrusions. This type of wear is more difficult to observe due to several factors. First, evidence of dorsal and edge wear is partial1y removed by edge rejuvenation on many specimens. Second, the ridge or protrusion wear is only present on heavily worn specimens. Finally, while the tool edge is easy to examine by rotating the artifact under the microscope along the edge, the ridge wear can on ly be observed by turning the artifact many different times in hopes of catching reflecting 1 ight just right. The easiest way to find dorsal flake ridge wear is to first locate the most heavily worn section of the edge and then check the adjacent flake ridges. Heavily worn sections of the edge are invariably accompanied by rounded and polished $f l a k e$ ridges or protruding areas of the dorsal surface.

Striations are on four of the most heavily worn specimens. The striations are only found on extremely worn sections of the tool which always occur near the center of the semicircular end. On all four examples, the striations are on $7 y$ on very steep sections of the edge and oriented perpendicular to the edge. The striations are less than a millimeter from the edge on the ventral face, continue over the edge, and onto the dorsal face up to $1.7 \mathrm{~mm}$ from the edge. On the very 1 imited areas of the four artifacts that have striations, there seem to be a parallel series of closely spaced striations. The striations, when viewed under 30-l60X, are seen as wide, shallow grooves with rounded and polished edges rather than sharp scratches.

The presence of we11-worn edge remnants adjacent to unworn or 1ightly worn sections of the edge provides good evidence of edge rejuvenation. In addition, several specimens have very little indication of wear along what appears to be a freshly flaked edge. These are interpreted as rejuvenated tools that were never used again or were used for such a 1 imited amount of time that no appreciable amount of wear was produced. Evidence of prior use is found in the form of tiny wear remnants on protruding ridges along the edge or on ridges that are still present on the dorsal surface. In other examples, edge rejuvenation is present along one continuous section of the 
TABLE 6. END SCRAPER (UI) ATTRIBUTE DATA

\begin{tabular}{|c|c|c|c|c|c|c|c|c|c|c|c|c|c|}
\hline \multirow[b]{2}{*}{$\begin{array}{l}\text { Lot } \\
\text { Number }\end{array}$} & \multirow[b]{2}{*}{$\begin{array}{l}\text { Material } \\
\text { Type }\end{array}$} & \multirow[b]{2}{*}{$\begin{array}{l}\text { Flake } \\
\text { Type }\end{array}$} & \multirow[b]{2}{*}{$\begin{array}{l}\text { Trimming } \\
\text { Location }\end{array}$} & \multirow[b]{2}{*}{$\begin{array}{l}\text { Platform } \\
\text { Type }\end{array}$} & \multirow{2}{*}{\multicolumn{2}{|c|}{ Metric $A$}} & \multirow{2}{*}{\multicolumn{2}{|c|}{$\begin{array}{c}\text { Attributes } \\
T \text { WT }\end{array}$}} & \multicolumn{5}{|c|}{ Microwear Attributes } \\
\hline & & & & & & & & & $\begin{array}{l}\text { Edge Rounding } \\
\text { and Polishing }\end{array}$ & $\begin{array}{l}\text { Ridge } \\
\text { Rounding }\end{array}$ & Striations & $\begin{array}{l}\text { Edge Reju- } \\
\text { venation }\end{array}$ & $\begin{array}{l}\text { Edge Damaged } \\
\text { Sides }\end{array}$ \\
\hline 56 & 1 & 1 & 3 & 1 & 23 & 19 & 5 & 2.2 & $x$ & $x$ & & $x$ & \\
\hline 56 & 1 & 4 & 3 & 3 & & & & & & & & & \\
\hline 56 & $2^{\circ}$ & 4 & 3 & 3 & & & & & & & & & \\
\hline 70 & 1 & 2 & 3 & 1 & 15 & 18 & 4 & 1.3 & $x$ & $x$ & & & \\
\hline 70 & 1 & 4 & 2 & 3 & & & & & & & & & \\
\hline 102 & 2 & 1 & 3 & 1 & 27 & 20 & 7 & 4.0 & $x$ & $x$ & & $x$ & \\
\hline 108 & 1 & 4 & 2 & 3 & & & & & & & & & \\
\hline 109 & 1 & 5 & 3 & 3 & & & & & & & & & \\
\hline 111 & 1 & 4 & 4 & 2 & 28 & 26 & 7 & 5.2 & $x$ & & & $x$ & \\
\hline 131 & 2 & 4 & 4 & 3 & & & & & & & & & \\
\hline 131 & 3 & 1 & 4 & 1 & 28 & 21 & 6 & 4.1 & $x$ & $x$ & $x$ & & \\
\hline 131 & 1 & 2 & 5 & 1 & 33 & 20 & 3 & 3.2 & $x$ & $x$ & & $x$ & $x$ \\
\hline 131 & 1 & 4 & - & 3 & & & & & & & & & \\
\hline 156 & 1 & 1 & 1 & 1 & 29 & 17 & 2 & 1.5 & $x$ & $x$ & & & \\
\hline 157 & 1 & 5 & 4 & 2 & 26 & 20 & 7 & 3.8 & $x$ & & & $x$ & $x$ \\
\hline 158 & 1 & 1 & 1 & 1 & 26 & 19 & 4 & 1.9 & $x$ & $x$ & & $x$ & \\
\hline 187 & 1 & 5 & 1 & 3 & & & & & & & & & \\
\hline 191 & 1 & 2 & 2 & 1 & 33 & 17 & 7 & 4.1 & $x$ & & & $x$ & \\
\hline 194 & 1 & 2 & 3 & 1 & 36 & 25 & 7 & 6.9 & $x$ & $x$ & $x$ & $x$ & \\
\hline 195 & 1 & 4 & - & 3 & & & & & & & & & \\
\hline 214 & 1 & 4 & - & 3 & & & & & & & & & \\
\hline 246 & 1 & 4 & 3 & 3 & & & & & & & & & \\
\hline 252 & 1 & 2 & 1 & 1. & 20 & 15 & 3 & 1.1 & $x$ & $x$ & & & $x$ \\
\hline 258 & 1 & 4 & 3 & 3 & & & & & & & & & \\
\hline 261 & 1 & 4 & - & 3 & & & & 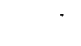 & & & & & \\
\hline 264 & 1 & 5 & 4 & 3 & & & & & & & & & \\
\hline 269 & 1 & 4 & - & 3 & & & & & & & & & \\
\hline 274 & 1 & 5 & - & 3 & & & & & & & & & \\
\hline 275 & 1 & 2 & 2 & 1 & 38 & 31 & 10 & 10.0 & $x$ & $x$ & & & $x$ \\
\hline 279 & 1 & 5 & 2 & 3 & & & & & & & & & \\
\hline $281-1$ & 1 & 4 & 4 & 2 & 30 & 20 & 6 & 3.3 & $x$ & & & $x$ & $x$ \\
\hline 283 & 2 & 2 & 1 & 1 & 24 & 16 & 8 & 3.2 & $x$ & $x$ & & & \\
\hline 284 & 1 & 4 & 1 & 3 & & & & & & & & & \\
\hline 371 & 1 & 4 & 4 & 2 & 19 & 19 & 4 & 1.5 & $x$ & $x$ & $x$ & $x$ & $x$ \\
\hline 314 & 1 & 5 & 3 & 3 & & & & & & & & & \\
\hline 316 & 1 & 4 & - & 3 & & & & & & & & & \\
\hline
\end{tabular}


TABLE 6. (continued)

\begin{tabular}{|c|c|c|c|c|c|c|c|c|c|c|c|c|c|}
\hline \multirow[b]{2}{*}{$\begin{array}{l}\text { Lot } \\
\text { Number }\end{array}$} & \multirow[b]{2}{*}{$\begin{array}{l}\text { Material } \\
\text { Type }\end{array}$} & \multirow[b]{2}{*}{$\begin{array}{l}\text { Flake } \\
\text { Type }\end{array}$} & \multirow[b]{2}{*}{$\begin{array}{l}\text { Trimming } \\
\text { Location }\end{array}$} & \multirow[b]{2}{*}{$\begin{array}{l}\text { Platform } \\
\text { Type }\end{array}$} & \multirow{2}{*}{\multicolumn{4}{|c|}{$\begin{array}{l}\text { Metric Attributes } \\
\mathrm{L} W \mathrm{~T} \text { WT }\end{array}$}} & \multicolumn{5}{|c|}{ Microwear Attributes } \\
\hline & & & & & & & & & $\begin{array}{l}\text { Edge Rounding } \\
\text { and Polishing }\end{array}$ & $\begin{array}{l}\text { Ridge } \\
\text { Rounding }\end{array}$ & Striations & $\begin{array}{l}\text { Edge Reju- } \\
\text { venation }\end{array}$ & $\begin{array}{l}\text { Edge Damaged } \\
\text { Sides }\end{array}$ \\
\hline 316 & 1 & 1 & 4 & 1 & 24 & 22 & 5 & 2.8 & $x$ & $x$ & $x$ & & \\
\hline 318 & 1 & 4 & 1 & 3 & & & & & & & & & \\
\hline 319 & 1 & 4 & - & 3 & & & & & & & & & \\
\hline 320 & 1 & 4 & 1 & 3 & & & & & & & & & \\
\hline 320 & 1 & 1 & 2 & 1 & 26 & 15 & 5 & 1.9 & $x$ & & & $x$ & \\
\hline 320 & 1 & 4 & - & 3 & & & & & & & & & \\
\hline 326 & 1 & 5 & - & 3 & & & & & & & & & \\
\hline 327 & 1 & 2 & 2 & 1 & 45 & 25 & 9 & 9.1 & $x$ & $x$ & & $x$ & $x$ \\
\hline 330 & 1 & 4 & 1 & 3 & & & & & & & & & \\
\hline 331 & 1 & 1 & 3 & 1 & 24 & 23 & 6 & 3.4 & $x$ & $x$ & & $x$ & \\
\hline 336 & 1 & 4 & - & 3 & & & & & & & & & \\
\hline 338 & 1 & 1 & 3 & 1 & 21 & 19 & 5 & 1.8 & $x$ & & . & $x$ & \\
\hline 339 & 1 & 2 & 1 & 1 & 16 & 15 & 7 & 1.4 & $x$ & & & $x$ & \\
\hline 340 & 1 & 4 & - & 3 & & & & & & & & & \\
\hline 341 & 1 & 2 & 1 & 1 & 19 & 17 & 5 & 1.2 & $x$ & & & $x$ & \\
\hline 342 & 1 & 1 & - & 1 & 23 & 14 & 4 & 1.4 & $x$ & $x$ & & & \\
\hline 343 & 1 & 4 & 3 & 3 & & & & & & & & & \\
\hline $354-7$ & 1 & 4 & 2 & 3 & & & & & & & & & \\
\hline 368-1 & 1 & 2 & 1 & 1 & 48 & 26 & 8 & 10.5 & $x$ & $x$ & & $x$ & $x$ \\
\hline 375 & 1 & 1 & 3 & 1 & 23 & 18 & 3 & 1.2 & $x$ & $x$ & & & $x$ \\
\hline 375 & 1 & 1 & 1 & 1 & 34 & 24 & 7 & 5.3 & $x$ & $x$ & & & \\
\hline 386 & 1 & 2 & 1 & 1 & 26 & 22 & 7 & 3.8 & $x$ & $x$ & & & $x$ \\
\hline 397 & 1 & 4 & 1 & 3 & & & & & & & & & \\
\hline 420 & 1 & 5 & 1 & 3 & & & & & & $\therefore$ & & & J \\
\hline 433 & 1 & 4 & 1 & 3 & & & & & & & & & \\
\hline 433 & 1 & 4 & 1 & 3 & & & & & & & & & \\
\hline 473 & 1 & 1 & 1 & 1 & 34 & 19 & 5 & 2.7 & $x$ & & & $x$ & $x$ \\
\hline $523-3$ & 1 & 1 & 3 & 1 & 34 & 20 & 6 & 4.1 & $x$ & & & $x$ & \\
\hline
\end{tabular}

Legend

Material Type: 1 = fine-grained chert; 2 = white chert; 3 = quartzite.

Flake Type: 1 = interior flake; 2 = secondary flake; 3 = primary flake; 4 = decorticate chip; 5 = corticate chip.

Trimming Location: $1=$ end only; 2 = end and one side; $3=$ end and two sides; 4 = circumference; $5=$ side only.

Platform Type: 1 = intact platform; 2 = modified platform; 3 = platform missing (i.e., chip).

Metric Attributes: $L=$ length; $W=$ width; $T=$ thickness $(\mathrm{mm}) ; W T=$ weight $(\mathrm{g})$.

Microwear Attributes: $x=$ present, see text for explanations. 
edge until a heavily worn and severely rounded steep section of the edge is encountered. These heavily worn areas appear to have prevented the user from finishing the edge rejuvenation. One such specimen has ring cracks along the worn area, attesting to the force used in an unsuccessful attempt to remove the dull section of the tool. An additional fact which may evidence rejuvenation is that some of the end scrapers are noticeably smal 1er. These tend to be more completely trimmed and shaped than other specimens.

A11 of the wear patterns discussed are consistent with scraper wear. About a third of the examined tools also have indications of random nicking or spalling and bifacial edge damage. Although the random nicking is also present along the bit end of several specimens, it most often occurs along one or both sides away from the rounded and polished bit end. The random nicking or spalling was noticed on the ventral face; similar spalling is no doubt present on the dorsal face but is concealed by edge trimming. Bifacial edge damage occurs on several specimens along one side. The term "bifacial edge damage" is used to refer to a series of small step fractures that occur on both faces along one side of a tool that 1 acks edge trimming (i.e., has end trimming on $1 y$ or end and side trimming on opposite side). Both random nicking and bifacial edge damage probably reflect use of the side edge of the end scraper to perform some short-term cutting or sawing function. The absence of edge rounding and polish or more extensive edge damage along the tool side edges in question, argues that the wear is neither similar to the predominate end scraper usage nor the result of a repeated 1 ong-term function. In other words, the additional wear patterns must represent incidental use of the tool much 1 ike that represented by the modified debitage category MD2.

Several additional aspects of the end scraper wear pattern study deserve mention. Despite a careful search, no definite indication of hafting modification or haft wear was observed. If these end scrapers were hafted, one would seemingly expect to find either some type of haft modification such as notching or edge grinding, or evidence of haft polish on the flake ridges on the proximal section of the tool. The absence of these evidences may suggest that the end scrapers at the Hinojosa site were hand-held tools. This suggestion contradicts Hester's (1977:20) intuitive assertion that "given the sma 11 size of the specimens, they must have been hafted for use. . . ." It is also possible that the hafting method did not require hafting modification or result in distinctive wear. Wedel (1970) illustrates a variety of hafted scrapers from the Great P1ains, including archaeological and ethnographic specimens. In particular, several specimens are shown which have sma 11 scrapers set in an antler handle with some type of mastic or resin.

The presence of striations on four heavily worn tools led the author to try and locate striations on the most heavily worn sections of other end scrapers. It was assumed that the striations were easy to overlook and might require higher magnification to observe. No additional definite striation patterns were found. Several explanations for the 1 imited occurrence of striations are considered: (1) the striations may suggest that the four tools were used on a different material than the other 26 specimens; (2) striations only occur after extensive amounts of use; and (3) striations are present but not observed. While the first explanation cannot be ruled out, the other two explanations in combination seem most likely. Striations were 
on ly observed on the most heavily worn specimens on the most heavily worn sections of the tool where large, smooth, highly reflective areas were present. The striations were only clear under higher magnification $(>30 \mathrm{X})$ and by using low angle oblique lighting. Hence, it seems likely that less obvious striations were present but not observed due to the difficulty of coordinating low angle 1 ighting on smal1, rounded areas under higher magnification. An added factor that hampered examination of the many smal 1 , polished projections is that many tools are made of highly reflective, fine grain chert, hence it is difficult to isolate the reflected polish.

In summary, the wear patterns on the $41 \mathrm{JW} 8$ end scrapers are highly patterned and consistent with the hypothesis that Late Prehistoric end scrapers were in fact used to process animal hides. These artifacts were often resharpened when the used worn edge no longer functioned efficiently. The presence of additional wear on about a third of these tools suggests that end scrapers were also used to perform spontaneous secondary functions. The absence of the nonscraper wear on the scraper-worn end may suggest that these secondary functions were contemporary with the primary function. The Hinojosa site end scrapers may have been employed as short-term $f l a k e$ knives when necessary by using the side of the tool.

\section{(U2) Miscellaneous Scrapers (N=3; Fig. 8,o-q)}

Three unifaces were recovered from $41 \mathrm{JW} 8$ which are not end scrapers. A11 three have unifacially worked edges along one 1 ateral edge and 1 ack the semicircular end trimming of group Ul. These unifaces could be termed "side scrapers." Due to the smal1 number of artifacts in this category, they are briefly described on an individual basis.

The unifacial artifact from Lot 159 ( $F i g .8,0)$ is a secondary flake which has trimming on one side; the opposite side and distal end are covered by cortex. Other than the absence of end trimming, this specimen is similar to the Ul group in terms of size, morphology, and edge angle. No noticeable wear was observed microscopical7y. It is $37.6 \mathrm{~mm}$ in length, $26.5 \mathrm{~mm}$ in width, $8.0 \mathrm{~mm}$ in thickness, and weighs $7.7 \mathrm{~g}$.

The uniface from Lot 327 ( $F$ ig. 8,p) is made on a thick tertiary fiake of a poor quality, whitish chert that has numerous tiny voids partialiy filled by crystals. One side is crudely flaked (many hinge fractures) to form a very thick, convex working edge. Microscopic examination reveals that the artifact had been resharpened prior to discard. Smal1 remnants of the previous edge show extreme rounding and edge polish. The polish is rather general rather than faceted and very high, and is confined to within $1.3 \mathrm{~mm}$ of the edge. A few apparent striations were observed on the ventral surface of the edge and perpendicular to the edge. The wear and futile attempt at edge rejuvenation are consistent with scraper wear. It is $41.8 \mathrm{~mm}$ in 1 ength, $26.1 \mathrm{~mm}$ in width, $15.3 \mathrm{~mm}$ in thickness, and weighs $15.8 \mathrm{~g}$.

The unifacial artifact, found in Feature 9 (Lot 472-15; Fig. 8,q), is a thick decorticate chip that is yellow to white in color and has numerous bedding plane flaws. It is similar in size, shape, and appearance to the Lot 327 U2 specimen. The proximal section of the flake has been snapped off, however, 
the break occurs along a flawed area which may have taken place prior to the manufacture of the tool. One edge (distal edge of original $f 1$ ake) has a thick, convex bit that was formed by flaking and numerous hinge fractures. The edge is severely battered and has a few bifacial flake removals. Microscopic examination suggests that the artifact was discarded after a futile attempt at edge rejuvenation which apparently removed al1 traces of wear. It is $42.0 \mathrm{~mm}$ in width and $18.6 \mathrm{~mm}$ in thickness.

\section{NONCHIPPED MODIFIED STONE}

Stone artifacts modified by battering, grinding, or grooving were uncommon at $41 \mathrm{JW} 8$ in contrast to the many chipped stone implements. Most of the nonchipped modified stone artifacts are fragments of complete tools. The visible wear patterns and tool morphologies suggest that the following functional artifact types are present: hammerstones, grinding slabs, manos, abrading stones, and a pipe bow 1. Sandstone, quartzite, chert, calcium carbonate, and volcanic rock types are all represented in the collection. Of these, calcium carbonate is the only material available in the site vicinity. The absence of complete nonchipped modified stone artifacts and the fact that most of the raw materials are nonlocal strongly suggest these were valued artifact types that were only discarded when nonfunctional. Complete examples of most of these artifact types are illustrated in Hester (1980a), Ha 11, B1 ack, and Graves (1982), or Turner and Hester (1985).

A11 nonchipped modified stone artifacts are given a single artifact code (MS) due to the comparatively smal1 number of these artifacts. For provenience of the specific types, a lot number 1 ist is provided in each artifact group description.

\section{(MS1) Ground Stone $(N=25)$}

The ground stone artifact category consists of a 11 tool fragments with one or more artificially smoothed faces or facets. Most ground stone artifacts from $41 \mathrm{JW} 8$ are fragments of sma11, thin grinding 51 abs with $f 1$ at or concave smoothed surfaces. Five specimens are fragments of rounded cobbles with convex, smoothed surfaces. These represent manos or hand-held milling stones used in conjunction with grinding 51 abs to pulverize organic materials, presumably, plant remains. Two of the manos are made of quartzite and have some indications of battering along the tool edge; these may have also functioned as hammerstones. One atypical ground stone artifact (Lot 342) is a sma 11, b1unt-pointed calcium carbonate fragment, $1.4 \mathrm{~cm}$ in 1 ength, worn smooth, and slightly polished. Material types represented by the ground stone tools are sandstone (18), calcium carbonate (4), and quartzite (2). 51 ab fragment 1 ot numbers are $62(2), 63,71,131(2), 134,144,147,157$, $186,187,226,253,301,334,340,342$, and 351. Mano fragment 1 ot numbers are $56,62,70(2), 513$. 


\section{(MS2) Hammerstones ( $N=7$; Fig. 9, a, b)}

Seven hammerstones (two complete and five fragmentary) were recovered from 41. JW 8. A hammerstone is a rounded stone cobble used as a percussor to chip siliceous stone. Hammerstones typically exhibit battering wear on protruding edges or ends. One specimen (Fig. 9,a) made of silicified wood is an exhausted core that was recycled and used as a hammerstone. Material types are chert (1), silicified wood (1), volcanic rock (2), and quartzite (3). Lot numbers are $56(2), 62,66,126,131$, and 522-1.

\section{(MS3) Abraders $(N=6)$}

Five fragmentary abrading stones were recovered from $41 \mathrm{JW}$ 8. An abrading stone or an abrader is a stone cobble or $s 1 \mathrm{ab}$ that has one or more man-made grooves. The grooves typically appear $V$ - or U-shaped in cross section and are 2-5 cm in length. The grooves are bel ieved to be the result of biface edge abrading, the grinding or smoothing of the edge of a bifacial chipped stone tool. This is a basic step of flintknapping. The abraders may have al so been used to shape bone or shell artifacts. Al1 six specimens are made of a relatively hard calcium carbonate. Lot numbers are 56, 63(2), 104, 131 , and 459-2.

\section{(MS4) Sandstone Pipe Bowl (N=I; Fig. 9, C, $\left.C^{\circ}, d\right)$}

One usual artifact found at the Hinojosa site is a fragment of a decorated tubular pipe bow 1. This artifact is made of buff-colored sandstone. The material has pebble-sized rock inclusions, occasional voids, and medium to coarse sand grains rather poorly cemented by calcium carbonate. The exterior and interior surfaces are ground smooth but remain uneven due to the poor quality of the material.

The interior surface is slightly smoother than the exterior. The interior of the bowl (Fig. 9,c) is constricted to a diameter of approximately $20 \mathrm{~mm}$ some $2 \mathrm{~cm}$ above the base. The interior diameter at the base is approximately $30 \mathrm{~mm}$. The maximum interior diameter based on the preserved portion of the artifact is about $35 \mathrm{~mm}$. The maximum exterior bow 1 diameter is approximately $58 \mathrm{~mm}$. The pipe bow 1 wal 15 range from 18 to $21 \mathrm{~mm}$ except at the base, where the wal1s taper to a rounded edge.

The exterior surface of the pipe bow1 (Fig. 9, $C^{\prime}$ ) has been decorated with thick asphaltum designs and fugitive red film. Close examination reveals that the asphaltum was applied in a molten state, and that the fugitive red film (iron oxide paint) was added afterward to fill in the areas of the pipe without asphaltum. Based on the preserved portion of the pipe bow 1 , the decorative motif seems to be a geometric design (Fig. 9,d) consisting of four red ovals (fugitive red $f i 7 \mathrm{~m}$ ) evenly spaced and outlined by wide black (asphaltum) dividers. Asphaltum and fugitive red film were al so used to decorate ceramic vessels at $41 \mathrm{JW} 8$ and other Late Prehistoric sites in southern Texas. 


\section{METHODS}

The analytical techniques chosen to examine the $41 \mathrm{JW} 8$ ceramics were 1 argely based on the author's experience gained during his analysis of prehistoric ceramics on the Nueces River Project (Ha11, Black, and Graves 1982; Ha11, Hester, and B1ack 1986). The poor condition of most the Hinojosa site prehistoric ceramics and the extreme fragmentation of al1 vessels ruled out any hope of vessel reconstruction such as Highley's (1986) work with the 41 LK 201 collection. A preliminary examination of several dozen sherds revealed a high degree of homogeneity in the 41 JW 8 assemblage. Given the 1 arge sample size, high degree of homogeneity, and the poor condition of the majority of the collection, it was decided to concentrate on a detajled analysis of a select sample. One hundred of the better-preserved sherds were careful1y examined microscopical1y.

The 100 sherd sample represents the larger and better-preserved sherds, rim sherds, decorated sherds, and other atypical specimens. Each lot bag was examined by the author for evidence of sherds with preserved surface finishes. Thus many smaller sherds not suffering from extreme weathering were also examined. Often a lot bag would contain two to five sherds from a single vessel (i.e., the sherds were identical in surface and paste characteristics). In these cases a maximum of two identical sherds was examined from a single lot. The 100 sherd sample was selected from 36 lot bags.

The select sample, while not statistically representative of the 41 JW 8 ceramic assemblage, does contain examples of virtually all variations observed within the total sample. Unusual sherds are overrepresented in the select sample. However, since decorative techniques only appear on a few of the sherds from a given vessel and some forms of decoration are extremely ephemera 1, the percentage of decorated vessels estimated by the select sample ratios is probably too 1 ow. The sampling technique is felt to be adequate for the purposes of describing the ceramic assemblage and comparing it with regional ceramic assemblages.

\section{ATTRIBUTE DEFINITIONS}

For each sherd the following attributes were examined: exterior surface treatment, postfiring decoration, interior surface treatment, paste matrix, paste inclusions, sherd thickness, and vessel fragment. Due to the sma 11 size of even the larger fragments, vessel form can only be guessed at in most cases. Each attribute is defined and described next.

\section{Exterior Surface Treatment}

Exterior surface treatment describes the vesse 1 surface treatment prior to firing. The Hinojosa site assemblage is characterized by extremely standardized exterior surface treatment. Virtual1y al1 sherds have we11smoothed exterior surfaces which have been floated to bring fine clay particles to the surface, thus concealing sand and bone particles and providing a surface which can be polished. Eight percent of the select sample lacks exterior burnishing (polishing). Thirty-three percent have 
highly burnished exterior surfaces, and 58\% have 1 ight7y burnished exterior surfaces. One sherd does not have a preserved exterior surface. Highly burnished surfaces have a highly reflective, even surface, marred only by postdepositional scratching or weathering. Lightly burnished surfaces have low 7 uster and/or uneven polishing. Unburnished surfaces have no visible surface luster. This attribute can usual1y be determined macroscopical1y. Postdepositional weathering undoubtedly effects the luster of the surface finish. Where possible, this factor was taken into consideration (i.e., if a sherd had a remnant of a highly pol ished surface surrounded by an eroded matte surface it was considered highly burnished).

\section{Postfiring Decoration}

Only two forms of decoration were observed, fugitive red filming and aspha1tum painting. Twelve percent of the select sample have traces of asphaltum adhering to the exterior. Only one sherd has asphaltum connected with a broken edge (edge mending). The other 11 sherds have either asphaltum 1 ines of various widths or merely traces of asphaltum in small areas. It appears the asphaltum was applied in molten form after the vessel was fired. Four sherds have fugitive red $f i 1 \mathrm{~m}$ on the exterior surface. One of these, a sma 11 rim sherd, also has fugitive red film on the rim and the interior surface. Fugitive red film is believed to be iron mineral pigment such as earthy hematite (red ochre; Hal1, Black, and Graves 1982). Fugitive red is always app 1 ied to burnished surfaces. The exact mechanism of application is unknown but it appears to be a postfiring decoration. Microscopic examination and chemical testing are often necessary to spot and confirm postfiring decorative techniques. The "Lewis Method" was used to positively identify asphaltum. This chemical test involves placing drops of two chemicals (isopentane and Toluene). on smal1 amounts of scrapings of suspected aspha1tum. Isopentane will not dissolve asphaltum while Toluene will (see Ha 1 1, Black, and Graves [1982:445] for a detailed explanation).

\section{Interior Surface Treatment}

Twenty-two of the sherds have burnished interiors, 31 have wet-brushed interiors, 32 have smoothed interiors, and 12 have uneven surfaces, two sherds do not have preserved interior surfaces, and the handle fragment has no interior surface. Wet-brushed surfaces exhibit a series of paral 1el ridges and furrows created by a brush (frayed stick?) while the clay was sti 11 wet ( $\mathrm{Ha} 11$, Black, and Graves 1982:444). The wet brushing serves to make the surface even, cover coil welds, and perhaps texture the surface.

Smoothed surfaces are those that 1 ack brush marks and burnishing but have tactually smooth, even surfaces. These surfaces are probably created with a wet finger after the vesse 1 has been formed. The final surface treatment type, uneven surfaces, describes essentially unfinished surfaces that 1 ack smoothing, burnishing, or wet brushing. Coil 1 ines, surface 1 umps, and finger indentations are commonly visible. As will be discussed, the interior surface treatment is often related to vessel form and function. Interior surface treatment can usually be determined macroscopical1y, however, microscopic examination with oblique 1 ighting is often useful. 


\section{Paste Matrix}

A11 ceramics are composed of various constituents, including clay, silt, and sand as well as intentionally added inclusions such as bone. The term "paste matrix" refers to the texture and grain size of the ceramic mixture excluding the intentionally added nonplastic inclusions. In other words, the paste matrix is used here to refer to the clay mixture derived from natural sources. Three types of paste matrices are defined: fine, silty pastes (24 sherds); coarse, silty pastes ( 32 sherds); and sandy pastes (44 sherds). The paste matrix must be evaluated by examining a fresh sherd break microscopical1y. The author used a variable-powered 01 ympus binocular microscope fitted with a micrometer in one eyepiece. The micrometer was calibrated for 30X. At 30X, fine silt particles (less than $0.0156 \mathrm{~mm}$ ) are not visible while coarse silt particles $(0.031-0.0625 \mathrm{~mm})$ appear as distinguishable particles. Sand grains are easily visible at $30 x$.

Fine, silty pastes are very fine grained and are typically not very reflective. Coarse, silty pastes are relatively fine grained and usually reflective. Sandy pastes are usually very coarse grained and highly reflective. Silty pastes contain comparatively little sand by definition. Sandy pastes may have moderate to profuse sand quantities. Of course, sandy pastes also have silt and clay particles that appear as a finer grain matrix around and between the individual sand grains. Thus the term "paste matrix" is herein used to refer to the dominant paste constituent other than added temper. Sand is assumed to be an unintentional paste inclusion. The three paste matrix types are obviously derived from differing clay sources as will be discussed.

\section{Paste Inclusions}

Crushed bone was added to all but four of the select sample. The quantity of bone was estimated by examining the fresh break microscopically under 10-20x. The author developed considerable skil1 in estimating inclusion density during the Choke Canyon study (see Ha11, B1 ack, and Graves 1982:399; Ha11, Hester, and Black 1986). Three quantity values were used: profuse (over 25\% by volume), mederate $(5-25 \%)$, and sparse $(>5 \%)$. Profuse quantities of bone occurred in 16 sherds, moderate quantities in 53 sherds, and sparse quantities in the remaining 27 sherds that contained bone. The particle size of the crushed bone typically varied in each sherd from very fine $(<.125 \mathrm{~mm})$ to granular (>2 mm).

Sand grains were observed in al 1 but five of the select sample sherds. As mentioned, sand is assumed to be an unintentional inclusion owing to the difficulty of distinguishing between naturally occurring sand present in the clay and intentionally added sand. Most of the sand grains were subangular to subrounded in morphological shape. Occasionally sherds were examined with predominately wel1-rounded or predominately angular sand grains. The author has previously argued that variation in sand grain morphology suggests differing clay sources (Ha11, B1 ack, and Graves 1982).

A few other paste inclusion types were observed, including hematite, quartzite fragments, resin bubbles, and untempered clay spheres. These are 
considered unintentional inclusions. Small particles of hematite were observed in only three sherds. Resin bubbles were observed in 11 sherds. Quartzite and untempered clay spheres were each observed in four sherds. In addition, two sherds had coarse to granular-sized white inclusions of unknown ,composition (caliche?). These incidental inclusions have been documented in south Texas ceramics and have been discussed in some detail by Hall, Black, and Graves (1982:442-443) and Hal1, Hester, and Black (1986:381-382).

\section{Sherd Thickness}

The maximum thickness of each sherd was measured to the nearest millimeter using a pair of vernier calipers. The $99 \mathrm{rim}$ and body sherds have an average thickness of $6.1 \mathrm{~mm}$ and range between 3 and $12 \mathrm{~mm}$. The thickness of the sandy paste sherds (44) averages $6.7 \mathrm{~mm}$ while the silty paste sherds average $5.7 \mathrm{~mm}$.

\section{Yessel Fragment}

The term "vessel fragment" refers to the section of the vessel from where a given fragment originated. The select sample consisted of seven rim sherds, one handle fragment, and 92 body sherds. Three of the body sherds appear to be fragments of pipe bow 1s. These sherds have smal1 diameter curvatures, thick wal15, and charred interior surfaces. Similar attributes were associated with pipe fragments recovered from Choke Canyon Reservoir (Ha11, B1 ack, and Graves 1982; Highley 1986).

\section{Vessel Forms}

Vessel form could not be determined for most of the ceramic fragments recovered from 41 JW 8 due to the extremely fragmented nature of the collection. The rim sherds, a few unusual sherds, and inferences from the surface treatment a 17 ow some speculation on vessel form. Bow 1 forms are suggested by certain rim sherds (Fig. 10,a-e), and by the fact that 22\% of the select sample have burnished interior surfaces. A well-finished, polished interior surface suggests an open vessel form (bow 1). Constricted neck vesse15, such as ollas, are suggested by rim sherds (Fig. 10,f), a single handle fragment, and the fact that many sherds are noticeably finished more poorly on the interior. At Choke Canyon Reservoir, the olla forms had poorly finished interiors (Hal1, B Tack, and Graves 1982). Certain rim forms (Fig. 10,g) appear to be from partially constricted neck forms such as jars. A final vessel form represented at $41 \mathrm{JW} 8$ is the pipe bow?.

Thus the ceramic assemblage from the Hinojosa site represents a very 1 imited and simple range of functional vessel forms. Cooking, water storage, food storage, and smoking are functions of the inferred vessel forms. The figurine fragment discussed next is the on 7 y nonuti 1 itarian ceramic form found at $41 \mathrm{JW} 8$. 


\section{CERAMIC FIGURINE FRAGMENT}

One unusual ceramic object recovered from $41 \mathrm{JW} 8$ appears to be a fragment of a figurine ( $\left.F i g .10, h, h^{\prime}\right)$. This artifact was not included in the select samp 1e. The object is $3.7 \times 1.65 \times 1.45 \mathrm{~cm}$ and weighs $9 \mathrm{~g}$. The cigar or thumb-shaped object is gray tan in color. The surface has been smoothed and very 1 ightly polished. Design elements include tiny punctations, a shallow groove, and several wavey incised 1ines. Due to the unusual nature of the artifact, it was not broken to examine the paste. Based only on surface examination, the object appears to be made from a sandy paste with some bone temper. In other words, the object appears to be made from the same materials as many of the other ceramic fragments at the Hinojosa site. This may suggest that the figurine is a locally made artifact.

Ceramic figurine fragments are known from several sites in southern Texas and a 1 ong the Texas Gulf coast (Chandler 1978). The specimen from 41 JW 8 most closely resembles a figurine found at a site in San Patricio County (Chandler 1978:344). The complete form and the function of these rare artifacts are not known. They may represent some type of effigy object or fetish.

\section{CERAMIC SUMMARY AND DISCUSSION}

The prehistoric ceramic materials from $41 \mathrm{JW} 8$ form a 1 arge collection of sma 11 fragments. The average weight per sherd of the ceramics recovered from the Wagon Trail Area is only $1.16 \mathrm{~g}$. Many of the sherds are so badly weathered that surface treatment could not be determined. The collection is fairly homogeneous in most characteristics. Surface colors range from tan to gray to flesh. Fire clouds are common, especially on the exterior surfaces. Most exterior surfaces, unless clouded, are clearer and brighter in color (better oxidized) than the interior surfaces. Exterior surfaces are almost always smoothed, floated, and burnished. Interior surfaces are usually less wel1 finished and often smoothed with an implement that left brush marks (a frayed stick?). Vessel forms are 1 imited to simple, functional forms such as bow $15,011 \mathrm{as}$, and jars except as noted. It is estimated that one-fifth to one-fourth of the vessels represented by the collection were decorated. Asphaltum 1 ines are the dominant form of decoration a 1 though fugitive red filmed vessels are present. Much of the variation noted within the collection can be correlated with paste composition.

Several interesting differences are noted between the silty paste ceramics and the slightly less numerous sandy paste ceramics. Based on the select sample attributes, these differences include sherd thickness, surface finish, and surface color. The silty paste sherds average $1 \mathrm{~mm}$ less in thickness than the sandy paste sherds $(5.7 \mathrm{vs} .6 .7 \mathrm{~mm})$. Si tity paste sherds tend to be highly burnished more often than the sandy paste sherds. The surface color of the silty paste sherds tend to be flesh colored while the sandy paste sherds tend to be tan colored. It was also observed that the silty paste sherds are stronger than the friable sandy paste sherds. Silty paste sherds tend to have moderate to profuse quantities of bone while sandy paste sherds tend to have sparse to moderate bone quantities. 

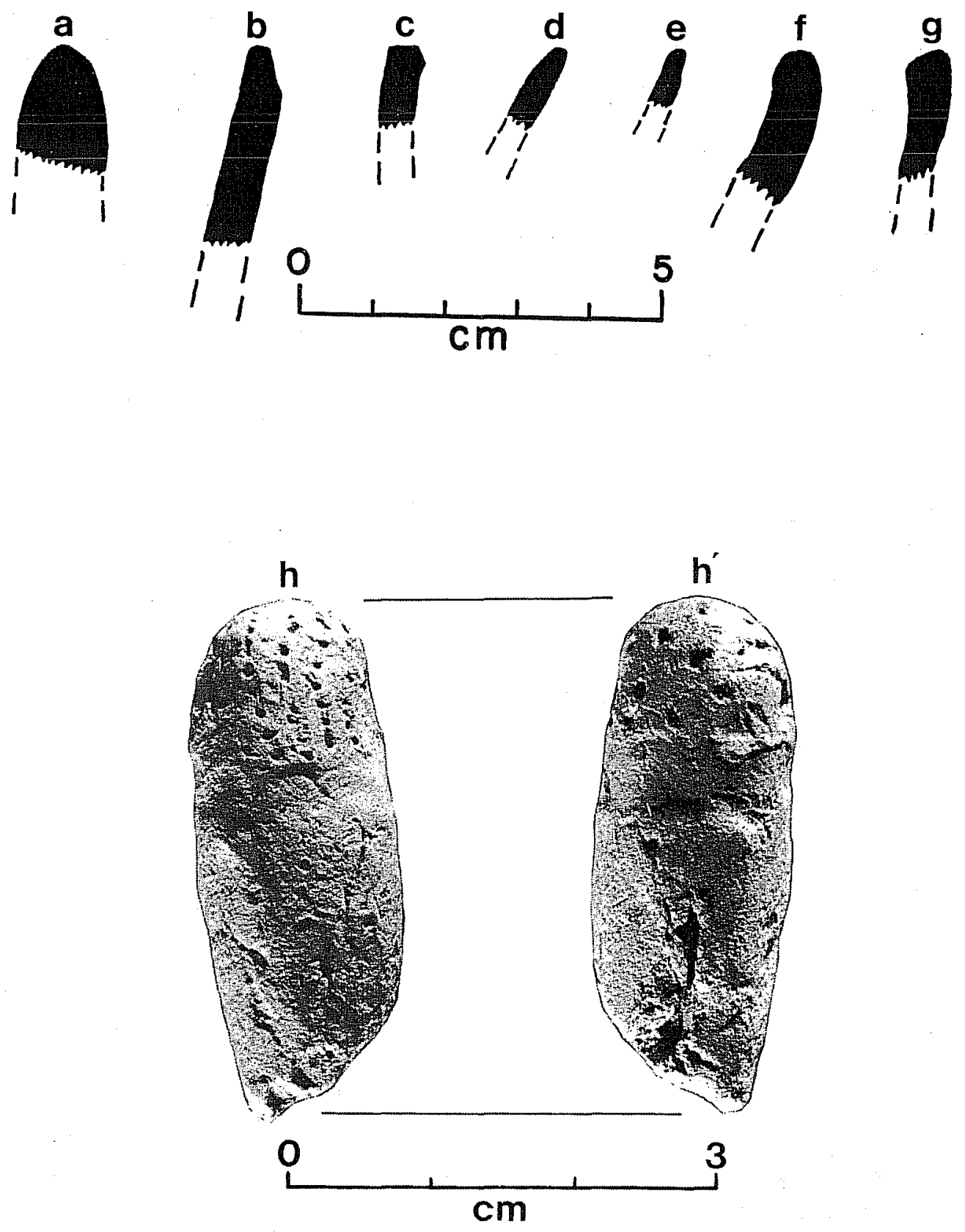

Figure 10. Ceramic Artifacts. a-g, rim sherd profiles (interior surfaces on the right); $h, h^{*}$, figurine fragment. Lot numbers: a, 459-1; b, 110; $c, 448$; d, 28I;e, $441 ; f, 61 ; g, 384 ; h, 516$. 
The observed differences are interpreted as technological rather than cultural in nature. Silty pastes with bone temper allow the construction of stronger vessels with relatively thin walls. Silty paste vessel surfaces take a higher polish because the fine-grained paste compacts and covers inclusions better than the coarser grain sandy pastes. Sandy pastes need less bone temper, but must be thicker than silty paste vessels to make a durable vessel. Interestingly, asphaltum and fugitive red decoration occur in equal quantities on silty and sandy paste ceramics. It is suggested that the observed differences simply reflect the fact that prehistoric potters had to use slightly different techniques when using a sandy paste clay than they would have used with a silty paste clay. It is predicted that a study of reconstructed vessels from south Texas would reveal differences in vessel form that could be correlated with paste characteristics. $011 \mathrm{a}$ and jar forms are more likely to have been made from silty pastes with bone temper. Sandy pastes are probably better suited for bow 1 forms and possibly pipe bowls.

In the report on the 1975 field work at $41 \mathrm{JW}$ 8, "one possible Rockport ware sherd" was noted (Hester 1977:26). The present analysis did not find any clear examples of Rockport ware. Rockport ware ceramics are typically thin, sandy paste sherds that are gray to tan in color and often have asphaltum decoration (Suhm and Jelks 1962; Campbel1 1962). As mentioned, most of the sandy paste ceramics at 41 JW 8 are thicker than the silty paste sherds, and virtual1y al1 of the select sample have bone temper. Rockport ware ceramics are usually identified on the basis of surface characteristics such as color and asphaltum decoration and their general sandy paste. Careful studies of the pastes are few in number. Perhaps the most important is a paste study done by Story (1968) of the Ingleside Cove ceramics (Rockport ware). Story's careful microscopic examination revealed a great deal of paste variation. It is interesting to note that bone temper was present in a significantly 1 arge percentage of the sherds and that bone-tempered, sandy paste sherds constituted one of the most numerous paste groups at the site.

This author has noted the presence of bone tempering in a number of collections of sandy paste coastal pottery from the Freeport area (BI ack and Cox 1983) to the Corpus Christi area (Mokry and Black ms.). It is argued here that the sandy paste ceramics of the Coastal Bend region and the bonetempered ceramics of inland south Texas commonly share attributes (sandy paste, bone temper, and asphaltum decoration) and are both basically functional pottery with 1 imited variation in form (water jugs or ol 1 as are the most common form in both areas). The most important difference is herein seen as the original clay source. The sandy clay of the coastal area is seen as a superior raw material that allowed the creation of thin-walled vessels. Sandy paste clay from inland sources is more 1 ikely to be an al 1uvial material that has coarser grain clay and 1 arger sand size, hence could not be used to form thin-walled vessels. The finer grain in 1 and clays, on the other hand, were used in conjunction with massive amounts of bone temper to create vessels as thin as the coastal wares.

The most important point of this discussion is that many of the differences between the coastal and inland ceramic traditions in southern Texas are seen as more a factor of raw material availability than cultural preference. The numerous shared attributes and the overall similarity in basic form and 
function suggest that the two traditions may share a common origin. There are significant differences, such as the form variation and the decorative motifs. Thus, the two traditions are distinct, however, they overlap in many attributes, as the Hinojosa sample attests.

\section{BAKED CLAY LUMPS}

Sma 11, irregularly shaped 1 umps of baked clay were recovered in moderate quantities from $4 I \mathrm{JW}$ 8. These 1 umps range from tennis ball size to peasized with most 1 umps less than golf ball size. The baked clay 1 umps, while irregularly shaped, are generally rounded and oval to spherical. No evidence of purposeful shaping, smoothing, or manufacture was observed. Surface colors are tan to orange to ye110w and usually obscured by thin, 1 ight gray, calcareous coatings. Fresh breaks reveal the same tan-orange-yel1ow-colored matrix in most 1 umps, although a few have darker, incompletely oxidized, gray cores. A number of the baked clay objects are broken and were examined microscopical1y. Virtual1y al1 have a very sandy clay matrix with occasional voids, pebbles, and root impressions. No trace was observed of bone, flakes, or snails.

Baked clay lumps (objects, bal1s, or nodules) are very common constituents in South Texas Gulf Coastal Plain site deposits. Various explanations have been advanced to explain these 1 umps as Black (1978) and more recently Smith (1982) have reviewed. Both authors agree with Corbin's (1963) explanation that most baked or burned clay objects result from building an open fire on a clay-rich soil surface. The heat of the fire "bakes" the underlying clayrich 50i1, thus forming sma 11 hardened 1umps. Smith (1982:36) concludes: "It now seems clear that many south Texas soils contain one or more chemical compounds that respond to the heat of a fire such that the matrix is bound up and hardened. ..." It is suggested here that the "chemical compounds" are nothing more than the various clay minerals present in most soils within the South Texas Gulf Coastal Plain. One of the properties of $c$ lay is that when heated, the water within the clay is removed, leaving a hardened durable substance, ceramic material.

Several aspects of the baked clay 1 umps from $41 \mathrm{JW} 8$ remain puzzling. First, the baked clay lumps appear far sandier than the typical soil matrix at the site. Second, the absence of any flakes, bone, or snail shell fragments in any of the examined 7 umps is surprising in view of the frequency of these materials within the soils at the site. No explanation for these inconsistencies with the site soil matrix is immediately apparent.

\section{MODIFIED BONE AND SHELL}

Each of the bone and shel1 items, which have been modified by cutting, grinding, smoothing, and incising to form tools or ornaments, is discussed in the following few pages. The bone items are ulna tools, a bone needle, and bone beads. Both mussel shel1 and marine she11 were modified. 


\section{Bone Needle}

The bone needle (Lot 113; Fig. 11,e) is a small bone splinter which has been smoothed to form a slender, rounded object not unlike a toothpick. It is $3.3 \mathrm{~cm}$ in length (broken) and has a maximum diameter of $4 \mathrm{~mm}$. The artifact is somewhat weathered but has highly polished traces in some areas. Many obvious scratch marks were observed perpendicular to the long axis of the needle. On close inspection, these proved to be rodent gnaw marks that occurred in paired clusters. It is suggested that this artifact was used on some type of relatively soft material (leather or plant fiber) in some type of sewing function. The remnants of the highly polished areas attest to repeated use. Similar tools have been found in southern, central, and southwestern Texas. The complete tool would have most 1 ikely had a rounded proximal end with a small hole drilled to thread the fiber or leather strand.

\section{Bone Beads}

Seven bird bone beads (Fig. $10, f-h$ ) were found at 41 JW 8 . A71 are made from a thin, hol 1 ow 1 ong bone shaft that appears to be a $1 \mathrm{eg}$ bone from a turkeysized bird. All seven are similarly made and are of approximately the same diameter, 5-7 mm. They range in length from $7 \mathrm{~mm}$ to $20 \mathrm{~mm}(7,10,10,12$, 12, 12, and $20 \mathrm{~mm}$ ). A11 appear to have been made by the groove and snap method. Four beads are only partially smoothed on the snapped edges, hence showing the construction technique. The remaining three have very we 11 smoothed and polished ends. All the bone beads have polished areas ranging from 1 ightly polished that may just be the result of handiing to highly polished that appear to be purposeful.

A11 seven bone beads were found in the Wagon Trail Area and could represent a single broken bone bead necklace. Very similar bone beads were recovered in very large quantities from a burial found at the Arroyo de los Muertos site near Laredo (MCGraw 1983). The burial, of a young woman and her infant, had hundreds of bone beads that were present as grave offerings. Most of these beads were arranged as neck 1 aces and bracelets, although some 1 oose beads were found away from the wrist and neck region of the burial suggesting that some beads were sewn on the clothes of the deceased. The Laredo burial is not wel1 dated; however, it is thought to be Late Prehistoric in age. Bird bone beads have been found at many Late Prehistoric sites in southern Texas, such as several of the Zavala County sites (Hester and Hi11 1975:14), 41 LK 201 (Highley 1986), and 41 MC 296 (Ha7 1, Hester, and Black 1986:334).

\section{MODIFIED SHELL}

A smal1 number of modified shel1 artifacts were found at the Hinojosa site. Seven fragments are freshwater mussel shel 1, and 15 marine shel1 fragments have been modified by cutting, grooving, and/or grinding. A11 appear to be fragments of she11 tools, ornaments, or ornament manufacturing debris. 


\section{Shaped Mussel Shell}

A number of musse 1 shell fragments that were recovered from the site appear to have been shaped by cutting and/or grinding. Many of these, upon close examination, appear to be fortuitously broken fragments that have a regular shape. Seven fragments have definite evidence of modification. Undoubtedly other shaped fragments were present but not identified. Five of the seven fragments have angular shapes that tend to be rectanguloid in outline. The other two fragments have oval outlines. With the exception of two irregular, angular fragments, these mussel shell pieces appear to represent she 11 ornament blanks that were never finished. The edges of most were formed by the use of a very sharp instrument (probably a flake) to cut the shell. Some of the edges appear to have been completely cut while others seem to be on $1 \mathrm{y}$ partialiy cut and then snapped. Several of the fragments have smooth edges that appear to have been ground down. The absence of suspension holes and the unfinished look of these seven fragments suggest that they represent ornament blanks that were never completed.

The specimen from Lot 60 (Fig. 12,b) is a thick, oval fragment with smoothed edges. It is $21 \times 24 \mathrm{~mm}$.

The specimen from Lot 69 is a smal1, rectangular fragment with cut and smoothed edges. It is $13 \times 14 \mathrm{~mm}$.

The specimen from Lot 295 ( $F$ ig. 12, a) is a sma 11 , rectangu 7 ar fragment that has been cut on three edges. It is $11 \times 13 \mathrm{~mm}$.

The two specimens from Lot 255 are sma11, irregular fragments with angular cut edges. They are $6 \times 9 \mathrm{~mm}$ and $9 \times 14 \mathrm{~mm}$.

The specimen from Lot 280 is a square fragment with cut and ground edges. It is $7 \times 9 \mathrm{~mm}$.

The specimen from Lot 522-2 (Fig. $12, \mathrm{C}$ ) is a 1 arge, oval fragment with ground edges. This musse 1 she 11 may have been chipped. It measures $21 \times 44 \mathrm{~mm}$.

\section{Incised Mussel Shell}

Two mussel shel1 artifacts were found in association with Feature 7 , the living surface documented in the southern portion of the site. One (Lot 3542; Fig. 12,d) is a beautifully made pendant. The pendant is triangular and smoothed on all three edges with a biconically drilled suspension hole $(3 \mathrm{~mm}$ in diameter). It is made from the edge section of a 1 arge, $01 d$ musse 1 that must have been collected from a major river such as the Nueces River (Harold Murray, personal communication). It is $22 \times 38.5 \mathrm{~mm}$. On the interior face a geometric design is incised. The design consists of a double-incised 1 ine extending down from the edge of the suspension hole to the curving edge near the bottom. Two parallel-incised 1 ines, spaced $7 \mathrm{~mm}$ apart, are perpendicular to the first line, extending from the double line to one edge of the artifact. Five smaller parallel-incised 1 ines, spaced 1 to $2 \mathrm{~mm}$ apart, are between the larger parallel lines, dividing the space into six tiny panels. The entire design looks something 1 ike an upside down flagpole and flag. 
Another incised fragment (Lot 343-4; Fig. 12,e) is made of thin musse 1 she11. Its out ine shape is irregularly angular. The edges are cut, and it is $12 \times$ $18 \mathrm{~mm}$. A series of six paral1el-incised 1 ines, spaced 1.5 to $3 \mathrm{~mm}$ apart, covers the interior surface. One corner of the artifact is broken off along an incised 1 ine. The function of this artifact is not known.

\section{Marine Shell}

Nineteen marine shel1 fragments were recovered from 41 JW 8, including two fragments found in 1975 (Hester 1977:Fig. 7). Most of these fragments are either ornament or tool fragments or manufacturing debris. Table 81 ists the proveniences (1 ot numbers) and identification of each fragment. The identifications were made by Gentry Steele. Most fragments (such as Fig. 12,f,g) are smal1 pieces which have chipped or irregularly broken edges and are thought to be debris resulting from the manufacture of she 11 ornaments or tools. These will not be described in detail. The specimens that are definitely tools or ornaments are described.

The specimen ( $F$ ig. $12, h$ ) from Lot 51 , recovered in 1975, is a fragment of a discoidal bead. Hester (1977) identified this as a conch fragment; Steele identified it as a Bivalvia fragment. The projected outline diameter is about $20 \mathrm{~mm}$. The suspension hole is biconically drilled and is about $3.5 \mathrm{~mm}$ in diameter.

The specimen from Lot 55, also-recovered in 1975 (Fig. 12, $i$ ), is a rectangular fragment of a ribbed marine she11. Hester (1977) identified it as a Dinocardium fragment; Steele identified it as a Laevicardium fragment. Several of the edges have cut marks but are otherwise rough.

One Lot 56 fragment (Fig. 12,k) is a piece of a 1 arge Laevicardium she 11. Most of the edges are irregularly broken, however, one edge is heavily smoothed and rounded. This edge is the outer shell edge but appears to have been used for some sort of scraping function.

Another Lot 56 fragment (Fig. 12,1) is a conch (Busycon) body whor 1 section. The tip is rounded and smoothed. It is faceted and polished by use.

The specimen (Fig. 12,i) from Lot 131 is a hinge section of a Callista that has been smoothed and pol ished by use.

\section{HISTORIC ARTIFACTS}

A number of historic artifacts were recovered from the upper excavation levels at $41 \mathrm{JW}$ 8. Most of these artifacts represent the 20 th-century ranching and farming occupation of the area. A few historic items may date to the mid-19th-century. Al1 historic artifacts recovered from the site clearly postdate the prehistoric occupation and are considered to be of very minor importance. 


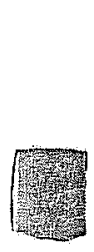

a

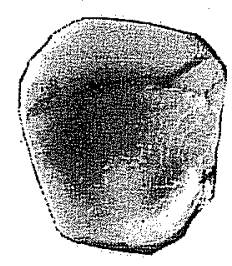

b
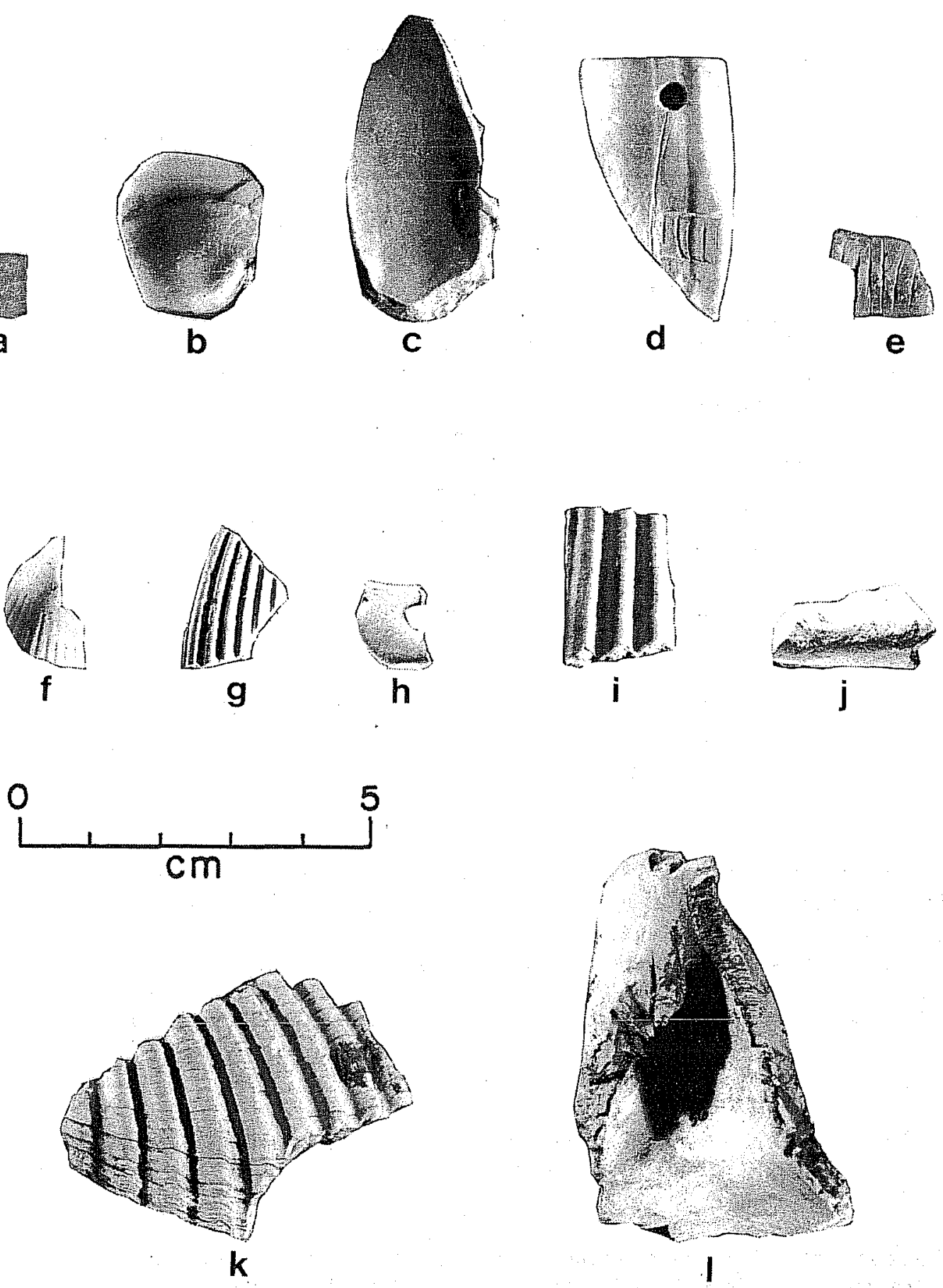

|Figure 12. Modified Shel1 Artifacts. a-c, cut mussel she11; d, mussel she11 pendant; $e$, incised mussel she11; f,g, marine shell fragments, h, marine she 11 bead; $i-1$, marine she11. Lot numbers: a, 295; b, 60; $c, 522-2$; d, 354-2; e, 343-4, f, 333; g, 56; h, 5l; i, 55; j, 131; k, 56; 1, 56 . 
TABLE 8. MARINE SHELL IDENTIFICATIONS

\begin{tabular}{lll} 
Lot Number & Taxon & Material Description \\
\hline $51(1975)$ & Bivalvia & fragment, bead section \\
$55(1975)$ & Laevicardium & fragment with cut edge \\
56 & Laevicardium & fragment with smoothed edge \\
56 & Busycon & body whor fragment, smoothed and polished \\
56 & Bivalvia & fragment with cut edge \\
71 & Bivalvia & 2 fragments \\
61 & Callista & 2 hinge fragments \\
98 & Bivalvia & fragment, weathered smooth edge \\
120 & Bivalvia & fragment with cut edges \\
121 & Callista & fragment with cut edge \\
131 & Bivalvia & fragment with cut edges \\
131 & Callista & hinge fragment, smoothed \\
176 & Bivalvia & ribbed fragment \\
311 & Bivalvia & fragment \\
333 & Bivalvia & fragment \\
339 & Bivalvia & fragment with cut edges \\
345 & Callista & fragment with cut edge
\end{tabular}

Metal artifacts are the bulk of the historic materials. Twentieth-century meta 1 items consist of plain wire fragments, barbed wire fragments, fence stap 1es, wire nails, .22 caliber rimfire cartridge she11.s, sheet metal fragments, bottle caps, screws, an electric connector, and aluminum foil. The only metal item that may date to the 19th century is a hand-forged singletree center clip and hook. This device was commonly used in the 19th century to connect wagons to the horse's traces. It seems appropriate that this wagon part was recovered from the "Wagon Trail Area" (Lot 266).

A few 20th-century glass fragments were recovered. These consist of clear window pane fragments; clear and brown bottle fragments; and a smal1, white 4-hole button.

A bone button was also recovered. This artifact is $17 \mathrm{~mm}$ in diameter and is about $2 \mathrm{~mm}$ thick. The front face has a circular central recess $8 \mathrm{~mm}$ in diameter with five cylindrically drilled holes. Bone buttons in Texas generally predate the Civil War (Anne Fox, personal communication).

A small number of historic ceramics were also recovered from $41 \mathrm{JW} 8 . \quad$ Four sherds of a crudely made stoneware were found. These range in thickness from 8 to $12 \mathrm{~mm}$. The red exterior is poorly smoothed and partially covered with a 1 ight gray to b1ack burnished s 1 ip. . The core and interior surface are a uniform gray color. Based on the surface finish and curvature, these sherds probably represent fragments of a 1 arge water jug (Anne Fox, personal communication). Similar ceramics have been found in early historic contexts (mid 
19th-century or earlier) in the Falcon Reservoir area (collection on file, CAR). Two smal1 fragments of a lead-glazed earthenware were found. These represent Mexican-made ceramics dating to after 1850 (Anne Fox, personal communication). One small stoneware sherd with a burnished gray exterior was also recovered.

The singletree center $\mathrm{clip}$ and hook, bone button, and stoneware and earthenware ceramics probabiy represent a mid-19th-century occupation in the site area. These items can most $1 \mathrm{ikely}$ be attributed to the initial construction of the nearby Amargosa Stage Stop which was bui1t sometime prior to 1876. 


\section{SPECIAL STUDIES}

The analyses that were done of the 1981 materials are detailed in these special studies to provide critical data on many aspects of the prehistoric occupation such as subsistence, and information on the environmental conditions. A number of consultants studied aspects of the site for which they had particular expertise. Gentry Steele, a physical anthropologist and zooarchaeologist at Texas A\&M University (TAMU), studied the faunal materials from the site. John Jones, a graduate student in paleobotany at TAMU, examined the charred botanical remains. Harold Murray, a malacologist at Trinity University, identified the freshwater mussel shel1s recovered from the site. Richard G. Holloway, a palynologist at TAMU, examined soil samples for pol1en. Ralph Robinson, a graduate student in paleobotany at TAMU, studied phytoliths recovered from the site. The author interpreted the results of the radiocarbon assays done by several institutions. Additional studies were done by the author.

\section{ANALYSIS OF YERTEBRATE FAUNAL REMAINS (D. Gentry Steele)}

The faunal assemblage from the Hinojosa site (4l JW 8) represents a very significant south Texas vertebrate sample for several reasons. It is from a single component Late Prehistoric site occupied around 1250-1500 A.D., thus providing a faunal assemblage from a discrete period of time. The sample is one of the largest faunal assemblages examined from south Texas. Finally, the assemblage indicates that the bone is remarkably well preserved and in provenience so that there does not appear to have been a great amount of dispersal before deposition or dissolution of bone during the period of deposition.

\section{SAMPLE}

The site has been excavated twice. Faunal remains recovered during the first field season in 1975 were examined by Bil1y Davidson and reported by Hester (1977). The examined portion consisted of $7000 \mathrm{~g}$ of bone (number of bone fragments was not recorded). A sample of the fauna 1 assemblage recovered during the second field season, 1981, was examined by the present author and consisted of 3041 identifiable fragments (the total weight of fragments was not recorded). The mean weight of a selected sample of bone fragments examined from the 1981 faunal assemblage was $0.15 \mathrm{~g}$ which is slightly smaller than the $0.37 \mathrm{~g}$ mean weight of bone fragments recovered from 41 LK 201, another south Texas site (Steele 1986). It should be noted that both of these means are based on material recovered from 1/4-inch screen and by hand picking of bones (see Steele and DeMarcay 1986 for significance of fine screening for faunal samples).

Subjectively, the bone assemblage from 41 JW 8 was composed predominately of highly comminuted bone, a significant portion of which was also burned. The great majority of breaks observed on the bone were spiral fractures which occurred while the bone was fresh and contained a high collagen content. Most of the few fractures which appeared to have occurred after the bone had dried and was friable, occurred quite recently as indicated by the 1 ack of 
staining or patination of the fractured surfaces. A few of these fragments, however, evidenced fine 1 ine weather cracks which indicate that these bones at least had been exposed to dessication as well as freezing and thawing prior to burial. A microscopic examination of bone fragments indicated that they had been subjected to no appreciable chemical dissolution during their period of deposition. In these respects, the bone assemblage from $41 \mathrm{JW} 8$ compares favorably with the we11-preserved bone assemblages from 41 LK 201 (Steele 1986), 41 MC 222 (Steele and Hunter 1986), and 41 MC 296 (Steele and Hunter 1986).

The following analysis is based upon an examination of al1 modified bone (Table 7); al1 bone from identified features (Tab1e 10); al1 bone plotted on site maps (Tab1e 11); and a 11 bone from Units N104 E94, N104 E95, E104 E96, N105 E94, N105 E95, N105 E96, N108 E94, N108 E95, N109 E94, and E109 E95 (Table 12). The bone from these samples were recovered by hand sorting during the process of excavation and from sieving a 11 matrix through 1/4-inch screens. Additional two-liter samples from each feature were screened through a U.S.A. standard testing sieve no. 35 with an opening size of 500 micrometers. Potentially identifiable bone (teeth, complete bones, and fragments with articular ends) were picked from this sample (see Section VII: Water Separation). These materials were added to the analysis.

\section{DIETARY PATTERNS}

Various reports based upon analyses of faunal remains recovered from south Texas sites have emphasized the diversity of the faunal assemblages (Hester and Hi11 1975; Hester et a 1. 1975; Hester 1975, 1977; Steele and Mokry 1985; Steele 1986; Steele and Hunter 1986), and the assemblage from 41 JW 8 corroborates these previous assessments. Davidson identified 30 taxa recovered during the 1975 field season, and the remains of 33 taxa recovered during the 1982 field season (Table 9). The combined sample consists of 45 identified taxa containing at least 31 genera.

Upon more careful examination, the sample contains the remains of fishes, birds, amphibians, reptiles, and mammals. Of these classes, mammals are by far the most commonly represented. Part of the reason for the greater representation of the mammals is that the bones of the other classes are smaller and more fragile, therefore more subject to destruction and 1oss. Even when this bias against the recovery of the smaller vertebrates is taken into account the mammals stil 1 represent by far the 1 argest number of species identified, and the class whose skeletal elements are most commonly recovered. This preponderance of mammalian remains in south Texas sites has been noted previously (Steele 1986; Steele and Hunter 1986), and it probably reflects the fact that mammals are the most consistently available and easily harvestable vertebrates in the region. It is a 1 so apparent that when the amount of meat contributed by each class of vertebrates is considered, the mammals again are the most important. This is simply because most species of mamma 75 are considerably 7 arger than other vertebrates.

Upon closer examination of the mammals (see Table 9), 19 taxa were recovered, including opossums, artiodacty 15 , 1agomorphs, carnivores, insectivores, and rodents. Of these, the remains of artiodactyls and lagomorphs are most 
TABLE 9. SYSTEMATIC LIST OF THE IDENTIFIED VERTEBRATE REMAINS RECOVERED FROM 41 JW 8 DURING THE 1975 AND 1981/1982 FIELD SEASONS

Vertebrate Remains*

Field Season

$1975 \quad 1981 / 1982$

Phylum Chordata

Subphylum Vertebrata

Class indeterminate (vertebrates)

$\times$

C1ass Osteichthyes

Order indeterminate (fishes)

$\times \quad \times$

Order Cypriniformes

Family Ictaluridae

Genus indeterminate (catfishes)

$\times \quad x$

Order Perciformes

Family Sciaenidae

Genus Aplodinotus

A. grunniens (freshwater drum)

$\times$

Class Aves

Order indeterminate (birds)

$x$

$\times$

Order Anseriformes

Family Anatidae

Genus indeterminate (ducks, geese, and swans) $\times$

Order Gal1iformes

Family Meleagridae

Genus Meleagris

M. gallopavo (wild turkey)

$\times$

$x$

Order Falconiformes

Family indeterminate (birds of prey)

$\times$

$x$

Order Ciconi iformes

Family Ardeidae

Genus indeterminate (herons)

$\times$

Order Strigiformes

Family Cuculidae

Genus Geococcyx

G. cal ifornianus (greater roadrunner)

$\times$

Class Amphibia

Order Anura

Family Ranidae

Genus Rana

Species indeterminate (frogs)

$\times$ 
TABLE 9. (continued)

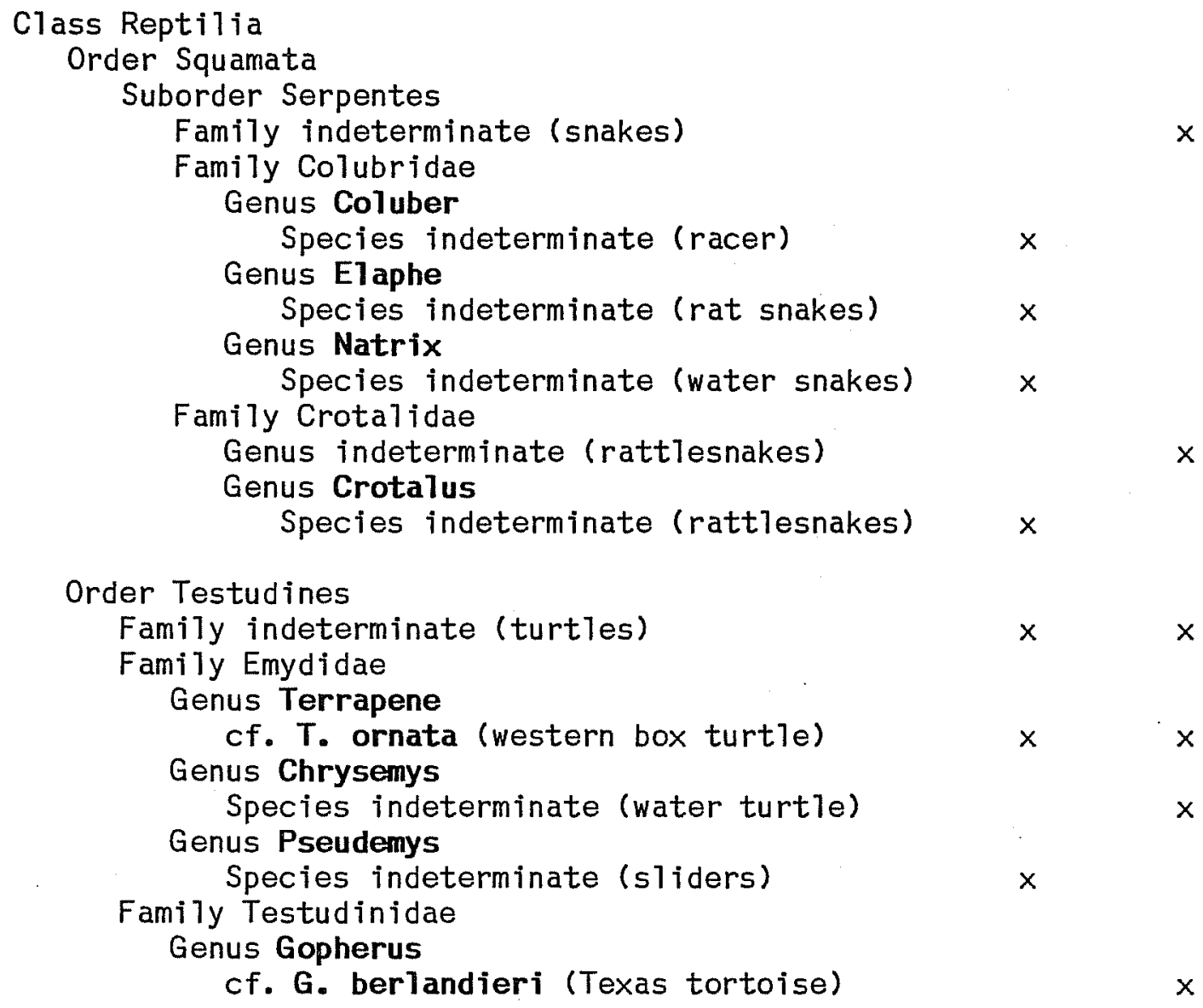

Family Cervidae Genus Odocoileus

0. virginianus (white-tailed deer) $x=x$

Family Tayassuidae Genus Dicotyles

D. tajacu (collared peccary) $x$ 
TABLE 9. (continued)

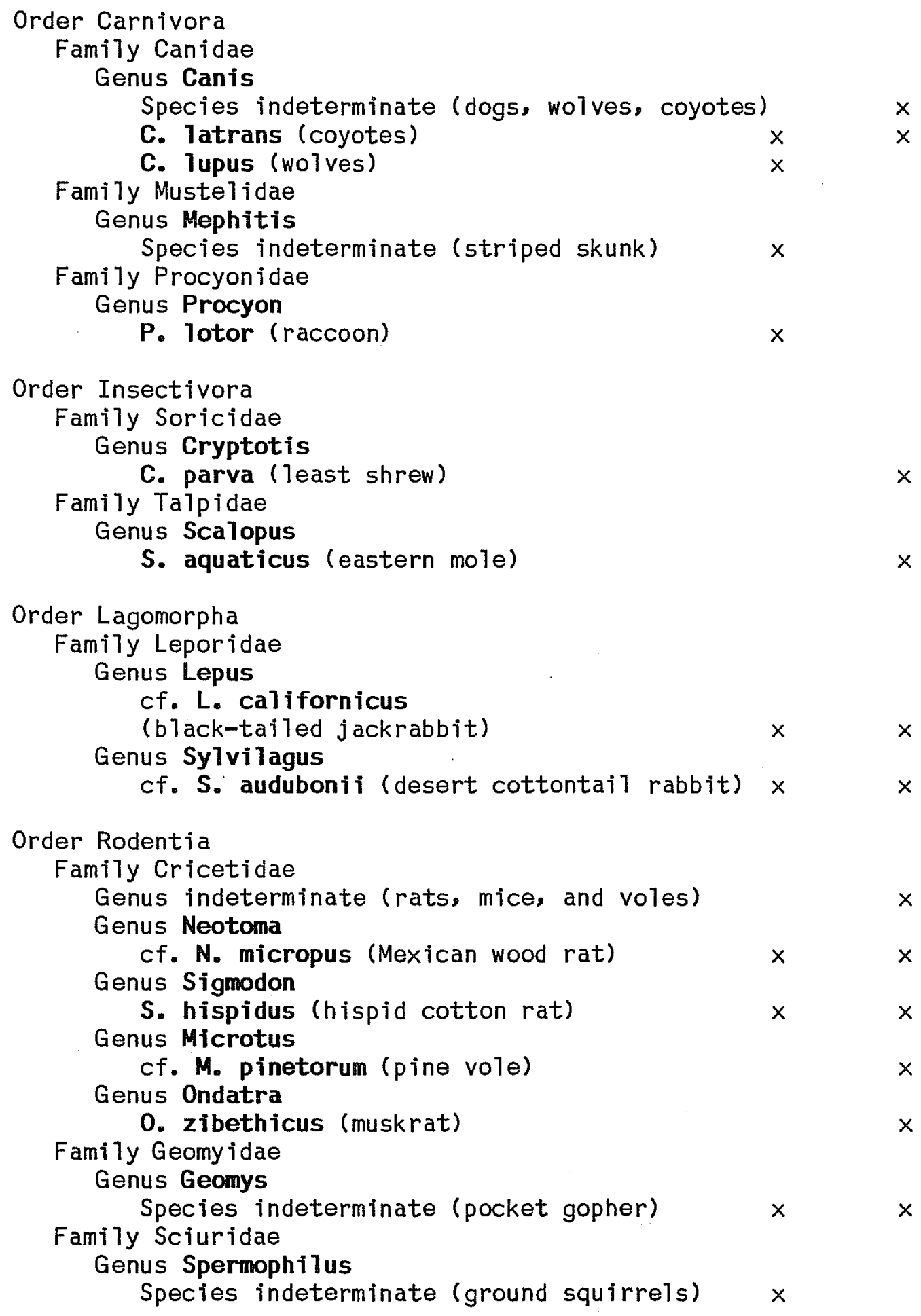

*The vernacular name is listed in parentheses beside the identified taxon. 


\begin{tabular}{|c|c|c|c|c|}
\hline $\begin{array}{l}\text { Feature } \\
\text { Number }\end{array}$ & $\begin{array}{l}\text { Lot Number } \\
\text { Item Number }\end{array}$ & Taxon & Material & Comments \\
\hline $\mathrm{F} .2 \mathrm{~A}$ & $\begin{array}{l}156-1 \\
156-2 \\
156-3 \\
156-4 \\
182-1,2,3 \\
182-4\end{array}$ & $\begin{array}{l}\text { Odocoileus } \\
\text { Mammalia } \\
\text { Aves } \\
\text { Testudines } \\
\text { Bison } \\
\text { Bison }\end{array}$ & $\begin{array}{l}\text { ulna fragments } \\
23 \text { fragments } \\
\text { long bone fragments } \\
\text { scapula fragment } \\
3 \text { humerus segments } \\
\text { carpal }\end{array}$ & $\begin{array}{l}\text { many exhibit spiral fractures } \\
\text { based on size, two individuals } \\
\text { are represented }\end{array}$ \\
\hline $\mathrm{F} .2 \mathrm{~B}$ & $\begin{array}{l}165-1 \\
183-1\end{array}$ & $\begin{array}{l}\text { Mammalia } \\
\text { Bison }\end{array}$ & $\begin{array}{l}19 \text { fragments } \\
\text { left femur segment }\end{array}$ & spiral fractures present \\
\hline $\mathrm{F} .3^{*}$ & $\begin{array}{l}184-1 \\
184-2 \\
184-3 \\
184-4 \\
184-5,6,10,11,12 \\
184-5 \\
184-5,6,8,10,12 \\
184-7 \\
184-8 \\
184-9 \\
184-12\end{array}$ & $\begin{array}{l}\text { Meleagris } \\
\text { Odocoileus } \\
\text { Neotoma } \\
\text { Odocoileus } \\
\text { Gopherus } \\
\text { Lepus } \\
\text { Mammal ia } \\
\text { Odocoileus } \\
\text { Aves } \\
\text { Bison } \\
\text { Scalopus }\end{array}$ & $\begin{array}{l}\text { left femur } \\
\text { phalange } \\
\text { left ulna, right mandible } \\
\text { left tibia segment } \\
5 \text { carapace and plastron } \\
\text { fragments } \\
\text { left femur } \\
6 \text { fragments } \\
\text { right mandible } \\
\text { femur fragment } \\
\text { right humerus segment } \\
\text { humerus, } 2 \text { vertebrae, } \\
2 \text { phalanges, occipital }\end{array}$ & $\begin{array}{l}\text { spiral fracture } \\
\text { some exhibit spiral fractures } \\
\text { smalt bird } \\
\text { possibly represents an intrusive } \\
\text { individual }\end{array}$ \\
\hline $\mathrm{F} .5$ & $\begin{array}{l}304-1 \\
304-2 \\
304-3 \\
304-4\end{array}$ & $\begin{array}{l}\text { Canis } \\
\text { Sylvilagus } \\
\text { Mammalia } \\
\text { Osteichthyes }\end{array}$ & $\begin{array}{l}\text { right and left upper } \\
\text { molars } \\
\text { left zygomatica } \\
\text { fragment } \\
\text { vertebra }\end{array}$ & smal1 species \\
\hline
\end{tabular}


TABLE 10. (continued)

\begin{tabular}{|c|c|c|c|c|}
\hline $\begin{array}{l}\text { Feature } \\
\text { Number }\end{array}$ & $\begin{array}{l}\text { Lot Number } \\
\text { Item Number }\end{array}$ & Taxon & Material & Comments \\
\hline$F \cdot 6^{\S}$ & $\begin{array}{l}397-11,16 \\
397-13 \\
397-14 \\
397-15 \\
397-17 \\
\text { unplotted }\end{array}$ & $\begin{array}{l}\text { Mamma } 1 \text { ia } \\
\text { Microtus } \\
\text { Terrapene } \\
\text { Odocoileus } \\
\text { Odocoileus } \\
\text { Gopherus }\end{array}$ & $\begin{array}{l}3 \text { fragments } \\
\text { right mandible } \\
\text { plastron fragment } \\
2 \text { vertebrae } \\
\text { left ulna } \\
\text { plastron fragment }\end{array}$ & $\begin{array}{l}\text { butcher marks and spiral } \\
\text { fractures } \\
\text { subaduit } \\
\text { subaduit }\end{array}$ \\
\hline$F .7^{++}$ & $\begin{array}{l}353-1 \\
353-4 \\
353-6 \\
353-7 \\
354-1,7 \\
354-5 \\
354-6 \\
354-7 \\
354-7 \\
454-1 \\
454-2,4,5 \\
454-3\end{array}$ & $\begin{array}{l}\text { Odocoileus } \\
\text { Anseriformes } \\
\text { Sylvilagus } \\
\text { Odocoileus } \\
\text { Mammalia } \\
\text { Lepus } \\
\text { Odocoileus } \\
\text { Ictaluridae } \\
\text { Serpentes. } \\
\text { Bison } \\
\text { Mammalia } \\
\text { Antilocapra }\end{array}$ & $\begin{array}{l}\text { phalange } \\
\text { left humerus } \\
\text { left maxilla } \\
\text { metapodial epiphysis } \\
4 \text { fragments } \\
\text { left scapula } \\
\text { right talus } \\
\text { vertebra } \\
\text { vertebra } \\
\text { left tibia segment } \\
\text { l1 fragments } \\
\text { lumbar vertebra }\end{array}$ & $\begin{array}{l}\text { goose or swan sized shaft } \\
\text { removed by cutting } \\
\text { cf. S. audubonii } \\
\text { subadult } \\
\text { al1 spirally fractured with } \\
\text { butcher marks } \\
\text { weathered } \\
\text { some bison sized } \\
\text { adult }\end{array}$ \\
\hline $\mathrm{F} .8^{+}$ & $\begin{array}{l}442-1 \\
442-2 \\
442-3 \\
442-4 \\
442-5 \\
463-3\end{array}$ & $\begin{array}{l}\text { Mamma } 1 \text { ia } \\
\text { Odocoileus } \\
\text { Odocoileus } \\
\text { Odocoilleus } \\
\text { Odocoileus } \\
\text { Odocoileus }\end{array}$ & $\begin{array}{l}\text { vertebrae fragments } \\
\text { phalange } \\
\text { metapodial } \\
\text { phalange } \\
\text { vertebra } \\
\text { caudal vertebra }\end{array}$ & $\begin{array}{l}\text { adult } \\
\text { adult } \\
\text { probab1y } \\
\text { a11 one } \\
\text { individual } \\
\text { adult }\end{array}$ \\
\hline
\end{tabular}


TABLE 10. (continued)

Feature Lot Number

Number Item Number

Taxon

Materia]

Comments

\begin{tabular}{|c|c|c|c|}
\hline$F .8^{+}$ & $\begin{array}{l}483-1 \\
485-1,3,4 \\
485-2 \\
525-1,21 \\
525-2 \\
525-3 \\
525-4 \\
525-5 \\
525-6 \\
525-7 \\
525-8 \\
525-9 \\
525-10 \\
525-11 \\
525-12 \\
525-13 \\
525-14 \\
525-15 \\
525-17 \\
525-18 \\
525-19 \\
525-20 \\
525-22 \\
526-1 \\
526-2 \\
526-3,4\end{array}$ & $\begin{array}{l}\text { Odocoileus } \\
\text { Odocoileus } \\
\text { Mammalia } \\
\text { Mammalia } \\
\text { Mammalia } \\
\text { Terrapene } \\
\text { Odocoileus } \\
\text { Odocoileus } \\
\text { Odocoileus } \\
\text { Odocoileus } \\
\text { Mammalia } \\
\text { Terrapene } \\
\text { Odocoileus } \\
\text { Odocoileus } \\
\text { Odocoileus } \\
\text { Odocoileus } \\
\text { Odocoileus } \\
\text { Odocoileus } \\
\text { Lepus } \\
\text { Odocoileus } \\
\text { Odocoileus } \\
\text { Terrapene } \\
\text { Odocoileus } \\
\text { Mammalia } \\
\text { Odocoileus } \\
\text { Odocoileus }\end{array}$ & $\begin{array}{l}\text { calcaneus } \\
3 \text { metapodials } \\
2 \text { vertebrae fragments } \\
26 \text { fragments } \\
\text { rib fragments } \\
\text { femur, carapace } \\
\text { calcaneus fragment } \\
\text { radius fragment } \\
\text { maxilla fragment } \\
\text { molar fragment } \\
\text { fragment } \\
\text { radius, humerus } \\
\text { radius fragment } \\
\text { radius fragment } \\
\text { metacarpal } \\
\text { rib fragment } \\
\text { scapula fragment } \\
\text { rib fragment } \\
2 \text { vertebrae } \\
\text { mandible fragment } \\
\text { phalange } \\
2 \text { carapace scutes } \\
\text { radius fragments } \\
8 \text { fragments } \\
\text { metacarpal } \\
2 \text { lumbar vertebrae }\end{array}$ \\
\hline$F \cdot 9^{x}$ & $\begin{array}{l}472-2,4,6 \\
472-10,14 \\
472-16,17,20\end{array}$ & $\begin{array}{l}\text { Mamma } 1 \text { ia } \\
\text { Mamma 1 ia } \\
\text { Mamma lia }\end{array}$ & $\begin{array}{l}90 \text { fragments } \\
\text { fragments } \\
\text { fragments }\end{array}$ \\
\hline
\end{tabular}

adult, 1 is spiral fractured

1arge mamma 1

large mammal

cf. T. ornata fragments

1arge mamma 1

cf. T. ornata

\section{cf. T. ornata}

7arge mamma 1

very large individual

variety of species represented variety of species represented variety of species represented 
TABLE 10. (continued)

\begin{tabular}{|c|c|c|c|c|}
\hline $\begin{array}{l}\text { Feature } \\
\text { Number }\end{array}$ & $\begin{array}{l}\text { Lot Number } \\
\text { Item Number }\end{array}$ & Taxon & Material & Comments \\
\hline$F .9^{\text {d }}$ & $\begin{array}{l}472-3,9,11 \\
472-5 \\
472-8 \\
472-12 \\
472-13 \\
472-18 \\
\text { unplotted }\end{array}$ & $\begin{array}{l}\text { Gopherus } \\
\text { Dicotyles } \\
\text { Neotoma } \\
\text { Bison } \\
\text { Bison } \\
\text { Testudines } \\
\text { Sigmodon }\end{array}$ & $\begin{array}{l}15 \text { carapace and plastron } \\
\text { fragments } \\
\text { mandibular fragment } \\
\text { left humerus } \\
\text { left ulna fragment } \\
\text { radius fragment } \\
\text { carapace fragment } \\
\text { right innominate }\end{array}$ & $\begin{array}{l}\text { cf. N. micropus } \\
\text { spirally fractured } \\
\text { with butcher marks }\end{array}$ \\
\hline F.10 & $\begin{array}{l}265-1,3,6 \\
265-2 \\
265-4 \\
265-5 \\
292 \text { unplotted }\end{array}$ & $\begin{array}{l}\text { Mammalia } \\
\text { Bison } \\
\text { Bison } \\
\text { Didelphis } \\
\text { Bison } \\
\text { Odocoileus }\end{array}$ & $\begin{array}{l}24 \text { fragments } \\
\text { left femur segment } \\
\text { metapodial segment } \\
\text { left innominate } \\
\text { tibia fragment, } \\
\text { right humerus fragment, } \\
\text { and } 17 \text { other fragments } \\
\text { left humerus, vertebra, } \\
2 \text { phalanges }\end{array}$ & $\begin{array}{l}\text { bison-sized mammal bones } \\
\text { spirally fractured } \\
\text { subadult } \\
\text { subadult } \\
\text { subadult } \\
\text { some spiral fractures } \\
\text { spiral fractures }\end{array}$ \\
\hline
\end{tabular}

Note: Many of the Lot 525 deer bones had spiral fractures and butcher marks.
* Plotted items for F.3 are shown in Figure 18.
a Plotted items for F.9 are shown in Figure 19.
$\S$ Plotted items for F.6 are shown in Figure 21 .
+ Plotted items for F.8 are shown in Figure 22 .
$++P$ lotted items for F.7 are shown in Figure 23 . 
TABLE 11. TABULATION OF THE NONFEATURE PLOTTED BONES, WTA UNITS

\begin{tabular}{|c|c|c|c|c|}
\hline Unit & $\begin{array}{l}\text { Lot Number } \\
\text { Plot Number }\end{array}$ & Taxon & Material & Comments \\
\hline $\begin{array}{ll}\text { N105 } & \text { E96 } \\
\text { NI05 } & \text { E96 }\end{array}$ & $\begin{array}{l}377-1 \\
515-1\end{array}$ & $\begin{array}{l}\text { Odocoileus } \\
\text { cf. Odocoileus }\end{array}$ & $\begin{array}{l}\text { left radius } \\
\text { phal ange }\end{array}$ & adult \\
\hline $\begin{array}{ll}\text { N105 } & \text { E97 } \\
\text { N105 } & \text { E97 } \\
\text { N105 } & \text { E97 } \\
\text { N105 } & \text { E97 } \\
\text { N105 } & \text { E97 } \\
\text { N105 } & \text { E97 } \\
\text { N105 } & \text { E97 } \\
\text { N105 } & \text { E97 }\end{array}$ & $\begin{array}{l}293-1,2 \\
293-3,4 \\
293-5 \\
293-6 \\
293-7,8 \\
315-1 \\
315-1,3,4 \\
315-2,5\end{array}$ & $\begin{array}{l}\text { Odocoileus } \\
\text { Bison } \\
\text { Meleagris } \\
\text { Canis } \\
\text { Odocoileus } \\
\text { Didelphis } \\
\text { Odocoileus } \\
\text { Bison }\end{array}$ & $\begin{array}{l}2 \text { lumbar vertebrae } \\
2 \text { long bone fragments } \\
\text { tibia segment } \\
\text { left tibia } \\
\text { vertebrae } \\
\text { left mandible } \\
3 \text { vertebrae } \\
2 \text { femur segments }\end{array}$ & $\begin{array}{l}\text { adult } \\
\text { burned and weathered } \\
\text { spirally fractured } \\
\text { as large as C. latrans } \\
\text { old adult } \\
\text { subadult }\end{array}$ \\
\hline $\begin{array}{ll}\text { N106 } & \text { E94 } \\
\text { N106 } & \text { E94 } \\
\text { N106 } & \text { E94 } \\
\text { N106 } & \text { E96 } \\
\text { N106 } & \text { E94 }\end{array}$ & $\begin{array}{l}379-3 \\
379-4,5 \\
379-8 \\
523-1 \\
523-2\end{array}$ & $\begin{array}{l}\text { Lepus } \\
\text { Testudines } \\
\text { Odocoileus } \\
\text { Odocoileus } \\
\text { Bison }\end{array}$ & $\begin{array}{l}\text { right femur } \\
2 \text { carapace scutes } \\
\text { petrosal } \\
\text { phalange } \\
\text { long bone fragment }\end{array}$ & $\begin{array}{l}\text { adult } \\
\text { adult } \\
\text { spirally fractured }\end{array}$ \\
\hline $\begin{array}{ll}\text { N106 } & \text { E95 } \\
\text { N106 } & \text { E95 } \\
\text { N106 } & \text { E95 } \\
\text { N106 } & \text { E95 } \\
\text { N106 } & \text { E95 } \\
\text { N106 } & \text { E95 }\end{array}$ & $\begin{array}{l}384-1 \\
384-2,3 \\
384-4 \\
384-6 \\
384-7 \\
385-1\end{array}$ & $\begin{array}{l}\text { Odocoileus } \\
\text { Lepus } \\
\text { Artiodactyla } \\
\text { Odocoileus } \\
\text { Canidae } \\
\text { Odocoileus }\end{array}$ & $\begin{array}{l}\text { right upper premolar } \\
\text { left maxilla fragments } \\
\text { proximal and distal phalanges } \\
\text { right mandible segment } \\
\text { upper canine } \\
\text { left calcaneus }\end{array}$ & $\begin{array}{l}\text { old adult } \\
\text { adult } \\
\text { old adult } \\
\text { adult, weathered }\end{array}$ \\
\hline $\begin{array}{ll}\text { N107 } & \text { E94 } \\
\text { N107 } & \text { E94 }\end{array}$ & $\begin{array}{l}380-1 \\
380-1\end{array}$ & $\begin{array}{l}\text { Odocoileus } \\
\text { Sylvilagus }\end{array}$ & $\begin{array}{l}\text { phal ange } \\
\text { left mandible }\end{array}$ & $\begin{array}{l}\text { adult } \\
\text { cf. S. auduboniti }\end{array}$ \\
\hline $\begin{array}{ll}\text { N107 } & \text { E95 } \\
\text { N107 } & \text { E95 } \\
\text { N107 } & \text { E95 } \\
\text { N107 } & \text { E95 }\end{array}$ & $\begin{array}{l}382-1 \\
382-2 \\
382-3 \\
382-4\end{array}$ & $\begin{array}{l}\text { Sylvilagus } \\
\text { Canis }\end{array}$ & $\begin{array}{l}\text { ulna } \\
\text { upper premolar } \\
\text { right mandible } \\
\text { right mandible }\end{array}$ & $\begin{array}{l}\text { adult } \\
\text { cf. S. audubonii } \\
\text { old adult }\end{array}$ \\
\hline
\end{tabular}


TABLE 11. (continued)

\begin{tabular}{|c|c|c|c|c|c|}
\hline Unit & & $\begin{array}{l}\text { Lot Number } \\
\text { Plot Number }\end{array}$ & Taxon & Material & Comments \\
\hline N107 & E95 & $383-1$ & Odocoiteus & atlas & adult \\
\hline N107 & E96 & $516-5$ & Bison & radius segment & subadult \\
\hline N107 & E97 & $281-4$ & Gopherus & carapace scute & \\
\hline N107 & E97 & $281-5$ & Odocoileus & upper premolar & old adult \\
\hline N107 & E97 & $281-6$ & Odocoileus & molar & old adult \\
\hline N107 & E97 & $281-9,11$ & Artiodactyla & 2 phalanges & \\
\hline N107 & E97 & $294-1$ & Odocoileus & humerus & adult \\
\hline N107 & E97 & 294-2 & & tibia segment & adult, spirally fractured \\
\hline N107 & E97 & 294-3 & Bison & vertebra & adu $7 t$ \\
\hline N107 & E97 & $323-1$ & Bison & vertebrae, 5 fragments & some spirally fractured \\
\hline N107 & E97 & $323-2$ & Testudines & carapace scute & \\
\hline N107 & E98 & $185-1$ & Bison & talus & adult \\
\hline N108 & E96 & $393-1$ & cf. Chrysemys & plastron scute & \\
\hline N108 & E96 & $393-2$ & Canis & right maxilia & old adult \\
\hline N108 & E96 & $521-1$ & Odocoileus & left talus & weathered \\
\hline N108 & E96 & $521-2$ & Sciuridae. & right femur segment & adult \\
\hline N108 & E96 & $521-2$ & Mammalia & metatarsal & \\
\hline N108 & E97 & 295-1 & Lepus & right innominate adult & \\
\hline N108 & E97 & $295-2$ & Mamma 1 ia & tarsal element & \\
\hline N108 & E97 & $295-3$ & Odocoileus & right ulna & adu7t \\
\hline N108 & E97 & $329-1$ & Mamma 1 ia & fragment & burned \\
\hline N108 & E97 & $329-2$ & Testudines & plastron scute & \\
\hline N108 & E97 & $329-3$ & Geomys & left femur & \\
\hline N108 & E97 & $329-3,4$ & Gopherus & plastron and & \\
\hline N108 & E97 & $329-7,8$ & & carapace scutes & \\
\hline
\end{tabular}


TABLE 11. (continued)

\begin{tabular}{|c|c|c|c|c|}
\hline Unit & $\begin{array}{l}\text { Lot Number } \\
\text { Plot Number }\end{array}$ & Taxon & Material & Comments \\
\hline $\begin{array}{ll}\text { N108 } & \text { E98 } \\
\text { N108 } & \text { E98 }\end{array}$ & $\begin{array}{l}303-1 \\
303-2\end{array}$ & $\begin{array}{l}\text { Antilocapra } \\
\text { Mammalia }\end{array}$ & $\begin{array}{l}\text { lower molar } \\
28 \text { fragments }\end{array}$ & adult \\
\hline NI08 El00 & $429-1$ & Odocoileus & ulna & adult \\
\hline $\begin{array}{ll}\text { N108 } & \text { E101 } \\
\text { N108 } & \text { E101 }\end{array}$ & $\begin{array}{l}434-1 \\
435-1\end{array}$ & $\begin{array}{l}\text { Antilocapra } \\
\text { Artiodactyla }\end{array}$ & $\begin{array}{l}\text { right mandible } \\
\text { vertebra }\end{array}$ & $\begin{array}{l}\text { old adult } \\
\text { adult }\end{array}$ \\
\hline $\begin{array}{ll}\mathrm{N} 108.5 & \text { El03 } \\
\text { N108.5 } & \text { E103 }\end{array}$ & $\begin{array}{l}477-1 \\
477-2\end{array}$ & $\begin{array}{l}\text { Chrysemys } \\
\text { Odocoileus }\end{array}$ & $\begin{array}{l}\text { innominate } \\
\text { petrosal }\end{array}$ & large specimen \\
\hline $\begin{array}{ll}\text { N109 } & \text { E96 } \\
\text { N109 } & \text { E96 }\end{array}$ & $\begin{array}{l}396-1 \\
396-2\end{array}$ & $\begin{array}{l}\text { Canidae } \\
\text { Lepus }\end{array}$ & $\begin{array}{l}\text { left radius } \\
\text { left mandible }\end{array}$ & adult \\
\hline N109 E97 & $302-1$ & Antilocapra & right humerus & adult, spirally fractured \\
\hline $\begin{array}{ll}\text { N109 } & \text { El02 } \\
\text { N109 } & \text { El02 } \\
\text { N109 } & \text { El02 }\end{array}$ & $\begin{array}{l}478-1 \\
478-2 \\
478-3,4\end{array}$ & $\begin{array}{l}\text { Cryptotis } \\
\text { Sylvilagus } \\
\text { Mammalia }\end{array}$ & $\begin{array}{l}\text { left mandible } \\
\text { left talus } \\
20 \text { fragments }\end{array}$ & $\begin{array}{l}\text { cf. S. audubonii } \\
\text { smal1 and medium-sized } \\
\text { animals. }\end{array}$ \\
\hline $\begin{array}{ll}\text { NIII } & \text { El00 } \\
\text { NIIl } & \text { E100 }\end{array}$ & $\begin{array}{l}463-1 \\
463-2\end{array}$ & Odocoileus & $\begin{array}{l}\text { ulna } \\
\text { radius }\end{array}$ & $\begin{array}{l}\text { adult } \\
\text { adult }\end{array}$ \\
\hline N111 ElOI & $483-1$ & Odocoileus & right calcaneus & weathered \\
\hline
\end{tabular}


TABLE 12. TABULATION OF THE VERTEBRATE REMAINS RECOVERED FROM SELECTED WTA UNITS

\begin{tabular}{|c|c|c|c|c|}
\hline Provenience & $\begin{array}{l}\text { Lot } \\
\text { Number }\end{array}$ & Taxon & Material & Comments \\
\hline N104 E94 L.I & 310 & $\begin{array}{l}\text { Mammalia } \\
\text { Serpentes }\end{array}$ & $\begin{array}{l}49 \text { fragments } \\
\text { vertebra }\end{array}$ & 16 burned \\
\hline N104 E94 L.2 & 369 & $\begin{array}{l}\text { Odocoileus } \\
\text { Lepus } \\
\text { Sylvilagus } \\
\text { Neotoma } \\
\text { Serpentes } \\
\text { Testudines } \\
\text { Terrapene }\end{array}$ & $\begin{array}{l}\text { three tooth } \\
\text { fragments, talus } \\
\text { fragment } \\
\text { left ulna, cranial } \\
\text { fragments } \\
\text { right mandible, } \\
\text { calcaneus } \\
\text { right humerus } \\
\text { vertebra } \\
3 \text { carapace fragments } \\
\text { right humerus, scutes, } \\
\text { innominate }\end{array}$ & $\begin{array}{l}\text { subaduit } \\
\text { cf. S. audubonit } \\
\text { cf. N. micropus }\end{array}$ \\
\hline N104 E94 L.3 & 370 & $\begin{array}{l}\text { Vertebrata } \\
\text { Osteichthyes } \\
\text { Serpentes } \\
\text { Terrapene } \\
\text { Mammalia } \\
\text { Odocoileus } \\
\text { Canis } \\
\text { Sylvilagus } \\
\text { Neotoma }\end{array}$ & $\begin{array}{l}8 \text { fragments } \\
\text { vertebra } \\
9 \text { vertebrae } \\
7 \text { carapace and } \\
\text { plastron fragments } \\
194 \text { fragments } \\
5 \text { teeth, metapodials, } \\
\text { phalanges, vertebrae } \\
\text { fragments } \\
\text { left femur } \\
\text { molar, vertebra } \\
\text { right humerus }\end{array}$ & $\begin{array}{l}\text { some spiral } \\
\text { fractures } \\
\text { cf. C. familiaris } \\
\text { based on size }\end{array}$ \\
\hline N104 E94 L.5 & 456 & Antilocapra & left innominate & spiral fractures \\
\hline N104 E95 L.I & 313 & $\begin{array}{l}\text { Vertebrata } \\
\text { Testudines } \\
\text { Odocolleus }\end{array}$ & $\begin{array}{l}112 \text { fragments } \\
\text { plastron fragment } \\
\text { molar fragment }\end{array}$ & 36 burned \\
\hline N104 E95 L.2 & 368 & $\begin{array}{l}\text { Crotalidae } \\
\text { Terrapene } \\
\text { Odocoileus } \\
\text { Lepus } \\
\text { Sylvilagus } \\
\text { Sigmodon } \\
\text { Scalopus }\end{array}$ & $\begin{array}{l}2 \text { vertebrae } \\
6 \text { carapace, } \\
\text { plastron scutes } \\
\text { molar fragment } \\
\text { axis vertebra } \\
\text { left calcaneus, } \\
\text { humerus } \\
\text { right mandible } \\
\text { right humerus }\end{array}$ & cf. S. audubonii \\
\hline N104 E95 L.3 & 375 & Odocoileus & phalange & \\
\hline N104 E96 L.I & 314 & $\begin{array}{l}\text { Vertebrata } \\
\text { Ictaluridae } \\
\text { Terrapene } \\
\text { Sylvilagus }\end{array}$ & $\begin{array}{l}165 \text { fragments } \\
\text { vertebra } \\
\text { carapace scute } \\
\text { right femur }\end{array}$ & $\begin{array}{l}56 \text { burned and many } \\
\text { spirally fractured }\end{array}$ \\
\hline
\end{tabular}


TABLE 12. (continued)

\begin{tabular}{|c|c|c|c|c|}
\hline Provenience & $\begin{array}{l}\text { Lot } \\
\text { Number }\end{array}$ & Taxon & Material & Comments \\
\hline N1O4 E96 L.2 & 514 & $\begin{array}{l}\text { Chrysenys } \\
\text { Mammalia } \\
\text { Odocolleus }\end{array}$ & $\begin{array}{l}\text { vertebra } \\
2 \text { fragments } \\
\text { metacarpal }\end{array}$ & spirally fractured \\
\hline N104 E96 L.3 & 376 & $\begin{array}{l}\text { Bison } \\
\text { Odocoileus } \\
\text { Canis } \\
\text { Didelphis }\end{array}$ & $\begin{array}{l}\text { left femur } \\
\text { left femur, } \\
\text { vertebra } \\
\text { lumbar vertebra } \\
\text { sacrum, vertebra }\end{array}$ & $\begin{array}{l}\text { burned } \\
\text { very large specimen }\end{array}$ \\
\hline N104 E96 L.4 & 413 & $\begin{array}{l}\text { Mammalia } \\
\text { Didelphis }\end{array}$ & $\begin{array}{l}2 \text { fragments } \\
\text { vertebra }\end{array}$ & $\begin{array}{l}\text { bison size, } \\
\text { spirally fractured, } \\
\text { weathered }\end{array}$ \\
\hline N105 E94 L.I & 311 & Mammalia & 66 fragments & 22 burned \\
\hline N105 E94 L.2 & 371 & $\begin{array}{l}\text { Terrapene } \\
\text { Mammal fa } \\
\text { Odocotleus }\end{array}$ & $\begin{array}{l}\text { carapace fragment } \\
2 \text { fragments } \\
\text { phalanges }\end{array}$ & \\
\hline N105 E94 L.3 & 372 & $\begin{array}{l}\text { Chrysemys } \\
\text { Mammaifia }\end{array}$ & $\begin{array}{l}\text { carapace scute } \\
\text { fragment }\end{array}$ & spiral fracture \\
\hline N105 E95 L.1 & 312 & $\begin{array}{l}\text { Testudines } \\
\text { Vertebrata }\end{array}$ & $\begin{array}{l}3 \text { carapace fragments } \\
196 \text { fragments }\end{array}$ & 51 burned \\
\hline N105 E95 L.2 & 373 & $\begin{array}{l}\text { Terrapene } \\
\text { Gopherus } \\
\text { Odocolleus } \\
\text { Lepus }\end{array}$ & $\begin{array}{l}\text { carapace scute } \\
\text { plastron scute } \\
\text { right mandible } \\
\text { left mandible }\end{array}$ & old adult \\
\hline N105 E96 L.1 & 316 & $\begin{array}{l}\text { Vertebrata } \\
\text { Testudines } \\
\text { Terrapene } \\
\text { Odocolleus }\end{array}$ & $\begin{array}{l}211 \text { fragments } \\
\text { humerus } \\
3 \text { carapace scutes } \\
3 \text { fragments including } \\
\text { petrosal, premolar, } \\
\text { phalange }\end{array}$ & $\begin{array}{l}\text { many spirally } \\
\text { fractured }\end{array}$ \\
\hline N105 E98 L.3 & 352 & $\begin{array}{l}\text { Mammalia } \\
\text { Bison } \\
\text { Odocoileus } \\
\text { Canidae }\end{array}$ & $\begin{array}{l}\text { fragment } \\
\text { vertebrae fragments } \\
\text { left innominate } \\
\text { vertebra }\end{array}$ & $\begin{array}{l}\text { bison size, } \\
\text { spiral fracture }\end{array}$ \\
\hline N108 E94 L.I & 324 & $\begin{array}{l}\text { Vertebrata } \\
\text { Neotoma }\end{array}$ & $\begin{array}{l}170 \text { fragments } \\
\text { right femur }\end{array}$ & 60 burned \\
\hline N108 E94 L.2 & 517 & $\begin{array}{l}\text { Aplodinotus } \\
\text { Serpentes } \\
\text { Testudines } \\
\text { Terrapene }\end{array}$ & $\begin{array}{l}\text { vertebra } \\
3 \text { vertebrae } \\
3 \text { plastron fragments } \\
2 \text { carapace scutes }\end{array}$ & \\
\hline
\end{tabular}


TABLE 12. (continued)

\begin{tabular}{|c|c|c|c|c|}
\hline Provenience & $\begin{array}{l}\text { Lot } \\
\text { Number }\end{array}$ & Taxon & Material & Comments \\
\hline NI08 E94 L.2 & 517 & $\begin{array}{l}\text { Odocoileus } \\
\text { Lepus } \\
\text { Sylvilagus }\end{array}$ & $\begin{array}{l}\text { upper and lower } \\
\text { molars } \\
\text { right talus, left } \\
\text { tibia, right radius } \\
\text { right calcaneus, } \\
\text { left ulna, vertebra }\end{array}$ & \\
\hline N108 E94 L.3 & 389 & $\begin{array}{l}\text { Vertebrata } \\
\text { Serpentes. } \\
\text { Testudines } \\
\text { Aves } \\
\text { Canis } \\
\text { Sylvilagus } \\
\text { Sigmodon } \\
\text { Cricetidae }\end{array}$ & $\begin{array}{l}82 \text { fragments } \\
4 \text { vertebrae } \\
\text { right femur } \\
\text { metatarsal } \\
\text { upper third molar } \\
\text { right humerus, } \\
\text { femur segment } \\
\text { right innominate } \\
\text { right femur }\end{array}$ & $\begin{array}{l}31 \text { burned, many } \\
\text { spirally fractured } \\
\text { femur from subadult } \\
\text { cf. Microtinae }\end{array}$ \\
\hline N108 E94 L.4 & 424 & $\begin{array}{l}\text { Vertebrata } \\
\text { Serpentes } \\
\text { Testudines } \\
\text { Sylvilagus }\end{array}$ & $\begin{array}{l}4 \text { fragments } \\
\text { vertebra } \\
1 \text { carapace scute } \\
\text { right maxilla }\end{array}$ & cf. C. audubonti \\
\hline N108 E95 L.I & 327 & $\begin{array}{l}\text { Vertebrata } \\
\text { Scalopus }\end{array}$ & $\begin{array}{l}300 \text { fragments } \\
\text { right humerus }\end{array}$ & $\begin{array}{l}110 \text { burned, many } \\
\text { spiraliy fractured }\end{array}$ \\
\hline N108 E95 L.2 & 520 & $\begin{array}{l}\text { Vertebrata } \\
\text { Osteichthyes } \\
\text { Serpentes } \\
\text { Testudines } \\
\text { Gopherus } \\
\text { Bison } \\
\text { Odocoileus } \\
\text { Canis } \\
\text { Lepus } \\
\text { Sylvilagus }\end{array}$ & $\begin{array}{l}111 \text { fragments } \\
\text { cranial fragment } \\
3 \text { vertebrae } \\
4 \text { carapace scutes } \\
\text { femur } \\
\text { right lower molar } \\
\text { phalange } \\
\text { upper canine } \\
\text { left maxilla } \\
\text { right innominate }\end{array}$ & $\begin{array}{l}18 \text { burned, many } \\
\text { spirally fractured }\end{array}$ \\
\hline N108 E95 L.3 & 392 & $\begin{array}{l}\text { Vertebrata } \\
\text { Terrapene } \\
\text { Sylvilagus } \\
\text { Sigmodon }\end{array}$ & $\begin{array}{l}56 \text { fragments } \\
3 \text { carapace fragments } \\
\text { metatarsal } \\
\text { right mandible }\end{array}$ & $\begin{array}{l}19 \text { burned, some } \\
\text { spirally fractured }\end{array}$ \\
\hline N108 E95 L.4 & 427 & $\begin{array}{l}\text { Vertebrata } \\
\text { Testudines } \\
\text { Sylvilagus }\end{array}$ & $\begin{array}{l}5 \text { fragments } \\
\text { femur } \\
\text { premaxilla }\end{array}$ & \\
\hline N109 E94 L.I & 325 & $\begin{array}{l}\text { Vertebrata } \\
\text { Sylvilagus }\end{array}$ & $\begin{array}{l}98 \text { fragments } \\
\text { right humerus }\end{array}$ & $\begin{array}{l}40 \text { burned, many } \\
\text { spirally fractured }\end{array}$ \\
\hline
\end{tabular}


TABLE 12. (continued)

\begin{tabular}{|c|c|c|c|c|}
\hline Provenience & $\begin{array}{l}\text { Lot } \\
\text { Number }\end{array}$ & Taxon & Material & Comments \\
\hline N109 E94 L.2 & 518 & $\begin{array}{l}\text { Vertebrata } \\
\text { Serpentes } \\
\text { Testudines } \\
\text { Terrapene } \\
\text { Gopherus } \\
\text { Odocoileus } \\
\text { Lepus } \\
\text { Sylvilagus }\end{array}$ & $\begin{array}{l}215 \text { fragments } \\
4 \text { vertebrae } \\
\text { humerus } \\
\text { carapace fragment } \\
\text { carapace and plastron } \\
\text { scutes } \\
\text { molar } \\
\text { left calcaneus, } \\
\text { right humerus } \\
\text { left scapula, right } \\
\text { humerus, left } \\
\text { innominate }\end{array}$ & $\begin{array}{l}67 \text { burned, many } \\
\text { spirally fractured }\end{array}$ \\
\hline N109 E94 L.3 & 390 & $\begin{array}{l}\text { Vertebrata } \\
\text { Testudines } \\
\text { Terrapene } \\
\text { Mammalia } \\
\text { Odocoileus } \\
\text { Lepus } \\
\text { Sylvilagus } \\
\text { Cricetidae }\end{array}$ & $\begin{array}{l}78 \text { fragments } \\
\text { humerus } \\
13 \text { carapace and } \\
\text { plastron scutes } \\
3 \text { fragments } \\
\text { phalange } \\
\text { left uina } \\
\text { right humerus } \\
\text { right femur }\end{array}$ & $\begin{array}{l}11 \text { burned } \\
\text { cf. Microtinae }\end{array}$ \\
\hline N109 E94 L.4 & 425 & Vertebrata & 10 fragments & 7 burned \\
\hline N109 E95 L.1 & 326 & $\begin{array}{l}\text { Terrapene } \\
\text { Sylvilagus }\end{array}$ & $\begin{array}{l}\text { carapace scute } \\
\text { right maxilla }\end{array}$ & \\
\hline N109 E95 L.2 & 519 & $\begin{array}{l}\text { Vertebrata } \\
\text { Osteichthyes } \\
\text { Serpentes } \\
\text { Terrapene } \\
\text { Falconi formes } \\
\text { Mammalia } \\
\text { Odocoileus } \\
\text { Lepus } \\
\text { Sylvilagus }\end{array}$ & $\begin{array}{l}185 \text { fragments } \\
\text { cranial fragment } \\
3 \text { vertebrae } \\
6 \text { carapace and } \\
\text { plastron scutes } \\
\text { phalange } \\
2 \text { fragments } \\
6 \text { molar fragments } \\
\text { left maxilla, } \\
\text { calcaneus } \\
\text { right humerus, right } \\
\text { radius, left femur, } \\
\text { left mandible }\end{array}$ & $\begin{array}{l}68 \text { burned, many } \\
\text { spirally fractured }\end{array}$ \\
\hline N109 E95 L.3 & 391 & Odocoileus & $\begin{array}{l}\text { tibia segment, } \\
\text { phalange }\end{array}$ & tibia from subadult \\
\hline N109 E95 L.4 & 426 & $\begin{array}{l}\text { Vertebrata } \\
\text { Ondatra }\end{array}$ & $\begin{array}{l}10 \text { fragments } \\
\text { right femur }\end{array}$ & 6 burned \\
\hline
\end{tabular}


While this may explain the greater faunal diversity during the Pleistocene, it may not explain the greater diversity observed at $41 \mathrm{JW} 8$, and the sites occupied within the Choke Canyon basin during the Holocene. The widely accepted model for climatic changes during the Holocene suggests that the epoch has been characterized by increasing seasonality and increasing dessication. If this model is correct, the greater diversity seen within the 7 ast few thousand years may reflect the presence of a greater abundance of wet 7 ands, and poorly drained grasslands. These habitats could have occurred in the region if more water was available, even though the seasonality and ambient temperatures remained as they are today. The presence of the extant western and Mexican derived fauna in prehistoric sites tends to support this view.

\section{DESCRIPTION OF TAXA}

Presented is the description of the taxa recovered from $41 \mathrm{JW} 8$ during the 1981 field season. Information presented for each taxon includes the provenience of the material and what was recovered. Notes about the taxa which are pertinent to their classification, interpreting human behavior from the remains, or information pertinent to environmental reconstruction are also presented. Classification of the fishes follows Blair et a 1. (1968). Classification of the amphibians and reptiles follows conant (1975). Classification of the birds follows Robbins, Brunn, and Zim (1966). Classification of the mammals follows Davis (1974), Hall (1981), Schmidly (1977, 1983), and Steele (1986). Where these authors differ this report fol lows Stee $1 e^{\prime}$ s assessment.*

PHYLUM CHORDATA

SUBPHYLUM VERTEBRATA

CLASS indeterminate (vertebrates)

Referred Materia 1: Material consists of fragments of unidentified bone.

Remarks: Material assigned to this taxon consists predominately of undiagnostic slivers of bone. While most of this material is probably from mamma1s, the assignment to that class was not unequivocal. Much of the material exhibited spiral fractures, suggesting that the bone was broken while fresh, and much of the material was burned or scarred by carnivores and rodents.

*Editor's Note: Because of the nature of this section, the headings will be presented in a different format than the rest of the report. 
CLASS OSTEICHTHYES

ORDER indeterminate (fishes)

Referred Material: Material is one cranial fragment and one vertebra.

Remarks: These fragments represent two different specimens judging from the size of the remains, and quite possibly two different species.

ORDER CYPRINIFORMES

FAMILY ICTALURIDAE

GENUS indeterminate (catfishes)

Referred Material: The material is one vertebra.

Remarks: Specimen appears to have been from a small fish.

ORDER PERCIFORMES

FAMILY SCIAENIDAE

Aplodinotus grunniens (freshwater drum)

Referred Material: The material is one vertebra.

Remarks: Specimen appears to have been from a moderate-sized fish.

CLASS AVES

ORDER indeterminate (birds)

Referred Material: The specimen is one metatarsal.

Remarks: The specimen is from a bird the approximate size of a chicken.

ORDER ANSERIFORMES

FAMILY ANATIDAE

GENUS indeterminate (ducks, geese, and swans)

Referred Material: The specimen is a left humerus. 
Remarks: The specimen was the size of a goose or swan. The shaft had been cut from the proximal end which was recovered.

ORDER GALLIFORMES

FAMILY MELEAGRIDAE

Meleagris gallopavo (wild turkey)

Referred Materia 1: Material consists of one complete left femur and one proximal tibia segment.

Remarks: Positive identification was possible because of the completeness of the specimen. The tibia segment was spiraliy fractured.

ORDER FALCONIFORMES

FAMILY indeterminate (birds of prey)

Referred Material: The specimen is one complete distal phalange.

Remarks: The specimen was from an adult bird.

CLASS REPTILIA

ORDER SOUAMATA

SUBORDER SERPENTES

FAMILY indeterminate (snakes)

Referred Material: The material consists of isolated vertebrae from several localities within the site:

Remarks: Although specific taxa could not be identified from the vertebra, it appeared that several different specimens were represented, and possibly more than one taxon.

FAMILY CROTALIDAE

GENUS indeterminate (rattlesnakes)

Referred Material: The specimen is one vertebra.

Remarks: The vertebra appears to have been from a moderate-sized rattlesnake. 


\section{ORDER TESTUDINES}

\section{FAMILY indeterminate (turties)}

Referred Material: The material consists of carapace and plastron fragments.

Remarks: Most of the material probably represents the taxa identified below. There were, however, some fragments which could not be assigned to the following taxa.

\section{FAMILY EMYDIDAE}

Terrapene cf. T. ornata (western box turtle)

Referred Material: The material consists of carapace and plastron fragments from several localities within the site.

Remarks: Although not all material assignable to the genus could be assigned to the species $T$. ornata, all material which could be classified at the species level was T. ornata. Terrapene ornata is the species inhabiting the region today.

\section{Chrysemys}

SPECIES indeterminate (water turtie)

Referred Material: The specimen is one plastron scute.

Remarks: This is the on $7 y$ specimen representative of a water dwelling turtle recovered from the site.

\section{FAMILY TESTUDINIDAE}

Gopherus cf. G. berlandieri (Texas tortoise)

Referred Material: The material consists of carapace and plastron fragments.

Remarks: This taxon was the second most commonly recovered turtle from the site. Because of the incomplete and fragmentary nature of the material it could be positively assigned only to the level of genus. The material does, however, compare favorably with $G_{\text {. }}$ berlandieri, the species which inhabits the region today. 


\section{CLASS MAMMALIA}

ORDER indeterminate (mammals)

Referred Materia 1: The material is predominately postcranial fragments scattered throughout the site.

Remarks: Most of this material, judging from the size and thickness of the bone fragments, represents comminuted artiodacty 1 remains; however, because of the comminuted nature of the material no positive identification could be made. It should also be noted that a great proportion of this material was spirally fractured and burned. A smaller proportion of the material also evidenced gnawing scars from rodents and carnivores, and weathering of the cortical surface.

ORDER MARSUPIALIA

\section{FAMILY DIDELPHIDAE}

Didelphis virginiana (Virginia opossum)

Referred Material: The material consists of a left mandible, one sacrum, and one vertebra.

Remarks: Although opossums are relatively easy to capture as they forage at night, remains of the species occur relatively infrequently in faunal assemblages in south Texas (see Steele 1986; Steele and Hunter 1986). This l.ow density in the assemblages may indicate a low incidence of nocturnal hunting by the humans or a lower density of the opossums than exists today.

ORDER ARTIODACTYLA

FAMILY indeterminate (artiodacty $7 s$ )

Referred Material: The material consists of postcranial fragments recovered from areas throughout the site.

Remarks: Most of the material was either deer or pronghorn, but could not be positively identified as one or the other. The other remains of artiodactyls recovered from the site, bison and peccary, could usually be assigned to species.

FAMILY BOVIDAE

Bison bison (bison)

Referred Material: The material consists of dental and postcranial fragments recovered throughout the site. 
Remarks: Bison remains have been found in other Late Prehistoric south Texas sites so their occurrence here is not unexpected (Hester and Hill 1972, 1975; Hester 1975; Hester et a 1. 1975; Steele and Mokry 1985; Steele 1986; Steele and Hunter 1986). Al1 of the bison remains show spiral fracturing and some show charring. It is also apparent from an examination of the remains that more than one adult is represented in the faunal assemblage, at least one subadult and at least two adults. From one feature (2A) three humerus segments were found, and based upon the size differences of the fragments two individuals were represented.

\section{FAMILY ANTILOCAPRIDAE}

\section{Antilocapra americana (pronghorn)}

Referred Material: The material consists of postcranial and cranial remains from several areas within the site.

Remarks: Pronghorn remains have been reported previously from this site (Hester 1977) and from other sites in the region (Hester and Hill 1972, 1975; Hester 1975; Hester et a 1. 1975; Steele and Mokry 1985; Steele 1986; Steele and Hunter 1986). In addition to the material positively identified as pronghorn there is also the possibility that additional material identified as artiodactyl also represents this species. The remains, however, do not appear to be as plentiful as those of deer.

\section{FAMILY CERVIDAE}

Odocoileus virginianus (white-tailed deer)

Referred Material: The material consists of cranial and postcranial remains recovered from all areas of the site.

Remarks: White-tailed deer remains were the most commonly identified elements found at $41 \mathrm{JW} 8$, and on this basis it is reasonable to infer that the species was a major dietary element for the inhabitants. Although there was a wide age range represented in the assemblage, subadult to old adu $1 \mathrm{t}$, there were no remains of foetal deer or deer less than six months old. Since no cranial elements from the frontal region were found it could not be determined if any of the specimens were taken while they were in antler either. Therefore, the deer sample cannot substantiate a spring or fall occupation of the site. One additional comment about the species should be made. Deer from south Texas are recognized as some of the 1 argest extant white-tailed deer, and some of the specimens recovered indicated that exceptionally 1 arge deer were in the region during Late Prehistoric times as wel1. 
FAMILY TAYASSUIDAE

Dicotyles tajacu (collared peccary)

Referred Materia1: The material is a mandibular fragment from Feature 9.

Remarks: Previously the collared peccary and the armadillo have been considered historically recent intruders into south Texas (Hester 1977, 1980a). Recently, however, with larger faunal assemblages undergoing scrutiny, remains of the col1 ared peccary have been recovered in situ from Late Prehistoric components at this site and 41 LK 201 (Stee 1e 1986); and from surface collections at Late Prehistoric sites in Nueces County (Steele and Mokry 1985), Kleberg County (Smith 1984a), and McMul1en County (Steele and Hunter 1986). The possible presence of peccary from Late Archaic levels has a 7 so been reported by Steele (1986) from 41 LK 201.

Of the four artiodacty 15 represented in the faunal assemblage at $41 \mathrm{JW} 8$, the collared peccary is represented by the fewest remains. Since relatively few peccary remains have been recovered at other sites, their presence raises a series of questions. Are the identifications positive? If they are positive, could they represent intrusive elements? Or, does the 1 ow incidence of peccary remains reflect their minima 1 utilization or availability. The material reported from Nueces County, Live Oak County, McMullen County, and this site were a 11 examined by the author, and the material compared favorably with positively identified peccary remains housed in the comparative fauna 1 collections at Texas A\&M University. Since positive identification of at least some of the material seems assured, that raises the question of the association of the peccary remains with Late Prehistoric materials at $41 \mathrm{JW} 8$ and the other sites. Since no other evidence of mixing is indicated in Feature 9 from this site, the association at $41 \mathrm{JW} 8$ seems valid. The material recovered from the Late Prehistoric 1evels at 41 LK 201 consisted of a left upper first incisor, a humerus fragment, and a left calcaneus, and al1 were recovered from three different locations with in the site. Again, since no inordinate amount of mixing of remains was reported at this site, these associations also seem valid. The surface finds from Nueces, McMullen, and Kleberg Counties could conceivably have been mixed with 1 ater material, but Steele and Mokry (1985) report no historical material from 41 NU 102 and 41 NU 103, the two sites from which the peccary material was recovered. It appears then that at least some of these peccary remains, if not a 11 of them, are validly associated with the Late Prehistoric (and possibly the Late Archaic as we11). Why the hunters and gatherers were harvesting so few peccary is more difficult to assess. At the present time there appears to be no way to determine whether peccary remains are scarce because they were scarce in the 
area, or whether they were not favored as game by the human inhabitants. Considering the catholic diet of the inhabitants one would predict that the former reason is the more probable one.

ORDER CARNIVORA

FAMILY CANIDAE

\section{Canis}

SPECIES indeterminate (dogs, wolves, and coyotes)

Referred Material: The material consists of cranial and postcranial remains from various areas within the site.

Remarks: Previous faunal analysis of the site identified both coyote and the gray wolf within the bone assemb 7 age. The material recovered during the second period of excavation, and reported here, was too incomplete to attain positive species identification. On the basis of the size range of the materia1, however, it appears that both the coyote and the domesticated dog are represented in the assemblage. Based upon dental remains, adult and old adult specimens were represented in the assemblage. None of the canid material showed evidence of spiral fractures, charring, or gnawing damage.

The material suggestive of dog is smaller than coyote skeletal material, but significantly larger than the gray or red fox skeletal material. The problem one encounters in making positive identification of domestic dog remains is that few, if any, discrete traits are distinctive of the domestic dog, and its size overlaps the foxes and the coyotes. Given these problems, positive identification requires a we11-preserved skeleton or some cultural associations that suggest the remains are those of a dog. Remains of dog have a 1 so been reported from 41 NU 11 (Hester 1975); and Steele (1986) reported a tibia.of a canid which was smaller than a coyote. He noted, however, that the evidence was too tenuous to warrant al locating the remains positively to that species.

\section{ORDER INSECTIVORA}

FAMILY SORICIDAE

\section{Cryptotis parva ( Teast shrew)}

Referred Materia 1: The specimen is a left mandible from N108 E94, Lot 389. 
Remarks: This is the first fossil record for this species within south Texas and possibly the state. Schmidly (1983:40) states that a critical component of its habitat is the presence of dense herbaceous ground cover, especially grasses.

FAMILY TALPIDAE

Scalopus aquaticus (eastern mole)

Referred Materia 1: The material consists of a humerus, two vertebrae, two phalanges, and the occipital bone.

Remarks: Most of the remains of this species were found with:.. Feature 3, and could therefore represent the remains of a single individual. Since moles are burrowing mammals which inhabit the region today, it is possible that these remains represent an intrusive specimen into the archaeological assemb 1 age. On the other hand, its association in Feature 3 makes it possible for that one specimen to be a part of the archaeological assemblage.

\section{ORDER LAGOMORPHA}

\section{FAMILY LEPORIDAE}

Lepus californicus (black-tailed jackrabbit)

Referred Material: The material consists of cranial and postcranial remains scattered throughout the site.

Remarks: Hulbert (1979) has noted the difficulty in distinguishing Lepus cal ifornicus from Sylvilagus aquaticus, the largest cottcntail rabbit. In spite of his reservations, the present author has identified this material as black-tailed jackrabbit. This assessment is based upon the author's observations that while S. aquaticus is as large as the blacktailed jackrabbit, the bones are more gracile. This is particularly noticeable in the mandible. Hulbert (1979) 1ists mean mandibular length for $L$. cal ifornicus as $17.9 \pm 0.9$ and mean mandibular depth at the fourth premolar as $13.2 \pm 1.0 \mathrm{~mm}$ The same measurements 1 isted for S. aquaticus are $17.7 \pm 0.7$ and $11.8 \pm 0.7 \mathrm{~mm}$, respectively. Two mandibular fragments recovered from 41 JW 8 were complete enough to measure mandibular depth at the fourth premolar. One specimen (N106 E94, Lot 384) had a mandibular depth of $13.7 \mathrm{~mm}$, and the second specimen (N109 E96, Lot 396), 14.4 mm. Both of these specimens fall near or greater than the mean for mandibu 1 ar depth for L. californicus, and outside of the range of one standard deviation for $S$. aquaticus. 
For the small mammals, both the black-tailed jackrabbit and the desert cottontail rabbit were the most frequently represented species within the bone assemblage.

Sylvilagus cf. S. audubonii (desert cottontail rabbit)

Referred Materia 1: The material consists of cranial and postcranial remains scattered throughout the site.

Remarks: Steele (1986) reviewed the taxonomy of the cottontail rabbits, and this report follows his assessment. Most of the material recovered from 41 JW 8 could only be assigned to the genus since the material was so comminuted. However, the consistently very small size of the remains warranted the tentative assignment of the material to $S$. audubonil, the smallest of the Texas cottontail rabbits.

ORDER RODENTIA

FAMILY CRICETIDAE

GENUS indeterminate (rats, mice, and voles)

Referred Materia1: The material consists of long bones recovered from scattered localities within the site.

Remarks: Material referred to this taxon represents the long bones of indigenous mice which could not be assigned to genus on the basis of the material recovered.

Neotoma cf. N. micropus (Mexican wood rat)

Referred Material: The material consists of cranial and postcranial remains recovered from various localities within the site.

Remarks: The pack rat which is found within the area today is N. micropus, the 1 argest species of pack rat. The material recovered from 41 JW 8 falls within the size range of this species, and on this basis has been tentatively assigned to that species.

\section{Ondatra zibethicus (muskrat)}

Referred Materia 1: The specimen is a right femur recovered from N108 E94, Lot 426.

Remarks: The muskrat today is restricted to the upper reaches of the Rio Grande, the Pecos River, and the northern and 
eastern edges of the state. This represents the second subfossil record for the species in the southwestern part of the state, the species has al so been reported from Live Oak County (Steele 1986). Since the species prefers marshy areas, or along creeks, it strongly indicates that nearby Chiltip in Creek, or some other resource, contained a year-round supply of ponded or slow running water.

\section{Sigmodon hispidus (hispid cotton rat)}

Referred Materia 1: Material consists of cranial and postcranial fragments at various localities within the site.

Remarks: This species is ubiquitous throughout the state today, and a common inhabitant of grassiand communities.

\section{Microtus cf. M. pinetorum (pine vole)}

Referred Material: The specimen is a right mandible from Feature 6, Lot 397.

Remarks: There are extant records for two species of voles occurring in Texas, M. ocrogaster in far east Texas and $\mathbf{M}$. pinetorum in northeast and central Texas (Schmid7y 1983). In subfossil samples, M. ocrogaster has been identified from deposits in San Patricio County (Raun and Laugh in 1972), and M. pinetorum in Goliad County (F1ynn 1983), Kerr County (Roth 1972), Hil 1 County (Je1ks 1962), Montague County (Dalquest 1965), Travis County (Lundelius 1974), and Live Oak County (Steele 1986). While these two species are quite similar in morphology and size, M. pinetorum tends to be slightly sma 11 er. The specimen recovered from 41 JW 8 compared more favorab $7 y$ with M. pinetorum than M. ocrogaster. This specimen represents the southernmost' record for the species. Schmidly (1983:205) states that the species preferred habitat is poorly drained, wet grassiands.

\section{FAMILY GEOMYIDAE}

\section{Geomys}

SPECIES indeterminate (pocket gopher)

Referred Material: The specimen is one femur from N108 E97, Lot 329.

Remarks: While the femur could be identified to genus, specific identification was not possible. The genus is represented in the faunal community of the region today. 
ANALYSIS OF MACROBOTANICAL MATERIALS (John G. Jones)

\section{INTRODUCTION}

The paleoenvironmental conditions in south Texas are not well known. This is due in part to the generally poor preservation of both pollen and plant macrofossil evidence. Though recently there have been a number of important paleoenvironmental studies conducted in this area (Bryant and Riskind 1977; Dering 1982; Holloway 1986), and a summary review of the region (Bryant and Hol 1 oway 1985), much is stil1 unknown and is in need of additional study. Hopefully, the results presented in this report may be of value to the further understanding of the paleoenvironment of the region.

Charcoal and plant remains were recovered from the Hinojosa site (4l JW 8) during excavations in 1981 and 1982. This site is located north of Alice, Texas, in Jim Wells County, in the Tamaulipan Biotic Province (Blair 1950). This province is characterized as a thorny, brush plain dominated today by Prosopis (mesquite), Acacia (acacia), Mimosa (mimosa), Celtis (hackberry), Leucophy 11 um (cenizo), Aloysia (whitebrush), and Opuntia spp. (cacti).

\section{METHODOLOGY}

A11 samples recovered were generally small and fragmentary. Seed specimens large enough to have identifiable morphological features and charcoal samples 1 arge enough to possess a series of growth rings, which are needed for making identifications, were analyzed. Identifications were made at the lowest possible taxonomic classification level (i.e., family, genus, or species). Identifications were based on morphological comparisons with reference specimens maintained in the macrobotanical collections at Texas A\&M University. For charcoal specimens, which comprised the majority of the samples, clear transverse surfaces were examined utilizing the snap method (Lenney and Casteel 1975). Because of the generally small size of the specimens, longitudinal and tangential sections could not be made, thus all charcoal identifications were based on transverse section identifications.

A11 seed identifications were based on the Texas A\&M University comparative seed collections. Dr. Hugh D. Wilson, of the Texas A\&M University Biology Department provided more specific identifications of seeds in the Chenopodiaceae and Phytollacaceae families.

\section{RESULTS AND DISCUSSION}

The results of this study are presented in Table 13. Data have been arranged by feature number, horizontal and vertical provenience, and lot number. The majority of the charcoal specimens recovered from the site were identified as either Prosopis (mesquite) or Acacia. Both genera, generaliy tend to be found in the same types of ecological habitats, and are members of the family Fabaceae. The lack of adequate comparative materials exhibiting the total range of taxonomic variation, and the high degree of morphological similarity in the woods of these species prevented positive identification beyond the general level of Prosopis/Acacia. In some cases, however, when a specific 
TABLE 13. RESULTS OF MACROBOTANICAL ANALYSIS

Lot

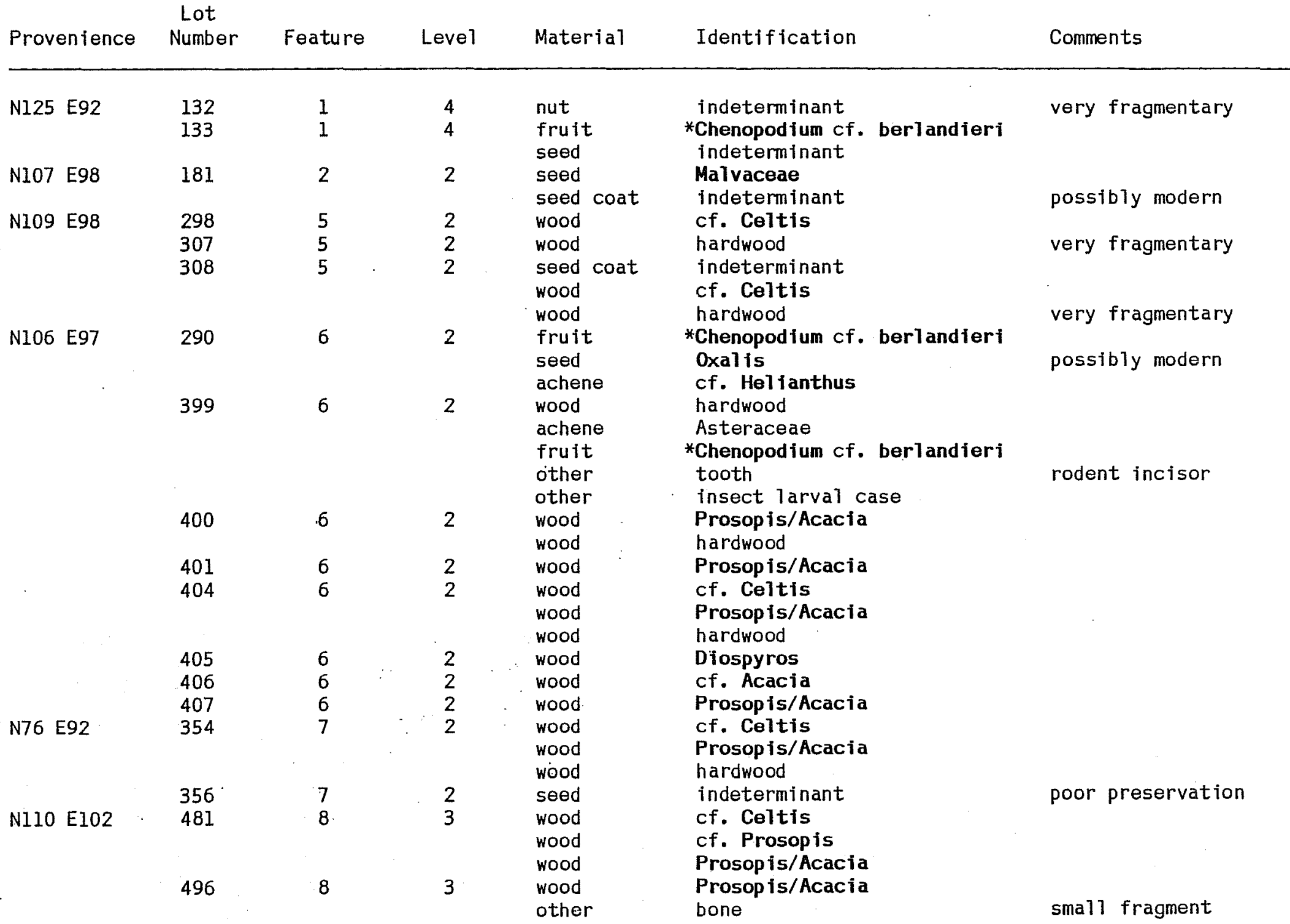


TABLE 13. (continued)

\begin{tabular}{|c|c|c|c|c|c|c|}
\hline Provenience & $\begin{array}{l}\text { Lot } \\
\text { Number }\end{array}$ & Feature & Level & Material & Identification & Comments \\
\hline N109 El02 & 485 & 8 & 3 & $\begin{array}{l}\text { wood } \\
\text { wood } \\
\text { wood }\end{array}$ & $\begin{array}{l}\text { cf. Celtis } \\
\text { cf. Prosopis } \\
\text { Prosopis/Acacia }\end{array}$ & \\
\hline \multirow[t]{2}{*}{ N110 E101 } & 494 & 8 & 3 & $\begin{array}{l}\text { wood } \\
\text { caryopsis }\end{array}$ & $\begin{array}{l}\text { hardwood } \\
\text { Setaria }\end{array}$ & smal1 fragments \\
\hline & 525 & 8 & 3 & $\begin{array}{l}\text { wood } \\
\text { wood } \\
\text { wood } \\
\text { wood } \\
\text { wood } \\
\text { bark }\end{array}$ & $\begin{array}{l}\text { cf. Celtis } \\
\text { cf. Acacia } \\
\text { cf. Prosopis } \\
\text { Prosopis/Acacia } \\
\text { hardwood } \\
\text { hardwood }\end{array}$ & fragmentary \\
\hline N108 E102 & 472 & 9 & 3,4 & $\begin{array}{l}\text { wood } \\
\text { wood } \\
\text { bark }\end{array}$ & $\begin{array}{l}\text { Prosopis/Acacia } \\
\text { hardwood } \\
\text { hardwood }\end{array}$ & \\
\hline \multirow[t]{2}{*}{ N108 E96 } & 363 & **WTA Col.2 & 1 & $\begin{array}{l}\text { achene } \\
\text { seed } \\
\text { seed } \\
\text { seed } \\
\text { fruit } \\
\text { seed } \\
\text { wood }\end{array}$ & $\begin{array}{l}\text { Asteraceae } \\
\text { Oxal is } \\
\text { Malvaceae } \\
\text { Sol anum rostratum } \\
\text { *Chenopodium } \\
\text { Phytolaccaceae } \\
\text { hardwood }\end{array}$ & $\begin{array}{l}\text { possibly modern } \\
\text { possibly modern } \\
\text { small fraaments }\end{array}$ \\
\hline & 378 & WTA Col.2 & 2 & $\begin{array}{l}\text { wood } \\
\text { seed } \\
\text { caryopsis } \\
\text { fruit } \\
\text { seed }\end{array}$ & $\begin{array}{l}\text { hardwood } \\
\text { Malvaceae } \\
\text { Gramineae } \\
\text { *Chenopodium } \\
\text { *Phytolaccaceae }\end{array}$ & small fragments \\
\hline N108 E96 & 402 & WTA Col. 2 & 3 & $\begin{array}{l}\text { fruit } \\
\text { seed }\end{array}$ & $\begin{array}{l}\text { *Chenopodium cf. berlandieri } \\
\text { indeterminant }\end{array}$ & fragmentary \\
\hline $\begin{array}{ll}\text { N74 } & \text { E91 } \\
\text { N75 } & \text { E91 }\end{array}$ & $\begin{array}{l}452 \\
337 \\
345\end{array}$ & WTA Col.2 & $\begin{array}{l}4 \\
3\end{array}$ & seed coat & indeterminant & \\
\hline N75 E91 & 345 & & 2 & $\begin{array}{l}\text { wood } \\
\text { wood } \\
\text { wood } \\
\text { other }\end{array}$ & $\begin{array}{l}\text { cf. Celtis } \\
\text { Prosopis/Acacia } \\
\text { hardwood } \\
\text { bone }\end{array}$ & small fragment \\
\hline N76 E91 & 343 & & 2 & $\begin{array}{l}\text { other } \\
\text { wood } \\
\text { wood }\end{array}$ & $\begin{array}{l}\text { snail shell } \\
\text { cf. Prosopis } \\
\text { Prosopis/Acacia }\end{array}$ & \\
\hline
\end{tabular}


TABLE 13. (continued)

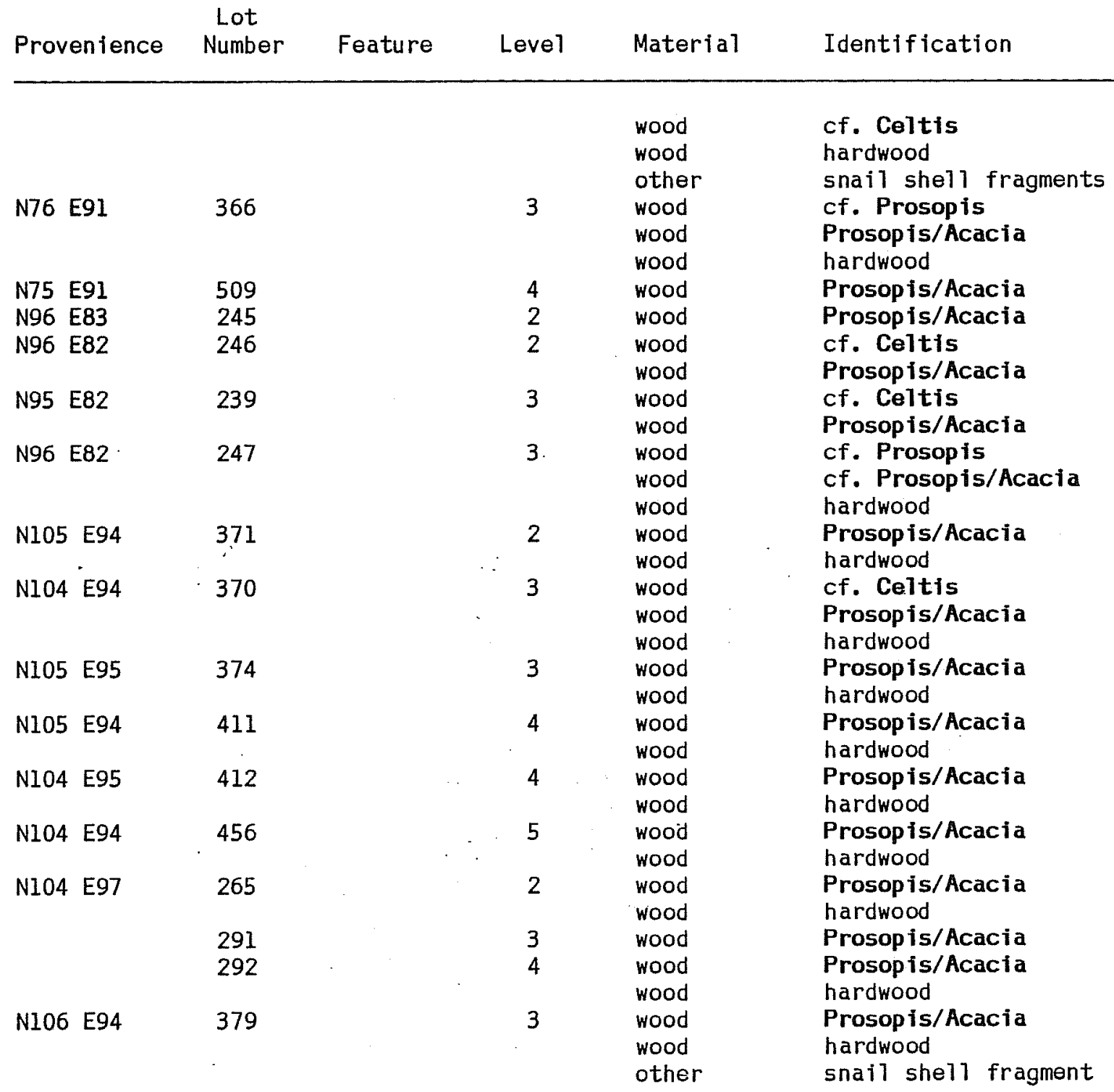

Comments 
TABLE 13. (continued)

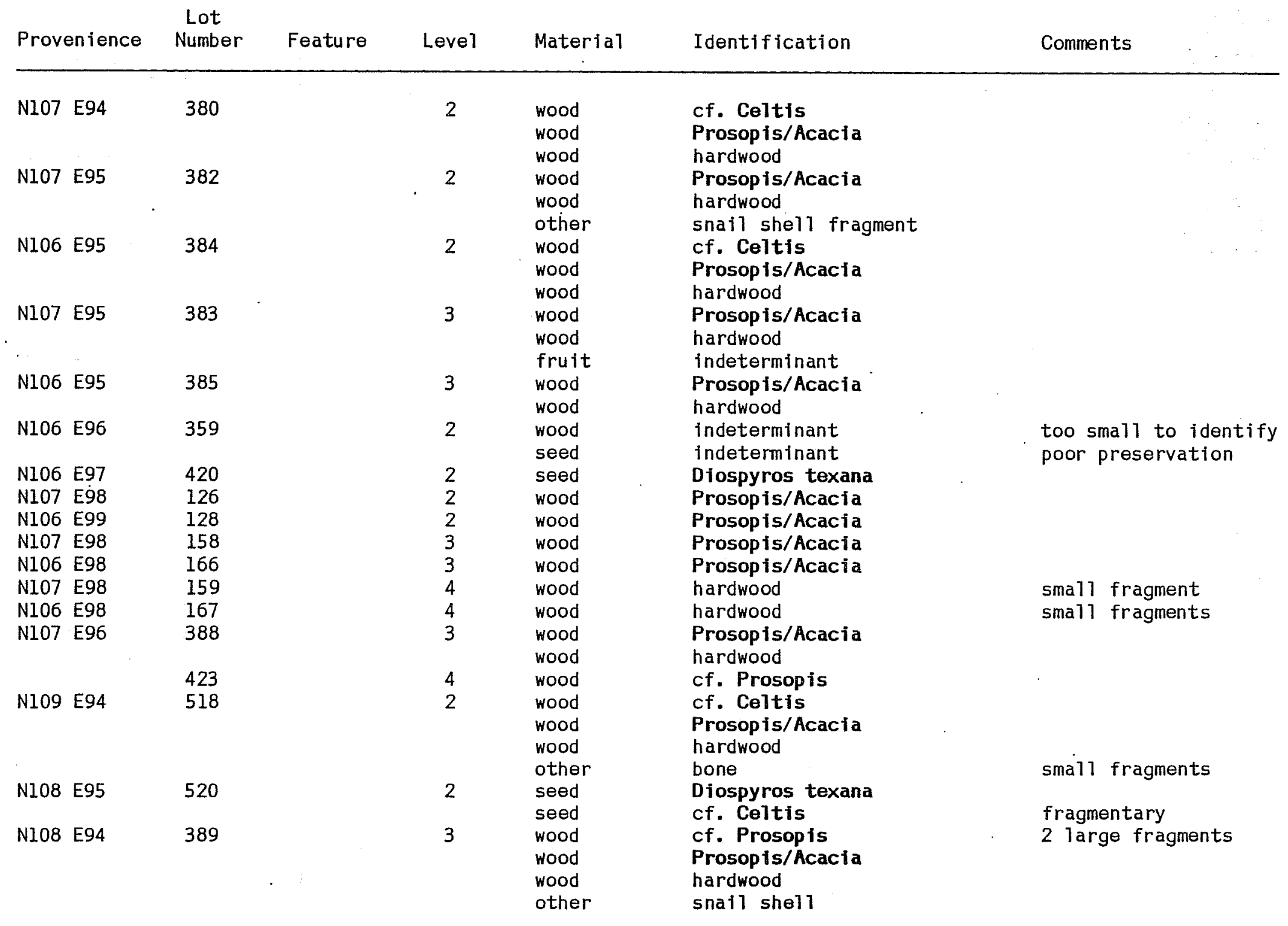


TABLE 13. (continued)

Lot

Provenience Number Feature Level Material Identification. Comments

\begin{tabular}{|c|c|c|c|c|c|}
\hline & & & other & bone & 1 large fragment \\
\hline N109 E95 & 426 & 4 & wood & Prosopis/Acacia & \\
\hline N108 E97 & 329 & 4 & wood. & Prosopis/Acacia & \\
\hline N108 E100 & 430 & 3 & wood & Prosopis/Acacia & \\
\hline N109 E101 & 473 & 2 & $\begin{array}{l}\text { wood } \\
\text { wood } \\
\text { other }\end{array}$ & $\begin{array}{l}\text { Prosopis/Acacia } \\
\text { hardwood } \\
\text { bone }\end{array}$ & \\
\hline N108 El01 & 434 & 1 & wood & Prosopis/Acacia & \\
\hline N109 E96 & 522 & 2 & wood & Prosopis/Acacia & \\
\hline N111 E93 & 262 & 2 & wood & Prosopis/Acacia & \\
\hline N110 E92 & 254 & 3 & $\begin{array}{l}\text { wood } \\
\text { wood }\end{array}$ & $\begin{array}{l}\text { Prosopis/Acacia } \\
\text { hardwood }\end{array}$ & \\
\hline \multirow[t]{3}{*}{ Elll Elol } & 448 & 2 & $\begin{array}{l}\text { wood } \\
\text { wood }\end{array}$ & $\begin{array}{l}\text { Prosopis/Acacia } \\
\text { hardwood }\end{array}$ & \\
\hline & 464 & 3 & $\begin{array}{l}\text { wood } \\
\text { wood }\end{array}$ & $\begin{array}{l}\text { Prosopis/Acacia } \\
\text { hardwood }\end{array}$ & \\
\hline & 483 & 4 & wood & Prosopis/Acacia & \\
\hline $\mathrm{N} 123^{\circ} \mathrm{E} 106$ & 508 & Matrix Z.1 & $\begin{array}{l}\text { wood } \\
\text { nut } \\
\text { seed }\end{array}$ & $\begin{array}{l}\text { hardwood } \\
\text { indeterminant } \\
\text { indeterminant }\end{array}$ & $\begin{array}{l}\text { smal1 fragments } \\
\text { small fragments }\end{array}$ \\
\hline \multirow[t]{2}{*}{$\mathrm{N} 125 \mathrm{E} 92$} & 109 & 4 & $\begin{array}{l}\text { wood } \\
\text { wood } \\
\text { wood }\end{array}$ & $\begin{array}{l}\text { cf. Celtis } \\
\text { cf. Prosopis } \\
\text { Prosopis/Acacia }\end{array}$ & \\
\hline & & & wood & hardwood & very fragmentary \\
\hline \multirow[t]{3}{*}{ Off Site } & 500 & ***NNS Z.1 & $\begin{array}{l}\text { seed } \\
\text { seed }\end{array}$ & $\begin{array}{l}\text { Malvaceae } \\
\text { *Phytolaccaceae }\end{array}$ & \\
\hline & & & $\begin{array}{l}\text { achene } \\
\text { seed coat }\end{array}$ & $\begin{array}{l}\text { Asteraceae } \\
\text { indeterminant }\end{array}$ & $\begin{array}{l}\text { possibly modern } \\
\text {.possibly modern }\end{array}$ \\
\hline & 502 & $* * * N P S \quad Z .3$ & $\begin{array}{l}\text { seed } \\
\text { seed }\end{array}$ & $\begin{array}{l}\text { indeterminant } \\
\text { indeterminant }\end{array}$ & $\begin{array}{l}\text { fragmentary } \\
\text { fragmentary }\end{array}$ \\
\hline
\end{tabular}

* Identified by Dr. Hugh D. Wilson, Texas A\&M University, Biology Department

* Column 2 controlled volume sample

*** Background Noise Pit South, Zone 1, Zone 3 
charcoal specimen was more than several centimeters long and exhibited sufficient numbers of diagnostic characteristics, then the specimen was noted as comparing favorably (cf.) to a specific genus.

Several specimens of charcoal, belonging to the Ulmaceae family, were recovered and probably are of the genus Celtis (hackberry). Because of the presence of this plant, specifical1y Ce1tis pal1ida, in the area today as well as the presence of charred Celtis seeds recovered archaeologically, it seems 1 i.kely that this charcoa 1 is from Celtis plants. Diospyros (persimmon) wood was also recovered, though this appears to be of minor importance as a fuel resource.

Several charred seeds were identified, and 7 ike the charcoal specimens, represent species that are found in the area today. Items recovered that may represent prehistoric diet are Diospyros texana, Chenopodium $c f$. berlandieri, and a possible example of Helianthus. Seeds, in general, seemed to have suffered more than the woods in terms of preservation. This is reflected by the 1 arger number of indeterminate seeds noted in Table 13. Some noncharred seeds were recovered that may be of a modern intrusive origin, such as Sol anum rostratum (buffalobur) and $0 \times a 1$ is (wood sorre1). These were, in a 11 cases, recovered from either Leve1 1 or 2, or from the background noise pit. These are identified and noted under comments in Table 13. In some cases, snail shel1s and bone fragments, both charred and noncharred, were recovered. These were present in the soil and ash matrix which was often included in the field charcoal samples. For purposes of future analysis, they were separated, and their presence was noted in Table 13.

As Bryant and Hol loway (1985) have noted for south Texas, there appears to have been a mosaic paleovegetation in that region consisting of areas of up 1 ands dominated by grasses and semiarid shrubby vegetation and a complementary more mesic vegetation along protected lower areas and drainages where moisture was more abundant. Since Prosopis and Acacia are currently found in both xeric upland and mesic riparian habitats, it is difficult to determine the precise sources of these specimens recovered in the archaeological deposits of this site. What I suspect is that these plants were exploited in both types of south Texas habitats.

Archaeological materials recovered were in all cases, species found in the area today, suggesting no major environmental changes during at least the past 600 years. Instead, as Bryant and Hol 1 oway (1985) have proposed, the region of south Texas has probably undergone continuous localized changes in microenvironments which may have shifted from xeric to more mesic or from mesic to more xeric depending upon the local availability of moisture. Similar conclusions also are noted in a number of other studies conducted in the same general area of south Texas and northeastern Mexico. These include Dering (1982), Holloway (1986), and the study of the pollen record from the Chihuahuan desert by Bryant and Riskind (1978).

\section{CONCLUSION}

Analysis of the macrobotanical materials from site $41 \mathrm{JW} 8$ suggests that the vegetational setting 600 years ago contained the same elements as we see in 
the region today. Then, as now, the vegetational composition most probably consisted of a mosaic of xeric and mesic plants which expanded or contracted their ranges depending upon the availability of molsture. In south Texas, Prosopis/Acacla wood was the major wood component recovered, however, Celtis and, to a lesser extent, Dlospyros were also present. These materials suggest the exploitation of both xeric and mesic plant habitats. Plant materials in prehistoric times were probably not transported great distances, and the archaeological evidence suggests that the Hinojosa site was a single component campsite. Thus, ecological trends or reconstructions cannot safely be made based on $7 y$ on one small area over a short period of time. It is hoped that future macrobotanical and polien analyses will be conducted for this region of Texas and that those results will further expand our current knowledge of the present paleoenvironmental reconstructions.

\title{
ERESHHATER BIYALYES (Harold D. Murray)
}

Freshwater bivalves (mussel shel1s) were recovered in relatively smal1 numbers from $41 \mathrm{JW}$ 8. Only intact bivalve she11s or bivalve umbos were collected. A11 of these were examined and identified when possible by comparison with the author's bivalve collection at Trinity University, San Antonio, Texas. Based on this examination, the following bivalve families and species are represented:

\author{
Sphaerifidae \\ Sphaerium sp. \\ Unionidae \\ Anodonta imbecillis \\ Cyrtonaias tampicoensis \\ Lampsilis teres \\ Lampsitis sp. \\ Toxolasma parva
}

It should be noted that Toxolasma is the same as Caruncu 1 ina. Caruncul ina is an older, invalid genus name that is common in the literature.

\section{AGE OF THE SPECIMENS}

Accurate aging of the specimens is difficult because the annual growth 1 ines may be false as the result of environmental factors. Normally the growth cessation 1 ines or rings (grooves or indentations on the outer surface of the bivalve) are caused by the annual cessation of growth during the winter. Aging of the specimens is ideal1y accomplished by counting the number of annual rings. However, the annual rings can be easily confused with growth cessation 1 ines caused by environmental stress. For example, a drought could result in a cessation of growth and form a ring very similar to annual growth rings. Thus, the aging of the specimens must be approached conservatively. The following are the approximate ages of the identified species: 


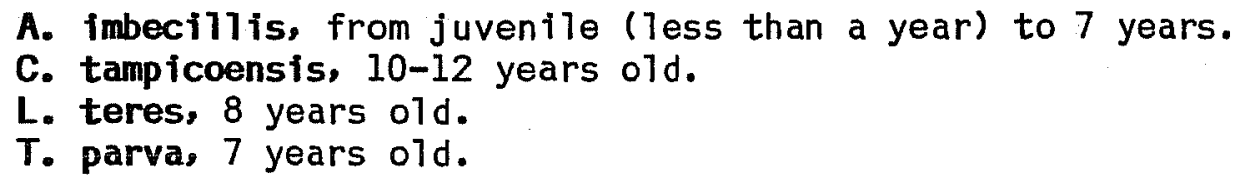

Because mussels cannot survive extended dry periods and because at least one species, C tampicoensis, is about 12 years $01 \mathrm{~d}$, it is suggested that the nearest stream (the most 1 ikely collection source, Chiltipin Creek) had a permanent source of water which 1 asted 12 or more years during the occupational period of the site. It is assumed that specimens were not transported from a source of water some distance away. Since these species require a fish host for the parasitic, glochidal stage one must assume a permanent body of water greatly exceeding 12 years in order to have it populated by the correct species of host fish. This does not necessarily imply that Chiltipin Creek itself was a permanent body of water for such a long period as the host fish could have moved upstream from a permanent body of water (San Fernando (reek?).

\section{THE COLLECTION}

Over 95\% of the identified bivalves at $41 \mathrm{JW} 8$ is Toxolasma parva, the smal lest unionid species which rarely exceeds $4 \mathrm{~cm}$. Most of the T: parva were 1ess than $25 \mathrm{~mm}$. The preferred habitat of T. parva is sha11 ow (50$200 \mathrm{~cm}$ ), quiet water in soft mud. One specimen of Sphaerium was present and $1 \mathrm{ives}$ in the same habitat. Several specimens of Anodonta imbec 111 is were identified (discussed 1 ater), and it also lives in the same habitat. The larger Cyrtonais tampicoensis and Lampsilis teres, which were found in sma.11 numbers, are more often found in deeper water (greater than $200 \mathrm{~cm}$ ) in a variety of habitats (i.e., mud, mud-sand, mud-cobble, or cobble-sand). The distribution of the species suggests that most of the collections were made along the shore in shallow water.

Significance of Anodonta imbecil115: The presence of several specimens of $A$ imbec 111 is is important. Examinations of much 1 arger samp 1 es $(18,000 \pm$ valves) from the Choke Canyon Reservoir area (Murray 1982) and a study of mussels from 41 GD 21 on Coleto Creek near Victoria (Fox 1979:57-61) revealed no representatives of the genus Anodonta. It was interpreted that Anodonta was introduced to the area by European settlers. The specimens from the Hinojosa site cast doubt on that opinion; however, the site is a comparative1 y young site (ca. 600 years old). Possibly the genus appeared in this area at about this time or sightly earlier.

Significance of Cyrtonaisis tampicoensis: A11 previous studies of bivalves from prehistoric sites in southern Texas (cited previously) have shown the predominant species collected to be Cyrtonaisis tampicoensis. Furthermore, a11 the streams, rivers, and 1 akes which have been studied in the south Texas area current 1 y have C. tampicoensis as the most common species in terms of numbers of individuals. The Hinojosa site only has a couple of individuals of this species. This difference is unexplained; however, several questions can be posed: 
1. Was the habitat inadequate (i.e., was the stream too small for the species)? The species grows quite 1 arge and may reach $100 \mathrm{~mm}$ or more in length.

2. Were they present but not collected?

3. Were they collected but transported elsewhere to be used as tools or ornaments?

None of the three possibilities can be ruled out; however, the first seems most 1 ikely. It does not seem 1 ikely that a larger species used at many other sites in southern Texas would have been ignored in favor of a sma 11 species (T. parva). It also seems improbable that tool or ornament usage would have not been evidenced at 41 JW 8 in view of the worked musse 1 and marine shel 1s that were recovered. It may be significant that both of the previous studies were done in areas with much larger streams or rivers.

Lampsilis sp: Several sma 11 fragments were clearly Lampsil is; however, because there is a second species of Lampsilis possible in the area, no positive species identification could be made.

\section{SUMMARY}

Based on the recovered bivalves, the impression of the nearby stream (Chiltipin (reek) during the active period of site occupation is that it was a smal1 (couple of meters wide), constantly running (possibly artesian source), shallow (a half of a meter deep) stream. The substrate bottom was probably mud or mud-sand base.

\section{RADIOCARBON ASSAYS}

Large samples of wel 1-preserved wood charcoal were recovered from three horizontaliy and vertically discrete cultural features during the 1981-1982 season at $41 \mathrm{JW}$ 8. Samples from each feature were submitted for radiocarbon assay. The resulting dates were expected to confirm the previous assays recovered from the site as well as the relative dating provided by stratigraphy and associated artifacts. The dates were expected to fal1 between A.D. 1200 and 1500 and average between A.D. 1300 and 1400. Unfortunately, the radiocarbon assays recefved range between A.D. 660 and 1570 (uncorrected midpoints) and are furthermore inconsistent within individual features. Thus, the radiocarbon assays present serious problems in interpretation as w111 be discussed.

Initially, four charcoal samples were submitted for assay; two samples (Features 6 and 8) were sent to the Center for App 1 ied Isotope Research at the University of Georgia, and two (Features 5 and 6 ) were sent to the Radiocarbon Laboratory at The University of Texas at Austin. Two radiocarbon 1 aboratories were used to provide crosschecks on the dating. The first dates were received from the Georgia 1 aboratory. The sample from Feature 6 was assayed at $525 \pm 65$ B.P. (UGa-4541), which was in 1 ine with expectations. The samp 1 e from Feature 8 was assayed at $1290 \pm 65$ B.P. (UGa-4540), which is 
more than twice as old as expected. In order to check this date a second charcoal sample from Feature 8 was submitted to the Austin 1 aboratory.

The three assays received from the Austin 1 aboratory on $7 y$ added to the prob 1 em. Feature 5 was assayed at $520 \pm 90$ B.P. (TX-4652), which is within the expected range. Feature 6 was assayed at $970 \pm 60$ B.P. (TX-4653), which is over 400 years older than the assay from the Georgia 1aboratory. Feature 8 was assayed at $500 \pm 60$ B.P., which is in 1 ine with our expectations but some 790 years younger than the comparable Georgia 1aboratory assay. Thus, on the two features dated by both 1 aboratories the resulting assays differed by hundreds of years. Moreover, the differences were not consistent between 1 aboratories; on Feature 6 the Georgia 1 aboratory's date was much younger than the Austin 1aboratory's, while on Feature 8, the Aust in 1aboratory's date was much younger than the Georgia 1 aboratory's.

In order to resolve the problems Salvatore Valastro of The University of Texas at Austin and John Noakes of the University of Georgia agreed to obtain assays on additional samples from the two features in question at no additional cost. Valastro pointed out to the author that although the samples were from discrete features, therefore archaeologically identical, the charcoal sent to each 1 aboratory cannot be considered scientifical1y identical unless a large sample from each feature is pulverized and split exactly. Valastro agreed to chemically pretreat and split samples from the two features in question and send half of each sample to the Georgia 1 aboratory for additional assays.

The resulting assays only partially improved the situation: Feature 6 was assayed at $1090 \pm 110$ B.P. by the Aust in 1 aboratory (TX-4886) and $655 \pm 70$ B.P. by the Georgia 1 aboratory (UGa-5289), while Feature 8 was assayed at 700 \pm 80 B.P. by the Austin 1 aboratory $(T X-4887)$ and $380 \pm 185$ B.P. by the Georgia 1aboratory (UGa-5290). While the split assays from Feature 8 over1 apped within the two-sigma leve1, the split assays from Feature 6 did not. John Noakes agreed to run one final assay on Feature 6 charcoal to attempt to resolve the problem. The resulting assay fell in 1 ine with the two Austin 1 aboratory assays from Feature 6: $930 \pm 70$ B.P. (UGa-5280).

At the present time, then, 12 radiocarbon assays have been determined from charcoal samples col 1ected from 41 JW 8. Table 14 summarizes a 11 of the radiocarbon assays from $41 \mathrm{JW} 8$. These assays, with the exception of TX2206, which has an extreme 1 y 1 arge error range, have-been corrected by the ca 1 ibration based on the consensus data of the 1979 radiocarbon workshop ( $\mathrm{K} 7$ ein et a 1. 1982) and plotted in Figure 13. Tab 1 e 14 and Figure 13 show the ambiguity of the assays and $i 11$ ustrate the problem of how to interpret these dates. Given the facts that the recovered charcoal samples were very we 11 preserved, were from seemingly ideal contexts, and that two of the features have four or five radiocarbon assays each, the inconsistent results are particularly distressing. The following discussion will review some of the factors involved in the radiocarbon assay process in an attempt to explain why the resulting assays did not meet our expectations.

The field notes, plan maps, and photographs were careful1y reexamined several times after the anomalous dates were received. As discussed el sewhere in this report, the stratigraphy and artifact associations strongly suggest that 
TABLE 14. RADIOCARBON ASSAYS

\begin{tabular}{lccl}
\hline $\begin{array}{l}\text { Samp 1e } \\
\text { Number }\end{array}$ & $\begin{array}{c}\text { Radiocarbon } \\
\text { years B.P. }\end{array}$ & $\begin{array}{c}\text { Years B.P. } \\
5730 \pm 1 / 2-1 \mathrm{ffe}\end{array}$ & \begin{tabular}{l} 
Provenience \\
\hline
\end{tabular} \\
\hline $\begin{array}{l}\text { Tx-2206 } \\
\text { Tx-2207 }\end{array}$ & $650 \pm 1230$ & $669 \pm 1220$ & 1975 "bone bed" \\
& $580 \pm 50$ & $596 \pm 50$ & 1975 Unit H, Leve1 1 \\
Tx-4652 & $520 \pm 90$ & $535 \pm 90$ & Feature 5 \\
UGa-4541 & $525 \pm 65$ & $540 \pm 65$ & Feature 6 \\
Tx-4653 & $970 \pm 60$ & $998 \pm 60$ & Feature 6 \\
Tx-4886 & $1090 \pm 110$ & $1122 \pm 110$ & Feature 6 \\
UGa-5289 & $655 \pm 70$ & $674 \pm 70$ & Feature 6 \\
UGa-5280 & $930 \pm 70$ & $930 \pm 70$ & Feature 6 \\
UGa-4540 & $1290 \pm 65$ & $1327 \pm 65$ & Feature 8 \\
Tx-4654 & $500 \pm 60$ & $515 \pm 60$ & Feature 8 \\
Tx-4887 & $700 \pm 80$ & $720 \pm 80$ & Feature 8 \\
UGa-5290 & $380 \pm 185$ & $391 \pm 185$ & Feature 8
\end{tabular}

a11 of the cultural deposits in the Wagon Trail Area of the site represent an occupation closely related to the Toyah phase of central Texas (Jelks 1962; Prewitt 1982; Prewitt 1985) and thus can be expected to date to no earlier than A.D. 1300 in southern Texas. All three features were relatively undisturbed. Their proximity to the current ground surface and the degree of bioturbation noted at the site might explain minor contamination with more modern carbon-bearing materials but not with earlier materials. Deeper stratigraphic testing below the Toyah horizon occupation produced very 1 ittle evidence of earlier occupations and 1 ittle or no organic material. The only possible earlier evidence consisted of flakes and one comparatively deeply buried rock cluster (Feature 1) that had no charcoal whatsoever. Thus, a review of the field data suggests that the features in question shou $7 d$ date to after A.D. 1300. Similar Late Prehistoric components at two sites in the Choke Canyon Reservoir area of south Texas, 41 MC 296 and 41 LK 201, have been radiocarbon dated well after A.D. 1300 (Ha 1 1, Black, and Graves 1982; Ha 11 , personal communication).

The radiocarbon assays from $41 \mathrm{JW} 8$ were al1 run on chunk wood charcoal samples that are wel1 suited for analysis. Chunk wood charcoal is subject to contamination in a 1 imited number of ways. Fine rootlets may be present in the charcoal, however, most of these were removed prior to sending the samples to the radiocarbon laboratories, and the laboratories were advised of this possibility. Standard sample preparation procedures should have removed the remaining rootlets. In addition, rootlet contamination would yield 1 ater dates rather than earlier dates. A possible factor that could cause the dates to come out too old has been called "post-sample-growth error" (Ralph 


\section{Radiocarbon Assays - 41JW 8}

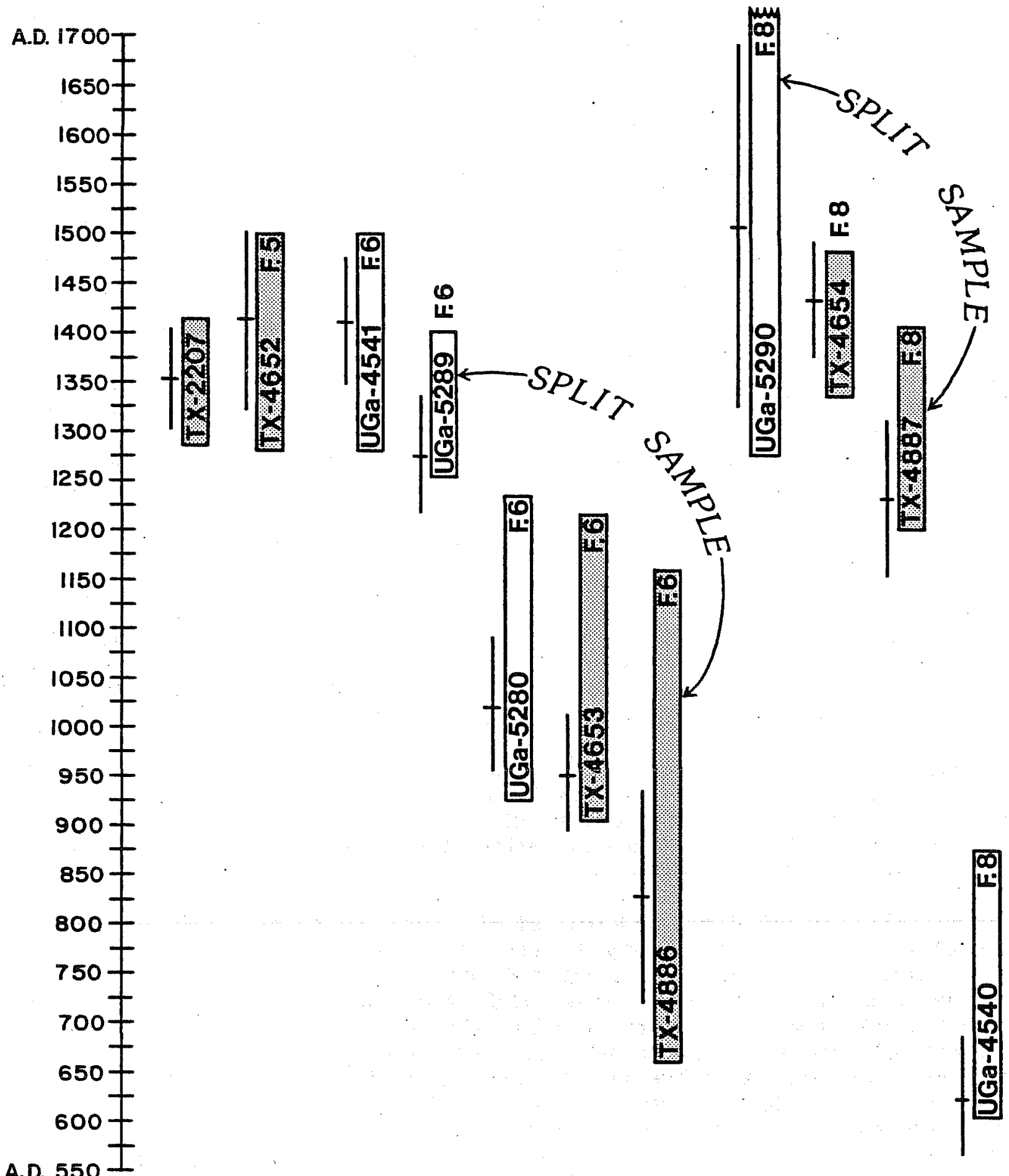

Figure 13. Radiocarbon Assays from 41 JW 8. 
1971:4). This error occurs in cases where the dated wood is significant1y older than the event being dated. This could occur if the heart wood from old trees had been burned in the fires that resulted in Features 6 and 8 . In this part of south Texas, there are very few trees that 1 ive more than 100200 years, hence this factor cannot likely explain why some of the dates are 400 to 800 years older than the associated artifacts.

Most of the other sources of radiocarbon assay error concern the mechanics of how the samples were processed in the radiocarbon 1 aboratory. Erroneous dates can result from a number of stages in the processing, including sample pretreatment, equipment calibration, and sample counting time (Raiph 1971; Fleming 1977; Browman 1981). Several studies comparing dates run by different laboratories on replicative samp les from we 11-dated contexts have shown significant variation between laboratories. Browman (1981:254) states that the major reason for discrepancies between samples less than 2000 years old is an error in the calibration of the reference standard. Clark (1975:252-253) analyzed 192 independent replicative observations by various 1 aboratories on tree ring samples. He concluded: "There can be no doubt that on the average the variability between replicate observations is far in excess of the variability expected in view of the quoted standard errors" (ibid.:252). Recent comparisons of tree ring dates during calibration studies have shown systematic but comparatively small differences between comparatively smal1 groups of cooperating laboratories (K1ein et a1. 1982; Stuiver 1982).

Within the 1 ast two decades, it has been demonstrated that the amount of carbon-14 present in the atmosphere has systematically varied over at least the past 7000 years (Browman 1981). Since the validity of radiocarbon dating has been based on the assumption that the amount of atmospheric carbon-14 is a constant, the systematic deviations have to be taken into account. $A$ number of calibration curves and charts have been published, including Ralph, Michael, and Han (1973), Damon et a1. (1974), Clark (1975), Klein et al. (1982), and Stuiver (1982). Each is based on a comparison between dendrochronogically dated tree ring samples and careful radiocarbon assays of these samples. All of the cited calibrations agree on most of the major deviations; they disagree to some extent on the minor deviations or "wiggles" present in some calibrations and the mathematical techniques used to "smooth" the curves (Browman 1981:256-257).

The calibration published by Klein et a1. (1982) represents the most widespread effort to date to compile tree ring dates. As mentioned, this cal ibration is the result of a major workshop held in Tucson. Arizona, in 1979 (Michael and Klein 1979). This calibration should gain rapid acceptance over the next few years. Unti 1 now the archaeologist had to choose between several calibrations which varied significantly for certain date ranges. One very positive aspect of the new calibration is the ease with which a nonspeclalist can calibrate a date. Several of the available calibrations 1 ack the clear cut tables and user instructions that accompany the klein et a 1. (1982) calibration.

It is very important to note that a radiocarbon date is not a fixed absolute date but rather a statistical estimate of the absolute date range within which the actual or "true" date, a sample ceases to accumulate radioactive 
carbon, occurs. Most authorities on the subject of radiocarbon dating stress the fact that radiocarbon assays are usually expressed with an error factor (p1us or minus) of one standard deviation (one sigma). This means that the actual date has two in three (68\%) statistical chances of falling within the error range given in the assay. This also means that the "truel date of one out of three radiocarbon assays wil1 not fal1 within the one-sigma range. The use of a two-sigma error range will increase the statistical chance to 95\%. The cal ibrated date ranges shown in Figure 13 reflect the $95 \%$ confidence level range.

Radiocarbon assays are norma 11 y reported using the Libby carbon-14 half- 1 ife of 5568 (by standard agreement). Conversion to the more accurate carbon-14 ha $1 \mathrm{f}-1$ ife of 5730 is accomp 1 ished by mu 1 tiplying the reported radiocarbon date (years B.P. from the 1950 radiocarbon standard) by 1.029. For example, TX-4652 (520 \pm 90$)$ is converted to $535 \pm 90(520 \times 1.029=535)$. The onesigma range is then determined by adding and subtracting the one-sigma error. This is shown in Figure 13 by the horizontal bar (5730 half-life date midpoint) and the vertical 1 ine (standard one-sigma error range). Using the preceding example, the one-sigma range is 625 to 445 B.P. or A.D. 1325 to 1505. The B.P. date is converted to the Christian calendar by subtracting the B.P. date from 1950 (positive numbers are A.D. dates, and negative numbers are B.C. dates).

The Klein et a1. (1982) calibration is calculated simply by looking up the standard assay (Libby half-life date B.P) in the calibration tables (dates in 10-year intervals) and reading the calibrated date range given for the closest sigma error (provided for 20, 50, 100, 150, 200, and 300 year errors). A though some rounding off is necessary, the table has been constructed to yield 95\% confidence interval date ranges. The general effect of the calibration upon the 41 JW 8 assays (vertical bars in Fig. 13) is that the older dates are shifted somewhat 1 ater while the younger dates are shifted slightly earlier. These corrections do not negate the fact that something is drastically wrong with the suite of radiocarbon assays from $41 \mathrm{JW} 8$.

If one were to assume that a 11 the dates are basical1y correct, then one would have to conclude that two discrete features ( 6 and 8 ) both had a mixture of charcoal dating to between A.D. 1300 and 1400 and some 300 to 700 years earlier. This seems highly unlikely, and it is therefore assumed that some of the dates are incorrect. The problem then becomes to try and decide which dates are incorrect.

If one assumes that all of the charcoal from the site was deposited during a single occupation, then this occupation can be dated by finding the time interval with the greatest number of overlapping dates. Seven of the eleven calibrated dates have error ranges that overlap between A.D. 1350 and 1400 . This overlap falls within the expected range based on artifact association and stratigraphy. This possibility is considered most likely by the author. If true, this means that two dates were determined by each 1 aboratory that were 300 to 700 years too old. In other words, the sample processing techniques at both laboratories were apparently inconsistent. 
If, on the other hand, one assumes that the charcoal dated from the site was deposited over a longer time span or during several occupations, then each feature should be examined separately. The fact remains that the majority of the assays fit within the expected date range; hence at least one occupation dates to between A.D. 1350 to 1400. Feature 5, with only a single assay, appears to date to this occupation. Feature 8 has three out of four assays that fall within this same occupation. The fourth assay (UGa-4540) is clearly wrong. Feature 6 has two date clusters. The first two dates determined by the Georgia 1 aboratory fit within the A.D. 1350 to 1400 occupation. The third, the Georgia 1 aboratory assay, and both the Austin laboratory assays, overlap between A.D. 925 and 1150. By virtue of numerical superiority, one must assume that the earlier date range is applicable to Feature 6. However, there is no physical evidence that Feature 6 is any earlier than the other two features. In fact. Feature 6 is slightly higher in elevation (and closer to the surface) than either of the other two features and has some Toyah phase artifacts (pottery sherds, a sma 11 end scraper, and an arrow point fragment) that are clearly in direct association. In other words, the possibility that Feature 6 actual 1 y dates to between A.D. 945 and 1010 is considered very unlikely.

The conclusion about the radiocarbon assays from $41 \mathrm{JW} 8$ is that the radiocarbon laboratories did not use consistent, reproducible procedures. This conclusion is strengthened by an examination of the two pairs of samples that were sent to the Austin laboratory for pretreatment and splitting. In June of 1983, following the discovery of the initial inconsistencies, the author removed a 1 arge charcoal sample from the charcoal sample bags from both features in question (Features 6 and 8 ). These were proper 1 y packaged and sent to the Austin laboratory for pretreatment and sp 1 itting. Valastro processed and split the samples and sent one-half of each sample to the Georgia laboratory. Given the serious nature of the inconsistencies (both laboratories agreed to run additional samples without charge), one assumes that the samples were treated with more than normal caution to insure that comparable results were obtained. Therefore, both pairs of dates should have been close together. This was not the case. On Feature 8, the Austin laboratory dated the sample at $700 \pm 80$ while the Georgia 1 aboratory dated the sample at $380 \pm 185$. This pair does overlap within the calibrated twosigma range, however, this is only due to the very large error factor of the Georgia laboratory date. On Feature 6, the Austin 7 aboratory dated the sample at $1090 \pm 110$ while the Georgia 1 aboratory dated the sample at $655 \pm 70$. This pair does not even over 7 ap at the two-sigma range (calibrated or uncalibrated).

An earlier draft of this section of the report was sent to both 1 aboratories along with a request for additional information on how each sample was processed and for any suggestions for possible sources of error. The resulting responses may partial1y explain the discrepancies. The assays produced by each 1 aboratory are examined below.

Four of the six valid assays from the Austin 1aboratory (TX-2206 not considered due to 1 arge error factor) overlap between A.D. 1350 and 1400 when calibrated. The remaining two dates, both from Feature 6, overlap between about A.D. 900 and 1150. It is significant to note that the assays determined by the Austin 1 aboratory for each of the problematic features, 6 and 8 , 
are internally consistent. That is to say, both assays for each feature are statistical1y consistent (they overlap).

By contrast, the five assays from the Georgia laboratory are noticeably inconsistent. Of the three assays from Feature 6 , two overlap between A.D. 1300 and 1400 (calibrated) while the third agrees with the older assays determined by the Austin laboratory. The two Georgia 1aboratory assays from Feature 8 are 350 years apart from overlapping. Thus, the Georgia 1aboratory assays are not internal1y consistent.

Both laboratories use the benzene method for sample preparation and a 1 iquid scintillation counter for counting the radiocarbon. Both 1 aboratories use the new NBS (National Bureau of Standards) oxalic acid RM 49 standard that is referenced to the old NBS standard. In addition, the Austin 1 aboratory also periodical 1 y uses 12,000-year-01d tree and modern tree (1840) samp les from Arizona as reference crosschecks. Both 1 aboratories report assays based on the Libby half-life (5568) and tied to the standard 1950 reference point. Thus, the two laboratories use similar basic processing techniques that should yield similar results.

The difference between the 1 aboratories involves the sample preparation techniques that were used on the $41 \mathrm{JW} 8$ samp les. The Austin 7 aboratory used the same pretreatment procedure for each sample. First, the sample is examined, and obvious contaminants are removed (dirt, roots, etc.). Next, it is boiled in a $2 \%(0.2 \mathrm{~N}) \mathrm{HC} 1$ solution for 30 minutes to one hour to remove calcareous material such as 1 imestone. Next, the sample is rinsed and then boiled with a $2 \%(0.2 \mathrm{~N})$ sodium hydroxide solution to remove any humic acids which might be present. Then, the HCl boil is repeated, and the sample is rinsed a final time with distilled water. After thorough drying, the charcoal is picked piece by piece for the final sample. This procedure was used for al1 the assays sent to the Austin 1 aboratory and a 7 so for the sp 1 it samples assayed by the Georgia 7 aboratory (UGa-5289 and UGa-5290). The length of counting time varies at the Austin laboratory from a minimum of 24 hours to 48 hours depending on the quality and age of the sample (i.e., an amp le sample of a relatively young date is not counted as long as a small sample of an older date).

The Georgia laboratory used similar procedures for the $41 \mathrm{JW} 8$ sample with one seemingly significant exception--the alkali (sodium hydroxide) boil. Samples UGa-4540 and UGa-4541 were not bolled in an alkali bath "due to the we1 1 preserved nature of the charcoal" (Noakes 1984). Noakes went on to say: "This, I admit, may have been an error but repeated distilled water rinsing indicated that the samples were of a very clean condition." He also suggested that based on his past experience "the [41 JW 8] problem 1 ies in the chemical preparation." The letter from John Noakes also revealed the reason for the 1 arge error factor for UGa-5290; a vacuum 1 ine ruptured during the chemical synthesis, and much of the sample was lost.

Val astro and Noakes both reported that they had checked their 7 aboratory records and had double-checked their counting equipment and found no irregularities or indications of malfunctioning equipment. Therefore, we should expect consistent results for the samples which were pretreated with the full acid and alkali baths and in which no loss of sample occurred. The 
sp 1 it Feature 6 sample assays (TX-4886 and UGa-5289) meet this requirement as we 11 as two of the other Feature 6 assays (TX-4653 and UGa-5280). As Figure 13 shows, while three of these assays are consistent and overlap when cal ibrated between A.D. 925 and 1150, the fourth assay (UGa-5289) agrees with the A.D. 1300 to 1400 expected range.

In the final analysis, the problem of inconsistent radiocarbon assays from 41 JW 8 cannot be solved based on the current data. Three out of four of the valid dates for Feature 6 are 150 to 375 years older than expected. Given recent confirmation of the fact that Toyah phase related materials in southern Texas date after A.D. 1300 (Prewitt 1985; Ha 11. Hester, and B1 ack 1986), the Feature 6 dates are anomalous. One possible explanation for the anomalous dates is that they fall within or near one of the "flat" regions in the calibrated curves (K1ein et a 1. 1982:114). The "f 1 at" regions of the curve are "periods when the C-14 in the atmosphere has decreased at a rate greater than the $1.2 \mathrm{mil}$ per 10 years" (ibid.). Based on the published data, the errors resulting from the "flat" region would not account for the magnitude of the Feature 6 anoma $7 y$.

\section{FINAL CAVEATS}

A recent in depth discussion of radiocarbon techniques concluded that: "Radiocarbon dating now has the potentiality of far surpassing even the most optimistic plaudits it received a quarter of a century ago" (Browman 1981:287). This author cannot agree. Numerous colleages have cited other examples of serious discrepancies between and within radiocarbon 1 aboratories (including other 1 aboratories not mentioned here) on comparable samples.

This problem has serious consequences for the archaeologist. It appears necessary to have a large number of assays for each occupational component or feature at a given site to be able to distinguish between good dates and erroneous dates and to get an accurate idea of the dating range. This effectively means that site components or features with on $1 y$ a 1 imited number of charcoal samples cannot be confidently radiocarbon dated. The archaeological 1 iterature is repleat with examples of components, features, and even sites which are discussed as being firmly dated on the basis of a single radiocarbon assay. The use of single dates in such a confident manner is simply irresponsible.

Another common misuse of radiocarbon assays involves the quoted or calibrated assay midpoint. The midpoints of radiocarbon assays are frequently cited and discussed as if the midpoint is an accurate estimate of the actual date. In fact, the assay midpoint is only the central point in a much larger two-sigma range in which the true date can be expected to occur 95\% of the time. Thus, radiocarbon assays should always be discussed as ranges or very clearly stated as rough approximations. The use of numerous overlapping assays is necessary to accurately define the date ranges of site components. An excellent example of this approach is provided by the George C. Davis site radiocarbon dating (Story and Valastro 1977).

The implication for archaeologists of the aforementioned problems is clear: many (perhaps most) features, components, and sites cannot be accurately 
dated by radiocarbon dating alone. This is because of the nature of radiocarbon dating as a statistical approach and the 1 ack of adequate samples of datable carbon from many (if not most) features, components, and sites.

Finally, this author would like to make some recommendations to archaeologists who rely on radiocarbon assays. One suspects that 1 ike the author, prior to the Hinojosa site experience, most archaeologists have never taken the time to understand how radiocarbon dating really works. Previously, this author used radiocarbon dates rather carelessly; if a date "looked right," it was used uncritical $1 y$, if not it was ignored or exp 1 ained away. In order for radiocarbon dating to 1 ive up to the "optimistic plaudits" mentioned, the tool of radiocarbon dating must be used for what it is rather than for what we archaeologists would like it to be. Toward this end the following suggestions are offered:

(1) Archaeologists should take time to careful1y investigate the radiocarbon 1 aboratories to which he or she sends samples. The pretreatment methods, equipment calibration standards, and counting times used by a given laboratory can seriously effect how the date will come out. If samples are to be split and sent to two 1 aboratories, it behooves the archaeologist to make sure that both laboratories use essentially identical methods, or else the results are 1 iable to be inconsistent.

(2) Archaeologists should work more closely with radiocarbon scientists at al1 stages of the process, from the field circumstances to the final interpretations. Each feature, component, or site is unique and should be treated as such.

(3) Radiocarbon 1 aboratories should provide as standard information the processing details for each sample. Some 7 aboratories make a standard practice of this, many others do not. Most information could be summarized in three to five pages. The pretreatment variation, the sample count times, and any problems in processing for each sample should be reported to the archaeologist.

(4) It is very obvious that a detailed comparative study needs to be made of the radiocarbon 7 aboratories that provide data to archaeologists. This study would reveal which procedures are and are not producing reliable results and would provide a means to evaluate and compare data received from various radiocarbon 1 aboratories.

\section{PERDIZ ARROW POINT SPECIAL STUDIES}

A comparatively large sample of Perdiz arrow points (100) and fragments of other arrow points (64; most of which are probably Perdiz fragments) was recovered from $41 \mathrm{JW} 8$. These were found in virtually all excavation units in most excavation levels except for the lowest nonproductive levels. The large arrow point sample was used for three special studies in addition to the wear pattern examination discussed in Section VI. These studies are an evaluation of a projectile point neck width dating formula hypothesis, a look at plow-damaged arrow point distribution, and a study of arrow point breakage patterns. 


\section{NECK WIDTH HYPOTHESIS}

Bi11 Fawcett (1978) has suggested that a mathematical relationship exists between the neck width of centra 1 and southern Texas Late Archaic and Late Prehistoric projectile points and time. Simply stated, Fawcett contends that projectile point neck width gradually decreased through time. Furthermore, he argues that the average neck width for a group of projectile points from a single component can be used to derive an estimate of the occupation date. Fawcett derived a "mean neck-width formula" from measurements of projectile points from south, centra1, and coastal Texas sites that had discrete occupation levels dated by radiocarbon assays. Fawcett (1978:137) then used the Perdiz point data from 41 JW 8 presented in Hester (1977) as a test of his mathematical mode1. Based on his measurement from photographs of 27 Perdiz points from the 1975 testing and surface collection, Fawcett determined the mean neck width of the 27 illustrated points was $7.5 \mathrm{~mm}$ and estimated that the Hinojosa site dated to A.D. 1327. This date is very close to the mean date of the two radiocarbon assays from 1975 (although one of the dates had a plus or minus of 12301). Fawcett (1978:137) concluded that "a single application of the formula demonstrates the accuracy of this formula dating methodology."

A number of weaknesses in Fawcett's methodology are readily apparent. First, he makes the unstated assumption that south, central, and coastal Texas prehistories were so similar that projectile point size (or at least projectile point neck width) was uniform at any point in time and changed diachronically at a uniform rate. Second, his data was mostly derived from measurements of photographs of select projectile points; hence he assumes that the photographed points were representative of the entire sample from a given occupation 1 evel and that measurements from photographic representations are accurate. Fawcett also assumes each radiocarbon assay is accurate, although he uses various 1 inear regression correction factors to adjust she 11 and snail assays. Finally, while fawcett cites the site references, radiocarbon assays, and mean neck widths, no data is provided on sample size or even the type of projectile point being measured.

The validity of al 1 of Fawcett's assumptions can be serious ly chal lenged. The absence of the sample size and type data makes it impossible to evaluate the formula. These problems aside, the idea presented by fawcett is an interesting one. If an accurate neck-width formula could be constructed then many site components could be dated that lack carbon preservation. In an effort to provide better neck-width data and to test Fawcett's basic premise, the Perdiz points from the 1981 season were accurately measured. A11 measurements were made of the actual specimens using calipers.

The sample of Perdiz points from the 1981 season at 41 JW 8 was much 7 arger and better controlled than the 1975 sample. A total of 77 Perdiz points with measurable stem (neck) widths was recovered. The mean stem width of this total was $58.7 \mathrm{~mm}$. The neck-width formula devised by Fawcett is:

$$
Y=.832(X)-.0099 \text {, }
$$

where $X$ is the neck width in millimeters, and $Y$ is the estimated age in hundreds of years B.P. (before the radiocarbon present, A.D. 1950). Using 
this formula, an estimated age of 487 B.P. (A.D. 1463) is derived by plugging in the site mean $(.832 \times 5.87-.0099=4.87 \times 100=487 ; 1950-487=1463)$. This date is within the range of the radiocarbon assays but is about 100 years 1 ater than the A.D. $1350-1400$ period in which this author believes the site was occupied.

The neck-width model was further tested by looking at the distribution of neck widths within the excavated sample from 41 JW 8 . The following assumptions were made: (1) it was assumed that the site deposits result from repeat $v i s i t s$ to the site by related groups over several generations, and (2) it was assumed that the Perdiz points in the lower excavation levels were deposited before those in the upper 1evels. Given these assumptions and Fawcett's hypothesis one would expect that the Perdiz points from the lower levels would have a larger mean neck width than those from the upper levels.

The samp 7 e of Perdiz points from the Wagon Trail 1 Area was used to evaluate the neck-width hypothesis because this area was felt to be less disturbed than most other excavation areas and had associated radiocarbon assays. The WTA Perdiz points were divided into two groups. Those from Levels 1 and 2 were placed in the upper group while those from Levels 3 and 4 were placed in the lower group. Unfortunately, Perdiz points were more numerous in the upper levels. Nonetheless, the resulting means tentatively appear to support Faveett's hypothesis. The lower group had a mean neck width of $6.51 \mathrm{~mm}(\mathrm{~N}=9)$ while the upper group had a mean neck width of $5.48 \mathrm{~mm}(N=22)$. Plugging these means into the neck-width formula one arrives at estimated dates of A.D. 1409 for the 1 ower group and A.D. 1495 for the upper group.

It is interesting that the 41 JW 8 Perdiz point neck-width dates appear to be within the range of most of the radiocarbon assays. The 85-year spread between the lower sample and the upper sample does not seem to be an unreasonable estimate of the length of the prehistoric occupation. However, certain caveats seem to be warranted. First, the neck-width means were based on comparatively small sample sizes; the addition or subtraction of one or two unusual1y 1 arge or smal1 neck widths would significantly alter the mean. Second, and perhaps most important, Fawcett's neck-width formula was not derived from a large we 11-control led sample.

It is suggested that in spite of the many weaknesses in Fawcett's neck-width hypothesis, the basic premise may have merit. Projectile points do genera 1$1 y$ decrease in size through time during the Late Archaic and Late Prehistoric periods in central and southern Texas. However, it remains to be demonstrated whether the decrease in projectile point size can be mathematically 1 inked to neck width through time. This author does not bel jeve that the original formula was accurately constructed. A more reliable formula could be constructed by the accurate measurement (beyond the photographic measurement of complete illustrated specimens) of projectile points from a series of comparatively well-dated single component sites such as 41 JW 8 or from isolated components. Crucial to the accuracy of the formula is the sample size of each projectile point type and the accuracy of the radiocarbon dating of the components represented by the projectile point types. 


\section{PLOW DAMAGE STUDY}

The Hinojosa site is located on the edge of an agricultural field that has been plowed for many years. Many of the artifacts recovered from the site bear scars, breaks, and iron deposits ( $p l$ ow damage visible on the artifacts in Fig. 6) that attest to frequent plowing. During the artifact analysis, it became apparent that a majority of the 1 ithic artifacts from the surface and first level had been struck at least once with the plow. It was also observed that the artifacts from the lower levels had not been disturbed by plowing. In an effort to document the extent of the plow zone a study was made of 157 Perdiz arrow points (AI) and arrow point fragments (A4).

Arrow points were chosen for the study because of the large number of specimens and their relatively wide vertical and horizontal distribution. It was observed that iron deposits left by plowing are most commonly found on the ridge scars of bifacial artifacts. Hence, the more numerous 1 ithic items such as flakes might not show damage as often as bifacially chipped artifacts. The arrow points are the most numerous bifacial artifact group at $41 \mathrm{JW}$ 8. The 157 specimens represent a 11 the Al and A4 artifacts that were placed in bags with full provenience information. Other Al and A4 specimens were on 1 y 1 abeled by 1 ot number and were not included simply to save the author the time from having to look up the provenience. The 157 specimens are considered an adequate sample.

Each arrow point or fragment was examined under 10X-20X magnification for the presence of iron deposits ( 1 low marks). As mentioned, plow damage is evidenced by breaking, scarring, and iron deposits. Virtually all 1 ithic artifacts that appear plow damaged have surface traces of iron. These plow marks appear as isolated dark surface deposits or a 1 inear series of deposits that usually occur on $f l a k e$ ridge tops or near the artifact edge. Under magnification, the edges of the plow marks appear maroon to red to orange in color. Some care had to be exercised as a small percentage of the examined artifacts had iron inclusions within the chert and red-stained areas that could be confused with plow marks. Somewhat more common were silver to gray metal traces. These represent contact with the galvanized 1/4-inch screen hardware cloth during the excavation recovery process.

About 35\% of the 157 specimens have noticeable plow marks. Assuming that the samp le is representative of a 11 the artifacts, over one-third of a 11 the artifacts recovered from the site have been displaced by plowing. On a vertical basis the 157 specimens have a highly significant distribution. of the four arrow points recovered from the surface, three had plow marks. Although this is a small sample of surface material, almost every surfacecollected artifact of any type examined by the author had obvious plow marks. Level 1 specimens have plow marks on 38 out of 74 (51\%). Level 2 specimens have plow marks on 14 out of $45(31 \%)$. None of the 22 specimens from Leve 13 or the 12 specimens from Levels 4-6 have plow marks. This correlates very well with the profile illustrations and observations that the plow zone was approximately $20 \mathrm{~cm}$ thick.

Discussions with relatives of the landowner and with the tenant farmer revealed that the site was never deep plowed to their knowledge. The Hinojosa family told the author that the family had acquired the property in 
the early 1900s by hiring workers from Mexico to hand grub several hundred acres in the site vicinity. The Hinojosa property was deeded to the family in exchange for the 1 and clearing. Thus, the site was spared the severely destructive deep root plowing often used in more recent times to clear 1 and in southern Texas (Dusek 1982). In fact, the plow marks observed on the 41 JW 8 specimens could be more accurately called "disk" marks as most probably represent the shallow disking that precedes planting. A disk plow has several closely spaced rows of metal (iron) disks that 1 iterally cut up compacted soil and agricultural waste and allow the soil to absorb more moisture. Each row of disks turns in the opposite direction of the adjacent row. Thus, an artifact would probably be displaced only a few centimeters by disking.

\section{ARROW POINT BREAKAGE PATTERNS}

A breakage study was made of al1 specimens identified as Perdiz points ( $A 1$, $N=100$ ) and a 11 unidentifiable arrow point fragments ( $A 4, N=87$ ). As mentioned, the majority of the A4 fragments are thought to be broken Perdiz points. This statement is supported by the fact that Perdiz points account for about $92 \%$ of the identifiable arrow points.

The purpose of the study was to look at how Perdiz points had been broken and to attempt to correlate the breakage patterns with functional interpretations. The study was prompted by recent observations on a sma 11 samp 1 e of Perdiz points recovered at 41 LK 67 (Brown et a 1. 1982:42-43). Brown noticed that most of the Perdiz points found at 41 LK 67 had transverse snaps of the proximal section (stem) and/or the distal tip. He suggested that arrow points striking a hard substance (stone, wood, or bone) would tend to shatter, while an arrow point striking a soft substance such as animal tissue or soil would break once embedded due to stress caused by the weight of the shaft. Brown argued that an arrow point embedded in soft material would be susceptible to transverse snapping of the blade and the stem.

As Brown notes, the two extant examples of hafted Perdiz points found in dry central Texas caves, were both snapped at the top of the foreshaft. The remaining stem fragments measured 7 and $10 \mathrm{~mm} 10 \mathrm{ng}$. The missing stem sections of the 41 LK 67 Perdiz points appear to have been 1 ess than $7 \mathrm{~mm}$, leading Brown to suggest that "a somewhat different breakage pattern must be implied, probably involving breakage of the stems inside the haft due to lateral stress on impact" (ibid.:43). Brown unsuccessful1y attempted to 1ook for similar breakage patterns in the archaeological 1 iterature and noted the problem of bias against illustrating broken specimens.

A1 1 of the Al and A4 specimens from 41 JW 8 were divided into categories based on the location and angle of the breaks. Most of the breaks were transverse snap breaks. The original categories were based on schematic drawings of Perdiz points showing the various break 1ocations. Some categories with minimal numbers were combined with closely related break categories. Figure 14 shows examples of most of the common break categories recognized at $41 \mathrm{JW}$ 8. Tables 15 and 16 show a breakdown of the examined specimens. The tables are organized by the location(s) of the missing 


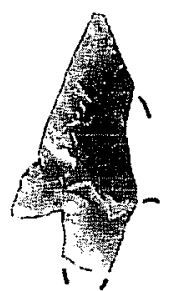

a

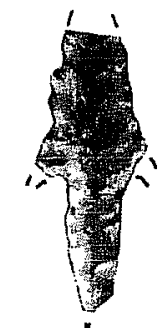

b

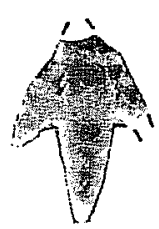

C

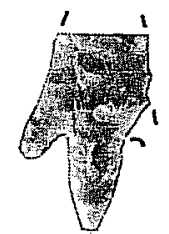

d

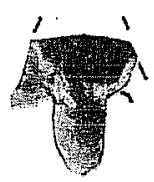

e
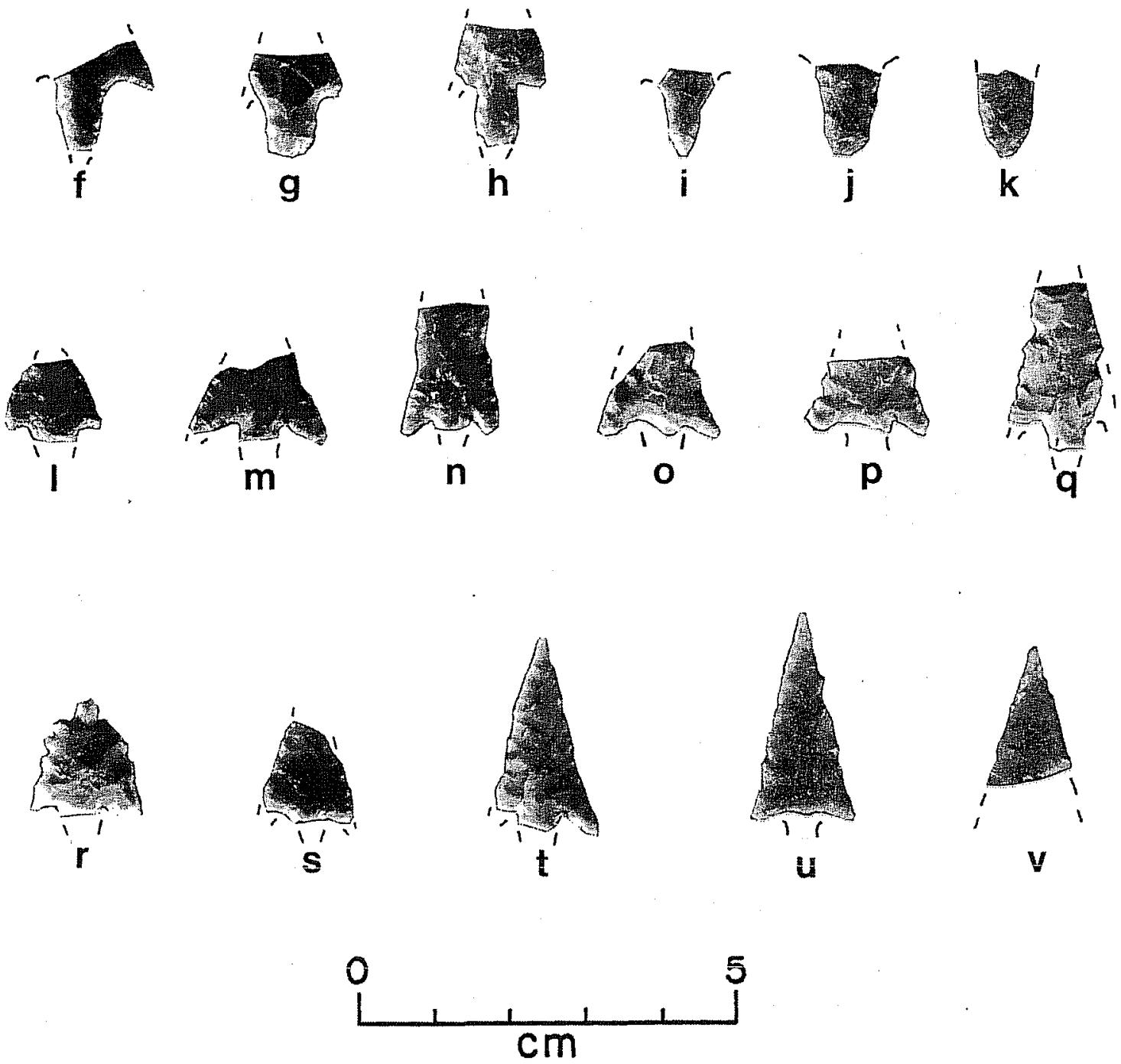

Figure 14. Arrow Point Fragments. a-h, Perdiz (AI); i-v, miscel1 aneous (A4). Lot numbers: $a, 440 ; b, 254 ; c, 514 ; d, 434 ; e, 328 ; f, 57 ; g, 126$; $h, 191 ; i, 179 ; j, 259 ; k, 487 ; 1,437 ; m, 384 ; n, 513 ; 0,523 ; p, 342$; $q, 342 ; r, 328 ; s, 321 ; t, 313 ; u, 433 ; v, 433$. 
TABLE 15. (AI) ARROW POINT BREAKAGE

\begin{tabular}{|c|c|c|c|c|c|c|c|}
\hline Missing: & DT & 18 & $2 \mathrm{~B}$ & LS & US & EB & Count \\
\hline & $\begin{array}{l}x \\
x \\
x \\
x \\
x \\
x \\
x\end{array}$ & $\begin{array}{l}x \\
x\end{array}$ & $\begin{array}{l}x \\
x \\
x\end{array}$ & $\begin{array}{l}x \\
x \\
x \\
\\
x \\
x \\
x\end{array}$ & $x$ & . & $\begin{array}{r}7 \\
17 \\
3 \\
2 \\
2 \\
2 \\
2 \\
12 \\
3 \\
18 \\
3 \\
1 \\
1\end{array}$ \\
\hline Total & 35 & 32 & 9 & 11 & 2 & 18 & 73 \\
\hline
\end{tabular}

TABLE 16. (A4) ARROW POINT BREAKAGE

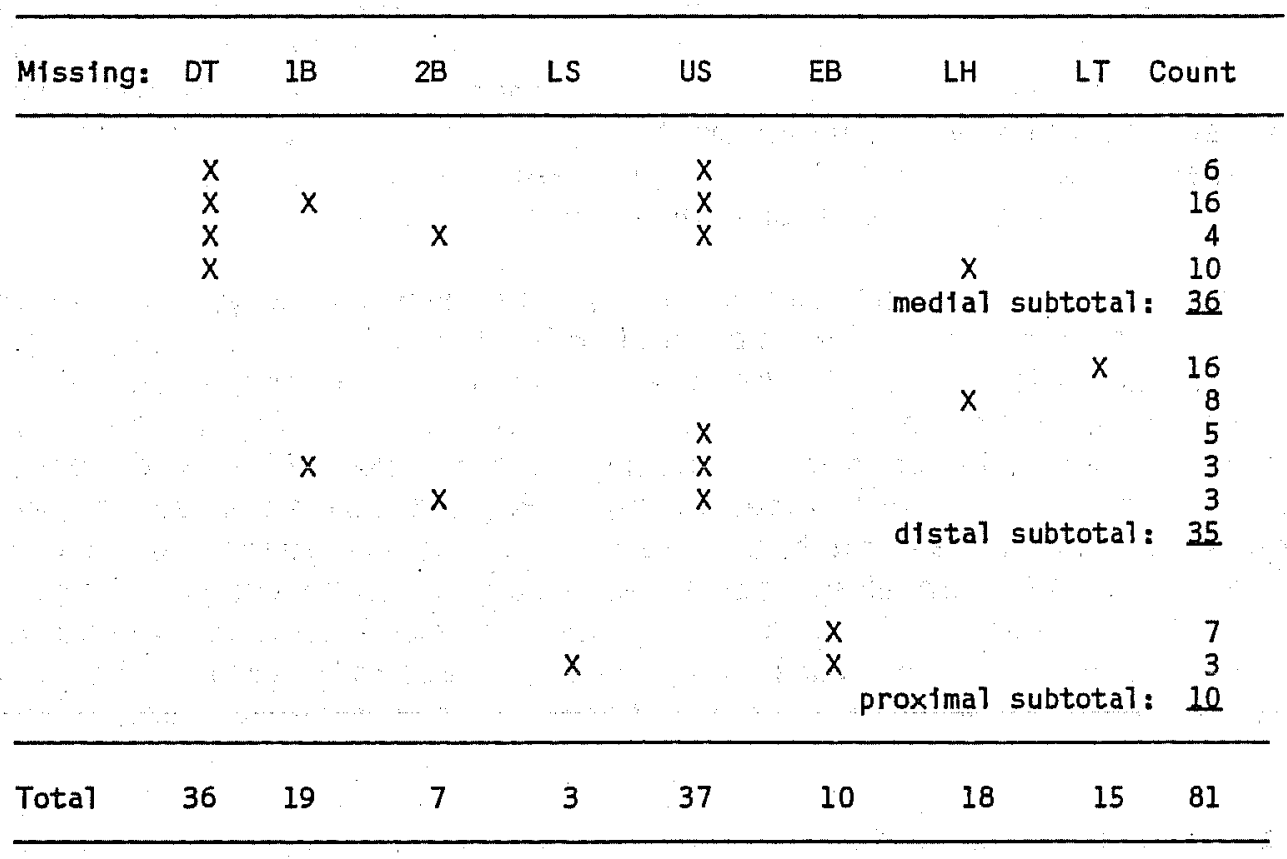

Note: DT= distal tip (less than one-third biade)

$1 B=$ one barb

$2 B=$ two barbs

$L S=$ lower stem (less than one-third stem)

US= upper stem (more than one-half stem)

$E B=$ entire blade (above stem)

$\mathrm{LH}=$ lower half (l ower bl ade section and stem)

$L T=$ lower two-thirds (all but distal tip) 
portions of each fragment. The breakage categories and patterns for each group ( $A 1$ and $A 4$ ) are discussed next.

Table 15 contains data on on 1 y 73 of the 100 Al specimens. This total includes neither the 24 specimens that are completely intact (four of which were never finished) nor the three thermaliy fractured specimens. Of the 73 broken specimens, 35 (48\%) are missing the distal tip. A11 but four of these 35 have transverse snap fractures. The four atypical specimens have acutely angled snap fractures. of the 73 broken specimens, 41 (56\%) are missing one or both barbs. Most of the barb fractures are snap fractures. Of the 73 broken specimens, 13 have stem fractures. Of these, 11 (15\% of broken AI specimens) are missing only the lower few millimeters. Of the 73 fragmented Al specimens, $18(25 \%)$ are complete stem fragments. Two of these have triangular or wedge-shaped remnants of the blade. The remaining 16 have transverse snap fractures at the top of the stem.

Table 16 contains data on 81 of the 87 A4 specimens. This total does not include three definitely unfinished fragments, two thermally fractured fragments, or one indeterminate fragment. Of the 81 fragments, 35 can be classified as distal sections, 36 as medial sections, and 10 as proxima 1 fragments. Of the $81,36(44 \%)$ are missing the distal tip, $37(46 \%)$ are missing most of the stem, and 26 (32\%) are missing one or both barbs. It shou $1 \mathrm{~d}$ be noted that 7 of the 10 proximal fragments are narrow pointed fragments that this author feels are more likely to be stem sections than distal tips. Conversely, the 16 distal fragments that are missing the lower two-thirds are pointed and appear most likely to be distal sections rather than stem fragments. As with the AI specimens, except for a small number of acute snap fractures, al1 specimens have transverse snap fractures.

The fact that almost al1 of the $A I$ and $A 4$ fragments have transverse snap fractures is interesting. Two technological factors, thinness and heat treatment, may contribute to the breakage pattern. The complete Al specimens averaged less than $3 \mathrm{~mm}$ in thickness. This author has found thin flakes to be much more susceptible to snap fracture than thicker flakes or other thick artifacts. The heat treatment noted on many Perdiz points also increases the brittleness of chert. Given that the Perdiz arrow point is an extremely fragile projectile tip, breakage can be expected to have resulted from almost any stress. The susceptibility to breakage may have been compensated by the fact that Perdiz points are simply made from relatively small flakes and are thus cheap and easy to manufacture (in terms of raw material and effort).

A study of combined breakage data (Tables 15 and 16) reveals that many of the smaller arrow point fragments were not recovered. For examp le, 71 fragments were missing the distal tip, yet only 16 (23 counting the pointed "proximal" fragments) tips were recovered. At least 83 barb fragments are missing; none were recovered. The absence of these tiny fragments is no doubt due to the use of 1/4-inch mesh screening. The stem fragments are better represented; 39 fragments are missing most or a 11 of the stem, and 28 stems were recovered.

More of the stem fragments consisted of the entire stem rather than only the lower section of the stem which suggests that the $41 \mathrm{JW} 8$ specimens were hafted similarly as the known examples (Jelks 1962; $01 d s$ 1965). Some 
fragments are missing only the lower portion of the stem (14 specimens). These are comparable to the 41 LK 67 specimens and may as Brown suggests be due to 1 ateral stress on impact.

If Brown is correct, the transverse snap fractures noted on a 1 arge majority of the $41 \mathrm{JW} 8$ arrow point fragments are 1 arge 1 y related to impact stress. The recovery of numerous distal and medial sections at the site suggests that the projectile impact either occurred at the site or that the target animals were brought back to the camp. The latter is evidenced by the relatively 1 arge quantity of medium to 1 arge mammal bones recovered from the site.

\section{SOILS CHEMISTRY}

Soils chemistry is a nonartifactual form of analysis which can provide important supplementary data for the interpretation of an archaeological 1ocality. While some initial attempts have been made to analyze chemical aspects of archaeological site sediments in southern and south-central Texas (B1 ack and MCGraw 1985), very 1ittle comparative data is currently available for the region. Black and McGraw (1985) discuss this problem and make some comparisons between the soils chemistry results from the Panther Springs Creek site (41 BX 228) and the few other south-central Texas sites for which there is data. Over most of south Texas almost no previous studies have been done.

The soils chemistry work reported herein is thus somewhat of a pioneering study in the region. A major purpose of this study is simply to demonstrate that soils chemistry is effected by the hunters and gatherers who occupied 41 JW 8 and many other similar localities in southern Texas. If the changes in soil chemistry can be 1 inked to cultural occupations and features, then this type of analysis has a definite potential application in future research in the region.

At 41 JW 8 we are dealing with a known prehistoric locality and recognizable cultural features. The soils chemistry samples were collected from known rather than unknown contexts, thus the excavations guided the soils chemistry testing. If it can be demonstrated that the prehistoric occupations are marked by changes in soil chemistry and that particular features are associated with soil chemistry anomalies within the occupation zone, we can suggest that future studies attempt to use soils chemistry testing to guide excavations.

\section{SOILS CHEMISTRY BACKGROUND}

Shackley (1975) has discussed the application of soils chemistry to archaeological problems at some length. Among the possible changes in soils chemistry due to human occupation are changes in soil ph, organic matter content, and phosphate content to name but a few. Of these, phosphate distribution has proven to be the most effective indication of human activity and was chosen as the major soils chemistry method used in this study. 
It has long been known that the distribution of phosphate is influenced and often concentrated by man's activities. Animal and plant tissue, teeth, bones, and excrement a 11 contain phosphorus in the form of orthophosphate (Lewis 1978). In calcareous soil conditions, such as those present at $41 \mathrm{JW} 8$, calcium phosphate compounds are formed when orthophosphates are added to the sail. These compounds are insoluble and tie down the phosphate and prevent lateral or vertical migration under most conditions. Thus, an area where man has deposited organic materials and wastes can be expected to have more phosphate than an unoccupied area. This fact has been used for many years to help determine the nature of man's 1 and use in many different parts of the world. Black and McGraw (1985) summarize and provide references for the use of phosphate analysis to document man's activities.

\section{METHODS}

With the exception of the soils chemistry results obtained during the pollen pretesting, al1 of the soils chemistry analysis"was conducted by the author. The methods that are briefly outlined are obtained from Dr. Donald R. Lewis in a two-part archaeometry course (ANT 6973) offered at the graduate level by the UTSA Anthropology Department. Dr. Lewis supervised the author's work and provided invaluable advice. Most of the details of the methods outlined are derived from detailed papers prepared by Dr. Lewis. The work was conducted in the Archaeometry Laboratory at the UTSA.

\section{Phosphate Spot Testing}

Phosphate spot testing is a relatively quick, inexpensive method of determining if phosphate is present and if so, in what relative quantity. The method has been widely used in archaeological applications and is discussed in detail by various authors (Woods 1975; Eidt 1977, 1984; Lewis 1978).

In brief, spot testing involves the placement of a sma11 quantity of soil (100-200 mg) on a circular paper filter, adding drops of two chemical solutions at careful1y measured time intervals and watching the resulting reaction. Samples without phosphate will not stain the filter, while samples with 1 arge quantities of phosphate will turn the central portion of the filter very dark blue. Two minutes after the last solution is added, the final evaluation of the spot test ranking is made. Al1 of the 41 JW 8 samples were stabilized at the two minute mark by dipping the stained filter into a solution of sodium citrate. The stabilized filters retained the approximate color intensity at the time of stabilization for several months. Two years 1 ater, the colors are faded, however, the filters can still be compared for relative values.

The spot test ranking is based on four parameters: the length of time before blue appears, the approximate closure of the blue ring around the sample, the length of the color rays extending out from the sample, and the intensity of the color (Woods 1975). The author attempted to use this rating system, but found that a 11 of the samples collected within the occupation area at $41 \mathrm{JW} 8$ had considerable quantities of phosphate, turned blue instantaneously, and had complete ring closures. The length of the color rays were discovered to 
be partially a function of the quantity of soil used. Thus, the intensity of the color was the only factor that could be used to distinguish most of the samples. It was found that the stabilization allowed the visual comparison of al1 the samples. The spot test ranking given, as follows, was based on a side-by-side visual comparison. A ranking of one indicates very 1 ittle phosphate whereas a six indicates a very high quantity of phosphate.

During the spot testing it was observed that the quantity of soil had some effect on the size of the area of the filter that was covered by blue. A simple experiment was conducted using four soil samples (from the same provenience) that varied between 10 and $40 \mathrm{mg}$. Each sample was processed and the resulting filters compared. While all four had equally intense coloration, the size of the resulting stain increased with quantity. This experiment suggests that while $10-20 \mathrm{mg}$ of soil is an adequate sample, size consistency is important for accurate comparisons.

\section{Total Phosphate Determination}

A more accurate determination of the quantity of phosphate present in soil can be made using more sophisticated chemical procedures. As noted by Lewis (1978), phosphate can be divided into three fractions or types, 1 abile, bound, and mineral. The process of fractionation yields the total phosphate determination and the percentage of each constituent fraction. This method is time consuming, and it requires considerable equipment. However, the percentage of the phosphate fractions allows a more thorough understanding of the nature of the activities which resulted in the phosphate distribution.

Alternatively, the total phosphate can be determined by using spectrophotometric techniques. Basically this involves extracting phosphate from a soil sample, adding a colormetric reagent to form a blue color, and measuring the intensity of the blue color using a spectrophotometer. The quantity of phosphate is determined by comparing the spectrophotometer readings of the soil samples with the readings obtained on a series of samples of known phosphate content. The basic method was developed to determine the phosphate content of natural water (Murphy and Riley 1962). This method has been modified by Lewis to fit the nature of the samples (soil instead of water) and adapted for the equipment available at the CAR Archaeometry Laboratory. A detailed outi ine of the method is on file at the CAR.

\section{Results}

Table 17 provides the phosphate data for al1 of the processed samples. Phosphate spot tests were conducted on 42 samples. The total phosphate amounts were determined for 22 of the 42 spot tested samples. The data show a great deal of consistency as well as patterning that can tentatively be 1 inked to the prehistoric occupation.

It is significant that the highest spot test rankings and total phosphate quantities occur within the most intensive occupation zone, the WTA, as defined by excavation and from the cultural features. The two off-site columns, the Noise Pit South (NPS) and the Wheat Field Noise Pit (WFNP), had 
TABLE 17. PHOSPHATE TESTING RESULTS

\begin{tabular}{|c|c|c|c|}
\hline $\begin{array}{l}\text { Lot } \\
\text { Number }\end{array}$ & Provènience & $\begin{array}{l}\text { Spot Test } \\
\text { Ranking }\end{array}$ & $\begin{array}{c}\text { Total Phosphate } \\
\text { ppm }\end{array}$ \\
\hline & $\begin{array}{l}\text { F.5 A.I. }(0,0) \\
\text { F.5 A.I. }(0,-10) \\
\text { F.5 A.I. }(0,-20) \\
\text { F.5 A.I. }(0,-50) \\
\text { F.5 A.I. }(0,10) \\
\text { F. } 5 \text { A.I. }(0,150) \\
\text { F.5 A.I. }(0,200) \\
\text { F. } 5 \text { A.I. }(-10,0) \\
\text { F.5 A.I. }(-50,0) \\
\text { F. } 5 \text { A.I. }(-100,0) \\
\text { F.5 A.I. }(-150,0) \\
\text { F.5 A.I. }(10,0) \\
\text { F.5 A.I. }(20,0)\end{array}$ & $\begin{array}{l}6 \\
6 \\
4 \\
5 \\
6 \\
4 \\
4 \\
6 \\
4 \\
4 \\
3 \\
6 \\
6\end{array}$ & $\begin{array}{r}1144 \\
499 \\
573\end{array}$ \\
\hline 361 & WTA Col. 1, L.1 & 5 & 893 \\
\hline 362 & WTA Col. 1, L. 2 & 5 & 895 \\
\hline 403 & WTA Col. 1, L.3 & 4 & 717 \\
\hline 451 & WTA Col. 1, L.4 & 3 & 298 \\
\hline 363 & WTA Col. 2, L.1 & 5 & 1348 \\
\hline 378 & WTA Col. 2, L.2 & 5 & 764 \\
\hline 402 & WTA Col. 2, L.3 & 4 & \\
\hline 452 & WTA Col. 2, L.4 & 2 & 179 \\
\hline 489 & WFNP Z.1 & 1 & \\
\hline 491 & WFNP Z.2 & 1 & 20 \\
\hline 493 & WFNP Z.3 & 1 & \\
\hline 500 & NPS Z.1 & 1 & \\
\hline 490 & NPS Z.2 & 1 & 55 \\
\hline 502 & NPS Z.3U & 1 & \\
\hline 507 & NPS Z.3L & 1 & \\
\hline 501 & N80 El02 Z.1 & 3 & \\
\hline 498 & N80 El02 Z.2U & 3 & \\
\hline 504 & N80 E102 Z.2L & 2 & \\
\hline 508 & N123 E106 Z.1 & 5 & \\
\hline 495 & N123 E106 Z.2 & 3 & 282 \\
\hline 505 & N123 E106 Z.3 & 2 & \\
\hline 405 & $\mathrm{~F} .6 \mathrm{~A}$ & 5 & 1397 \\
\hline 406 & F.6B & 4 & 868 \\
\hline 400 & $\mathrm{~F} .6 \mathrm{C}$ & 6 & 1493 \\
\hline 401 & $\mathrm{~F} .6 \mathrm{D}$ & 4 & $796 / 808$ \\
\hline 404 & $\mathrm{~F} .6 \mathrm{E}$ & $6 / 6$ & $1529 / 1597$ \\
\hline 407 & $\mathrm{~F} .6 \mathrm{~F}$ & 5 & 649 \\
\hline 496 & $\mathrm{~F} .8$ & 5 & 762 \\
\hline 242 & N96 E82 L.2 rock cluster & 3 & \\
\hline
\end{tabular}

Note: $p p m=$ parts permillion; A.I. = Axial Interval; WTA = Wagon Trail Area; WFNP = Wheat Field Noise Pit; NPS = Noise Pit South; $U$ = Upper; $L=$ Lower; L. = Leve 1 
the lowest phosphate quantities. In fact, the samples from these areas had almost no phosphate. It is particularly interesting to note that the samples from the middle of a fertilized wheat field registered the lowest total phosphate determination of the 22 samples.

With in the samples collected from the occupation area, several patterns are apparent. The four columns (WTA Columns 1 and 2, N80 E102, and N123 E106) a 11 show a decrease in phosphate with depth. This is consistent with the fact that the prehistoric occupation was concentrated within the upper three levels (equivalent to Zones 1 and 2). The WTA columns indicate higher phosphate quantities than the other two columns. This is consistent with the fact that much greater quantities of cultural material were recovered in the WTA. With in the WTA, the highest phosphate quantities are associated with Features 5 and 6 , the two definite cooking features (hearths).

A comparison of the phosphate spot tests ranks with the total phosphate determinations (Table 18) shows that while the average of each rank is progressively higher in total phosphate the ranges of the upper three categories partially overlap. This suggests that spot test differences of only one rank cannot be considered significant unless backed by total phosphate determinations. The fact that the rank averages are consistent suggests that spot testing is a valid method of determining overall relative quantities.

Two different total phosphate determinations were made on three samples as shown in Table 17. In each case the two determinations are in close agreement. However, it should be noted that the paired determinations were made from different concentrations of the same soil extract. Thus, no attempt was made to take subsamples of a soil sample and run a complete extraction and determination of each. In a 11 likelihood, given the variation in phosphate content of the samples from different areas within Feature 6, subsampling would result in greater variation.

\section{AXIAL INTERVAL SAMPLING}

Axial interval sampling, as outlined in Section III, was an experimental method of obtaining soil samples for phosphate testing in and around key features. Feature 5, a cluster of burned rock and charcoal (see Section VIII) was selected as a trial case for axial interval sampling. In brief: this involved superimposing a two-dimensional grid centered over Feature 5 and colleting small soil samples $(75 \mathrm{cc})$ at intervals within and around the feature. The grid was oriented on cardinal directions. The samples were identified by cartesian coordinates that reflect the distance in centimeters from the midpoint $(0,0)$. The north-south grid line was designated the $X$-axis and the east-west grid 1 ine the $Y$-axis. The first coordinate was a positive number north of the midpoint, and the second coordinate was a positive number east of the midpoint. Thus, sample $(0,200)$ was collected $2 \mathrm{~m}$ due east of the midpoint, while sample $(-150,0)$ was collected a meter and a half due south of the feature midpoint.

Figure 15 illustrates the axial interval samp 1 ing conducted at Feature 5. Phosphate spot tests were done on all of the axial interval samples. Figure 15 shows that the quantity of phosphate is much higher within and immediately 
168 Hinojosa Site, 41 JW 8

\section{AXIAL INTERVAL SAMPLING FEATURE 5}

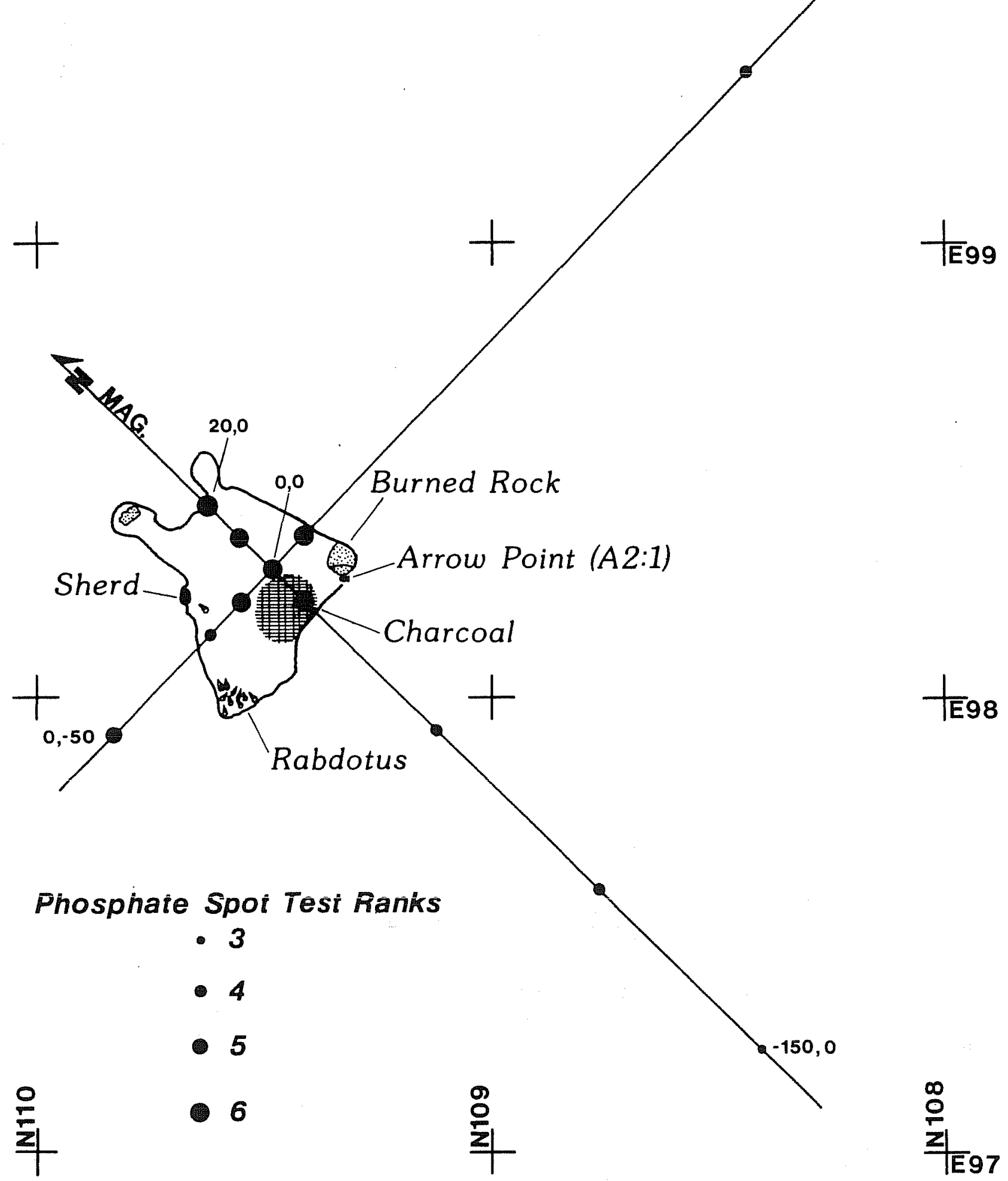

Figure 15. Axial Interval Sampling, Feature 5. 
TABLE 18. A COMPARISON OF SPOT TEST RANKS TO TOTAL PHOSPHATE

\begin{tabular}{crrrr} 
& \multicolumn{5}{c}{ Total Phosphate } \\
\cline { 3 - 5 } Spot Test Rank & High & Low & Average & Samp le Count \\
& & & & \\
6 & 2392 & 1144 & 1750 & 6 \\
5 & 1397 & 649 & 958 & 7 \\
4 & 868 & 499 & 722 & 7 \\
3 & 298 & 282 & 290 & 2 \\
2 & 179 & 179 & 179 & 1 \\
1 & 55 & 20 & 38 & 2
\end{tabular}

adjacent to the central feature area than in the surrounding area. The highest total phosphate reading from the site was from a sample collected in the center of Feature 5.

\section{ADDITIONAL SOILS CHEMISTRY}

Fourteen soil samples were submitted to the Soil Testing Laboratory at Texas A\&M University by Richard Holloway, the project pollen analyst. The purpose of this test was to determine the likelihood of pollen preservation as discussed in Section VII (Pollen Analysis). A secondary benefit is that the tests provide additional soils chemistry data from $41 \mathrm{JW} 8$. Table 19 presents the results of these tests. The Soil Testing Laboratory provides a standardized report that rates the amount of key chemical constituents based on agricultural usages. Most of the results are reported in parts per million (ppm). Each test category is briefly discussed next.

The soil $\mathrm{pH}$ of the 14 samples ranged from 7.7 to 8.1 , a fairly consistent range of mildly alkaline readings. The soil phosphorus readings were of 1 imited value because the maximum detection level was $150 \mathrm{ppm}$, and most of the samples measured over this. As expected, the samples from the Noise Pit South averaged significantly lower in phosphorus than the samples from the site area. One unusual anomaly was reported. The WTA Col. 1, L.2 sample (Lot 362) was found to have only $11 \mathrm{ppm}$ of phosphorus. This figure does not agree with the other samples from the WTA and with the total phosphate determinations made by the author. It is assumed that the Soil Testing Laboratory result is in error.

Nitrogen levels ranged from 3 to $18 \mathrm{ppm}$ and showed no particular patterning.

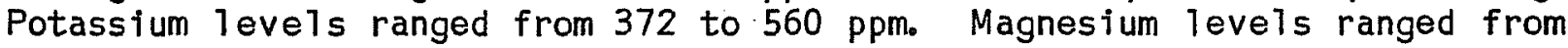
305 to $756 \mathrm{ppm}$. Both potassium and magnesium had higher average amounts from the WTA samples as opposed to the Noise Pit South. The calcium readings were al1 over the maximum detection 1eve1, $4000 \mathrm{ppm}$, indicating very calcareous soils. The percentage of organic matter ranged from $1.00 \%$ to $6.40 \%$. The WTA samples had a higher average organic matter content than the Noise Pit South 
TABLE 19. SOILS TESTING LABORATORY RESULTS

\begin{tabular}{|c|c|c|c|c|c|c|c|c|}
\hline \multirow[b]{2}{*}{$\begin{array}{l}\text { Lot } \\
\text { Number }\end{array}$} & \multirow[b]{2}{*}{ Provenience } & \multirow[b]{2}{*}{$\mathrm{pH}$} & \multirow[b]{2}{*}{$\begin{array}{l}\text { Phos- } \\
\text { phorus }\end{array}$} & \multirow[b]{2}{*}{$\begin{array}{l}\text { Nitro- } \\
\text { gen }\end{array}$} & \multicolumn{2}{|c|}{ ppm } & \multirow[b]{2}{*}{$\begin{array}{l}\text { Cal- } \\
\text { cium }\end{array}$} & \multirow[b]{2}{*}{$\begin{array}{l}\text { Organic } \\
\text { Matter }\end{array}$} \\
\hline & & & & & $\begin{array}{c}\text { Potas- } \\
\text { sium }\end{array}$ & $\begin{array}{c}\text { Magne- } \\
\text { sium }\end{array}$ & & \\
\hline 361 & WTA Col. 1 L. 1 & 7.8 & $>150$ & 3 & 560 & 395 & $>4000$ & $1.86 \%$ \\
\hline 362 & WTA Col.1 L.2 & 7.9 & 11 & 3 & 532 & 405 & $>4000$ & $1.93 \%$ \\
\hline 403 & WTA Col. $1 \mathrm{~L} .3$ & 7.9 & $>150$ & 16 & 468 & 440 & $>4000$ & $1.65 \%$ \\
\hline 451 & WTA Col. 1 L.4 & 7.9 & 133 & 11 & 408 & 455 & $>4000$ & $1.72 \%$ \\
\hline 500 & NPS Z.1 & 7.8 & 48 & 3 & 428 & 360 & $>4000$ & $2.32 \%$ \\
\hline 490 & NPS Z.2 & 7.8 & 36 & 3 & 380 & 305 & $>4000$ & $1.00 \%$ \\
\hline 502 & NPS Z.3U & 7.7 & 35 & 3 & 372 & 365 & $>4000$ & $1.37 \%$ \\
\hline 405 & F. 6 (A) & 7.8 & $>150$ & 3 & 512 & 420 & $>4000$ & $2.48 \%$ \\
\hline 404 & F.6 (E) & 7.9 & $>150$ & 16 & 756 & 500 & $>4000$ & $6.40 \%$ \\
\hline 407 & $\mathrm{~F} .6$ (F) & 8.1 & $>150$ & 3 & 492 & 440 & $>4000$ & $2.16 \%$ \\
\hline 307 & F.5 (S. $1 / 2 U)$ & 7.8 & $>150$ & 5 & 468 & 435 & $>4000$ & $3.28 \%$ \\
\hline 309 & F.5 (S. $1 / 2 \mathrm{~L})$ & 7.9 & $>150$ & 18 & 508 & 480 & $>4000$ & $3.28 \%$ \\
\hline 497 & F.8 upper & 8.0 & $>150$ & 3 & 396 & 410 & $>4000$ & $1.44 \%$ \\
\hline 488 & F.8 lower & 8.0 & $>150$ & 3 & 460 & 475 & $>4000$ & $3.64 \%$ \\
\hline
\end{tabular}

samples. Within the WTA, the feature samples had noticeably higher organic matter readings than the nonfeature samples. It should be noted that the organic matter readings reflect only the available carbon, hence, most of the additional carbon provided by charred botanical materials was not measured (R. Holloway, personal communication).

In summary, the soil testing results from Texas A\&M confirm trends noted in the phosphate testing conducted by the author. The fact that phosphorus, potassium, magnesium, and organic matter readings al1 average higher from the intensively occupied site area (the WTA) than the off-site area (the NPS) suggests that the prehistoric occupation at the Hinojosa site significantly altered the overal1 soil chemistry.

\section{CONCLUSIONS}

The phosphate testing of soil samples from $41 \mathrm{JW} 8$, a though 1 imited in scope, provides a basis and some supporting data for the hypotheses which fol 10w. The hypotheses are the tentative conclusions or interpretations of the 41 JW 8 data.

1. Intensively occupied Late Prehistoric hunter and gatherer sites in southern Texas have much higher phosphate concentration than adjacent nonsite areas. 
2. Certain types of cultural features such as cooking hearths result in very localized phosphate anomolies (extremely high concentrations).

3. Spot tests are adequate for defining occupation zones but must be combined with total phosphate determinations to accurately define anomolies within intensively occupied site areas.

4. Intensive prehistoric occupation areas may also show increased quantities of other aspects of soils chemistry such as magnesium, potassium, and organic matter.

Future researchers in the region will have the opportunity to test the above hypotheses and to expand the application of phosphate testing in southern Texas. One potential approach would be the use of spot tests on soil samples collected from shovel tests. The use of a systematic method of shovel test location, such as transect or grid sampling, should al low accurate determination of the intensively occupied site areas.

The total phosphate determination method could be used within an intensively occupied zone to define anomalies caused by cultural features. Phosphate tests from samples associated with other types of cultural features (in addition to hearths) may also demonstrate anomalies. A fractionation study of various cultural features might provide more specific functional evidence.

It should be noted that the Hinojosa site is comparatively recent in contrast to many sites in southern Texas. It remains to be seen whether the high phosphate readings found in intensive occupation zones and some cultural features at the Late Prehistoric site of 41 JW 8 are al so found at Archaic sites in the region.

\section{WATER SEPARATION}

Fifty-eight soil samples were collected at the Hinojosa site for the purpose of recovering cultural materials missed by the use of 1/4-inch mesh screening. These soil samples consist of feature matrix samples, on-site control column samples, and off-site control column samples. The samples ranged in volume from two liters to more than six liters. A two-liter sample from 29 of the soil samples was processed using water separation techniques. The major goal of the water separation program was to recover microfauna and charred botanical remains.

The experience gained in previous attempts at flotation (Black and McGraw 1985) guided the 4 I JW 8 water separation program. McGraw constructed a flotation device at the CAR 1 aboratory nicknamed the "Izum of Texas." This device is a modified version of the Davis and Wesolowsky (1975) original Macedonian "Izum" with certain improvements suggested by the Bodner and Rowlett (1980) flotation system. Detailed plans of the device are on file at the CAR.

The water separation device is built around two 55-gallon drums positioned such that the first drum is higher than the second. The first barrel has a metal rebar rack about 10 inches below the top on which a wooden sluice box 
is placed. The sluice box has a stainless steel fine mesh screen bottom and six-inch wooden sides. One end of the box is only four inches high and has a metal 1 ip that extends outward for several inches. One side of the first barre1-has a wide notch cut six inches deep into the top edge of the barrel to which has been soldered a sheet metal spillway. The sluice box is placed in the first barrel so that the metal 1 ip extends out over the metal spi 11 way. The second barrel is placed under the metal spillway to catch water overflowing the first barrel. The second barrel has a metal rebar rack a few inches below the top on which is placed a shallow tray with a stainless steel fine mesh screen bottom. Water enters the system through a relatively low pressure hose attached to a squared-off S-shaped plastic pipe device that is 1 owered into the first barrel. The pipe device forces the water stream upward and allows directional control of the water stream. An assortment of sma 11 drainage hoses are connected to both barrels at various depths to control the water level and to allow drainage.

The system works most effectively when both barrels are full of water and the water intake matches the outtake. One person can manage the system, although two people make it much easier. The water separation procedure is begun by slowly adding a measured amount of soil (two 1iters) into the sluice box while a gentle stream of water is directed with the pipe device through the bottom of the box. Most of the soil quickly washes through the fine screen and sinks to the bottom of the barre1. The material with a specific gravity less than that of water, the light fraction, floats to the top, while the heavy fraction stays in the bottom of the sluice box. The light fraction materials follow the water flow over the metal 1 ip of the box, across the spll1way, and into the shallow tray in the second barrel. After all of the soil has been removed from the sluice box and all of the floating materials have washed into the second barrel, the sluice box and shallow tray are emptied into other shallow trays with fine mesh screen bottoms. A fine stream of water is useful in washing al1 of the materials out of the collecting box and tray and into the drying trays.

The resulting 1 ight and heavy fractions are allowed to dry for several hours and then placed in separate containers (bags, jars, or vials). The 1 ight fraction usually consists of roots, small snail shel1s, charcoal, charred seeds, and occasionally pieces of bone. The heavy fraction usually consists of rock fragments, flint $f l$ akes, 1 arger snail shel $1 \mathrm{~s}$ and fragments, pottery sherds, water-logged charcoal, bones, and baked clay 1 ump fragments. Feature matrix samples usually had large quantities of both fractions while the offsite samples rarely had anything other than a few roots and snails.

Using two peop 1 , it took 6 to 12 minutes per two-1iter sample from the beginning to the drying rack, once the system was working proper $7 y$. The samples with higher clay content were noticeably more time consuming than sandy loam samples. When the set up and clean up time is added in, the actual time spent per sample is between 15 and 20 minutes. A ful1-time water separation program with an adequate number of drying screens could achieve much more efficent processing times.

One of the most important factors in evaluating a water separation system is the flotation recovery rate (Wagner 1982). Wagner developed a simp 1 e and inexpensive method of testing flotation rates using charred poppy seeds. 
This method involves the addition of a known quantity of charred poppy seeds into a measured soil sample prior to processing. During the sorting process, the poppy seeds are counted and compared to the initial count. The resultant ratio can be used to compare the recovery efficiency of various systems. A11 the processed samples had either 25 or 50 poppy seeds added. Virtually a11 of the recovered seeds were found in the 1 ight fraction as would be expected. The recovery rate was calculated for 10 of the samples and ranged from a low of 36 out of 50 to a high of 25 out of 25 and averaged $81 \%$. The actua 1 recovery is probably somewhat higher, but some samples had tremendous quantities of charcoal which hindered the search.

A total of 23 of the processed samples was sorted several months after processing. Time was not available to completely sort out all of the various constituent materials, hence on $1 y$ the microfauna and charred seeds were extracted. Even so, the sorting process is extremely time consuming. A sample from the occupation area required one to three hours to sort depending on the nature of the sample. Of the faunal materials, only identifiable bone was pulled (i.e., complete bones, teeth, or bones with articular ends). Many samp les had 1 iterally thousands of tiny bone fragments.

Table 20 provides data on various aspects of the water separation samples, including provenience, sample size, poppy seed recovery, and cultural material recovery. The relative amounts of some cultural materials are given to indicate the nature of the sample.

The 41 JW 8 water separation efforts were very 1 imited in scope. The potential value of the approach is demonstrated by the resulting botanical data alone (Section VII: Analysis of Macrobotanical Materials). Steele (Section VII: Analysis of Vertebrate Faunal Remains) made some use of the microfauna recovered from the water separation at 41 JW 8 and has elsewhere emphasized the importance of fine screen samples for faunal interpretations (DeMarcay and Steele 1986). However, it should be emphasized that to make the most effective use of water separation at a southern Texas archaeological site we are going to have to devote a great deal more time and energy to this type of analysis. Larger samples from more widespread contexts will be necessary as wel1 as complete processing, sorting, and analysis. These efforts will be expensive and very time consuming. The potential benefits are more complete subsistence and environmental data.

It has been argued (Section IV and Ha11, Black, and Graves 1982) that most of the prehistoric inhabitants of inland south Texas relied more on plant resources than animals for basic subsistence. This is a difficult assertion to prove, largely because we have so 1 ittle solid information on the plant remains in southern Texas sites. Limited water separation analysis at $41 \mathrm{BX} 228$ (BIack and MCGraw 1985) and 41 JW 8 have demonstrated that charred botanical remains are indeed present in at least some Archaic and Late Prehistoric contexts in the region.

Similarly, it has been argued that climatic changes in southern Texas are at least partially responsible for some of the cultural changes that have been observed (Gunn et a1. 1982, and this report). One of the more effective ways of examining climatic or environmental change or stability is through examining the floral and faunal changes through time. This report 
TABLE 20. WATER SEPARATION DATA

\begin{tabular}{|c|c|c|c|c|c|c|c|c|}
\hline \multirow{2}{*}{$\begin{array}{l}\text { Lot } \\
\text { Number }\end{array}$} & \multirow[b]{2}{*}{ Provenience } & \multicolumn{7}{|c|}{ Items of Recovery } \\
\hline & & PS & $H B$ & MF & CS & FF & $\mathrm{CH}$ & SN \\
\hline 363 & WTA Col. 2 L.I & & & $x$ & $x$ & $x$ & $x$ & $x$ \\
\hline 378 & WTA Co1. 2 L. 2 & & $x$ & $x$ & $x$ & $x$ & $x$ & $x$ \\
\hline 402 & WTA Col. 2 L.3 & $22 / 25$ & & $x$ & $x$ & $x$ & $x$ & $x$ \\
\hline 452 & WTA Col. 2 L. 4 & $22 / 25$ & & $x$ & $x$ & & $\mathrm{~F}$ & $x$ \\
\hline 500 & NPS Z.1 & & & & $?$ & & & $x$ \\
\hline 490 & NPS Z.2U & & & & $?$ & & & $x$ \\
\hline 502 & NPS Z.3U & & & & & & $F$ & $x$ \\
\hline 507 & NPS Z.3L & & & & & & & $x$ \\
\hline 508 & N123 E106 Z.1 & & & $x x$ & $x$ & $x$ & $x$ & $x$ \\
\hline 495 & N123 E106 Z.2 & & & $x$ & & & $F$ & $x$ \\
\hline 505 & N123 E106 Z.3 & $25 / 25$ & & $x$ & & & $F$ & $x$ \\
\hline 132 & $\mathrm{~F} .1$ & & $x$ & $x$ & $?$ & $x$ & $x$ & $x$ \\
\hline 133 & near $F .1$ & $21 / 25$ & $x$ & $x$ & $x$ & & $x$ & $x$ \\
\hline 181 & F.2 & $39 / 50$ & & $x$ & $x$ & $x x$ & $x$ & $x$ \\
\hline 243 & F.4 & $40 / 50$ & & & & & $\mathrm{~F}$ & $x$ \\
\hline 307 & F.5 & & $x$ & $x x$ & & $x$ & $x x$ & $x$ \\
\hline 308 & F. 5 & & $x$ & $x X$ & $x$ & $x$ & $x$ & $x$ \\
\hline 290 & F. 6 & $36 / 50$ & $x$ & $x x$ & $x X$ & $x$ & $x$ & $x$ \\
\hline 399 & $\mathrm{~F} .6$ & & & $x X$ & $x$ & $x x$ & $x x$ & $x$ \\
\hline 359 & near $F .6$ & $23 / 25$ & & $x$ & $x$ & $x x$ & $x$ & $x$ \\
\hline 356 & $\mathrm{~F} .7$ & $38 / 50$ & & $x$ & & $x x$ & $x$ & $x$ \\
\hline 494 & F. 8 & $38 / 50$ & $x$ & $x$ & $x$ & $x$ & $x x$ & $x$ \\
\hline 496 & F. 8 & & $x$ & $x x$ & & $x x$ & $x X$ & $x$ \\
\hline
\end{tabular}

Note: $\quad P S=$ poppy seed, $H B=$ burned hackberry seeds, $M F=$ microfauna, $C S=$ charred seeds, $F F=f 1$ int $f 1$ akes, $C H=$ charcoa 1, sn $=1$ and snai $1 s, X=$ present, $X X=$ numerous, $F=$ flecks, ? = uncertain.

demonstrates that faunal materials, in particular the smaller fauna that is best recovered through fine screening, can provide environmental data.

PQLLEN ANALYSIS (Richard G. Hol loway)

\section{INTRODUCTION}

Fourteen soil samples from $41 \mathrm{JW} 8$ were sent for analysis to the Palynology laboratory at Texas A\&M University. These samples were obtained from a column in the main excavation area, three features in the main area, and a column from an off-site area for testing. 


\section{METHODS AND MATERIALS}

Prior to chemical extraction of the pollen, the samples were sent to the soil testing laboratory at the Texas Agricultural Experiment Station located on the campus of Texas A\&M University. The results of this analysis are presented in Table 19. On the basis of the soil test results, it was decided to analyze four of these samples. The four chosen for further analysis were: (1) Lot 362, WTA Co1. 1, L.2; (2) Lot 404, F.6E; (3) Lot 309, F.5, 1ower south one-half; and (4) Lot 488, F.8, charcoal cluster.

Thirty (30) mls of soil was initially treated with $10 \% \mathrm{HC} 1$ to remove carbonates. The residue was screened through $150 \mathrm{~mm}$ mesh screen and treated with $70 \% \mathrm{HF}$ overnight to remove the silicates. Remaining inorganic particles were removed by heavy density separation using $\mathrm{ZnCl}_{2}$ (S.G. 1.99-2.00). A second treatment of $\mathrm{ZnCl}_{2}$ was used to attempt to reduce the 1 arge organic fraction. The residue was acetylated (Erdtman 1960) to remove extraneous organic particles, dehydrated using an ethanol series, and transferred to $1000 \mathrm{cs}$ silicon oil with butanol. The pollen residue was examined under the microscope using $400 \mathrm{X}$ magnification.

\section{RESULTS AND DISCUSSION}

After screening two slides, only a few isolated pollen grains were encountered. These represented 1 ow spine composites and a few oak grains. These grains are extremely resistant and, thus, would have been expected. A large number of fungal spores and additional plant debris were encountered. These 14 samples all had extremely $10 \mathrm{w}$ percentages of organic matter (Table 19) in addition to having a high $\mathrm{pH}$. These two characteristics made the recovery of pollen problematic, at best.

Some pollen was present in the sample but because of the heavy concentration of other plant materials, the pollen could not be concentrated in the residue. Any attempt at oxidation of the plant debris would have likewise oxidized the pollen grains. Additional attempts at heavy density separation would likely have proved futile as the plant materials and pollen have essentially the same specific gravity. Additionally, pollen might have been trapped and held within the solution by the larger plant particles.

This problem of 1 ittle pollen recovery coupled with excessive organic material is quite common throughout central and south Texas. Pollen samples were examined from a number of archaeological sites thoughout this area (Bryant and Holloway 1985) with the same results. Additionally, high pH values associated with these soils would have served to severely reduce the probability of pollen recovery (Holloway 1981).

It is indeed unfortunate that a better understanding of the paleoenvironmental conditions of this site were not possible. The high $\mathrm{pH}$ values, extremely low quantity of organic material, and the inability to sufficiently concentrate the pollen residues, all preclude the analysis of the fossil pollen from this sample. 


\section{BIOSILICA ANALYSIS (Ra7ph L. Robinson)}

Poor preservation of organic microfossil and macrofossil evidence of prehistoric vegetation has hampered efforts to reconstruct paleoenvironments in many areas of Texas, including the geographical area in which the study area is located. The Hinojosa site, $41 \mathrm{JW} 8$, is in an ecotone between the western margin of the Western Gulf Coastal Plain and the eastern margin of the Rio Grande Plain. Gould (1969) placed Jim Wells County in two vegetational regions, with a smal1 portion of the eastern edge of the county in the Gulf Prairies and Marshes Region and the greatest part of the county in the South Texas Plains Region. Ecotones are ideal research areas because of the dynamic equilibrium of biotic communities.

Macrofossil evidence of silica accumulator biota--biosilica, or phytoliths as they are commonly known,--was found to be well preserved and abundant in the sediments of the Hinojosa site. Scanning Electron Microscopy (SEM) and Light Microscopy were used to analyze the biosilica assemblage extracted from four sediment samples. The biosilica assemblage was deposited by: the Poaceae (Grass Family); three grass subfamilies, the Panicoideae (tal1 grasses), the Pooideae (humid and/or cool environment grasses), and the Chloridoideae (short grasses); the cf: Cyperaceae (Sedge Family); at least three species within the U1maceae (E1m Family), U1mus crassifolia Nutt. (Cedar E1m), Ce1tis pa 11 ida Torr. (Grajeno), and Celtis cf. 1 aevigata Wil1d. (Texas Sugarberry); the Boraginaceae (Borage Family), Ehretia anacua (Teran and Berl.) I.M. Johnst. (Anacua); and the Spongi11 ideae (Freshwater Sponge Family). Based upon the environmental requirements of the biota which produced this biosilica assemblage, it is suggested that the environment of the Hinojosa site at A.D. 1350-1400 was similar to that of today but with more available moisture. It is also suggested that the January mean minimum temperature was probably not below 36 to $40^{\circ} \mathrm{F}$.

\section{BIOSILICA ANALYSIS: MATERIALS AND METHODS}

The materials and methods used in this analysis are discussed in five divisions: Processing of Sediment Samples, Processing of Flora and Fauna, Mounting of Samples for Light Microscopy, Mounting of Samples and Operating Procedures for Scanning Electron Microscopy, and Analysis Methodology.

\section{Processing of Sediment Samples}

Step 1. Sample Selection. Four sediment samples from the Hinojosa site were selected for processing. Samples 1, 2, and 3 were from Col. 1, and Sample 7

Note: Robinson did not complete the final stage of his analysis: the quantification of the biosilica assemblage from each sample. Thus, the interpretations in this section are based on relative impressions rather than statistically valid counting procedures. The sample provenience of the illustrated specimens (Figs. 16 and 17) has not been identified. 
was from F.6. Table 21 summarizes Step 1 of the processing method and describes the samples. Before volume and weight measurements were taken, all roots and macrofossils except very small charcoal and snail shell fragments were removed and described.

Step 2. Removal of water soluble organic and inorganic compounds. Each sample was dispersed with a solution of $5.56 \mathrm{~g}$ of sodium hexametaphosphate per 1 iter of distilled water and decanted after 1.5 to 3.75 hours of sedimentation. This step was repeated three times. Standard Sedimentation Tables were used in all stages of processing, including rinses.

Step 3. Removal of carbonates and the 1 ess than $5 \mu \mathrm{m}$ fractions. Carbonates were removed in two stages: (a) 3\% hydrochloric acid at room temperature for 2.5 hours; (b) concentrated hydrochloric acid was then added and heated at $100^{\circ} \mathrm{C}$ for 1.5 hours. Samples were stirred every 15 minutes during this step. The samples were then rinsed and decanted after sedimentation to remove the less than $5 \mu \mathrm{m}$ fraction.

Step 4. Removal of organic compounds. A 3:1 mixture of concentrated nitric acid/saturated solution of sodium chlorate in water, heated at $100^{\circ} \mathrm{C}$ for 6.5 hours was used to remove organic compounds. Each sample was then rinsed five times with sedimentation time a 11 owed to retain the greater than $5 \mu m$ size fractions.

Step 5. Exotic known. One Lycopodium spore tablet containing 12,500 \pm 250 spores was added to each sample, dissolved with $10 \%$ hydrochloric acid, and rinsed to remove chlorides.

Step 6. Sedimentation. The Step 2 dispersant solution was used to isolate and remove the $5 \mu \mathrm{m}$ to 1 ess than $10 \mu \mathrm{m}$ size fraction. Standard Sedimentation Tables were used. Dispersal and sedimentation were repeated 10 times, and the remaining fraction ( $10 \mu \mathrm{m}$ and 1 arger) was rinsed twice. The $5 \mu \mathrm{m}$ to 1 ess than $10 \mathrm{\mu m}$ fraction was then microscopically examined for biosilica.

Step 7. Heavy density separation. A 2.3 specific gravity solution of zinc bromide, distilled water, and hydrochloric acid was used for the heavy density separation of biosilica from the heavier quartz and other minerals. The $10 \mu \mathrm{m}$ and greater fraction was placed in bent, U-shaped sections of 3/8inch (inside diameter) Nalgene clear plastic tubing. The amount of water present in each sample was calculated, and the necessary amount of 2.5 specific gravity solution was added to each sample and vortexed to bring the specific gravity to 2.3. The heavy 1 iquid with a specific gravity of 2.3 was added, vortexed, and the tubing $\mathrm{placed}$ in a 50-mi centrifuge tube containing water. The samples were then centrifuged at 1500 gravities for 10 minutes. After centrifuging, the plastic tubing was removed from the centrifuge tube and clamped between the lower, heavy fraction and the upper, lighter fraction. This step was repeated three times. The light fraction of the samples, which contains the biosilica, and the exotic known was then placed in 250-m 1 centrifuge containers, diluted with water and hydrochloric acid to a specific gravity of less than 1.5, and decanted after centrifuging. After repeated rinses to remove the bromide and hydrochloric acid, the 1 ight fraction was transferred to three-dram glass vials. For a more detailed description of biosilica processing techniques, refer to Robinson (1982). 
TABLE 21. SUMMARY OF STEP I OF BIOSILICA PROCESSING

\begin{tabular}{|c|c|c|c|c|c|c|}
\hline $\begin{array}{l}\text { Sample } \\
\text { Number }\end{array}$ & Provenience & $\begin{array}{l}\text { Lot } \\
\text { Number }\end{array}$ & $\begin{array}{l}\text { Blosilica } \\
\text { Processing } \\
\text { Number }\end{array}$ & $\begin{array}{l}\text { Volume } \\
\text { Processed }\end{array}$ & $\begin{array}{l}\text { Weight } \\
\text { of Sample } \\
\text { (g) }\end{array}$ & Description \\
\hline 1 & WTA Col. 1 L.1 & 361 & 192 & $10 \mathrm{cc}$ & 12.70 & $\begin{array}{l}\text { light gray, sandy loam; } \\
\text { Celtts spp. seed, roots, } \\
\text { and charcoal }\end{array}$ \\
\hline 2 & WTA Col. 1, L.2 & 362 & 193 & $10 \mathrm{cc}$ & 12.70 & $\begin{array}{l}\text { light gray, sandy loam; } \\
\text { snail shel I fragments } \\
\text { (Rabdotus spp.), worm } \\
\text { casts and roots }\end{array}$ \\
\hline 3 & WTA Col. 1, L.3 & 403 & 194 & $10 \mathrm{cc}$ & 13.90 & $\begin{array}{l}\text { light gray, sandy loam; } \\
\text { snail shel } 1 \text { fragments } \\
\text { (Rabdotus spp.), complete } \\
\text { snail she 1, discolda?, } \\
\text { whorls on same plane; } \\
\text { rodent bone and roots }\end{array}$ \\
\hline 7 & F.6 (matrix area $B$ ) & 406 & 195 & $10 \mathrm{cc}$ & 13.80 & $\begin{array}{l}\text { light gray, sandy loam; } \\
\text { snaf1 she } 1 \text { fragments } \\
\text { (Rabdotus spp.), mamma } 1 \\
\text { bone fragment, roots and } \\
\text { charcoal }\end{array}$ \\
\hline
\end{tabular}




\section{Processing of Flora and Fauna}

During the past seven years an extensive comparative collection of biosilica has been prepared using the following methods:

\section{A. Processing of Flora}

Step 1. Plants are collected, identified, and pressed. A detailed record is kept in a permanent record log of exact location, collection date, soil type, and associated plants. Several plants of the same species are collected so that an example of the plant remains are on permanent file. Selected plant parts are removed, washed, dried at $100^{\circ} \mathrm{C}$, and weighed.

Step 2. Phytoliths are separated from the plant tissues by oxidation using the same solution used in Step 4 of the sediment processing procedure, centrifuged to retain all size fractions, and rinsed.

Step 3. Phytoliths are stored in three-dram glass vials.

\section{B. Processing of Fauna}

Step 1. Sponges are collected, washed, and dried as detailed above. A record is kept in a permanent record $1 \mathrm{og}$ of collection date, 1 ocation, and environmental conditions. Accurate identification can only be made after processing and microscopic analysis of spicules.

Step 2. Nitric acid is used to destroy the tissues, leaving only the diagnostic spicules and a few adhering diatoms and phytoliths. Samples are rinsed and centrifuged until all traces of acid are removed.

Step 3. The spicules are transferred to three-dram glass vials for storage.

\section{Mounting of Samples for Light Microscopy}

Two types of slides were prepared for 1 ight microscopy: (1) 1 iquid, and (2) solid mounting media. (1) Several drops of the sample, biosilica in distilled water, were pipetted on a cleaned microscope slide, covered with a cleaned coverstip, and sealed with fingernail polish. (2) Several drops of the sample were pipetted on a cleaned coversilip and al1owed to dry for several hours. Four drops of Permount were placed on a cleaned microscope slide and allowed to dry for several minutes to a $110 \mathrm{w}$ excess toluene to evaporate. The microscope slide was then inverted and placed on the coverslip, and allowed to dry. This method of mounting insures that the biosilica will be on one plane, on or near the coverslip, and therefore will require minimum racking of the microscope during transects. Liquid mounting media (1) was used for $41 \mathrm{JW} 8$ biosilica samples and comparative biosilica samp les; solid mounting media (2) was used on 7 y for comparative biosilica samples. A Nikon Optiphot Microscope with Hoffman Modulation Contrast was used for a 11 ight microscopy. 


\section{Mounting of Samples and Operating Procedures for Scanning Electron Microscopy (SEM)}

A cleaned glass coverslip was attached to a cleaned, polished SEM stub with double stick tape. Four drops of the sample were pipetted on the coverslip and allowed to dry for 12 hours at $90^{\circ} \mathrm{C}$. This is an effective method of attachment as biosilica adheres to the glass coverslip as desiccation occurs. Carbon paint was applied to the upper edge of the SEM stub and the underneath side of the attached coverslip to enhance electrical conduction. This prevents the buildup of electrons and the resulting charging of samples. The samples were sputter coated with $20 \mathrm{~nm}$ of gold-palladium, using a Technics, Inc., Hummer. A11 photomicrographs were made on a Jeol-25S II Scanning Electron Microscope using Kodak Tri-X Pan film. The operating conditions of the SEM which remained constant are as follows: working distance of $10 \mathrm{~mm}$, $190 \mathrm{~m}$ objective aperture, and zero degrees of tilt. Variable operating conditions such as keV of accelerating voltage, condenser setting, and magnification are 1isted in the captions of Figures 16 and 17.

\section{Analysis Methodology}

The analysis was conducted in five steps: 1. Light Microscopy Analysis, 2. SEM Analysis, 3. Classification, 4. Calculation of Biosilica Sum, and 5. Analysis of Spectra and Diagrams.

Step 1. Light microscopy analysis. Light microscopy of the $41 \mathrm{JW} 8$ biosilica and Lycopodium spores mounted in water was the first step of microscopic analysis. A11 samples were scanned in transects at 100X, 200X, and 400X. 1000X was used to examine individual, small phytoliths from grasses. As biosilica was observed, a probe was pressed against the coverslip, rotating the specimen so the morphology of al1 surfaces could be seen. Unusual types were drawn. Biosilica and Lycopodium spores were counted.

Step 2. SEM analysis. One $41 \mathrm{JW} 8$ sample (Sample 3) was selected for SEM analysis as light microscopy had revealed that a wide variety of diagnostic phytolith types were present. A four-drop sample of Sample 3 was scanned with the SEM, and 27 photomicrographs were taken of selected types of the hundreds of phytoliths examined. Biosilica counts were not made during SEM scans because: (1) the expense of SEM analysis; (2) many types of biosilica are difficult to identify without the observation of three-dimensional morphological characteristics which can be seen in a liquid mounting medium; and (3) SEM reveals only the external morphology of biosilica which is transparent in transmitted 1 ight, and internal morphology is valuable taxonomical1y. The wide range of magnification and the depth of field of SEM photomicrographs does make them extremely valuable for taxonomic analysis when used in combination with 1 ight microscopy.

Step 3. Classification. The types of biosilica observed during 1 ight microscopy and SEM were compared to comparative samples (II). Light microscopy was used to examine comparative samples in 1 iquid and solid mounting media. Drawings made using 1 ight microscopy were utilized (Robinson 1982). Several hundred SEM photomicrographs were also utilized. Four of 
these photomicrographs are shown in Figures 16,a,c,d and 17,g. The types of biosilica observed were classified according to (1) three-dimensional morphology: (2) the tissues in which they were deposited in vitro; and (3) the taxa of organisms which produced the tissues (Table 22). The resolution of the taxonomic level of identification (family to species of organism) is dependent upon taphonomic variables and the diagnostic value of a type or suite of types (assemblages) which could be identified with certainty.

Step 4. The counts made during 1 ight microscopy are used to calculate a valid biosilica sum of the biosilica assemblage. The biosilica sum is converted into three types of spectra and diagrams: (a) relative frequency; (b) concentration or actual frequency; and (c) influx.

(a) Relative frequency is simply a percentage frequency of types of biosilica or the number of individual members of one type of biosilica divided by the number of individual members of al1 types of biosilica considered.

(b) The concentration of biosilica per cubic centimeter of matrix is calculated using the formula shown:

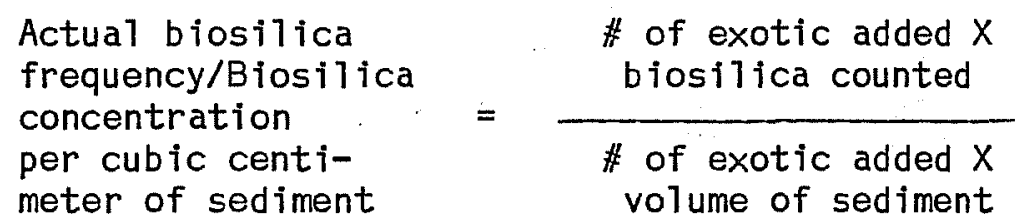

(c) The biosilica influx is the actual frequency of biosilica concentration deposited per square centimeter per year. Influx is calculated as follows:

$$
\begin{aligned}
& \text { Biosilica influx } \\
& \text { per square centi- } \\
& \text { meter per year }
\end{aligned}=\frac{\text { Actual biosilica frequency }}{\text { rate of sediment deposition }}
$$

*Biosilica influx calculations are limited by the assumption that depositional rates within a stratigraphic unit are uniform. High resolution stratigraphic analysis is necessary for high resolution biosilica influx values.

Step 5. Analysis of spectra and diagrams. The three types of spectra and diagrams are then analyzed to determine the type of community of silicaaccumulating biota which produced the biosilica assemblage, and therefore the local paleoenvironment or paleomicroenvironment. Relative vegetationa 1 biomass or change in vegetational biomass through time can be discerned with spectra and diagrams from reliably dated columns from stratified sediments. The carrying capacity of the environment can then be inferred from the relative biomass. 
Figure 16. SEM Photomicrographs of Phytoliths from 41 JW 8 and Comparative Collection Plants.

a, comparative collection: Tripsacum dactyloides (L.) L., (Eastern Gammagrass), Poaceae, Panicoideae, Andropogoneae; bilobate panicoid short cel1 phytolith, ventral orientation length: $25 \mu \mathrm{m} ; 12.5 \mathrm{keV}$ accelerating voltage, condenser setting 12;

b, Poaceae, Panicoideae; bilobate panicoid short cell phytolith, dorsal or ventral orientation, length: $17 \mu \mathrm{m}$; $15 \mathrm{keV}$ accelerating voltage, condenser setting 12;

c, comparative collection: Phalaris caroliniana Walt., (Carolina Canarygrass), Poaceae, Pooideae (Festucoideae), Aveneae; elongate festucoid short cell phytolith, dorsal/lateral orientation, length: $27 \mathrm{\mu m}$; $12.5 \mathrm{keV}$ accelerating voltage, condenser setting 12;

d, comparative collection: Hordeum pusillum Nutt., (Little Barley), Poaceae, Pooideae (Festucoideae), Triticeae; elongate festucoid short cel1 phytolith, dorsal/1ateral orientation, length: $34 \mu \mathrm{m} ; 12.5 \mathrm{keV}$ accelerating voltage, condenser setting I;

e, Poaceae, Pooideae (Festucoideae); elongate festucoid short cell phytolith, dorsal/lateral orientation, length: $24 \mu \mathrm{m} ; 12.5 \mathrm{keV}$ accelerating voltage, condenser setting;

f, Poaceae, Pooideae (Festucoideae); elongate festucoid short ce11 phyto 1 ith, ventral/1ateral orientation, 1ength: $83 \mu \mathrm{m} ; 12.5 \mathrm{keV}$ accelerating voltage, condenser setting 1 . 


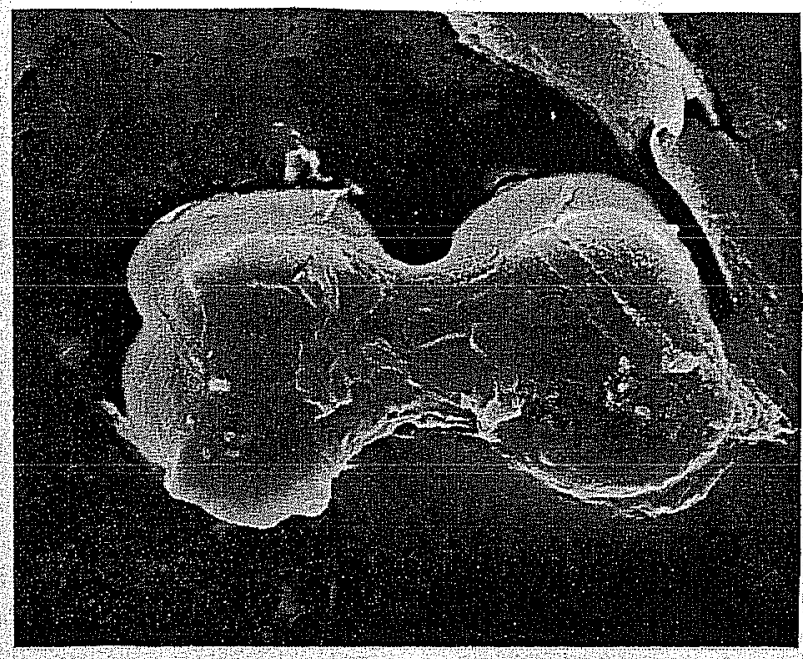

a

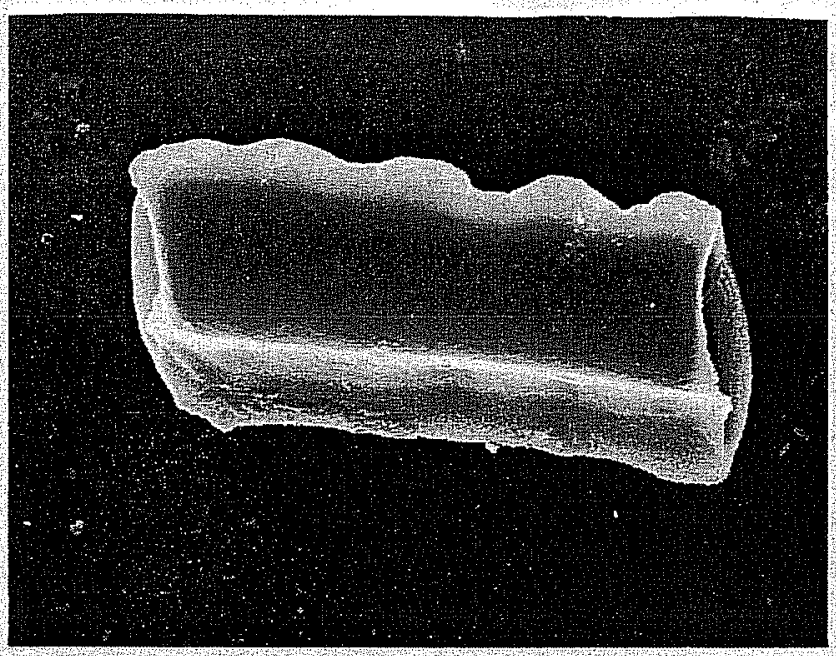

c

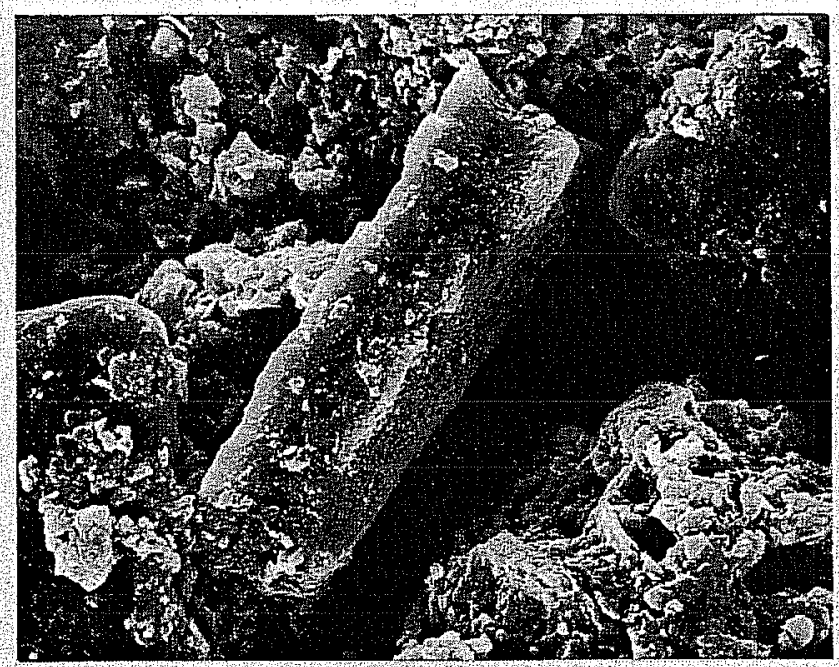

e

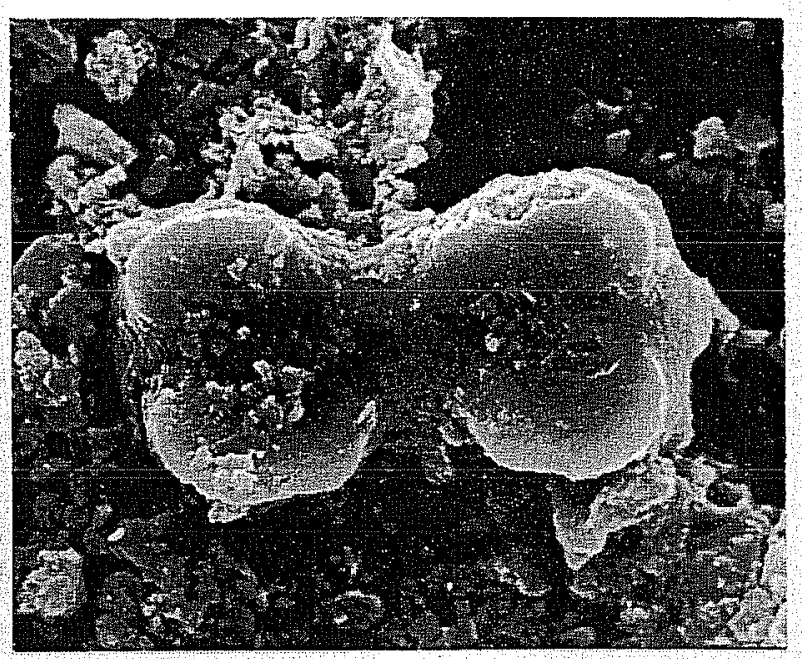

b
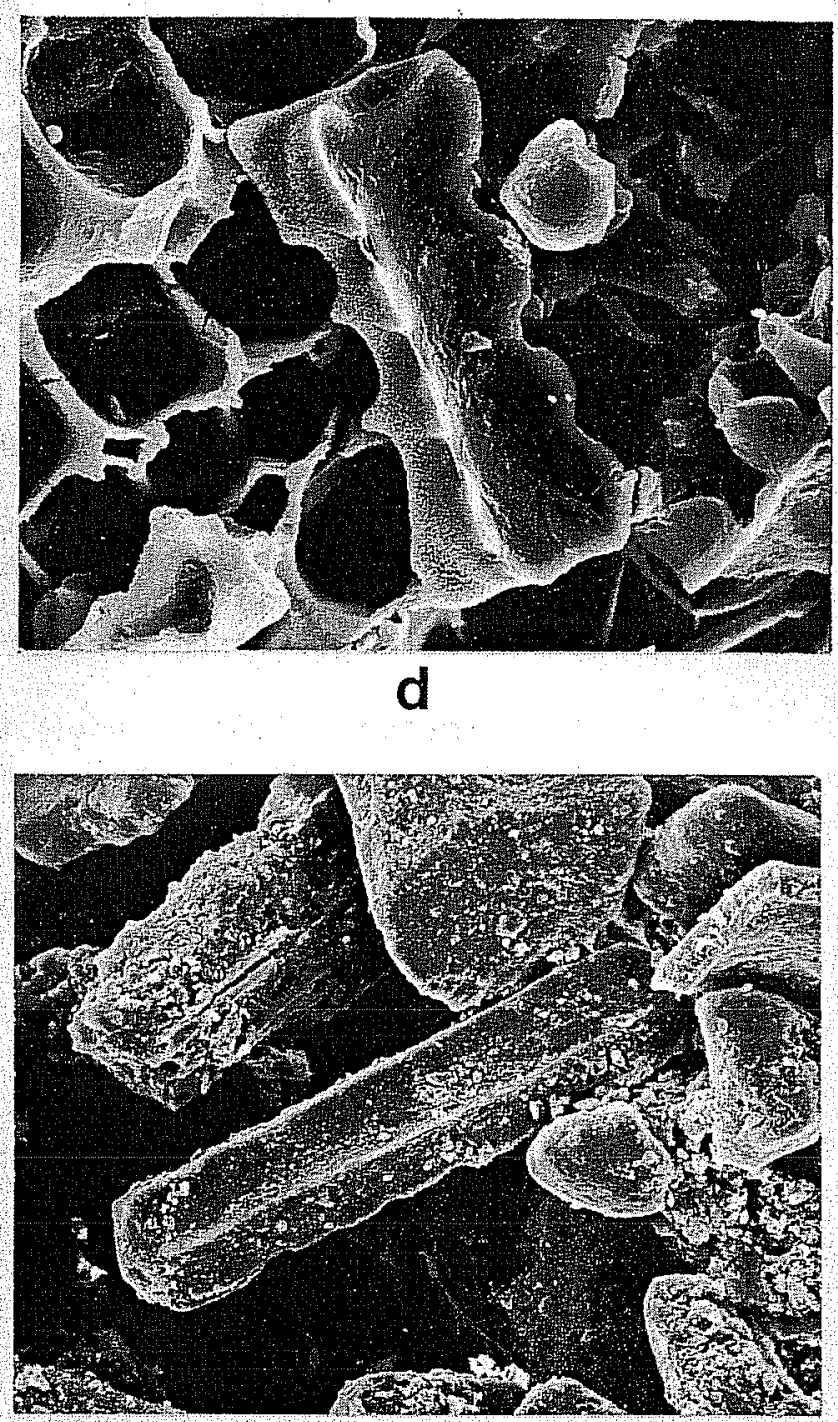
Figure 17. SEM Photomicrographs of Phytoliths from 41 JW 8 and Comparative Collection Plants.

a, comparative collection: Phalaris caroliniana Walt., (Carolina Canarygrass), Poaceae, Pooideae (Festucoideae), Aveneae; trichome, 1 ateral orientation, length: $52 \mu \mathrm{m} ; 12.5 \mathrm{keV}$ accelerating voltage, condenser setting 12 ;

b, Poaceae; panicoid or chloridoid bul 1 iform cell phytolith, dorsa 1 or ventral orientation, width: $47 \mu \mathrm{m} ; 12.5 \mathrm{keV}$ accelerating voltage, condenser setting $l$;

c, center: UTmaceae, Celtis spp.; trichome base, dorsal or ventral orientation, width: $40 \mu \mathrm{m}$; t: Poaceae, Pooideae (Festucoideae); festucoid trichome, 1ateral orientation, 1ength of base: $35 \mu \mathrm{m}$; 12.5 keV accelerating voltage, condenser setting 1 ;

d, center: UTmaceae, Celtis cf. laevigata Wi 17 d., (Texas Sugarberry); trichome base with surrounding epidermal cells (tissue fragment), dorsal orientation, width: $31 \mu \mathrm{m} ; 12.5 \mathrm{keV}$ accelerating voltage, condenser setting 1 ;

e, cf. Ulmaceae, Celtís spp.; trichome, dorsal orientation, width: $53 \mu \mathrm{m} ; 15 \mathrm{keV}$ accelerating voltage, condenser setting 12;

f, Ulmaceae; trichome, dorsal orientation, width of base: $33 \mu \mathrm{m}$; $12.5 \mathrm{keV}$ accelerating voltage, condenser setting 1. 


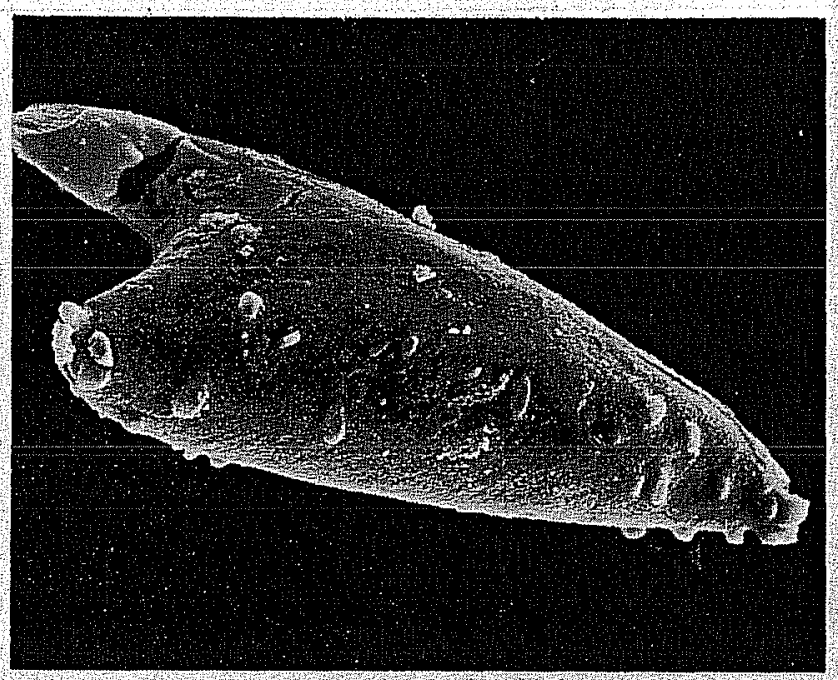

a

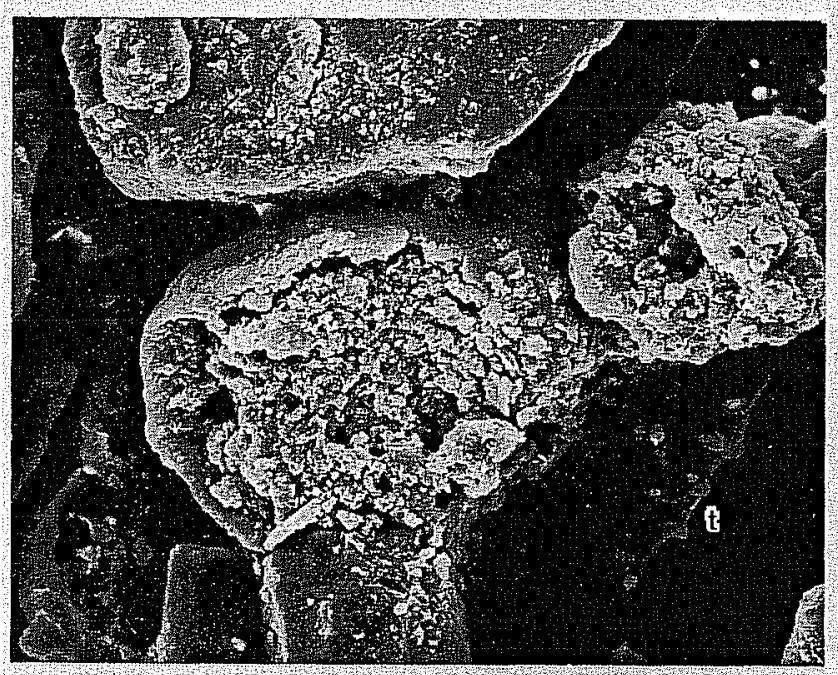

C

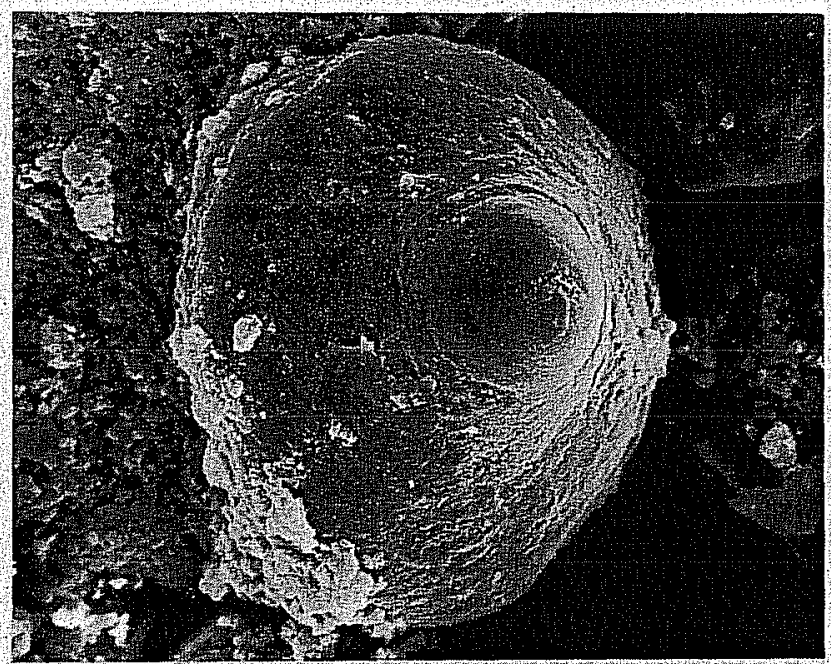

e

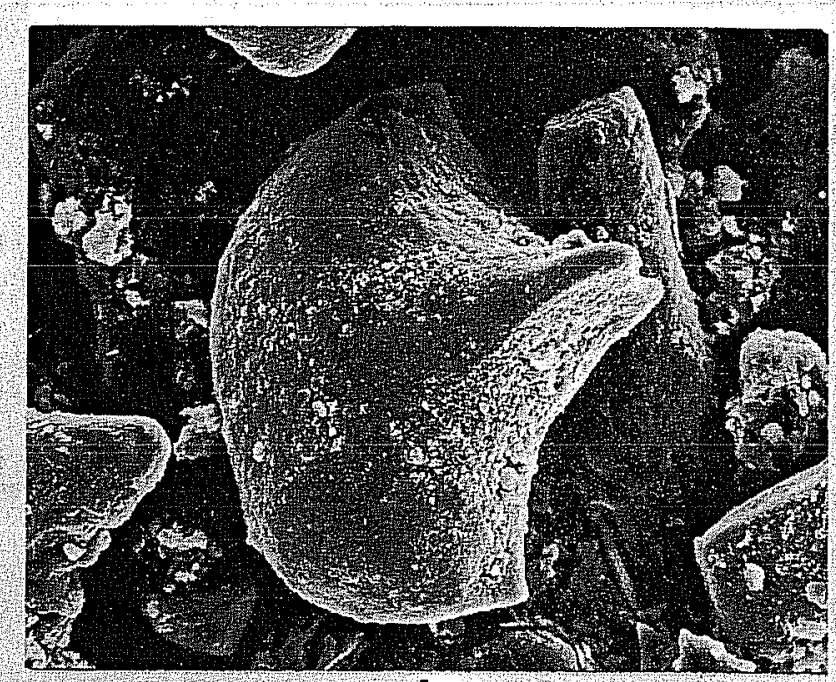

b
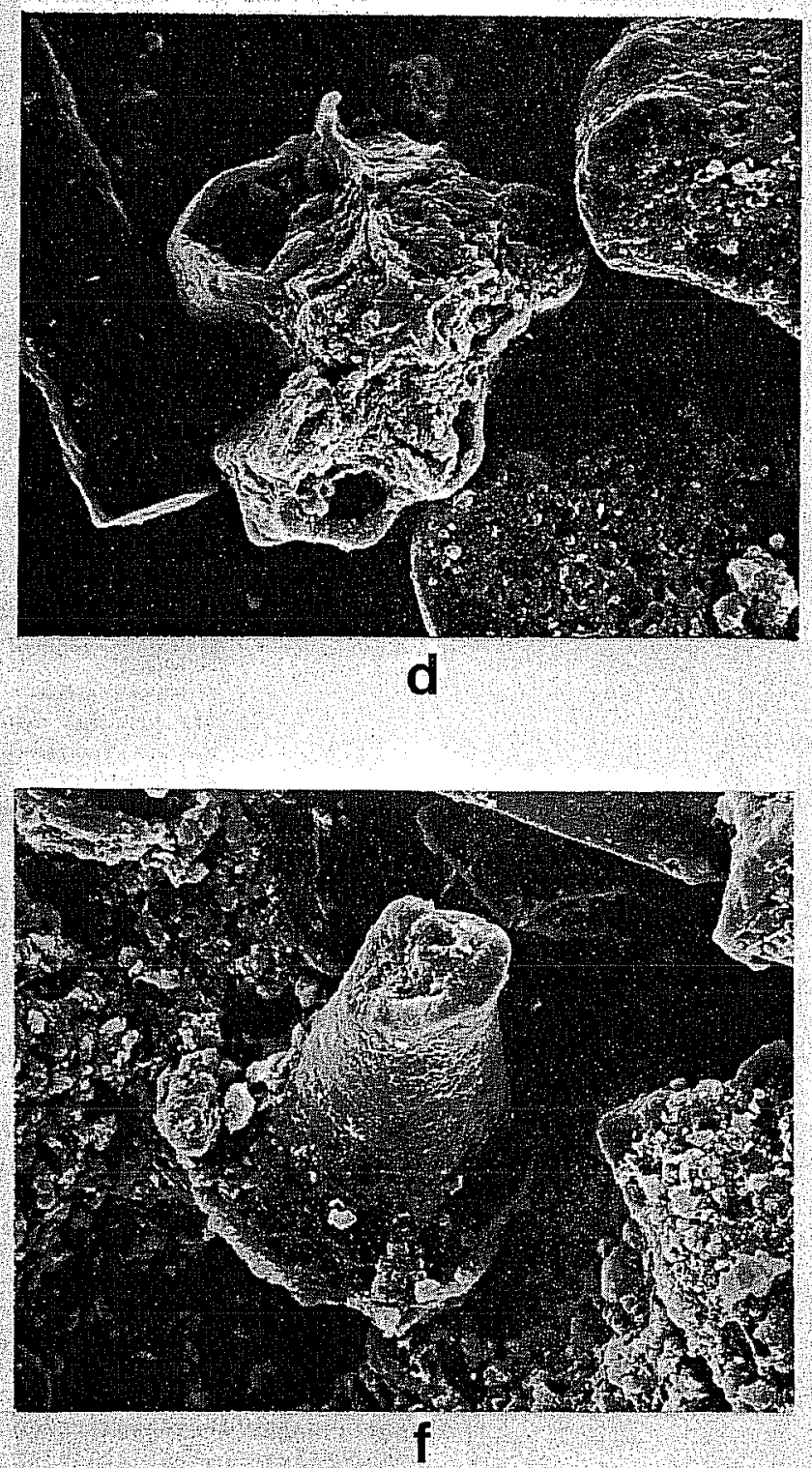


\section{TABLE 22. TYPES OF BIOSILICA IN 41 JW 8 SEDIMENT}

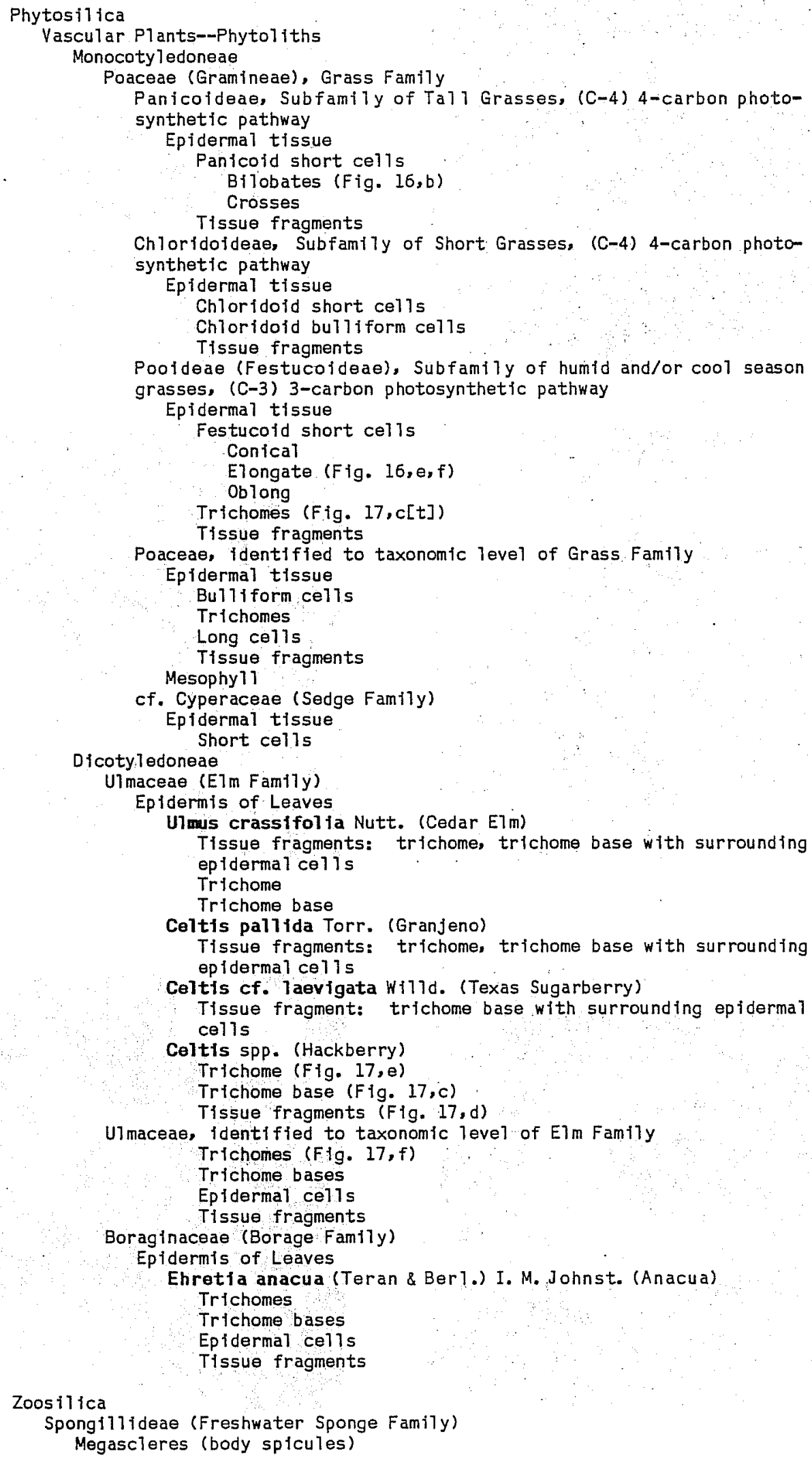




\section{BIOSILICA ANALYSIS: RESULTS AND CONCLUSIONS}

The results of this analysis are summarized in Table 22 and 11 lustrated in Figure $16, b, e, f$ and $F i g u r e ~ 17, h, i, j, k$, and 1 . At this time, Step $V$ of the analysis has not been completed; the results are a description of the assemblage of biosilica extracted from the $41 \mathrm{JW} 8$ sediments and the paleoecological implications.

As shown in Table 22, the Poaceae (Grass Family) is represented by phytoliths of several genera of the Panicoideae (tall grasses), several genera of the Pooideae (humid and/or cool environment grasses), and the Chloridoideae (short grasses). There is probably at least one genera of the Cyperaceae (Sedge Family) present. Phytoliths of two families of trees were identified, the U1maceae (EIm Fami7y) and the Boraginaceae (Borage Fami7y). The UTmaceae are represented by UImus crassifol 1 a (Cedar Elm), Celtis pal1 ida (Granjeno), and Celtis cf. 1aevigata (Texas Sugarberry). One member of the Boraginaceae was present, Ehretia anacua (Anacua).

Spicules of the Spongil1ideae (Freshwater Sponge Family) were also observed. These aquatic animals were probably from Chiltipin Creek. As freshwater sponges attach themselves to available substrate, the spicules may have been introduced into the site sediment by local inhabitants in the act of bivalve mollusk procurement. I have found several freshwater sponges attached to the shel1s of living freshwater bivalves. The possibility also exists that the sponge spicules are present because of alluvial or aeolian deposition.

The biosilica assemblage from the Hinojosa site suggests an environment similar to that of today but with more available moisture. Most of the taxa identified are present in the South Texas Plains Region and/or the Gulf Coastal Plain Region in the modern environment. When individual taxa within the assemb 1 age are considered, the presence of Ehretia anacua (Anacua) and the grasses in the subfamily Pooideae (Festucoideae) are especially important as environmental indicators. Anacua and the Pooideae grasses are extant in the modern environment.

Ehretia anacua (Anacua) is an indicator of paleotemperature, with a natural geographical range of: north to Hays and Travis Counties; east to Harris County; west into the South Texas Plains Region and the Mexican states of Nuevo Leon and part of Coahui 1a; and southward into the Mexican states of Tamaul ipas, Guanajuato, and Veracruz (Correl1 and Johnston 1970; Vines 1977). A drought-resistant species, Anacua's main limiting environmental factor is temperature. At the northern boundary of its natural range, the Anacua is represented by a few, possibly relect, populations which are seasonal1y partially deciduous. The January mean minimum temperatures (JMMT) for Hays and Travis Counties are $40^{\circ} \mathrm{F}$ and $41^{\circ} \mathrm{F}$, respectively. Planted as ornaments as far north as Dallas County with a JMMT of $36^{\circ} \mathrm{F}$, the Anacua die in excessively cold winters (Correl1 and Johnston 1970). In the area of the Western Gulf Coastal Plain Region (Victoria County and part of Goliad County), where Anacua is most abundant (in Texas), the JMMT is $46^{\circ} \mathrm{F}$. It is therefore suggested that the JMMT during the occupation of the Hinojosa site at A.D. 1350-1400 was probably not less than 36 to-40\% , or-w-ith-in-7-to 1-1-F of the present JMMT of $47^{\circ} \mathrm{F}$ for $\mathrm{Jim}$ Well $1 \mathrm{~s}$ County. The possibility exists that winter temperatures went well below the projected means and that the 
population of Anacua was reestablished by surviving relect populations and/or that reestablishment took place because of the food procurement activities of man, as the drupes of Anacua are sweet and edible.

The grasses within the subfamily Pooideae (Festucoideae) are important indicators of mesic, cool season, or cool humid environments. of the 523 species of grasses in the extant flora of Texas, only 86 native species and varieties are of the subfamily Pooideae. Of these 86 taxa, on 1 y nine have been found in the South Texas Plains Region, and 17 in the southwestern part of the Gulf Prairies and Marshes Region (Gould 1969). Phytoliths from these grasses are usually uncommon in modern soil samples from most regions of Texas. When found in samples of sediments from archaeological sites, they are usual1y part of the biosilica assemblages from mesic environmental conditions (Robinson 1982).

The biosilica assemb 1 age from $41 \mathrm{JW} 8$ is very similar to assemb 1 ages from mesic periods at 41 GD 21, Coleto Creek, Goliad County, Texas (Robinson 1979); and 41 LK $31 / 32$ and 41 LK 201, Choke Canyon, Live Oak County, Texas (Robinson 1982). Both of these areas of study are also on the western margin of the Western Gulf Coastal Plain in south Texas.

Additional interdisciplinary research in this area of Texas will prove or disprove the proposed mesic interval of approximately A.D. 1350-1400. The investigation of carbon isotope ratios of bone collagens of Bison bison from archaeological sites could provide an independent test. An increase of the Poofdeae (C3) grasses in the diet of Bison bison should be detectable in the $13{ }^{112} \mathrm{C}$ ratios of their bone collagens.

\section{ACKNOWLEDGMENTS}

The facilities of the Palynology Laboratory, Archeobotany Laboratory, Department of Anthropology, Texas A\&M University, College Station, Texas, were used for al1 stages of processing and analysis with the exception of Electron Microscopy.

The facilities of the Electron Microscopy Center, Texas A\&M University, College Station, Texas, were used for Scanning Electron Microscopy, photomicrograph development, and printing.

Last, I would 7 ike to thank Suzanne G. Teel, College Station, Texas, for manuscript editing and typing. 


\section{CULTURAL FEATURE ANALYSIS}

Three types of cultural features were recognized at the Hinojosa site: bone clusters, rock/charcoal clusters, and living surfaces. A1l three feature types are interpreted as occupational features. Most of the features were recovered from the main excavation block (Wagon Trail Area). Feature exposure and analysis were emphasized in the research design and during the project. Discrete cultural features, such as the features from $41 \mathrm{JW} 8$, are thought to represent activity loci during discrete occupational episodes. Thus, the careful exposure and analysis of these features can provide behavioral inferences concerning the activities resulting in the cultural features.

Nine features were forma 11 y recorded and assigned feature numbers in the field. Two additional features were designated as formal features and assigned feature numbers during the analysis. A11 features were carefully exposed, mapped, and photographed in the field. Matrix samples, axial interval samples, and charcoal samples were collected from some features as noted. A11 radiocarbon assays from the 1981 season were determined from feature charcoa1. Each feature is described in detail. A summary of the interpretations and special studies is provided with each feature description. Further details are discussed in appropriate sections of this report.

\section{BONE CLUSTERS}

Five discrete bone clusters (recorded as four features) were recorded during the 1981 season. A bone cluster is simply a distinct concentration of bone. The bone clusters at 41 JW 8 were very wel1-preserved concentrations, tight 1 y clustered, and with 1 ittle or no evidence of surface exposure. All of the bone clusters are interpreted as discard piles of bone refuse disposed of after processing and/or meat consumption. The "bone bed" uncovered at 41 JW 8 in 1975 (Hester 1977) appears to have been a large bone cluster.

This author strongly believes that the bone clusters at $41 \mathrm{JW} 8$ are the result of efficient butchering and processing techniques used by the former inhabitants of the site. The faunal consultant (Steele) has cautioned the author that the subject of bone modification has recently received considerable attention (Binford 1981). The fact that the bones are severely fragmented does not necessarily mean that the animals were butchered and that the bones were efficiently processed by the inhabitants. Other agents, such as animal scavengers, rodents, natural weathering, and ungulate traffic can also be responsible for fauna 1 fragmentation. Thus the mechanisms of breakage cannot be determined without careful taphonomic analysis that is beyond the scope of this project. Nonetheless, the discrete nature of the faunal clusters, the extreme fragmentation of almost all bones containing marrow, the cut marks noted on some bones, the occurrence of diverse species within discrete deposits, and the heavy burning of some bone are interpreted by this author as being the product of an efficient system of animal butchering, bone processing, and bone disposal. 
It should also be noted that the we11-preserved nature of the bone found within the bone clusters does not necessarily demonstrate rapid burial. Steele (personal communication) pointed out that bone experts will not make such an evaluation based on bone condition without an analysis of the depositional environment of the fauna. This author has observed weathered bone in southern Texas on many different occasions. Based on these observations, the bones surviving on the surface for a period of several months to several years are almost always severely sun bleached, cracked, and/or animal gnawed. Modern discrete bone clusters (dead animals) are usually disarticulated and scattered within a few weeks. The $41 \mathrm{JW} 8$ bone clusters showed 7 ittle or no evidence of such exposure and scattering. Hence, it is hypothesized that the Hinojosa site bone clusters are well preserved in part due to being rapidly buried. This hypothesis awaits confirmation by a regional taphonomic study.

\section{FEATURE 2}

Provenience: N106 E98 and N107 E98, Level 2, 10 to $24 \mathrm{~cm}$ below the surface (99.87-99.73). Lot numbers: 156, 165, 181, 182, and 183.

Dimensions: Irregular, Feature $2 \mathrm{~A}$ measured approximately $40 \mathrm{~cm}(\mathrm{~N}-\mathrm{S}) \times 23 \mathrm{~cm}$ $(E-W)$; Feature $2 B$ measured rough 7 y $18 \mathrm{~cm}$ in diameter.

Associations: Charcoal flecks, three modified f1akes (MD2), a core, a sma11 oval biface (FBI), an end scraper (UI), and a flat unmodified limestone slab.

Radiecarbon Assays: None, inadequate charcoal sample.

Special Sampling: A matrix sample was taken from Feature 2A (Lot 181). A two-1iter sample was water separated (see Section VII: Water Separation).

Description: Feature 2 consisted of two clusters of fragmented animal bone and associated artifactual material. No difference was observed between the feature matrix and the surrounding soil. Each cluster is described below.

Feature $2 \mathrm{~A}$ consisted of fragmented deer, turtle, bird, and bison bone as we 11 as the flat rock, the oval biface, and the end scraper al ready mentioned. Three bison humerus fragments from Feature $2 \mathrm{~A}$ appear to represent at least two individuals. A large amount of splintered long bone fragments was recovered from the cluster along with numerous Rabdotus 1 and snails and a few charcoal flecks. The identifiable bone fragments were not oriented in a consistent direction. A17 materials were very tightly clustered except for an unidentifiable large mammal bone fragment located some $50 \mathrm{~cm}$ west of the main cluster.

Feature 2B consisted of a bison femur fragment with postmortem crushing and spiral fractures and 19 unidentifiable fragments of a medium to 1 arge mamma 1 (deer or bison). One of the fragments was burned. Several flakes, including a secondary $f 1$ ake and two modified $f 1$ akes (MD2), and a small core were recovered from Feature $2 \mathrm{~B}$. Small charcoal flecks were noted against some of the bone fragments; however, no other evidence of direct burning was noted (i.e., the feature area did not appear to have been the scene of a fire). 
Interpretation: Both clusters appear to represent two separate although associated features. These clusters were the first two of five bone clusters found at the site. They were recorded as a single feature due to their close physical proximity. In retrospect, they probably should have been given separate feature designations.

Both clusters appear to be discarded refuse dumps. The tight nature of the clusters (bones stacked one against the other) and the relatively good condition of the bone (unweathered although adversely affected by the moist soil conditions at the time of exposure) may suggest that these materials were deposited in smal1, shallow holes (pits?) and covered with soil. The two clusters represent separate events, although these events were probably close together in time. Some of the fragmentation of the bone may well have been caused by traffic on the "wagon trail," the area in which the feature was located.

\section{FEATURE 3}

Provenience: N106 E98, Leve1 3, 99.71-99.66.

Dimensions: $36 \mathrm{~cm}(E-W) \times 16 \mathrm{~cm}(\mathrm{~N}-\mathrm{S})$.

Associations: No cultural materials other than bone (Table 23) were found in direct association with. Feature 3 . Feature 3 occurred between the two clusters of Feature 2 on a horizontal basis but slightly lower in elevation.

\section{Radiocarbon Assays: None.}

Special Sampling: A matrix sample was taken from the central area of the feature. This sample has not been analyzed.

Description: Feature 3 consisted of a smal1, compact cluster of animal bone; most were fragmented. The feature was in the form of a tightly clustered arc or crescent as shown in Figure 18. No difference was observed between the feature matrix and the surrounding soil. An interesting aspect of the feature is the diversity of species identified from the bone assemblage. At least seven different animals contributed to the assemblage, including bison, deer, jackrabbit, turtle, turkey, wood rat, and mole. The bones are unburned and in comparatively excellent condition. All of the 1 arger elements collected, such as a bison humerus, a deer tibia, a deer mandible, and unidentified bone from 1 arge mammals and some of the smaller animal bone, are fractured.

Interpretation: Feature 3 like all of the bone clusters recorded at $41 \mathrm{JW} 8$ appears to be a discard pile of butchered and processed animal bone. The tight stacking of the bone in a smal1 cluster suggests intentional placement. The absence of any evidence of scattering or weathering may suggest that the bone was not exposed on the surface for any length of time. 
TABLE 23. PLOTTED ITEMS ASSOCIATED WITH FEATURE 3

\begin{tabular}{|c|c|c|c|}
\hline Lot Number & Item Number & Elevation & Identification \\
\hline 184 & 1 & 99.67 & turkey left femur \\
\hline 184 & 2 & 99.66 & deer phalange \\
\hline 184 & 3 & -- & $\begin{array}{l}\text { wood rat right mandible and } \\
\text { left ulna fragment }\end{array}$ \\
\hline 184 & 4 & 99.69 & deer left tibia fragment \\
\hline 184 & 5 & 99.70 & $\begin{array}{l}\text { jackrabbit femur fragment, } \\
\text { tortoise plastron (scute), } \\
\text { and medium to large mammal } \\
\text { skul1 fragment }\end{array}$ \\
\hline 184 & 6 & 99.69 & $\begin{array}{l}\text { tortoise plastron (scute) } \\
\text { and large mammal long bone } \\
\text { fragment }\end{array}$ \\
\hline 184 & 7 & 99.71 & $\begin{array}{l}\text { deer right mandible frag- } \\
\text { ment }\end{array}$ \\
\hline 184 & 8 & 99.67 & $\begin{array}{l}\text { sma } 11 \text { bird femur and a } \\
\text { large mammal rib fragment }\end{array}$ \\
\hline 184 & 9 & 99.67 & $\begin{array}{l}\text { bison right humerus frag- } \\
\text { ment }\end{array}$ \\
\hline 184 & 10 & 99.66 & $\begin{array}{l}\text { tortoise plastron (scutes) } \\
\text { and } 1 \text { arge mammal long bone } \\
\text { fragments }\end{array}$ \\
\hline 184 & 11 & 99.68 & tortoise plastron (scutes) \\
\hline 184 & 12 & --- & $\begin{array}{l}\text { unplotted items from lower } \\
\text { section of feature: tor- } \\
\text { toise plastron and carapace } \\
\text { scutes, large mammal long } \\
\text { bone fragment, and eastern } \\
\text { mole pha1 anges (2), verte- } \\
\text { brae (2), humerus and oc- } \\
\text { cipital }\end{array}$ \\
\hline
\end{tabular}

Note: The faunal elements (except item 12) are plotted by item number on a map of the feature in Figure 18. 

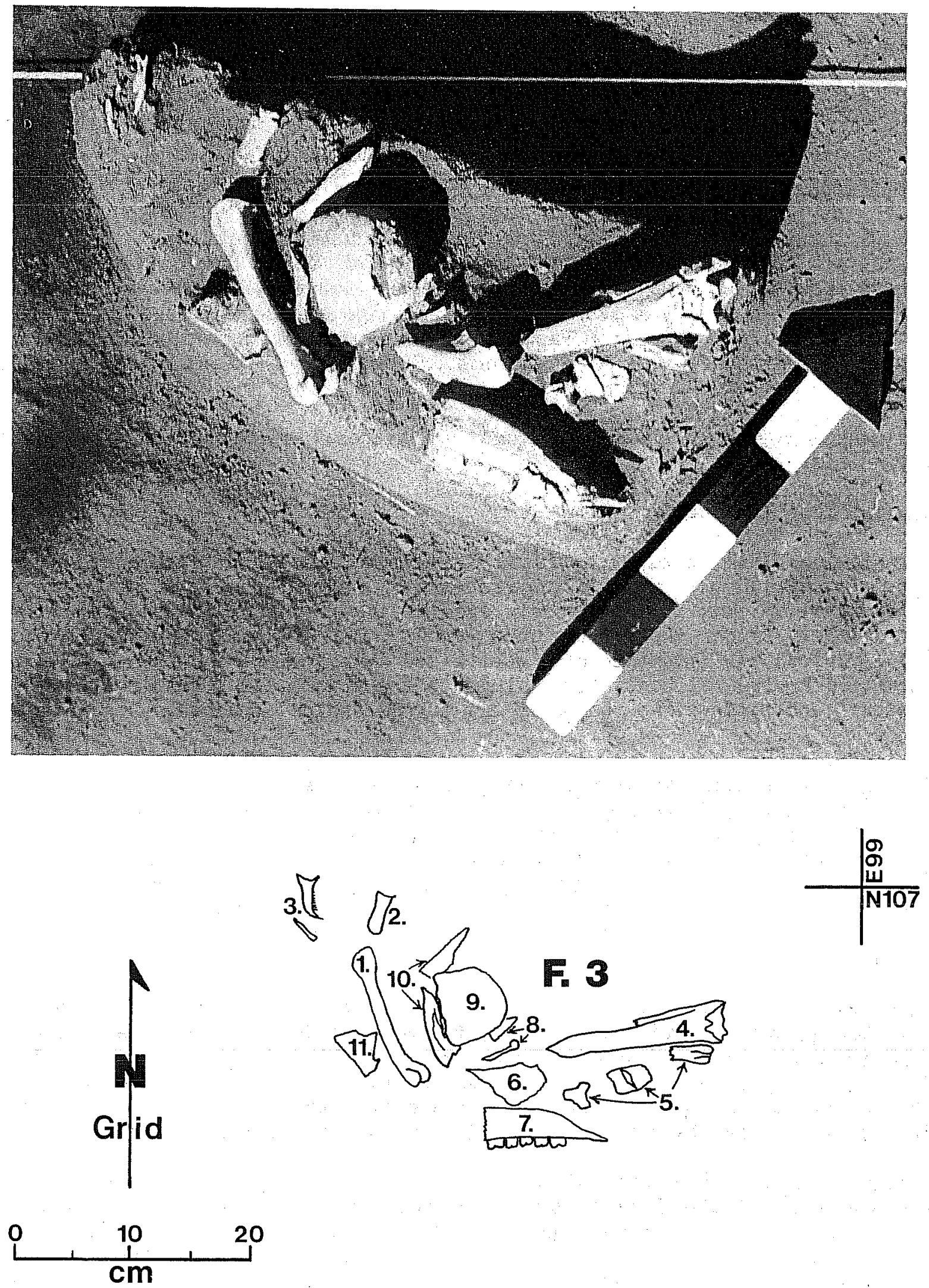

Figure 18. View of Feature 3 and $P 1$ an Map. North arrow in photograph points to magnetic north. Refer to Table 23 for the identification of the numbered items in plan map. 


\section{FEATURE 9}

Provenience: N108 E102, Levels 3 and 4 and N108.5 El03, Leve1 2, 99.8299.71.

Dimensions: Approximately $73 \mathrm{~cm}(\mathrm{~N}-\mathrm{S}) \times 10-13 \mathrm{~cm}(\mathrm{E}-\mathrm{W})$.

Associations: Two 1ithic artifacts were found with in Feature 9, a modified tertiary flake (MD2) and a thick unifacial tool (U2). Other items found in direct association were a thermally fractured chert spal1, several chunks of charcoal, several very small musse 1 valves, and a number of 1 and snails. The plotted items recovered from Feature 9 are shown in Figure 19 and 1 isted in Table 24. Feature 8 was located some 1.5 to $2 \mathrm{~m}$ to the west of Feature 9 at a slightly higher elevation.

Radiocarbon Assays: None; the amount of charcoal recovered was inadequate for an assay.

Special Sampling: None.

Description: The feature consisted of a tight cluster of fragmented animal bone arranged in a narrow, elongated area. Some of the bone were stacked three elements deep. At least six species are identifiable from the faunal assemblage: bison, three types of rodents, javelina, and turtle. In addition, several rib fragments of a deer-sized mammal were recovered. With the exception of the rat bones, al1 elements are fragmented. Most of the bison elements and bison-sized fragments are burned, spiral fractured, or have cut marks.

The spatial arrangement of the feature suggests that the contents were placed in a long, narrow depression and were not simply piled on a surface. Unfortunately, the feature matrix was no different from the surrounding soil and, thus, a pit or depression outline could not be detected. Turtle plastron, fire discolored and broken into two 1 arge sections, formed the upper 1 ayer. Several comparatively large chunks of charcoal were recovered in the upper portion of the feature. No evidence of direct burning (of the feature area) was detected.

This feature was very carefully excavated by Kenneth M. Brown who noted the orientation and direction of dipping for most of the 1 inear bone fragments. Most elements were oriented more or less parallel to the long axis of the feature and predominately dipped to the north. The bone elements were obviously tightly packed and placed one atop the other. Several of the 1 arger bison elements were the deepest elements in the feature.

Interpretation: Feature 9 appears to be a purposeful bone disposal pile. The location of the feature near the edge of the bluff and the spatial arrangement of the contents suggest that the discarded bone was placed in a narrow erosional gul ley. The absence of any evidence of sedimentation or weathering suggests that the feature was quickly covered soon after deposition. The nature of the bone (fragmented, butchered, and burned) suggests the interment probably followed processing and/or consumption which included removal of a 11 meat and marrow processing. 


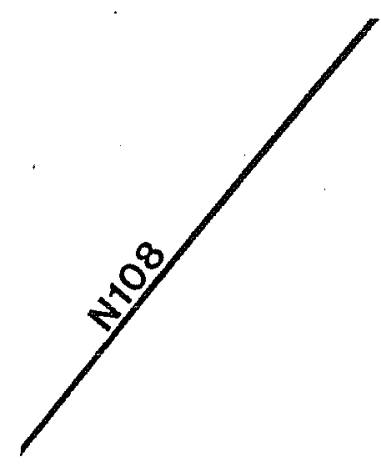

F. 9
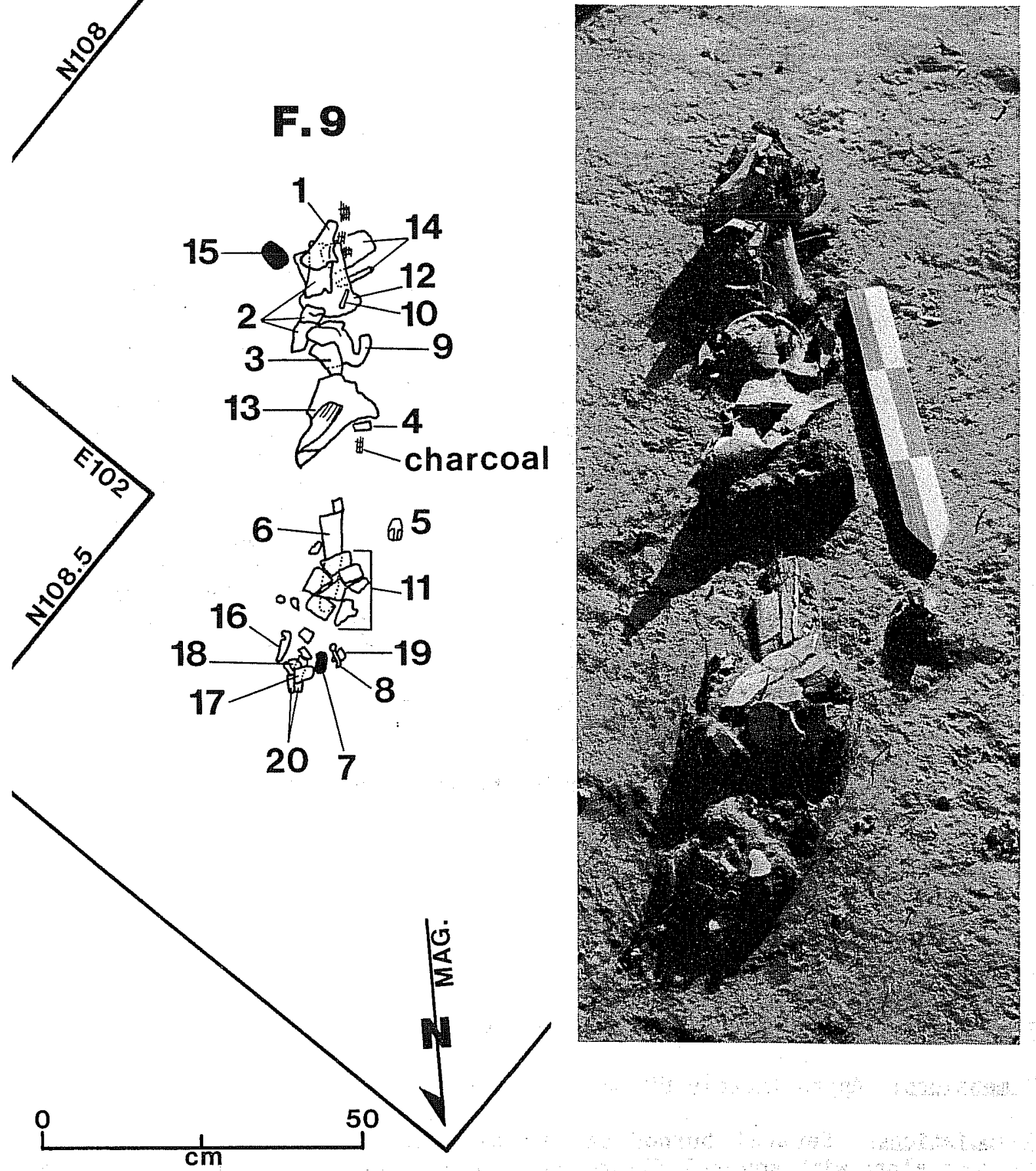

Figure 19. Plan Map and View of Feature 9. The photograph is an oblique view taken from the magnetic north end of the feature looking south. Refer to Table 24 for the identification of the numbered items in the plan map. 
TABLE 24. PLOTTED ITEMS FROM FEATURE 9

\begin{tabular}{|c|c|c|c|}
\hline Lot Number & Item Number & Elevation & Identification \\
\hline $\begin{array}{l}472 \\
472 \\
472 \\
472 \\
472\end{array}$ & $\begin{array}{l}1 \\
2 \\
3 \\
4 \\
5\end{array}$ & $\begin{array}{l}99.82 \\
99.77 \\
99.79 \\
99.80 \\
99.78\end{array}$ & $\begin{array}{l}\text { deer ulna tool } \\
\text { bison size long bone fragments } \\
\text { tortoise plastron fragments } \\
\text { large mammal fragment } \\
\text { javelina mandibular fragment }\end{array}$ \\
\hline $\begin{array}{l}472 \\
472 \\
472 \\
472 \\
472\end{array}$ & $\begin{array}{l}6 \\
7 \\
8 \\
9 \\
10\end{array}$ & $\begin{array}{l}99.78 \\
99.80 \\
99.79 \\
99.76\end{array}$ & $\begin{array}{l}1 \text { arge mamma } 1 \text { fragments } \\
\text { modified tertiary flake (MD2) } \\
\text { wood rat humerus } \\
\text { tortoise p } 1 \text { astron fragments } \\
\text { sma } 11 \text { mammal fragment }\end{array}$ \\
\hline $\begin{array}{l}472 \\
472 \\
472 \\
472 \\
472\end{array}$ & $\begin{array}{l}11 \\
12 \\
13 \\
14 \\
15\end{array}$ & $\begin{array}{l}99.80 \\
99.73 \\
99.73 \\
99.71 \\
99.74\end{array}$ & $\begin{array}{l}\text { tortoise plastron fragment } \\
\text { bison ul na fragment } \\
\text { bison radius fragment } \\
\text { bison size marrow fragments } \\
\text { unifacial tool (U2) }\end{array}$ \\
\hline $\begin{array}{l}472 \\
472 \\
472 \\
472 \\
472\end{array}$ & $\begin{array}{l}16 \\
17 \\
18 \\
19 \\
20\end{array}$ & $\begin{array}{l}99.77 \\
99.78 \\
99.80 \\
99.80 \\
99.76\end{array}$ & $\begin{array}{l}\text { large mamma } 1 \text { long bone fragment } \\
\text { large mamma } 1 \text { long bone fragment } \\
\text { tortoise scute fragment } \\
\text { burned corticate chip } \\
\text { deer size rib fragments }\end{array}$ \\
\hline
\end{tabular}

Note: The faunal elements are plotted by item number on a map of the feature in Figure 19.

FEATURE 10

Provenience: N104 E97, Leve7s 2-4, 99.94-99.68.

Dimensions: Approximately $60 \mathrm{~cm}$ (grid N-S) $\times 50 \mathrm{~cm}$ (grid E-W).

Asseciations: Several burned calcareous concretions were found within the cluster along with several $\mathrm{fl}$ lakes and a mussel she 11 . Feature 6 was located some $1.5 \mathrm{~m}$ to the grid north. The faunal elements recovered from Feature 10 are 1 isted in Table 10.

Radiocarben Assays: None.

Special Sampling: None. 
Description: Feature 10 was a loosely clustered bone concentration. The feature was not originally designated as such in the field due to the somewhat scattered nature of the bone. As the excavations progressed, the elements were plotted in situ and were eventualiy recognized as aspects of a cultural feature. Contributing to the difficulty of feature recognition were several disturbances and the fact that the feature extended through portions of three separate 1 evels. A rodent run and several 1 arge mesquite roots intruded into the feature and caused displacement of the bone. Other than the rodent run fil 1 , no difference was noted between the matrix around the faunal elements and the adjacent soil.

Nine faunal elements are identified from Feature 10: four deer bones, four bison bones, and an opossum bone. Most of the bison elements are from a subadult. The homogeneous nature of the elements (size, species, and condition) helps to confirm the validity of the belated feature designation. Most of the bone are fragmented, including a number of bison and deer size fragments that could not be identified. Much of the bison bone and some of the deer bone are spiral fractured and/or burned.

Interpretation: Feature 10, like the other bone cluster features, is interpreted as a refuse dump of processed animal bone. The vertical extent of the feature (over $25 \mathrm{~cm}$ from the uppermost element to the lowest) suggests that the discarded bone was placed in a hole. The pit out 1 ine was not detected. The homogeneous nature of much of the bone suggests that the feature represents a single event. Feature 10 was probably more tightly clustered prior to the perietration of several very 1 arge mesquite tree roots which caused considerable displacement.

\section{ROCK /CHARCOAL FEATURES}

Five discrete rock/charcoal features were recorded during the 1981 season. A rock/charcoal feature is a distinct concentration of burned rock (calcium carbonate concretions) and/or charcoal. These features obviously represent fire-related activities such as cooking hearths, warmth hearths, or hearth discard piles. Often associated with these features are faunal and artifactual materials. Charcoal from three of these features provided ample material for the radiocarbon assays.

\section{FEATURE 1}

Provenience: N125 E92, Level 4, 30-38 cm below the surface.

Dimensions: Approximately $20 \mathrm{~cm}(\mathrm{~N}-\mathrm{S}) \times 30 \mathrm{~cm}(\mathrm{E}-\mathrm{W})$.

Associations: There was very 1 ittle in direct association with Feature 1 except a few unburned and burned unidentifiable bone fragments and several smal1 burned rocks. A pottery sherd and an end scraper (UI) were recovered from the level containing the feature. 
Special Sampling: Matrix samples were taken with in the feature and $75 \mathrm{~cm}$ grid north of the feature. Both samples had low to moderate quantities of burned hackberry seeds, microfauna, charred seeds, snails, and a few small charcoal chunks.

Description: Feature 1 consisted of a sma11, irregularly shaped charcoal stain (not illustrated). Small amounts of bone and burned rock occurred within the feature but not in a significantly greater density than the surrounding excavation 1 eve 15 . The matrix of the feature appeared dark gray brown in comparison to the surrounding soil. Filled-in rodent runs and burrows surrounded much of the feature. These disturbances had noticeably looser soil texture.

Interpretation: The feature occurred on a ground surface that sloped to the grid north. Several poorly defined rock clusters were observed in 1 ower levels ( 9 and 11 ). The overall deep nature of the cultural deposits in the excavation unit and the noticeable slope of the sedimentation suggest that the area was filled in by slope wash from the higher ground to the grid west. Feature 1 is thought to represent either hearth residue washed into an erosional feature (smal1 depression) or possibly an animal burrow that fil1ed in with burned cultural material. It should be noted that the wall of the excavation unit revealed a greater amount of disturbance than any other unit. The end scraper from Level 4 has plow marks and is the most deeply buried artifact from the site that is known to have been plow damaged. Littie cultural significance is attached to the feature.

\section{FEATURE 4}

Prevenience: N100 E93 and N100 E94, Level 6, 48-58 cm below the surface.

Dimensions: The main cluster measured $46 \mathrm{~cm}$ (grid N-S) $\times 49 \mathrm{~cm}$ (grid $\left.E-W^{\prime}\right)$; a few sma 11 rocks were scattered outside the main concentration.

Asseciations: None.

Radiocarbon Assays: None.

Special Sampling: A matrix sample was collected from between the rocks and the rock pedestals (created during feature exposure). It is interesting to note that of all the feature matrix samples or on-site column samples that were water separated, the sample from Feature 4 had the least amount of cultural material.

Description: Feature 4 consisted of a small cluster of burned rock with a few scattered rocks occurring at the same elevation up to $1.2 \mathrm{~m}$ away from the main cluster (not illustrated). Little or no difference was noted in the appearance of the feature matrix in comparison to the surrounding soil. No associated cultural material (artifacts, faunal material, charcoal) was present. The feature was more or less circular but was not tightly clustered or formal in appearance. 
Interpretation: The feature is interpreted as some sort of fire-related cultural feature remnant, such as a weathered hearth or a stone boiling dump. Due to the absence of cultural associations, 1 ittle significance is attached to Feature 4. It is possible that Feature 4 is the result of an earlier occupation at the site.

\section{FEATURE 5}

Provenience: N109 E98 and N109 E97, Levels 2 and 3, 99.87-99.75.

Dimensions: Approximately $40 \mathrm{~cm}(\mathrm{~N}-\mathrm{S}) \times 50 \mathrm{~cm}(\mathrm{E}-\mathrm{W})$.

Associations: An expanding stem arrow point (A2:1) and a body sherd were found in direct association with the feature along with several unburned bone and mussel shell fragments, 10 Rabdotus snails, 3 Helicina snails, and a tertiary flake.

Radiocarbon Assays: TX-4652, $520 \pm 90$ (see Section VII: Radiocarbon Assays).

Special Sampling: Four matrix samples were collected from various areas of the feature. Considerable quantities of cultural materials were recovered from the two samples which were water separated. Feature 5 was one of the trial cases for the axial interval sampling as described in Section VII (Soils Chemistry). High quantities of phosphate were found within and immediately adjacent to Feature 5 as is shown in Figure 15.

Description: Feature 5 (Fig. 20,b) was a sma11, tight cluster of charcoa1stained soil, ash, charcoal, and associated cultural material. In plan the feature was irregularly circular; the feature profile revealed a $12-\mathrm{cm}$-deep pit in which the cultural materials were located (Fig. 20,a). The upper portion (detection surface) of Feature 5 had an outer ring of charcoalstained soi 1, and in the center was a very loose ash 1 ens. The pit sloped from grid east to form a slightly undercut outline which reached a maximum depth on the grid west side of the feature. In addition to the charcoalstained soil and ash lens, concentrations of intense charcoal staining, baked clay (not shown in profile), and large intact chunks of wood charcoal were in the pit fil1. The feature matrix was further distinguished by motti ing (snail, burned rock, and bone fragments).

Four faunal species contributed elements to Feature 5: coyote, cottontail rabbit, a smal1 unidentified $f i s h$, and an unidentified large mammal (probably deer or bison). In addition, a number of unburned whole and fragmented Rabdotus 1 and snails were recovered. The charred wood from the feature could only be identified as some type of hardwood. A charred seed coat was recovered during flotation of the lower feature fill, however, it could not be identified.

Interpretation: Feature 5 is believed to be the remains of a sma 11 fire hearth. The hearth appears to have been contained within a small pit. The presence of several pockets of bone and baked clay adjacent to but not within 


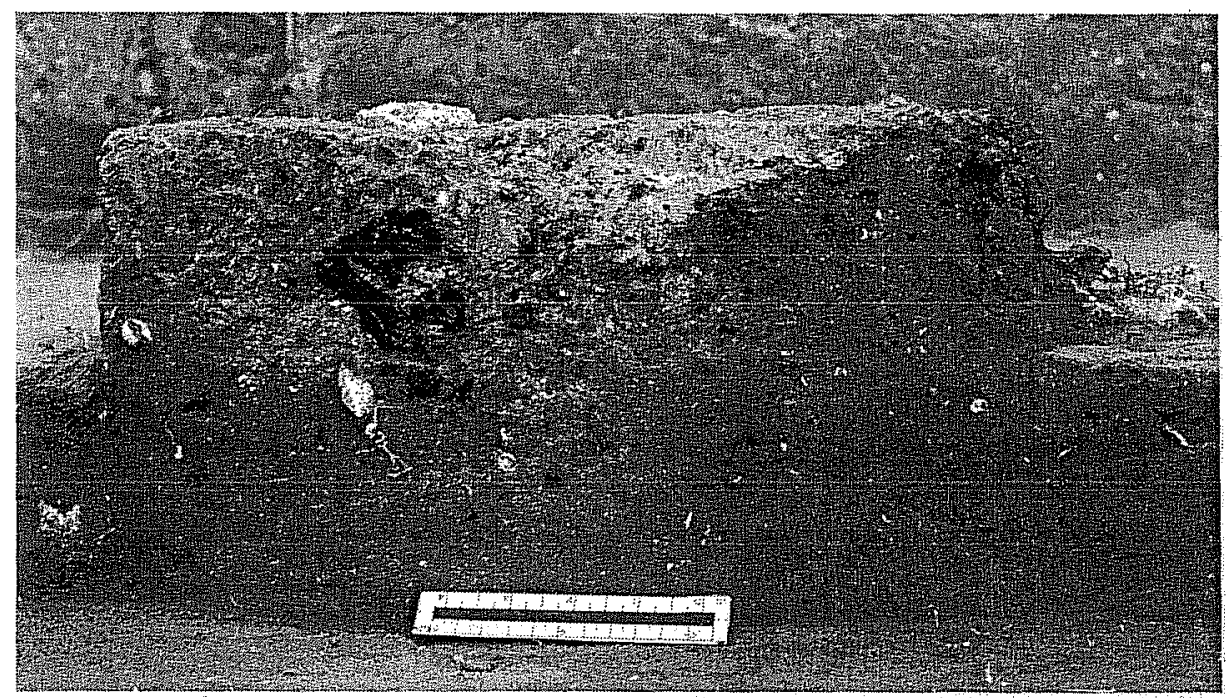

a

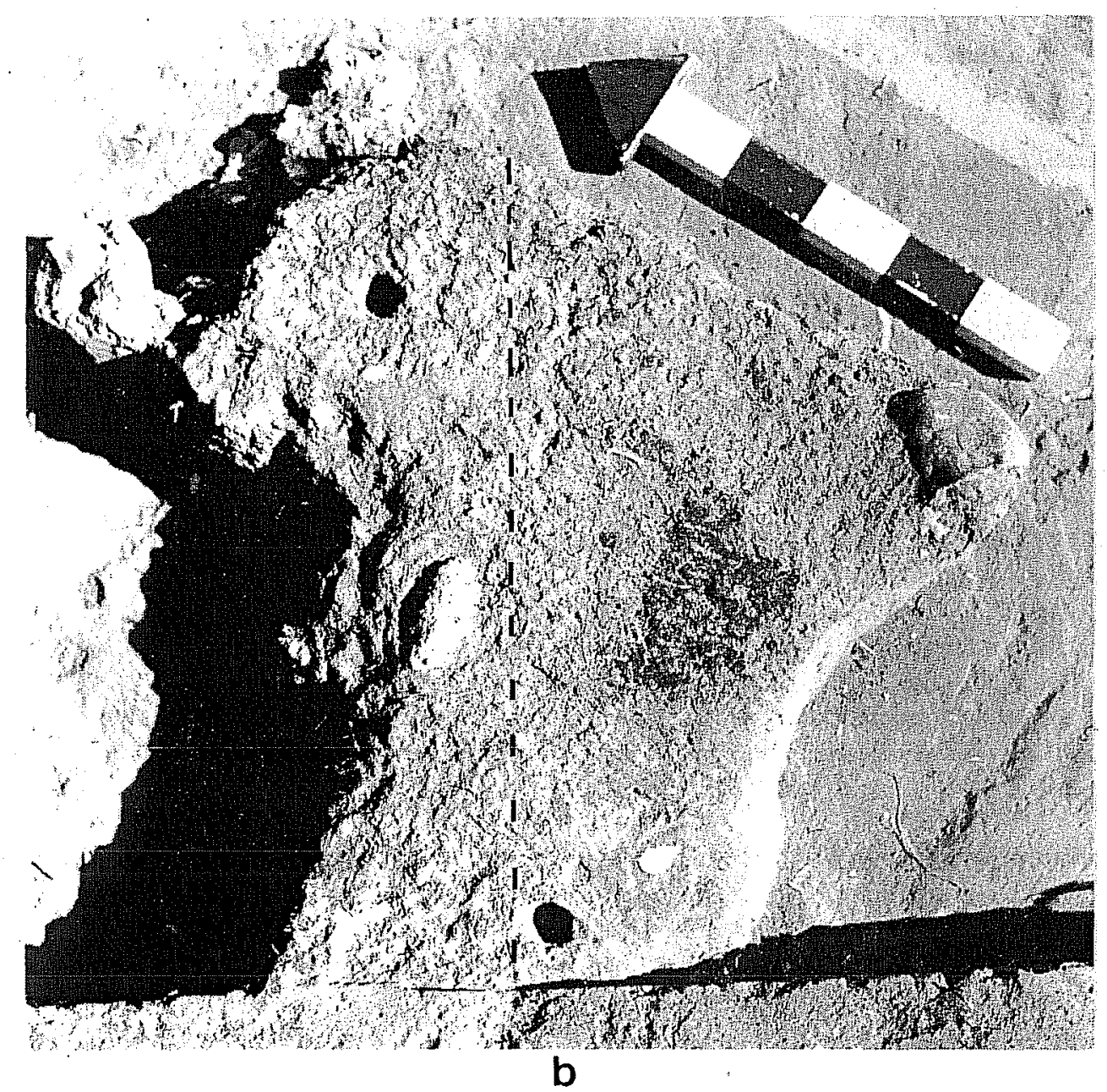

Figure 20. Views of Feature 5. a, view to the northwest of the cross section of feature along dashed 1 ine shown in $b$; $b$, overhead $v$ iew of pedestaled feature. 
the pit suggests reuse of the feature at least once. The fact that the pit fi 11 appears 1 ayered and undisturbed suggests that it was not cleaned out after the final use. The absence of intense soil discoloration around the pit edges and the small size of the feature suggest comparatively 1 itt 1 e repeated use in contrast to Feature 6.

\section{FEATURE 6}

Provenience: $\quad N 106$ E97 and N106 E96, Levels 2 and 3, 99.96 (detection surface) to 99.88 (bottom of lowest plotted artifact); small pit below main feature extends to a depth of 99.81 .

\section{Dimensions: Approximately $80 \mathrm{~cm}(\mathrm{~N}-\mathrm{S}) \times 130 \mathrm{~cm}(\mathrm{E}-\mathrm{W})$.}

Associations: Numerous artifacts were directly associated with Feature 6: an arrow point fragment, two body sherds, an end scraper, two biface fragments, one trimmed tertiary flake, two modified secondary flakes, a modified decorticate chip, and various faunal elements. The 17 items that were piece plotted in Feature 6 are 1 isted in Table 25 and shown in Figure 21 . Additional flakes, sherds, and arrow points were recovered at the same elevation range in close association with the feature. Feature 6 was located on the east edge of Feature 1l, the apparent $1 \mathrm{iving}$ surface that was exposed in the western half of the Wagon Trail excavation area. Features $2 \mathrm{~A}, 2 \mathrm{~B}$, and 3 were located just east of Feature 6 at 1 ower depths. Feature 10 was 1 ocated just south of Feature 6 and was first detected at about the same elevation.

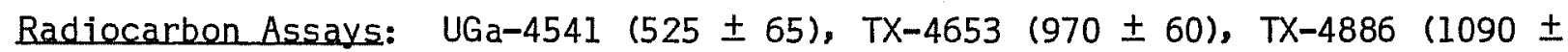

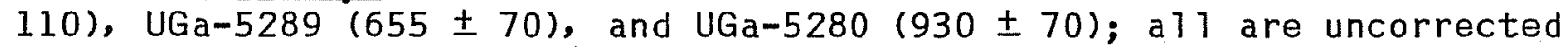
assays. See Section VII (Radiocarbon Assays) for a detailed discussion of these widely varying assays.

Special Sampling: Eleven matrix samples and seven charcoal samples were collected from various portions of the feature. In 1 ieu of an axial interval samp 1 ing (due to the fact that much of the surrounding excavation area was al ready excavated below the feature 1eve1), a series of samples was collected along a grid north-south transect (grid 1ine E97). Phosphate testing of the various matrix areas of Feature 6 showed comparatively high readings, ranging from 649 to $1597 \mathrm{ppm}$.

Description: A complicated fire feature, Feature 6 was composed of overlapping charcoa1, Rabdotus snail she115, ash, baked clay, and charcoa1stained soil concentrations within and around a roughly circular cluster of burned rocks (Fig. 21). In addition, a small pit extended below the main feature level on the northeast edge of the feature.

Feature 6 was exposed, excavated, and removed during a one-month period (November 18-December 18). This rather 1engthy excavation period was due to the following: (1) the feature was extended into two units and four levels; (2) we wanted to expose the entire western half of the Wagon Trail Area to the same level (thus we were able to confidently tie in Feature 6 with Feature 11); (3) we wanted to leave the feature exposed for the principal investigator, NPS, IAS-D and SCS representatives, and the news media to see; 
TABLE 25. PLOTTED ITEMS ASSOCIATED WITH FEATURE 6

\begin{tabular}{|c|c|c|c|}
\hline Lot Number & Item Number & Elevation & Identification \\
\hline 397 & 1 & 99.91 & modified secondary flake (MD2) \\
\hline 397 & 2 & 99.94 & end scraper (UI) \\
\hline 397 & 3 & 99.94 & trimmed tertiary flake (MDI) \\
\hline 397 & 4 & 99.94 & body sherd \\
\hline 397 & 5 & 99.94 & modified decorticate chip (MD2) \\
\hline 397 & 6 & 99.91 & biface fragment (FB3) \\
\hline 397 & 7 & 99.92 & modified secondary flake (MD2) \\
\hline 397 & 8 & 99.94 & biface proximal fragment (FBI) \\
\hline 397 & 9 & 99.88 & body sherd \\
\hline 397 & 10 & 99.90 & arrow point distal fragment (A4) \\
\hline 397 & 11 & 99.93 & bison-sized long bone fragment \\
\hline 397 & 12 & 99.90 & mammal caudal vertebra \\
\hline 397 & 13 & 99.88 & vole right mandible \\
\hline 397 & 14 & 99.90 & turtle plastron fragment \\
\hline 397 & 15 & 99.91 & deer thoracic vertebrae (2) \\
\hline 397 & 16 & 99.93 & mammal vertebral fragment \\
\hline 397 & 17 & 99.91 & deer ulna \\
\hline
\end{tabular}

Note: See Figure 21 for horizontal location of cultural materials plotted by item number.

and (4) the careful exposure and recording of this comp 1 icated feature was very time consuming. During most of the month only the upper surface of the feature was exposed, and this was covered by plastic except when work on the feature was actively taking place. The plastic kept the moisture content of the feature relatively constant.

As the feature was exposed and excavated, a number of more-or-less discrete concentrations were discerned. These were excavated, collected, and sampled separately as matrix areas A-F. Materials from mixed uncertain contexts were bagged separately. Most of the six matrix areas appeared to be separate depositions, although some were arbitrarily divided to look for differences in matrix composition across the feature. Each matrix area is described next.

Matrix area $A$ was a lobe (irregular mass protruding out from the 1 arger matrix area C/E on the grid east side of the rock cluster) located on the grid southeastern portion of the feature. This area consisted of charcoaistained soil mixed with ash, baked clay fragments, and large chunks of charcoal. Several of the charcoal chunks were incompletely oxidized, suggesting that the fire was extinguished rather than allowed to burn down to 


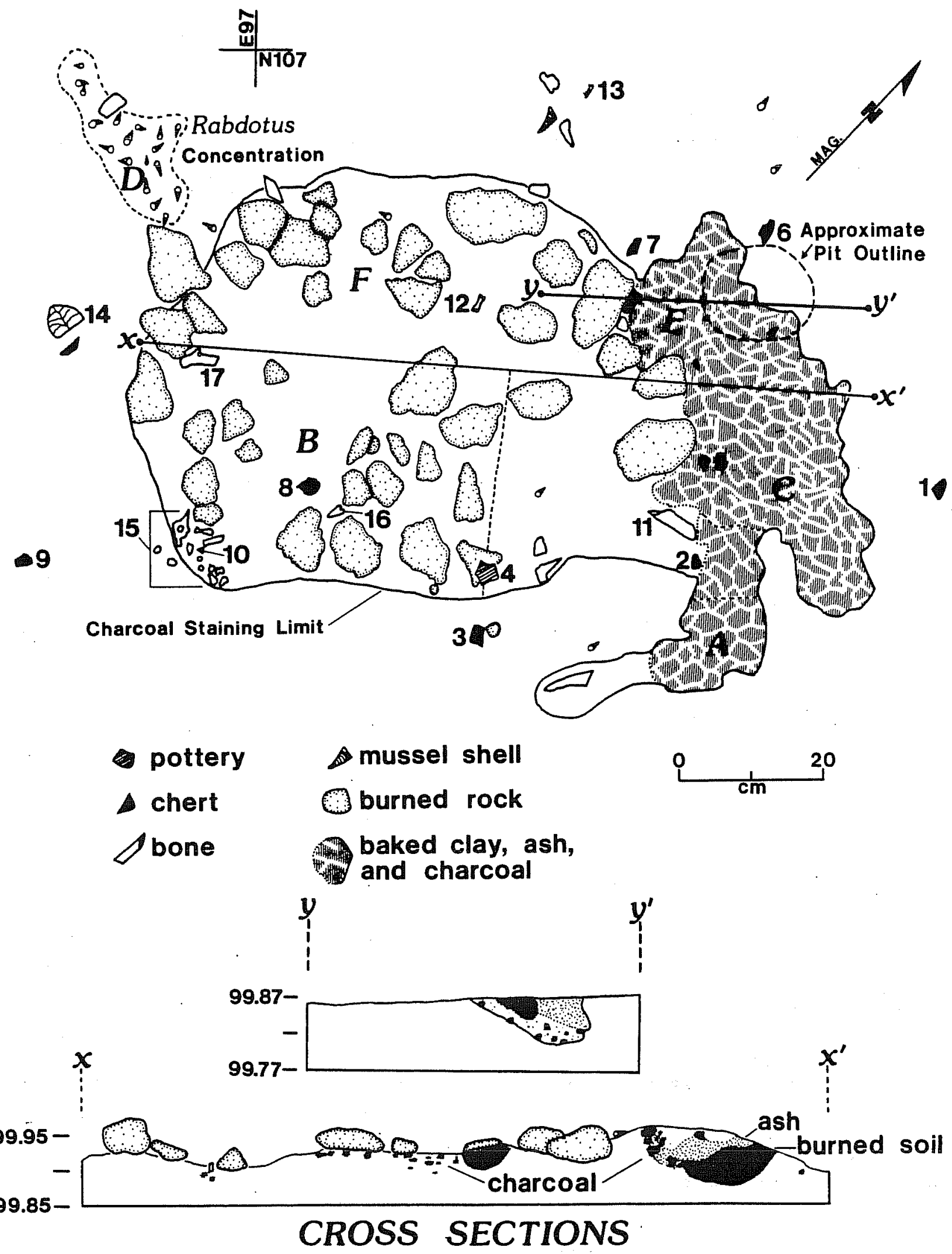

Figure 21. P1an Map and Profile of Feature 6. Numbered items are 1 isted in Table 25. 
a bed of ashes. The fact that area $A$ extended out from the central feature area suggests that it represents a feature clean-out episode.

Matrix area $B$ consisted of $f i l 1$ in the southern half of the feature directly under and between the rock cluster. The area $B$ matrix contained considerable quantities of charcoa 1 , most 1 ocated in a thin 1 ayer directly beneath the rocks. Plotted items $4,8,10$, and $15-17$ were 1 ocated in area $B$. Matrix areas $B$ and $F$ were arbitrarily divided at the first cross section 1 ine $\left(x-x^{\circ}\right.$; Fig. 21).

Matrix area $C$ was 10 ated in the southern ha $1 \mathrm{f}$ of the 1 arge feature fil 1 lobe, east of the rock cluster. The first cross section 1 ine divides areas $C$ and $E$ arbitrari1y. Areas $C$ and $E$ are distinguished from the other matrix areas, both by location and a difference in fill characteristics. The fill of the C/E area had a much greater ash and baked Clay content than any other area of Feature 6 . Numerous chunks of charcoal were a1so recovered. Plotted item 5 was found within area $C$.

Matrix area $D$ was the lobe of concentrated Rabdotus snails that extended to the grid northwest from the rock cluster. Very 1 ittle charcoal or ash was recovered from this 1 obe.

Matrix area $E$ was located in the northern half of the feature area, east of the rock cluster (see the area C discussion). The pit feature, discussed 1 ater, originated within or was covered by area $E$. Area $E$ had particularly noticeable concentrations of ash and crumbly yellow clay on the northern edge of the area.

The final matrix area, $F$, was the northern counterpart to area $B$. Area $F$ contained particularly large quantities of charcoal and very dark charcoalstained soil but very little baked clay and no visible ash. It is significant to note that many of the charcoal fragments in area $F$ appeared to be from finger-sized sticks. These fragments were concentrated directiy beneath the rocks--as if the rocks were placed atop a small stick fire and not disturbed after the final usage.

The pit feature was filled with ash and charcoal and measured approximately $12 \mathrm{~cm}(\mathrm{~N}-\mathrm{S}) \times 16 \mathrm{~cm}(\mathrm{E}-\mathrm{W})$. The pit was not recognized until the feature was partial1y excavated and cross sectioned, and the upper materials had been removed. The first cross section ( $F$ ig. 20, $x-x^{\prime}$ ) was grid south of the pit and did not intersect the pit. The pit was discovered during the final removal of the level containing the lower portion of the grid northern feature area (see Fig. 20,y- $y^{\circ}$ for a view of the second cross section showing the pit). For this reason the elevation of the original surface of the pit is not known, although it clearly occurred within the main feature level (approximately 99.96-99.88). The bottom of the pit was at 99.81, and the pit was at least $7 \mathrm{~cm}$ in depth. In profile the Feature 6 pit is very similar to the Feature 5 pit. Both have asymmetrical cross sections appearing undercut on one side and gradually sloping on the other.

The rock cluster around which the other aspects of the feature were arranged contained about 20-30 burned rock fragments at 1 east $5 \mathrm{~cm}$ in maximum diameter. A11 of the rock appeared to be either weathered, low grade (soft) 
1 imestone nodules or calcium carbonate concretions weathered prior to use. This description is typical of the eroding, calcareous material found on the slope of the ridge across the creek. The rock was heavily burned, and some were fragmented in situ (presumably due to thermal shock). The rocks were arranged in an irregular circular pattern with more in the outer ring than the central area of the cluster. Al1 rocks appeared to 1 ie on the same surface, at about 99.93-99.90.

Charred botanical remains were identified from two general matrix samples collected from the feature (mixed matrix areas). Charred Chenopodium fruits and Asteraceae achenes (an achene is a small, dry, hard fruit) were identified from both samples. One sample also had an 0xal is fruit which may be modern. These plant remains are all edible fruits, although they could have been introduced as accidently charred material.

Interpretation: Feature 6 is a very interesting example of a hearth feature evidencing several reuse episodes. The recovered faunal and botanical materials associated with the various feature matrix areas clearly indicate that Feature 6 was a cooking hearth. We can infer that bison, deer, turtle, Rabdotus 1 and snails, and several plant fruits were consumed in the vicinity of and possibly cooked in Feature 6.

The two pottery fragments recovered from in and around the feature are some of the 1 argest and best-preserved sherds recovered from the site. Both show carbonization on the exterior surface. This can be interpreted as resulting from the breakage of a cooking vessel in the feature vicinity. Two 1 ines of evidence support this possibility. First, the presence of uncharred bone and snails on top of and adjacent to the feature suggests that some food items were not directly roasted in the fire. The proposed mechanism for cooking food without direct roasting is by boiling within the ceramic vessel represented by the sherds. The second supporting observation is the placement of rocks in a small cluster with a small central rock-free opening. It will be recalled that the rocks were placed directly on top of the charcoal and that some of the charcoal under the rocks was incompletely carbonized, as if the rocks partialiy extinguished the charcoal directly underneath. Therefore, the rock cluster may have functioned as a cooking stand.

Another interesting aspect of Feature 6 is the 1 obes of charred soi1, ash, baked clay, and charcoal that extended to the east of the rock cluster. These appear disturbed in contrast to the layered appearance of the matrix and rocks with in the rock cluster. These lobes (matrix areas $A$, $C$, and $E$ ) are interpretated as hearth clean-out deposits representing earlier episodes of feature use. As many as three clean-out episodes may be evidenced by the extent of the lobes and by the difference in composition. (especially between areas $A$ and $C / E$ ). The burned rocks are both thoroughly burned and fragmented which may result from the reuse of the same rocks through several use episodes. If the rocks were used only for the episode represented by the rock cluster then the bottoms of the rocks should have been more heavily burned than the tops, which they were not.

It is interesting to note that the phosphate readings from the matrix areas (arbitrarily divided) are similar and also different from the other areas. The phosphate sample from matrix area $B(868 \mathrm{ppm})$ is comparable to that from 
area $F(649 \mathrm{ppm})$ and very different from the matrix area $C$ (1493 ppm) and $E$ ( 1529 and $1597 \mathrm{ppm}$ ) readings. These differences lend support to the separation of the major lobes.

The smal1 pit beneath fill lobe E provides possible evidence of an additional use episode. During one of the feature use episodes, perhaps a secondary fire was built within the pit and produced the fill lobe which covered the pit.

The Rabdotus concentration (area.D) on the northwest side of the rock cluster is interpreted as a refuse dump--perhaps the remains of a pot of 1 and snail soup.

In summary, Feature 6 is interpreted as an extraordinarily we11-preserved cooking feature that evidences repeated reuse of the same hearth. It is argued that meat, snails, and fruits from several species were cooked and consumed in and around the hearth. The 1 arge amount of charcoal, ash, baked clay, charcoal-stained soil, and fire-reddened soil in and around the feature attests to the intensity of use in this area. The fill lobes and the pit evidence several use episodes of the feature. The presence of 1 ithic tools, particularly the modified and trimmed flakes and the end scraper, may suggest that faunal processing took place around the feature. However, the fact that most of these 1 ithic tools were found on top of the fill may argue that they were discarded after the final use of the hearth. It is suggested that Feature 6 may be functional1y associated with one or several of the nearby bone clusters, Features $2 \mathrm{~A}, 2 \mathrm{~B}, 3$, and 10. The various aspects of Feature 6 , combined with the functional association of one or more of the bone clusters, form an almost complete sequence of prehistoric behavior.

\section{FEATURE 8}

Provenience: Feature 8 was centered in N110 ElOI and extended slightly west into N110 E100, south into N108 E100, southeast into N109 E102, and east into N110 E102. The feature was exposed in Levels 2 and 3 of these site units between an elevation of 99.87 and 99.76 .

Dimensions: The charcoal occurred within an irregular oval area measuring roughly $1.45 \mathrm{~m}(\mathrm{~N}-\mathrm{S}) \times 1.2 \mathrm{~m}(\mathrm{E}-W)$. The bone covered a 1 arger area, $2.3 \mathrm{~m}$ $(E-W) \times 1.5 \mathrm{~m}(\mathrm{~N}-\mathrm{S})$. The rock clusters measured roughly $65 \mathrm{~cm}(E-W) \times 55 \mathrm{~cm}$ $(\mathrm{N}-\mathrm{S})$ (grid northeast cluster) and $70 \mathrm{~cm}(\mathrm{NE}-\mathrm{SW}) \times 35 \mathrm{~cm}$ (NW-SE).

Asseciations: Thirty-six items of cultural material in association with Feature 8 were piece plotted. These items include a Perdiz arrow point and many faunal elements (see Table 26 and Figure 22). In addition to the plotted items, a number of other 1 ithic, ceramic, and faunal materials were recovered from within and adjacent to the feature.

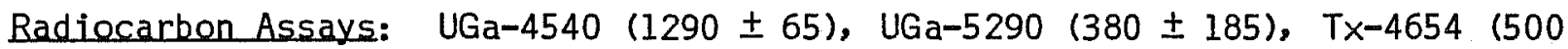
$\pm 60)$, Tx-4887 (700 \pm 80); a 11 are uncorrected and uncalibrated assays. See Section VII (Radiocarbon Assays) for a detailed discussion of the varying results of these radiocarbon assays. 
Special Sampling: Four matrix samples and a number of bags of charcoal were collected. The recovery of cultural materials, in particular charcoal, $f 1$ akes, and microfauna was very good from the two water-separated matrix samples. In fact the Lot 496 matrix sample had so much charcoal it was very difficult to sort. The phosphate level was al so tested from the Lot 496 sample. The reading of $762 \mathrm{ppm}$, while relatively high, is noticeably lower than the high readings from the central sections of Features 5 and 6 . This difference may wel1 be an artifact of the 1 imited phosphate samp 1 ing of Feature 8.

Description: Feature 8 was a loosely clustered concentration that consisted of a thin layer of charcoa1, two irregular rock clusters, and a large amount of anima 1 bone, most disarticulated, fragmented, and butchered deer bone. Definite evidence of postdepositional disturbance was noted in the form of 1 arge plant roots and several rodent runs. Even so, the feature appears to be the result of several overlapping activity episodes.

The charcoal layer was encountered near the surface of detection of the feature (approximate 1 y 99.89). The 1 ayer was thin ( $5 \mathrm{~cm}$ or 1 ess) and was composed of a very 1 arge number of chunk wood charcoal.fragments. Figure 22 shows the approximate extent of the charcoal 1 ayer. The 1 ayer was very discrete and seems to have been deposited on a surface which slopes very gently from the grid east (toward creek) to the grid west. The charcoal 7 ayer occurred within a 1 ightly mottled gray brown fine sandy clay loam that follows the same slope. The underlying matrix was an homogeneous gray brown fine sandy clay loam. slightly coarser (1ess clay) and browner. A firedamaged Perdiz point (plotted item 33) was found within the upper portion of the charcoal layer.

The rock cluster on the grid south and east side of the feature occurred within the charcoal 1 ayer. While most of the rocks were found within the charcoal 1 ayer, a few rocks on the far grid east side of the feature were directly above the charcoal. Some of the rocks appeared to have been fractured in situ. The bottom elevations of the rocks in this cluster ranged from 99.86 to 99.77 , although most were 99.80 or higher.

The second rock cluster was located on the grid northwest side of Feature 8, below to slightly within and on the edge of the charcoal cluster. The rock bottom elevations ranged from 99.84 to 99.77 ; most were 99.80 or 1 ower. No charcoal was found beneath any of the rocks in this cluster.

The numerous animal bone fragments associated with Feature 8 occurred over a wider area than either the burned rock or the charcoal 1 ayer. Most of the bone fragments were found around the edges of the rock and charcoal concentration, although some elements were found within. The bones were scattered, except for several small clusters (plotted items 9, turtie bone cluster; 25, cluster of 1 arge mammal bones; 23 and 24, two deer vertebrae which may have been articulated; and 28, several mammal vertebrae that were poorly preserved). None of the bones are burned. Most bones are fragmented. Spiral fractures and butcher marks (cuts) are present on several deer bones. As mentioned, the majority of the bones are identified as deer bones. The plotted bones ranged in bottom elevation from 99.87 to 99.76 , with most occurring above 99.80 . 
TABLE 26. PLOTTED ITEMS ASSOCIATED WITH FEATURE 8

\begin{tabular}{|c|c|c|c|}
\hline $\begin{array}{l}\text { Lot } \\
\text { Number }\end{array}$ & $\begin{array}{l}\text { Item } \\
\text { Number }\end{array}$ & Elevation & Identification \\
\hline 525 & 1 & 99.84 & large mammal rib fragments \\
\hline 525 & 2 & 99.82 & large mammal rib fragments \\
\hline 525 & 3 & 99.82 & turtle carapace scute, femur \\
\hline 525 & 4 & 99.80 & deer calcaneus \\
\hline 525 & 5 & 99.78 & deer radius fragment \\
\hline 525 & 6 & 99.83 & deer maxilla fragment \\
\hline 525 & 7 & 99.82 & deer molar \\
\hline 525 & 8 & 99.76 & large mammal fragment \\
\hline 525 & 9 & 99.83 & turtle radius and humerus \\
\hline 525 & 10 & 99.85 & deer radius fragment \\
\hline 525 & 11 & 99.79 & deer radius fragment \\
\hline 525 & 12 & 99.80 & deer metacarpal fragment \\
\hline 525 & 13 & 99.82 & deer rib fragment \\
\hline 525 & 14 & 99.85 & deer scapula fragments \\
\hline 525 & 15 & 99.78 & deer rib fragment \\
\hline 525 & 16 & 99.83 & arrow point distal fragment (A4) \\
\hline 525 & 17 & 99.79 & jackrabbit vertebrae (2) \\
\hline 525 & 18 & 99.87 & deer mandible fragment \\
\hline 525 & 19 & 99.80 & deer phalange \\
\hline 525 & 20 & 99.82 & turtle carapace scutes ( 2 ) \\
\hline 525 & 21 & 99.81 & deer size fragments \\
\hline 525 & 22 & 99.80 & deer radius fragments \\
\hline $526-3$ & 23 & 99.76 & deer lumbar vertebra \\
\hline $526-4$ & 24 & 99.76 & deer lumbar vertebra \\
\hline $526-1$ & 25 & 99.76 & large mammal fragments ( 8 ), deer metacarpal \\
\hline $483-1$ & 26 & 99.74 & deer calcaneus \\
\hline $463-3$ & 27 & 99.79 & deer caudal vertebra \\
\hline $442-1$ & 28 & 99.82 & mammal vertebrae fragments \\
\hline $442-2$ & 29 & 99.83 & deer phalange \\
\hline $442-3$ & 30 & 99.84 & deer metapodial \\
\hline $442-4$ & 31 & 99.83 & deer phalange \\
\hline $442-5$ & 32 & 99.84 & deer vertebra \\
\hline $443-1$ & 33 & 99.90 & Perdiz point ( $A I)$ \\
\hline $485-1$ & 34 & 99.81 & deer metapodial fragment \\
\hline $485-2$ & 35 & 99.82 & mammal vertebrae fragments \\
\hline $485-3$ & 36 & 99.80 & deer metapodial fragment \\
\hline $485-4$ & 37 & 99.81 & deer metapodial fragment \\
\hline
\end{tabular}

Note: The faunal elements are plotted by item number in Figure 22. The lot numbers are used in the faunal section (VII) of this report, which provides a detailed description of a 11 the feature bone (a) so see Table 10). 


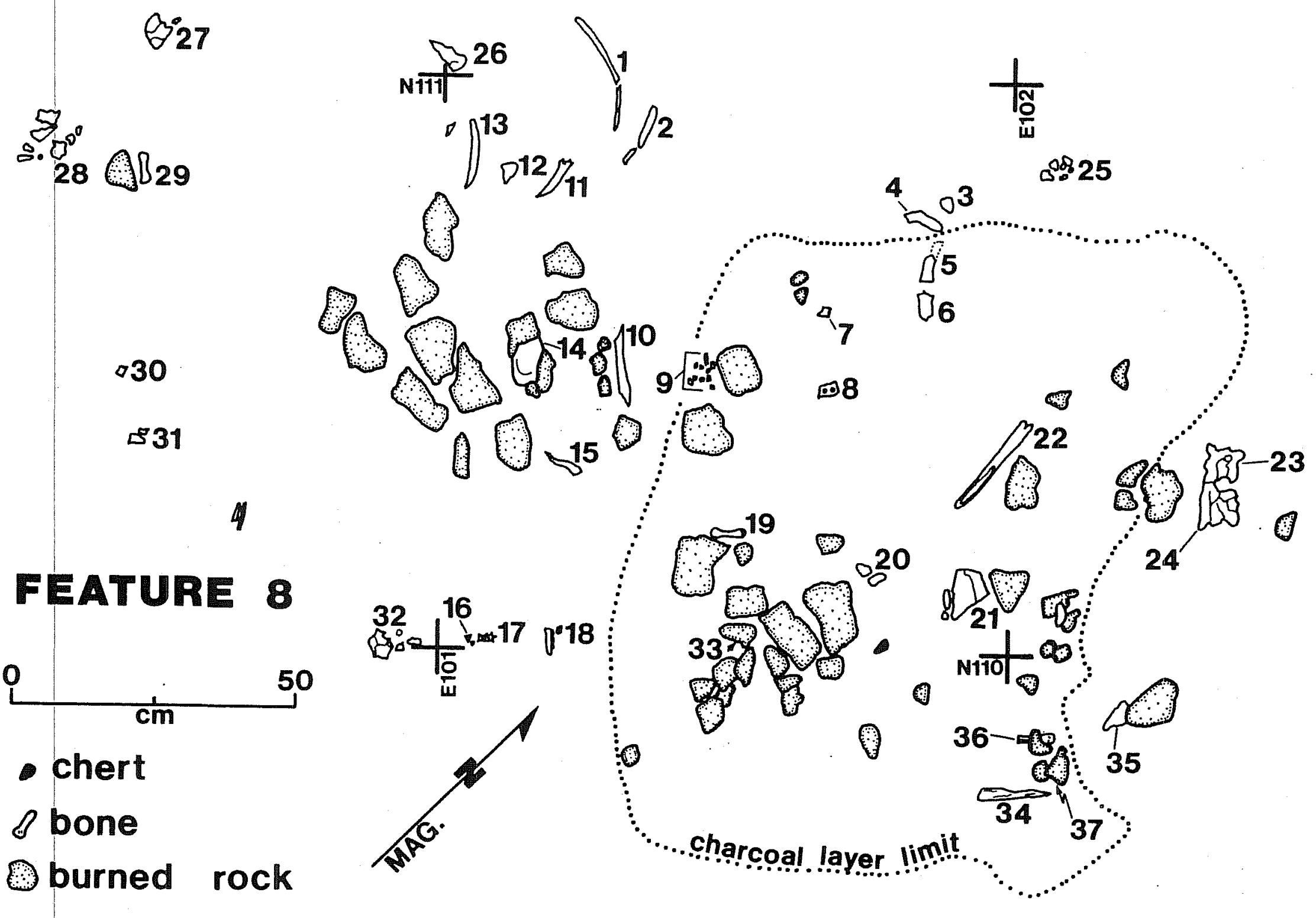

Figure 22. Plan Map of Feature 8. Numbered items are 1isted in Table 26. 
Interpretation: Feature 8 is somewhat difficult to interpret. The 1 ack of any evidence of fired soi 1 , ash, or baked clay suggests that the charcoal 1 ayer is not a primary deposit. The irregular rock clusters do not seem to form definite hearths such as the ring of rocks in Feature 6 . On the other hand, some of the rocks are fragmented in place (in other words, two fragments found side by side fit together). Perhaps the rocks split after deposition due to root penetration along thermal stress fractures.

The faunal materials may suggest a discrete activity--the butchering of a 1 arge deer. A 1 arge quantity of deer bones was recovered from Feature 8 representing several parts of the body of an adult deer. The bone is fragmented and spiral fractured with butcher marks; al1 support the feature interpretation. However, while most of the deer bones are of an adult, it cannot be stated that they were of the same animal. Nor can we rule out the possibility that the faunal materials are the result of more than one disposal episode. The lower surface of almost al1 the bones was below the bottom of the charcoal 1ayer, hence we can infer that the bone was deposited prior to the charcoal.

A plausible explanation for Feature 8 is that it represents a deer butchering episode (or the resulting disposal thereof), subsequently covered by a deposit of stained soil, rock, and charcoal. In the absence of any evidence of natural deposition, it is argued that the faunal remains were intentiona $11 y$ covered. The 1 owest fil1 1 deposit is represented by the northwestern rock cluster. From evidence on the opposite side of the feature, a profile suggests that a layer of mottled sandy clay loam was placed over a stable surface (which apparently the bones lay jumbled on). With in this soil 1 ayer were the charcoal layer and the southeastern rock cluster. It is suggested that the faunal remains were covered with a series of smaller deposits (basket loads?) removed from a fire hearth. The rock clusters, the mottled soil, and charcoal layers al1 seem to be different deposits (10ads?). Features 5 or 6 could have been the source of this fill.

\section{LIVING SUREACES}

A 1 iving surface is a discrete surface with an accumulation of occupational debris. The surface may be recognized stratigraphically as a physical interface or by the exposure of associated artifactual material lying on a common surface. At the Hinojosa site, the living surfaces were recognized by large accumulations of artifactual material vertically clustered on more or less 1 evel surfaces. The actual surfaces were not stratigraphical1y distinct except for the increased cultural material.

Two 7 iving surfaces were recognized. Both were only partially exposed as it was observed that material continued into the excavation unit walls. The presence of small intact clusters of cultural material and wel1-preserved fragile artifacts, such as bone tools and shell ornaments, suggests that the 1 iving surfaces were buried fairly rapidly. Both 1 iving surfaces were exposed below the plow zone. The presence of large quantities of highly fragmented cultural material in the upper levels in several areas of the site suggests that later 1 iving surfaces have been disturbed. 
The 7 iving surfaces. were recognized at 41 JW 8 when concentrated cultural materials were exposed in situ in several excavation units at approximately the same elevation. An effort was made to record as much of the material in place as possible. Often, however, the concentrations were so dense that isolated bone fragments, snails, flakes, and burned rock were removed in order to allow exposure of clustered materials, identifiable bone, and diagnostic artifacts. Thus, the living surface il1ustrations and inventories are biased toward these materials. This bias can be partially overcome by looking at the cultural material frequencies for the unit-levels containing the 1 iving surfaces. It should be noted that without in situ exposure, living surfaces would show up as horizons (horizontal concentrations) in cultural material distributions.

The excavation of 1 arge contiguous blocks is necessary to recognize and expose $1 \mathrm{iving}$ surfaces. The excavation areas at $41 \mathrm{JW} 8$ were 1 arge enough to detect two 1 iving surfaces; however, much 1 arger excavations would be necessary to fully expose these "macro" features. Recent excavations at the Rowe Valley site in Wi 11 iamson County by the Texas Archeological Society have demonstrated the value of exposing very 1arge site areas (Prewitt 1982, 1983, 1984). Thus, it must be recognized that the interpretation of a 7 iving surface is 1 imited by the 1 ack of knowledge of the actual size of the feature and the surrounding and related "macro" and "micro" features.

\section{FEATURE 7}

Provenience: N75 E91 and E92, N76 E91 and E92, 99.68 to 99.62. The feature continued into the grid north, west, and south wal1s.

Dimensions: The dimensions were impossible to define due to limited excavation and problems with leaf cutter ants. The exposed area measured about $2 \times 2.4 \mathrm{~m}$.

Asseciations: Numerous artifacts and bones were found on the surface. These are shown in Figure 23, and the plotted items are identified in Table 27. The "bone bed" feature, uncovered in 1975, was located immediately grid south of the section of Feature 7 exposed in 1981.

Radiocarbon Assays: None.

Special Sampling: Two matrix samples were collected.

Description: Feature 7 (Figs. 23 and 24), a concentration of cultural material, was partially sampled in 1981 and possibly in 1975. The 1975 testing of the "bone bed" and associated materials was not recorded as precisely as the 1981 excavations, but the 1981 feature description is incomplete due to problems with a leaf cutter ant bed. Therefore, the following discussion is based on $1 y$ on a partial sample of the feature and 1 imited information extracted from the 1975 field notes.

It is apparent that Units N75 E92 and N76 E92 were centered on an extreme1y dense concentration of cultural material found primarily within a 6-cm-thick 1 ayer. Within this concentration were a 1 arge number of bone fragments; 
TABLE 27. PLOTTED ITEMS ASSOCIATED WITH FEATURE 7

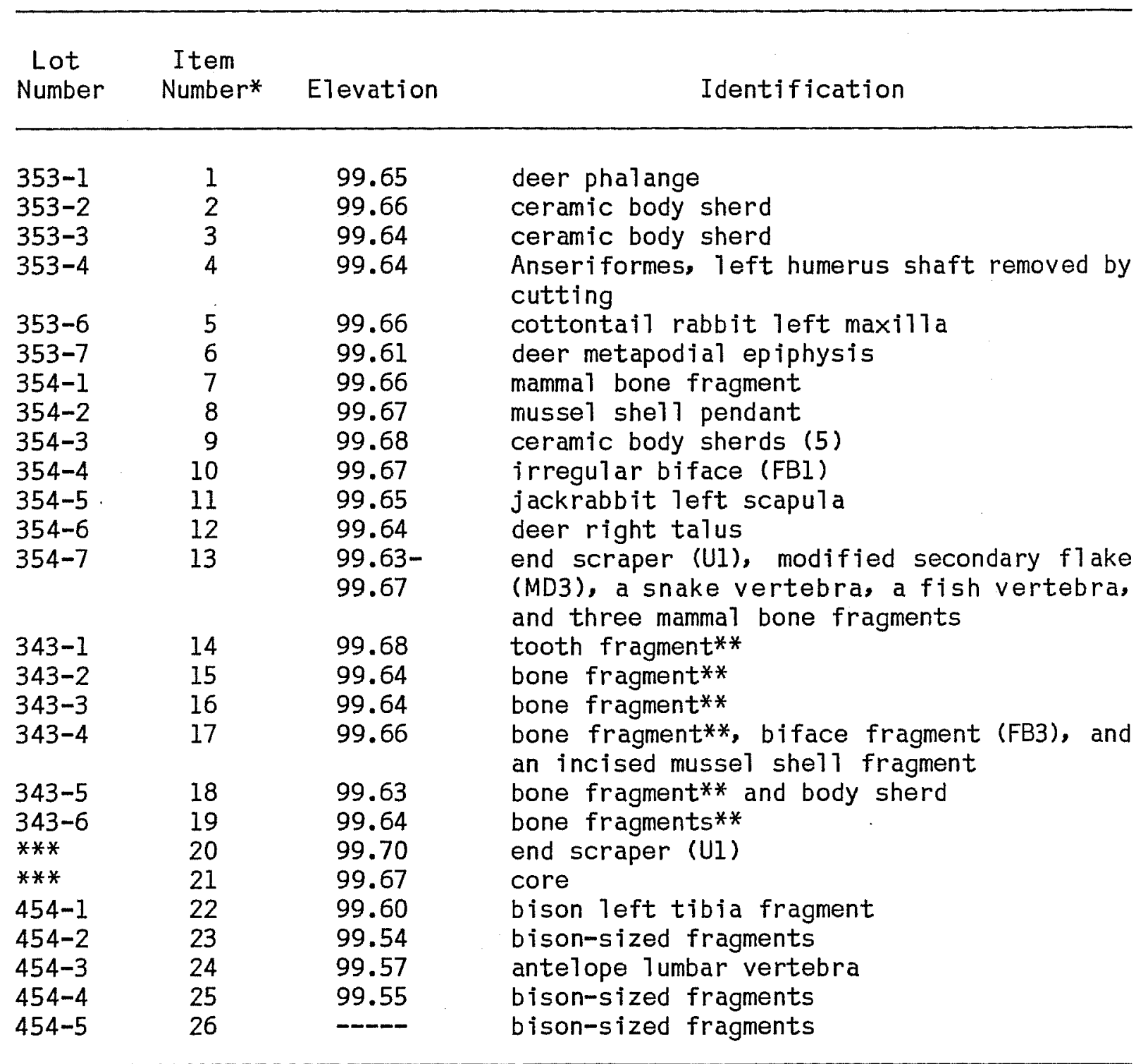

* Items 1-21 are plotted in Figure 23. The lot numbers are used elsewhere in this report to provenience these artifacts.

**Faunal materials from Lot 343 were not analyzed.

***Items 20 and 21 were recovered from N76 E93, a unit which was not completed due to ant problems and is not otherwise analyzed. These items are not mentioned or inventoried elsewhere in this report. 


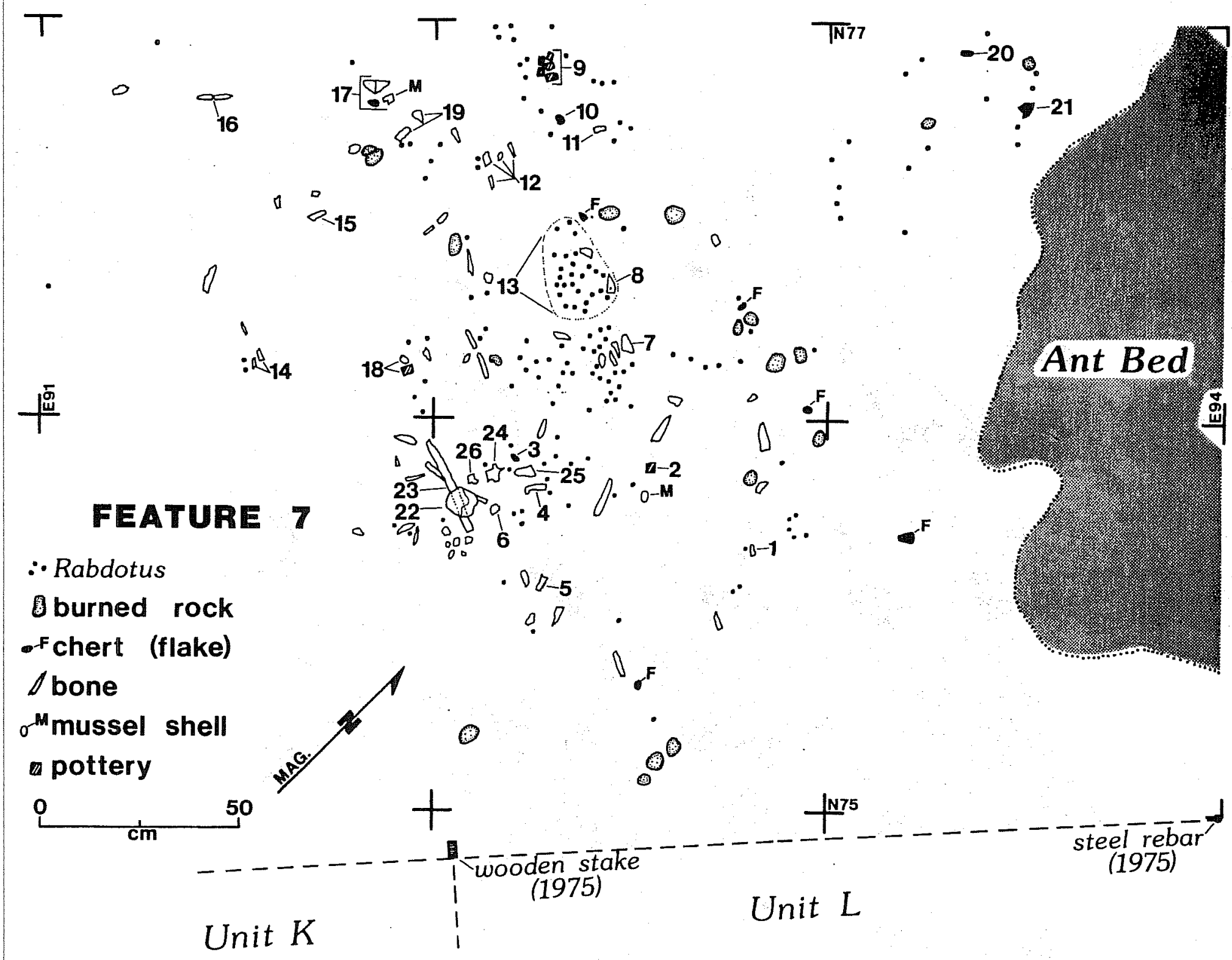

Figure 23. Plan Map of Feature 7. Numbered items are 1isted in Table 27. 


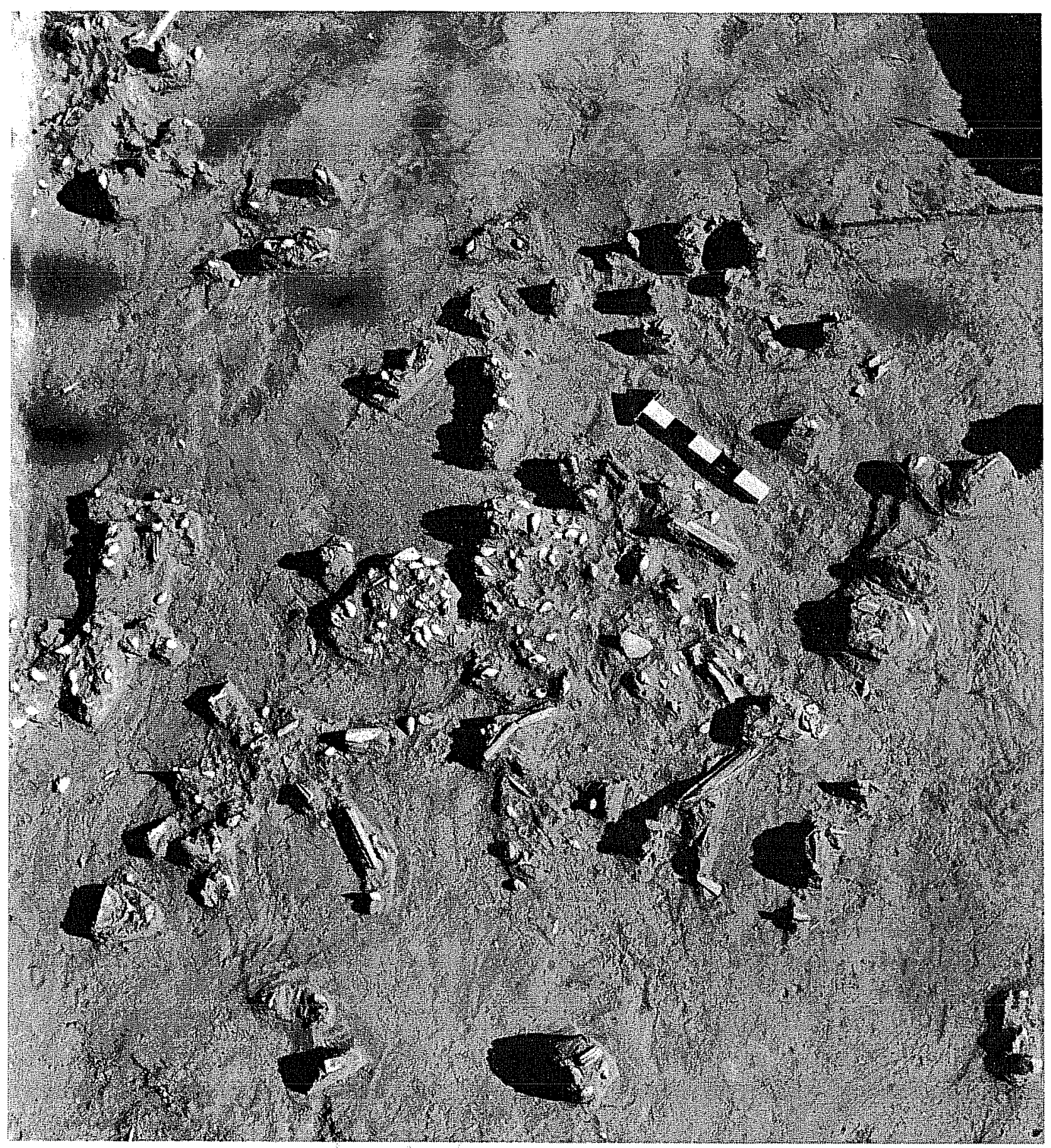

Figure 24. View of Feature 7. Note concentrated Rabdotus and fragmented bone. 
very 7 arge amounts of Rabdotus snails, including three clusters; a musse 1 she11 pendant, a piece of incised mussel she11; pottery sherds; biface fragments; and many modified and unmodified flakes. In addition, a small cluster of bone elements was uncovered within and below the concentrated 1 ayer.

The sma11 bone cluster was not given a separate feature designation, however, it was similar to the formally recorded cluster features. The bones represent a bison-sized 1 arge mammal and are badly fragmented. One bison bone and a pronghorn bone were identified with this fragmented cluster. The upper portions of several of the bone fragments were first detected at the same Teve 1 as Feature 7.

Four of the mammal fragments found in Feature 7 (items 7 and 13) are spiral1y fractured and have butcher marks. This suggests that the area may have been used for butchering animals.

Several hundred Rabdotus 1 and snails were recovered in association with Feature 7. Three clusters were apparent. The central cluster (Fig. 23, item 13) had 36 large snails, several artifacts, and bones. The Rabdotus clusters are comparable to those found within Feature 11.

Two incised mussel shel1 artifacts and a goose or duck humerus with a cut and snap brake, indicating the shaft was purposeful 1 y removed, were recovered from Feature 7. One of the mussel shell artifacts is a complete pendant (Fig. 12,d). The other is a fragment that may represent manufacturing debris. It is possible that the Feature 7 area was a mussel and bone working area.

Interpretation: Feature 7 is thought to represent a 1 iving surface or activity area deposited in a single occupational episode. This living surface is associated with the small cluster of bison bone found within and below the feature and possibly with the "bone bed" found in 1975. The "bone bed" was located about 1.5 to $2 \mathrm{~m}$ to the east of the central area of Feature 7 (as exposed). It is suggested that the "bone bed" was a 1 arge bone disposal feature (cluster), i.e.s a small erosional gully filled with butchered bone (most 1 y bison) and covered. Feature 7 may be the center of the butchering activity area from which the "bone bed" materials were derived. Due to the aforementioned problems, this interpretation must be considered tentative.

\section{FEATURE 11}

Provenience: Across most of the western two-thirds of the main Wagon Trail Area excavation block between approximately 99.95 and $99.85 \mathrm{~m}$ in elevation.

Dimensions: The defined portion of Feature 11 covers an area measuring $6 \times 5 \mathrm{~m}$ (NW-SE $\times$ SW-NE). The living surface obviously continues to the south and west. Most of the plotted items were found between 99.92 and 99.88 on a more or less level surface. 
Feature 11. It is not possible to enumerate all of the associated materials as many items were found on the screen or were otherwise not plotted in place. Figure 25 shows the approximate extent of Feature 11 and the distribution of the major plotted items. These consist of some 50 plotted bone elements, three ulna tools, three Rabdotus clusters (not including the cluster on the edge of Feature 6), three end scrapers, six modified flakes, seven ceramic sherds, a Perdiz arrow point, and four miscel 1 aneous 1 ithic tool fragments.

Radiocarbon Assays: See Feature 6.

Special Sampling: None.

Description: Feature 11 was a concentration of cultural materials all on the same surface level. The surface was defined by the artifact elevations and was not otherwise physically discrete. The concentration occurred at the bottom of the $\mathrm{plow}$ zone. It is $1 \mathrm{ikely}$ that other materials related to the feature have been displaced by plowing. The absence of materials east of the E98 grid 1 ine may be an artifact of the "wagon trail" or road on the inside of the fence.

One interesting aspect of Feature 11 was the occurrence of several sma 11 Rabdotus clusters. Four of these are shown in Figure 25 and are visible in the foreground of Figure 26. Each sma 11 cluster of 1 arge Rabdotus 1 and snails contained 20 to 40 snails and was vertically and horizontally discrete. Numerous scattered Rabdotus snails were found in Feature 11 . The clusters may represent smal1 piles of snail shel1s that were discarded after the snails had been consumed (or removed for consumption). Several other slight ly less discrete clusters were noted during the excavations within Feature 11 as well as other proveniences within the site.

Interpretation: Feature 11 is interpreted as a concentration of cultura 1 material left on a common surface after a single occupational episode. This is evidenced by the large number of items found vertically clustered at roughly 99.90, some 20 to $30 \mathrm{~cm}$ below the surface. The interpretation that the materials were deposited during a single occupational episode is based on the presence of intact artifact clusters (Rabdotus, bone fragments, and Features 6 and 10) and the presence of a number of fragile items that are well preserved. It is argued that if the surface had not been covered fairly rapidly by sediments and decomposed organic matter (1eaves and such) the clusters would not have survived intact, and the fragile items would have been poorly preserved.

A number of activites obviously contributed debris to the Feature 11 surface. Feature 6, as has been discussed, is believed to be a cooking hearth used for several cooking episodes. Feature 10 is interpreted as a faunal disposal pit dug from the Feature 11 surface or possibly higher. The three ulna tools (one pointed aw 1 and two blunt-tip flakers) attest to flintknapping and sewing/weaving activities. The end scrapers and modified flakes suggest hide working and other activities. The overall impression of the feature is of a discard area for the refuse of many activities. Feature 11 is obviously a part of a much 1 arger distributional pattern that cannot be accurately defined without the excavation of a much 1 arger surrounding area. 


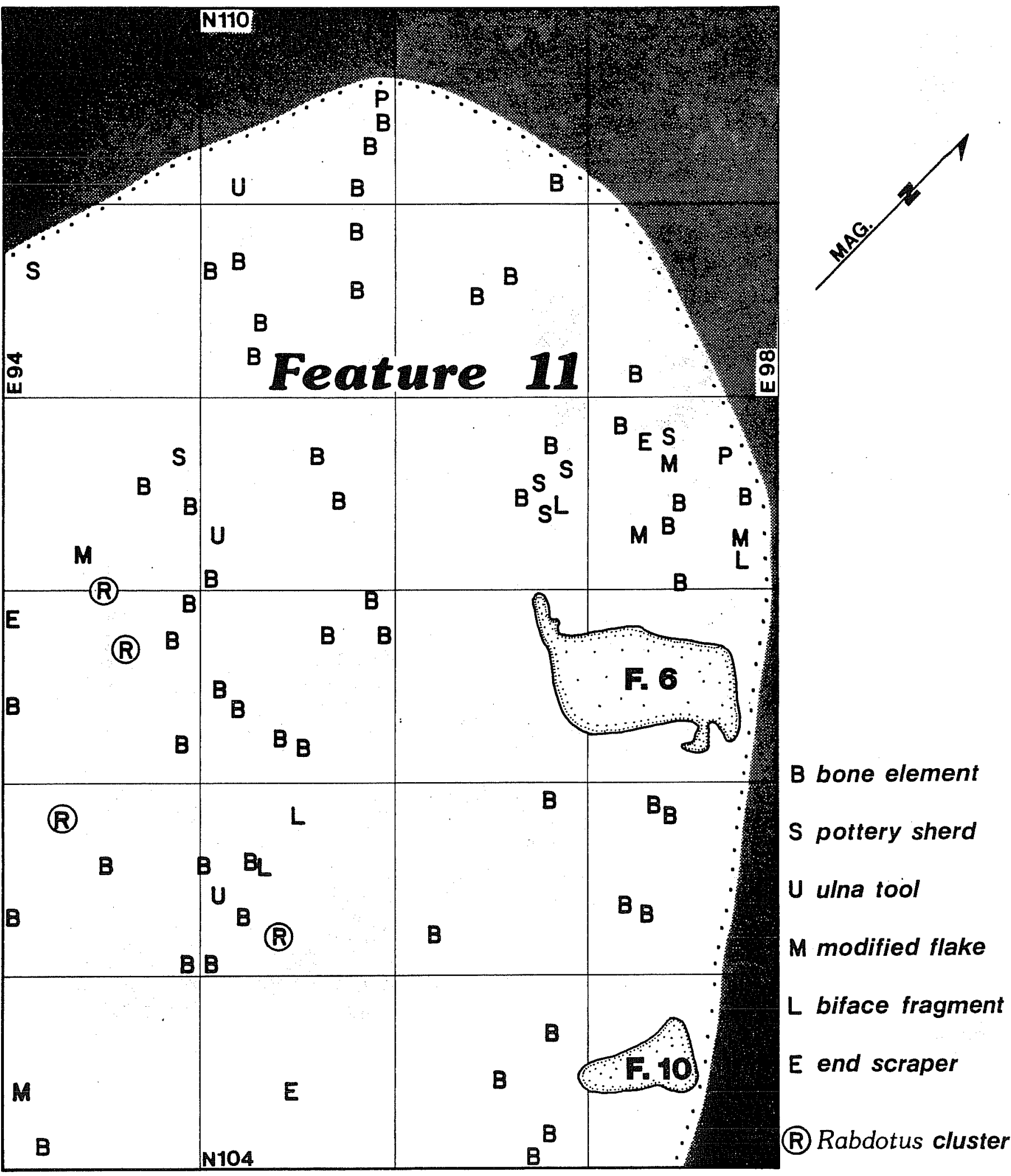




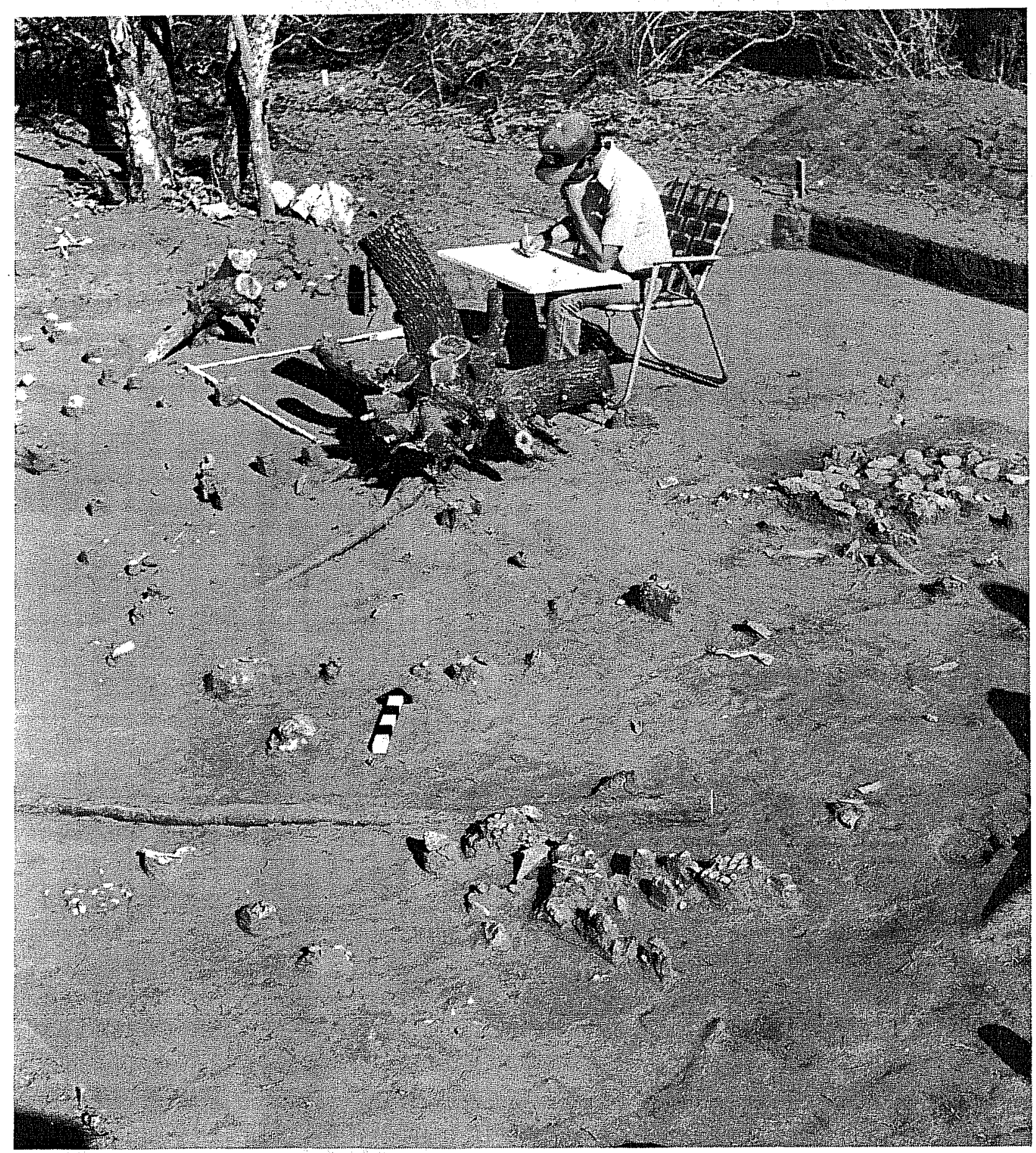

Figure 26. View of Feature 11. Courtenay Jones is plotting Feature 11 items. Feature 6 is visible on extreme right side. 


\section{ARTIFACT AND FEATURE DISTRIBUTIONS}

The distributions of the artifacts and features found at $41 \mathrm{JW} 8$ during the 1981 season are discussed both for the overall site and for each excavation area. The emphasis here is $p 1$ aced on the discussion of the artifacts and features found in the major excavation block, the Wagon Trail Area. The raw data on the artifact distributions are presented in Appendix 1.

\section{OVERALL DISTRIBUTIONS}

On a site-wide basis, the cultural materials are strongly concentrated in the upper $30 \mathrm{~cm}$. A few excavation areas exhibit deeper distributions; however, very little evidence was found of earlier occupations or more than one horizon. Unfortunately, the bulk of the cultural materials was recovered from Levels 1 and 2 in a 11 areas of the site. Levels 1 and 2 occur whol $1 \mathrm{y}$ and partially, respectively, within the plow zone at the site. This is documented by the study of plow-damaged arrow points (Section VII: Perdiz Arrow Point Special Studies), the absence of intact features in Level 1 and Leve1 2 (except in the WTA), and the excavation wall profiles (Fig. 27).

The virtual absence of any physical evidence of an earlier occupation or deeper horizons and the 1 ack of earlier chronological indicators suggest that the cultural materials can be attributed to a single component. There is some evidence in the. Wagon Trail Area that the Late Prehistoric component represents several repeat visits to the site by the same group or closely related groups. Even so, all of the primary occupation materials are restricted to a single horizon in any one excavation unit. In other words, there are no examples of significant cultural material concentrations in nonadjacent levels within any excavation unit. In all cases where cultural materials were found below Level 3, the quantities of almost all materials tapered dramatically. It is also significant that the excavation units with the deeper distributions of cultural materials were also the units with the most evidence of postdepositional disturbance.

\section{HORIZONIAL ARTIFACT DISTRIBUTIONS}

Based on the preceding reasoning, it can be assumed that materials found in any excavation level are attributable to the Late Prehistoric component. Thus the horizontal distributional patterns are used for a comparison of the various excavation areas. Table 28 shows the horizontal distribution of various artifact categories by excavation area. Each excavation area is physically separated from the other areas as shown in Figure 1 . Due to the variation in excavation area size from a $1-\times 2-m$ area (N123 ElO6) to an irregular area with 48 contiguous $1-\mathrm{m}^{2}$ (WTA), the excavation areas are compared on the basis of the unit cell averages (density).

A unit cell at $41 \mathrm{JW} 8$ is the smal lest provenience unit, the $1-\mathrm{m}^{2}$. The unit ce 11 averages are calculated by totaling al1 the cultural material counts or weights of a given category for every level within an excavation area and dividing the resulting total by the number of unit cells in the area. For examp 1 e, 63 Perdiz points were found in the 48 unit ce 11 s of the WTA. The 

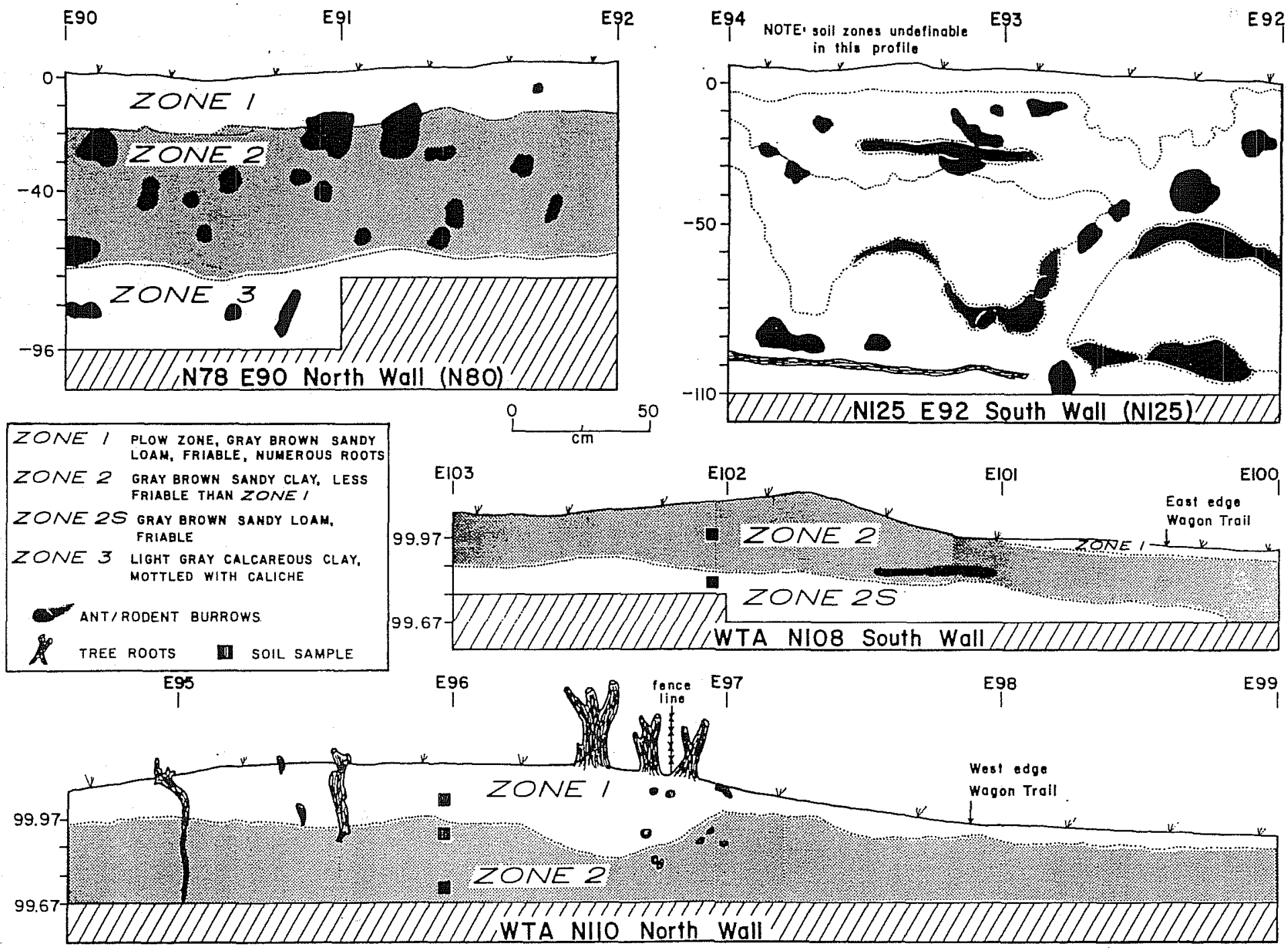

Figure 27. Excavation Unit Profiles. 
TABLE 28. HORIZONTAL ARTIFACT DENSITIES BY EXCAVATION AREA

\begin{tabular}{|c|c|c|c|c|c|c|c|c|c|c|c|c|c|c|c|}
\hline $\begin{array}{c}\text { Excavation } \\
\text { Area }\end{array}$ & $\left\{\begin{array}{c}\text { Number } \\
\text { of Cel1s }\end{array}\right.$ & $\begin{array}{l}\text { Arrow } \\
\text { I. Al }\end{array}$ & $\begin{array}{l}\text { Points } \\
\text { A4 }\end{array}$ & Bifaces & I U-1 & I Sherds & I MD & D & I Cores & & Rabdotus & 1 & Mussel & & $\mathrm{BRW*}$ \\
\hline & 1 & I & 1 & 1 & 1 & 1 & 1 & 1 & 1 & & & 1 & & & \\
\hline "Bone Red". & 8 & 10.88 & 11.00 & i 2.00 & 11.00 & 11.88 & i 11.00 & I 204.75 & 10.50 & & 184.12 & i & 0.75 & & 1.05 \\
\hline & 1 & I & 1 & 1 & 1 & 1 & 1 & 1 & 1 & & & I & & & \\
\hline N78 E90 & 1 & 11.00 & 10.75 & 4.00 & 0.25 & I 16.50 & i 9.00 & i 175.75 & 10.00 & 1 & 266.00 & i & 1.75 & & 1.63 \\
\hline & 1 & i & 1 & 1 & .. & 1. & i & 1 & 1 & & & 1 & & & \\
\hline N80 El02 & 4 & 10.75 & 10.00 & 0.50 & 10.25 & 2.25 & 5.50 & 133.25 & 10.00 & & 48.50 & i & 0.50 & & 0.25 \\
\hline & 1 & 1 & 1 & 1 & I & 1 & 1 & 1 & 1 & & & 1 & & & \\
\hline N92 E92 & 1 & 11.50 & 0.75 & 2.50 & 10.75 & 13.75 & 1.15 .00 & 132.00 & 10.25 & 1 & 73.75 & i & 0.75 & & 0.98 \\
\hline & 1 & 1 & I & 1 & I & I & 1 & I & I & & & 1 & & & \\
\hline N95 E82 & 1 & 11.50 & 0.00 & 11.00 & 0.75 & 4.25 & 12.25 & I 125.25 & 10.75 & 1 & 15 & i & 0.50 & & 2.31 \\
\hline & 1 & 1 & 1 & 1 & 1 & 1 & 1 & 1 & 1 & & & 1 & & & \\
\hline N100 E93 & 1 & 0.50 & 1.00 & 3.25 & 10.00 & 8.00 & 112.75 & 1113.75 & 0.50 & 1 & 75 & i & 1.00 & & 2.37 \\
\hline & 1 & 1 & $i$ & i & $i$ & i & I. & $i$ & $i$ & & & i & & & \\
\hline WTA & 48 & 1.31 & 11.33 & 2.27 & 10.75 & 7.60 & 10.48 & I 162.77 & 0.31 & | & 14 & i & 1.79 & & 0.75 \\
\hline & 1 & 1 & 1 & I & 1 & I & i & 1 & 1 & & & i & & & \\
\hline N123 E106 & i & 0.50 & 10.00 & 0.00 & 0.00 & 0.50 & 1.00 & 12.00 & 10.00 & $\mid$ & 158.50 & i & 1.50 & & 0.40 \\
\hline & 1 & 1 & 1 & 1 & 1 & 1 & 1 & I & I & & & 1 & & & \\
\hline $\mathrm{N} 125$ E92 & 1 & 11.00 & 10.50 & 3.25 & 11.50 & 8.75 & 115.00 & 133.75 & 10.75 & | & 724.00 & I & 39.00 & & 6.40 \\
\hline & $i$ & i & i & i & i & i & i & i & i & & & i & & & \\
\hline Artifact & 1 & 1 & 1 & I & I & 1 & 1 & 1 & 1 & $\mid$ & & 1 & & & \\
\hline Totals & 82 & 96 & 84 & 183 & 50 & 675 & 883 & 112,330 & 28 & & 19,103 & I & 269 & & 100.97 \\
\hline & 1 & I & 1 & 1 & I & 1 & 1 & & I & & & & & & \\
\hline Aver & i & i & I & I & i & 1 & 1 & 1 & i & & & i & & & \\
\hline Densities & $\cdot$ & 11.17 & 11.06 & 2.23 & 10.71 & 8.23 & 10.77 & 1150.36 & 10.34 & & 232.96 & & 3.28 & & 1.23 \\
\hline
\end{tabular}

*Burned Rock Weight (BRW) in k1lograms. A11 other ftems are counts. 
ce 11 average is 1.31 (63 divided by 48). Note that it does not matter how many excavation levels were dug in a given unit cell because this is a cell average rather than a level average.

The artifact categories not shown in Table 28 are represented by so few specimens that a horizontal distribution has 1 ittle relevance. In some cases several artifact categories are combined. All the complete and fragmentary bifaces ( $B$ and $F B$ ) are combined except for the arrow points. $A 11$ the modified debitage categories (MD) and al1 the debitage categories (D) are combined.

Table 28 shows that most artifact categories are not evenly distributed among the excavation units, an unsurprising observation. Two of the areas, N80 El02 and N123 El06 have very 1 ow concentrations of a 11 materials and are considered to be out of the major occupation zone. It is significant that these two areas are the easternmost excavations on the very edge of the bluff top overlooking the creek.

A11 of the remaining areas with moderate to high artifact distributions are considered part of the main occupation area. It is thus apparent that the western, northern, and southern 1 imits of the site were not reached by the excavations. It should be noted that Table 28 is organized so that the southernmost area is at the top, and the northernmost area is at the bottom. Thus, one can see at a glance some north-south trends in the artifact distributions. For example, the Perdiz points occur in the greatest density in the central areas of the site (as tested) while the pottery sherd density is greater in the southern areas.

It is interesting that the southernmost areas (the "bone bed" area and N78 E90) and the northernmost unit (N125 E92) have most of the highest artifact densities at the site. Other trends are apparent; however, it is difficult to place much emphasis on the significance of these trends as they are based on comparatively 1 ittle testing. The reader is reminded that the 1981 investigations were not oriented toward sampling the entire site but rather locating a we11-preserved area and focusing on a block excavation.

Each excavation area will be summarized in terms of the significant artifact distributions and features. Postdepositional disturbances that could have effected the distributions are also discussed as well as vertical distributions. Some inferences as to activity areas are drawn.

\section{"BONE BED" AREA}

Our attempts to open a major excavation block in the "bone bed" area of the site were seriously hampered by a huge leaf cutter ant nest (Figs. 1 and 23 ). This was unfortunate because the artifact densities were comparatively high in this area. The highest cell density rate for debitage at the site was recorded for this area. Above average densities of end scrapers, sherds, modified debitage, and cores were also recovered in this area. The other artifact categories have moderate densities in the "bone bed" area that are slightly below the site average for most categories. 
The eight cells in the "bone bed" area were excavated to a depth of 30 or $40 \mathrm{~cm}$ below the surface (Level 3 or 4). As is the case over most of the site, the artifact quantities were lower in Levels 3 and 4 than Levels 1 and 2. Feature 7 was recorded in this excavation area in the 1 ower portion of Leve1 2. Just south of the 1981 excavations in this area, the "bone bed" was uncovered in 1975 (Hester 1977). In all likelihood, extensive excavations in this vicinity would produce additional intact features. This area is considered to be within the intensive occupation zone at the Hinojosa site.

\section{N78 E90}

Unit N78 E90 is just north of the "bone bed" area and has comparable artifact densities. The highest densities of bifaces and pottery sherds at the site were recovered from N78 E90. Above average debitage, Rabdotus, and burned rock densities were a 1 so recorded. The four cel1s were excavated through Level 5 (two cel1s), Leve1 7, and Level 8. The highest recovery of most artifact categories occurred in Leve1 2 or 3. A1 1 artifact categories except Rabdotus tapered off in the lower levels. The Rabdotus recovery actual1y increased somewhat in Leve1 7. No explanation is readily apparent as this increase is not correlated with increases in other categories. No cultural features were recorded. Moderate ant and rodent disturbances were noted in this area (Fig. 27) and may have contributed to the presence of smal1 numbers of artifacts in the lower levels.

\section{N80 E102}

Unit N80 E102 is located on the bluff edge and appears to have been on the margin of the occupation area. The excavations were conducted through Level 3 (two cel1s), Leve1 4, and Level 5. A11 categories of artifacts occurred in low to very low densities. Ant, rodent, and root disturbances were noted.

\section{N92 E92}

Unit N92 E92 had high densities of Perdiz points, bifaces, end scrapers, sherds, and modified debitage. The excavations were continued through Level 3 (two cells) and Level 5 (two cells). The upper two levels had very high densities, Levels 3 and 4 had very 1 ittle cultural material, and Level 5 was sterile. Other than the plow zone, no disturbances were noted. No features were exposed.

\section{N95 E82}

Unit N95 E82 was the westernmost excavation at the site and was placed within the wheat field that was planted during the 1981 field season. The clay content of the soil in this area was higher than other tested areas of the site. Higher than average densities of Perdiz points, modified debitage, end scrapers, cores, and burned rock were recovered. The excavations continued 
to Leve1 3 (two cel1s), Level 4, and Level 5. Once again, high artifact densities were evidenced in the upper two levels, low densities in Level 3 , and almost nothing in the lowest two levels.

One smal1 rock cluster was exposed in Level 2. This cluster did not have a noticeable concentration of charcoal or a we 11-defined shape, therefore it was not formally recorded as a cultural feature. The cluster was found in the lower portion of the plow zone and was probably partially displaced. A phosphate spot test of the cluster matrix indicated only a moderate level of phosphate.

The artifact recovery and the rock cluster suggest that the N95 E82 area was with in the main occupation zone.

\section{N100 E93}

Unit N100 E93, a four-cel1 area, was 1 ocated just south of the WTA. A11 cel 15 were excavated through Level 6. As with most areas, high densities of cultural materials were recovered from the upper two levels. The biface, modified debitage, core, and burned rock densities were higher than the site average. Interestingly, a minor increase in cultural material occurred in Level 6 where a smal1 cluster of burned rock (Feature 4) was recorded. The rock cluster was associated with a slight increase in debitage and 1 itt $1 e$ else. The absence of charcoal or artifacts, which could have provided chronological information, 1 imits the interpretation of this feature. As it is the deepest feature found at the site, it could date to an earlier brief occupation.

\section{N123 E106}

Unit N123 El06 was a two-cell excavation area placed on the very edge of the bluff toward the northern end of the site. Both cells were excavated through Level 8. Low to very low densities of cultural material were recovered from a11 1evels. Minor changes in density were observed on a vertical basis as materials were recovered in al1 levels. The wall profile revealed that the deposits sloped markedly from west to east (toward the creek). The cultural materials in the unit are thought to be derived from slope wash deposits of materials originally deposited up the slope (to the west). Several 1 arge rodent runs were observed. This area is interpreted as being down slope from the occupation zone and out of the main site area.

\section{N125 E92}

Unit N125 E92 was a four-cel1 area and the deepest excavation at the site. A1 1 cel1s were excavated through Leve1 11. Once again very high densities of cultural material were recovered from the upper two levels, while low densities were recovered from the lower levels. Minor increases in debitage and burned rock were recorded for several of the cells in Levels 7 through 9. A sma 11 rock cluster (Feature 1) was recorded in Leve1 4. Rock scatters. were recorded in Leve1s 3 and 9. These burned rock accumulations are not regarded 
as particularly significant due to the extreme disturbance noted in the area. During the excavation, many areas with noticeably unconsolidated (1oose) soil were noted and attributed to rodent activity. When the excavation wall was profiled (Fig. 27), the extent of the disturbance was so great that any apparent cultural feature was suspect. It is hypothesized that the severely disturbed area is the result of field leveling activites. The high densities of certain artifacts indicate the area was within the main occupation zone.

The N125 E92 area contained the highest densities of unifaces, cores, Rabdotus, mussel umbo, and burned rock of any area at the site. The Rabdotus, mussel umbo, and burned rock densities are in particular, far and above any densities in evidence in the other portions of the site. This may be partialiy explained by the severe disturbance in the area. Perhaps field leveling resulted in the area being filled by adjacent surface materials. On the other hand, these densities could indicate a major activity area, where mussels and snails were cooked or discarded.

\section{WAGON TRAIL AREA}

The WTA excavations were the main focus of the 1981 field season. The excavations began with two separate four-cel 1 units that were eventual 1 y connected as the area was expanded to:48 cel 1s and a smal1 $0.5-\times 1-m$ unit (added to expose Feature 9). In comparison to the other excavation areas, the WTA had the highest density of arrow point fragments (AI) and above average densities of Perdiz arrow points, bifaces, end scrapers, debitage, and Rabdotus snails. The densities of all other categories were slightly below the site average except for burned rock which was noticeably scarce. Three to six levels were excavated in each cell, with most excavated through Leve1 4. The greatest densities were recovered from the upper two levels; however, moderate quantities were al so recovered from Levels 3 and 4 .

As has been mentioned, the WTA was less disturbed than any other tested area of the site. The plow zone effected the upper level and a half on the field side of the fence. The large mesquite trees along the fence caused some disturbance by their roots. Just inside the fence on the creek side, the soil was compacted by traffic along the "wagon trail" or field road. Other disturbances were caused by rodent and insect burrowing. The presence of seven we1 1-preserved features attests to the relatively minor degree of postdepositional disturbance in the area.

The comparatively 1 arge excavation area warrants a closer 1 ook at the artifact and feature distributions in the WTA. Figures 28 through 33 are distributional maps of various artifact categories and features in the WTA. The artifact density maps were prepared by extracting the raw data from the provenience charts in Appendix 1 and plotting the numbers on $p 1$ an maps of the area. Various combinations of levels were used depending on the artifact category. For example, most al1 the sherds were found in Levels 1 and 2, hence these levels were combined for the density map. Burned rock occurred in al1 levels, hence maps were constructed for Leve1s 1 and 2 and Levels 3 and 4. The density intervals were chosen by 1 isting a 11 the cell totals for any given category (for example, the Level 1 and 2 totals of sherds) and looking for breaks in the distributions. In this way the highest densities 


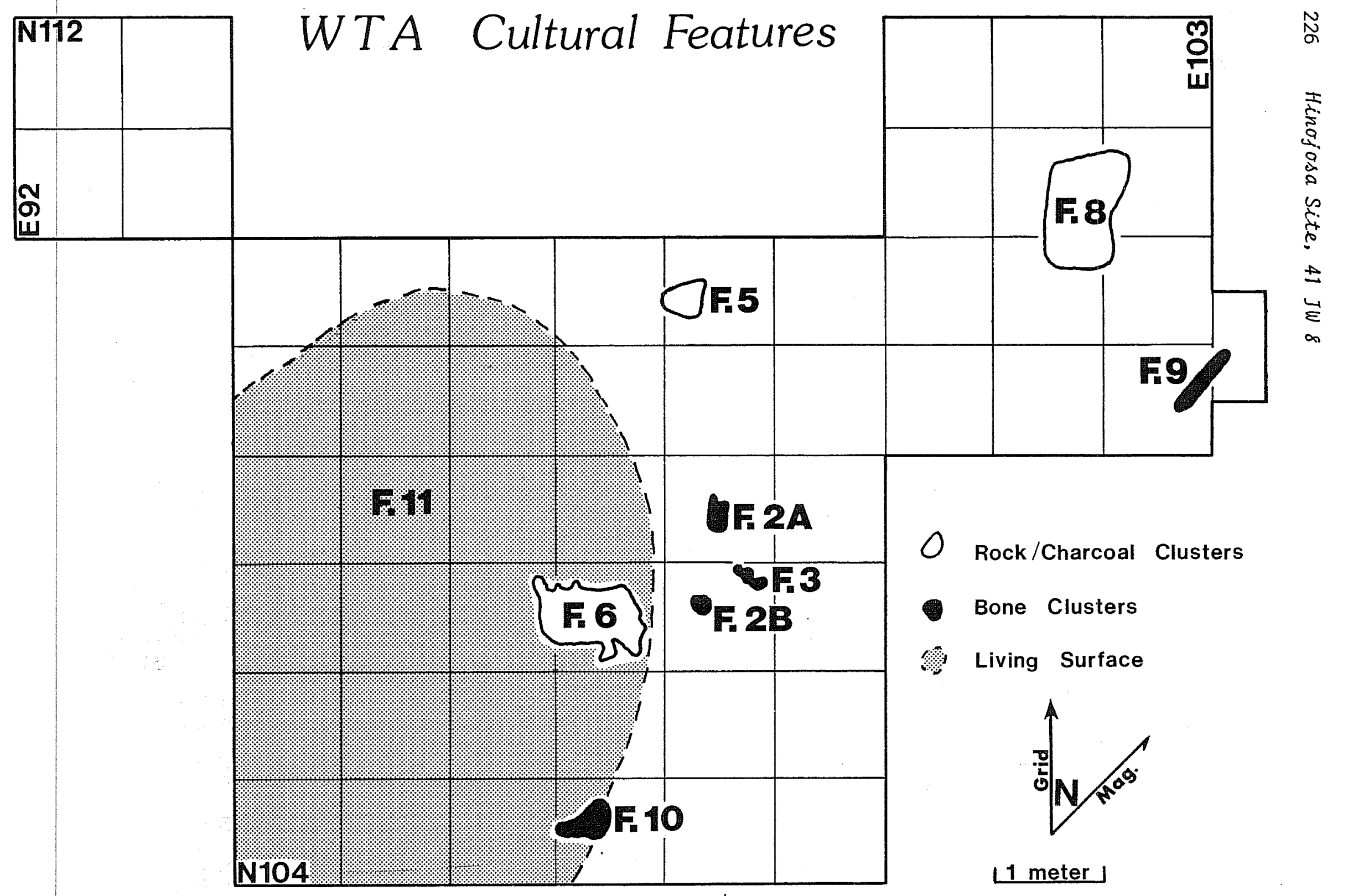

Figure 28. WTA Cultural Feature Distribution. 
for any given category are highlighted. The resulting maps al 10 w us to compare the distributions of various artifact categories across the WTA.

Overal1, most artifact categories have higher densities in the western half of the WTA than the eastern half. In particular the northeast cell block (WTANE) has comparatively low densities of many artifact categories. In fact if this block were removed from the WTA cel1 averages, the WTA would have noticeably higher densities of most artifact categories. It is significant that the WTANE is on the edge of the creek bluff. All of the excavations near the bluff edge revealed comparatively low artifact densities. This suggests that most of the site occupation occurred away from the edge of the bluff.

The distribution of the cultural features in the WTA somewhat contradicts the previous statement as two of the features (Features 8 and 9) were found near the bluff edge. As Figure 28 shows, a 11 of the features in the WTA were found in the eastern half of the area except Feature 1l, the 1 iving surface. It is difficult to determine if the WTA features are contemporaneous or represent activites from several reoccupations. The rock/charcoal cluster features (5, 6, and 8) have overlapping radiocarbon assays, however, the majority of the Feature 6 assays are earlier than the assays from Features 5 and 8 . The bone cluster features $(2 \mathrm{~A}, 2 \mathrm{~B}, 3,9$, and 10) are generally lower in elevation than the rock/charcoal features; however, since they are interpreted as bone disposal features that were placed in small pits or erosional features it is 1 ikely that some or all are contemporaneous with the other features. It may be significant that none of the rock/charcoal or bone clusters over 1 ap horizontal1y. If one were found directly or partially above another, then multiple occupations could be inferred. Thus, the possibility that a 11 the features are contemporaneous cannot be ruled out.

The mapped artifact distributions show a number of reasonably djstinct concentrations that suggest specific activity areas. It should be noted that the 1-m cel1 may not provide enough resolution to accurately define activity areas. Based on the block excavations at a number of sites in the Choke Canyon Reservoir area, Hall (personal communication) believes that 50$\mathrm{cm}$ provenience cel1 $1 \mathrm{~s}$ are needed. Hal1 argues that the $1-\mathrm{m}$ ce 11 masks the distribution of smal1 activity areas. Nonetheless, the distribution maps of the WTA do reveal artifact clustering at the $1-m$ cell resolution that suggests behavioral patterning. The distributional patterns of each plotted artifact category are discussed next.

The WTA distribution of Rabdotus 1 and snails is plotted for Level 2 in Figure 29 (upper). Level 2 was chosen because the Rabdotus quantities were higher in most units in Level 2, and they were associated with Feature 11 which had several plotted clusters of snails. The single cel 1 recovery rates in Level 2 ranged from a 1 ow of seven in N109 El02 to a high of 378 in N106 E95. Most of the higher densities of Rabdotus snails were found in the western half of the WTA. Two definite anomolies are present, the N106 E95 concentration and a concentration of 253 found in N105 E99. Both of these squares have much higher quantities of Rabdotus than the surrounding squares. These are interpreted as disposal piles of snails. Four smal1 clusters were defined within Feature 11. These four clusters occur a meter to a meter and a half away from the center of N106 E95 and almost ring the ce11. It may be 

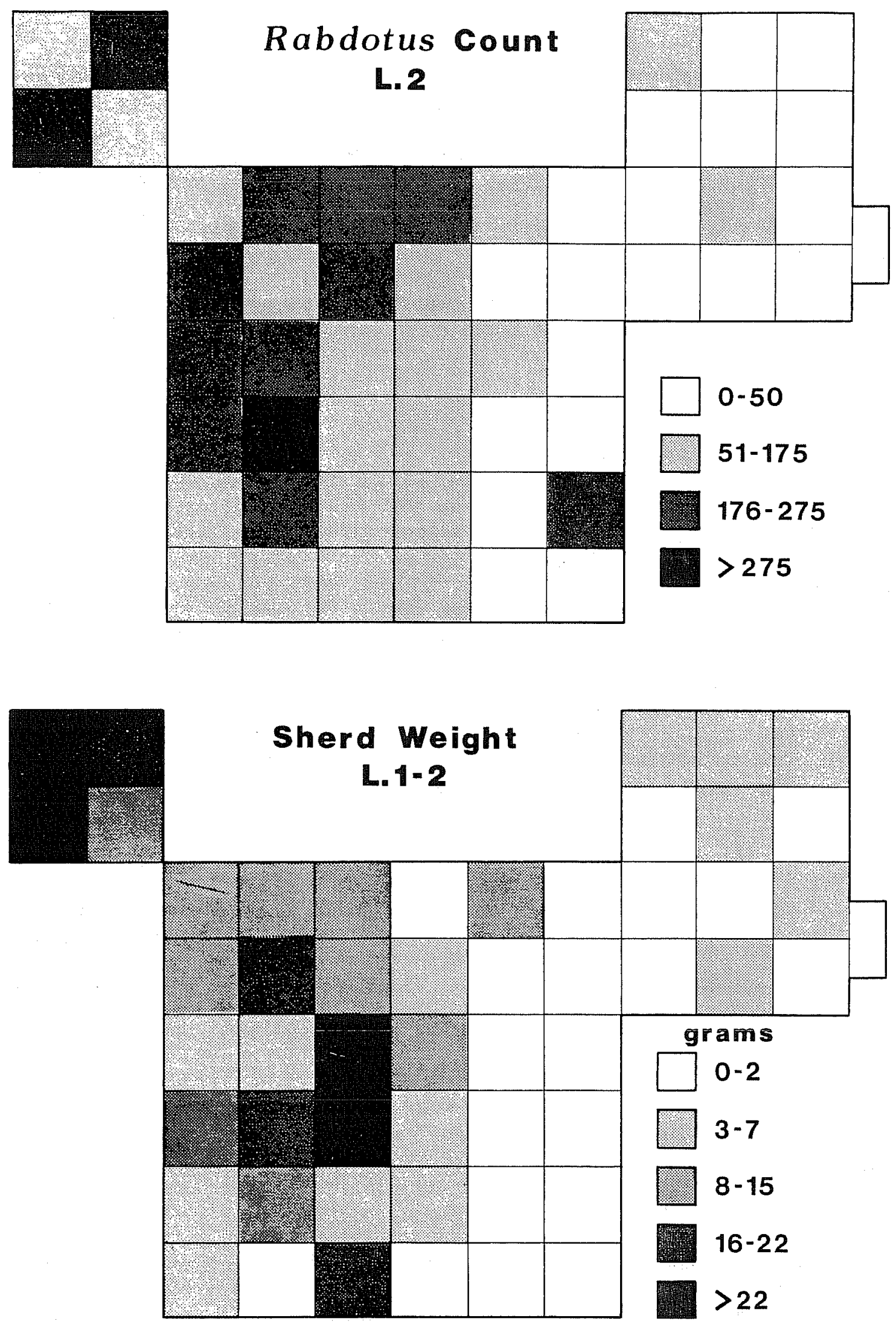

Figure 29. WTA Rābdotus Dístribution, Level- 2 and WTA Sherd Weight, Levels 1 and 2. 

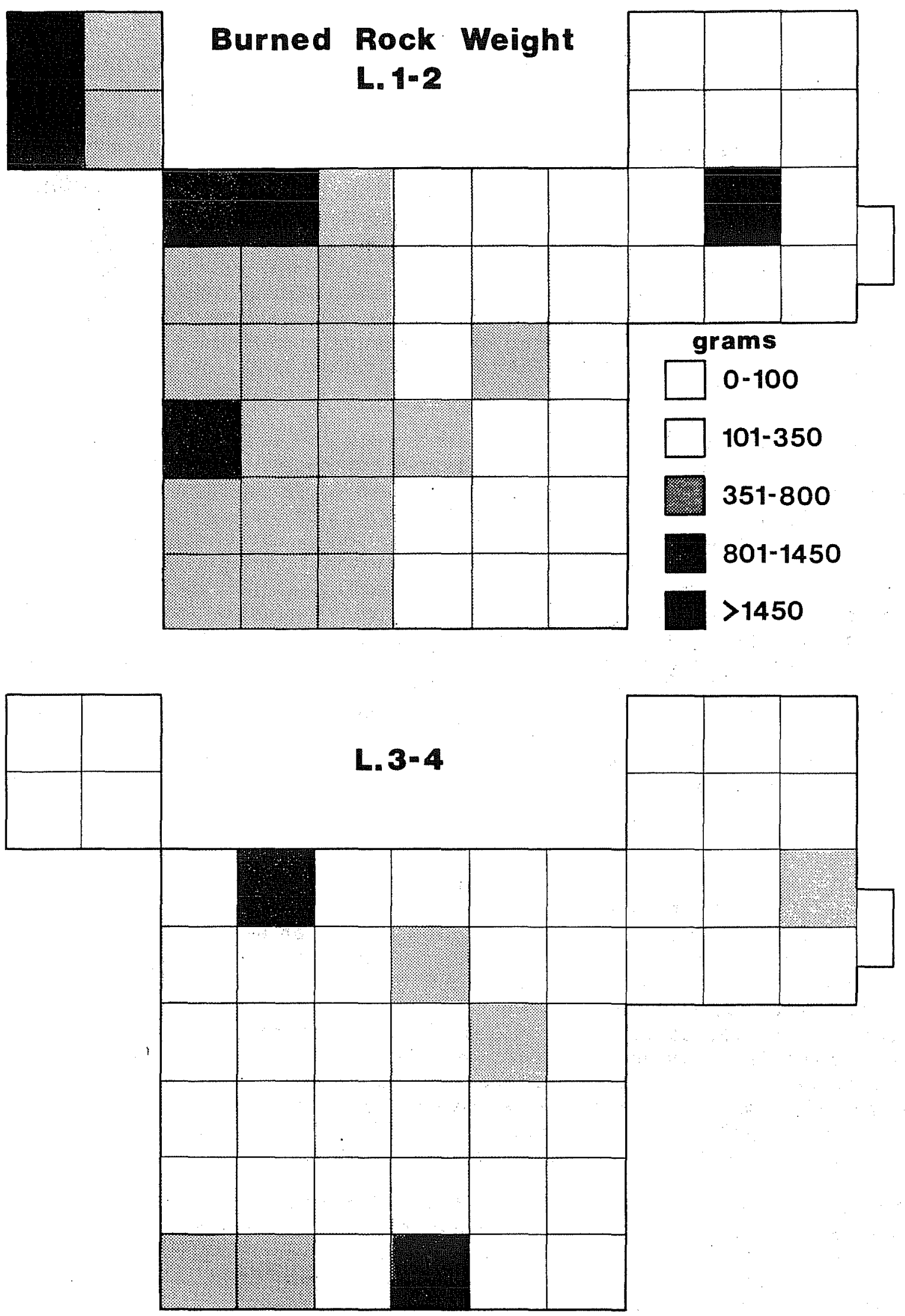

Figure 30. WTA Burned Rock Distribution, Levels 1, 2, 3, and 4. 
significant that the two anomalies occur east and west of the two features interpreted as primary hearths or cooking features (5 and 6). If these distributions are assumed to be contemporary, then one could suggest that the snails were being discarded away from the most likely cooking locations.

It is interesting to note that Rabdotus snail.s appear to be negatively correlated with the bone clusters. Very few Rabdotus shel 1s were found in association with any of the bone clusters. This suggests that snail processing/disposal was a separate activity from bone processing/disposal. This could be attributed to several different reasons: (1) snail gathering was not done when animal meat was available; (2) snail and meat processing/ disposal activities were conducted by separate members of the group; or (3) the two activities were conducted at different times of the year (during different occupations).

Figure 30 shows the distribution of burned rock in Leve1s 1 and 2 and Levels 3 and 4. The Level 1-2 map shows consistently higher rock densities in the western half of the WTA. This map also shows at least five anomalies with noticeably higher quantities of burned rock. It is interesting that the rock/charcoal cluster features are only partially correlated with the high density cel1s. The Level 3-4 map shows consistently less rock than the upper map, but also shows five higher density anomalies. These lower anomalies are not correlated with any of the rock/charcoal cluster features. Two of the concentrations on the lower map are correlated with upper map anomalies, therefore probably reflect single disposal events. The fact that overal1, the cells with high burned rock density are not directly associated with fire features suggests that these distributions may be 1 inked to disposal patterns. The presence of three anomalies on each map that do not over 1 ap with lower or higher anomalies may suggest temporal differences in occupation. The lowest anomalies presumably represent earlier disposal events than the overlying upper anomalies. This supports the idea that the site deposits represent several repeat occupations.

Figure 29 (1 lower) shows the WTA distribution of ceramics in Levels 1 and 2. Once again, the highest densities occur in the western half of the WTA, and several higher density clusters or anomalies can be defined. The higher densities of pottery sherds show wider distributions than the snail or rock concentrations. The central higher density cluster occurs immediately west of Feature 6. It will be recalled that Feature $\sigma$ is interpreted as possibly having been used to cook (boil?) snails in a ceramic vessel. In fact the ceramic and Rabdotus anomalies west of Feature 6 do overlap. The other major ceramic concentration occurs in the four-ce 11-block on the northwest corner of the WTA. Both ceramic anomalies may represent the main sherd distribution of broken vessels. This possibility is difficult to evaluate in view of the extremely fragmented nature of the ceramic sample.

Figure 31 (upper) shows the WTA distribution of baked clay in Levels 1-3. Comparatively smal1 quantities of baked clay were recovered. Baked clay was typical1y recovered as smal1 1 umps and is interpreted as resulting from building fires within or on top of clay-rich soil. Although baked clay was found in association with both Feature 5 and Feature 6, the higher density ce 17 surround these features. This may partialiy be a result of the removal of considerable quantities of baked clay in the matrix samples collected from 

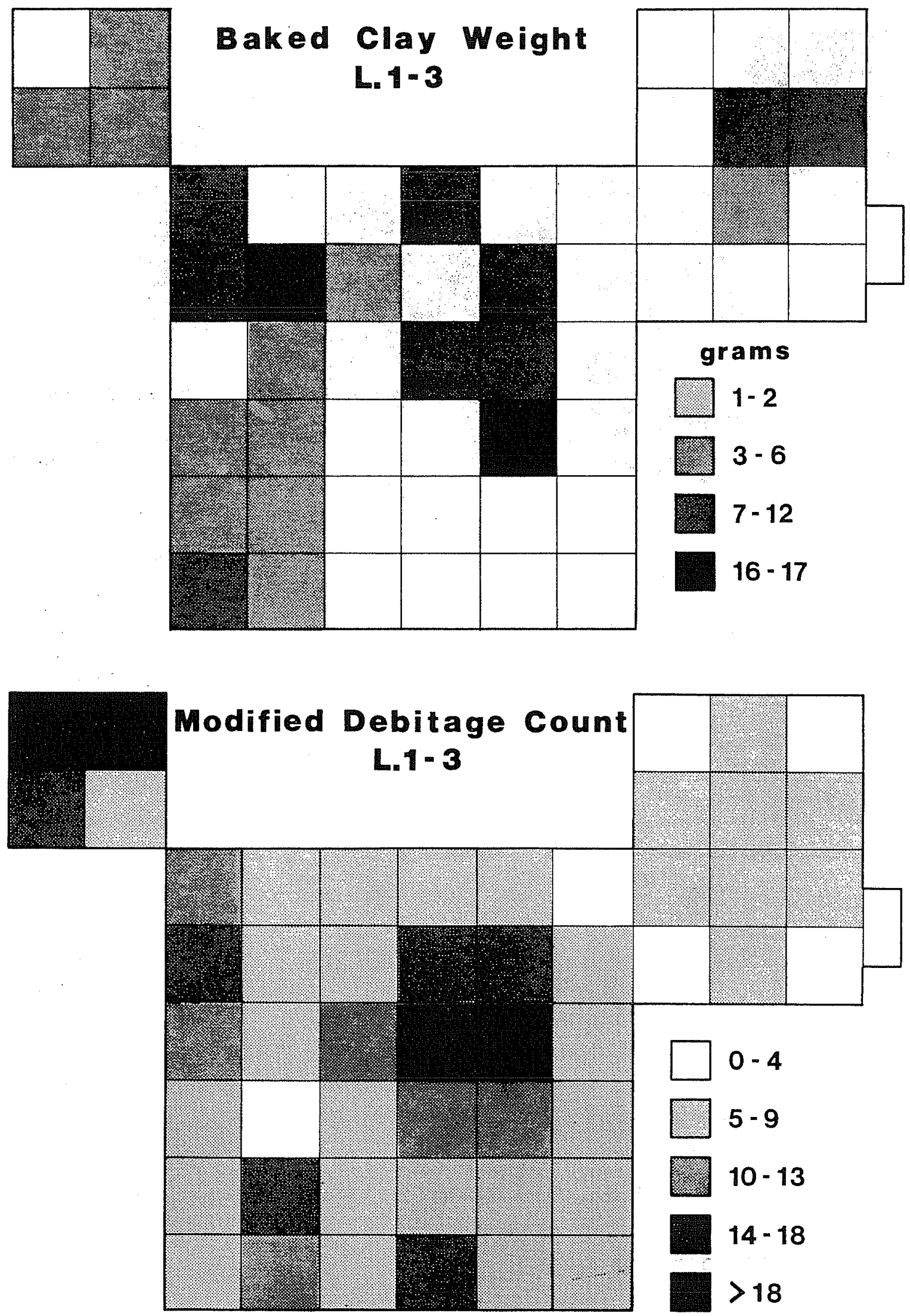

Figure 31. WTA Baked C1ay Distribution, Leve1s 1-3 and Modified Debitage Distribution, Leve1s 1-3. 


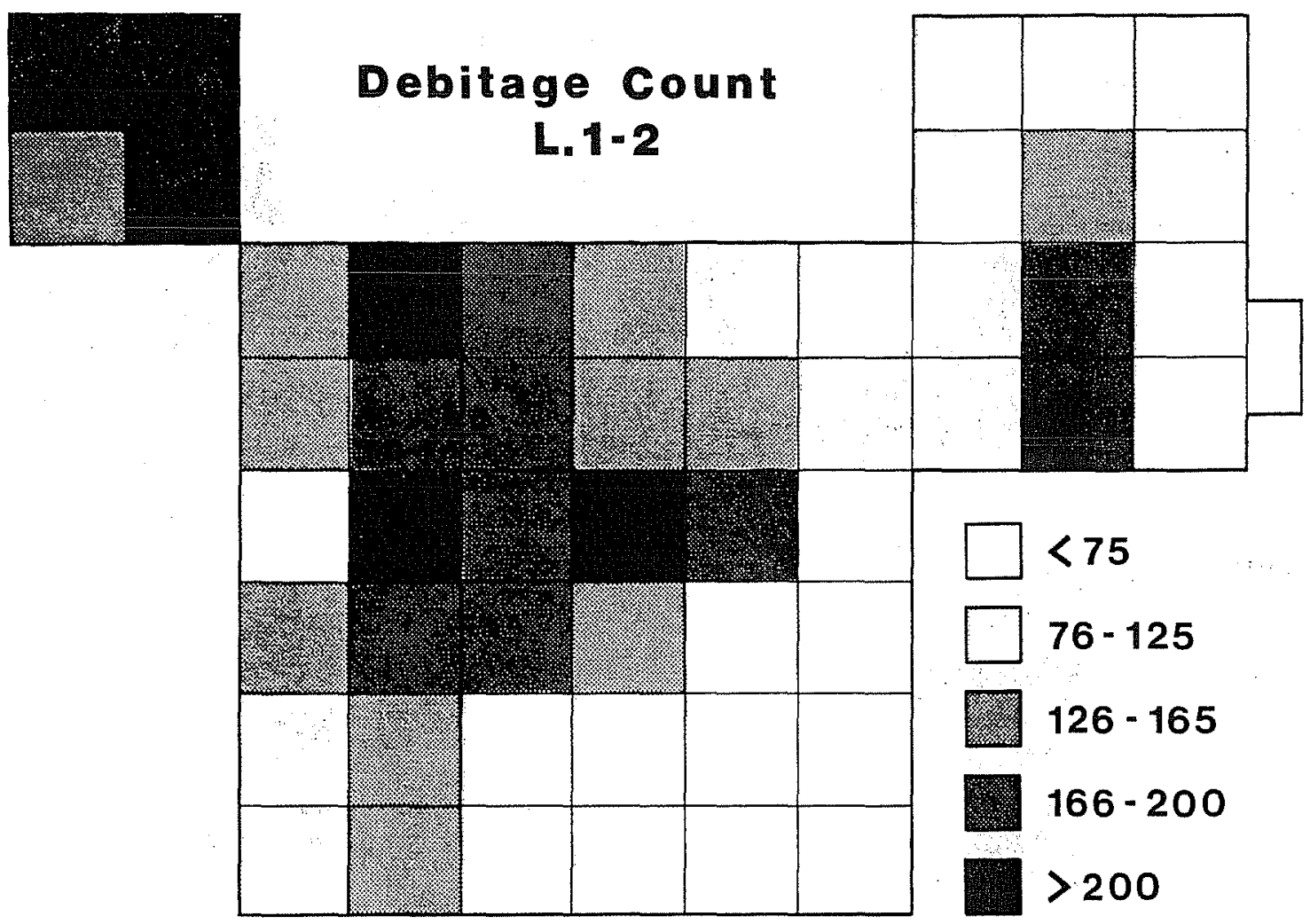

\begin{tabular}{|c|c|c|c|c|c|c|c|c|c|}
\hline \multirow{2}{*}{$\begin{array}{l}0 \\
0 \\
0\end{array}$} & \multirow{2}{*}{$\frac{0}{000}$} & \multicolumn{6}{|c|}{ Biface Fragments and Cores } & O & 0 \\
\hline & & & & & & & & 00 & \\
\hline & & $\begin{array}{l}0 \\
0 \\
0\end{array}$ & 0 & 0 & 00 & 00 & & O & O \\
\hline & & 00 & & 0 & & 0 & 00 & .. & 0 \\
\hline & & 0 & 000 & $\begin{array}{l}0 \\
0 \\
0\end{array}$ & $\begin{array}{l}00 \\
00\end{array}$ & $\begin{array}{l}0 \\
0 \\
0\end{array}$ & 0 & & \\
\hline & & 000 & - & ${ }_{0}^{0}$ & 0 & 00 & 00 & O Bifa & \\
\hline & & 00 & 0 & - & 0 & & 00 & & \\
\hline & & 00 & - & 0 & $\begin{array}{l}10 \\
0\end{array}$ & & 0 & & \\
\hline
\end{tabular}

Figure 32. WTA Cores, Biface Fragments, and Debitage Distributions. 
these features. The matrix baked clay has not been quantified. Feature 8 is directly associated with a baked clay anomalie. Several of the burned rock and baked clay concentrations coincide or overlap. Both are obviously related to fire activities.

Figure 32 shows the Leve1 1-2 distributions of debitage, bifacial fragments, and cores in the WTA. Table 29 shows the cell densities of biface fragments and cores by the plotted frequency ranges. The biface frequency is highly correlated with debitage frequency; progressively more bifaces were found in the cells with progressively higher debitage quantities. With one exception, the density of the cores is also positively correlated with increased debitage. These correlations and the map distributions provide good evidence for a major flintknapping activity area located in the northwest quadrant of the main WTA excavation block.

Figure 31 (lower) shows the WTA distribution of modified debitage in Levels 1-3. Several high density concentrations are apparent. The 1 argest concentration is centered in the area between Features 5 and 6 . This concentration partially overlaps the debitage, biface, and core concentration, but appears to represent a separate activity area. The density of modified debitage was compared to the density of debitage by looking at the distribution of ce 11 density rankings. In general, the higher densities of debitage are associated with higher densities of modified debitage. However, the cel1s with on $1 y$ a moderate density of debitage (126-165) have the highest average modified debitage densities. This may indicate that while modified debitage pieces (informal flake tools) are more 1 ikely to be found in areas with higher debitage quantities they have a separate distribution, thus may represent separate activities.

Figure 33 (upper) shows the distribution of end scrapers (UI) and beveled knives (BI) in the WTA (a11 levels). Interestingly, the illustration clearly shows that while end scrapers have a much wider distribution, the beveled

TABLE 29. WTA DEBITAGE RECOVERY COMPARED WITH BIFACE FRAGMENT AND CORE FREOUENCIES

Debitage Density Number of Cells Biface Frequency Core Frequency

$\begin{array}{crrr}<75 & 7 & 0.86 & 0.00 \\ 76-125 & 19 & 1.05 & 0.21 \\ 126-165 & 11 & 1.91 & 0.36 \\ 166-200 & 12 & 2.08 & 0.17 \\ >200 & 3 & 2.67 & 1.00\end{array}$

Note: This table was constructed on the basis of the data derived from Appendix 1 and shown in Figure 32. 


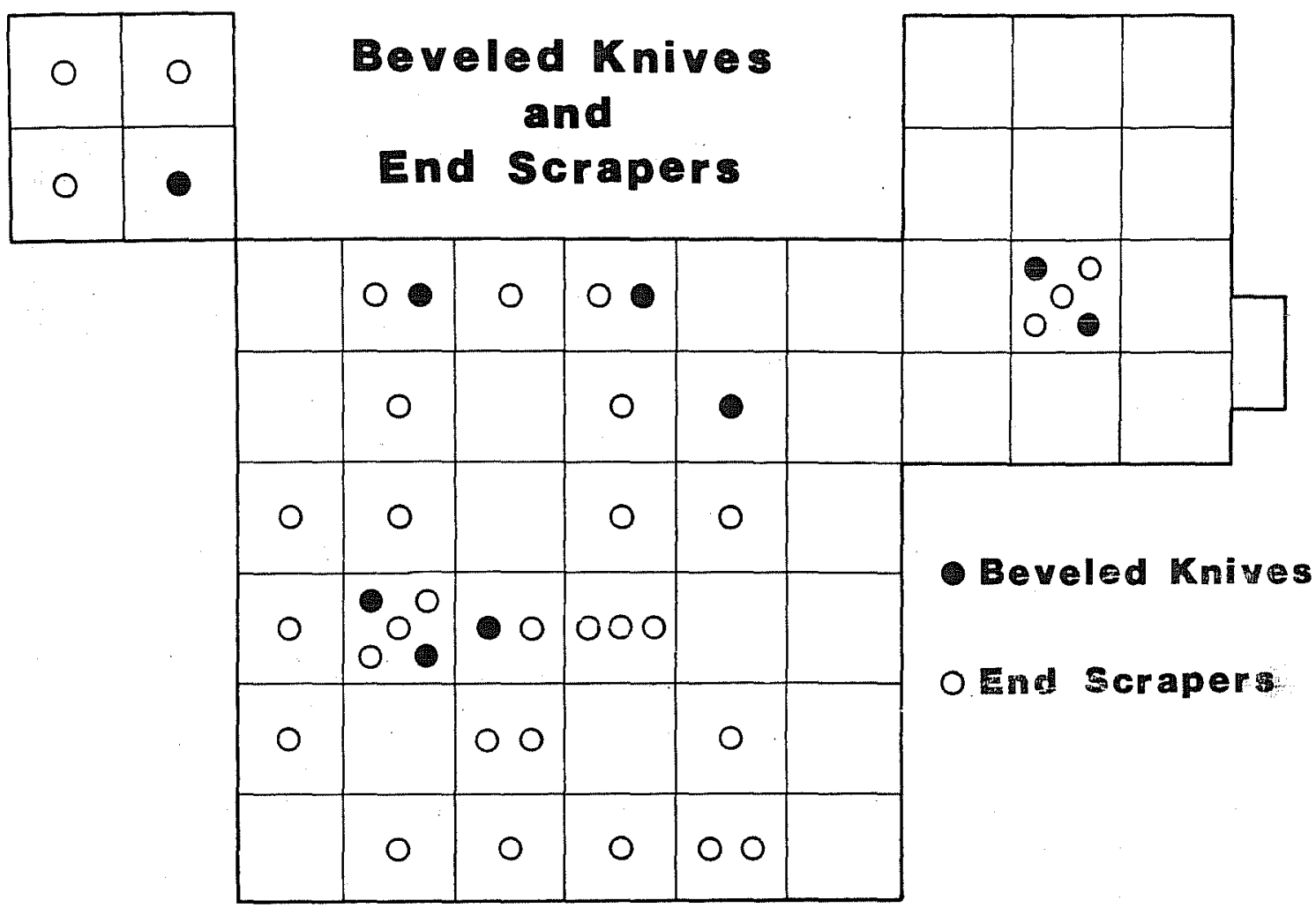

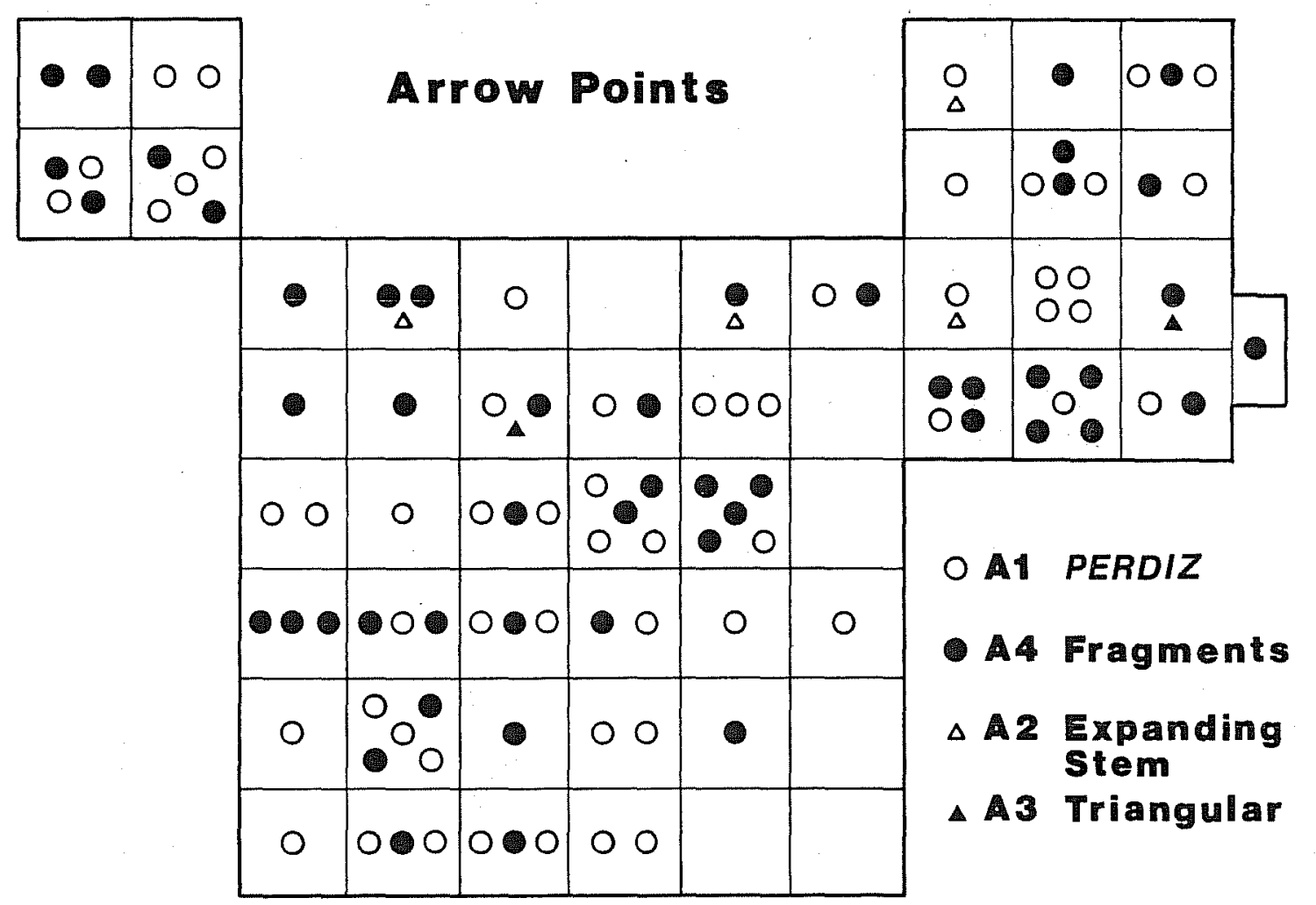

Figure 33. WTA End Scrapers, Beveled Knives, and Arrow Points Distributions. 
It is argued elsewhere in this report that the peoples who occupied the Hinojosa site had a technological inventory specifically adapted to the exploitation of 1 arge mammals. Perdiz arrow points killed the anima1s, beveled knives were used to butcher the animals, and end scrapers were used to process the hides. The fact that virtually every deer, bison, and pronghorn bone (except phalanges and teeth) is broken suggests intensive processing. Also many of these fragmented bones are spikal fractured, burned, or have cut marks which supports this interpretation. The bone clusters themselves suggest that the 1 arger mamma 15 (as we 11 as smal1er anima 1s) were efficient1y processed and then carefully disposed of. Thus, we appear to be dealing with a group of people who were actively seeking and fully exploiting the large mammal resources available in the area.

A11 of the bones identified at the site are from animals that probably could be found in the immediate site vicinity. The environmental setting model (Fig. 2) suggests that diverse habitats were available very near the site. Under favorable environmental conditions (adequate moisture), such as posited for the site occupational period, the local vicinity could be characterized as a "high resource density" area (Hester 1981:122). The wide variety of animals identified at the site also suggests that al 1 of the available animal habitats were exploited. The larger mammals were probably hunted by the adult males, and the women and children hunted and snared smaller animals and gathered a variety of supplementary resources. The males probably had to go some distance from the site to find the larger mammals at times. This may be documented by the general scarcity of deer, bison, and pronghorn cranial materials, as presumably the entire carcasses would not have been brought to camp for distant kills. On the other hand, virtually the entire deer skeleton is represented in the collection; hence at least some deer were killed close enough to camp to bring back the complete carcass. Thus, we can infer that several exploitive patterns are represented.

Cultural Pattern: The cultural pattern represented by the Late Prehistoric occupation at the Hinojosa site is clearly related to the Toyah phase of central Texas (Je1ks 1962; Prewitt 1982, 1985). This is further discussed in the following two sections of this report.

\section{RESEARCH HYPOTHESES}

Hypothesis \#l, Site Function: That the site represented a Late Prehistoric pattern of repeated seasonal occupation (winter to spring) emphasizing a specialized resource (bison and pronghorn).

As has been discussed, the evidence suggests occupation during al 1 or most of the warm months rather that the cooler months. This does not rule out the possibility of winter occupation. The specialized resource was deer as the major species followed by bison and pronghorn. Repeated occupation is definitely evidenced. The expectations are evaluated individually (refer to Section II for a complete 1 isting of each expectation).

1. The block excavations did evidence most of the predicted features, including refuse discard areas (the bone cluster features), cooking areas (Features 5 and 6 ), and occupational features (Features 7 and 11). These 
features were not overlying each other, and they do not occur at a single elevation or surface. No area was identified as a "bison processing area"; however, the clusters of end scrapers and beveled knives in the WTA, as wel1 as the presence of bison bones in most of the bone cluster features, are evidence of bison processing.

2. No meat weight analysis was done; the relative importance of meat in the diet was based on the rough proportion of bone recovered from the site (see Section VII: Analysis of Vertebrate Faunal Remains). The most numerous bones collected were deer rather than bison. Bison and pronghorn were secondary to deer in importance at $41 \mathrm{JW} 8$.

3. Minimum individual analysis was not done; based on the relative numbers of elements, a large number of smaller faunal species were indeed harvested as supplementary resources.

4. No specific study was done of the bison bone distribution because all of the bone was not studied. The fact that al1 of the bison bone recovered is fragmented and that many fragments have spiral fractures or cut marks, argues that the resource was maximized.

5. No winter occupation was evidenced. A warm month, spring to fal1 occupation was evidenced.

6. The excavations revealed minimum evidence of an earlier occupation. If any earlier occupation is actually present, it is very different and of very 1 ittle extent.

7. The closest similarities to $41 \mathrm{JW} 8$ in terms of the Late Prehistoric material culture are found at other sites in southern Texas, including 41 LK 201 (Highley 1986), 41 MC 296 (Ha11, Hester, and Black 1986), and the Berclair site (Hester and Parker 1970). A11 of these sites are closely related to the Toyah phase of central Texas and are considered as Toyah horizon sites by this author. This concept will be discussed in the following sections.

Hypothesis \#2, Bison-Hunter's Chipped Stone Tool Kit: That Perdiz arrow points, end scrapers, and beveled knives make up the chipped stone tool kit used during the Late Prehistoric in south and central Texas for hunting and processing bison.

The artifacts collected at the Hinojosa site suggest that this specialized tool kit was present, and the tools were used as hypothesized. However, it is now recognized that deer were more important than bison and also that antelope were important. Thus, the tool kit could be better termed the "artiodactyl-hunters chipped stone tool kit." Bison bones have been given a prominent $p l a c e$ in the analyses of collections from similar sites; hence the common inference that bison hunting was the most important subsistence activity. It is predicted that faunal studies at similar Toyah horizon sites will also show that deer is the dominant artiodactyl. Bison as the largest animal was no doubt highly prized and sought after, however, deer were more common. The same tool kit was no doubt used for both. 
The two expectations were more or less borne out by the excavations with some modifications.

1. All three of the tools (Al, UI, and BI) were found in indirect association with the artiodactyl remains.

2. The wear and breakage patterns of the three tools are consistent with the hypothesized functions as discussed in Sections VI and VII (Perdiz Arrow Point Studies). Perdiz points have 1 ight wear patterns that intuitively resemble what would be expected from a projectile tip used to hunt 1 arge mammals. The end scrapers have very patterned wear that is very consistent with hide scraping. The beveled knives also show patterned wear that is consistent with use as a meat or hide cutting tool. Extensive replicative studies would be required to confirm these functions and to rule out other similar functions, nonetheless, on an intuitive assessment, the tools have the hypothesized wear patterns.

Hypothesis \#3. Function of cluster Features: That burned rock clusters at 41 JW 8 represented different functions such as cooking hearths, warmth hearths, or discard piles.

Some differences were observed in rock cluster features at the Hinojosa site. Cooking hearths were definitely present. Warmth hearths may or may not have been present. The concept of the "warmth hearth" is hard to demonstrate. While fires may have been built just to keep warm, this will be very difficult to ever prove. Discard piles were probably present. Feature 8 consisted of two rock clusters that 1 acked a regular shape and direct evidence of burning. These are suggested to have been discard piles. This is a difficult assertion to prove due to the possibility that the clusters could be cooking hearths that were exposed on the surface long enough for al 1 the charcoal, ash, and baked clay to have been destroyed by weathering. Thus, the expectations can only be partially evaluated.

1,a. Cooking hearths were identified. Feature 5, which had 1 itt 1 e burned rock, and Feature 6 , which had a distinct ring of burned rock, are both cooking hearths. Evidence of this is direct burning (stained soil), ash, charcoal, baked clay, charred plant remains (seeds and fruits), charred and uncharred bone, and very high phosphate levels.

1,b. Features $8,1,4$ (the rock clusters), and several rock clusters not formally recorded could be interpreted as discard piles. They generally 1 acked the evidence of direct burning, charcoal, ash, and charred food remains. They also had 1 ower phosphate readings than the definite cooking hearths. They could also be weathered cooking hearths.

2. Functionally related artifact clusters were found in apparent association with the two cooking hearth features. Feature 6 was found on one edge of the 1 iving surface, Feature 11. Within Feature 11, artifact clusters suggest a number of activities such as flintknapping and hide scraping. In addition, many of the bone clusters (Features $2 \mathrm{~A}, 2 \mathrm{~B}, 3$, and 10) may be associated with the cooking hearths. It can be stated, contrary to be my original expectation, that similar activities were 
evidenced around the possible discard piles. In fact, Feature 8 is associated with bone clusters and several artifact concentrations.

Hypothesis \#4, The "Bone Bed" Activity Area: That the bone bed area functioned as a bison butchering/processing and bone disposal area.

This hypothesis cannot be evaluated due to the fact that we were not able to open an excavation block around the "bone bed" because of the problems with leaf cutter ants as discussed in Section III. However, the recognition of six other features with clustered bone at the site suggests that the "bone bed" was simply a larger example of the same type of feature, a bone disposal area. The expectations are not reviewed.

\section{ADDITIONAL PROBLEMS}

Lithic Sources: As discussed in Section VI, two areas are thought to have been the sources for most of the siliceous. stone used at $41 \mathrm{JW} 8$. The most important source was probably along the Nueces River some $35 \mathrm{~km}$ east of the site. The secondary source was the hil1top gravel 1 ag deposits in northwest Duval County and vicinity, a minimum of $45 \mathrm{~km}$ from $41 \mathrm{JW} 8$.

Projectile Point Neck Width Hypothesis: As discussed in Section VII (Perdiz Arrow Point Special Studies), the Hinojosa site Perdiz points were used to evaluate the hypothesis advanced by Fawcett (1978). While the $41 \mathrm{JW} 8$ data seem to support the hypothesis, shortcomings in the construction of the original formula limit the application of this dating technique. The idea remains viable and could be better evaluated if more single component samples were measured. 


\section{THE LATE PREHISTORIC IN SOUTHERN TEXAS}

The term "Late Prehistoric" is used herein and in most archaeological references in southern Texas to refer to the prehistoric cultural era immediately preceding the onset of historic contact. This period begins around A.D. 1000 in southern Texas and continues until historic contact in the 16th and 17th centuries. The Late Prehistoric era is marked by the introduction of the bow and arrow and pottery over most of southern and central Texas. Other terms such as "Neo-american" (Suhm, Krieger, and Jelks 1954) and "Neoarchaic" (Prewitt 1981a) refer to this same era.

In comparison with earlier cultural periods such as the Archaic era, the Late Prehistoric is better understood. This is because many Late Prehistoric sites are better preserved than older sites (less time to deteriorate), and they are more visible (closer to the surface), hence more likely to have been found, recorded, and tested. The ethnographic record, although very incomplete, provides some historic documentation of the Late Prehistoric groups and cultural patterns as they rapidly changed after historic contact. Thus, the Late Prehistoric era is the best known prehistoric cultural period in southern Texas prehistory.

\section{PREVIOUSLY DEFINED CULTURAL PATIERNS}

A number of Late Prehistoric cultural patterns (variously termed complexes, aspects, foci, or phases) have been defined or hypothesized for south Texas and adjacent regions. Although the southern Texas Late Prehistoric cultural patterns share some similarities with southwest and southeast Texas as well as northeastern Mexico, central Texas provides the most similar and significant comparative data. Hence, the following discussion will review only the cultural patterns relevant to south and central Texas. These are the Central Texas Aspect (Austin and Toyah phases), the Brownsvil1e complex, the Rockport complex, the Turtle Creek phase, and the unnamed Dimmit/Zavala pattern. These Late Prehistoric patterns are based on varying degrees of archaeological study, and some may very well prove to be invalid cultural constructs. A summary of each pattern follows.

\section{CENTRAL TEXAS ASPECT}

Major References: Suhm, Krieger, and Jelks (1954); Jelks (1962); and Prewitt (1981a).

Geographical Distribution: Large area of central and south-central Texas, perhaps extending into south Texas.

Material Culture:

Austin phase: Scallorn arrow points, small dart points, Friday knives.

Toyah phase: Perdiz arrow points, beveled knives, flake drills, end scrapers, bone tools, Leon Plain pottery. 
Temporal Placement: The Austin phase has been dated to between A.D. 700 and 1300 and the Toyah phase to between A.D. 1300 and 1750 (Prewitt 1981a). Prewitt (1985) has recently suggested that both phases began earliest in northern central Texas and progressively later as one moves south.

Discussion: The Central Texas Aspect has been validated by a 1 arge number of excavations. It has been suggested that the Toyah phase can be 1 inked to the historic Jumano (Kel1 ley 1947) or the Tonkawa (Suhm 1959). Jelks (1962:99) suggested that the Toyah phase ended before historic contact.

The Toyah phase has long been recognized as an abrupt change in adaptation. Shafer (1971) and Greer (1976) have suggested that the Austin phase represents the original inhabitants of central Texas while the Toyah phase represents new peoples. The Toyah assemblage has been interpreted as a Plains-1ike adaptation emphasizing bison hunting (Hester and Parker 1970; Shafer 1971; Prewitt 1981a). Shafer (1971) has suggested that horticulture was introduced into northern central Texas during the Toyah phase and that semipermanent villages may have been established. Ceramic tradewares in the northern and eastern sections of central Texas suggest considerable interaction with eastern and northeastern horticultural groups (Greer 1976).

Recent excavations at the Rowe Valley site (4l WM 437) by the Texas Archeological Society field school have uncovered the largest area yet exposed of a Toyah phase site (Prewitt 1982, 1983, 1984). Field school director Elton R. Prewitt believes that the upper component at the site represents a 1 ate Toyah phase occupation (ca. A.D. 1700) by a Wichita speaking Tonkawa group. A circular campsite arrangement is typical of Plains groups. Flintknapping activity areas have been exposed as well as butchering and bone disposal areas. Ceramics recovered at the site indicate trade with protohistoric Caddoan groups. No historic materials have been recovered.

\section{BROWNSYILLE COMPLEX}

Major References: MacNeish (1958); Prewitt (1974); Hester and Ruecking (1969); and Mal1ouf, Baskin, and Killen (1977) contains an excellent summary.

Geographical Distribution: Rio Grande delta of extreme southern Texas (Hidalgo, Willacy, and Cameron Counties).

Material Culture: Sophisticated shel1 working technology (tools and ornaments), cemetery sites, triangular arrow points, trade contacts with Huastecan and northern Mexico desert areas.

Temporal Placement: The date is unknown but is presumably A.D. 1200-1600.

Discussion: Much of the Brownsville complex is known only from surface collections, principally those collected by A. E. Anderson in the 1930 s. Recent researchers have pointed out the need for "considerable refinement" in this cultural construct (Mallouf and Zavaleta 1979:28). 


\section{ROCKPORT COMPLEX}

Major References: Suhm, Krieger, and Jelks (1954); Campbell (1958); and Corbin (1974).

Geographical Distribution: Confined to a narrow band 20-25 miles wide along the central Gulf coast of Texas from approximately Baffin Bay to the Colorado River.

Material Culture: Perdiz, Fresno, Scallorn, Starr, Padre, and bulbar stemmed arrow points, and Rockport ware ceramics (sandy paste with asphaltum decoration).

Temporal Placement: Approximately A.D. 1000 to the 19th century.

Discussion: Campbe11 (1958:168) bel jeves that the Rockport focus (complex) can be partially 1 inked to the historic Karankawa groups. In a recent paper certain to be controversial. Herman Smith (1984b) argues that the Karankawa, who he 7 inks with the Rockport complex, were recent immigrants (after A.D. 1200) from the Carribean. This argument is based 1 argely on a single 1 inguistic study (Landar 1968) that 1 inks a very 1 imited Karankawa vocabulary to the Carib 1 anguage group. Newcomb $(1983: 362)$ has discredited this 1 ink in an excellent summary of the Karankawa. Smith fails to provide a single comparison of Karankawa material culture or subsistence to that of the Carib Indian groups. Smith al so fails to recognize that Rockport ware ceramics share similarities with upper Texas coast and in 1 and south Texas ceramics (form, bone-tempering, and asphaltum decoration). Excavations at many sites along the coast (Corbin 1974) have shown considerable continuity between the Archaic Aransas focus and the Late Prehistoric Rockport complex. This author would argue that the Karankawa represent native groups whose ancestors can be traced to the Archaic cultures in the area. Further refinement of the Rockport complex is obviously needed.

\section{TURTLE CREEK PHASE}

Major Reference: Mitchell (1978).

Geographical Distribution: South-central Texas along the Balcones Escarpment on the southeastern edge of the Edwards Plateau.

Material Culture: Edwards arrow points and Pueb10 III trade pottery(?).

Iemporal Placement: Poorly established but presumably early in the Late Prehistoric.

Discussion: The Turtle Creek phase as defined apparently reflects the major distribution of the Edwards point. Mitchell believes that it is the initial phase of the Late Prehistoric and predates Scallorn and Perdiz points. This phase has yet to be substantiated by excavation (BTack and McGraw 1985).

It does appear 1 ikely that the Edwards point is an early arrow point in the area. Recent excavations at the Rainey site, a well-stratified sink hole 
site in Bandera County, suggest that Edwards points predate Scal1orn points (Henderson n.d.). However, it should be noted that an untyped crude expanding stem arrow point found at the Rainey site may predate the Edwards point.

The main problem with the Turtle Creek phase is that it remains poorly defined. A cultural phase cannot be defined on the basis of a single artifact type. The Edwards point and crude expanding stem arrow points clearly represent the initial Late Prehistoric phase in south-central Texas. The definition and understanding of this phase will require further work.

\section{DIMMIT-ZAVALA PATTERN}

Major References: Hester and Hill (1975); Montgomery (1978); and Hester (1978).

Geographical Distribution: Dimmit and Zavala Counties on the tributaries of the Nueces River.

Material Culture: Perdiz, Scallorn, Zavala, and possibly triangular arrow points, end scrapers, blades, manos, beveled knives, and bone-tempered pottery.

Temporal Placement: The radiocarbon dates generally are late (i.e., A.D. 1450 to 1750), although the Late Prehistoric probably begins in the area somewhat earlier.

Discussion: The Dimmit-Zavala pattern is the result of an intensive study of the area; hence the geographical pattern is actually the boundaries of the study area. This area has two distinctive patterns, one along Tortugas Creek and the paral1el Nueces River drainage and the other near the Chaparrosa Creek and the Turtle Creek confluence. One important aspect of the DimmitZavala pattern is the apparent 1 ack of temporal separation between the smaller Late Archaic dart points and the expanding and contracting stem arrow points. It has been suggested that several projectile point forms were in use at the same time (Hester 1975:114).

The preceding references provide data on settlement patterns, subsistence remains, intrasite patterning, and dating. This study area is one of the best known Late Prehistoric occupation areas in the region. Subsistence appears to have been based on plant resources and small mammals, rodents, and reptiles; bison were infrequently killed (probably due to scarcity in the area). Deer and pronghorn were the major large animals.

\section{LATE PREHISTORIC CHRONOLOGY IN SOUTH TEXAS}

It has 1 ong been recognized that the Late Prehistoric era in central Texas begins with the expanding stem arrow point (Scal1orn) during the Austin phase. The Toyah phase follows and is marked by the widespread adoption of the contracting stem arrow point (Perdiz). In south-central Texas, the Austin phase appears to be predated by occupations characterized by Edwards 
arrow points and as yet undefined crude expanding stem points (Henderson n.d.). In southern Texas the chronology has been less clear; at many sites, expanding and contracting stem points seem to occur together, leading Hester and $\mathrm{Hi1T}$ (1975:18) to suggest that they were contemporaneous. Recent work in the Choke Canyon Reservoir area (Ha11, B1ack, and Graves 1982; Ha11, Hester, and Black 1986) has documented the earlier occurrence of expanding stem arrow point assemblages and the comparatively late occurrence of components with assemblages similar to the Toyah phase materials.

The two best examples of the earlier Late Prehistoric occupation in the Choke Canyon area are two sites in McMullen County, 41 MC 222 and 41 MC 296. At the Skillet Mountain site, 41 MC 222, Scal1orn and Edwards arrow points were found with bone-tempered sandy paste ceramics and a 1 arge collection of faunal remains, including bison. The radiocarbon dates from 41 MC 222 have a considerable range, however, they best overlap between A.D. 1300-1350. The most important aspect of this is the association of pottery, bison, and expanding stem arrow points at around A.D. 1300. Site 41 MC 296 is important because it has stratified deposits that include an earlier Late Prehistoric component with expanding stem arrow points and a later component with contracting stem arrow points. The radiocarbon dates from the early Late Prehistoric component at 41 MC 296 range from A.D. 800 to 1325 and cluster best between A.D. 1225-1300. The later component clusters nicely between A.D. 1425-1500.

Another Choke Canyon site, 41 LK 201, has a very good 1 ate component of the Late Prehistoric with two consistent radiocarbon dates that range between A.D. 1425-1650. This site shares many similarities with $41 \mathrm{JW} 8$ as well as a number of other sites in southern and central Texas. These similarities are Perdiz points, bone-tempered pottery, smal1 end scrapers, flake drills, beveled knives, and extensive faunal remains, including deer and bison.

The strong similarities between the Choke Canyon and the central Texas Late Prehistoric sequence are very significant. Hall believes that these similarities suggest that central Texas peoples were moving into southern Texas and bringing their distinctive assemblages with them. Prewitt has recently compiled radiocarbon data which supports this interpretation. Prewitt (1985) argues that the Austin and Toyah phases were both introduced to central and southern Texas from the southern Plains (through north Texas) in successive waves. He supports this contention by radiocarbon assays that he bel ieves show the Austin phase beginning in north-central Texas about A.D. 600 , in centra 1 Texas by A.D. 700 , and in south-central Texas by A.D. 850. Similarly, the Toyah phase was first introduced in north-central Texas around A.D. 1250, in central Texas at A.D. 1350, and south Texas by A.D. 1450. Such an explanation would solve the problem of why Late Prehistoric dates in southern Texas have always seemed to fall 1 ater than comparable components in central Texas (Hester 1975).

In order to evaluate the relationship between southern and central Texas a brief comparative study was made of selected south and central Texas Late Prehistoric sites. The emphasis was placed on sites in southern Texas that have either a Toyah horizon assemblage or have been radiocarbon dated to after A.D. 1200. Figure 34 shows the location of the sites for which data were complied. Table 31 provides comparative attribute data for each site. 


\section{Selected Late Prehistoric Sites}

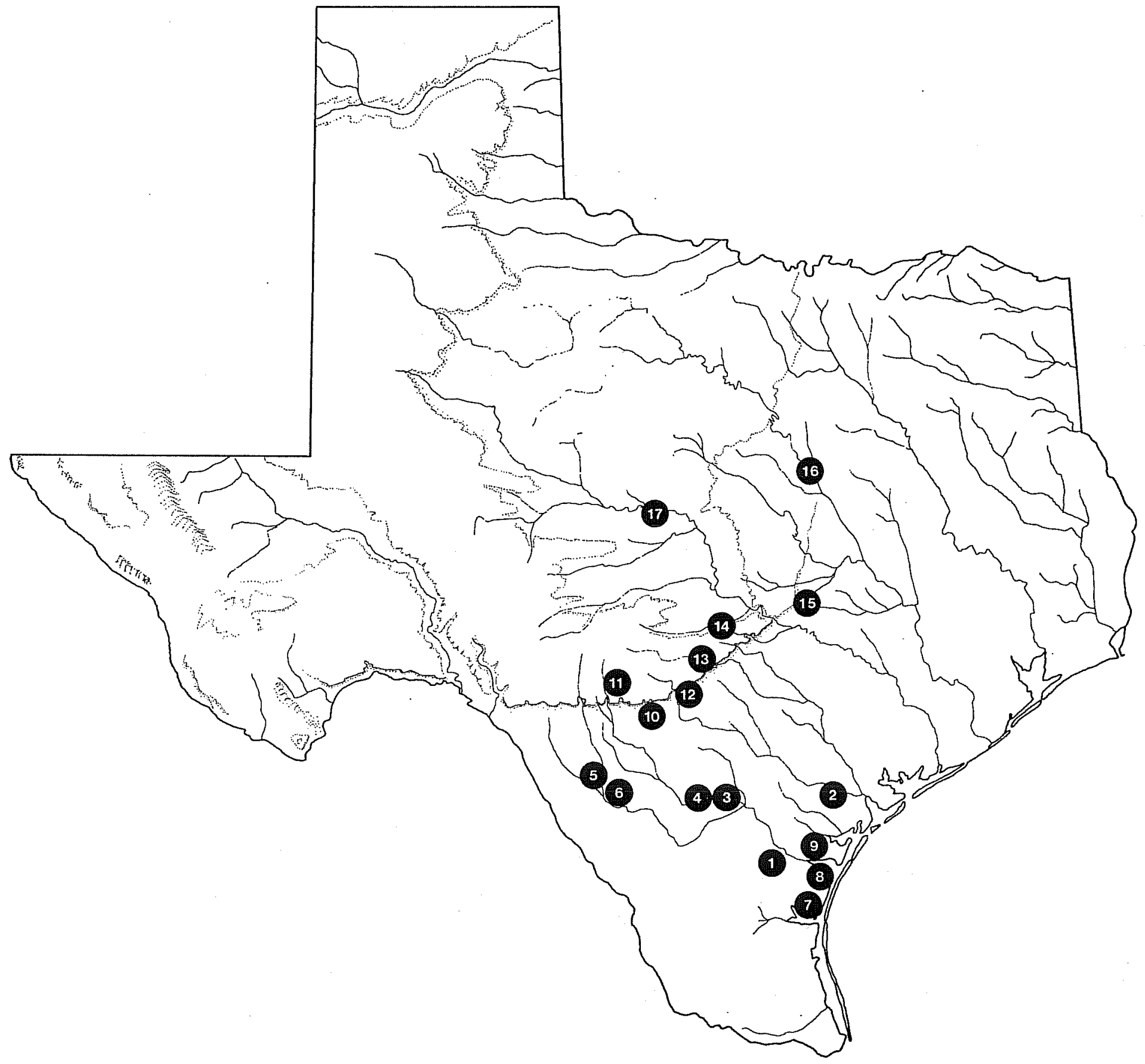

Figure 34. Location of Select Late Prehistoric Sites. Refer to Table 31 for identification of each site represented by the numbers on this map. 


\section{TABLE 31. COMPARATIVE DATA ON SELECT LATE PREHISTORIC SITES}

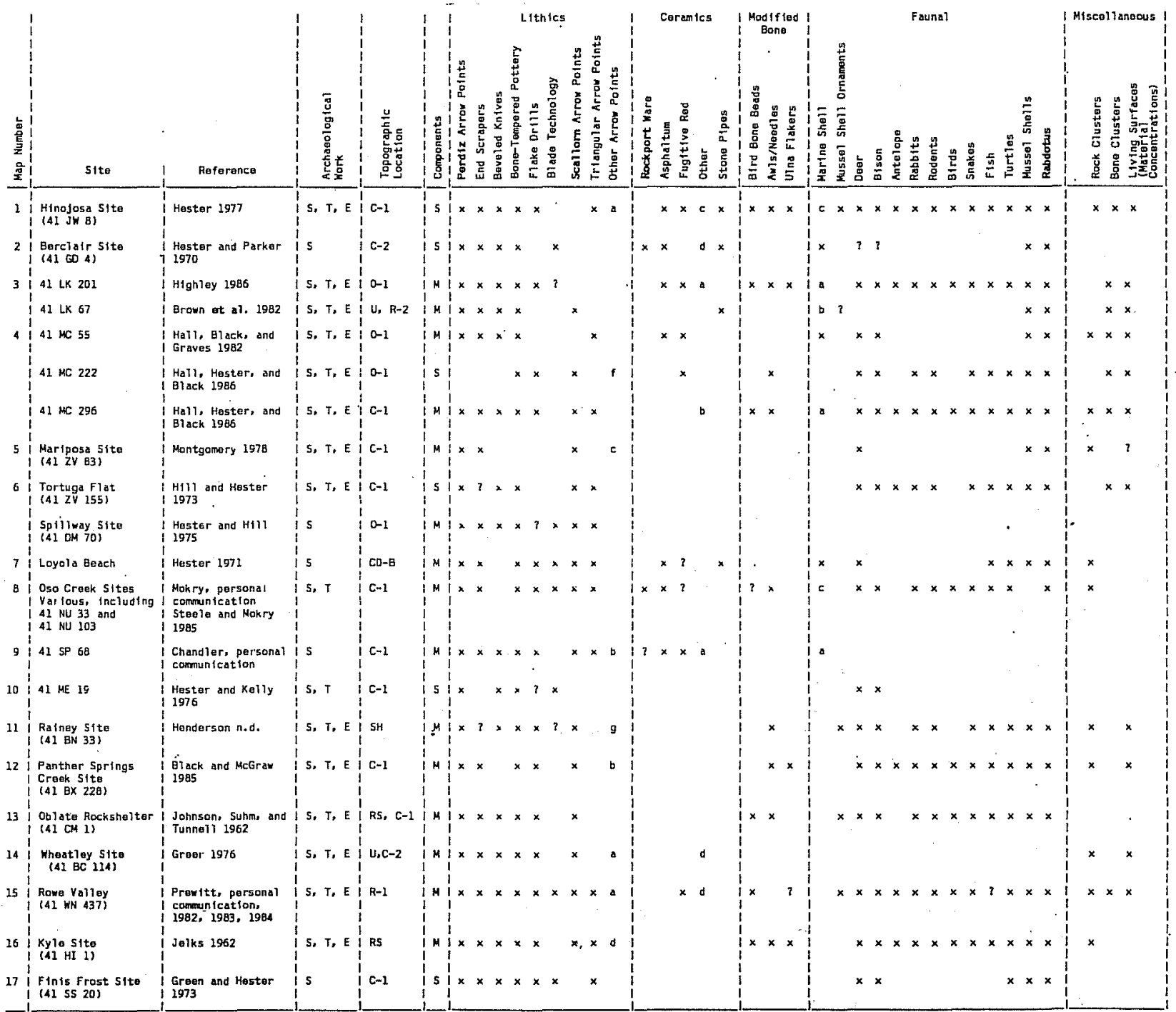

NOTE: The map numbers for each stte (or group of related sites) are shown 1 n Figure 34.

KEY: Archaeological Work: S=surface, T=testing, E=excavation

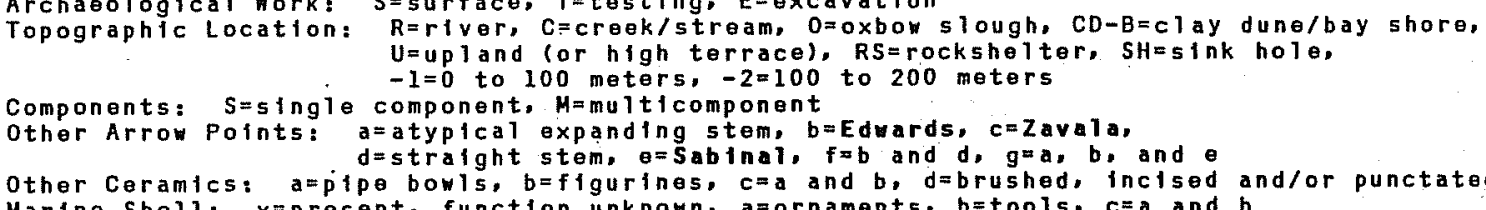
Marine Shell: xepresent, function unknown, $a=0$ rnaments, $b=t o o l s, c=a$ and $b$ 
Table 32 provides a 1 ist of Late Prehistoric radiocarbon assays from south Texas. Figure 35 plots al1 33 of the calibrated dates from Table 32. Figure 36 shows the dates which can be 1 inked to the expanding stem arrow point (Austin horizon) and those which can be linked to the contracting stem arrow point (Toyah horizon). The use of the term "horizon" will be explained later.

In genera1, the attributes of Late Prehistoric Toyah phase sites in central Texas are found at many sites in south Texas. Major differences, other than sampling problems, are few. South Texas sites almost always have the 2beveled knife rather than the Plains 4-beveled knife (Brown et a1. 1982). South Texas sites also have more marine shel1 artifacts and pottery with asphaltum and/or fugitive red decoration. Central Texas Toyah sites often have traces of trade ware from eastern Texas (particularly 1 ate Caddoan wares). In addition, domesticated corn has been found at a few central Texas sites (Jelks 1962; Shafer 1971; Harris 1985) suggesting that some horticulture may have been practiced. Other differences are minimal. Sites from both regions have a wide variety of animal species in faunal assemblages. The most important food species is invariably either deer or bison. It is difficult to compare the Late Prehistoric sites from south and central Texas without concluding that the two regions are closely 1 inked.

If the southern Texas Late Prehistoric is indeed strongly 1 inked with central Texas peoples, then the cultural constructs of the region need to be reassessed. Archaeologists working in south Texas have avoided using the central Texas phase designations for many years, even though the Late Prehistoric materials they found were often very similar to those found in central Texas. This reluctance stemmed from differences in radiocarbon dates and associated materials as well as settlement patterns. Another problem in $1 \mathrm{inking}$ the two areas is precisely because the two areas are considered separate cultural regions.

Figure 35 shows 33 calibrated radiocarbon dates from Late Prehistoric sites in southern Texas. These form a very even distribution when arranged by the earliest end member of each date range. Although a few dates range before A.D. 1000, the majority range after A.D. 1050. Similarly, although a few dates range after A.D. 1600, most are before A.D. 1525. Figure 36 shows the 30 dates which can be assigned to either the Austin horizon or the Toyah horizon. Although considerable overlap occurs, the majority of the Austin horizon dates clearly cluster earlier than the majority of the Toyah horizon dates. The dashed horizontal 1 ines show the approximate main cluster range for each horizon. Most of the Austin horizon dates fal1 between A.D. 1075 and 1375. The majority of the Toyah horizon dates fall between A.D. 1300 and A.D. 1600. Thus, the dichotomy between expanding stem and contracting stem arrow point assemblages long defined in central Texas is also evidenced in southern Texas.

It should be pointed out that the radiocarbon dates used to illustrate the Austin/Toyah dichotomy in south Texas are a 11 from $41 \mathrm{JW} 8$ or the Choke Canyon sites. The dates from mixed assemblages in western south Texas (assay numbers 31-33 in Table 32) are very 1ate. It is 1 ikely that the Austin and Toyah horizons may not have spread intact into many areas of south Texas. We do not have radiocarbon data from much of southern Texas; thus, the 
TABLE 32. LATE PREHISTORIC RADIOCARBON ASSAYS FROM SOUTH TEXAS

\begin{tabular}{|c|c|c|c|c|c|}
\hline $\begin{array}{l}\text { Assay } \\
\text { Number }\end{array}$ & Site & Association & $\begin{array}{l}\text { Sample } \\
\text { Number }\end{array}$ & Assay & $\begin{array}{c}\text { Cal ibrated } \\
\text { Range }\end{array}$ \\
\hline \multirow[t]{2}{*}{$\begin{array}{l}1 \\
2 \\
3 \\
4 \\
5 \\
6 \\
7 \\
8 \\
9\end{array}$} & 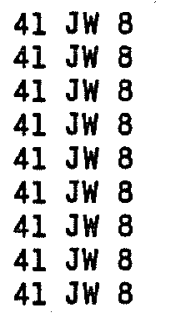 & $\begin{array}{l}\text { Toyah } \\
\text { Toyah } \\
\text { Toyah } \\
\text { Toyah } \\
\text { Toyah } \\
\text { Toyah } \\
\text { Toyah } \\
\text { Toyah } \\
\text { Toyah }\end{array}$ & $\begin{array}{r}T X-2207 \\
T X-4652 \\
\text { UGa-4511 } \\
T X-4653 \\
T X-4886 \\
\text { UGa-5289 } \\
\text { UGa-5280 } \\
T X-4654 \\
T X-4887\end{array}$ & $\begin{aligned} & 580 \pm 50 \\
& 520 \pm 90 \\
& 525 \pm 65 \\
& 970 \pm 60 \\
& 1090 \pm 110 \\
& 655 \pm 70 \\
& 930 \pm 70 \\
& 500 \pm 60 \\
& 700 \pm 80\end{aligned}$ & $\begin{array}{r}1285-1415 \\
1280-1500 \\
1330-1430 \\
905-1215 \\
660-1160 \\
1255-1400 \\
925-1235 \\
1335-1480 \\
1200-1405\end{array}$ \\
\hline & · & \multicolumn{4}{|c|}{ assays 1-9 presented in this report } \\
\hline $\begin{array}{l}10 \\
11\end{array}$ & $\begin{array}{lll}41 & M C & 222 \\
41 & M C & 222\end{array}$ & $\begin{array}{l}\text { Austin } \\
\text { Austin }\end{array}$ & $\begin{array}{l}T X-2875 \\
T X-2876\end{array}$ & $\begin{array}{l}700 \pm 150 \\
710 \pm 50\end{array}$ & $\begin{array}{l}1050-1420 \\
1230-1340\end{array}$ \\
\hline \multicolumn{6}{|c|}{ assays 10-11 from Hall, Black, and Graves (1982) } \\
\hline $\begin{array}{l}12 \\
13 \\
14 \\
15 \\
16 \\
17 \\
18 \\
19 \\
20 \\
21 \\
22 \\
23 \\
24 \\
25 \\
26 \\
27 \\
28 \\
29 \\
30\end{array}$ & $\begin{array}{lll}41 & M C & 222 \\
41 & M C & 222 \\
41 & \text { LK } & 201 \\
41 & \text { LK } & 201 \\
41 & M C & 296 \\
41 & M C & 296 \\
41 & M C & 296 \\
41 & M C & 296 \\
41 & M C & 296 \\
41 & M C & 296 \\
41 & M C & 296 \\
41 & M C & 296 \\
41 & L K & 128 \\
41 & \text { LK } & 128 \\
41 & \text { LK } & 128 \\
41 & \text { LK } & 128 \\
41 & \text { LK } & 128 \\
41 & M C & 55 \\
41 & M C & 55\end{array}$ & $\begin{array}{l}\text { Austin } \\
\text { Austin } \\
\text { Toyah } \\
\text { Toyah } \\
\text { Toyah } \\
\text { Toyah } \\
\text { Toyah } \\
\text { Toyah } \\
\text { Toyah } \\
\text { Austin } \\
\text { Austin } \\
\text { Austin } \\
\text { Austin? } \\
\text { Austin } \\
\text { Austin } \\
\text { Austin } \\
\text { Austin } \\
\text { Toyah } \\
\text { Toyah }\end{array}$ & $\begin{array}{l}T X-4666 \\
T X-4694 \\
T X-4667 \\
T X-4668 \\
T X-4677 \\
T X-4678 \\
T X-4682 \\
T X-4683 \\
T X-4684 \\
T X-4685 \\
T X-4686 \\
T X-4687 \\
T X-4674 \\
T X-4671 \\
T X-4670 \\
T X-4665 \\
T X-4676 \\
T X-4692 \\
T X-4693\end{array}$ & $\begin{array}{r}360 \pm 60 \\
540 \pm 60 \\
360 \pm 50 \\
320 \pm 60 \\
430 \pm 80 \\
330 \pm 60 \\
450 \pm 60 \\
290 \pm 50 \\
320 \pm 60 \\
780 \pm 60 \\
750 \pm 70 \\
1110 \pm 60 \\
1030 \pm 70 \\
830 \pm 50 \\
660 \pm 50 \\
830 \pm 60 \\
670 \pm 60 \\
460 \pm 60 \\
760 \pm 80\end{array}$ & $\begin{array}{r}1415-1645 \\
1325-1425 \\
1415-1645 \\
1425-1655 \\
1340-1645 \\
1420-1655 \\
1390-1505 \\
1435-1665 \\
1425-1655 \\
1190-1315 \\
1210-1330 \\
785-1035 \\
885-1155 \\
1055-1270 \\
1250-1395 \\
1055-1270 \\
1245-1395 \\
1385-1500 \\
1055-1350\end{array}$ \\
\hline \multicolumn{6}{|c|}{ assays $12-30$ from Hall, Hester, and Black (1986) } \\
\hline 31 & 41 ZV 83 & $?$ & $T X-1526$ & $430 \pm 60$ & $1400-1515$ \\
\hline \multicolumn{6}{|c|}{ assay 31 from Montgomery (1978) } \\
\hline $\begin{array}{l}32 \\
33\end{array}$ & $\begin{array}{lll}41 & Z V & 155 \\
41 & Z V & 155\end{array}$ & $?$ & $\begin{array}{l}T X-1514 \\
T X-1515\end{array}$ & $\begin{array}{l}170 \pm 60 \\
410 \pm 40\end{array}$ & $\begin{array}{l}1640-1950 \\
1405-1605\end{array}$ \\
\hline
\end{tabular}

assays 32-33 from $\mathrm{H} 111$ and Hester (1973)

Note: The assay number is the number used in Figures 35 and 36 . The Assoclation is based on the central Texas Late Prehistoric phases ( Jelks 1962; Prewitt 1981a). The assays are glven in years B.P. (1950). The Klein cal ibration range is the two-sigma range given in years A.D. (KIein et al. 1982). 
252 Hinojosa Site, $41 \mathrm{JW} 8$

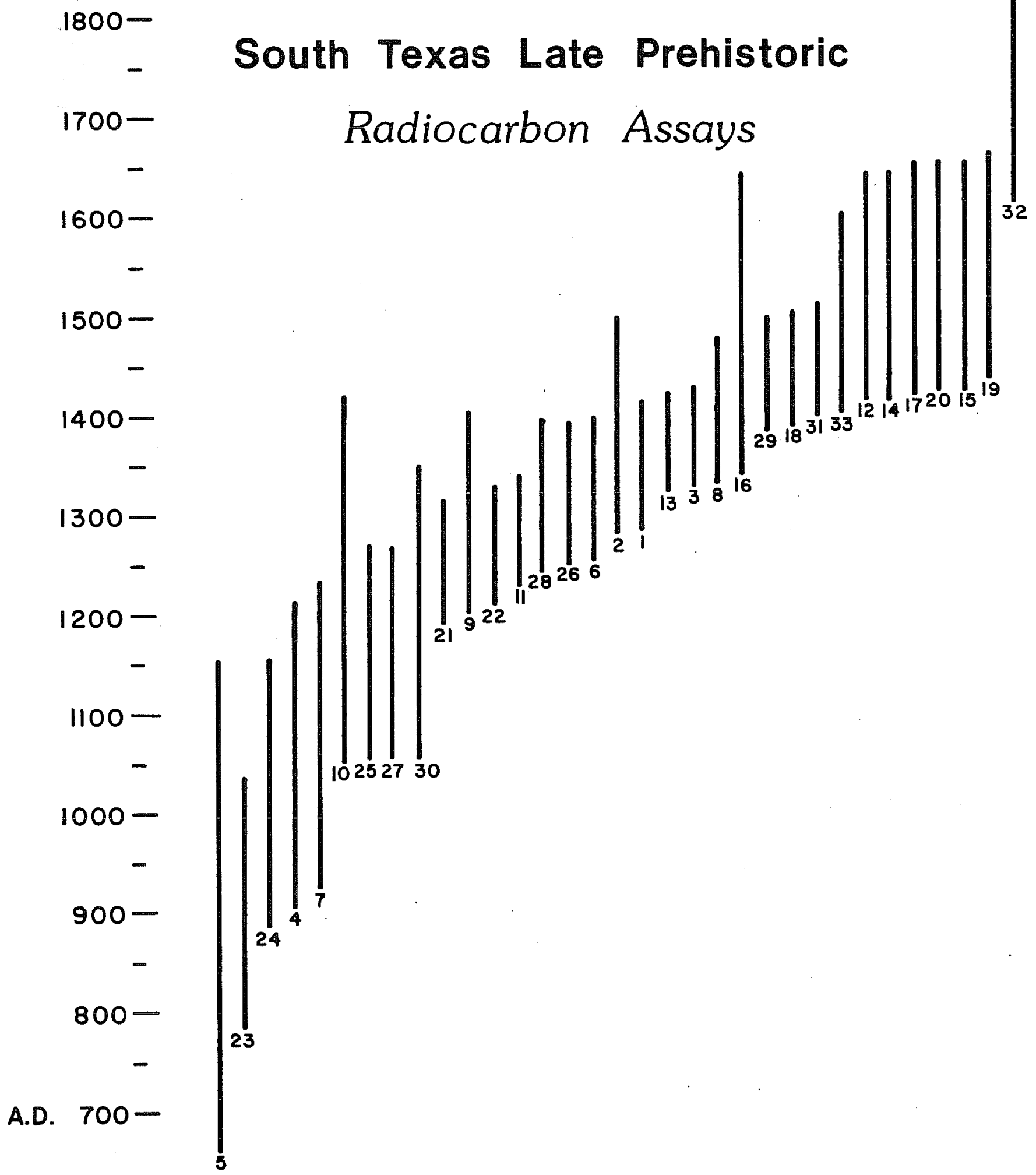

Figure 35. South Texas Late Prehistoric Radiocarbon Assays. 


\section{South Texas Late Prehistoric Horizons}

Radiocarbon Assays

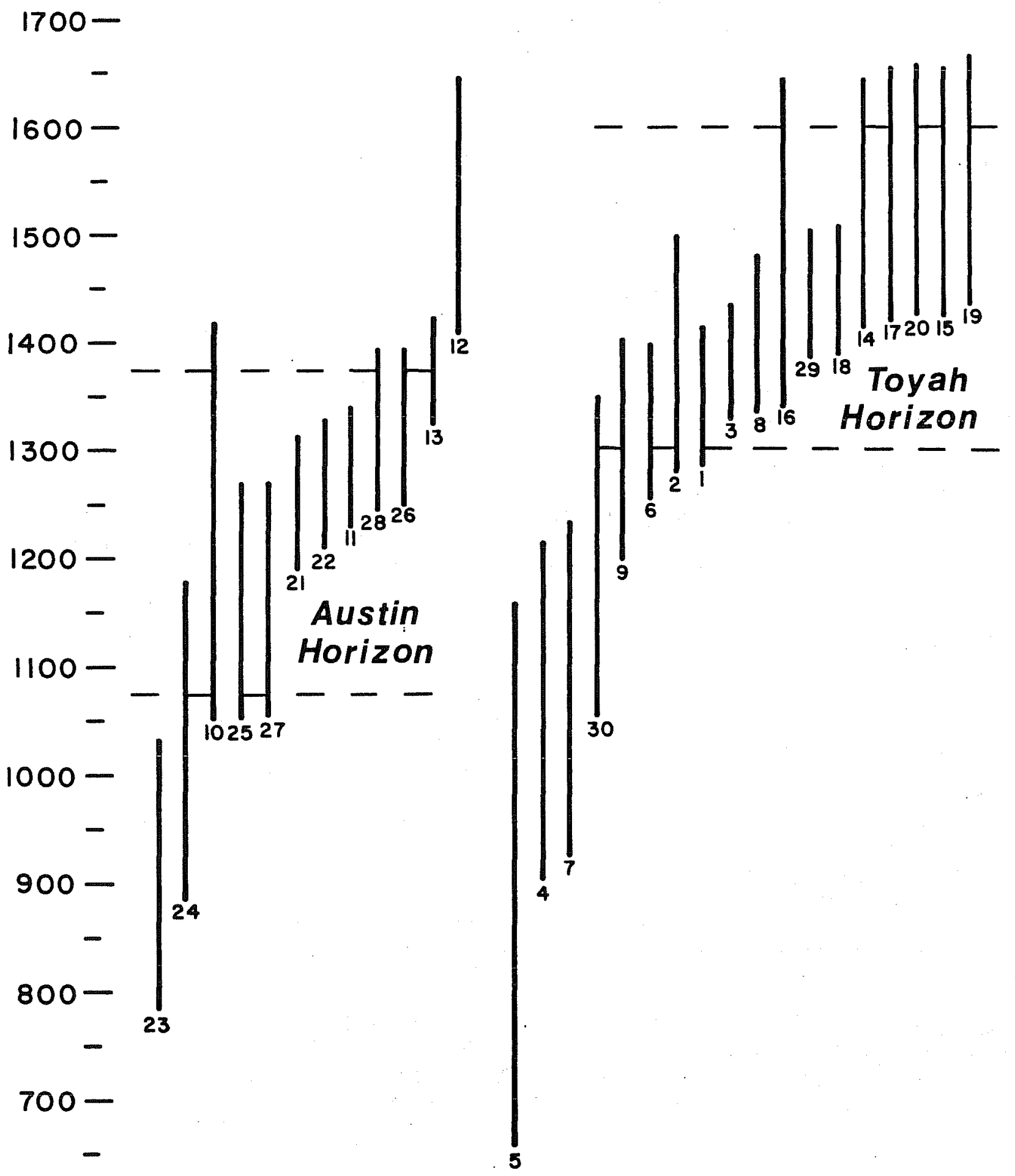

Figure 36. Radiocarbon Assays of Late Prehistoric Horizons in South Texas. 
chronology of the southern Texas Late Prehistoric needs considerable refinement. This refinement can only come from a much larger sample of radiocarbon assays from isolated components.

The Late Prehistoric radiocarbon data from south Texas suggests that Prewitt's estimates of when the central Texas phases (horizons) spread south may need to be modified. For example. Prewitt's (1985) estimate of the beginning of the Austin phase in his south cluster (which includes southcentra1 Texas) is A.D. 850. The Austin horizon does not appear to be present in the Choke Canyon area until after A.D. 1000. The Toyah horizon, on the other hand may be present in south Texas 150 years ear 1 ier than Prewitt's estimate of A.D. 1450. These differences may reflect the 1 ack of an adequate samp $1 e$ of radiocarbon assays. Prewitt's contention that Late Prehistoric dates generally begin later in south Texas does seem to be borne out by the south Texas data.

The following section will focus on the later part of the Late Prehistoric era in southern Texas and the cultural assemblage that has been defined as the Toyah focus (Jelks 1962) or phase (Prewitt 1982, 1985) of central Texas. It will be argued that this same assemblage is present in many areas of south Texas and represents a movement of centra 1 Texas cu 1 tura 1 patterns and/or peoples into southern Texas after A.D. 1350. The southern Texas sites with the Toyah- 1 ike assemb 1 ages are examples of a very broad cultural pattern that stretched over a several hundred year period, from far north-central Texas to far west-central Texas to deep southern Texas. It will be argued that this cultural pattern is perhaps best described as a horizon rather than a phase in recognition of the widespread nature of the pattern.

\section{THE TOYAH HORIZON}

A number of sites in southern Texas have been found which have Late Prehistoric components that can be closely linked to the Toyah phase of central Texas. The Hinojosa site, for example, has an artifact assemblage that save for a few minor differences could have been recovered from a central Texas Toyah rockshelter. The sites with Toyah-like components are the Kyle rockshelter in Hill County (north-central Texas), the Finis Frost site in San Saba County (west-central Texas), the Rowe Valley site in Williamson County (central Texas), the Berclair site in Goliad County (eastern south Texas), and the Hinojosa site in Jim Wells County (deep south Texas). The artifacts common to these and other sites are Perdiz arrow points, bone-tempered pottery, beveled knives, small end scrapers, and flake dri11s. A11 of these sites also appear to have bison bone.

These similarities have been pointed out elsewhere (Hester and Parker 1970) and have 1 ong been recognized. In the $41 \mathrm{JW} 8$ proposa 1 (Hester, Eaton, and B1ack 1980) we used the concept of the "bison-corridor" to suggest that the Toyah-1ike sites in southern Texas were the campsites of groups who followed the bison herds from central Texas. It was noted that these sites do not occur in the western part of south Texas toward the Rio Grande, in the lower Rio Grande Valley, or south of Jim Wel1s and Nueces Counties. We noted that the widespread occurrence of bison after A.D. 1300 fits Dil1ehay's (1974) 
model of periodic movement of bison out of the central and upper southern Plains and into the lower southern Plains.

The close similarity of many sites across a very 1 arge geographical area has created a problem with the constructs used to encompass these cultural1y related sites. Why not cal1 al1 of these sites by a single term given the widespread similarity? The most obvious choice is the Toyah phase. However, this phase was originally defined and has remained defined for central Texas only. Thus, archaeologists working in the region have used the more general term "Late Prehistoric" to avoid using a more specific term that had not been defined for south Texas. The time has come to recognize that we are definitely dealing with a single cultural tradition marked by innovative technological changes that were adopted over a very wide area within a few hundred years.

Prewitt (personal communication) believes that the phase concept should be expanded to a 11 ow for a cultural phenomena that is found over several cultural regions. Thus, he would term southern Texas sites 1 ike $41 \mathrm{JW} 8$ "Toyah phase" sites. This author has previous 1 y argued (Black and McGraw 1982, 1985) that the phase concept as applied to central Texas by Weir (1976) and Prewitt (1981a) far exceeds the original intention of the concept. WiTley and Phi11ips (1958) suggested that phases be applied to cultural regions which they believed should be restricted to relatively homogeneous geographical regions. Central Texas and south Texas are composed of a number of major geographical areas such as the Edwards Plateau, the Balcones Escarpment, the Gulf Coastal Plain, and the Blackland Prairie. If the application of the phase concept to central Texas is questionable, the extension to cover much of southern Texas is clearly stretching the phase concept far beyond its definition.

Perhaps, as Prewitt suggests, the time has come to redefine the phase concept to al 10w for just such a large geographical area. This author believes this is unnecessary; a concept al ready exists that can be applied to the problem, the "horizon."

The term "horizon" and its temporal counterpart, the "tradition," were thought by Willey and Phillips (1958:30) to be "the most practical means for effecting cultural-historical integration on a geographical scale 1 arger than that of the region." They define "horizon" as "a primarily spatial continuity represented by cultural traits and assemblages whose nature and mode of occurrence permit the assumption of a broad and rapid spread" (ibid.:33). They go on to note that while the site components (or other archaeological units) linked by a horizon are assumed to be contemporaneous, the temporal relationship may in fact be expected to be "sloped" rather than "horizonta1." This provision recognizes that it takes some time for a cutturat pattern to spread.

It is suggested that sites with artifact assemblages very similar to the central Texas Toyah phase materials in southern Texas, represent the spread of a cultural "horizon." It is interesting to note that most of the Toyah horizon sites in southern Texas occur 100-200 years after the Toyah phase begins in northern central Texas. This is an excellent example of the "sloped" temporal relationship during the spread of a horizon. It is a 1 so 
significant to note that certain changes in the assemblage do occur as the Toyah horizon spreads into south Texas. For example, the beveled knife form found in central Texas is the bipointed, diamond-shaped "Plains Knife" or "Harahey" biface, while the beveled knife form in southern Texas is the "2beveled quadrilateral biface" (Brown et a1. 1982). Another example is the use of asphaltum and hematite for pottery decoration in southern Texas. These forms of decoration are general1y absent from central Texas.

Although the concern here is with the Toyah horizon in southern Texas, similar assemblages also occur west and east of central Texas. The widest distribution is that of the Perdiz arrow point. Prewitt $(1981,1985)$ uses the Perdiz point as a "key index marker" of the Toyah phase. The Perdiz point can similarly be used as a "horizon marker" (Willey and Phillips 1958) to define the maximum spread of the horizon. In the case of the Toyah horizon, the Perdiz point had a wider distribution than most other elements of the assemblage. A distribution map of Perdiz points (Prewitt ms.) indicates a range across most of Texas from the northeast corner, to the southeast corner, to 41 JW 8 and farther south, and to the Big Bend area in west Texas.

Obviously, one cannot use the Perdiz point distribution alone to define the spread of the Toyah horizon. There are indications that most of the elements of the Toyah horizon also spread far west and southwest from central Texas. As one moves farther away from the apparent initial Toyah area, north-central Texas (Prewitt 1985), the assemblage becomes progressively more modified, no doubt indicating influences from other cultures. At the Finis frost site in San Saba County (Green and Hester 1973), the Toyah assemb 1 age is comp 1 ete. Farther west in the Big Bend region, Perdiz points, end scrapers, and beveled knives occur but bone-tempered pottery and flake dril1s apparently do not (Kel ley, Campbe11, and Lehmer 1940). Lehmer (1960:125-126) includes these materials in the Livermore focus which he suggests originated in the southwestern Plains. He notes how this complex sharply contrasts with others in the area and speculates that this "appears to represent a group of 1 ate plains hunters who were driven to take refuge in the mountain country by severe drought" (ibid.:126). South of the Big Bend region across the Rio Grande in Coahuila, Mexico, the Perdiz point and smal1 end scrapers are found within the Jora complex (Taylor 1966).

It is suggested that the appearance of the expanding stem arrow points across much of southern Texas after A.D. 1000 can also be interpreted as the spread of the "Austin horizon." However, unlike the Toyah horizon, the expanding stem arrow point assemblages do not appear to have a we11-defined tool kit that is unique to the related sites. It is interesting to note that ceramics in south Texas appear to have been initially introduced into the area along with expanding stem arrow points. This can be seen at several sites in the Choke Canyon area, including 41 MC 222, 41 MC 296, and possibly 41 LK 128 (Ha11, Black, and Graves 1982; Ha11. Hester, and Black 1986). Greer (1976:149-152) has suggested that ceramics may have first appeared in central Texas during the Austin phase. Ceramics have recently been found in apparent association with Scallorn and Edwards arrow points in south-central Texas at 41 BX 228 (B1 ack and McGraw 1985). 
It should be mentioned that expanding stem arrow points have been recently recognized as a minor component of Toyah horizon assemblages. The expanding stem arrow points found in isolated Toyah components are atypical of the we 1 1-defined expanding stem types, the Scal1 orn and the Edwards arrow points. The atypical expanding stem points are typically smaller and thinner than most Scal 1 orn and Edwards arrow points and often have very angular stems. These have been documented at $41 \mathrm{JW} 8$, at Rowe Valley (Prewitt ms. and personal communication), and at 41 LK 201 (Highley 1986). At many sites, atypical expanding stem arrow points have been classified as Scallorn points. For example, atypical expanding stem arrow points were found at the Wheatley site, 41 BC 114 (Greer 1976). Greer (1976:108) notes that the samp 1e of 13 "Scallorn" points at the Wheatley site "is a heterogeneous grouping of points general1y comparable to Scallorn forms." The il1ustrations in the Greer (1976) report show a very diverse group of points, few of which are typical of the defined type (Suhm and Jelks 1962:285-286). Greer (1976:141-147) uses the cooccurrence of the expanding stem arrow points and typical Toyah assemblage materials (Perdiz points, end scrapers, beveled knives, and pottery) to argue that Perdiz and Scallorn points, and by extension, the Toyah and Austin phases, were contemporaneous. Greer points out that virtually any expanding stem arrow point in Texas is usually called a "Scallorn" (except for Edwards points, of which he makes no mention). The recognition of atypical expanding stem points in definitely 1 ate contexts calls for the reexamination of expanding stem arrow point typology.

Further comments on the Toyah horizon in southern Texas are made in the following section of this report. 


\section{A TOYAH CAMPSITE IN SOUTHERN TEXAS}

The Clemente and Herminia Hinojosa site, $41 \mathrm{JW} 8$, is seen, as a result of this research, as a major campsite of Late Prehistoric, Toyah horizon peoples who repeated $1 y$ revisted the location during the 14 th century A.D. Some of the major interpretations derived from the analyses are summarized. These interpretations are organized by topics the author believes to be the most important in understanding the site.

\section{OCCUPATION PERIOD OF THE SITE}

The question of when the site was occupied is a bothersome one. The radiocarbon assays can be interpreted in several ways as discussed in Section VII (Radiocarbon Assays). It is clear that most of the assays indicate a occupation during the 14 th century A.D. The calibrated dates overlap best between A.D. 1350 and 1400. This time interval is assumed to be the major period of occupation at the site, although we have 1 ittle means of determining over what length of time the site was revisted. A comparison with the dates from other Toyah horizon sites in southern Texas (Section XI) shows that 41 JW 8 is the earliest Toyah horizon site yet documented in the region. Site 41 MC 55, from Choke Canyon, may a 1 so have a contemporaneous occupation as one assay (Assay 30 in Table 32) appears early. Sites 41 MC 296 and 41 LK 201 clearly date 1 ater than 41 JW 8. As has been noted, the probability of a l4th-century Toyah horizon occupation in deep south Texas is somewhat early according to Prewitt's estimation of the spread of the Toyah.

The dating of Feature 6 definitely represents a problem in interpretation. Three consistently early assays from this feature suggest a date before A.D. 1150, perhaps as early as A.D. 950. There is no physical evidence to 1 ink these older dates with pre-Toyah horizon cultural materials. These assays are clearly too early for the Toyah horizon. A11 of the Toyah assays for central Texas cited by Prewitt (1985) are after A.D. 1200. Based on our current knowledge, it seems unlikely that the early dates actually indicate a very early Toyah horizon occupation at the Hinojosa site. In 1 ieu of a readily acceptable explanation, the early dates from Feature 6 will remain enigmatic.

\section{SUBSISTENCE AT 41 JW 8}

Prior to the faunal study of the 1981 season materials, the Hinojosa site, 1 ike many Toyah horizon sites, was thought to be a bison hunters' camp (Hester 1977; Hester, Eaton, and Black 1980). Deer are now known to have been the most numerous species killed by the site occupants. Bison and pronghorn were the next most important species folt towed by sma 77 mammats such as rodents and rabbits. One of the remarkable aspects of subsistence at 41 JW 8 is the diversity of the faunal assemblage; 44 faunal taxa representing over 31 genera were recovered (Section VII: Analysis of Vertebrate Faunal Remains). Large and smal1 mamma1s, rodents, turt1es, snakes, birds, and fish were al1 identified. Studies of other Toyah horizon sites such as 41 LK 201 (Steele 1986) and 41 MC 296 (Steele and Hunter 1986) have shown similarly diverse faunal assemblages. This is also true of 
several of the non-Toyah Late Prehistoric sites in Zavala County (Hester and Hil 1 1975).

The importance of hunting and animal processing at the Hinojosa site is documented by the 1 arge amount of animal bone, the numerous projectile points and end scrapers, and the bone cluster features. The Wagon Trail Area, in particular, suggests a repeated pattern of bone processing and disposa 1. Most of the major 1 ithic tools, Perdiz points, end scrapers, and beveled knives have wear patterns that are consistent with meat and hide processing. Taken together and contrasted with the scarce evidence for plant processing, it is obvious that the inhabitants of $41 \mathrm{JW} 8$ were, first and foremost, hunters.

There is some significant evidence of other subsistence activities. Rabdotus snail collecting seems to have been a very important activity at $41 \mathrm{JW} 8$. In fact, Rabdotus snail shells were the most numerous item recovered from the site. Based on the densities of Rabdotus recovered from the site, it can be estimated that somewhere between a quarter and a third of a million of these 1 and snails were collected during the occupations at the site. The WTA distributional studies showed considerable clustering of the Rabdotus snails, with the largest concentrations associated with the 1 iving surface, Feature 11. Freshwater mussels played a decidedly smaller subsistence role. Low densities of musse 1 she $11 \mathrm{~s}$ were recovered in a 11 areas of the site except one. The strong concentration of mussel shel1s in Unit N125 E92 probab1y suggests an activity area. The relative scarcity and the extremely smal 1 size of most of the mussel shel1s from the site suggest they were not a major item in the diet.

Evidence of plant collecting and processing was also present at the Hinojosa site. Charred hackberry seeds were recovered from many contexts at the site, and probably represent a food resource. Uncharred hackberry seeds were very numerous; however, these may be of recent origin, perhaps introduced into the deposits $v i a$ rodent burrowing. Charred Chenopodium fruits were recovered from several contexts, including several feature matrices. Chenopodium and other charred plant seeds, persimmon and Helianthus, probably represent food items. Grinding stones were recovered in very 10 numbers from the site. Most grinding stones from the site are represented by small sandstone fragments recovered from the surface of the plowed field. Several factors may cause the importance of $p 1$ ant collecting to be underestimated. First, plant remains are notoriously poorly preserved in southern Texas, unlike animal bone. Second, ground stone tools represent more invested 1 abor and may have been more difficult to replace than chipped stone tools; hence more 1 ikely to have been removed from the site. Wooden mortars may also have been used at the site, similar to specimens found in northeastern Mexico and southwestern Texas (cf. Prewitt 1981b). Thus, while plant gathering seems to have been less important than hunting at $41 \mathrm{JW} 8$, it was no doubt a significant subsistence activity.

\section{ENYIRONMENTAL CONDITIONS DURING THE SIIE OCCUPATION}

The author believes that the spread of the Toyah horizon into south Texas and specifical1y to $41 \mathrm{JW} 8$ occurred during a period of increased rainfall in the 
region. This interpretation is not shared by some and can neither be convincingly substantiated nor refuted given our present knowledge. The arguments for and against this interpretation will be briefly reviewed. It is hoped that such a discussion will encourage others to conduct the careful studies necessary to confirm or deny this interpretation.

Climatic studies of the region have not yet achieved the resolution needed to understand the environmental conditions for the period. For example, Bryant and Shafer (1977) present a model of gradual dessication over the 1 ast 7000 years. Story (1980) suggests a steplike model with a general drying trend punctuated by several drought periods and intervals of increased moisture. Gunn et a1. (1982) use a rather varied array of climatologial indicators (from atmospheric radiocarbon, to Arctic glacial chronology, to a "south Texas climatic threshold") to predict a series of expected 1ong-term wet and dry periods in south Texas. In truth, we do not have enough data to understand past climatic fluctuations in south Texas.

One possible indication of climatic conditions is the identification of charred botanical remains from archaeological sites in south. Texas. Dering (1982), Holloway (1986) and Jones (Section VII: Analysis of Macrobotanical Materials) have identified most of the charred materials from the archaeological sites they have studied as common species present in the area today, such as acacia, mesquite, persimmon, hackberry, e1m, and others. Hol1 oway and Jones interpret this as indicating a stable environment. This author would strongly disagree. The fact that the wood species present several thousand or several hundred years ago are the dominant species today on $1 y$ provides evidence that no dramatic changes have occurred. For example, while a major climatic shift would no doubt bring new species into south Texas, a long drought or an extended period of moist conditions would probably change on $1 \mathrm{y}$ the species abundance, not the occurrence. In particular, the major trees present in the area, acacia and mesquite, will both thrive under more moist conditions (witness the 1 ake shore concentrations of these trees in south Texas!). Thus, environmental stability cannot be inferred by the presence or absence of hardy, prolific species. What is needed is data on climatically sensitive species such as grass species.

In 1 ieu of pollen preservation in southern Texas (cf. Hester 1977; Hol loway, Section VII: Pollen Analysis), phytoliths seem to hold the most promise for environmental reconstruction (Brown 1984). Unfortunately, on 1 y a few preliminary studies of phytoliths in south Texas have been published to date (Robinson 1979, 1982). Robinson has studied samples from 41 JW 8 (Section VII). He believes that the samples from the occupation zone in the WTA (Col. 1) show a large number of grass phytoliths (Pooideae) which are characteristic of cooler seasons and winter rainfal1. The increase in this type of phytolith has been found at several other sites; Robinson (1979, 1982) suggests that this indicates cooler/wetter conditions. Samples from above and below the occupation zone apparently have smaller amounts of the Pooideae phytoliths. Unfortunately, Robinson has not done the final step of his analysis, the quantification of the biosilica assemblage. Final interpretation of the phytolith data awaits publication of the completed studies of $41 \mathrm{JW} 8$ and other sites. 
Another type of data that may provide environmental data is faunal material. In the Choke Canyon area, Steele (1986) used the presence of diverse species (characteristic of western and eastern biotic provinces) in Late Prehistoric and Late Archaic contexts to argue that the Tamaulipan Biotic Province has been established in the region for several thousand years. Furthermore, Steele suggested that the greater diversity during the Late Prehistoric may indicate a more temperate climate with milder summers and winters. Particularly significant to the present argument, is Steele's identification of a number of species in Late Prehistoric contexts which are no longer present in the region.

Steele identifies several species from 41 JW 8 that may indicate a wetter environment, including the least shrew (Cryptotis parva), the eastern mole (Scalopus aquaticus), the muskrat (Ondatra zibethicus), and possibly the pine vole (Microtus cf. M. pinetorum). The Hinojosa site is on the southwestern or southern margin of al1 of these species ranges. The least shrew and the muskrat have not been previous $1 y$ documented in the area. Taken together these species indicate that the local environmental conditions were much wetter/cooler during the occupation of the site than today. However, it should be noted that the presence of a running stream may have been responsible for the local occurrence of most of these species.

Other probable indications of a perennial stream include mussel she11s, and the bones of fish, water turtle, aquatic bird, water snake, and raccoon. There seems to be little doubt that Chiltipin Creek was a permanent stream during the site occupation. The mussel species that were recovered (Section VII: Freshwater Bivalves) suggest a shallow stream with a muddy bottom and possibly an artesian source. This confirms Brune's (1981) suggestion that the Amargosa Springs, upstream from the site, was formerly (prior to the recent historic era) active on a year-round basis.

Numerous animal species also suggest an extensive grassland habitat in the site vicinity. Bison, pronghorn, least shrew, cotton rat, and pine vole are all primarily grassland species. The presence of bison in deep south Texas is considered particularly significant by this author. Diliehay (1974) presented a model of long-term fluctuations of bison on the Southern Plains. He suggested three general periods of bison presence separated by two periods of bison absence. Of interest here are Dillehay's Absence Period II (A.D. 500-1200-1300) and Presence Period III (A.D. 1200-1300-1550). Di1 lehay suggested that climatic shifts between wetter and drier conditions were responsible for shifts in the bison range. He cites a large number of sites in the Southern Plains that show a major increase in bison around A.D. 12001300. He a 150 cites evidence from the southwest that suggests that bison were moving south and east away from areas suffering from a major drought at about this time.

This author would suggest that the combined evidence at $41 \mathrm{JW} 8$ indicates a wetter environment in the vicinity of the site. Much of this evidence can be attributed to a reliable spring-fed stream. However, a substantial grass 7 and can also be inferred in the site vicinity. It is suggested that during the 14th century, much of south Texas (as wel 1 as much of the Southern P1ains) had increased rainfal1 (or at least more consistent rainfal1) that al lowed a short-term improvement of the grasslands. The inferred climatic shift to a 
slight1y wetter environment encouraged both the movement of bison and, perhaps, of people into the area.

\section{SITE FUNCTION}

The Hinojosa site is interpreted as a major campsite, or base camp. The site obviousiy served as a focus for activities that often involved travel to adjacent areas in search of various animal, plant, and mineral resources. At $41 \mathrm{JW} \mathrm{8}$, we see evidence of chert collecting and hunting trips that involved trave 1 to within $50 \mathrm{~km}$ away. The immediate site vicinity was the scene of many different activities. Most of these have been discussed elsewhere in this report: cooking; animal butchering, processing, and disposal; 1and snail and mussel collecting; plant gathering and processing; tool making and resharpening; fire building; shel1 ornament manufacturing; basketry weaving; and leather working to name only the more obvious. The breadth of these activities and the concentrated nature of the deposits suggest that the site may have been occupied for extended periods (perhaps several weeks or months) at a time.

\section{TOYAH HORIZON PEOPLES}

One question which seems pertinent is "who were the people who 1 ived at 41 JW 8 and other Toyah horizon sites in southern Texas?" Were they centra1 Texas peoples moving into south Texas as some have argued? Or were they native south Texans who merely adopted certain technologies of central Texas peoples?

of course, we may never know the answer to this question. The earliest descriptions of the Indians in the area were provided by Cabeza de Vaca (Campbe 11 and Campbe 11 1981). The Campbel 15 believe that Cabeza de Vaca passed through south Texas very near Jim We11s County in the 1530s. The Indian groups he described for the area, the Mariames, the Avavares, and possibly several others, appear to have been most interested in harvesting the prickly pear cactus fruit as discussed in Section $V$. The problem is that although some known behavioral aspects of these groups (1ike snail collecting) are evidenced at $41 \mathrm{JW} 8$, no conclusive 1 inks can be made. We did not find any obvious evidence of cactus fruit collecting. Cabeza de Vaca did not, of course, describe Perdiz arrow points, and he did not even mention pottery. Hence it is very difficult to say whether the group that inhabited the Hinojosa site survived in the area until the l6th century.

The alternative possibility is that the Hinojosa site was occupied by central Texas peoples. Prewitt (ms.) believes that the Rowe Valley site in Williamson County was occupied by Wichita-speaking Tonkawa groups long after Cabeza de $V$ aca had passed through southern Texas. The Toyah phase has also been tentatively 1 inked to the Tonkawa by Suhm (1959). Does the fact that the 41 JW 8 assemblage strongly resembles the Toyah phase materials from central Texas suggest that the Tonkawa camped in $\mathrm{Jim}$ Wells County? Hester and Parker (1970) posed the same question for the Berclair site in Goliad County. As they note, some early historic accounts do mention the presence of Tonkawa bands in various portions of the South Texas Gulf Coastal Plains. At the 
present time we simply cannot 1 ink the Toyah horizon to the Tonkawa or any other group, no matter how tempting it may be. We 1 ack the data necessary to make a direct $1 \mathrm{ink}$ between the prehistoric assemb 1 age and the historic peoples.

There is considerable evidence at the Hinojosa site that, whoever the peoples who camped there were, they were very familiar with south Texas. For example, the lithic materials at the site suggest that at least two source areas were used, the Nueces River east of the site and the hilltop gravels to the west and northwest of the site in Duval County or beyond. The Hinojosa site collection does not contain a single artifact made of a material that suggests a central Texas origin; al1 the raw materials are found in south Texas. Other indications of southern Texas familiarity are the 2-beveled knife, the 01 mos biface, and the asphaltum and fugitive red decorated pottery. There are also indications of coastal contact. The marine shel1 ornaments, tools, and fragments, as well as the asphaltum pebble and decoration on the pottery and stone pipe, evidence at least trade with coastal peoples. Toyah horizon sites have been documented in San Patricio County (Chandler, personal communication) and Nueces County (Mokry, personal communication). Hence it is likely that the peoples who camped at $41 \mathrm{JW} 8$ also visited the coast at times.

Thus, the question of who were the peoples that camped at the Hinojosa site, cannot yet be answered. They did have an artifact assemblage dominated by tool forms that originated far to the north in central Texas. However, they a 1 so used tool types found on $1 y$ in southern Texas. Whoever they were, the peoples who lived at the Hinojosa site and many other Toyah horizon sites in southern Texas, 1 eft behind some of the more distinctive archaeologica 1 remains yet documented in the region. 


\section{ACKNOWLEDGMENTS}

The author was aided by many individuals during the completion of the project and this report. Their cooperation and expertise made this report possible. It is with grateful appreciation that the author acknowledges the many contributions.

\section{EIELD CREW}

The extremely competent archaelogists who came to call Alice, Texas, "home" during the fall of 1981, made the field work a pleasure. The main crew consisted of E. Tom Miller, Cecil Peel, Mike Woerner, and Courtenay J. Jones. Kenneth M. Brown and Daniel R. Potter both contributed a productive week.

\section{ASSISTANI PROJECT ARCHAEOLOGISI}

A] Joachim McGraw helped the author supervise the field work and the 7 aboratory work. Al also built the water separation device (the Izum of Texas).

\section{LABORATORY CREW}

Beverly Marshal 1 Van Note did a thorough job of most of the laboratory processing, leaving the author with a well-organized batch of material. Courtney Jones also assisted in the 1 aboratory.

\section{LOGISTICAL SUPPORI}

The following individuals provided logistical support: Jack D. Eaton (CAR), John Roberts (SCS--A1ice), John Poindexter (UTSA--Photography), and Barbara Johnson (UTSA--Purchasing).

\section{ADMTNISTRATIVE SUPPORT}

Thomas R. Hester did an excell lent job as principal investigator; he provided the encouragement, advice, and management needed to see this report through to completion. Mary Lou Ell is cheerfully guided the author through the maze of paper work, deadlines, and correspondence.

\section{ADVISORS}

Many colleagues provided the author with invaluable advice on the field work, analysis, and interpretations as well as access to unpublished data. They include: Kenneth M. Brown, Vaughn M. Bryant, Jr., C. K. Chandler, E. Mott Davis, Anne Fox, Joel Gunn, Thomas R. Hester, C. Lynn Highley, Donald R. Lewis, Ed Mokry, Jr., Elton R. Prewitt, Dee Ann Story, and A1 B. Wesolowsky. Any shortcomings of this report are solely the author's responsibility. 


\section{CONSULTANTS}

The experts who contributed data and/or sections of this report are Richard G. Holloway, John G. Jones, Harold D. Murray, John Noakes, Ralph L. Robinson, D. Gentry Steele, and Salvatore Valastro, Jr. Much of what we learned about the Hinojosa site is due to their contributions.

\section{TYPISTS}

While most of this report was written by the author on his Zenith (2100) computer using Watchword; many of the tables and the editorial changes were made by Ann Young and Mary Lou ET 1 is using WordStar.

\section{EDITORS}

Thomas R. Hester, Carol Graves, Sharon Quirk, and Stephen L. B1 ack edited this report.

\section{BOOKKEEPERS}

Loyce Jurney and Kathy Hodgin kept the books straight.

\section{SPECIAL THANKS}

Eva Hinojosa Jimenez, Ramon Hinojosa, Dora Hinojosa Alaniz, and other descendants of $\mathrm{Cl}$ emente and Herminia Hinojosa, deserve special thanks for allowing the work to take place, providing access, and showing an interest in the project. It is hoped that this report will better explain why we were so interested in the far corner of the wheat field.

\section{EINAL AND MOST IMPORTANT}

The author's wife, Mary, provided the encouragement and tolerance without which this report would never have been completed. 


\section{REFERENCES CITED}

Barnes, V. E., project director

1975 Geologic At 1 as of Texas. Corpus Christi Sheet. Robert Hamilton Cuyler Memorial Edition. Bureau of Economic Geology, University of Texas at Austin.

Binford, L. R.

1981 Bones: Ancient Men and Modern Myths. Academic Press, New York.

Black, S. L.

1978 Archaeological Investigations at the Banquete Bend Site (41 NU 63), Nueces County, Texas. Center for Archaeological Research. The University of Texas at San Antonio, Archaeological Survey Report 63.

1980 The Early Archaic Component at the Panther Springs Creek Site. Paper presented at the Texas Archeological Society Annual Meeting, Austin.

1986 Prehistoric Ceramics. In The Prehistoric Sites at Choke Canyon Reservoir, Southern Texas: Results of Phase II Archaeological Investigations, by G. D. Ha11, T. R. Hester, and S. L. Black:337-391. Center for Archaeological Research, The University of Texas at San Antonio, Choke Canyon Series 10 .

Black, S. L. and I. W. Cox

1983 A Cultural Resource Survey of Dredge Disposal Sites Along the Gulf Intracoastal Waterway, Brazoria and Matagorda Counties, Texas. Center for Archaeological Research. The University of Texas at San Antonio, Archaeological Survey Report 124.

B1ack, S. L. and A. J. McGraw

1982 Central Texas Chronology: A View from South Central Texas. Paper presented at the Texas Archeological Society Annual Meeting, College Station.

1985 The Panther Springs Creek Site: Cultural Change and Continuity in the Upper Salado Creek Watershed, South-Central Texas. Center for Archaeological Research, The University of Texas at San Antonio, Archaeological Survey Report 100.

Blair, W. F.

1950 The Biotic Provinces of Texas. The Texas Journal of Science $2(1): 93-113$. 
Blair, W. F., A. P. Blair, P. Brodkorb, F. R. Cagle, and G. A. Moore 1968 Vertebrates of the United States. McGraw-Hi11, New York.

Bodner, C. C. and R. M. Rowlett

1980 Separation of Bone, Charcoal, and Seeds by Chemical Flotation. American Antiquity 45(1):110-116.

Bogush, E. R.

1952 Brush Invasion in the Rio Grande Plain of Texas. The Texas Journal of Science $4(1): 85-91$.

Box, T. W., J. Powe11, and D. L. Drawe

1967 Influence of Fire on South Texas Chaparral Communities. Ecology 48(6): 955-961.

Browman, D. L.

1981 Isotopic Discrimination and Correction Factors in Radiocarbon Dating. In Advances in Archaeological Method and Theory, Volume 4, edited by M. B. Schiffer:241-295. Academic Press, New York.

Brown, D. A.

1984 Prospects and Limits of a Phytol ith Key for Grasses in the Central United States. Journal of Archaeological Science $11: 345-368$.

Brown, K. M., D. R. Potter, G. D. Ha7l, and S. L. B1 ack

1982 Excavations at 41 LK 67. A Prehistoric Site in the Choke Canyon Reservoir, South Texas. Center for Archaeological Research, The University of Texas at San Antonio, Choke Canyon Series 7.

Brune, G.

1981 Springs of Texas. Volume 1. Branch-Smith, Inc., Fort Worth.

Bryant, V. M., Jr. and R. G. Holloway

1985 A Late-Quaternary Paleoenvironmental Record of Texas: An Overview of the Pollen Evidence. In Pol 1en Records of LateQuaternary North American Sediments, edited by V. M. Bryant, Jr., and R. G. Hol 1 oway:28-49. American Association of Stratigraphic Palynologists Foundation, Dallas, Texas. 
Bryant, V. M., Jr. and D. Riskind

1978 Late-Quaternary Pollen Records from the East-Central Periphery of the Chihuahuan Desert. In Transactions of the Symposium on the Biological Resources of the Chihuahuan Desert Region, edited by R. H. Wauer and D. H. Riskind:3-21. U.S. Department of the Interior, National Park Service, Transactions and Proceedings 3.

Bryant, V. M., Jr. and H. J. Shafer

1977 The Late Quaternary Paleoenvironment of Texas: A Mode1 for the Archeologist. Bulletin of the Texas Archeological Society $48: 1-25$.

Campbe1 1, T. N.

1947 The Johnson Site: Type Site of the Aransas Focus of the Texas Coast. Bulletin of the Texas Archeological and Paleontological Society 18:40-75.

1958 Archeology of the Central and Southern Sections of the Texas Coast. Bulletin of the Texas Archeological Society 29:145175.

1962 Origins of Pottery Types from the Coastal Bend Region of Texas. Bulletin of the Texas Archeological Society 36:331336.

1964 Appraisal of the Archeological Resources of Padre Island, Texas. Report submitted to the National Park Service.

1979 Ethnohistoric Notes on Indian Groups Associated with Three Spanish Missions at Guerrero, Coahuila. Center for Archaeological Research. The University of Texas at San Antonio, Archaeology and History of the San Juan Bautista Mission Area, Coahuila and Texas, Report 3.

1983 Coahuittecans and Their Neighbors. In Handbook of North American Indians, Volume 10, W. C. Sturtevant, general editor:343-358. Smithsonian Institution, Washington, D.C.

Campbe11, T. N. and T. J. Campbel1

1981 Historic Indians of the Choke Canyon Reservoir and Surrounding Area, Southern Texas. Center for Archaeological Research, The University of Texas at San Antonio, Choke Canyon Series 1.

1985 Indian Groups Associated with Spanish Missions of the San Antonio Missions National Historical Park. Center for Archaeological Research. The University of Texas at San Antonio, Special Report 16. 
Carlson, D. L., D. G. Steele, and H. L. Bruno

1982 Archeological Investigations at the Allison Site (41 NU 185), Nueces County, Texas. Texas A\&M University, Archeological Research Laboratory, Reports of Investigations 1.

Carr, J. T.

1967 The Climate and Physiography of Texas. Texas Water Development Board, Report 53.

Chadderdon, M. F.

1983 Baker Cave, Val Verde County, Texas: The 1976 Excavations. Center for Archaeological Research,. The University of Texas at San Antonio, Special Report 13.

Chandler, C. K.

1978 Two Clay Figurines from the Central Coastal Region of Texas. Bul letin of the Texas Archeological Society 49:341-348.

1982 Paleo-Indian Projectile Points from San Patricio County, Texas, Texas Coastal Bend. La Tierra 9(3):26-33.

1983 Notes on Some Bell Points from San Patricio County, Texas. La Tierra 10(3):7-10.

1984 Lithic Resources in the Texas Coastal Bend. La Tierra $11(1): 26-27$.

Chandler, C. K., F. Knolle, and M. M. Knolle

1983 Paleo-Indian Projectile Points from Jim Wells and Nueces County, Texas. La Tierra 10(2):23-27.

Clark, R. M.

1975 A Calibration Curve for Radiocarbon Dates. Antiquity 49:251266.

Coastal Environments, Inc.

1977 Cultural Resources Evaluation of the Northern Gulf of Mexico Continental Shelf. Prehistoric Cultural Resource Potential. Volume-1. CuTtura-7-Resource-Management-Studies, Nationa T-Park Service, Washington, D.C.

Conant, R.

1975 A Field Guide to Reptiles and Amphibians of Eastern and Central North America. Houghton Mifflin Company, Boston. 
Cook, 0. F.

1908 Changes of Vegetation on the South Texas Prairies. U.S. Department of Agriculture, Bureau Plant Identification, Circular 14.

Corbin, J. E.

1963 Archeological Materials from the Northern Shore of Corpus Christi Bay, Texas. Bulletin of the Texas Archeological Society $34: 5-30$.

1974 A Model for Cultural Succession for the Coastal Bend Area of Texas. Bulletin of the Texas Archeological Society 45:29-54.

Corre11, D. S. and M. C. Johnston

1970 Manual of the Vascular Plants of Texas. Texas Research Foundation, Renner.

Dalquest, W. W.

1965 New Plejstocene Formation and Local Fauna from Hardemann County, Texas. Journal of Paleontology 39:63-79.

Damon, P. E., C. W. Fergusson, A. Long, and E. I. Wallick

1974 Dendochronologic Calibration of the Radiocarbon Time Scale. American Antiquity 39(2):350-366.

Davenport, H. and J. K. Wells

1918- The First Europeans in Texas, 1528-1536. The Southwestern 1919 Historical Quarterly 22(2):111-142; 22(3):205-259.

Davis, E. M. and A. B. Wesolowsky

1975 The Izum: A Simple Water Separation Device. Journal of Field Archaeology 2:271-273.

Davis, W. B.

1974 The Mamma 15 of Texas. Texas Parks and Wild ife Department, Bulletin 41. Austin, Texas.

DeMarcay, G. B. and D. G. Steele

1986 The Value of Fine Screening on In1and Based Hunter-Gatherer Habitation Sites. Appendix VI in Archaeological Investigations at 41 LK 201, Choke Canyon Reservoir, by C. L. Highley:250-264. Center for Archaeological Research, The University of Texas at San Antonio, Choke Canyon Series 11. 
Dering, $P$.

1982 Analysis of Carbonized Botanical Remains From the Choke Canyon Reservoir Area. Appendix III in Archaeological Investigations at Choke Canyon Reservoir, South Texas: The Phase I Findings, by G. D. Ha 11 , S. L. B 1 ack, and C. Graves:518-530. Center for Archaeological Research, The University of Texas at San Antonio, Choke Canyon Series 5.

Dice, L. R.

1943 The Biotic Provinces of North America. University of Michigan Press, Ann Arbor.

Di1 lehay, T.

1974 Late Quaternary Bison Population Changes on the Southern Plains. Plains Anthropologist 19(64):180-196.

Drawe, D. L., A. D. Chamrad, and T. W. Box

1978 Plant Communities of the Welder Wildlife Refuge. Revised. Welder Wildlife Foundation, Sinton.

Dusek, C. L.

1982 The Impact of Brush Clearing on Archaeological Sites in the Choke Canyon Reservoir. Appendix IV in Archaeological Investigations at Choke Canyon Reservoir, South Texas: The Phase I Findings, by G. D. Hal1, S. L. B I ack, and C. Graves:531-540. Center for Archaeological Research. The University of Texas at San Antonio, Choke Canyon Series 5.

Eidt, R. C.

1977 Detection and Examination of Anthrosols by Phosphate Analysis. Science 197(4311):1327-1339.

1984 Advances in Abandoned Settlement Analysis: App 1 ication to Prehistoric Anthrosols in Columbia, South America. The Center for Latin America, University of Wisconsin, Milwaukee.

Epstein, J. F.

1979 Flint Technology and the Heating of Stone. In Early Technologies, edited by D. Schmant-Besserat:27-38. Undena Publications, Malibu, Cal ifornia.

Erdtman, G.

1960 The Acetolysis Method: A Revised Description. Svensk. Bot. Tidsk. 54. 
Everett, D. and P. A. Bandy

1981 Part I - Historical Resources of the Choke Canyon Reservoir Area in McMullen and Live Oak Counties, Texas. Part II Historical Archaeological Resources of the Choke Canyon Reservoir Area in McMullen and Live Oak Counties, Texas. Center for Archaeological Research, The University of Texas at San Antonio, Choke Canyon Series 2.

Fawcett, W. B., Jr.

1978 Chronology and Culture Process: A Methodological Consideration. In Wyoming Contributions to Anthropology, Spring 1978:133-138. Department of Anthropology, University of Wyoming, Laramie.

Fenneman, N. M.

1938 Physiography of the Eastern United States. McGraw-Hi11, New York.

Fladmark, K. R.

1978 A Guide to Basic Archaeological Field Procedures. Department of Anthropology, Simon Fraser University, Publication 4. Burnab7y, British Columbia.

Fleming, S.

1977 Dating In Archaeology: A Guide to Scientific Techniques. St. Martin's Press, New York.

Flynn, L. M.

1983 Faunal Analysis: 41 GD 30A. Appendix II in The Berger Bluff Site (4l GD 30A): Excavations in the Upper Deposits, 1979, by D. O. Brown. Center for Archaeological Research. The University of Texas at San Antonio, Archaeological Survey Report 115.

Fox, A. A.

1984 A Study of Five Historic Cemeteries at Choke Canyon Reservoir, Live Oak and McMul len Counties, Texas. Center for Archaeo1 ogical Research. The University of Texas at San Antonio, Choke Canyon Series 9.

1986 Archaeological Investigations at Historic Sites in the Choke Canyon Reservoir, Southern Texas. Center for Archaeological Research, The University of Texas at San Antonio, Choke Canyon Series 12. 
Fox, D. E.

1979 Archaeological Investigations of Two Prehistoric Sites on the Coleto Creek Drainage, Goliad County, Texas. Center for Archaeological Research. The University of Texas at San Antonio, Archaeological Survey Report 69.

Goddard, I.

1979 The Languages of South Texas and the Lower Rio Grande. In The Languages of Native America: Historical and Comparative Assessment, edited by L. Campbel 1 and M. Mithun:355-389. University of Texas Press, Austin.

Gould, F. W.

1969 Texas Plants: A Checklist and Ecological Summary. Revised Edition. Texas A\&M University, Texas Agricultural Experiment Station, College Station.

Gou1d, F. W. and T. W. Box

1965 Grasses of the Texas Coastal Bend. 2nd edition. Texas A\&M University Press, College Station.

Green, L. M. and T. R. Hester

1973 The Finis Frost Site: A Toyah Phase Occupation in San Saba County, Central Texas. Bulletin of the Texas Archeological Society $44: 69-88$.

Greer, J.W.

1976 Neo-American Occupation at the Wheatley Site, Pedernales Fal1s State Park, Blanco County, Texas. Bulletin of the Texas Archeological Society 47:89-169.

Gunn, J., T. R. Hester, R. Jones, R. L. Robinson, and R. A. Mahula

1982 Climatic Change in Southern Texas. Appendix VII in Archaeological Investigations at Choke Canyon Reservoir, South Texas: The Phase I Findings, by G. D. Hal T, S. L. Black, and C. Graves:578-596. Center for Archaeological Research. The University of Texas at San Antonio, Choke Canyon Series 5.

Hal1, E. R.

1981 The Mammals of North America. John Wiley and Sons, New York. 
Ha11, G. D.

1983 Allens Creek: A Study in the Cultural Prehistory of the Lower Brazos River Val1ey, Texas. Texas Archeological Survey, The University of Texas at Austin, Research Report 61.

Ha17, G. D., S. L. BTack, and C. Graves

1982 Archaeological Investigations at Choke Canyon Reservoir, South Texas: The Phase I Findings. Center for Archaeological Research, The University of Texas at San Antonio, Choke Canyon Series 5.

Ha17, G. D., T. R. Hester, and S. L. Black

1986 The Prehistoric Sites at Choke Canyon Reservoir, Southern Texas: Results of Phase II Archaeological Investigations. Center for Archaeological Research. The University of Texas at San Antonio, Choke Canyon Series 10.

Harris, E. S.

1985 An Archaeological Study of the Timmeron Rockshelter (4I HY 95), Hays County, South Central Texas. Southern Texas Archaeological Association. Special Publication 4.

Henderson, J.

n.d. Excavations at the Rainey Site, A Late Prehistoric Sink Hole Site in Bandera County, Texas. State Department of Highways and Public Transportation. Highway Design Division,

Publications in Archaeology, Report 33 (in preparation).

Henry, W. K., D. M. Driscol1, and J. P. McCormack

1975 Hurricanes on the Texas Coast. Center for Applied Geosciences, Texas A\&M University, College Station.

Hester, T. R.

1969 Archeological Investigations in K1eberg and Kenedy Counties, Texas. State Building Commission Archeological Program, Report 15.

1971 Loyola Beach: An Example of Aboriginal Adaptation to the Maritime Environment of the Lower Texas Coast. Florida Anthopologist 24(3):91-106.

1975 Late Prehistoric Cultural Patterns Along the Lower Rio Grande of Texas. Bulletin of the Texas Archeological Society 46:107125. 
Hester (continued)

1976 Hunters and Gatherers of the Rio Grande P 1 ain and the Lower Coast of Texas. Center for Archaeological Research, The University of Texas at San Antonio.

1977 Archaeological Research at the Hinojosa Site (41 JW 8), Jim Wel $1 \mathrm{~s}$ County, Southern Texas. Center for Archaeological Research. The University of Texas at San Antonio, Archaeological Survey Report 42.

1978 Background to the Archaeology of Chaparrosa Ranch, Southern Texas. Volume 1: Studies in the Archaeology of Chaparrosa Ranch. Center for Archaeological Research. The University of Texas at San Antonio, Specia1 Report 6.

1980a Digging Into South Texas Prehistory. Corona Publishing Company, San Antonio.

1980b A Survey of Paleo-Indian Archaeological Remains Along the Texas Coast. In Papers on the Archaeology of the Texas Coast, edited by L. Highley and T. R. Hester:1-12. Center for Archaeological Research. The University of Texas at San Antonio, Special Report 11.

1981 Tradition and Diversity Among the Prehistoric Hunters and Gatherers of Southern Texas. Plains Anthropologist 26(92) : 119-128.

1983 Late Paleo-Indian Occupations at Baker Cave, Southwestern Texas. Bulletin of the Texas Archeological Society 53:101119.

Hester, T. R. and F. A. Bass, Jr.

1974 An Archaeological Survey of Portions of the Chiltipin-San Fernando Creeks Watershed, Jim Wel 1 s County, Texas. Center for Archaeological Research. The University of Texas at San Antonio, Archaeological Survey Report 4.

Hester, T. R. and M. B. Collins

1974 Evidence for Heat Treating of Southern Texas Projectile Points. Bulletin of the Texas Archeological Society 46:219224.

Hester, T. R., J. D. Eaton, and S. L. Black

1980 A Proposal for Archaeological Investigations at Site $41 \mathrm{JW}$ 8, Chiltipin-San Fernando Watershed, Jim Wel 1 s County, Texas. Submitted to National Park Service-Denver in response to RFP 530050, JuTy 21, 1980. 
Hester, T. R., D. Gilbow, and A. Albee

1973 A Functional Analysis of Clear Fork Artifacts from the Rio Grande Plain of Texas. American Antiquity 38(1):90-96.

Hester, T. R. and R. F. Heizer

1973 Arrow Points or Knives? Comments on the Proposed Function of 'Stockton Points'. American Antiquity 38:220-221.

Hester, T. R., R. F. Heizer, and J. A. Graham

1975 Field Methods in Archaeology. 6th edition. Mayfield Publishing Company, Palo Alto, California.

Hester, T. R. and T. C. Hill, Jr.

1971 An Initial Study of a Prehistoric Ceramic Tradition in Southern Texas. Plains Anthropologist 16(52):195-203.

1972 Prehistoric Occupation at the Holdsworth and Stewart Sites on the Rio Grande Plain of Texas. Bulletin of the Texas Archeological Society 15:33-75.

1975 Some Aspects of Late Prehistoric and Protohistoric Archaeology in Southern Texas. The Texas Journal of Science 26(1-2):223228.

Hester, T. R., T. C. Hill, Jr., D. Gifford, and S. Holbrook

1975 Archaeological Salvage at Site 41 ZV 152, Rio Grande Plain of Texas. The Texas Journal of Science $26(1$ and 2$): 223-228$.

Hester, T. R. and T. C. Kelly

1976 Archaeological Investigations at Sites near Natalia, Medina County, Texas. Center for Archaeological Research, The University of Texas at San Antonio, Archaeological Survey Report 20.

Hester, T. R. and R. Parker

1970 The Berclair Site: A Late Prehistoric Component in Goliad County, Southern Texas. Bulletin of the Texas Archeological Society $41: 1-24$.

Hester, T. R. and F. A. Ruecking, Jr.

The Ayala Site. In Two Prehistoric Cemetery Sites in the Lower Rio Grande Valley of Texas. Bulletin of the Texas Archeological Society 40:147-157. 
Hibbard, C. W.

1960 An Interpretation of Pliocene and Pleistocene Climates in North America. In The President's Address:5-30. Michigan Academy of Science, Arts and Letters.

Highley, C. L.

1985 Modified Bone and Antler. In The Panther Springs Creek Site: Cultural Change and Continuity in the Upper Salado Creek Watershed, South-Central Texas, by S. L. Black and A. J. MCGraw:199-208. Center for Archaeological Research, The University of Texas at San Antonio, Archaeological Survey Report 100.

1986 Archaeological Investigations at 41 LK 201, Choke Canyon Reservoir, Southern Texas. Center for Archaeological Research, The University of Texas at San Antonio, Choke Canyon Series 11 .

Highley, L., A. Gerstle, and T. R. Hester

1977 An Archaeological and Historical Assessment of the Tule Lake Tract, Nueces County, Texas. Center for Archaeological Research, The University of Texas at San Antonio, Archaeological Survey Report 27.

Hightey, L., C. Graves, C. Land, and G. Judson

1978 Archeological Investigations at Scorpion Cave (4l ME 7), Medina County, Texas. Bulletin of the Texas Archeological Society 49:139-194.

Hi11, T. C., Jr.

1978 Pipes, Pots, and Little Indian Girls. La Tierra 5(3):26-29.

Hil1, T. C., Jr. and T. R. Hester

1973 A Preliminary Report on the Tortuga Flat Site: A Protohistoric Campsite in Southern Texas. Texas Archeology $17(2): 10-14$.

Hole, F. and R. F. Heizer

1973 An Introduction to Prehistoric Archeology. 3rd edition. Holt, Rinehart and Winston, Inc., New York.

Holloway, R. G.

1981 Preservation and Experimental Diagenesis of the Pollen Exine. Ph.D. dissertation, Texas A\&M University, College Station. 
Holloway (continued)

1986 Macrobotanical Analysis of Phase II Materials from the Choke Canyon Reservoir Area, Texas. Appendix II in The Prehistoric Sites at Choke Canyon Reservoir, Southern Texas: Results of Phase II Archaeological Investigations, by G. D. Hal 1, T. R. Hester, and S. L. B Tack:437-451. Center for Archaeological Research, The University of Texas at San Antonio, Choke Canyon Series 10.

Holloway, R. G. and H. J. Shafer

1979 Organic Residue Analysis in Determining Stone Tool Function. In Lithic Use-Wear Analysis, edited by B. Hayden:385-400. Academic Press, New York.

Hulbert, R. C.

1979 Linear Discriminant Analysis and Variability of Pleistocene and Holocene Leporidae of Texas. Unpublished M.A. thesis, The University of Texas at Austin.

Inglis, J. M.

1964 A History of Vegetation on the Rio Grande Plain. Texas Parks and Wildlife Department, Bulletin 45. Austin, Texas.

Jackson, A. T.

1940 Tubular Pipes and Other Tubes in Texas. Bul1 etin of the Texas Archeological and Paleontological Society 12:99-137.

Jelks, E. B.

1962 The Kyle Site: A Stratified Central Texas Aspect Site in Hill County, Texas. Department of Anthropology, The University of Texas at Austin, Archeology Series 5.

1975 The Use and Misuse of Random Samp 1 ing in Archeology. Jett Publishing Co., Normal, Illinois.

Johnson, L. Jr., D. A. Suhm, and C. D. Tunnel1

1962 Salvage Archeology of Canyon Reservoir: The Wunderlich, Footbridge and Oblate Sites. Texas Memorial Museum, Bulletin 5.

Johnson, M. C.

1963 Past and Present Grass 1 ands of South Texas and Northeastern Mexico. Ecology 44:456-465. 
Jones, F. B.

1975 Flora of the Texas Coastal Bend. Welder Wildl ife Foundation, Sinton, Texas.

Keeley, L. H.

1980 Experimental Determination of Stone Tool Uses. The University of Chicago Press, Chicago.

Kelley, J. C.

1947 The Lehmann Rock Shelter: A Stratified Site of the Toyah, Uvalde, and Round Rock Foci. Bulletin of the Texas Archeological and Paleontological Society 118:115-128.

Kelley, J. C., T. N. Campbe11, and D. J. Lehmer

1940 The Association of Archaeological Materials with Geological Deposits in the Big Bend Region of Texas. Sul Ross State Teachers College, Bulletin 21(3). Alpine.

Klein, J., J. C. Lerman, P.E. Damon, and E. K. Ralph

1982 Calibration of Radiocarbon Dates. Radiocarbon 24(2):103-150.

Kroeber, A. L.

1925 Handbook of California Indians. Bureau of American Ethnology, Bulletin 78.

Landar, H.

1968 The Karankawa Invasion of Texas. International Journal of American Linguistics 34:242-258.

Lehmer, D. J.

1960 A Review of Trans-Pecos Archeology. Bulletin of the Texas Archeological Society 29:109-144.

Lenney, L. and R. Castee 1

1975 Simp 1 ified Procedure for Examining Charcoal Specimens for Identification. Journal of Archaeological Science 2:153-159.

Lewis, D. R.

1978 Use of Phosphate Analysis for Determining Land Use. Bulletin of the Texas Archeological Society 49:309-317. 
Lundelius, E. L., Jr.

1974 The Last Fifteen Thousand Years of Faunal Change in North America. The Museum Journal XV:141-160.

MacNeish, R. S.

1958 Preliminary Archaeological Investigations in the Sierra de Tamaulipas, Mexico. Transactions, American Philosophical Society $48(6)$.

Mallouf, R. J., B. J. Baskin, and K. L. Killen

1977 A Predictive Assessment of Cultural Resources in Hidalgo and Wi 11 acy Counties, Texas. Texas Historical Commission, Office of the State Archeologist, Survey Report 25.

Mallouf, R. J. and A. N. Zavaleta

1979 The Unland Site. Texas Historical Commission, Office of the State Archeologist, Special Report 25.

McGraw, A. J.

1983 Arroyo de los Muertos and Other Prehistoric Terrace Sites Along the Rio Grande, Laredo, Texas. Center for Archaeological Research. The University of Texas at San Antonio, Archaeological Survey Report 106.

1984 Archaeology in the South Texas Sand Sheet: A Study of Chevron Properties in Brooks County. Center for Archaeological Research, The University of Texas at San Antonio, Archaeological Survey Report 129.

McGraw, A. J., B. J. Van Note, and C. J. Jones

n.d. Archaeology of the Brasada: A Cultural Resources Assessment of the Chevron Resources Company Properties in Northeastern Duval County, Texas. Center for Archaeological Research, The University of Texas at San Antonio, Archaeological Survey Report 113 (in preparation).

Mckinney, W. W.

1981 Early Holocene Adaptations in Central and Southwestern Texas: The Problem of the Paleoindian-Archaic Transition. Bulletin of the Texas Archeological Society 52:91-120.

Michae T, H. N. and J. Klein

1979 An International Calibration for Radiocarbon Dates. MASCA Journal $1(2): 56-57$. 


\begin{abstract}
Minzenmayer, F. E.
1979 Soil Survey of Jim Wells County, Texas. United States Department of Agriculture, Soil Conservation Service, in cooperation with the Texas Agricultural Experiment Station.

Mitche11, J. L.

1978 The Turtle Creek Phase: An Initial Late Prehistoric Component in Southern Texas. La Tierra 5(4):32-43.

Mokry, E. R., Jr.

n.d. Letter to S. B1ack and notes on Oso Creek Late Prehistoric sites in Nueces County. On file at the Center for Archaeological Research. The University of Texas at San Antonio.
\end{abstract}

Mokry, E. R., Jr. and S. L. Black

ms. A Pottery-Making Locality in Nueces County, Texas. Manuscript in preparation.

Montgomery, J. L.

1978 The Mariposa Site: A Late Prehistoric Site on the Rio Grande Plain of Texas. Center for Archaeological Research. The University of Texas at San Antonio, Special Report 6(2).

Mueller, J. W.

1974 The Use of Sampling in Archaeological Survey. Memoirs of the Society for American Archaeology 28.

Murphy, J. and J. P. Riley

1962 A Modified Single Solution Method for the Determination of Phosphate in Natural Waters. Analytical Chim. Acta. 27:31-36.

Murray, H. D.

1982 An Analysis of Unionids (Freshwater Mussels) Recovered in Phase I Archaeological Investigations at Choke Canyon Reservoir. Appendix $V$ in Archaeological Investigations at Choke Canyon Reservoir, South Texas: The Phase I Findings, by G. D. Ha11, S. L. B 1 ack, and C. Graves:541-555. Center for Archaeological Research, The University of Texas at San Antonio, Choke Canyon Series 5.

Nance, J. D.

1971 Functional Interpretations from Microscopic Analysis. American Antiquity $36: 361-366$. 
Newcomb, W. W.

1961 The Indians of Texas, from Prehistoric to Modern Times. University of Texas Press, Austin.

1983 Karankawa. In Handbook of North American Indians, Volume 10, W. D. Sturtevant, general editor:359-367. Smithsonian Institution, Washington, D.C.

Noakes, J.

1984 Letter to S. L. Black dated July 19, 1984, concerning radiocarbon assays of $41 \mathrm{JW} 8$.

$01 d s$, D. L.

1965 Report on Materials from Brawley's Cave, Bosque County, Texas. Bul 1etin of the Texas Archeological Society 36:111-152.

Patterson, P. E. and M. M. Ford

1974 Oso Creek Flood Control Project Area, Nueces County, Texas: A Report on the Archeological and Historical Resources, Texas. Sponsored by the Corps of Engineers. Texas Archeological Survey, The University of Texas at Austin, Research Report 35.

Prewitt, E. R.

ms. The Neoarchaic Stage. In Waco as a Frontier in Prehistory, edited by J. W. Fox (in preparation).

1974 Preliminary Archeological Investigations in the Rio Grande Delta Area of Texas. Bulletin of the Texas Archeological Society $45: 55-65$.

1981a Cultural Chronology in Central Texas. Bulletin of the Texas Archeological Society 52:65-89.

1981b A Wooden Mortar from the Stockton P1ateau of Texas. Journa 1 of Field Archaeology 8(1):111-117.

1982 The 1982 TAS Field School, Rowe Valley, Texas. Texas Archeology $26(3): 2-5$.

1983 Rowe Valley Revisited: The 1983 TAS Field School. Texas Archeology $27(3): 2-4$.

1984 Third Time Charm: The 1984 TAS Field School at Rowe Val ley (41 WM 437). Texas Archeology 28(3):1, 5, 6 .

1985 From Circleville to Toyah: Comments on Central Texas Chronology. Bulletin of the Texas Archeological Society $54: 201-238$. 
Price, W. A. and G. Gunther

1943 Certain Recent Geological and Biological Changes in South Texas, with Consideration of Probable Cause. Proceedings and Transactions of the Texas Academy of Science 1942:138-156.

Purdy, B. A. and H. K. Brooks

1971 Thermal Alteration of Silica Minerals: An Archaeological Approach. Science 173:322-325.

Radin, P.

1956 The Trickster: A Study in American Indian Mythology. Schocken Books, New York.

Ralph, E. K.

1971 Carbon-14 Dating. In Dating Techniques for the Archaeologist, edited by H. M. Michael and E. K. Ralph:1-49. MIT Press, Cambridge, Mass.

Ralph, E. K., H. N. Michael, and M. C. Han

1973 Radiocarbon Dates and Reality. MASCA Newsletter 9(1):1-20.

Raun, G. G. and H. E. Laugh7 in

1972 Sub-Recent Vertebrate Remains from a Site in Southern Texas with Comments on Microtus (Pedomys) 1 udovicianus. Southwestern Natural ist $16(3 \& 4): 436-439$.

Redman, C. L.

1974 Archaeological Sampling Strategies. An Addison-Wesley Module in Anthropology 55.

Robbins, C. S., B. Brunn, and H. S. Zim

1966 A Guide to Field Identification Birds of North America. Golden Press, New York.

Robinson, R. L.

1979 Biosilica and C7imatic Change at 41 GD 21 and 41 GD $21 \mathrm{~A}$. Appendix IV in Archaeological Investigations of Two Prehistoric Sites on the Coleto Creek Drainage, Goliad County, Texas, by D. E. Fox:102-113. Center for Archaeological Research, The University of Texas at San Antonio, Archaeological Survey Report 69. 
Robinson (continued)

1982 Biosilica Analysis of Three Prehistoric Archaeological Sites in the Choke Canyon Reservoir, Live Oak County, Texas: Preliminary Summary of $\mathrm{Cl}$ imatic Implications. Appendix VIII in Archaeological Investigations at Choke Canyon Reservoir, South Texas: The Phase I Findings, by G. D. Ha 11 , S. L. B 1 ack, and C. Graves:597-610. Center for Archaeological Research, The University of Texas at San Antonio, Choke Canyon Series 5.

Roemer, E., Jr.

1981 The 1979 Archaeological Survey of Portions of the Choke Canyon Reservoir in Live Oak and McMullen Counties, Texas. Center for Archaeological Research. The University of Texas at San Antonio, Choke Canyon Series 4.

Roth, E. L.

1972 Late Pleistocene Mamma 1s from Klein Cave, Kerr County, Texas. The Texas Journal of Science 24(1):75-84.

Ruecking, F. A., Jr.

1955 The Coahuiltecan Indians of Southern Texas and Northeastern Mexico. Unpublished M.A. thesis, Department of Anthropology, The University of Texas at Austin.

Sauer, C. 0 .

1950 Grass 1 and $\mathrm{Cl}$ imax, Fire and Man. Journal of Range Management $27: 5-11$.

Sayles, E. B.

1935 An Archaeological Survey of Texas. Medal1ion Papers 17:1-164. Schmid7y, D. J.

1977 The Mammals of Trans-Pecos Texas. Texas A\&M University Press, College Station, Texas.

1983 Texas Mammals East of the Balcones Fault Zone. Texas A\&M University Press, College Station.

Scifres, C. J.

1980 Integrating of Prescribed Burning With Other Brush Management Methods: The Systems Concept of Brush Management. In Prescribed Range Burning in the Rio Grande Plain, Texas:44-50. Texas Agricultural Extension Service, Col lege Station. 
Scifres, C. J. and D. M. Kelly

1979 Range Vegetation Response to Burning Thicketized Live Oak Savannah. Texas Agricultural Experiment Station B-1246. Texas A\&M University, College Station.

Scott, R. F.' IV and D. E. Fox

1982 Excavations at Sites 41 LK $31 / 32$ and 41 LK 202 in the Choke Canyon Reservoir, South Texas. Center for Archaeologica 1 Research, The University of Texas at San Antonio, Choke Canyon Series 8.

Sel1ards, E. H.

1940 Pleistocene Artifacts and Associated Fossils from Bee County, Texas. Bulletin of the Geological Society of America 51:16271657.

Shackley, M. L.

1975 Archaeological Sediments: A Survey of Analytical Methods. Halstead Press, John Wiley \& Sons, New York.

Shafer, H. J.

1971 Late Prehistory of Central Texas: 500 B.C. to A.D. 1700. Paper given at annual meeting, Texas Academy of Science, Nacogdoches.

Shafer, H. J. and T. R. Hester

1971 A Study of the Function and Technology of Certain Bifacial Tools from Southern Texas. Texas Historical Survey Committee, Archeological Report 20.

Sheets, P. D.

1973 Edge Abrasion During Biface Manufarture. American Antiquity $38: 215-218$.

Sketton, D.W. and J. Meridith

1977 Analysis of Therma 11 y Altered Chert from the Fayette Power Project. Appendix III in Archeological Investigations at the Fayette Power Project, Fayette County, Texas, by D. W. Skelton:211-226. Texas Archeological Survey, The University of Texas at Austin, Research Report 60.

Smith, H. A.

1982 Burned Clay Objects in Southern Texas Archaeological Sites: A Reevaluation. La Tierra 9(4):34-36. 
Smith (continued)

1983 An Archeological Assessment of the Baffin Bay Area of the Lower Texas Coast. Paper presented at 48th Annual Meeting of the Society of American Archaeologists.

1984a Prehistoric Settlement and Subsistence Patterns of the Baffin Bay Area of the Lower Texas Coast. Ph.D. dissertation, Southern Methodist University, Da11as, Texas.

1984b Origins and Spatial/Temporal Distribution of the Rockport Archaeological Complex, Central and Lower Texas Coast. Midcontinenta 1 Journal of Archaeology $9(1): 27-42$.

Sollberger, J. B.

1967 A New Type of Arrow Point with Speculations as to Its Origin. The Record 23(3).

1978 A New Type of Arrow Point with Speculations as to Its Origins. La Tierra $5(4): 13-20$

Steele, D. G.

1986 Analysis of Vertebrate Faunal Remains from 41 LK 201, Live Oak County, Texas. Appendix $V$ in Archaeological Investigations at 41 LK 201, Choke Canyon Reservoir, Southern Texas, by C. L. High 1 ey:200-249. Center for Archaeological Research, The University of Texas at San Antonio, Choke Canyon Series 11.

Steele, D. G. and C. A. Hunter

1986 Analysis of Vertebrate Faunal Remains from 41 MC 222 and 41 MC 296, McMulien County, Texas. Appendix III in The Prehistoric Sites at Choke Canyon Reservoir, Southern Texas: Results of Phase II Archaeological Investigations, by G. D. Hal1, T. R. Hester, and S. L. B 1 ack:452-502. Center for Archaeological Research. The University of Texas at San Antonio, Choke Canyon Series 10.

Steete, D. G. and E. R. Mokry, Jr.

1985 Archeological Investigations of Seven Prehistoric Sites Along Oso Creek, Nueces County, Texas. Bul1etin of the Texas Archeological Society 54:287-308.

Story, D. A.

1968 Archeological Investigations at the Central Texas Gulf Coastal Sites. State Building Commission. Archeological Program, Report 13. 
Story (continued)

1980 Adaptive Strategies of Archaic Cultures of the West Gulf Coast P1ain. Unpub 1 ished manuscript on file, Center for Archaeological Research. The University of Texas at San Antonio.

Story, D. A. and S. Valastro, Jr.

1977 Radiocarbon Dating and the George C. Davis Site, Texas. Journal of Field Archaeology 4:63-89.

Stuiver, $M$.

1982 A High-Precision Calibration of the A.D. Radiocarbon Time Scale. Radiocarbon 24(1):1-26.

Suhm, D. A.

1959 The Wi1 1 iams Site and Central Texas Archeology. The Texas Journal of Science 11:218-250.

Suhm, D. A. and E. B. Jelks

1962 Handbook of Texas Archeology: Type Descriptions. Texas Archeological Society, Special Publication 1 and Texas Memorial Museum, Bulletin 4. Austin.

Suhm, D. A., A. D. Krieger, and E. B. Jelks

1954 An Introductory Handbook of Texas Archeology. Bul 1etin of the Texas Archeological Society 25.

Taylor, W. W.

1966 Archaic Cultures Adjacent to the Northeastern Frontiers of Mesoamerica. In Handbook of Middle American Indians, edited by G. F. Ekholm and G. R. Willey 4:59-94. University of Texas Press, Austin.

The Texas Almanac

1983- The Dallas Morning News, Dallas, Texas. 1984

Thoms, A. V., J. L. Montgomery, and A. W. Portnoy

1981 An Archaeological Survey of a Portion of the Choke Canyon Reservoir in MCMullen and Live Oak Counties, Texas. Center for Archaeological Research. The University of Texas at San Antonio, Choke Canyon Series 3. 
Turner, E. S. and T. R. Hester

1985 A Field Guide to the Stone Artifacts of Texas Indians. Texas Monthly Press, Austin.

VeTa, A.

1982 Observations on Discoloration in Grain Sorghum and Land Snai1s. La Tierra 9(4):32-33.

Vines, R. A.

1977 Trees of East Texas. University of Texas Press, Austin.

Wagner, G. E.

1982 Testing Flotation Recovery Rates. American Antiquity $47(1): 127-132$.

Warren, J. E.

1984 A Cultural Resources Reconnaissance of the City of Alice Sanitary Landfi11, Jim Wel1s County, Texas. Mimeographed report, Texas Antiquities Committee Permit No. 427.

Wedel, W. W.

1970 Antler Tine Scraper Handles in the Central Plains. Plains Anthropologist $15(47): 36-45$.

Weed, C. S. and H. J. Shafer

1981 Archaeological Testing and Collecting at Choke Canyon Reservoir, Nueces River Project, Texas. Center for Archaeological Research. The University of Texas at San Antonio, Choke Canyon Series 6.

Weir, F. A.

1976 The Central Texas Archaic. Ph.D. dissertation, Washington State University. University Microfilms, Ann Arbor.

Weniger, $D$.

1984 The Explorers' Texas: The Lands and Waters. Eakin Press, Austin.

White, J. R.

1980 A Closer Look at Clusters. American Antiquity 45(1):66-74. 
Willey, G. R. and P. Phillips

1958 Method and Theory in American Archaeology. The University of Chicago Press, Chicago.

Wilmsen, E.

1970 Lithic Analysis and Cultural Inference. University of Arizona, Anthropological Papers 16. Tucson.

Woods, W.

1975 The Analysis of Abandoned Settlements by a New Phosphate Field Test Method. Journal of North American Archaeology 13(1-2).

Word, J. H.

1970 The Archeological Investigation. Part I in Excavations at Baker Cave, Val Verde County, Texas, by J. H. Word and C. L. Douglas:1-109. Bulletin of the Texas Memorial Museum 16.

Wylie, H. G.

1975 Tool Microwear and Functional Types from Hogup Cave, Utah. Tebiwa $17(2): 1-31$. 
290

Hinojosa Site, $41 \mathrm{JW} 8$

APPENDIX 1

PROVENIENCE DATA: LOT NUMBERS

Appendix 1 is a listing of all the lot numbers (catalog numbers) assigned to the materials recovered during the 1981-1982 season at 41 JW 8 (Lots 56-473). Lot numbers 1-55 were assigned during the initial testing of the site (Hester 1977).

Al 1 of the units 1 isted in the lot number 1 is are $1-\mathrm{m}^{2}$ ce ll. A11 of the coordinates refer to the datum (grid southwest) corner of each ce 11. Also given are level numbers and in some cases comments. Lot numbers were. assigned to feature materials within the various units and levels. Thus, Lot 126 contains the regular level recovery from N107 E98 L.2 while Lot 156 contains additional material recovered from Feature 2 in the same unit-level. Lot numbers were also assigned to matrix samples, CVS (constant volume samples), and occasionally charcoal or rock samples. Abbreviations used are the same as elsewhere in the report and 1 listed in Section I. 


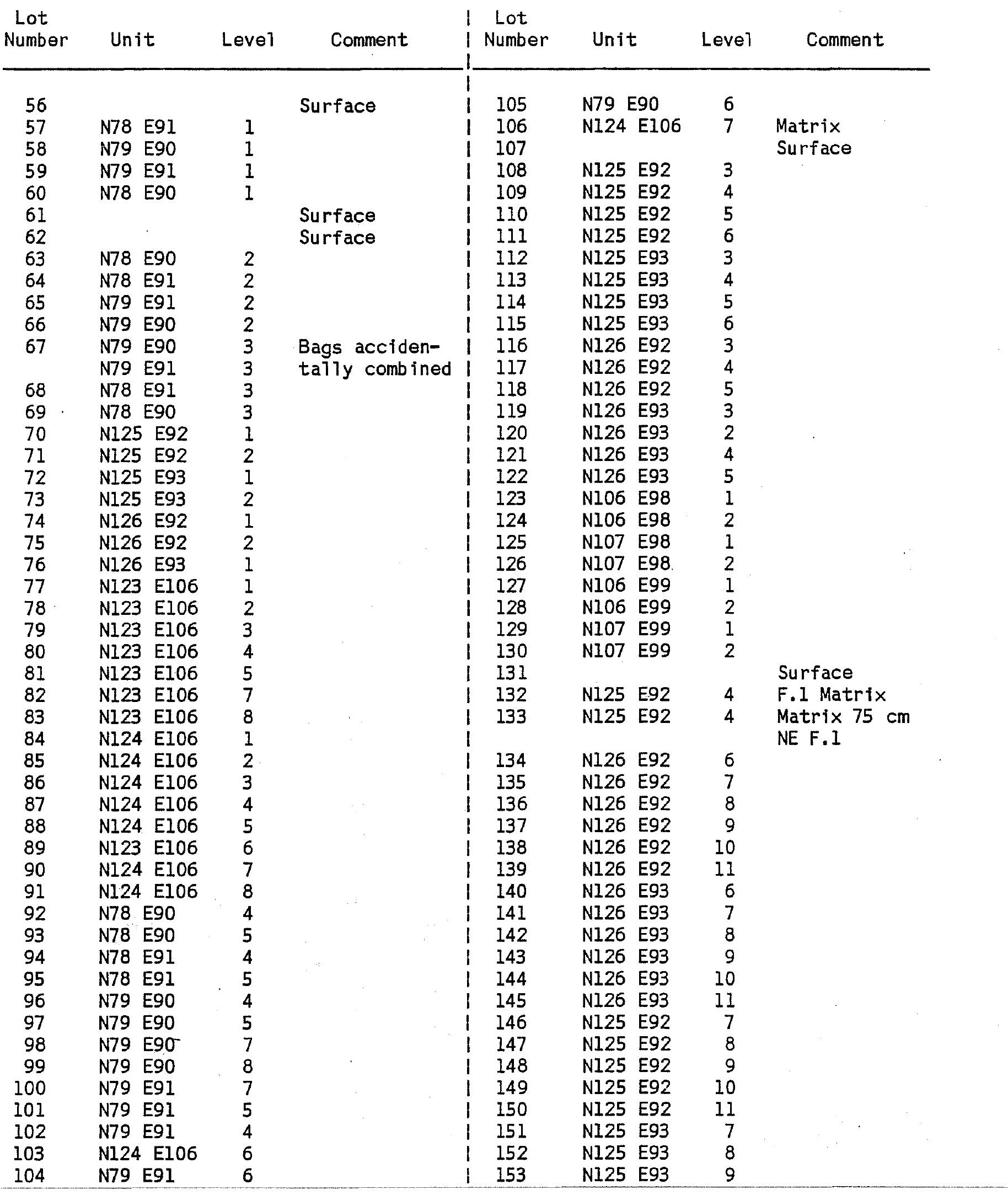


Lot Number Unit Level Comment Lot

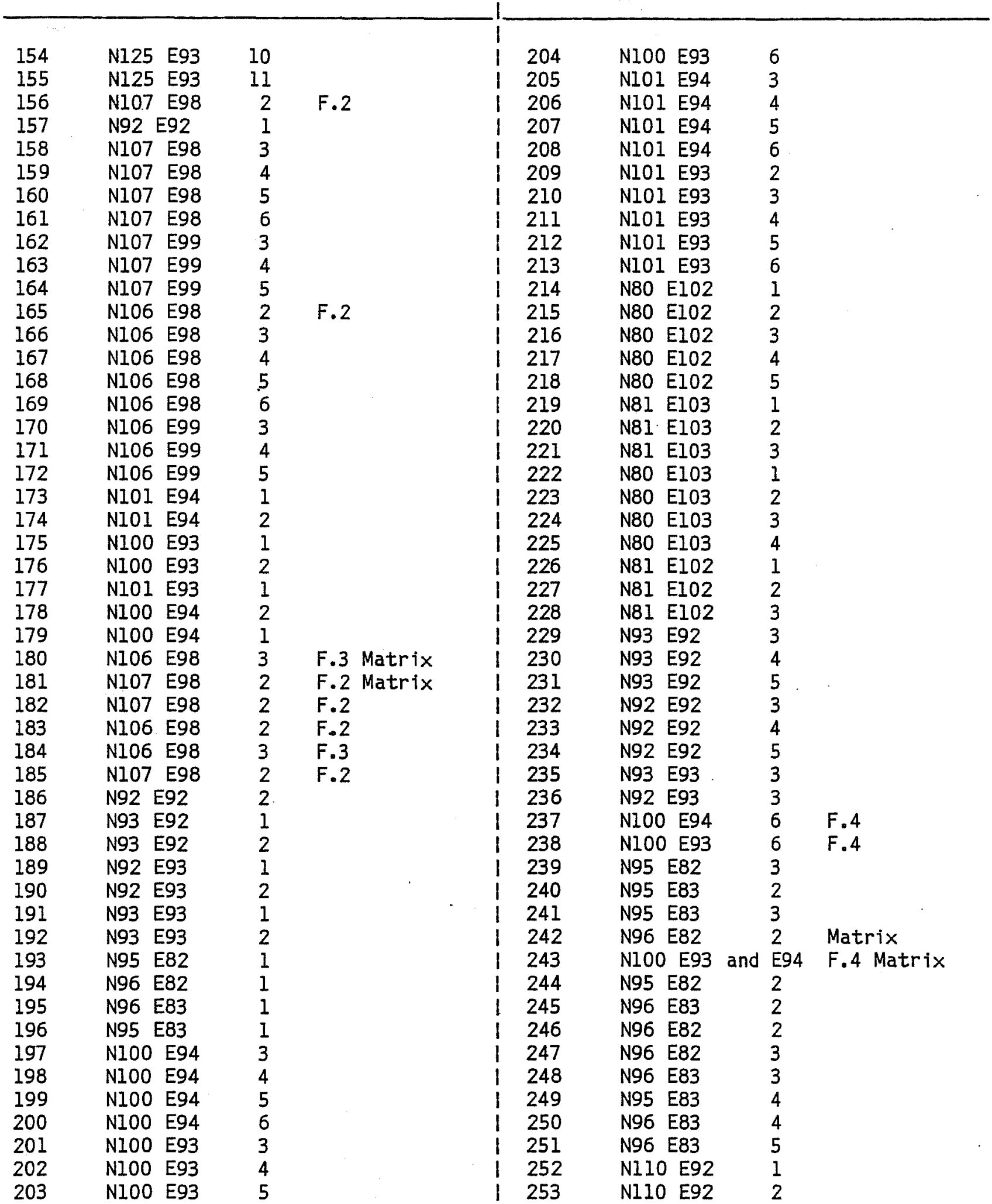


Lot

\begin{tabular}{|c|c|c|c|c|c|c|c|}
\hline $\begin{array}{l}\text { Lot } \\
\text { Number }\end{array}$ & Unit & Level & Comment & Lot & Unit & Level & Comment \\
\hline 254 & N110 E92 & 3 & & 301 & N109 E99 & 3 & \\
\hline 255 & N110 E93 & 1 & & $\begin{array}{l}1302 \\
1 \quad 302\end{array}$ & N109 E97 & 3 & \\
\hline 256 & N110 E93 & 2 & & 303 & N108 E98 & 3 & \\
\hline 257 & N110 E93 & 3 & & 304 & N109 E98 & 2 & F.5 \\
\hline 258 & N111 E92 & 1 & & 305 & N105 E98 & 3 & Matrix \\
\hline 259 & NIII E92 & 2 & & i 306 & N109 E98 & 2 & F.5 Matrix \\
\hline 260 & N111 E92 & 3 & & $i$ & & & (upper) \\
\hline 261 & N11l E93 & 1 & & i 307 & N109 E98 & 2 & F.5 Matrix \\
\hline 262 & N111 E93 & 2 & & 1 & & & $S 1 / 2$ \\
\hline 263 & NIII E93 & 3 & & 308 & N109 E98 & 2 & F.5 Matrix \\
\hline 264 & N104 E97 & 1 & & 1 & & & $\mathrm{~N} 1 / 2$ \\
\hline 265 & N104 E97 & 2 & includes F.10 & 309 & N109 E98 & 3 & $\begin{array}{l}\text { F.5 Matrix } \\
\text { S } 1 / 2\end{array}$ \\
\hline 266 & N105 E99 & 1 & & 310 & N104 E94 & 1 & \\
\hline 267 & N105 E99 & 2 & & i 311 & N105 E94 & 1 & \\
\hline 268 & N105 E99 & 3 & & 1312 & N105 E95 & $\vec{I}$ & \\
\hline 269 & N105 E98 & 1 & & i 313 & N104 E95 & 1 & \\
\hline 270 & N105 E98 & 2 & & 1 314 & N104 E96 & I & \\
\hline 271 & N104 E99 & 1 & & i 315 & N105 E97 & 4 & \\
\hline 272 & N104 E99 & 2 & & i 316 & N105 E96 & 1 & \\
\hline 273 & N104 E99 & 3 & & i 317 & N106 E94 & 1 & \\
\hline 274 & N104 E98 & 1 & & 318 & N107 E94 & 1 & \\
\hline 275 & N104 E98 & 2 & & 1. 319 & N107 E95 & 1 & \\
\hline 276 & N104 E98 & 3 & & 320 & N106 E95 & 1 & \\
\hline 277 & N105 E97 & 1 & & | 321 & N106 E96 & 1 & \\
\hline 278 & N105 E97 & 2 & & 322 & N107 E96 & $i$ & \\
\hline 279 & N106 E97 & I & & i 323 & N107 E97 & 4 & \\
\hline 280 & N107 E97 & 1 & & i 324 & N108 E94 & 1 & \\
\hline 281 & N107 E97 & 2 & & i 325 & N109 E94 & 1 & \\
\hline 282 & N108 E97 & 1 & & i 326 & N109 E95 & 1 & \\
\hline 283 & N108 E97 & 2 & & 1327 & N108 E95 & $\bar{I}$ & \\
\hline 284 & N109 E97 & 1 & & i 328 & N108 E96 & 1 & \\
\hline 285 & N108 E98 & 1 & & $\begin{array}{l}329 \\
1 \quad 3\end{array}$ & N108 E97 & 4 & \\
\hline 286 & N108 E98 & 2 & & i 330 & N109 E96 & 1 & \\
\hline 287 & N108 E99 & 1 & & 331 & N109 E97 & 4 & \\
\hline 288 & N109 E99 & 1 & & i 332 & N73 E92 & 1 & \\
\hline 289 & N109 E98 & 1 & & i 333 & N73 E92 & 2 & \\
\hline 290 & N106 E97 & 2 & F.6 Matrix & I 334 & N73 E92 & 3 & \\
\hline \multirow[t]{2}{*}{291} & N104 E97 & 3 & includes F.10 & 1335 & N74 E92 & 1 & \\
\hline & & & bone & 1336 & N74 E92 & 2 & \\
\hline \multirow[t]{2}{*}{292} & N104 E97 & 4 & includes F.10 & 1337 & N74 E92 & 3 & \\
\hline & & & bone & 338 & N75 E90 & 1 & \\
\hline 293 & N105 E97 & 3 & & 1339 & N75 E90 & 2 & \\
\hline 294 & N107 E97 & 3 & & 340 & N76 E90 & 1 & \\
\hline 295 & N108 E97 & 3 & & i 341 & N76 E90 & 2 & \\
\hline 296 & N108 E98 & 2 & & i 342 & N76 E91 & 1 & \\
\hline 297 & N108 E99 & 3 & & i 343 & N76 E91 & 2 & \\
\hline 298 & N109 E98 & 2 & & 344 & N75 E91 & 1 & \\
\hline 299 & N109 E98 & 3 & & i 345 & N75 E91 & 2 & \\
\hline 300 & N109 E99 & 2 & & 1346 & N75 E92 & 1 & \\
\hline
\end{tabular}




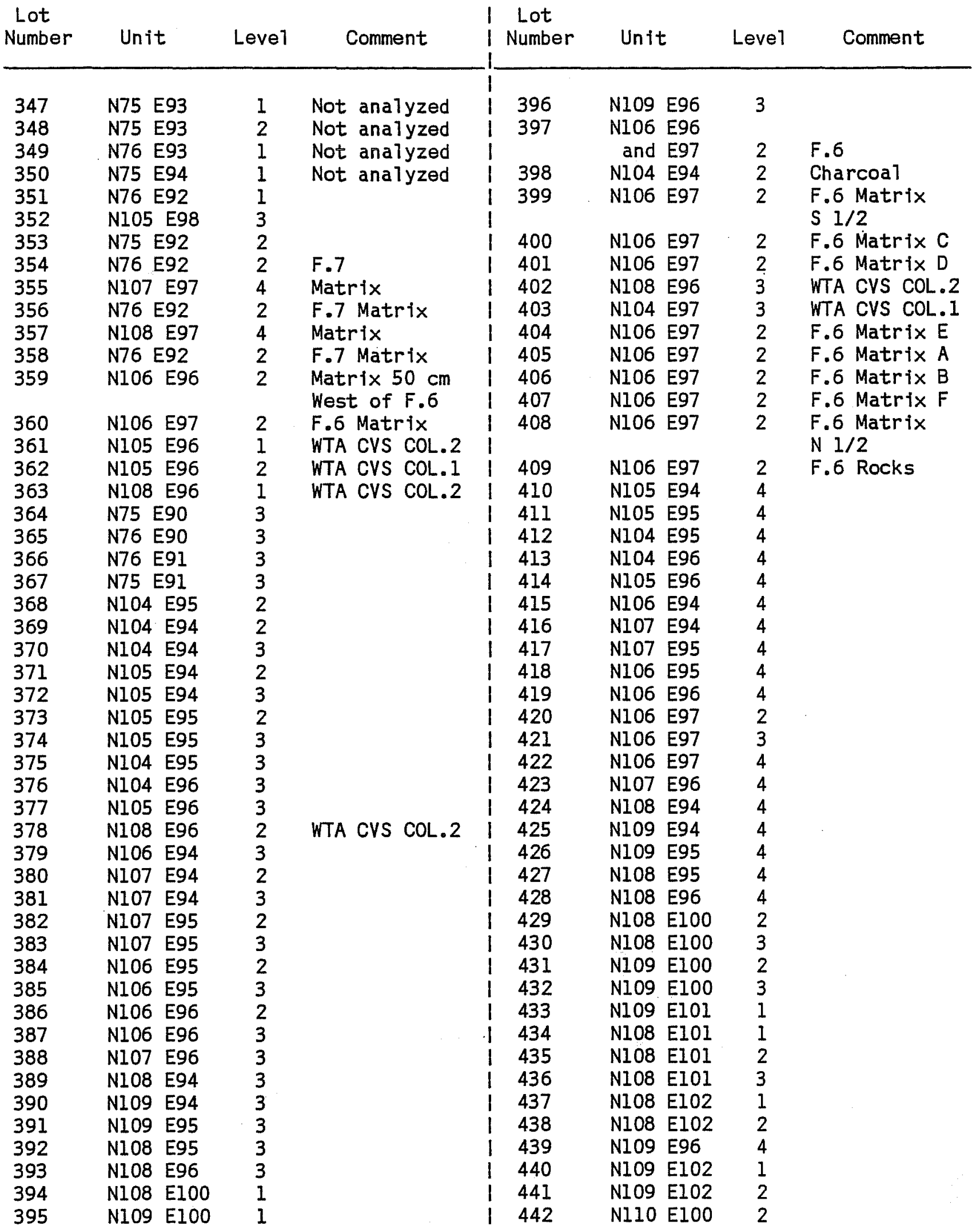




\begin{tabular}{|c|c|c|c|c|c|c|c|}
\hline $\begin{array}{l}\text { Lot } \\
\text { Number }\end{array}$ & Unit & Level & Comment & I Lot & Unit & Leve1 & Comment \\
\hline 443 & N110 E101 & 2 & & 490 & NSP & & $Z .2$ \\
\hline 444 & N110 E102 & 1 & & 491 & WFNP & & $\mathrm{Z} .2$ \\
\hline 445 & N110 E102 & 2 & & 1492 & N78 E90 & & North Wall \\
\hline 446 & N111 E100 & 1 & & 1 & & & Matrix Z.3 \\
\hline 447 & N111 ElO1 & 1 & & 493 & WFNP & & $\mathrm{Z} .3$ \\
\hline 448 & N111 ElOI & $\overline{2}$ & & | 494 & N110 E101 & 3 & F.8 Matrix \\
\hline 449 & $\mathrm{~N} 111 \mathrm{E} 102$ & 1 & & i 495 & N123 E106 & & Z.2 Matrix \\
\hline 450 & N111 El02 & 2 & & 1. 496 & N110 E102 & 3 & F.8 Matrix \\
\hline 451 & N104 E96 & $\overline{4}$ & WTA CVS COL. I & 1 497 & N110 E101 & 3 & F.8 Matrix \\
\hline 452 & N108 E96 & 4 & WTA CVS COL. 2 & 498 & N80 EI02 & & South Wall \\
\hline 453 & N106 E97 & 3 & F.6 Matrix & 1 & & & Matrix Z.2U \\
\hline 454 & N75 E92 & 3 & & i 499 & N78 E90 & & North Wall \\
\hline 455 & N104 E94 & 4 & & 1 & & & Matrix Z.2L \\
\hline 456 & N104 E94 & 5 & & 1500 & NPS & & Z.1 \\
\hline 457 & N108 E102 & 3 & & 1501 & N80 El02 & & South Wall \\
\hline 458 & N110 E100 & 1 & & 1 & & & Matrix Z.I \\
\hline 459 & N110 ElO1 & $i$ & & 502 & NPS & & $2.3 \mathrm{U}$ \\
\hline 460 & N110 El01 & 3 & & 1503 & N78 E90 & & $\mathrm{Z} .2 \mathrm{U}$ \\
\hline 461 & N110 E102 & 3 & & 1 504 & N80 E102 & & $\mathrm{Z} .2 \mathrm{~L}$ \\
\hline 462 & N111 El00 & 2 & & i 505 & N123 E106 & & Matrix 2.3 \\
\hline 463 & N11I El00 & 3 & & 1506 & N78 E90 & & North Wall \\
\hline 464 & NIII ElOl & 3 & & i & & & Matrix Z.I \\
\hline 465 & $\mathrm{~N} 111 \mathrm{E} 102$ & 3 & & I 507 & NPS & & $\mathrm{Z} .3 \mathrm{~L}$ \\
\hline 466 & NPS & 1 & & 508 & N123 E106 & & Matrix Z.1 \\
\hline 467 & NPS & 2 & & 1509 & N75 E91 & 4 & \\
\hline 468 & NPS & 3 & & 1510 & N75 E92 & 4 & \\
\hline 469 & NPS & 4 & & i 511 & N75 E93 & 4 & Not analyzed \\
\hline 470 & NPS & 5 & & 1512 & N76 E93 & 2 & Not analyzed \\
\hline 471 & NPS & 6 & & | 513 & N76 E92 & 3 & \\
\hline 472 & N108 E102 & 3,4 & F.9 & | 514 & N104 E96 & 2 & \\
\hline $47 \overline{3}$ & N109 E101 & 2 & & i 515 & N105 E96 & 2 & \\
\hline 474 & N109 E10I & 3 & & i 516 & N107 E96 & 2 & \\
\hline 475 & N108 E102 & 4 & & 1517 & N108 E94 & 2 & \\
\hline 476 & N108 E103 & 1 & & 1518 & N109 E94 & 2 & \\
\hline 477 & N108 E103 & 2 & & 1519 & N109 E95 & 2 & \\
\hline 478 & NI09 E102 & 3 & & 1520 & N108 E95 & 2 & \\
\hline 479 & N109 E102 & 4 & & | 521 & N108 E96 & 2 & \\
\hline 480 & N110 E100 & 3 & & 1 522 & N109 E96 & 2 & \\
\hline 481 & N110 El02 & 3 & $F .8$ & 523 & N106 E94 & 2 & \\
\hline 482 & N110 El02 & 4 & & i 524 & NI09 E101 & 2 & F.8 \\
\hline 483 & N111 E101 & 4 & & 1525 & N110 ElOI & 3 & $\mathrm{~F} .8$ \\
\hline 484 & N111 El02 & 4 & & 1526 & N110 E102 & 3 & F.8 \\
\hline 485 & N109 E102 & 3 & $F .8$ & 1527 & N110 E100 & 3 & F.8 Rocks \\
\hline 487 & N110 E101 & 4 & & | 528 & N106 E97 & 2 & F.6 Charcoal \\
\hline 488 & N109 EI01 & 2 & F.8 Matrix & i 529 & N109 E97 & 2 & \\
\hline 489 & WFNP & Z.1 & & i & & & \\
\hline
\end{tabular}




\section{APPENDIX 2}

DATA TABLE

Appendix 2 provides a complete breakdown of a 11 of the artifactual material recovered from al1 excavation units with the exception of the two noise pits (virtual1y no cultural material was recovered from these two units). The abbreviations used for the item headings follow; most are the artifact codes used in the text and discussed in detail in Section VI. The data table is divided into two sections: the WTA units and the remaining (miscellaneous) units. Within each of these sections the units are listed in order of sma 11 est to 1 argest north $(N)$ number and from smal lest to largest east (E) number. The levels from a given unit are listed in the order excavated (i.e., L.1, L.2, etc.).

\section{DATA TABLE CATEGORIES}

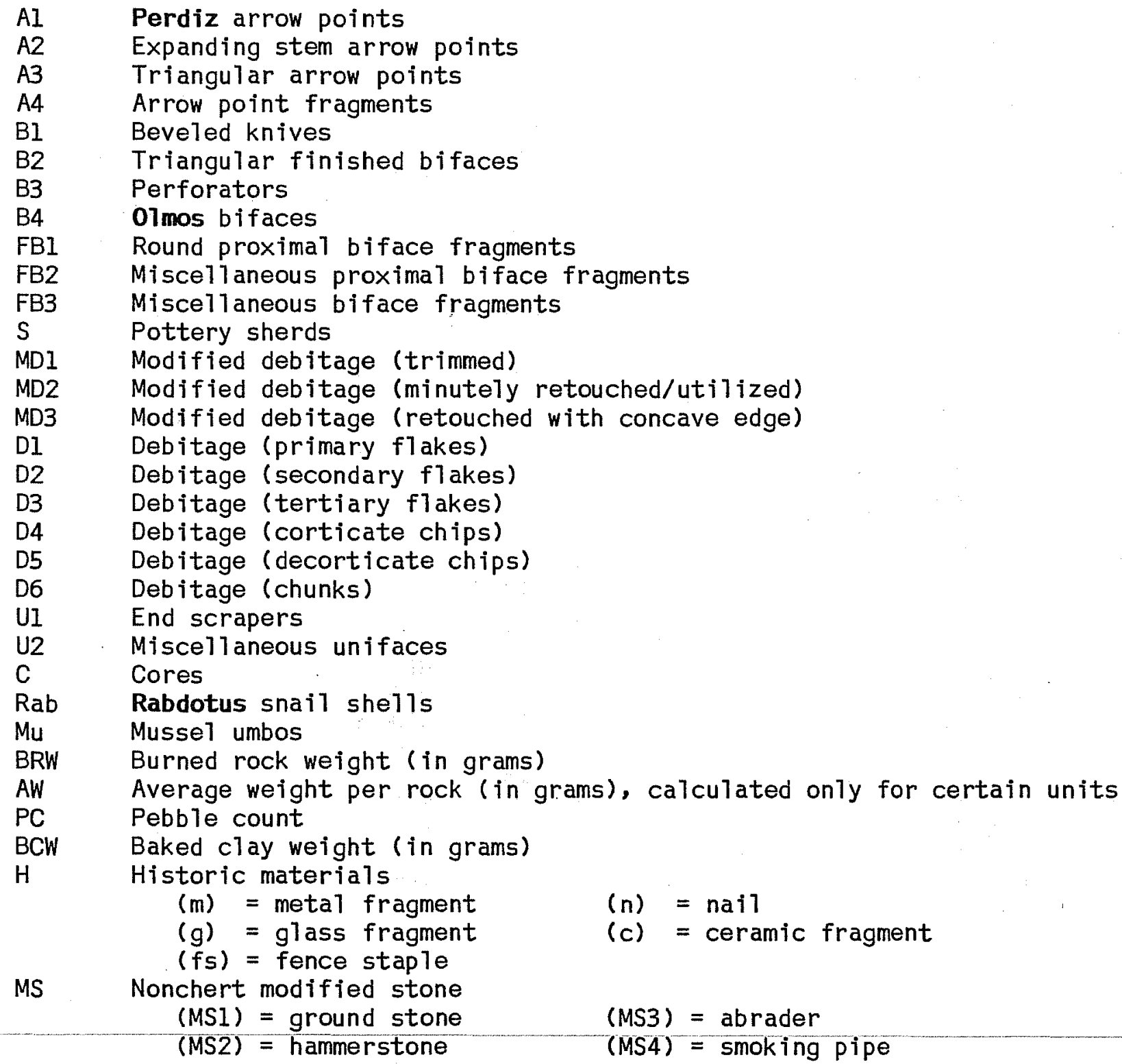


Wagon Trai1 Area Unyts

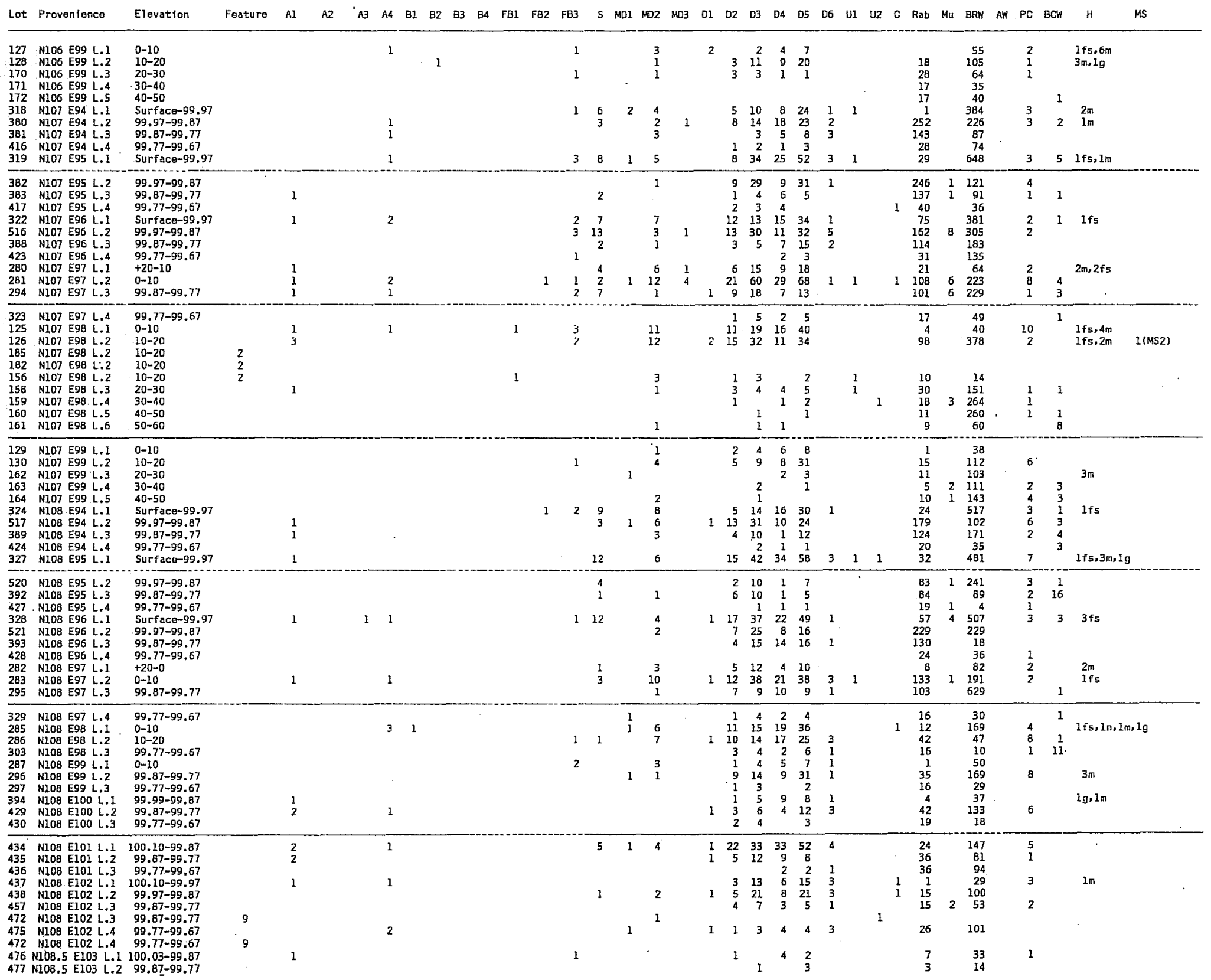


Hagon Tral1 Aroa Units

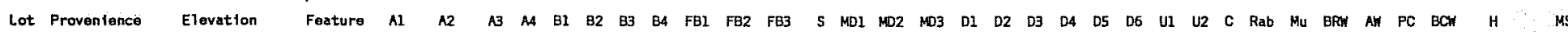

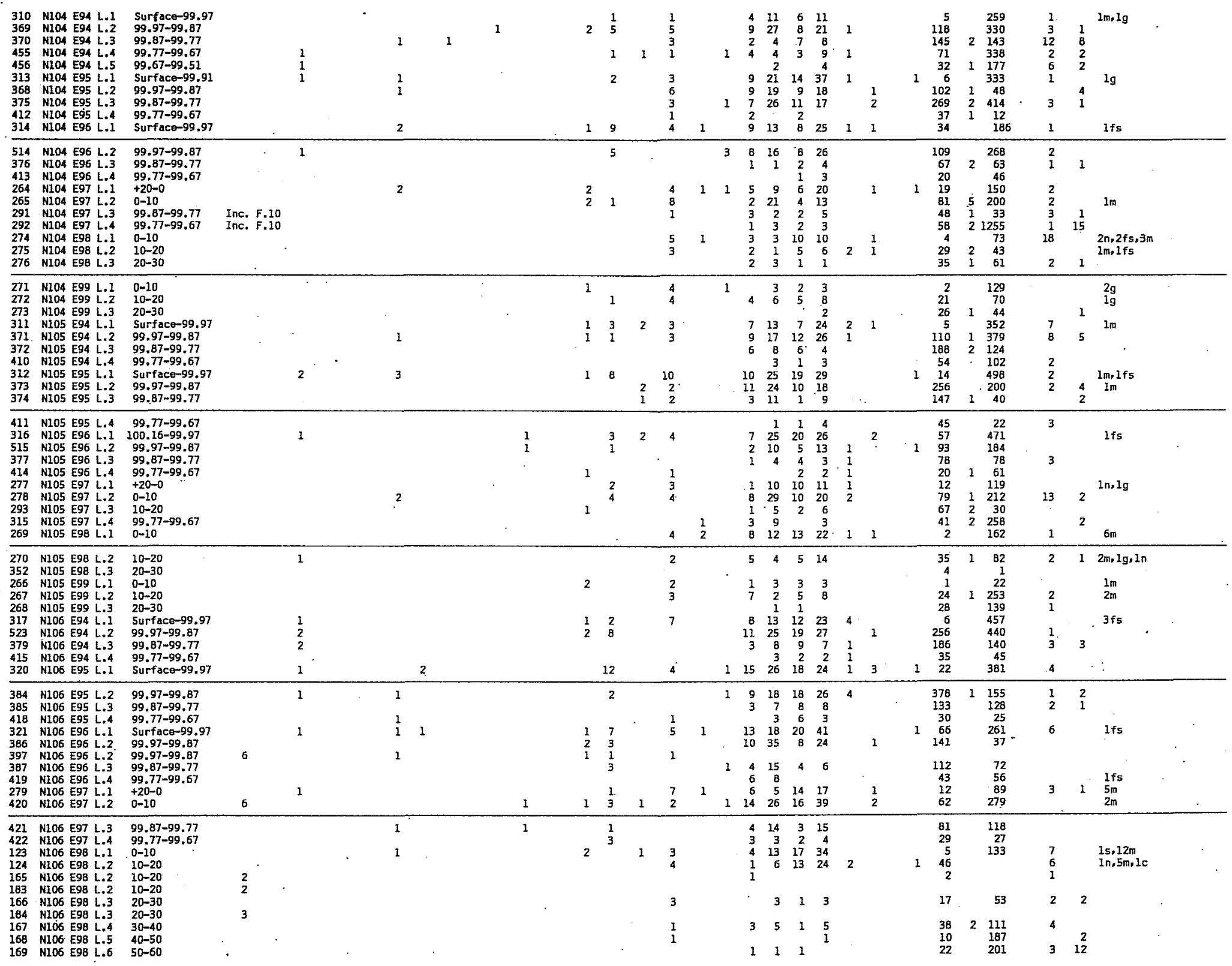


Wagon Trall Area Units

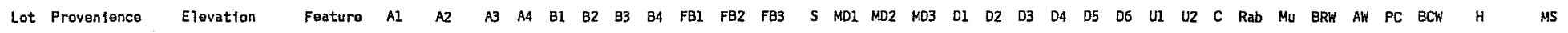

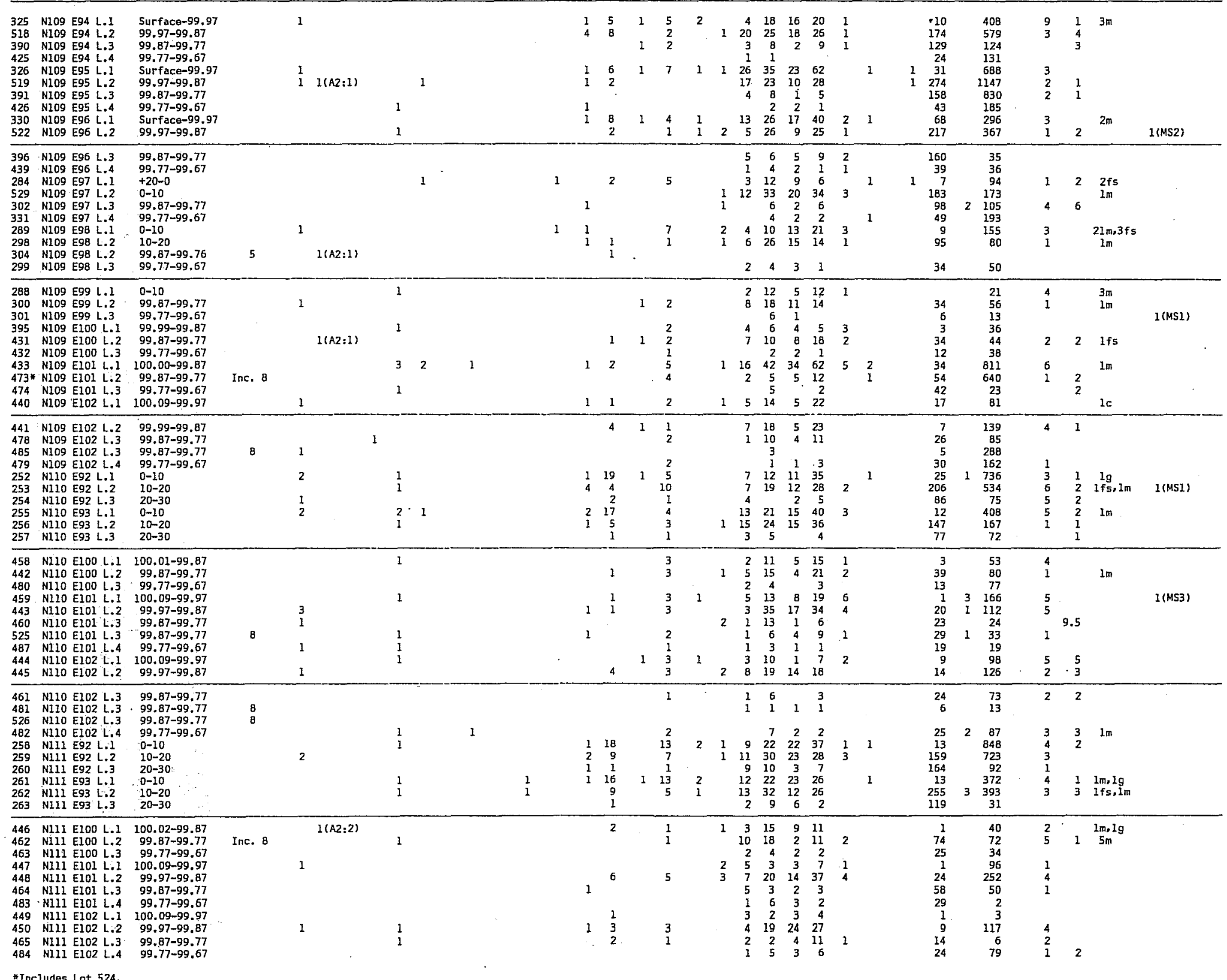


Miscellaneous Units

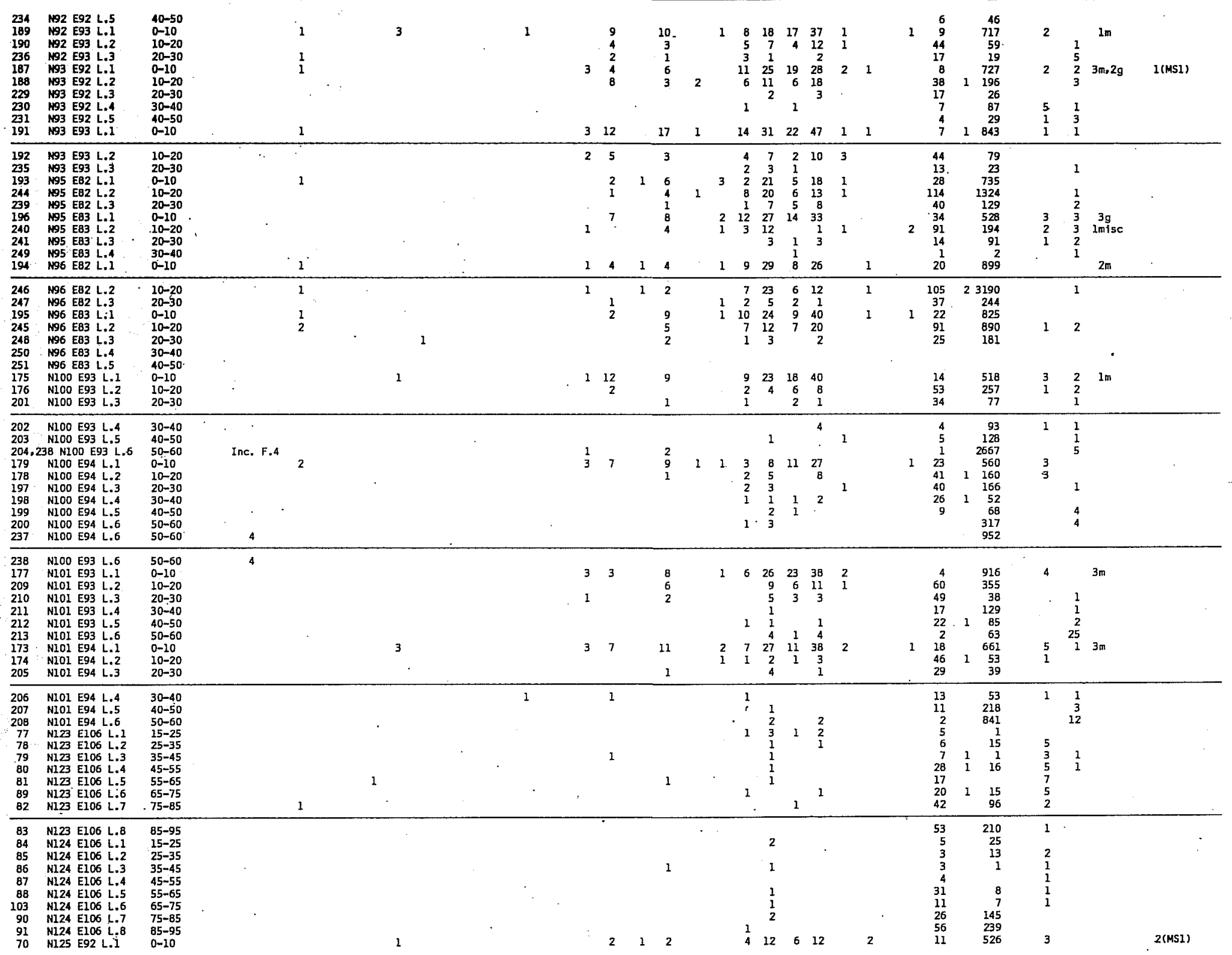


Miscel laneous Units

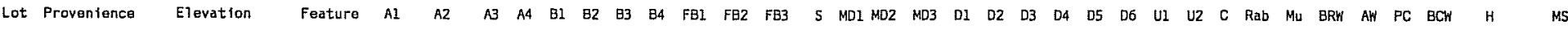

\begin{tabular}{|c|c|c|c|c|c|c|c|c|c|c|c|c|c|c|c|c|c|c|c|c|c|c|c|c|c|c|c|}
\hline $\begin{array}{l}332 \\
333 \\
334 \\
335 \\
336 \\
337 \\
338 \\
339 \\
364 \\
344\end{array}$ & 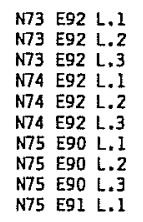 & $\begin{array}{l}0-10 \\
10-20 \\
99.62-99.52 \\
0-10 \\
10-20 \\
99.62-99.52 \\
99.83-99.72 \\
99.72-99.62 \\
99.62-99.52 \\
99.62-89.59 .72\end{array}$ & $\begin{array}{l}1 \\
1 \\
1\end{array}$ & & & & & & $\begin{array}{l}2 \\
2\end{array}$ & $\begin{array}{l}2 \\
3 \\
4 \\
2 \\
4 \\
6 \\
8\end{array}$ & 1 & $\begin{array}{l}4 \\
1 \\
1 \\
2 \\
2 \\
9 \\
6 \\
4\end{array}$ & & $\begin{array}{l}1 \\
1 \\
2 \\
1\end{array}$ & $\begin{array}{rr}8 & 1 \\
2 & 1 \\
4 & \\
14 & 1 \\
10 & 1 \\
1 & \\
7 & 1 \\
10 & 1 \\
11 & 2\end{array}$ & $\begin{array}{rl}11 & 1 \\
17 & 1 \\
6 & \\
12 & 1 \\
11 & 1 \\
2 & \\
13 & 1 \\
18 & 2 \\
1 & 2 \\
24 & 2\end{array}$ & $\begin{array}{rr}13 & 17 \\
10 & 16 \\
4 & 4 \\
15 & 24 \\
10 & 14 \\
4 & 12 \\
18 & 20 \\
23 & 21 \\
& 1 \\
24 & 32\end{array}$ & $\begin{array}{l}3 \\
6 \\
2 \\
\\
2 \\
1 \\
7\end{array}$ & $\begin{array}{l}1 \\
1 \\
1\end{array}$ & $\begin{array}{l}1 \\
2\end{array}$ & $\begin{array}{c}6 \\
12 \\
26 \\
6 \\
14 \\
33 \\
9 \\
81 \\
96 \\
14\end{array}$ & $\begin{array}{r}4 \\
1 \\
2 \\
2 \\
15 \\
14 \\
4 \\
4 \\
4 \\
2 \\
1 \\
1\end{array}$ & $\begin{array}{l}45526.9 \\
14413.5 \\
248 \\
540 \\
412 \\
142 \\
476 \\
281 \\
104 \\
764 \\
764\end{array}$ & $\begin{array}{r}2 \\
1 \\
7 \\
2 \\
2 \\
11 \\
4\end{array}$ & $\begin{array}{r}3 \\
4 \\
2 \\
6 \\
3 \\
14\end{array}$ & $\begin{array}{l}\text { In } \\
\text { lg }\end{array}$ & . \\
\hline $\begin{array}{l}345 \\
3467 \\
509 \\
346 \\
353 \\
454 \\
510 \\
340 \\
341 \\
365\end{array}$ & 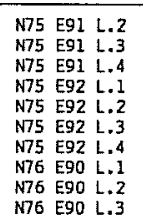 & $\begin{array}{l}99.72-99.62 \\
99.62-99.52 \\
99.52-99.42 \\
0-10 \\
10-20 \\
99.62-99.52 \\
99.52-99.42 \\
99.83-99.72 \\
99.72-99.62 \\
99.62-99.52\end{array}$ & 1 & $\begin{array}{l}1 \\
1 \\
1 \\
1 \\
1\end{array}$ & & & & 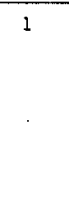 & $\begin{array}{l}1 \\
1 \\
1 \\
1\end{array}$ & $\begin{array}{l}2 \\
\\
8 \\
6 \\
1 \\
2 \\
7 \\
1\end{array}$ & $\begin{array}{l}1 \\
.\end{array}$ & $\begin{array}{l}3 \\
\\
7 \\
2 \\
1 \\
3 \\
4\end{array}$ & $\begin{array}{l}1 \\
4\end{array}$ & $\begin{array}{l}1 \\
\\
4 \\
2 \\
3 \\
3 \\
2\end{array}$ & \begin{tabular}{r|r}
11 & 1 \\
4 & \\
17 & \\
15 & 1 \\
5 & \\
3 & \\
14 & 1 \\
9 & 2 \\
6 & 1
\end{tabular} & $\begin{array}{cc}18 & 2 \\
1 & \\
1 & \\
20 & 1 \\
16 & 1 \\
9 & \\
3 & \\
15 & 1 \\
29 & 1 \\
12 & \end{array}$ & $\begin{array}{rr}24 & 44 \\
7 & 6 \\
1 & 6 \\
15 & 33 \\
19 & 15 \\
1 & 2 \\
4 & 4 \\
15 & 28 \\
19 & 16 \\
1 & 8\end{array}$ & $\begin{array}{l}1 \\
1 \\
6\end{array}$ & $\frac{1}{1}$ & & $\begin{array}{r}67 \\
98 \\
84 \\
9 \\
118 \\
78 \\
14 \\
14 \\
55 \\
114\end{array}$ & $\begin{array}{r}3 \\
3 \\
2 \\
2 \\
7 \\
2 \\
2 \\
2 \\
2 \\
3 \\
12 \\
2\end{array}$ & $\begin{array}{ll}332 & \\
228 & 18.8 \\
291 & \\
796 & 27.7 \\
241 & 27.3 \\
99 & 14.0 \\
216 & 14.0 \\
326 & \\
293 & \\
200 & 91\end{array}$ & 7. & \begin{tabular}{|r|}
1 \\
6 \\
13.1 \\
9 \\
5
\end{tabular} & $\begin{array}{l}1 \mathrm{~m} \\
2 \mathrm{~g}, 1 \mathrm{~m} \\
1 \mathrm{~g}, 1 \mathrm{~m}\end{array}$ & I (MS1) \\
\hline $\begin{array}{r}342 \\
343 \\
366 \\
351 \\
354 \\
513 \\
60 \\
63 \\
69 \\
92\end{array}$ & 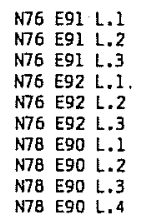 & $\begin{array}{l}99.83-99.72 \\
99.72-99.62 \\
99.62-99.52 \\
0-10 \\
10-20 \\
99.62-99.52 \\
0-10 \\
10-20 \\
20-30 \\
30-40\end{array}$ & $\begin{array}{ll}1 & \\
1 & 1(A Z: 2) \\
1 & \end{array}$ & $\begin{array}{l}2 \\
1 \\
1\end{array}$ & 1 & & 1 & & $\begin{array}{l}1 \\
3 \\
2\end{array}$ & $\begin{array}{r}3 \\
4 \\
2 \\
25 \\
3 \\
2 \\
12 \\
4 \\
2\end{array}$ & $\begin{array}{l}1 \\
2 \\
1\end{array}$ & $\begin{array}{r}6 \\
4 \\
13 \\
13 \\
2 \\
2 \\
2 \\
3 \\
3 \\
3 \\
2\end{array}$ & $\begin{array}{l}1 \\
1 \\
1\end{array}$ & $\begin{array}{r}3 \\
10 \\
1 \\
3\end{array}$ & $\begin{aligned} & 7 \\
& 13 \\
& 8 \\
& 36 \\
& 17 \\
& 12 \\
& 7 \\
& 6 \\
& 5\end{aligned}$ & $\begin{array}{ll}28 & 2 \\
47 & 3 \\
16 & \\
60 & 2 \\
30 & 1 \\
14 & \\
11 & 1 \\
14 & 1 \\
16 & \\
2 & \end{array}$ & $\begin{array}{rr}26 & 37 \\
34 & 43 \\
6 & 17 \\
29 & 74 \\
11 & 30 \\
3 & 13 \\
12 & 16 \\
14 & 23 \\
9 & 2\end{array}$ & $\begin{array}{l}4 \\
7 \\
1 \\
6 \\
1\end{array}$ & $\begin{array}{l}1 \\
1 \\
1\end{array}$ & 1 & $\begin{array}{c}11 \\
98 \\
107 \\
78 \\
121 \\
124 \\
13 \\
21 \\
84 \\
83\end{array}$ & $\begin{array}{r}4 \\
2 \\
21 \\
1 \\
5 \\
12 \\
3 \\
3 \\
2 \\
2\end{array}$ & $\begin{array}{ll}478 & \\
268 & \\
146 & 17.3 \\
572 & 11.4 \\
97.4 & 16.2 \\
246 & 19.0 \\
353 & 315 \\
315 & \\
233 & \\
42 & \end{array}$ & $\begin{array}{l}1 \\
2 \\
2 \\
3\end{array}$ & $\begin{array}{r}2 \\
17 \\
1 \\
\\
5\end{array}$ & $\begin{array}{l}29 \\
2 m\end{array}$ & $\begin{array}{l}\text { 1(MS1) } \\
\text { I(MS1) } \\
\text { I(MS1) } \\
2 \text { (MS3), } 1 \text { (MS1) }\end{array}$ \\
\hline $\begin{array}{l}93 \\
57 \\
54 \\
68 \\
94 \\
95 \\
58 \\
65 \\
57 \\
96\end{array}$ & 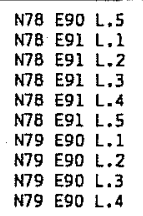 & $\begin{array}{l}40-50 \\
0-10 \\
10-20 \\
20-30 \\
30-40 \\
40-50 \\
0-50 \\
10-20 \\
20-30 \\
30-40\end{array}$ & . & 1 & & 1 & & & $\begin{array}{l}1 \\
2 \\
1 \\
2 \\
3\end{array}$ & $\begin{array}{l}8 \\
8 \\
7 \\
\\
3 \\
2 \\
2 \\
1\end{array}$ & $z$ & $\begin{array}{l}1 \\
3 \\
2 \\
2 \\
1\end{array}$ & 1 & 1 & $\begin{array}{r}3 \\
14 \\
7 \\
4 \\
6 \\
3 \\
3 \\
5 \\
4 \\
4\end{array}$ & $\begin{array}{rl}4 & \\
20 & 1 \\
29 & 1 \\
8 & \\
2 & \\
2 & \\
5 & 1 \\
4 & 1 \\
3 & \end{array}$ & $\begin{array}{rr}2 & 6 \\
14 & 30 \\
17 & 26 \\
3 & 10 \\
1 & 3 \\
3 & 2 \\
11 & 25 \\
11 & 15 \\
4 & 2\end{array}$ & $\begin{array}{l}2 \\
1\end{array}$ & & & $\begin{array}{r}87 \\
5 \\
9 \\
93 \\
98 \\
56 \\
56 \\
6 \\
\\
40\end{array}$ & 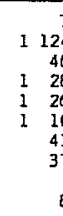 & $\begin{aligned} 76 \\
1243 \\
465 \\
282 \\
261 \\
103 \\
419 \\
378 \\
84\end{aligned}$ & $\begin{array}{l}3 \\
1 \\
. \\
1\end{array}$ & $\begin{array}{l}1 \\
1\end{array}$ & $\begin{array}{l}1 \mathrm{~m} \\
1 \mathrm{~g}\end{array}$ & 1 (MS2) \\
\hline $\begin{array}{r}97 \\
105 \\
98 \\
99 \\
59 \\
65 \\
67 \\
102 \\
101 \\
104\end{array}$ & 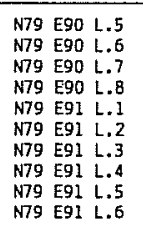 & $\begin{array}{l}40-50 \\
50-60 \\
60-70 \\
70-80 \\
0-10 \\
10-20 \\
20-30 \\
30-40 \\
40-50 \\
50-60\end{array}$ & 1 & $\frac{1}{1}$ & & & 1 & & 2 & $\begin{array}{l}1 \\
5 \\
9 \\
1 \\
1\end{array}$ & $\begin{array}{l}1 \\
1\end{array}$ & $\begin{array}{l}1 \\
2 \\
1 \\
1 \\
2\end{array}$ & 2 & $\begin{array}{l}1 \\
1\end{array}$ & $\begin{array}{l}1 \\
1 \\
\\
7 \\
6 \\
9 \\
3 \\
2 \\
1\end{array}$ & $\begin{array}{rl}3 & \\
1 & \\
2 & \\
14 & 2 \\
14 & 2 \\
9 & 1 \\
4 & \\
3 & \\
3 & \end{array}$ & $\begin{array}{rr}2 & 1 \\
& \\
& 1 \\
20 & 43 \\
20 & 19 \\
11 & 13 \\
1 & 4 \\
1 & 8 \\
1 & 3\end{array}$ & $\begin{array}{l}1 \\
3\end{array}$ & 1 & & \begin{tabular}{|c|}
35 \\
33 \\
21 \\
40 \\
10 \\
14 \\
144 \\
50 \\
29 \\
37
\end{tabular} & $\begin{array}{ll}1 & 2 \\
1 & 2 \\
1 & 1 \\
& 6 \\
& 6 \\
1 & 1 \\
3 & 1 \\
1 & 2 \\
& 2\end{array}$ & $\begin{array}{r}246 \\
219 \\
108 \\
67 \\
650 \\
156 \\
308 \\
135 \\
35 \\
258\end{array}$ & 2 & & $\stackrel{19}{1 \mathrm{~g}, 1 \mathrm{~m}}$ & 1 (MS3) \\
\hline $\begin{array}{l}100 \\
214 \\
215 \\
216 \\
217 \\
218 \\
222 \\
223 \\
224 \\
225\end{array}$ & 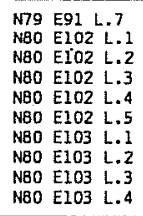 & $\begin{array}{l}60-70 \\
0-10 \\
10-20 \\
20-30 \\
30-40 \\
40-50 \\
0-10 \\
10-20 \\
20-30 \\
30-40\end{array}$ & 1 & & & & & & 1 & 3 & & $\begin{array}{l}2 \\
1 \\
4\end{array}$ & & & $\begin{array}{l}1 \\
1 \\
3\end{array}$ & $\begin{array}{l}2 \\
3 \\
8 \\
3 \\
3 \\
2\end{array}$ & $\begin{array}{rr} & 1 \\
4 & 5 \\
2 & 16 \\
& 1 \\
& 1 \\
& \\
1 & 12 \\
4 & 3 \\
1 & 1\end{array}$ & $\begin{array}{l}2 \\
1 \\
1\end{array}$ & 1 & & $\begin{array}{r}56 \\
16 \\
4 \\
39 \\
25 \\
17 \\
3 \\
1 \\
28 \\
7 \\
7\end{array}$ & 2 & $\begin{array}{r}96 \\
44 \\
10 \\
1 \\
2 \\
2 \\
165 \\
124 \\
11 \\
7\end{array}$ & $\begin{array}{r}3 \\
2 \\
15 \\
5 \\
1 \\
3 \\
3 \\
2 \\
2 \\
3\end{array}$ & & $3 \mathrm{~m}, 2 \mathrm{~g}$ & \\
\hline $\begin{array}{l}226 \\
227 \\
228 \\
219 \\
220 \\
221 \\
157 \\
186 \\
232 \\
233\end{array}$ & 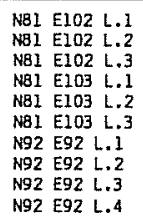 & $\begin{array}{l}0-10 \\
10-20 \\
20-30 \\
0-10 \\
10-20 \\
20-30 \\
0-10 \\
10-20 \\
20-30 \\
30-40\end{array}$ & $\begin{array}{l}1 \\
1 \\
1\end{array}$ & & & & & & 1 & $\begin{array}{l}7 \\
3 \\
1\end{array}$ & 1 & $\begin{array}{r}4 \\
4 \\
3 \\
11 \\
2\end{array}$ & & 1 & $\begin{array}{l}3 \\
1 \\
5 \\
4 \\
1\end{array}$ & $\begin{array}{r}3 \\
7 \\
6 \\
1 \\
18 \\
18 \\
2\end{array}$ & $\begin{array}{rr}2 & 4 \\
2 & 4 \\
4 & 14 \\
3 & 4 \\
& 1 \\
17 & 32 \\
8 & 17 \\
1 & 2 \\
1 & 3\end{array}$ & 2 & 1 & & $\begin{array}{r}3 \\
5 \\
17 \\
10 \\
4 \\
15 \\
5 \\
36 \\
28 \\
12\end{array}$ & $\begin{array}{r}1 \\
1 \\
\\
1 \\
1 \\
1 \\
7 \\
2 \\
1\end{array}$ & $\begin{array}{r}109 \\
114 \\
63 \\
57 \\
129 \\
167 \\
745 \\
225 \\
42 \\
45\end{array}$ & $\begin{array}{l}1 \\
4 \\
1 \\
3 \\
1 \\
2 \\
5 \\
2 \\
2 \\
2\end{array}$ & $\begin{array}{l}4 \\
2 \\
1\end{array}$ & $\begin{array}{c}2 \mathrm{~g} \\
1 \mathrm{~g}, 1 \mathrm{~m}\end{array}$ & $\begin{array}{l}1 \text { (MSI) } \\
1 \text { (MSI) }\end{array}$ \\
\hline
\end{tabular}


Miscelianeous Units

\begin{tabular}{|c|c|c|c|c|c|c|c|c|c|c|c|c|c|c|c|c|c|c|c|c|c|c|c|c|c|c|c|c|c|c|c|c|c|c|c|}
\hline Lot & Proventence & Elevation & Feature & $\mathrm{Al}$ & $A 2$ & A3 & A4 & BI & $\dot{\mathrm{B}} 2$ & B3 & 84 & FBl & $F B 2$ & FB3 & $\mathrm{s}$ & MDI & MD2 & MD3 & $\mathrm{Dl}$ & $\mathrm{D} 2$ & $\mathrm{DJ}$ & $D 4$ & D5 & DE. & UI & $\mathrm{u} 2$ & $C R$ & Rab & Mu $B$ & BRW A & AW $P$ & PC BC & BCW & $H$ & MS \\
\hline $\begin{array}{r}71 \\
108 \\
109 \\
110 \\
111 \\
146 \\
147 \\
148 \\
149 \\
150\end{array}$ & 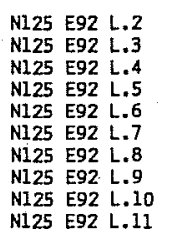 & $\begin{array}{l}10-20 \\
20-30 \\
30-40 \\
40-50 \\
50-60 \\
60-70 \\
70-80 \\
80-90 \\
90-100 \\
100-110\end{array}$ & & 1 & & & & . & & & & & & $\begin{array}{l}1 \\
1 \\
1\end{array}$ & $\begin{array}{l}5 \\
1 \\
2 \\
1 \\
\\
2 \\
1\end{array}$ & 1 & $\begin{array}{l}2 \\
1 \\
2 \\
1 \\
1\end{array}$ & + & 1 & $\begin{array}{ll}5 & 1 \\
3 & 1 \\
1 \\
3 \\
1 \\
1 \\
1 \\
1\end{array}$ & $\begin{array}{r}13 \\
5 \\
5 \\
3 \\
3 \\
1 \\
3 \\
4 \\
5 \\
3\end{array}$ & $\begin{array}{r}10 \\
5 \\
1 \\
1 \\
2 \\
3\end{array}$ & $\begin{array}{r}13 \\
5 \\
3 \\
3 \\
3 \\
1 \\
4 \\
5 \\
9 \\
1 \\
2\end{array}$ & 1 & $\begin{array}{l}1 \\
1 \\
1 \\
1\end{array}$ & & $\begin{array}{ll}1 & 1 \\
1 \\
1 \\
1 \\
1 \\
1\end{array}$ & $\begin{array}{r}35 \\
64 \\
120 \\
113 \\
104 \\
89 \\
111 \\
134 \\
108 \\
94\end{array}$ & $\begin{array}{ll} & 2 \\
& 5 \\
5 & 2 \\
4 & 4 \\
& 1 \\
8 & 1 \\
6 & 6 \\
5 & 4 \\
6 & 3 \\
4 & 2\end{array}$ & $\begin{array}{l}225 \\
540 \\
239 \\
414 \\
146 \\
149 \\
653 \\
420 \\
377 \\
249\end{array}$ & & $\begin{array}{r}3 \\
47 \\
37 \\
45 \\
10 \\
7 \\
6 \\
13 \\
9 \\
9 \\
5\end{array}$ & $\begin{array}{r}2 \\
1 \\
5 \\
\\
3 \\
11 \\
2\end{array}$ & - & 1(MS1) \\
\hline $\begin{array}{r}72 \\
73 \\
112 \\
113 \\
114 \\
115 \\
151 \\
152 \\
153 \\
154\end{array}$ & 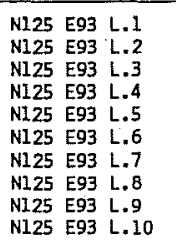 & $\begin{array}{l}0-10 \\
10-20 \\
20-30 \\
30-40 \\
40-50 \\
50-60 \\
60-70 \\
70-80 \\
80-90 \\
90-100\end{array}$ & & & & & 1 & & & & 1 & & & $\frac{1}{1}$ & $\begin{array}{r}12 \\
2\end{array}$ & 1 & $\begin{array}{l}6 \\
2 \\
1 \\
1 \\
\end{array}$ & & : & $\begin{array}{l}9 \\
5 \\
1 \\
\\
\end{array}$ & $\begin{array}{r}24 \\
8 \\
3 \\
3 \\
3 \\
3 \\
3 \\
4 \\
1 \\
1\end{array}$ & $\begin{array}{r}13 \\
4 \\
1 \\
\\
3\end{array}$ & $\begin{array}{r}37 \\
11 \\
3 \\
2 \\
2 \\
2 \\
2 \\
2\end{array}$ & 3 & & & & $\begin{array}{l}18 \\
46 \\
45 \\
63 \\
57 \\
57 \\
52 \\
62 \\
54 \\
57\end{array}$ & $\begin{array}{ll} & 5 \\
2 & 5 \\
5 & 3 \\
5 & 2 \\
5 & 1 \\
3 & 3 \\
3 & 3 \\
2 & 65 \\
1 & 17 \\
& 23\end{array}$ & $\begin{array}{l}524 \\
564 \\
392 \\
290 \\
175 \\
305 \\
344 \\
658 \\
1773 \\
7389\end{array}$ & 1 & $\begin{array}{r}2 \\
5 \\
2 \\
8 \\
\end{array}$ & $\begin{array}{r}81 \\
5 \\
8\end{array}$ & $1 \mathrm{~m}$ & \\
\hline $\begin{array}{r}155 \\
74 \\
75 \\
116 \\
117 \\
118 \\
134 \\
135 \\
136 \\
137\end{array}$ & 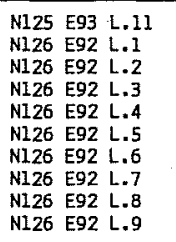 & $\begin{array}{l}100-110 \\
0-10 \\
10-20 \\
20-30 \\
30-40 \\
40-50 \\
50-60 \\
60-70 \\
70-80 \\
80-90\end{array}$ & & 1 & & & & & & & & 1 & & 2 & $\begin{array}{l}1 \\
2\end{array}$ & . & $\begin{array}{l}4 \\
4 \\
2 \\
1 \\
1 \\
1\end{array}$ & 2 & & $\begin{array}{l}6 \\
6 \\
2 \\
2 \\
2 \\
\cdot \\
3 \\
1\end{array}$ & $\begin{array}{r}20 \\
8 \\
1 \\
1 \\
1 \\
1\end{array}$ & $\begin{array}{l}9 \\
4 \\
1 \\
2 \\
2\end{array}$ & $\begin{array}{r}20 \\
5 \\
2 \\
1 \\
2 \\
1 \\
2 \\
1\end{array}$ & $\begin{array}{l}3 \\
1 \\
1 \\
1\end{array}$ & & & 12 & $\begin{array}{l}92 \\
9 \\
34 \\
56 \\
51 \\
70 \\
87 \\
66 \\
70 \\
86\end{array}$ & $\begin{array}{ll}4 & 45 \\
& 65 \\
1 & 17 \\
6 & 11 \\
6 & 1 \\
6 & 22 \\
4 & 26 \\
3 & 65 \\
1 & 15 \\
3 & 74\end{array}$ & $\begin{array}{l}4570 \\
690 \\
173 \\
103 \\
139 \\
230 \\
260 \\
697 \\
152 \\
744\end{array}$ & 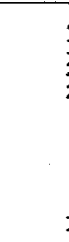 & $\begin{array}{ll}4 & 1 \\
1 & \\
2 & \\
2 & \end{array}$ & $\begin{array}{c}16 \\
1\end{array}$ & $\frac{1 \mathrm{~m}}{2 \mathrm{~m}}$ & $I$ (MS1) \\
\hline $\begin{array}{l}138 \\
139 \\
76 \\
120 \\
119 \\
121 \\
122 \\
140 \\
141 \\
142\end{array}$ & 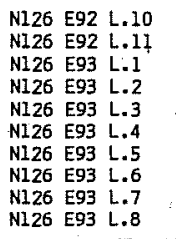 & $\begin{array}{l}90-100 \\
100-110 \\
0-10 \\
10-20 \\
20-30 \\
30-40 \\
40-50 \\
50-60 \\
60-70 \\
70-80\end{array}$ & & 1 & & & & & & 1 & . & & & 1 & $\begin{array}{l}2 \\
1\end{array}$ & $\begin{array}{l}1 \\
1\end{array}$ & $\begin{array}{l}5 \\
4 \\
1 \\
1 \\
1 \\
2\end{array}$ & & & $\begin{array}{ll}6 & \\
2 & 1 \\
& \\
1 & \\
3 & \\
2 & \end{array}$ & $\begin{array}{r}1 \\
2 \\
9 \\
10 \\
2 \\
1 \\
2 \\
\\
1\end{array}$ & $\begin{array}{l}1 \\
9 \\
9 \\
3 \\
2 \\
1 \\
1 \\
\\
1\end{array}$ & $\begin{array}{r}1 \\
16 \\
8 \\
2 \\
1 \\
3 \\
1\end{array}$ & 1 & & & $\begin{array}{r}7 \\
6 \\
6 \\
5 \\
5 \\
5 \\
5 \\
6 \\
1 \quad 6 \\
1\end{array}$ & $\begin{array}{l}70 \\
67 \\
7 \\
63 \\
50 \\
46 \\
55 \\
61 \\
62 \\
94\end{array}$ & $\begin{array}{ll}6 & 1 \\
4 & 2 \\
1 & 4 \\
3 & 3 \\
4 & 1 \\
8 & 2 \\
7 & 2 \\
5 & 3 \\
2 & 3 \\
9 & 3 \\
9 & \end{array}$ & $\begin{array}{l}150 \\
270 \\
416 \\
370 \\
147 \\
239 \\
232 \\
302 \\
373 \\
393\end{array}$ & & $\begin{array}{l}3 \\
1 \\
1\end{array}$ & \begin{tabular}{r|}
3 \\
2 \\
1 \\
2 \\
1 \\
12 \\
3 \\
11
\end{tabular} & . & \\
\hline $\begin{array}{r}143 \\
144 \\
145 \\
131 \\
61 \\
107 \\
56\end{array}$ & $\begin{array}{l}\text { N126 E93 L.9 } \\
\text { N126 E93 L.I0 } \\
\text { N126 E93 L.11 } \\
\text { General Surface } \\
\text { General Surface } \\
\text { General Surface } \\
\text { General Surface }\end{array}$ & $\begin{array}{ll} & 80-90 \\
\cdot & 90-100 \\
\cdot & 100-110 \\
\theta & \\
\theta & \end{array}$ & & $\begin{array}{l}2 \\
1\end{array}$ & $1(\mathrm{AZ}: 1)$ & & 1 & 1 & & 1 & & $\begin{array}{l}1 \\
1\end{array}$ & 1 & $\begin{array}{r}26 \\
3 \\
1\end{array}$ & $\begin{array}{r}20 \\
6 \\
5 \\
5\end{array}$ & & I & & & & 2 & & $\begin{array}{l}3 \\
1\end{array}$ & & 7 & & $\begin{array}{l}5 \\
6 \\
7\end{array}$ & $\begin{array}{l}53 \\
64 \\
79\end{array}$ & $\begin{array}{ll}1 & 5 \\
3 & 28 \\
5 & 270\end{array}$ & $\begin{array}{l}545 \\
280 \\
2793\end{array}$ & & $\begin{array}{l}2 \\
3 \\
3\end{array}$ & 7 & $\begin{array}{l}* \\
* \\
* \\
*\end{array}$ & $\begin{array}{l}1 \text { (MS1) } \\
* \\
* \\
* \\
*\end{array}$ \\
\hline
\end{tabular}

$* H=5 c ; M S=7$ (MS1), 4 (MS2), 2(MS3), I(MS4). 